\title{
STP-ECRTS - Thermal and Gas Analyses for Sludge Transport and Storage Container (STSC) Storage at T Plant
}

Prepared for the U.S. Department of Energy

Assistant Secretary for Environmental Management

Contractor for the U.S. Department of Energy

under Contract DE-AC06-08RL14788

CH2MHILL

Plateau Remediation Company

P.O. Box 1600

Richland, Washington 99352 
PRC-STP-00241

Revision 0

EDC \#: PRC-EDC-10-46288

\section{STP-ECRTS - Thermal and Gas}

\section{Analyses for Sludge Transport and Storage Container (STSC) Storage at T Plant}

Document Type: TR

Program/Project: STP

R. D. Crowe

Fluor Government Group

R. Apthorpe

S. J. Lee

M. G. Plys

Fauske \& Associates LLC

Date Published

April 2010

Prepared for the U.S. Department of Energy

Assistant Secretary for Environmental Management

Contractor for the U.S. Department of Energy

under Contract DE-AC06-08RL14788

CH2MHILL

Plateau Remediation Company

P.O. Box 1600

Richland, Washington

$\frac{\operatorname{Lan} \text { ay A Fouad }}{\text { Release Approval }}$

$\frac{4-29-10}{\text { Date }}$

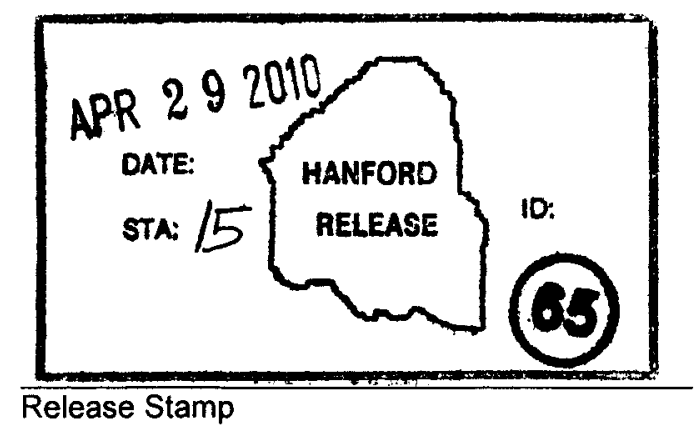

Approved for Public Release;

Further Dissemination Unlimited 
TRADEMARK DISCLAIMER

Reference herein to any specific commercial product, process,

or service by trade name, trademark, manufacturer, or

otherwise, does not necessarily constitute or imply its

endorsement, recommendation, or favoring by the United

States Government or any agency thereof or its contractors or subcontractors.

This report has been reproduced from the best available copy.

Printed in the United States of America

Total Pages: $\quad 305$ 


\section{TABLE OF CONTENTS}

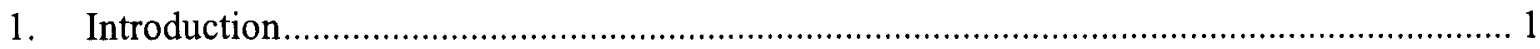

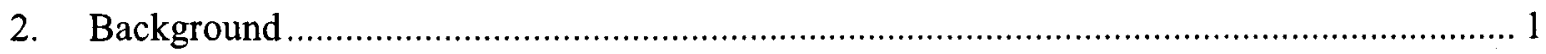

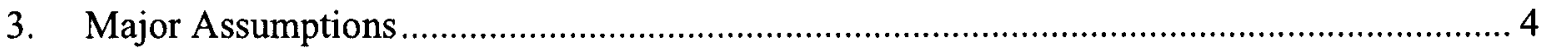

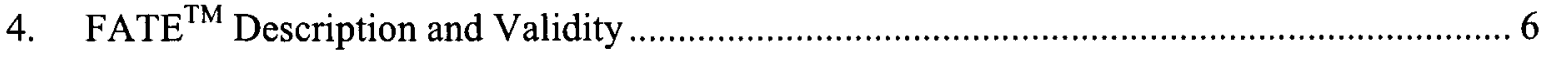

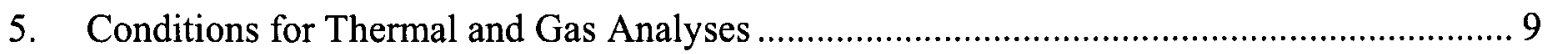

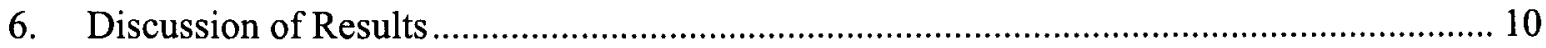

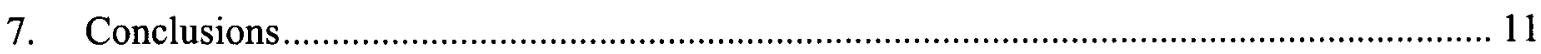

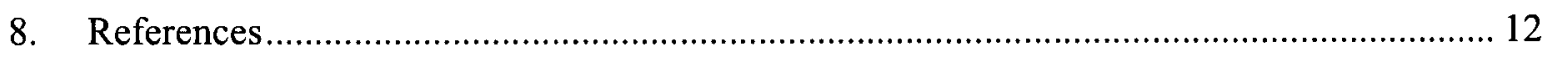

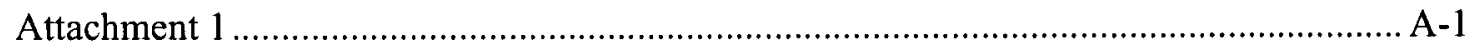

\section{TABLE OF TABLES}

Table 1 - Properties for Engineered Container and Settler Sludge ........................................... 2

Table 2 Well-Mixed and Stratified Settler Sludge Properties, Single $0.5 \mathrm{~m}^{3}$ Batch ................... 3

Table 3 Well-Mixed and Stratified KW Container Sludge Properties, $2 \times 0.8 \mathrm{~m}^{3}$ Batches .......... 4

Table 4 Sludge Interim Storage Cases Calculated............................................................ 9

Table 5 Transient Results Summary for KW Floor Sludge Shipping in an STSC .................... 10

\section{TABLE OF FIGURES}

Figure 1 FATE $^{\circledR}$ Model Representation for the STSC with Settler Sludge............................... 7

Figure 2 FATE ${ }^{\circledR}$ Model Representation for T Plant. ................................................................ 8 


\section{Introduction}

The Sludge Treatment Project (STP) is responsible for the disposition of sludge contained in the six engineered containers and Settler tank within the 105-K West (KW) Basin. The STP is retrieving and transferring sludge from the Settler tank into engineered container SCS-CON-230. Then, the STP will retrieve and transfer sludge from the six engineered containers in the KW Basin directly into a Sludge Transport and Storage Containers (STSC) contained in a Sludge Transport System (STS) cask. The STSC / STS cask will be transported to T Plant for interim storage of the STSC. The STS cask will be loaded with an empty STSC and returned to the KW Basin for loading of additional sludge for transportation and interim storage at $\mathrm{T}$ Plant.

CH2MHILL Plateau Remediation Company (CHPRC) contracted with Fauske \& Associates, LLC (FAI) to perform thermal and gas generation analyses for interim storage of STP sludge in the Sludge Transport and Storage Container (STSCs) at T Plant. The sludge types considered are settler sludge and sludge originating from the floor of the KW Basin and stored in containers 210 and 220, which are bounding compositions. The conditions specified by CHPRC for analysis are provided in Section 5. The FAI report (FAV/10-83, Thermal and Gas Analyses for a Sludge Transport and Storage Container (STSC) at T Plant) (refer to Attachment 1) documents the analyses. The process considered was passive, interim storage of sludge in various cells at $T$ Plant. The FATE ${ }^{\mathrm{TM}}$ code is used for the calculation. The results are shown in terms of the peak sludge temperature and hydrogen concentrations in the STSC and the T Plant cell. In particular, the concerns addressed were the thermal stability of the sludge and the potential for flammable gas mixtures.

This work was performed with preliminary design information and a preliminary software configuration.

\section{Background}

The STP will retrieve and transfer sludge from the six engineered containers directly into STSCs contained within the STS cask. The STS Cask is designed to stay on the transport trailer. The transport trailer is positioned in the modified annex building at the 105-KWest Basin building. A batch of retrieved sludge is allowed to settle within a STSC to concentrate the solids and clarify the supernatant. After a prescribed solids settling period, the supernatant is decanted and transferred through a sand filter to remove suspended sludge particles. The filtered supernatant is returned to the 105-K West Basin. Subsequent batches of sludge are added to the STSC, settled, and excess supernatant removed in the same manner as previously described until the prescribed quantity of sludge is collected in a STSC. The solids collected on the sand filter are fluidized and flushed directly in the STSC. The STSC and the STS cask are purged with argon gas and configured for transportation to T Plant. At T Plant the STSC is vented / purged, removed from the STS cask and placed in a cell for interim storage.

Three types of sludge will be placed separately in the STSC; 1) K East (KE) Engineered Container sludge, 2) K West (KW) Engineered Container sludge, and 3) Settler Tank sludge. KE Engineered Container sludge originated from vacuuming sludge from the floor of the 105-KE Basin and some fuel canister sludge into engineered containers within the 105-KE Basin. This sludge was then transferred into three engineered containers (SCS-CON-240, -250, -260) within the 105-KW Basin. KW Engineered Container sludge originated from vacuuming sludge from the floor of the $105-\mathrm{KW}$ Basin and some $\mathrm{KE}$ and $\mathrm{KW}$ fuel canister sludge into two engineered containers (SCS-CON-210 and -220) within the 105-KW Basin. Settler tank sludge is the less 
than $600-\mu \mathrm{m}$ fraction of sludge that originated from washing uranium metal fuel in the $105-\mathrm{KW}$ Basin, which is being transferred into engineered container SCS-CON-230. Characteristics of these three sludge types are provided in Tables 1 (from HNF-41051, revision 5 Preliminary STP Container and Settler Sludge Process System Description and Material Balance).

For the T Plant storage of STSCs, two sludge types and STSC geometries are considered. Settler sludge is stored in an STSC with an insert so that the sludge is in an annular configuration; KE Engineered Container or KW Engineered Container sludge are stored in an STSC without the insert. The STSC used for Settler tank sludge is designed as an ASME Section VIII pressure vessel with a centrally located inner cylinder. The STSC has $2: 1$ radius elliptical top and bottom heads. The inner diameter of the STSC is $\sim 1.5 \mathrm{~m}(58.5 \pm 0.5$-inches). The height of the STSC is $\sim 2.61 \mathrm{~m}$ (102.75-inches) from the bottom to the top of the elliptical heads. The outer radius of the cylinder inside the STSC is $\sim 0.3 \mathrm{~m}$ (12-inches). The annulus width inside the STSC is $\sim 0.43 \mathrm{~m}$ (17-inches). The volume of the annulus is $\sim 2.89 \mathrm{~m}^{3}$ however the STSC is only filled with $2.7 \mathrm{~m}^{3}$ of sludge slurry and $0.19 \mathrm{~m}^{3}$ of water used to flush the sludge transfer pipeline. The inner cylinder extends from 2-inches above the bottom of the STSC to the bottom of the top elliptical head. This inner cylinder is sealed at the bottom and opens at the top inside the STSC. The annulus space contains sludge whereas the inner cylinder is filled with water. The water contained inside the inner cylinder provides a heat transfer mechanism for heat generated from radiolytic decay and uranium metal reaction with water.

The volumes of each sludge type are determined based upon transient analyses of on-site transportation (HNF-41051). The STSC used for KE or KW Engineered Container sludge is the same design as the STSC used for Settler tank sludge, except there is no inner cylinder and the STSC capacity is $\sim 3.5 \mathrm{~m}^{3}$. The STSC is filled with $3.31 \mathrm{~m}^{3}$ of sludge slurry and $0.19 \mathrm{~m}^{3}$ of water used to flush the sludge transfer pipeline. Safety-basis sludge properties from HNF-41051 are used in this analysis are given in Table 1.

Table 1 - Properties for Engineered Container and Settler Sludge

\begin{tabular}{|c|c|c|c|c|c|c|c|}
\hline \multirow[t]{2}{*}{ Property } & \multicolumn{2}{|c|}{$\begin{array}{c}\text { KE Originating } \\
\text { Containers } 240,250, \\
260\end{array}$} & \multicolumn{2}{|c|}{$\begin{array}{c}\text { KW Originating } \\
\text { Containers } 210 \text { and } \\
220\end{array}$} & \multicolumn{2}{|c|}{$\begin{array}{c}\text { Settler* } \\
\text { Container } 230\end{array}$} & \multirow[t]{2}{*}{ Units } \\
\hline & Design & Safety & Design & Safety & Design & Safety & \\
\hline As Settled Density & 1.4 & 1.6 & 1.6 & 1.8 & 2.45 & 3.25 & $\mathrm{gm} / \mathrm{cm}^{3}$ \\
\hline $\begin{array}{l}\text { Percent Water in } \\
\text { Sludge }\end{array}$ & $75 \%$ & $75 \%$ & $74 \%$ & $74 \%$ & $70 \%$ & $70 \%$ & $\begin{array}{c}\text { Volume } \\
\%\end{array}$ \\
\hline Total Uranium & 0.11 & 0.38 & 0.28 & 0.59 & 1.34 & 2.1 & $\mathrm{~g} \mathrm{U} / \mathrm{cm}^{3}$ \\
\hline $\begin{array}{l}\text { Uranium Metal } \\
\text { Fraction in Settled } \\
\text { Sludge - Non- } \\
\text { Segregated }\end{array}$ & 0.006 & 0.030 & 0.030 & 0.082 & 0.052 & 0.163 & $\mathrm{~g} / \mathrm{cm}^{3}$ \\
\hline Decay Heat & 4.4 & 26 & 14 & 52 & 54.5 & 167 & $\mathrm{~W} / \mathrm{m}^{3}$ \\
\hline $\begin{array}{c}\text { Fissile Grams } \\
\text { Equivalent (FGE) }\end{array}$ & $7.02 \mathrm{E}+02$ & $3.48 \mathrm{E}+03$ & $1.56 \mathrm{E}+03$ & $7.28 \mathrm{E}+03$ & $7.34 \mathrm{E}+03$ & $2.96 \mathrm{E}+04$ & $\mathrm{FGE} / \mathrm{m}^{3}$ \\
\hline \multicolumn{8}{|c|}{ Sludge Expansion Factors } \\
\hline $\begin{array}{l}\text { Uranium Metal } \\
\text { Corrosion }\end{array}$ & 1.02 & 1.08 & 1.25 & 1.35 & 1.61 & 1.87 & unitless \\
\hline Gas Retention & 1.41 & 1.54 & 1.41 & 1.58 & 1.41 & 1.63 & unitless \\
\hline Combined & 1.43 & 1.66 & 1.76 & 2.13 & 2.26 & 3.04 & unitless \\
\hline
\end{tabular}


During filling of either STSC design, sludge slurry is received into the STSC and is settled by gravity. Excess water is removed by decantation from above the settled sludge and filtered to remove entrained solids. Subsequent batches of sludge are added to the STSC, settled and excess water decanted until the maximum volume of settled sludge in the STSC is obtained. The maximum volume of settled sludge in the STSC is determined from the thermal and gas analyses. Also, the effect of sludge segregation into multiple metal-rich and metal free layers during loading is considered. Stratification of sludge into uranium metal-enriched and metal-free layers may occur during batch sludge loading. Composition of stratified settler sludge is summarized in Table 2 and the composition of the KW Engineered Container sludge is summarized in Table 3.

Passive storage at T Plant may take place in either a standard cell (from the cell number 3R thru 20R) or in a long cell (cell 2R). Six STSCs are placed in a standard cell, and eight STSCs are placed in the long cell. One STSC is modeled in detail for its transient response. The effect of other STSCs that may be present in the cell is approximated by adding heat and hydrogen sources to the cell. See Section 3.0 of the attachment for more details on STSC and T Plant design.

The process cell is assumed to be ventilated at the average low ventilation rate, and the canyon temperature is assumed to be at its highest prescribed value. In alternate scenarios, cell response with loss of ventilation is examined. Overall, scenarios are defined for the various combinations of sludge types and STSC geometries, cell types, and ventilation type. See Section 6.0 of the attachment for a discussion of scenario definitions, and see Section 7.0 of the attachment for a detailed presentation of results.

Table 2 Well-Mixed and Stratified Settler Sludge Properties, Single $0.5 \mathrm{~m}^{3}$ Batch

\begin{tabular}{|l|c|c|c|}
\hline \multirow{2}{*}{ Property $^{(1,2,3)}$} & \multirow{2}{*}{ Well-Mixed } & \multicolumn{2}{|c|}{ Stratified (Layered) } \\
\cline { 2 - 4 } & & Metal Rich & Metal-Free \\
\hline Density, g/cc & 3.250 & 3.822 & 2.954 \\
\hline U metal concentration, g/cc & 0.1625 & 0.477 & 0.0 \\
\hline Total U concentration, g/cc & 2.050 & 2.695 & 1.716 \\
\hline Water volume fraction & 0.70 & 0.70 & 0.70 \\
\hline $\begin{array}{l}\text { Particle density, g/cc } \\
\text { (derived) }\end{array}$ & 8.500 & 10.409 & 7.513 \\
\hline $\begin{array}{l}\text { Fraction of sludge volume (layer } \\
\text { height) }\end{array}$ & $100 \%$ & $34 \%$ & $66 \%$ \\
\hline Metal mass fraction & 0.06373 & 0.15274 & 0.0 \\
\hline Oxide mass fraction & 0.84594 & 0.81195 & 0.87027 \\
\hline Non-uranium mass fraction & 0.09034 & 0.03531 & 0.12973 \\
\hline
\end{tabular}


The FATE ${ }^{\mathrm{TM}}$ sludge model considers pertinent phenomena at an appropriate level of detail (see Section 5 of the attachment). Notable model features include the correlation for the rate of uranium metal oxidation, the shrinking-core model for metal oxidation, local water evaporation into evolved hydrogen gas bubbles, representation of sludge properties consistent with the SNF databook, radiolysis, and mass and energy balances.

Heat sinks have idealized external boundary conditions. In most cases, the "inside" boundary condition is convection to the cell or other region atmosphere, while the "outside" boundary condition is insulated. This is valid for concrete for a time scale of about a day but not for several weeks, but the effect of a variation in external temperature is considered to be second-order with regard to its impact on cell temperature

The STSC and its contents are azimuthally symmetric, so that two-dimensional discretization in the axial and radial dimensions provides a sufficient description for the evolution of composition and temperature within the sludge and STSC structure.

While the temperature distribution in the sludge and STSC structure is distributed, the overlying water pool and gas spaces are well-mixed.

The STSC has two open, unfiltered vents open to the T Plant cell configured to provide a stack height to induce natural circulation. The inlet vent diameter is 2 inches $(0.0508 \mathrm{~m})$, and the outlet vent diameter is 4 inches $(0.1016 \mathrm{~m})$ with a stack height (elevation difference between the tops of the outlet and inlet) of 2 feet $(0.6096 \mathrm{~m})$.

Holes in the support skirt are sufficiently large and numerous to permit effective natural circulation heat transfer from the elliptical bottom head to gas inside the skirt and eventual convective exchange of gases inside and outside the skirt.

Key assumptions regarding sludge properties are:

Sludge is loaded in batches as described in the scenario descriptions. Within each batch, the sludge material is assumed to separate (or segregate) into a lower layer containing all the metallic uranium of the batch, and an upper layer that is metal-free. The composition of each layer is given by a model described in PRC-STP-00162 (Settler sludge) and PRCSTP-00220 (KW Engineered Container sludge).

Safety basis sludge properties define the batch properties.

Key assumptions regarding $\mathrm{T}$ Plant modeling are:

One STSC is modeled in detail for transient behavior, while the others are represented by average heat and hydrogen generation rates. The detailed STSC is referred to as the "active STSC". The validity of this assumption depends upon many factors including the arrival time of the previous STSCs, the prevailing cell temperature history, and the values chosen to represent the remaining STSCs.

Four other standard process cells containing STSCs are considered, and average heat sources are used for these cells. Considering these cells leads to a slight (around 10\%) reduction in circulation flow through the standard cell modeled in detail. Including these cells has no impact on cases considering cell $2 \mathrm{R}$ in detail since cell $2 \mathrm{R}$ is ventilated via a separate external earthen ware pipe to the ventilation duct while the standard cells each are directly connected to the ventilation duct. 
Worst case cover block gaps are assumed in the process cells and nominally worst case cover block gaps are assumed for the pipe trench, in order to minimize natural circulation flows with no ventilation. With ventilation, the choice of resistances is moot because the cell purge rate is sufficiently high as borne out by results.

Standard cells can have a natural circulation flow pattern involving the pipe trench, ventilation duct (i.e. air tunnel), and canyon, which is independent of the natural circulation flow pattern involving long cells (e.g. cell 2R) connected by the 24" external ventilation pipe.

The effect of the $T$ Plant stack is not considered for cases without ventilation. Diurnal temperature variations in the ambient are considered.

\section{FATE $^{\mathrm{TM}}$ Description and Validity}

The FATE ${ }^{\mathrm{TM}}$ computer program is used for this work (SNF-23281, 2004, Description of the Fauske \& Associates FATE 2.0 Computer Model) (the TM symbol will be dropped for simplicity). Some changes have been made to the baseline sludge model from these references, and they will be documented under Quality Assurance in follow-on work (see Section 5.3 of the attachment). FATE version 2.061 is used for this work.

The FATE sludge model was developed by FAI for the Hanford Spent Nuclear Fuel Program and the $\mathrm{K}$ Basins Closure Project under the FAI QA program. FATE has been used for K Basins sludge applications including scoping calculations, normal and off-normal behavior, and accidents including pump station spills and spray leaks at CVD.

Briefly, FATE can model heat transfer, fluid flow, and chemical reactions in sludge, its containers, a cask if present, a building or facility containing them, and the environment. Decay power, oxidation power, and conversion of metal to oxide with decrease of reactive surface area are included. Heat conduction in sludge and its container is allowed in one or more dimensions, according to the problem; natural convection occurs in overlying water or air. Pressure, temperature, gas composition, and exchange flows are considered in control volumes that typically consist of the container headspace and surrounding compartments.

The scope of calculations considered here is within the scope of model testing and previous applications, and does not involve untested model capabilities.

Figure 1 shows the FATE model for the STSC and sludge for the cases of settler sludge. Twodimensional axisymmetric heat conduction in sludge is modeled using 20 stacks of short disk heat conductors connected vertically for conduction, 10 in the cylindrical part and 10 in the bottom head of STSC. Each heat conductor has 20 radial nodes. Hence, each heat conductor node is approximately $3.7 \mathrm{~cm}$ in radial extent and $7.0 \mathrm{~cm}$ in height. Attachment A provides the corresponding list of regions, junctions, and heat sinks. Corresponding to each sludge heat conductor layer, the STSC wall is modeled as separate heat conductors. Heat generated in the sludge is conducted radially out to the STSC wall, where it is lost by convection and radiation to the cell atmosphere. Heat is also conducted vertically upward to the sludge top, where it is removed by overlying water. Figure 2 shows the FATE model representation for T Plant. 
PRC-STP-00241, Rev 0

Figure 1 FATE ${ }^{\circledR}$ Model Representation for the STSC with Settler Sludge.

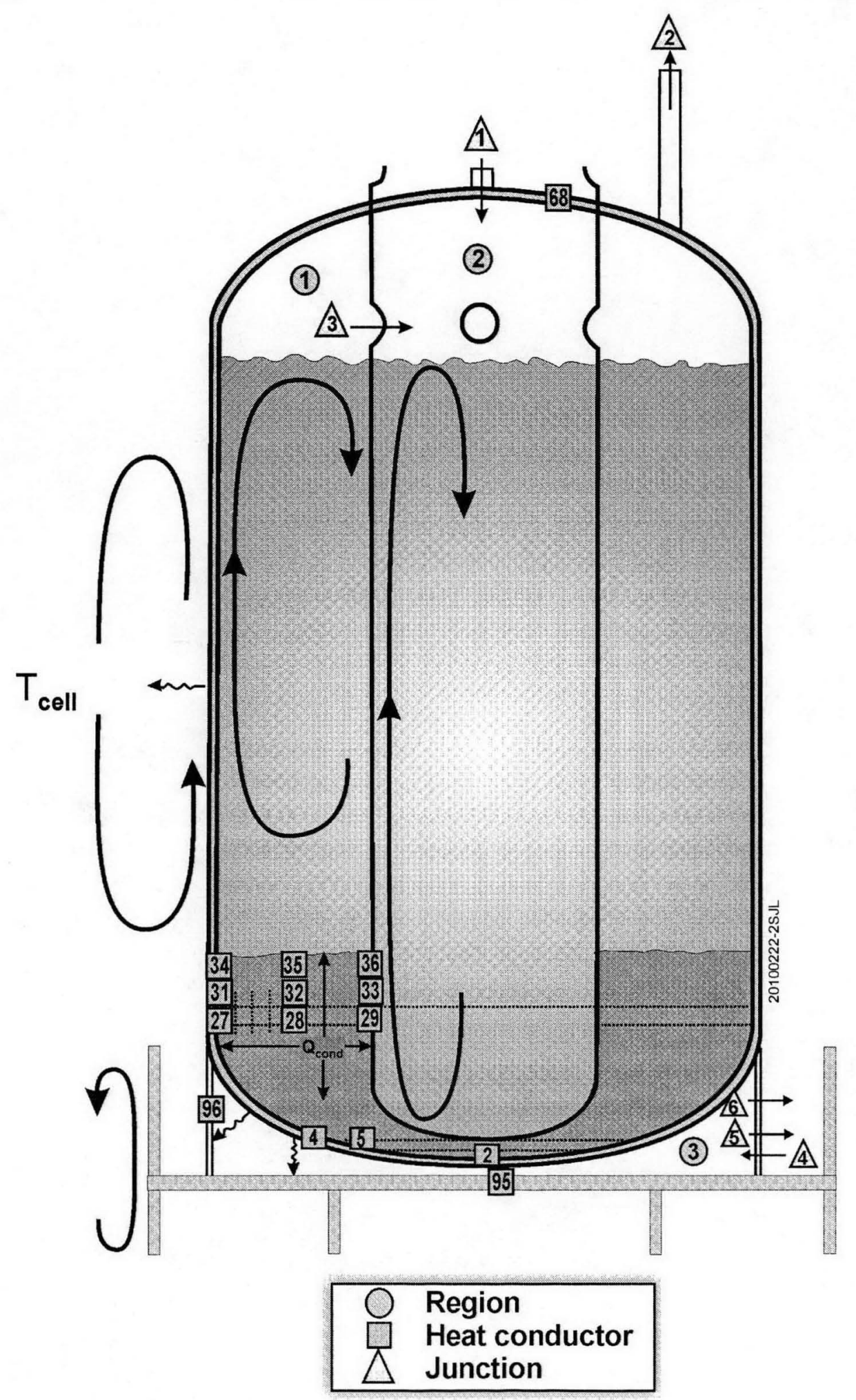


Figure 2 FATE ${ }^{\circledR}$ Model Representation for T Plant.

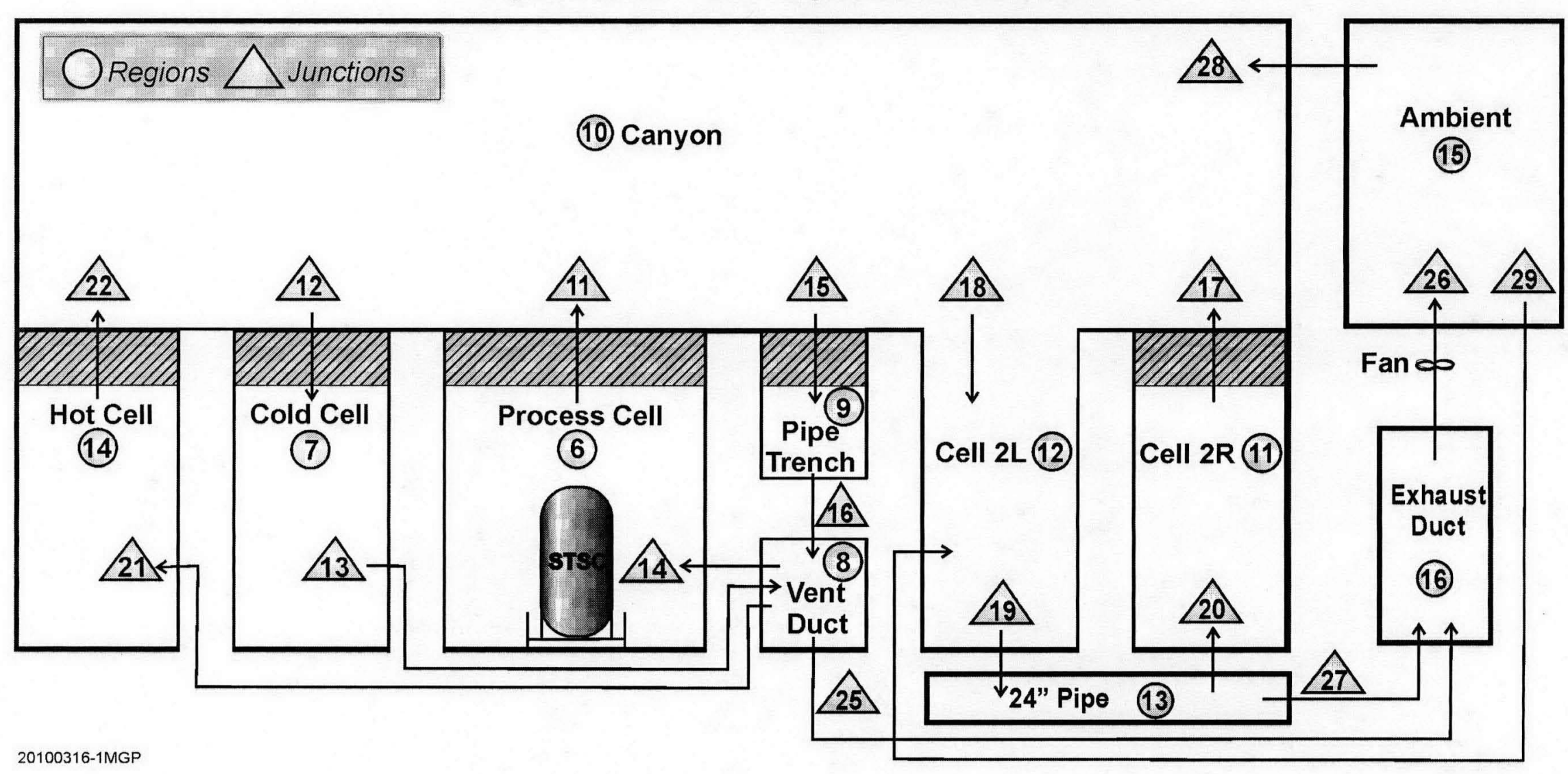




\section{Conditions for Thermal and Gas Analyses}

CHPRC specified eight cases for thermal and gas analysis by FAI, as listed in Table 4 . There are three main attributes distinguishing the cases:

Sludge type, volume, and STSC geometry. For settler sludge the volume is always $0.5 \mathrm{~m}^{3}$ and the STSC geometry includes the insert. For KW container sludge the volume is always $1.6 \mathrm{~m}^{3}$ and the STSC does not have an insert.

Cell containing the STSC. The STSC is placed in either a standard cell or else in cell long. There are always 6 STSCs in a standard cell and 8 STSCs in a long cell

T Plant Ventilation. Cases with and without T Plant ventilation are considered. With ventilation, the ventilation rate per cell is determined by the relative flow resistances as discussed in Attachment A.

Table 4 Sludge Interim Storage Cases Calculated.

\begin{tabular}{|c|c|c|c|c|c|c|}
\hline Case & $\begin{array}{c}\text { Name and } \\
\text { Input Files }\end{array}$ & Sludge Type & $\begin{array}{c}\text { Sludge } \\
\text { Volume }\end{array}$ & $\begin{array}{c}\text { STSC } \\
\text { Geometry }\end{array}$ & Ventilation & Cell Type \\
\hline $1 \mathrm{a}$ & CONTRF1 & $\mathrm{KW}$ floor & $1.6 \mathrm{~m}^{3}$ & No insert & Yes & Standard \\
\hline $1 \mathrm{~b}$ & CONTLF1 & $\mathrm{KW}$ floor & $1.6 \mathrm{~m}^{3}$ & No insert & Yes & $2 \mathrm{R}$ \\
\hline $2 \mathrm{a}$ & CONTRN1 & $\mathrm{KW}$ floor & $1.6 \mathrm{~m}^{3}$ & No insert & No & Standard \\
\hline $2 \mathrm{~b}$ & CONTLN1 & $\mathrm{KW}$ floor & $1.6 \mathrm{~m}^{3}$ & No insert & No & $2 \mathrm{R}$ \\
\hline $3 \mathrm{a}$ & SETTRF1 & Settler & $0.5 \mathrm{~m}^{3}$ & Insert & Yes & Standard \\
\hline $3 \mathrm{~b}$ & SETTLF1 & Settler & $0.5 \mathrm{~m}^{3}$ & Insert & Yes & $2 \mathrm{R}$ \\
\hline $4 \mathrm{a}$ & SETTRN1 & Settler & $0.5 \mathrm{~m}^{3}$ & Insert & No & Standard \\
\hline $4 \mathrm{~b}$ & SETTLN1 & Settler & $0.5 \mathrm{~m}^{3}$ & Insert & No & $2 \mathrm{R}$ \\
\hline
\end{tabular}

${ }^{(1)}$ Each case has two input files, a "case file" and a "base file" The case input file name is the same as the case name. The naming convention for cases and files is as follows:

Case name and case file. The case file defines case-specific boundary conditions including the cell geometry and sludge properties. The naming convention uses letter groupings as follows:

Initial 3 letters: CON for KW floor (containerized), SET for settler sludge, Letter 4: T for T Plant cell,

Letter 5, Cell type: $\mathrm{R}=$ regular, i.e. standard (cells 3 through 20 ), $\mathrm{L}=$ long (cell $2 \mathrm{R}$ ), and Letter 6, Ventilation type: $\mathrm{F}=\mathrm{T}$ Plant fans running, $\mathrm{N}=$ no fans.

Letter 7, Version number: 1

Base file. The base file contains defines the STSC geometry and the geometry of heat conductors representing the sludge. The base file for all $\mathrm{KW}$ floor sludge cases $(1 \mathrm{a}$ through $2 \mathrm{~b}$ ) is CON2STSC1.dat. The base file for all settler sludge cases ( $3 a$ through $4 \mathrm{~b}$ ) is SET1STSC1.dat.

${ }^{(2)}$ Sludge is stratified into metal-bearing (lower) and metal-free (upper) layers. In all $\mathrm{KW}$ floor sludge cases there are 2 pairs of layers corresponding to 2 batch loadings. In the settler sludge case there is one batch and one pair of layers. 
PRC-STP-00241, Rev 0

\section{Discussion of Results}

Calculation results are summarized in Table 5.

In all cases the transient duration simulated was 20 days. This duration is sufficient to allow maxima in sludge temperature, hydrogen generation rate, and STSC and cell hydrogen concentrations.

The cell hydrogen concentration is negligible in all cases with normal ventilation; without the ventilation fans, the peak cell hydrogen concentration reached $1.5 \%$. Correspondingly within the STSCs, with ventilation the STSC hydrogen concentration reached $1.6 \%$, and without ventilation it reached $3.3 \%$. In all cases the peak STSC hydrogen concentration was below the lean flammability limit of $4 \%$ hydrogen in dry air.

Table 5 Transient Results Summary for KW Floor Sludge Shipping in an STSC.

\begin{tabular}{|c|c|c|c|c|c|c|}
\hline Case & $\begin{array}{l}\text { Thermal } \\
\text { Stability }\end{array}$ & $\begin{array}{c}\text { Peak Sludge } \\
\text { Temperature } \\
{\left[{ }^{\circ} \mathrm{C}\right]}\end{array}$ & $\begin{array}{c}\text { Peak } \\
\text { Power } \\
{[W]}\end{array}$ & $\begin{array}{c}\text { Peak } \mathrm{H}_{2} \\
\text { Rate } \\
\text { [liter/day] }\end{array}$ & $\begin{array}{c}\text { Peak } \mathrm{H}_{2} \\
\text { Concentration } \\
\text { in Cell [\%] }\end{array}$ & $\begin{array}{c}\text { Peak } \mathrm{H}_{2} \\
\text { Concentration } \\
\text { in STSC [\%] }\end{array}$ \\
\hline $1 \mathrm{a}$ & Stable & $60^{\circ} \mathrm{C}$ at $16 \mathrm{~d}$ & 195 & 830 & $<0.1$ & 1.6 \\
\hline $1 b$ & Stable & $58^{\circ} \mathrm{C}$ at $16 \mathrm{~d}$ & 190 & 770 & $<0.1$ & 1.5 \\
\hline $2 a$ & Stable & $72^{\circ} \mathrm{C}$ at $15 \mathrm{~d}$ & 270 & 1300 & $\begin{array}{c}1.0 \\
\text { No ventilation }\end{array}$ & $\begin{array}{c}3.3 \\
\text { No ventilation }\end{array}$ \\
\hline $2 b$ & Stable & $67^{\circ} \mathrm{C}$ at $16 \mathrm{~d}$ & 210 & 1150 & $\begin{array}{c}1.5 \\
\text { No ventilation }\end{array}$ & $\begin{array}{c}3.1 \\
\text { No ventilation }\end{array}$ \\
\hline $3 a$ & Stable & $53^{\circ} \mathrm{C}$ at $8 \mathrm{~d}$ & 190 & 670 & $<0.1$ & 1.3 \\
\hline $3 b$ & Stable & $52^{\circ} \mathrm{C}$ at $8 \mathrm{~d}$ & 190 & 640 & $<0.1$ & 1.4 \\
\hline $4 a$ & Stable & $61^{\circ} \mathrm{C}$ at $9 \mathrm{~d}$ & 230 & 960 & $\begin{array}{c}1.0 \\
\text { No ventilation }\end{array}$ & $\begin{array}{c}2.8 \\
\text { No ventilation }\end{array}$ \\
\hline $4 b$ & Stable & $57^{\circ} \mathrm{C}$ at $10 \mathrm{~d}$ & 210 & 830 & $\begin{array}{c}1.5 \\
\text { No ventilation }\end{array}$ & $\begin{array}{c}3.0 \\
\text { No ventilation }\end{array}$ \\
\hline
\end{tabular}

There is no significant impact between the choice of storage in a standard cell (cases designated with a "a") or a long cell (cases designated with a "b"). The present calculations have considered cells fully loaded with the maximum number of STSCs because this will lead to the worst boundary condition for thermal response. In cases without active ventilation the number of STSCs in a cell affects natural circulation, which affects cell and STSC hydrogen concentrations; other scenario definition factors such as the effect of time of year on canyon and cell temperatures can also influence hydrogen concentrations. 
Ventilation availability plays the largest role in STSC thermal response. T-Plant ventilation is capable of cooling STSCs and removing hydrogen from the cell atmosphere. Without ventilation, the STSCs heat up more, and natural circulation through cover blocks is required to remove it from the cell.

The character of the sludge - volume, number of batches loaded, and material composition plays the next most significant role in determining the thermal behavior of an STSC. The singlebatch loading of Settler sludge concentrates uranium metal in the lower head of the STSC where heat transfer is the lowest. This is a worst-case scenario since it is likely that it will require more than one batch transfer to load a STSC with Settler sludge. Note that it is not deemed credible to load the KW Engineered Container sludge as a single batch in a STSC. However, KW Engineered Container sludge was modeled as the next worst-case scenario as two batches loaded into a STSC which similarly concentrates the uranium metal in the lower head of the STSC.

Cell size has the least effect on STSC thermal stability. Larger cells have more heat transfer area to the T Plant's thick concrete walls which tends to remove more heat in cases without ventilation. The increased cell volume dilutes hydrogen released from the STSC, leading to a denser atmosphere than the standard cells in no ventilation cases. In the cases with ventilation, the heat load from the additional older STSCs tends to slightly increase the cell and sludge temperature.

The attachment provides the first calculation of the behavior of sludge stored in STSCs at T Plant to employ a detailed building model that considers standard cells in various states, the long cells, and the pipe trench, and allows for natural circulation between the canyon and groups of cells. . The flow split between cells with fans on and the circulation patterns and rates with fans off are affected by assumptions that underlie the flow resistance values input to the model. It should be recognized that cover block gap resistances are based upon old specifications and selected field measurements of gaps at deck level. Actual flow and pressure balance conditions used at T Plant during contemporary operation may differ from what is documented in earlier references.

The circulation patterns and hydrogen concentrations with fans off are also affected by the assumed number of STSCs in a given cell and the number of cells containing STSCs, because these affect cell gas densities via their heat and hydrogen sources. It is also possible that the initial cell conditions, reflecting time of year and the thermal lag between the ambient, canyon, and cells, could influence the flow pattern for fans-off cases. The assumptions built into the T Plant model and fans-off scenarios require further review to ensure that conservative selections have been made.

\section{Conclusions}

Conclusions of from the discussion of results are:

- Sludge is thermally stable in all cases considered.

- The cell and STSC hydrogen concentrations never exceed $4 \%$ for all cases.

- The most important effect on results is ventilation versus no ventilation.

- Results are nearly identical for standard cell and long cell cases; this is the least significant effect.

- The worst cases examined are for KW Engineered Container sludge with no ventilation, cases $2 \mathrm{a}$ and $2 \mathrm{~b}, \mathrm{CONTRN} 1$ and CONTLN1. For CONTRN1 the peak hydrogen 
PRC-STP-00241, Rev 0

concentration is $1.0 \%$ in the cell and $3.3 \%$ inside the STSC, and the peak sludge temperature is $72^{\circ} \mathrm{C}$ which occurs at day 15 of the scenario. The cell hydrogen concentration is slightly higher for CONTLN1, about $1.5 \%$.

- T Plant flow conditions, flow resistances, and assumptions for fans-off scenarios should be reviewed to ensure that the contemporaneous configuration is correctly represented and that conservative scenarios have been identified with the updated version of FATE.

\section{References}

HNF-41051, revision 5, 2009, Preliminary STP Container and Settler Sludge Process System Description and Material Balance, CH2MHILL Plateau Remediation Company, Richland, Washington

IINF-SD-SNF-TI-0 15, revision 14A, 2009, Spent Nuclear Fuel Project Technical Databook, Vol. 2, Sludge, CH2MHILL Plateau Remediation Company, Richland, Washington

SNF-23281, 2004, Description of the Fauske \& Associates FATE 2.0 Computer Model, Fluor Hanford, Inc., Richland, Washington

STP-PRC-00162, 2009, Thermal and Gas Analyses for STSC Loaded with Settler Sludge, CH2MHILL Plateau Remediation Company, Richland, Washington 


\title{
PRC-STP-00241, Rev 0
}

\section{Attachment}

\section{FAI /10-83, Thermal and Gas Analyses for KW Engineered Container Sludge in the STSC / STS Cask}

\author{
Fauske \& Associates, LLC
}


PRC-STP-00241, Rev 0

This Page is intentionally left blank 
PRC-STP-00241, Rev 0

WORLD LEADER IN NULLEAR AND CHEMICAL PROCESS SAFETY

\section{Report No.: FAI/10-83}

Thermal and Gas Analyses for a Sludge Transport and Storage Container (STSC) at T Plant Revision 0

Project No.: DESH-12A

Submitted to:

CH2M Hill Plateau Remediation Company

K Basins Closure Project

Richland, Washington

Prepared by:

Robert Apthorpe, Sung Jin Lee, and Martin G. Plys

March, 2010 
FAl/10-83

PRC-STP-00241, Rev 0

Rev. 0

\section{Authorship and Review Summary}

\begin{tabular}{|c|c|c|}
\hline Section & Author & Reviewer \\
\hline 1 & M. Plys & S.J. Lee \\
\hline 2 & M. Plys & R. Apthorpe \\
\hline 3 & M. Plys & R. Apthorpe \\
\hline 4 & M. Plys & S.J. Lee \\
\hline 5 & M. Plys & R. Apthorpe \\
\hline 6 & M. Plys & R. Apthorpe \\
\hline 7 & R. Apthorpe & S.J. Lee, M. Plys \\
\hline 8 & M. Plys & S.J. Lee \\
\hline App. A & S.J. Lee & R. Apthorpe, M. Plys \\
\hline App. B & R. Apthorpe & S.J. Lee \\
\hline App. C & Various - see sections & Not Applicable \\
\hline
\end{tabular}




\section{TABLE OF CONTENTS}

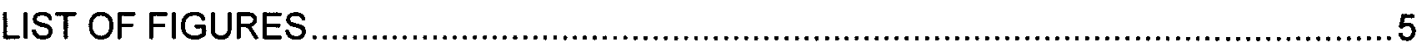

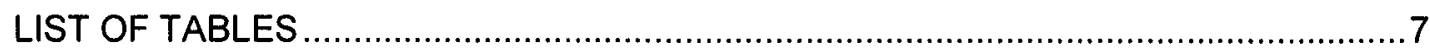

1.0 PURPOSE AND SCOPE 9

$\begin{array}{lll}2.0 & \text { SUMMARY OF RESULTS } & 10\end{array}$

3.0 REFERENCE STSC, SLUDGE, AND T PLANT DATA 11

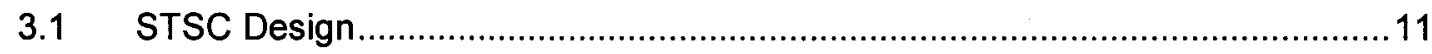

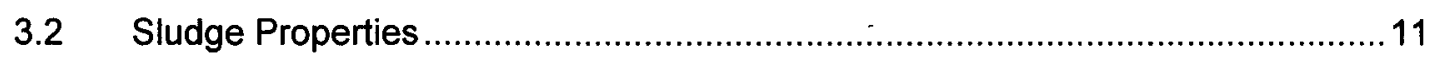

3.3 T Plant Cell Geometry and Conditions ...................................................... 17

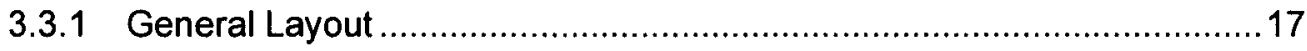

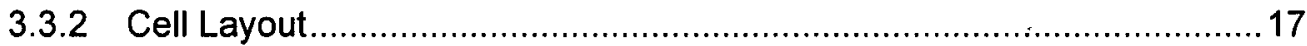

3.3.3 Ventilation Duct and Pipe Trench Layout ......................................... 18

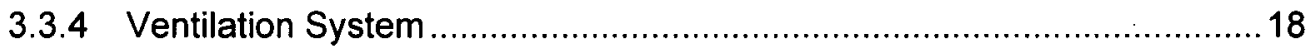

$\begin{array}{lll}4.0 & \text { ASSUMPTIONS } & 32\end{array}$

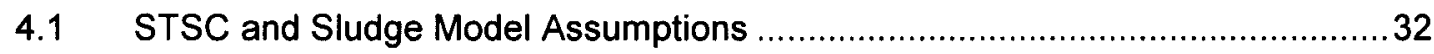

4.2 Sludge Property Assumptions ................................................................... 32

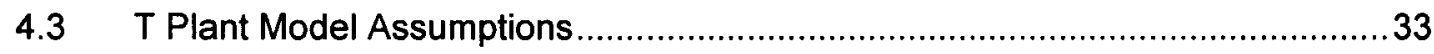

5.0 FATE ${ }^{T M}$ CODE DESCRIPTION, VALIDITY, AND APPLICATIONS 35

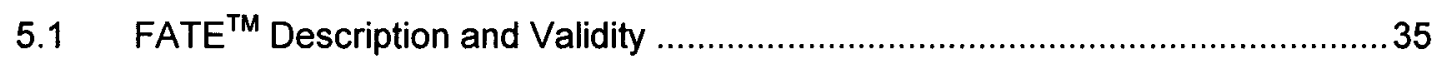

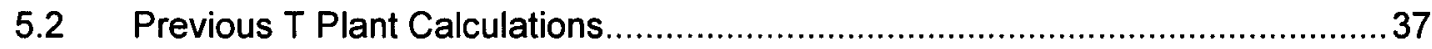

$5.3 \quad$ Validation of Selected FATE Model Improvements ..........................................37

$\begin{array}{lll}6.0 & \text { CALCULATION } & 39\end{array}$

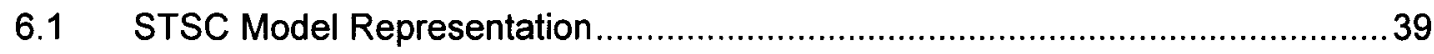

6.2 T Plant Model Representation .....................................................................4 44

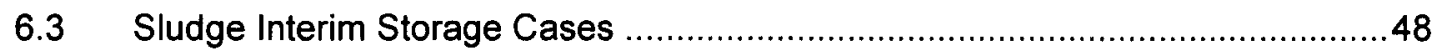

7.0 RESULTS AND CONCLUSIONS

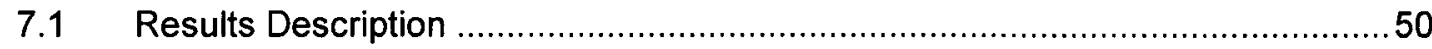

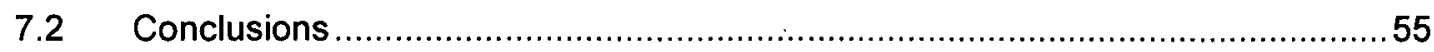

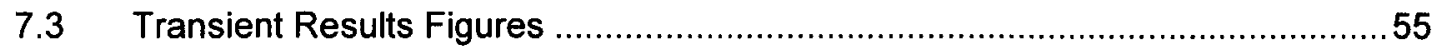

$\begin{array}{lll}\mathbf{8 . 0} & \text { REFERENCES } & 80\end{array}$

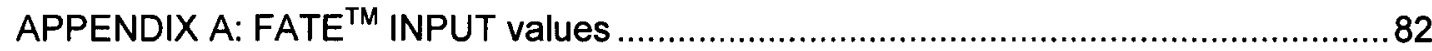




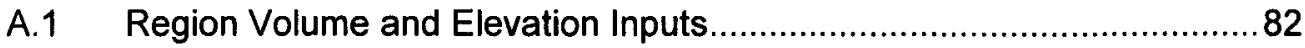

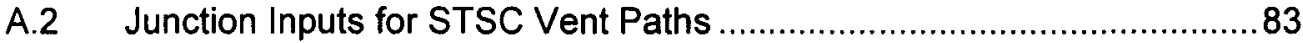

A.3 Junction Inputs for Cell Cover Blocks ................................................. 84

A.4 Heat Sink Inputs for Cell Heat Conductors .........................................88

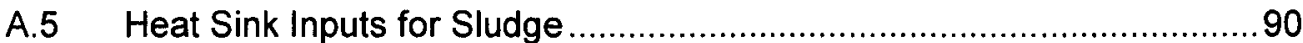

A.6 Heat and Hydrogen Sources ...........................................................93

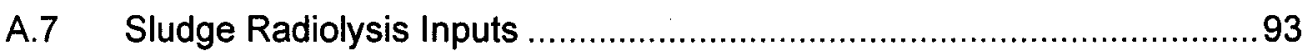

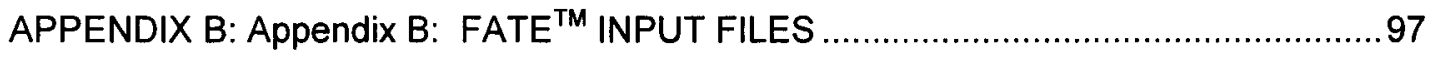

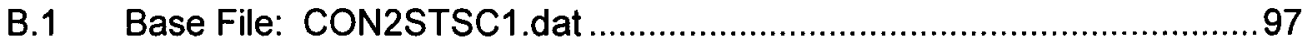

B.2 Base File: SET1STSC1.dat ............................................................111

B.3 Case File: CONTRF1.dat...........................................................126

B.4 Case File: CONTLF1 dat ..............................................................139

B.5 Case File: CONTRN1.dat .......................................................... 154

B.6 Case File: CONTLN1.dat.............................................................167

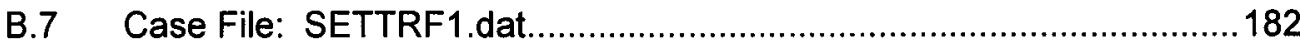

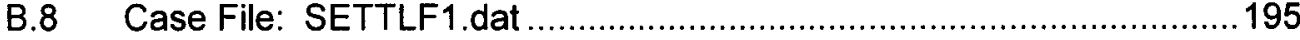

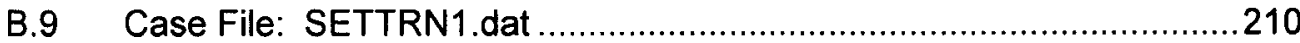

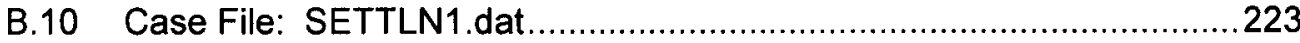

APPENDIX C: SELECTED FATE ${ }^{T M}$ MODEL IMPROVEMENT MEMOS .....................237

C.1 Buoyancy-Driven Flows in T Plant When the Ventilation System is Not Operating 238

C.2 FATE Ceiling Crack Flow Model and Testing ...................................250

C.3 T Plant Circulation Results Quick Look .............................................2258

C.4 Ventilation Holes in Skirt for STSC Container ................................263

C.5 FATE Natural Convection Heat Transfer Model Changes and Testing.271 
FAl $/ 10-83$

PRC-STP-00241, Rev 0

Rev. 0

Page 5 of 284

March, 2010

\section{LIST OF FIGURES}

Figure 3-1: STSC - Annular Design. 12

Figure 3-2: Simplified STSC without Insert 13

Figure 3-3: STSC Support Skirt. 14

Figure 3-4: T Plant Cutaway 20

Figure 3-5: T Plant Layout .21

Figure 3-6: Typical Cell Longitudinal Section. 22

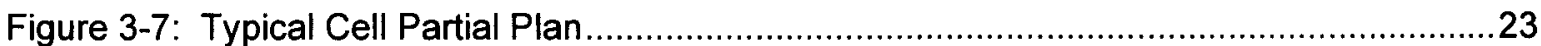

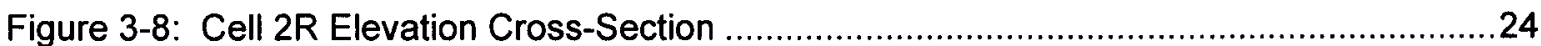

Figure 3-9: Cell 2L (left) and 2R (right) Longitudinal Section ...........................................25

Figure 3-10: T Plant Cross-Section with STSC Receiving Equipment.................................26

Figure 3-11: T Plant Detail Cross-Section with STSC Equipment .....................................27

Figure 3-12: Typical Cell Plan with STSC Equipment.................................................28

Figure 3-13: Standard Cell Block Elevation View with Typical Labyrinth Gaps .......................29

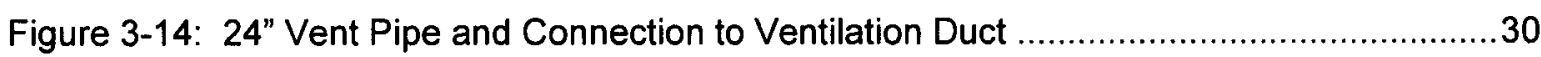

Figure 3-15: Pipe Trench Cover Block Plan and Elevation Views. .......................................31

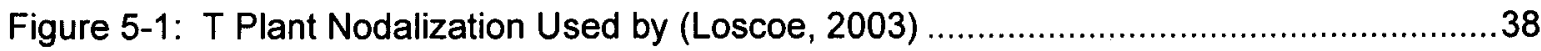

Figure 6-1: FATE Model Representation for the STSC with Settler Sludge. ...........................40

Figure 6-2: FATE Model Representation for the STSC with KW Container Sludge.................41

Figure 6-3: T Plant Model Representation, Regions and Junctions.....................................45

Figure 7-1: Peak Hydrogen Concentration in Cell ..........................................................52

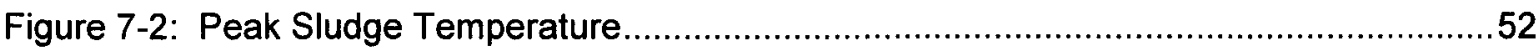

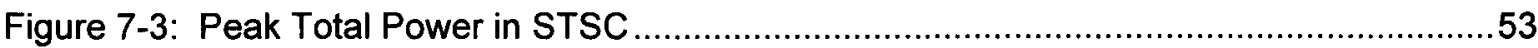

Figure 7-4: Case CONTRF1 Transient Results History (1 of 3) ........................................56 
FAl/10-83

PRC-STP-00241, Rev 0

Rev. 0

Page 6 of 284

March, 2010

Figure 7-5: Case CONTRF1 Transient Results History (2 of 3) .........................................57

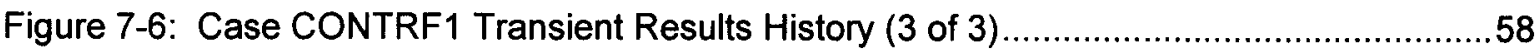

Figure 7-7: Case CONTLF1 Transient Results History (1 of 3) .........................................59

Figure 7-8: Case CONTLF1 Transient Results History (2 of 3) ............................................60

Figure 7-9: Case CONTLF1 Transient Results History (3 of 3) .......................................61

Figure 7-10: Case CONTRN1 Transient Results History (1 of 3) ......................................62

Figure 7-11: Case CONTRN1 Transient Results History (2 of 3) .........................................63

Figure 7-12: Case CONTRN1 Transient Results History (3 of 3) ......................................64

Figure 7-13: Case CONTLN1 Transient Results History (1 of 3) .........................................6

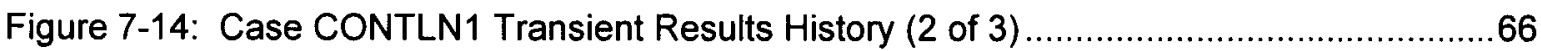

Figure 7-15: Case CONTLN1 Transient Results History (3 of 3) .......................................67

Figure 7-16: Case SETTRF1 Transient Results History (1 of 3) ..........................................68

Figure 7-17: Case SETTRF1 Transient Results History (2 of 3) ........................................69

Figure 7-18: Case SETTRF1 Transient Results History (3 of 3) ...........................................70

Figure 7-19: Case SETTLF1 Transient Results History (1 of 3 ) ...........................................71

Figure 7-20: Case SETTLF1 Transient Results History $(2$ of 3 ) ...........................................72

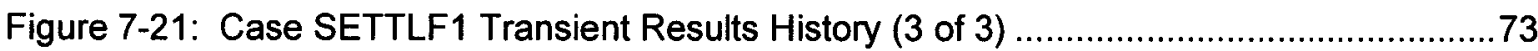

Figure 7-22: Case SETTRN1 Transient Results History (1 of 3 ) .........................................74

Figure 7-23: Case SETTRN1 Transient Results History (2 of 3) ........................................75

Figure 7-24: Case SETTRN1 Transient Results History (3 of 3) ........................................76

Figure 7-25: Case SETTLN1 Transient Results History (1 of 3) ...........................................77

Figure 7-26: Case SETTLN1 Transient Results History (2 of 3) .........................................78

Figure 7-27: Case SETTLN1 Transient Results History (3 of 3) .........................................79

Figure A-1: Worst Case Gap Widths for Cell 3L Cover Blocks. .............................................86 
FAl/10-83

PRC-STP-00241, Rev 0

Rev. 0

Page 7 of 284

March, 2010

\section{LIST OF TABLES}

Table 3-1: Well-Mixed and Stratified Settler Sludge Properties, Single $0.5 \mathrm{~m}^{3}$ Batch. 15

Table 3-2: Well-Mixed and Stratified KW Container Sludge Properties, $2 \times 0.8 \mathrm{~m}^{3}$ Batches .... 16

Table 3-3: T Plant Operating Conditions [Schmidt, 2009]...............................................19

Table 5-1: Summary of Pertinent FATE Reference Calculations...........................................36

Table 6-1: FATE STSC Nodalization for Settler Sludge ....................................................42

Table 6-2: FATE STSC Nodalization for KW Floor Sludge .................................................43

Table 6-3: FATE T Plant Nodalization, Regions and Junctions ........................................46

Table 6-4: FATE T Plant Nodalization, Heat Sinks .......................................................... 47

Table 6-5: Sludge Interim Storage Cases Calculated. .....................................................49

Table 7-1: Transient Results Summary for KW Floor Sludge Shipping in an STSC...............51

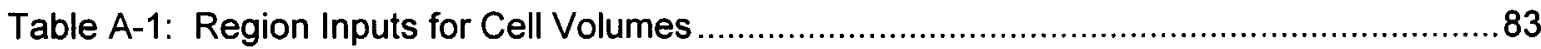

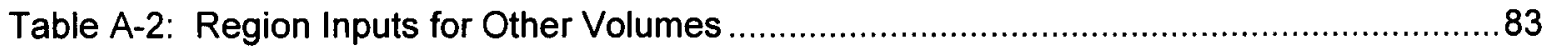

Table A-3: Junction Inputs for STSC Vent Paths to the Cell............................................ 84

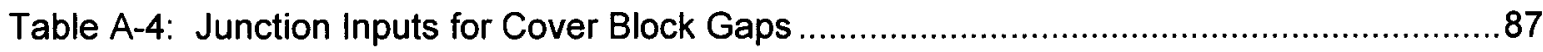

Table A-5: Heat Sink Inputs for Normal Cell Heat Conductors ............................................88

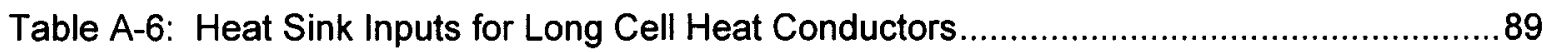

Table A-7: Sludge Node Dimensions in Elliptical Bottom Head ...........................................90

Table A-8: Heat and Hydrogen Generation of Typical STSCs........................................93

Table A-9: Fraction of Total Decay Energy, Reproduced from Michael E. Johnson, alpha beta and gamma decay fractions for sludge Rev 1.x/sx, February 23, 2010..............95

Table A-10: Sludge Properties of Closest Match to SNF-22059 Reference Types ..................95

Table A-11: Fraction of Energy Deposited to Water from SNF-22059..................................95

Table A-12: FATE Radiolysis Inputs - Fraction of Power Deposited to Water ........................96 
FAl/10-83

PRC-STP-00241, Rev 0

Page 8 of 284

Rev. 0

March, 2010

Table A-13: FATE Radiolysis Inputs - G Values 


\subsection{PURPOSE AND SCOPE}

The purpose of this report is to document transient thermal and gas generation analyses for interim storage of $\mathrm{KW}$ sludge in the Sludge Transport and Storage Container (STSC) at T Plant. The sludge types considered are settler sludge and sludge originating from the floor of the KW Basin and stored in containers 210 and 220 , which are bounding compositions.

The process considered here is passive, interim storage of sludge in various cells at $T$ Plant. The STSC design and T Plant geometry are described in Section 3 . The FATE ${ }^{\text {TM }}$ code is used for the calculation, as described in Section 5 along with a brief discussion of previous $T$ Plant interim storage calculations using FATE.

The results sought are the peak sludge temperature and hydrogen concentrations in the STSC and the T plant cell. In particular, we are concerned with thermal stability of the sludge and the potential for flammable gas mixtures. A list of key assumptions is given in Section 4 . Cases considered and the FATE model representations of the STSC and T Plant are described in Section 6, and results and conclusions are given in Section 7.

This work is performed with preliminary design information and a preliminary software configuration. 


\subsection{SUMMARY OF RESULTS}

This report presents transient calculations of temperatures, gas and heat generation, and gas compositions for passive storage of sludge in STSCs stored at T Plant. Two sludge types and STSC geometries are considered. Settler sludge is stored in an STSC with an insert so that the sludge is in an annular configuration, and KW container sludge is stored in an STSC without the insert. The volumes of each sludge type are determined based upon transient analyses of on-site transportation (Apthorpe, Lee, and Plys, 2010; Plys, Lee, and Apthorpe, 2009).

Safety-basis sludge properties from HNF-41051 are used in this analysis. Also, the effect of sludge segregation into multiple metal-rich and metal free layers during loading is considered. A list of key assumptions is given in Section 4.0.

Passive storage at $\mathrm{T}$ Plant may take place in either a standard cell from the cell number range 3 to 20, or in a long cell, cell 2R. Six STSCs are placed in a standard cell, and eight STSCs are placed in the long cell. One STSC is modeled in detail for its transient response. The effect of other STSCs that may be present in the cell is approximated by adding heat and hydrogen sources to the cell. See Section 3.0 for more details on STSC and T Plant design.

The process cell is assumed to be ventilated at the average low ventilation rate, and the canyon temperature is assumed to be at its highest prescribed value. In alternate scenarios, cell response with loss of ventilation is examined. Overall, scenarios are defined for the various combinations of sludge types and STSC geometries, cell types, and ventilation type. See Section 6.0 for a discussion of scenario definitions, and see Section 7.0 for a detailed presentation of results.

All configurations analyzed are thermally stable, with a peak sludge temperature of $72^{\circ} \mathrm{C}$ in the case of container sludge in a normal cell without ventilation. The remaining cases have peak sludge temperatures between $52^{\circ} \mathrm{C}$ and $61^{\circ} \mathrm{C}$.

The cell hydrogen concentration is negligible in all cases with normal ventilation; without the ventilation fans, the peak cell hydrogen concentration reached $1.5 \%$. Correspondingly within the STSCs, with ventilation the STSC hydrogen concentration reached $1.6 \%$, and without ventilation it reached $3.3 \%$. In all cases the peak STSC hydrogen concentration was below the lean flammability limit of $4 \%$ hydrogen in dry air.

There is no significant impact between the choice of storage in a standard cell or a long cell. The present calculations have considered cells fully loaded with the maximum number of STSCs because this will lead to the worst boundary condition for thermal response. In cases without active ventilation the number of STSCs in a cell affects natural circulation, which affects cell and STSC hydrogen concentrations; other scenario definition factors such as the effect of time of year on canyon and cell temperatures can also influence hydrogen concentrations. The impact of such factors has not been completely explored and demonstrated to be conservative. 


\subsection{REFERENCE STSC, SLUDGE, AND T PLANT DATA}

\section{$3.1 \quad$ STSC Design}

The design considered is an STSC, shown in Figure 3-1 (Johnson, 2009). Note that the diagram shows a central 24" insert. This insert is present for cases with settler sludge, but it is not present in cases with other container sludge. Figure 3-2 provides a simplified illustration of the STSC without the insert. The STSC body consists of elliptical lower and upper heads and a main cylindrical section. The support skirt welded to the lower head, Figure 3-3, features a series of holes allowing air circulation around the lower head.

\subsection{Sludge Properties}

$\mathrm{KW}$ settler sludge will be retrieved from engineered container 230 . Floor sludge is assumed to originate from engineered containers 210 and 220 which contain $\mathrm{KW}$ floor sludge. Sludge originating from the KE Basin is stored within the KW Basin in containers 240,250 , and 260. The compositions of the KW floor sludge in containers 210 and 220 and the Settler sludge in container 230 bound the composition of the KE sludge in containers 240,250, and 260 in terms of uranium metal content and total uranium. Therefore, using the $\mathrm{KW}$ sludge and Settler sludge in these analyses results in a conservative (i.e. higher) estimate of the hydrogen concentrations in the STSCs and in T Plant.

Stratification of sludge into uranium metal-enriched and metal-free layers may occur during batch sludge loading. Compositions of stratified settler sludge are summarized in Table 3-1, and compositions of KW floor sludge are summarized in Table 3-2. The basis for the settler sludge stratified layer compositions is given in Appendix A of (Plys and Johnson, 2009), and the basis for the KW floor sludge stratified layer compositions is given in Appendix A of (Plys et al, 2010). Note that there is a subtle difference in the definition of the uranium oxide stoichiometry between the two sludge types, reflecting differences in the extent of hydration of the oxide. 
FAl/10-83

PRC-STP-00241, Rev 0

Rev. 0

Figure 3-1: STSC - Annular Design.

Page 12 of 284

March, 2010

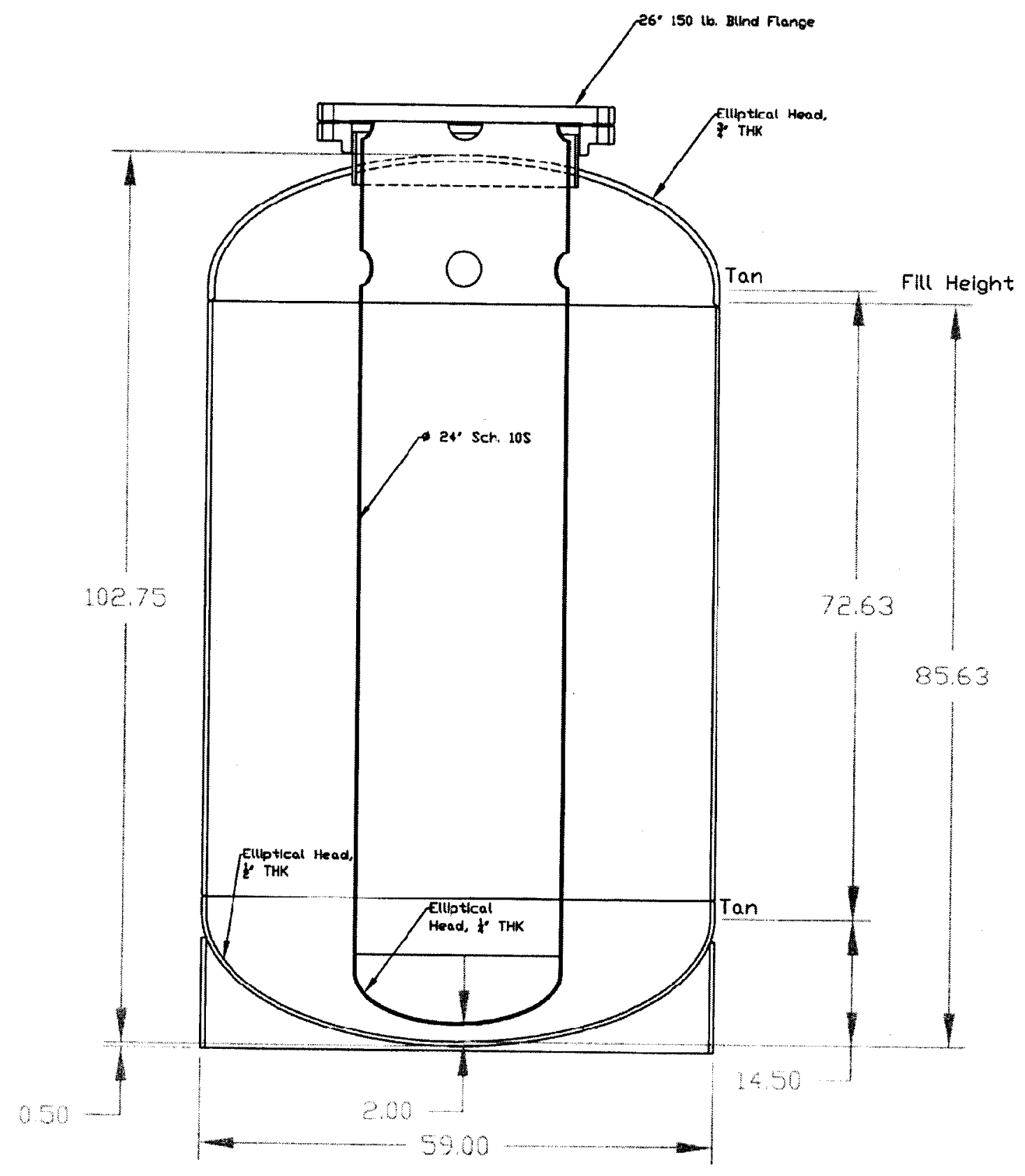


FAl/10-83

PRC-STP-00241, Rev 0

Rev. 0

Figure 3-2: Simplified STSC without Insert

Page 13 of 284

March, 2010

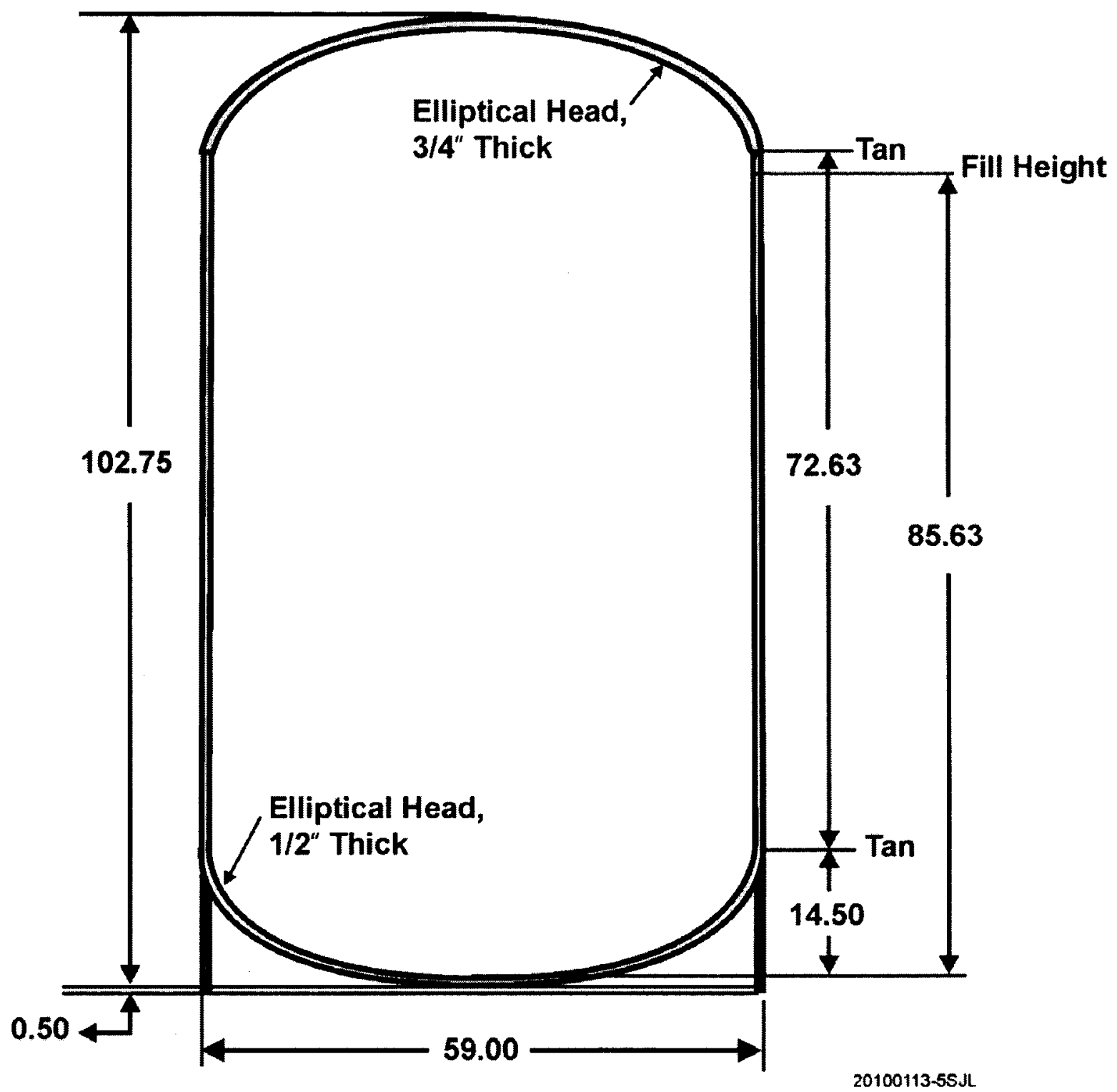


FAl/10-83

PRC-STP-00241, Rev 0

Rev. 0

Page 14 of 284

March, 2010

Figure 3-3: STSC Support Skirt.

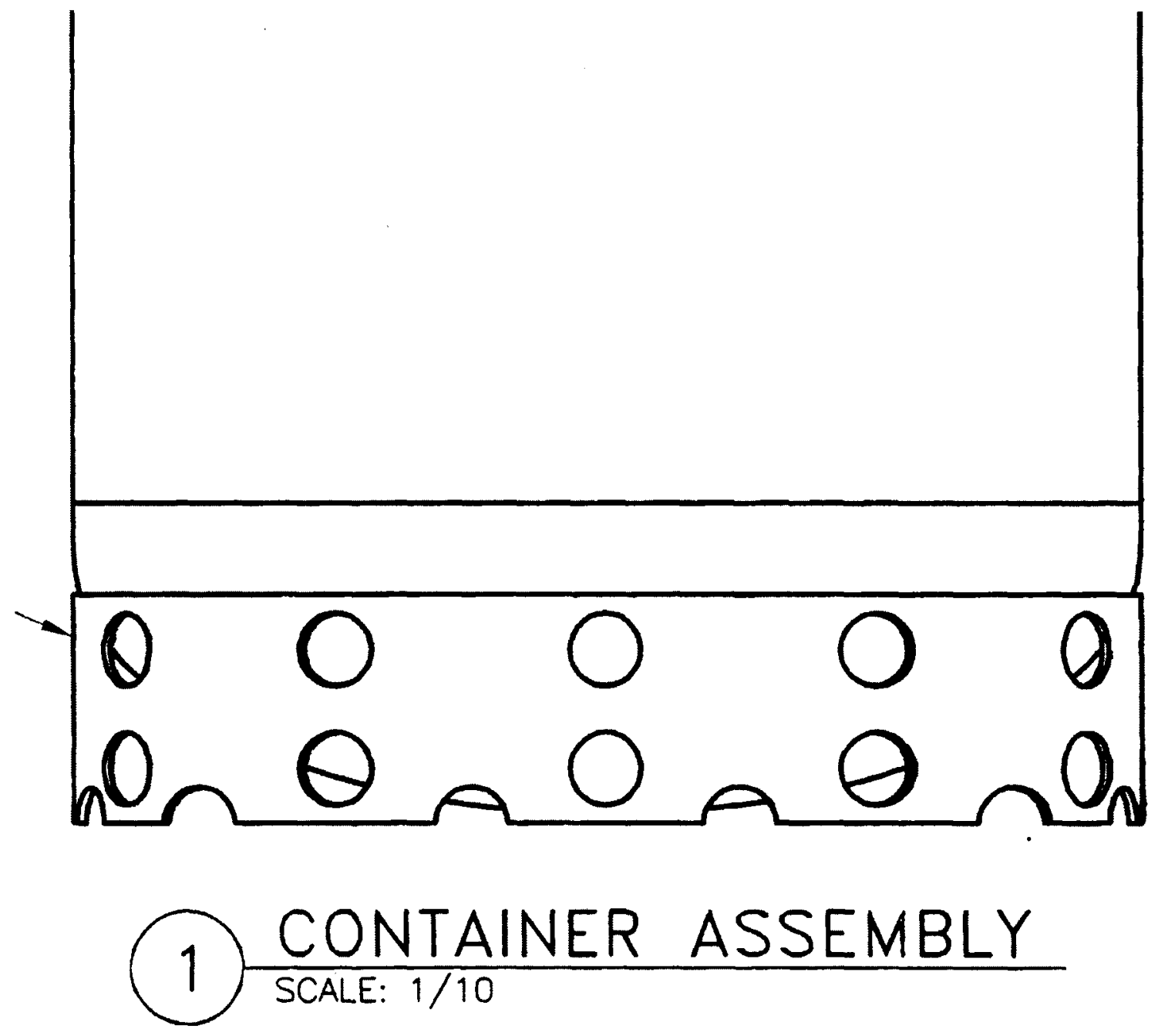


Table 3-1: Well-Mixed and Stratified Settler Sludge Properties, Single $0.5 \mathrm{~m}^{3}$ Batch.

\begin{tabular}{|c|c|c|c|}
\hline \multirow{2}{*}{ Property ${ }^{(1,2,3)}$} & \multirow{2}{*}{ Well-Mixed } & \multicolumn{2}{|c|}{ Stratified (Layered) } \\
\hline & & Metal-Rich & Metal-Free \\
\hline Density, g/cc & 3.250 & 3.822 & 2.954 \\
\hline$U$ metal concentration, $\mathrm{g} / \mathrm{cc}$ & 0.1625 & 0.477 & 0.0 \\
\hline Total U concentration, g/cc & 2.050 & 2.695 & 1.716 \\
\hline Water volume fraction & 0.70 & 0.70 & 0.70 \\
\hline $\begin{array}{l}\text { Particle density, } g / c c \\
\text { (derived) }\end{array}$ & 8.500 & 10.409 & 7.513 \\
\hline $\begin{array}{l}\text { Fraction of sludge volume } \\
\text { (layer height) }\end{array}$ & $100 \%$ & $34 \%$ & $66 \%$ \\
\hline Metal mass fraction & 0.06373 & 0.15274 & 0.0 \\
\hline Oxide mass fraction & 0.84594 & 0.81195 & 0.87027 \\
\hline Non-uranium mass fraction & 0.09034 & 0.03531 & 0.12973 \\
\hline \multicolumn{4}{|c|}{$\begin{array}{l}\text { (1) Reference: PRC-STP-00162, Plys and Johnson, } 2009 \text {. } \\
\text { (2) Metal material density is } 19.0 \mathrm{~g} / \mathrm{cc} \text {, and per SNF- } 7765 \text { the oxide material density is } \\
11.1 \mathrm{~g} / \mathrm{cc} \text { with a formula weight of } 272 \text {. The derived non-uranium material density is } \\
2.372 \mathrm{~g} / \mathrm{cc} \text {. } \\
\text { (3) Density, } U \text { metal concentration, Total U concentration, and water volume fraction are } \\
\text { fundamental given quantities for defined sludge streams. For well-mixed sludge, volume } \\
\text { fractions are derived from these four quantities. The metal-rich and metal-free layer values } \\
\text { for the top four quantities given here are derived from the volume fractions listed, which are } \\
\text { idealized based upon detailed settling model results. }\end{array}$} \\
\hline
\end{tabular}


FAl/10-83

PRC-STP-00241, Rev 0

Rev. 0

Page 16 of 284

March, 2010

Table 3-2: Well-Mixed and Stratified KW Container Sludge Properties, $2 \times 0.8 \mathrm{~m}^{3}$ Batches

\begin{tabular}{|c|c|c|c|}
\hline \multirow{2}{*}{ Property ${ }^{(1,2,3)}$} & \multirow{2}{*}{ Well-Mixed } & \multicolumn{2}{|c|}{ Stratified } \\
\hline & & Metal-Rich & Metal-Free \\
\hline Density, $g / c c$ & 1.800 & 1.8094 & 1.7937 \\
\hline$U$ metal concentration, $\mathrm{g} / \mathrm{cc}$ & 0.082 & 0.2050 & 0.0 \\
\hline Total U concentration, g/cc & 0.590 & 0.5987 & 0.5842 \\
\hline Water volume fraction & 0.74 & 0.74 & 0.74 \\
\hline $\begin{array}{lll}\begin{array}{l}\text { Particle } \\
\text { (derived) }\end{array} & \text { density, } & \text { g/cc } \\
\end{array}$ & 4.077 & 4.1132 & 4.0527 \\
\hline $\begin{array}{l}\text { Fraction of sludge volume } \\
\text { (layer height) }\end{array}$ & $100 \%$ & $40 \%$ & $60 \%$ \\
\hline Metal mass fraction & 0.0774 & 0.1917 & 0.0 \\
\hline Oxide mass fraction & 0.5811 & 0.4464 & 0.6723 \\
\hline Non-uranium mass fraction & 0.3415 & 0.3619 & 0.3277 \\
\hline \multicolumn{4}{|c|}{$\begin{array}{l}\text { (1) Reference: PRC-STP-00220, Plys et al, } 2010 \text {. } \\
\text { (2) Metal material density is } 19.0 \mathrm{~g} / \mathrm{cc} \text {, and per SNF-7765 the oxide material density is } 7.5 \mathrm{~g} / \mathrm{cc} \\
\text { with a formula weight of } 288.6 \text {. The derived non-uranium material density is } 2.086 \mathrm{~g} / \mathrm{cc} \text {. } \\
\text { (3) Density, } U \text { metal concentration, Total } U \text { concentration, and water volume fraction are } \\
\text { fundamental given quantities for defined sludge streams. For well-mixed sludge, volume } \\
\text { fractions are derived from these four quantities. The metal-rich and metal-free layer values } \\
\text { for the top four quantities given here are derived from the volume fractions listed, which are } \\
\text { idealized based upon detailed settling model results. }\end{array}$} \\
\hline
\end{tabular}


FAl/10-83

PRC-STP-00241, Rev 0

Rev. 0

Page 17 of 284

March, 2010

\subsection{T Plant Cell Geometry and Conditions}

\subsubsection{General Layout}

Building 221-T, or simply T Plant, is a large legacy reprocessing facility whose interior has been incompletely remediated from its original mission. T Plant is $850 \mathrm{ft}(259 \mathrm{~m})$ long, $74 \mathrm{ft}$ $(22.6 \mathrm{~m}) \mathrm{high}$, and $68 \mathrm{ft}(20.7 \mathrm{~m})$ wide and covers an area of $57,800 \mathrm{ft}^{2}\left(5370 \mathrm{~m}^{2}\right)$. It is made of reinforced concrete. A cutaway view of T Plant in Figure 3-4 shows the relative position of a process cell, the canyon, and various galleries that run past the cells.

A schematic floor plan layout in Figure 3-5 shows a "head end" set of four "long" cells $T B, T A, 1 L$, and $1 R$, long receiver and holding cells $2 L$ and $2 R$ respectively, and a remaining set of 36 standard process cells numbered $3 \mathrm{~L}, 3 \mathrm{R}, 4 \mathrm{~L} \ldots 20 \mathrm{R}$. Not shown in the layout, a corrugated steel wall divides the canyon between sections 1 and 2, so that the canyon volume above cells TB, TA, 1L, and $1 R$ is effectively isolated from the main canyon volume.

Cell $2 \mathrm{~L}$ is the location for STSC arrival and admission to T Plant. Unlike the rest of the cells, it is not covered by cell block covers described below. This cell opens to the receiving tunnel which is indicated in Figure 3-5. Cell $2 R$ is a candidate for storage of STSCs, and it differs only from the remaining cells of higher number by its dimension perpendicular to the $T$ plant axis. The current plan for cell use for STSC storage includes cell $2 R$ and selected standard cells.

\subsubsection{Cell Lavout}

A typical standard cell longitudinal section, meaning in the direction of the T Plant long axis, is shown in Figure 3-6. Each cell width is $20 \mathrm{ft}$ wide overall, of which $13 \mathrm{ft}$ is the actual open cell, and $3.5 \mathrm{ft}$ on either side consists of concrete. A plan view of a standard cell is shown in Figure 3-7. From Figure 3-6 and Figure 3-7, we see that the standard open cell width (length along the T-Plant axis) is $13 \mathrm{ft}$, and that the standard length (perpendicular to the axis on the plan view) is $17 \mathrm{ft} 8 \mathrm{in}$. Also, the cell is $28 \mathrm{ft}$ deep, but the upper $6 \mathrm{ft}$ are occupied by cover blocks, so the actual interior open depth is $22 \mathrm{ft}$, and the floor is slightly angled for drainage. To summarize, standard cell dimensions are $13 \mathrm{ft}(3.96 \mathrm{~m})$ wide, $17 \mathrm{ft} 8$ in long $(5.38 \mathrm{~m})$, and $22 \mathrm{ft}$ $(6.71 \mathrm{~m})$ deep. Cell $2 \mathrm{R}$ differs only in its length with respect to the other cells (perpendicular to the axis on the plan view), $27 \mathrm{ft} 6$ in $(8.38 \mathrm{~m})$ as shown in Figure 3-8. Cell $2 \mathrm{~L}$ is the receiver cell connected to the access tunnel, and it has a slightly lower elevation than $2 \mathrm{R}$, Figure 3-9 .

Thus far, only the ideal, empty cell dimensions have been described. Storage of STSC's requires installation of support assemblies as illustrated in Figure 3-10 through Figure 3-12. The big picture of Figure 3-10 shows the relationship between the storage cell, ventilation duct, pipe trench, and canyon, and other major longitudinal features of T Plant such as the electrical gallery, piping gallery, operations gallery, and crane gallery. Figure $3-11$ is a close-up for the cell illustrating the position of the support structure and holding pan for six STSCs. This figure clearly shows the slope of the cell floor and the fact that the STSCs will be held in an array about $4 \mathrm{ft}$ above the cell floor. There is a gap between the holding pan and the cell walls evident in both Figure 3-11 and Figure 3-12. Overall, there will be good natural circulation around the STSC's with or without operation of T Plant fans. 
A cross-section through standard cell cover blocks is indicated in Figure 3-11. The cell plan view with STSCs of Figure 3-12 shows an outer dash-dot perimeter describing the cover block labyrinth closure and the centerline locations of individual STSCs. Standard cell cover block and gap geometry are shown in more detail in Figure 3-13. These gaps allow communication between the cell and the canyon with ventilation (from canyon to cell) or without ventilation (possible flow in either or both directions). There are three "type 1" covers and one "type 2" or "key" cover. Cell 2R has two additional type 1 covers. Given the gap geometry, the flow resistance can be determined, and employed with various likely boundary conditions to predict the flow direction and magnitude without fan operation.

\subsubsection{Ventilation Duct and Pipe Trench Layout}

Along the long axis of T Plant, a ventilation duct and pipe trench pass along the standard cells from sections 3 through 20, Figure 3-10. Every standard cell has a 10" ventilation path to the ventilation duct, and in every section (pair of standard cells) there is a 10" ventilation path from the pipe trench to the ventilation duct. Five of the six long cells have similar ventilation paths to a 24 inch header external to the plant which is connected to the ventilation duct downstream of section 3, see Figure 3-14. The pipe trench is covered by a set of cover blocks similar to those covering the cells but of different thickness (only $4.5 \mathrm{ft}$ ) and with alternating labyrinth geometries, Figure 3-15.

The significance of these paths is that normal airflow in T Plant is from the canyon through the cover blocks, into the cells and pipe trench, and thereafter into the ventilation duct, the standard path from least contamination to most contamination. The flow resistances offered by the cell and pipe trench cover blocks govern the flow split between individual cells and the trench, and therefore the normal ventilation rate of a standard cell.

\subsubsection{Ventilation System}

Ventilation duct air exits T Plant at section 3 through a $4 \mathrm{ft}$ by $7 \mathrm{ft}(1.22 \mathrm{~m}$ by $2.13 \mathrm{~m})$ concrete duct that runs $145 \mathrm{ft}(44.2 \mathrm{~m})$ to a $130 \mathrm{~kW}$ electrical heater duct. The air is then pulled through four parallel filter trains each consisting of a pre-filter and two stages of HEPA filters, located above ground, each rated at $10,000 \mathrm{cfm}\left(4.72 \mathrm{~m}^{3} / \mathrm{s}\right)$ and with individual dampers. These four ducts are then combined into a single duct connected to the exhaust fans. The fan system consists of two fans in parallel.

Based on normal fan operation, T Plant canyon conditions are found in Table 4-25 of the SNF Sludge Databook (Schmidt, 2009), reproduced here as Table 3-3. The canyon pressure is maintained between -0.15 and -0.50 inches water gage per (Loscoe, 2003). Current canyon pressure and flow conditions may differ from those indicated by these references. Cell conditions depend upon canyon conditions, ventilation flow, and local heat sources.

It is important to recognize that the $T$ Plant ventilation system has functioned almost continuously throughout plant life, and that system downtime is nearly always related to plant maintenance, rather than inadvertent outage. For this work, in order to avoid the invocation of special controls, analyses are conducted with normal ventilation and without normal ventilation. 
Without fan operation, the flow between the process cell and the canyon via gaps in the cover blocks could proceed one-way from canyon to cell (normal direction) or from cell to canyon (reverse direction), or as a counter-current exchange flow in both directions. The actual flow pattern depends upon the net effect of global and local stack effects. The global stack effect will tend to draw canyon air into the ventilation duct, through the filters, and up the stack, promoting the normal flow direction. A local stack effect can exist for a process cell whose air density is lower than that of neighbor cells and the canyon, due to either local heating or sources of steam and hydrogen. In this case, air would be drawn from the ventilation duct, into the cell, and upward into the canyon; other process cells would have the normal flow direction and feed the ventilation duct. Finally, a cell with low gas density compared to that of the canyon could also have counter-current exchange flow through the gaps when the local stack effect is weak. In this case, higher density canyon air would flow downward at some gap locations, and lower density cell air would flow upward at the other locations.

Table 3-3: T Plant Operating Conditions [Schmidt, 2009]

\begin{tabular}{|c|c|c|}
\hline Parameter & Minimum & Maximum \\
\hline Airflow through canyon & $17,500 \mathrm{cfm}$ & $35,800 \mathrm{cfm}$ \\
\hline Canyon Temperature & $-7^{\circ} \mathrm{C}$ & $32^{\circ} \mathrm{C}$ \\
\hline
\end{tabular}


$\mathrm{FAl} / 10-83$

PRC-STP-00241, Rev 0

Rev. 0

Figure 3-4: T Plant Cutaway

T Plant Cutaway

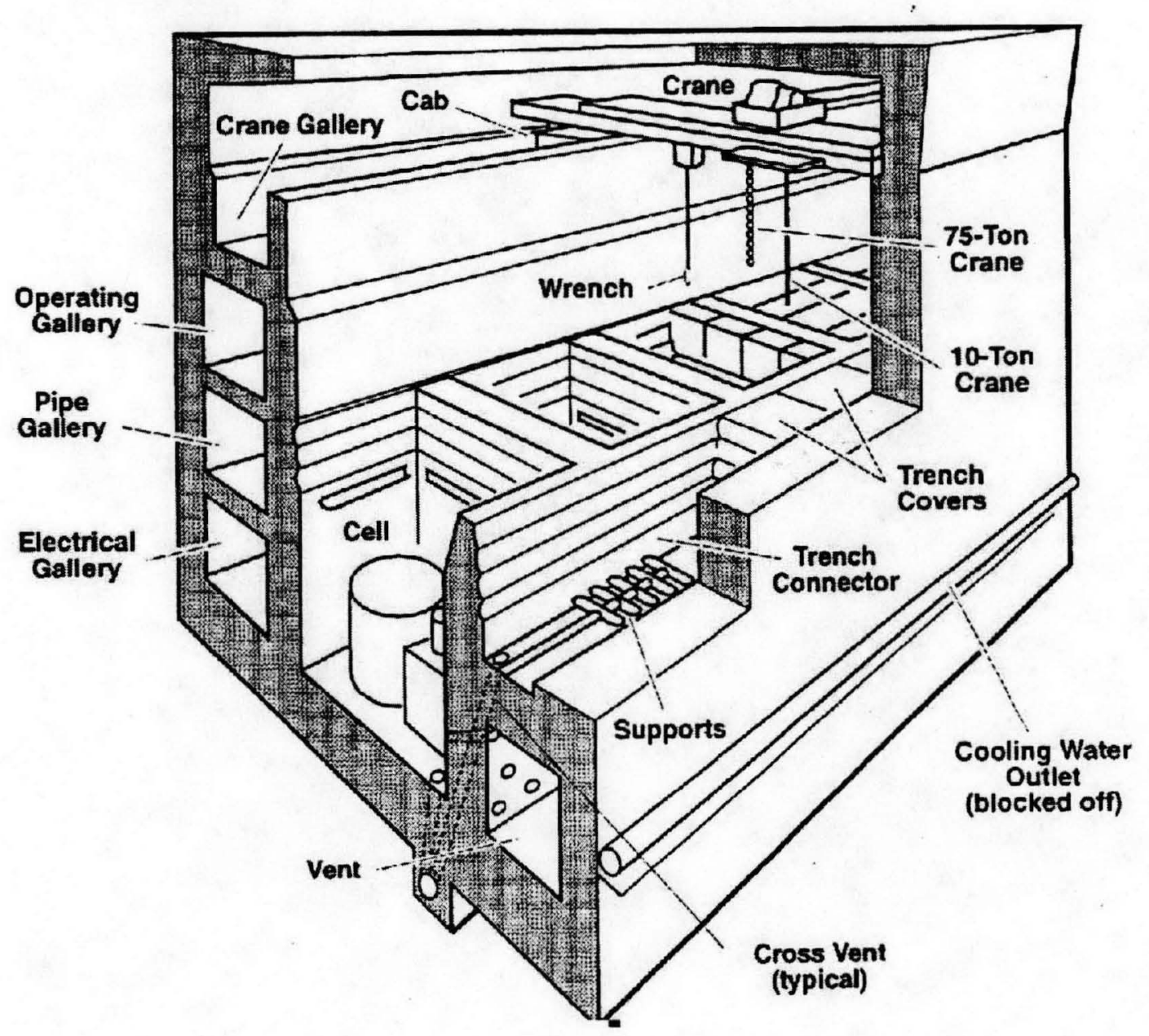


$\mathrm{FAl} / 10-83$

Rev. 0
PRC-STP-00241, Rev 0

Page 21 of 284

March, 2010

Figure 3-5: T Plant Layout

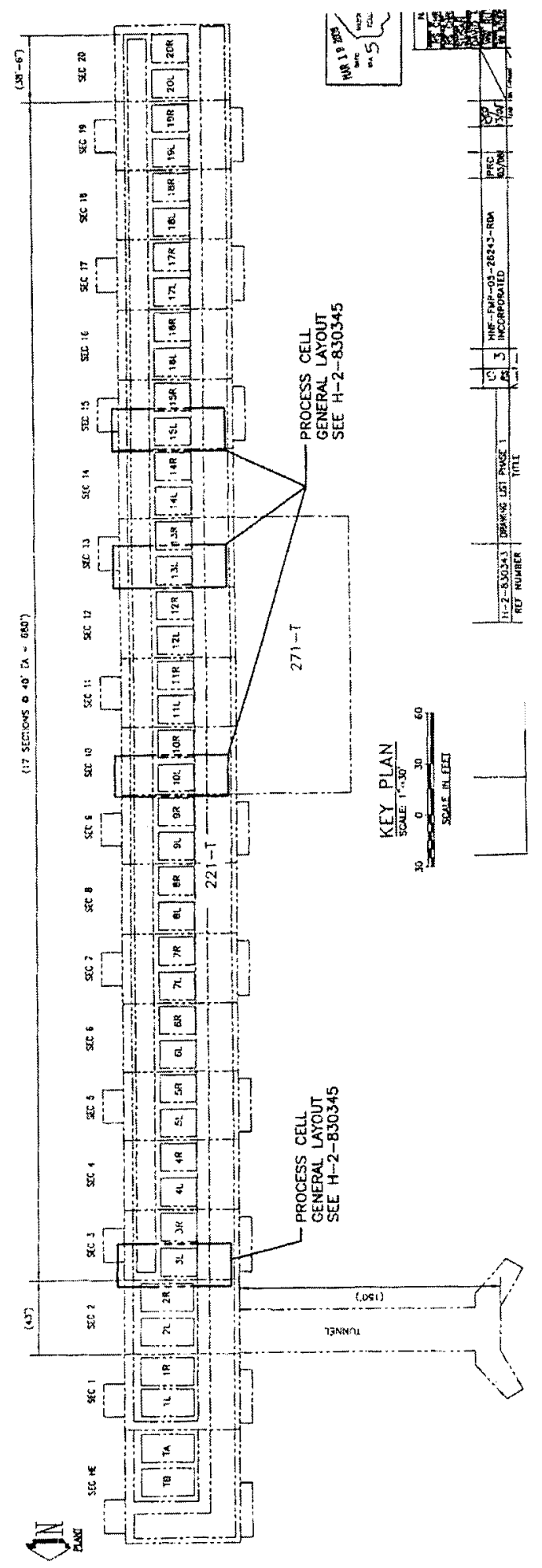


FAl/10-83

PRC-STP-00241, Rev 0

Rev. 0

Figure 3-6: Typical Cell Longitudinal Section

Page 22 of 284

March, 2010

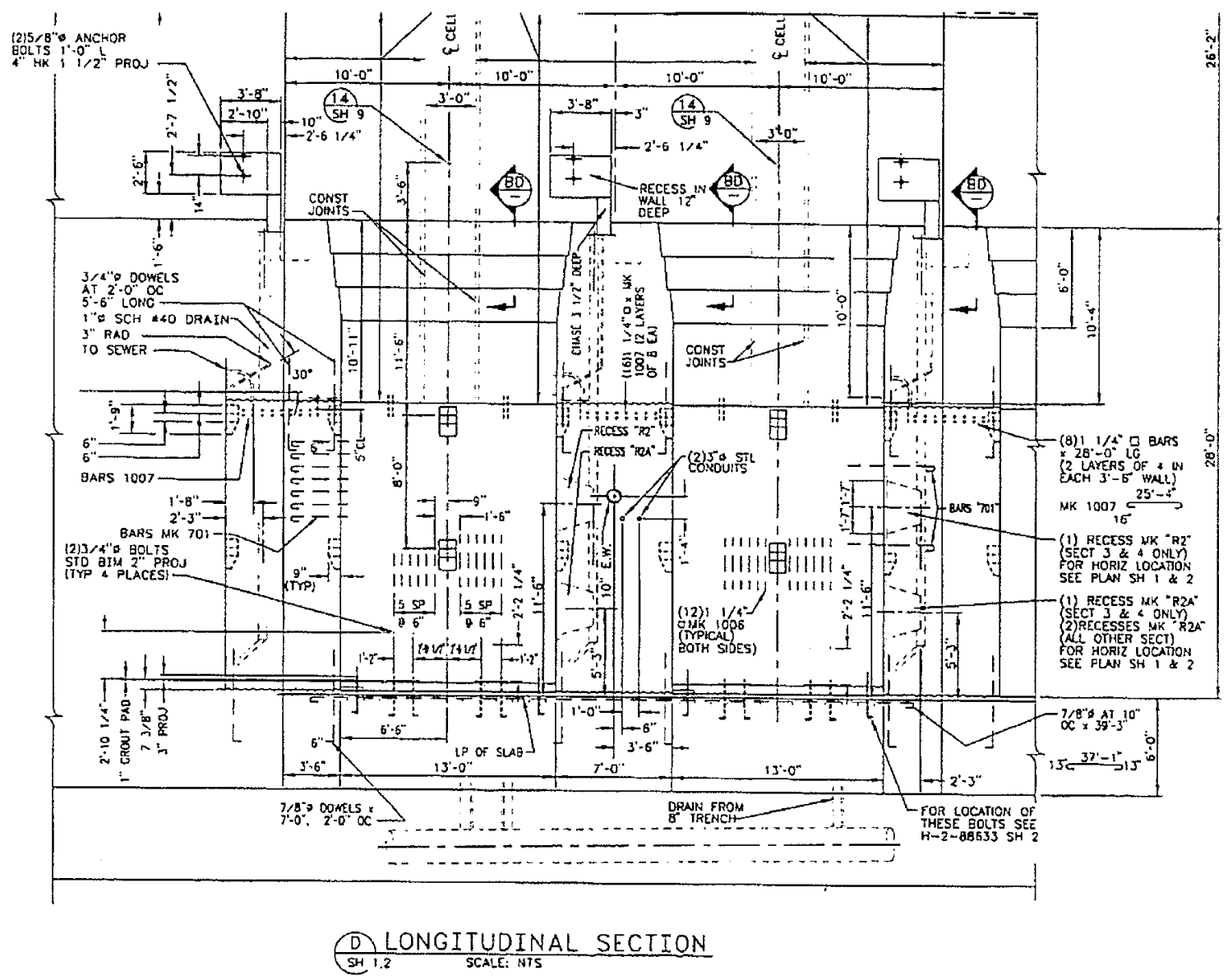


FAl/10-83

PRC-STP-00241, Rev 0

Rev. 0

Page 23 of 284

March, 2010

Figure 3-7: Typical Cell Partial Plan

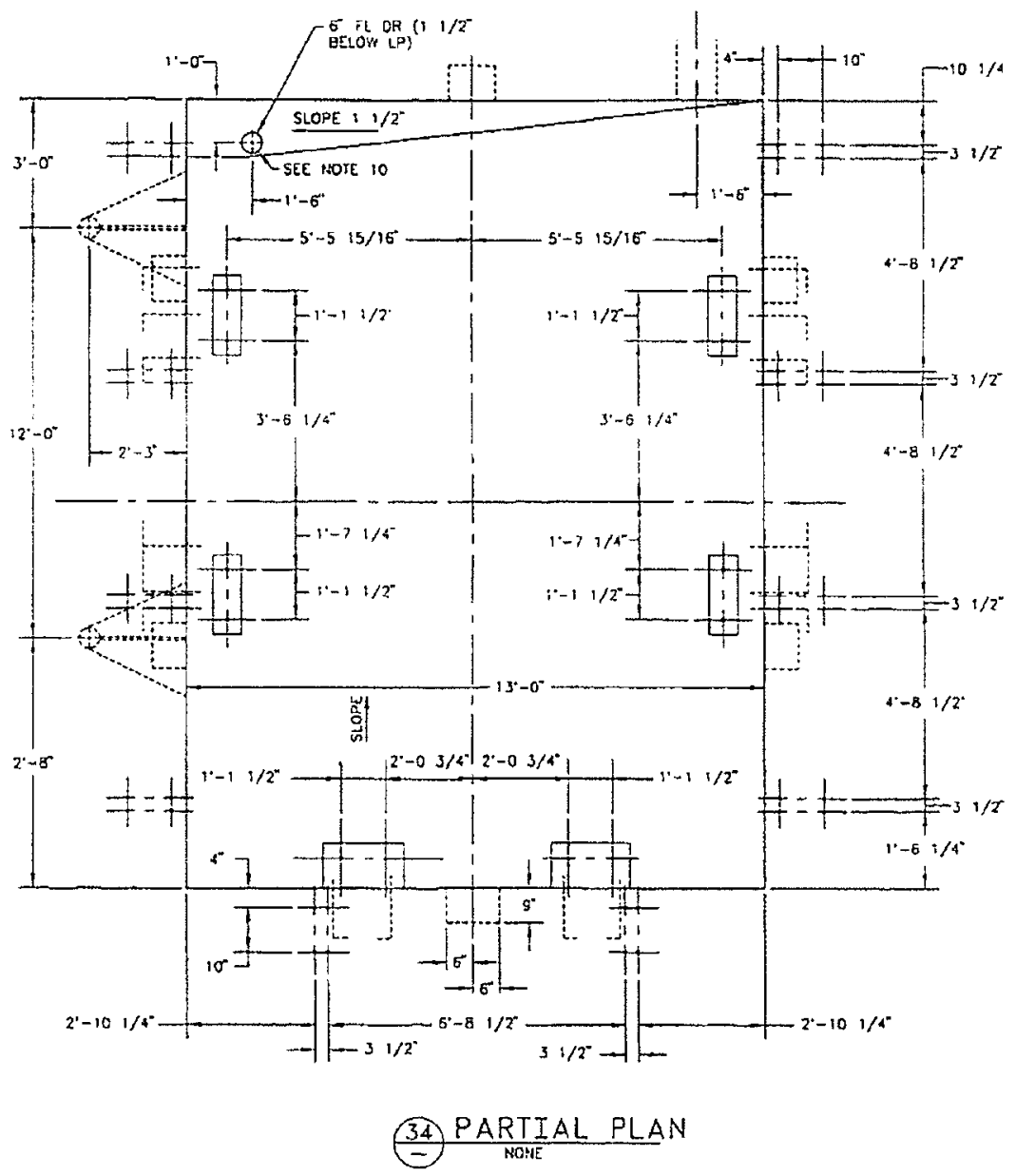


Figure 3-8: Cell 2R Elevation Cross-Section

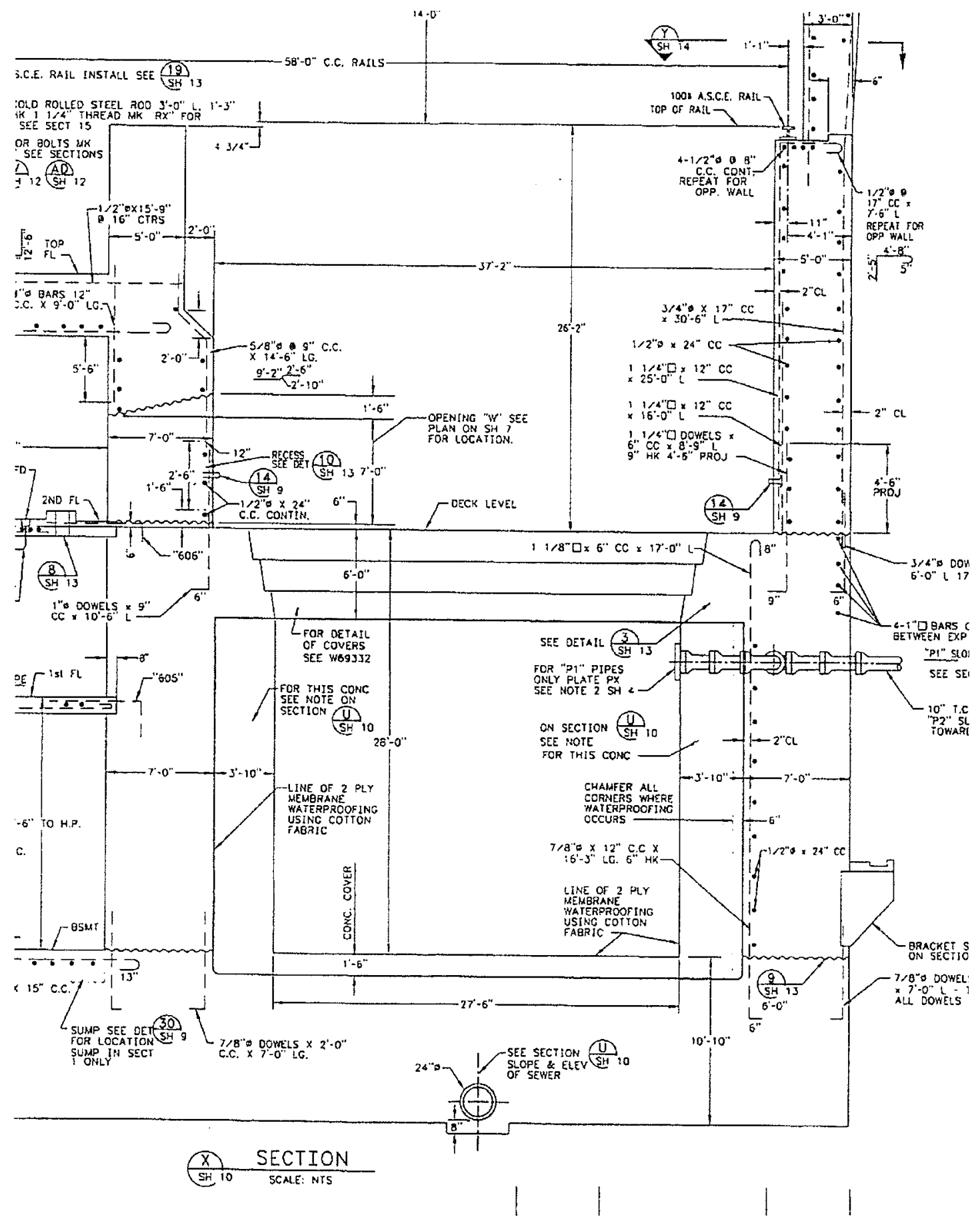


Figure 3-9: Cell 2L (left) and 2R (right) Longitudinal Section

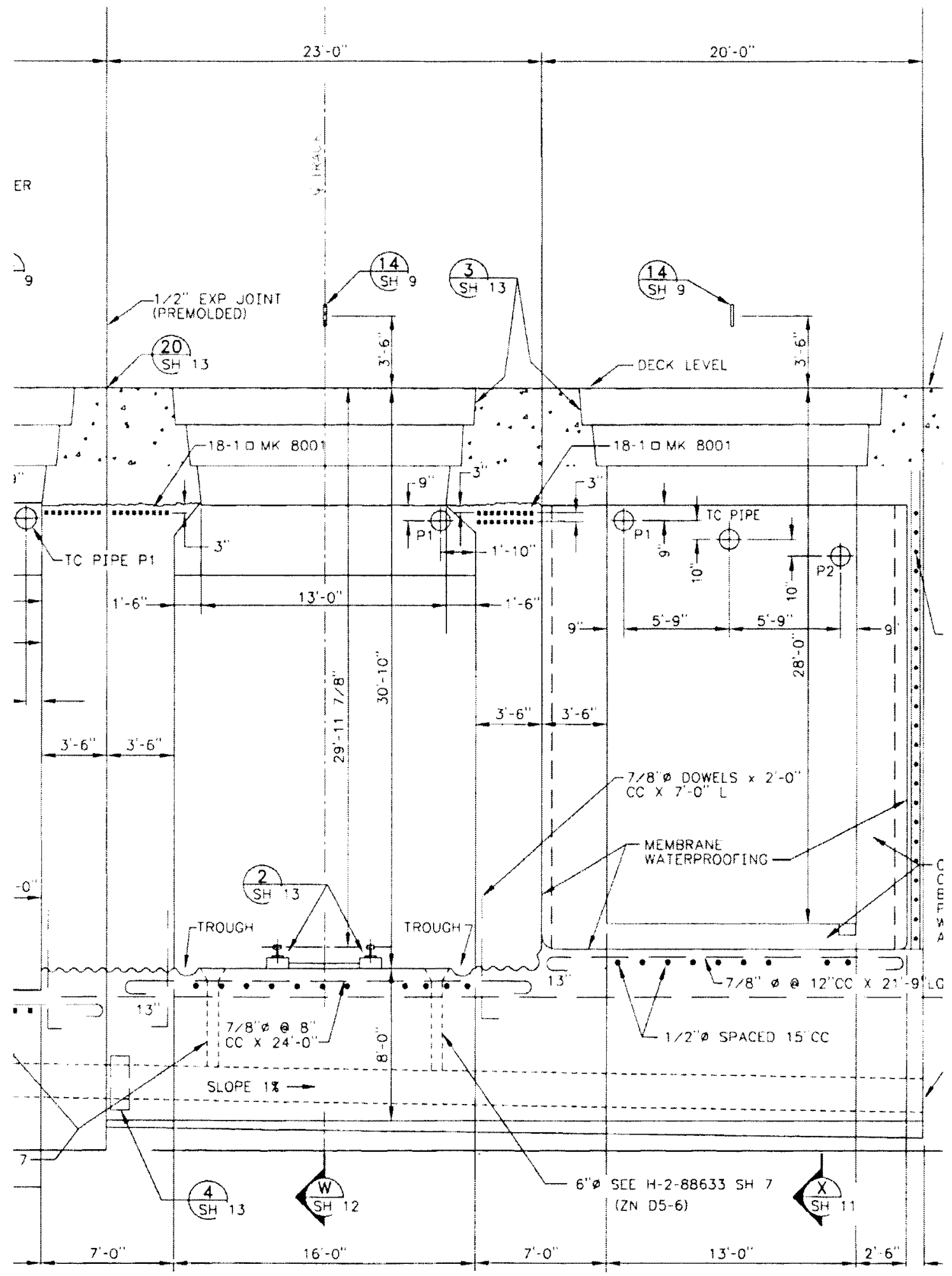


FAl/10-83

PRC-STP-00241, Rev 0

Rev. 0

Page 26 of 284

March, 2010

Figure 3-10: T Plant Cross-Section with STSC Receiving Equipment 
Figure 3-11: T Plant Detail Cross-Section with STSC Equipment

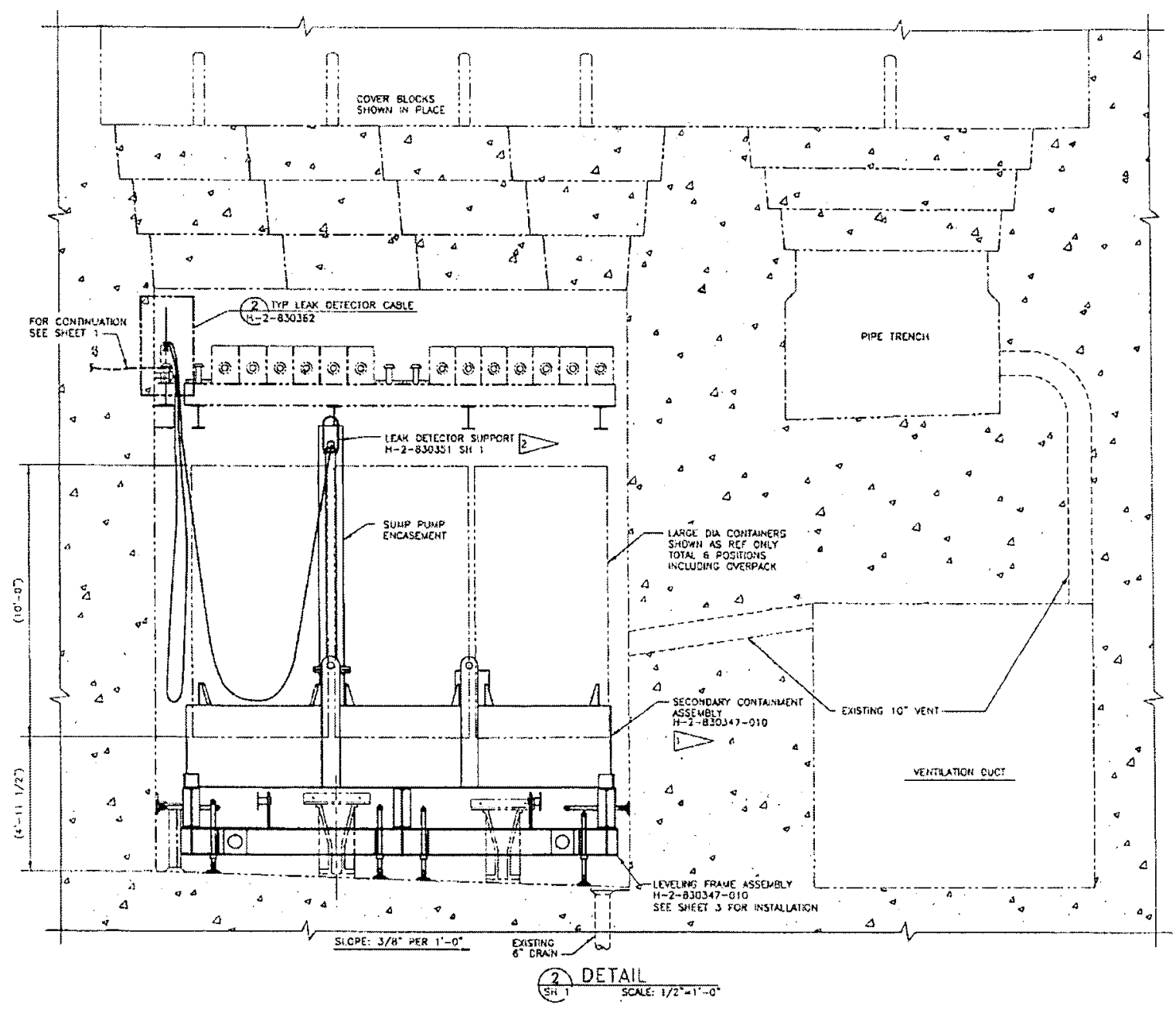


$\mathrm{FAl} / 10-83$

Rev. 0
PRC-STP-00241, Rev 0

Page 28 of 284

March, 2010

Figure 3-12: Typical Cell Plan with STSC Equipment

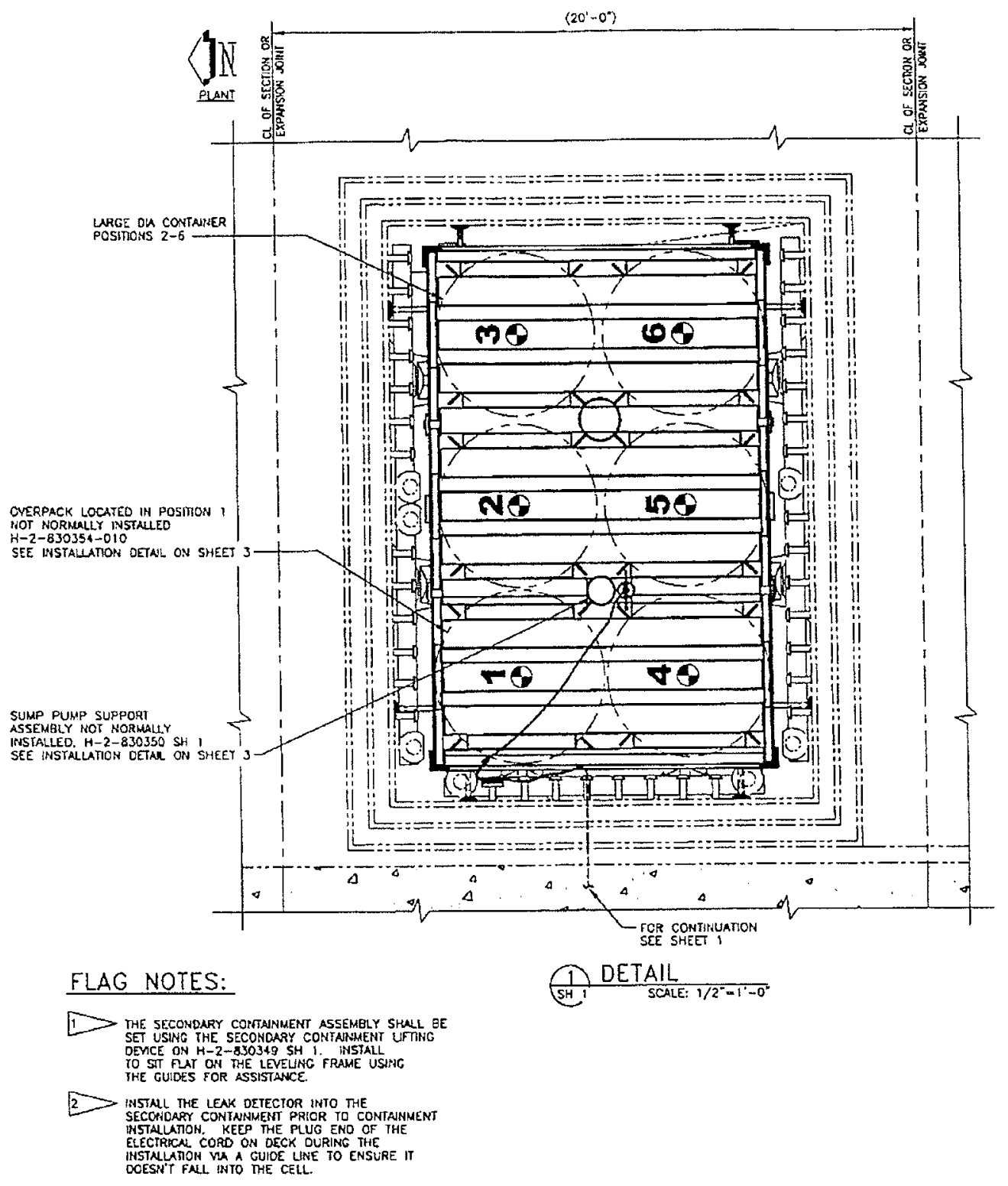


Figure 3-13: Standard Cell Block Elevation View with Typical Labyrinth Gaps

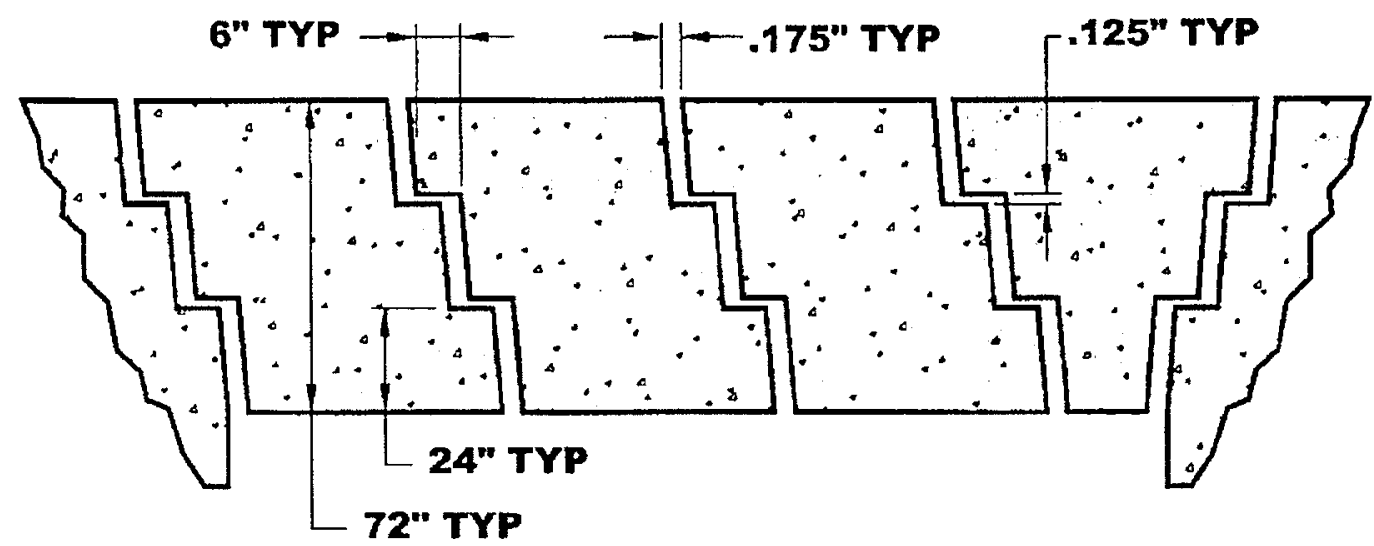


Figure 3-14: 24" Vent Pipe and Connection to Ventilation Duct

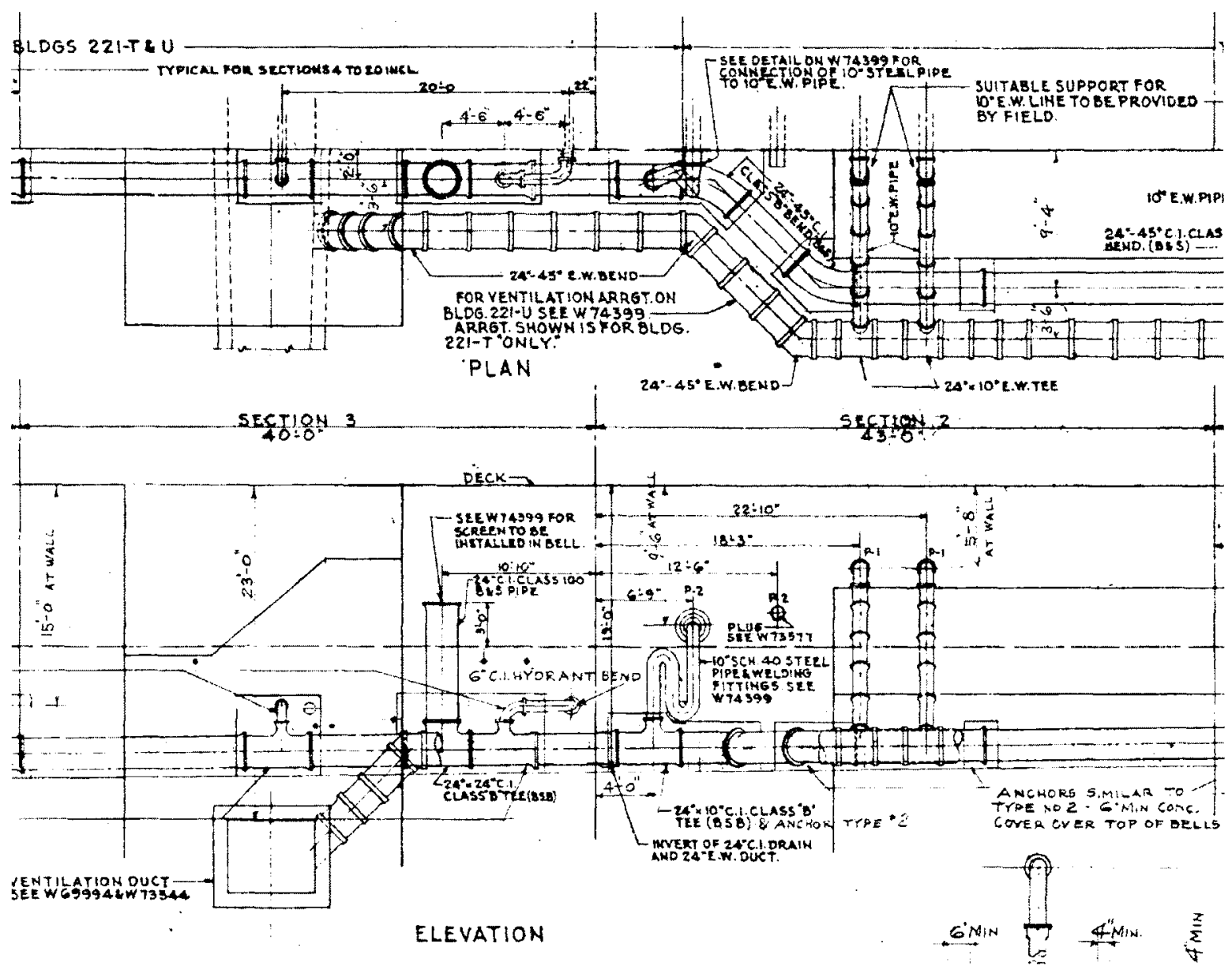




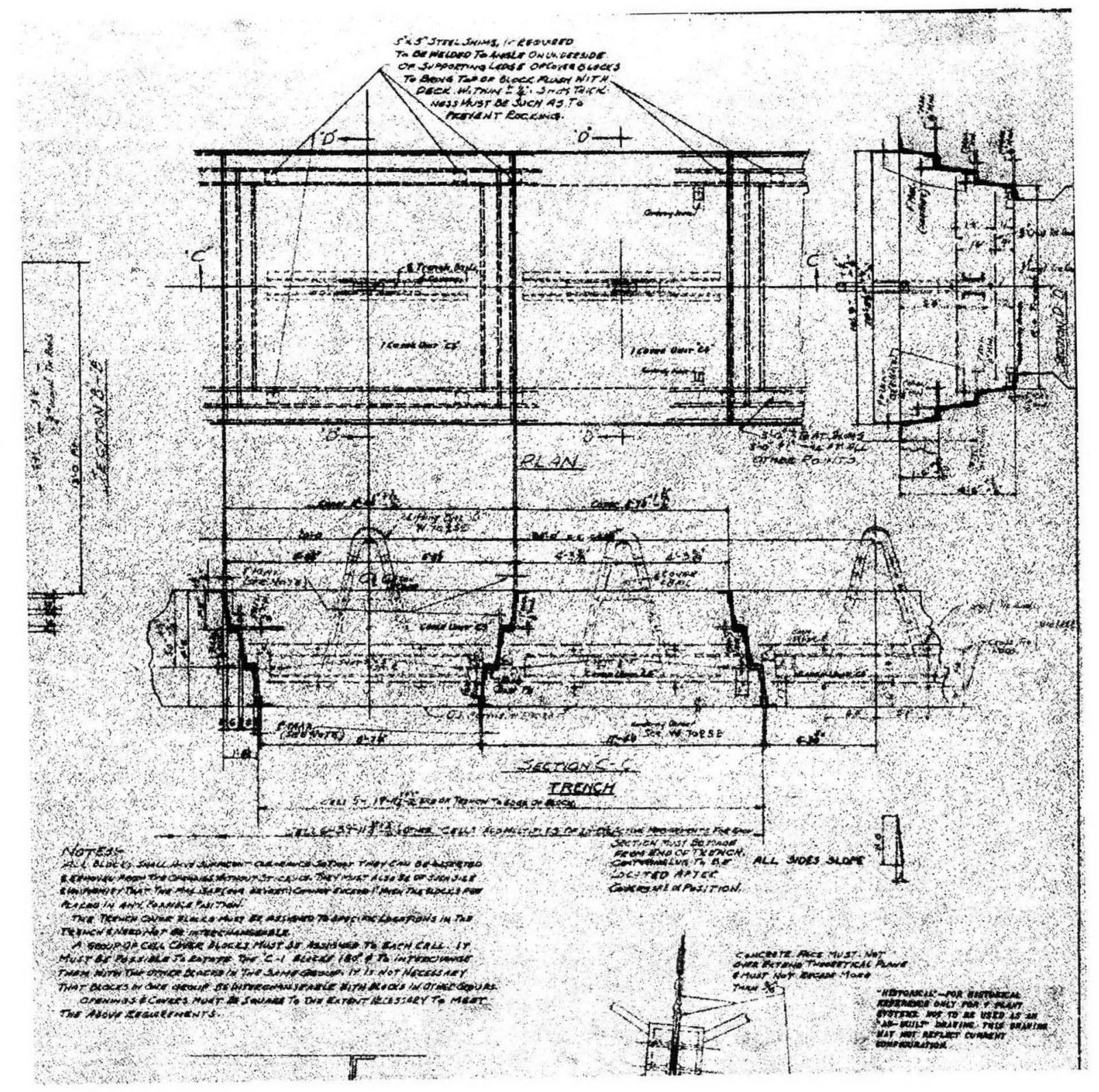




\subsection{ASSUMPTIONS}

\subsection{STSC and Sludge Model Assumptions}

Key assumptions regarding STSC modeling are:

1. The FATE $^{\text {TM }}$ sludge model considers pertinent phenomena at an appropriate level of detail (see Section 5). Notable model features include the correlation for the rate of uranium metal oxidation, the shrinking-core model for metal oxidation, local water evaporation into evolved hydrogen gas bubbles, representation of sludge properties consistent with the SNF databook, radiolysis, and mass and energy balances. The oxygen poisoning model is not employed for radiolysis in this work because of uncertainties in its many input parameters.

2. The STSC and its contents are azimuthally symmetric, so that two-dimensional discretization in the axial and radial dimensions provides a sufficient description for the evolution of composition and temperature within the sludge and STSC structure.

3. While the temperature distribution in the sludge and STSC structure is distributed, the overlying water pool and gas spaces are well-mixed.

4. Holes in the support skirt are sufficiently large and numerous to permit effective natural circulation heat transfer from the elliptical bottom head to gas inside the skirt and eventual convective exchange of gases inside and outside the skirt.

5. The STSC has two open, unfiltered vents open to the T plant cell configured to provide a stack height to induce natural circulation. The inlet vent diameter is 2 inches $(0.0508 \mathrm{~m})$, and the outlet vent diameter is 4 inches $(0.1016 \mathrm{~m})$ with a stack height (elevation difference between the tops of the outlet and inlet) of 2 feet $(0.6096 \mathrm{~m})$.

\subsection{Sludge Property Assumptions}

Key assumptions regarding sludge properties are:

1. Sludge is loaded in batches as described in the scenario descriptions. Within each batch, the sludge material is assumed to separate (or segregate) into a lower layer containing all the metallic uranium of the batch, and an upper layer that is metal-free. The composition of each layer is given by a model described in (Plys and Johnson, 2009). It is assumed that this model is applicable to the current loading plan.

2. Safety basis properties define the batch properties.

3. The fractions of decay power from alpha, beta, and gamma radiation are based upon isotopic compositions and an externally-supplied spreadsheet calculation described in Appendix A. This spreadsheet will be verified by $\mathrm{FAl}$ and described in a future revision of this work. 
4. The radiolysis model of SNF-22059 applies (see Appendix A). SNF-22059 provides a calculation of the fraction of alpha, beta, and gamma power that is absorbed by interstitial water, and therefore leads to radiolysis of water. This calculation was performed for several sludge types of interest at the time. A best match to those sludge types is found for sludge compositions used for this work, as identified in Appendix A, so that the power fraction absorbed by water for those reference compositions is used for the sludge compositions in this work. In a future revision of this work, the SNF-22059 calculation methodology will be applied to the sludge compositions considered.

\subsection{T Plant Model Assumptions}

Key assumptions regarding $T$ plant modeling are:

1. One STSC is modeled in detail for transient behavior, while the others are represented by average heat and hydrogen generation rates. The detailed STSC is referred to as the "active STSC". The validity of this assumption depends upon many factors including the arrival time of the previous STSCs, the prevailing cell temperature history, and the values chosen to represent the remaining STSCs. See Appendix $A$ for the assumed heat and hydrogen generation rates.

2. Four other standard process cells containing STSCs are considered, and average heat sources are used for these cells. Considering these cells leads to a slight (around 10\%) reduction in circulation flow through the standard cell modeled in detail. Including these cells has no impact on cases considering cell $2 R$ in detail.

3. Worst case cover block gaps are assumed in the process cell with the active STSC.

4. Worst case cover block gaps are assumed for the remainder of $T$ Plant cells, and nominally worst case cover block gaps are assumed for the pipe trench, in order to minimize natural circulation flows with no ventilation. With ventilation, the choice of resistances is moot because the cell purge rate is sufficiently high as borne out by results.

5. Standard cells can have a natural circulation flow pattern involving the pipe trench, ventilation duct, and canyon, which is independent of the natural circulation flow pattern involving long cells connected by the 24 " external ventilation pipe. This is true because the 24" pipe connects to the ventilation system downstream of the ventilation duct serving sections 3 through 20 . The nodalization does in fact implicitly allow for any deviation from this assumption.

6. Heat sinks have idealized external boundary conditions. In most cases, the "inside" boundary condition is convection to the cell or other region atmosphere, while the "outside" boundary condition is insulated. This is valid for concrete for a time scale of about a day but not for several weeks, but the effect of a variation in external temperature is considered to be second-order with regard to its impact on cell temperature. 
7. For cases with ventilation, the minimum ventilation flow of $17,500 \mathrm{cfm}$ from (Schmidt, 2009 ) is used, and the minimum canyon pressure of -0.15 inches water gage from (Loscoe, 2003) is used to calculate an effective resistance to air infiltration. The infiltration is assumed to be equally divided between inlet to cell $2 \mathrm{~L}$ (via the roll-up door) and paths direct to the canyon (such as the rear stairwell doors).

8. The effect of the T Plant stack is not considered for cases without ventilation.

9. Diurnal temperature variations in the ambient are considered. 


\subsection{FATETM CODE DESCRIPTION, VALIDITY, AND APPLICATIONS}

\subsection{FATETM Description and Validity}

The FATE ${ }^{\text {TM }}$ computer program is used for this work (Plys and Lee, 2004, Lee and Plys, 2006) (the TM symbol will be dropped for simplicity). Some changes have been made to the baseline sludge model from these references, and they will be documented under Quality Assurance in follow-on work (see Section 5.3). FATE version 2.061 is used for this work.

The FATE sludge model was developed by FAI for the Hanford Spent Nuclear Fuel Program and the $K$ Basins Closure Project under the FAI QA program. FATE has been used for $K$ Basins sludge applications including scoping calculations, normal and off-normal behavior, and accidents including pump station spills and spray leaks at CVD. A summary of pertinent investigations is given in Table 5-1. The most recent reference applications are for transportation of settler and KW container sludge in an STSC (Plys and Johnson, 2009, and Plys et al, 2010). Conceptual design calculations are found in (Lee and Conzen, 2009). Example calculations similar to those presented here were performed for the earlier LDC design (Plys et al, 2003 and Loscoe, 2003). Applications for sludge retrieval are given in (Plys, 2008), (Plys et al, 2008), and (Plys, Lee, and Epstein, 2009). Applications for sludge processing at elevated temperature are given in (Plys et al, 2006) and (Plys and Lee, 2006).

Briefly, FATE can model heat transfer, fluid flow, and chemical reactions in sludge, its containers, a cask if present, a building or facility containing them, and the environment. Decay power, oxidation power, and conversion of metal to oxide with decrease of reactive surface area are included. Heat conduction in sludge and its container is allowed in one or more dimensions, according to the problem; natural convection occurs in overlying water or air. Pressure, temperature, gas composition, and exchange flows are considered in control volumes that typically consist of the container headspace and surrounding compartments. Aerosol phenomena, combustion, and source terms evaluation can also be treated, but are not used in these calculations; see (Plys, 2007) and (Loscoe, 2003).

The scope of calculations considered here is within the scope of model testing and previous applications, and does not involve untested model capabilities. 
Table 5-1: Summary of Pertinent FATE Reference Calculations

\begin{tabular}{|c|c|}
\hline Reference & Application \\
\hline $\begin{array}{l}\text { Plys et al, } \\
\text { PRC-STP-00220 }\end{array}$ & $\begin{array}{l}\text { Transportation of KW floor sludge in an STSC (no annulus). Considers } \\
\text { stratification, various loadings, and two levels of insolation. }\end{array}$ \\
\hline $\begin{array}{l}\text { Plys and Johnson, } \\
\text { PRC-STP-00162 }\end{array}$ & $\begin{array}{l}\text { Transportation of settler sludge in an STSC, annular design. Considers } \\
\text { stratification, various loadings, and two levels of insolation. }\end{array}$ \\
\hline $\begin{array}{l}\text { Lee and Conzen, } \\
2009 \\
\text { FAl/09-264 }\end{array}$ & Transportation and storage calculations for conceptual designs. \\
\hline $\begin{array}{l}\text { Plys, Lee, and } \\
\text { Apthorpe, } 2009 \\
\text { FAl/09-065 }\end{array}$ & $\begin{array}{l}\text { Sludge process design guidance. Transportation and storage } \\
\text { calculations for conceptual designs. }\end{array}$ \\
\hline $\begin{array}{l}\text { Plys, Lee, and } \\
\text { Epstein, } 2009 \\
\text { FAl/08-30, R.1 }\end{array}$ & Thermal and gas behavior of containerized settler sludge. \\
\hline $\begin{array}{l}\text { Plys, et al, } 2008 \\
\text { FAl/08-32 }\end{array}$ & Thermal and gas behavior of containerized sludge. \\
\hline $\begin{array}{l}\text { Plys, } 2008 \\
\text { FAl/08-56 }\end{array}$ & Thermal and gas behavior for retrieval of KOP sludge. \\
\hline $\begin{array}{l}\text { Plys and Lee, } 2006 \\
\text { FAl/06-44 }\end{array}$ & High temperature sludge treatment corrosion process, normal operation \\
\hline $\begin{array}{l}\text { Plys et al, } 2006 \\
\text { FAl/06-35 }\end{array}$ & $\begin{array}{l}\text { High temperature sludge treatment corrosion process, accident } \\
\text { evaluation. }\end{array}$ \\
\hline $\begin{array}{l}\text { Loscoe, } 2003 \\
\text { HNF-12563 }\end{array}$ & $\begin{array}{l}\text { Accident scenarios at T Plant including hydrogen combustion during } \\
\text { receipt and storage }\end{array}$ \\
\hline $\begin{array}{c}\text { Plys, Lee, and } \\
\text { Malinovic, } 2002 \\
\text { FAl/02-13 }\end{array}$ & $\begin{array}{c}\text { User's manual for sludge models including example LDC transportation } \\
\text { and T plant storage calculations. }\end{array}$ \\
\hline $\begin{array}{l}\text { Plys and Lee, } 2002 \\
\text { FAl/02-11 }\end{array}$ & First LDC transportation and storage calculations. \\
\hline
\end{tabular}




\subsection{Previous T Plant Calculations}

The first calculations for T Plant were prepared for the HANSF Sludge manual (Plys, Lee, and Malinovic, 2002). In this document, the method for treating flow through gaps between the cover blocks is discussed in detail. The calculation geometry is similar to the geometry used here, namely, a single cell is in communication with the canyon via the cover block gaps.

A more detailed T Plant nodalization was prepared by (Loscoe, 2003), reproduced here as Figure 5-1. This nodalization was specifically selected in order to invoke FATE source term and aerosol models to predict leak path factors, which is the ultimate goal of FATE application to Hanford process safety analyses to replace dependence upon questionable handbook lookup values. As in any nodalization diagram, be aware that these are high-level representations; for example, the actual flow directions calculated by the model may be opposite those shown by the arrow heads.

Sludge was contained in a container known as the LDC at the time, and LDC dimensions and possible sludge loadings were similar to those of the STSC. Scenarios examined in this report were LDC overpressurization during receipt at T Plant, rapid LDC depressurization during venting upon receipt, hydrogen combustion in an LDC during receipt, LDC exposure to fire in the railroad tunnel, LDC overpressurization in a process cell, and hydrogen combustion in an LDC during water addition in a process cell. Note that the aerosol source term models were used to calculate release fractions and the transport of contamination.

\subsection{Validation of Selected FATE Model Improvements}

Appendix $\mathrm{C}$ contains $\mathrm{FAl}$ memoranda describing improved FATE $^{\mathrm{TM}}$ computer code models for modeling sludge behavior during transportation and storage.

Sections C.1 through C. 3 describe the theoretical basis for global natural circulation between standard cells and the canyon in T Plant, implementation and testing of the model for FATE Quality Assurance, and an example application demonstrating that the circulation flow predicted by FATE is in agreement with a simple hand calculation. The important conclusion of these memos is that such global circulation will exist, which is beneficial in achieving low hydrogen concentrations in a cell.

Sections C. 4 and C.5 describe the theoretical basis for natural convection heat transfer around the bottom head of an STSC, and implementation and testing of the model in FATE for FATE Quality Assurance. The important conclusion of these memos is that the holes in the STSC skirt are sufficient to credit this heat removal process, which is beneficial for thermal stability of sludge. 
FAl/10-83

PRC-STP-00241, Rev 0

Rev. 0

Page 38 of 284

March, 2010

Figure 5-1: T Plant Nodalization Used by (Loscoe, 2003)

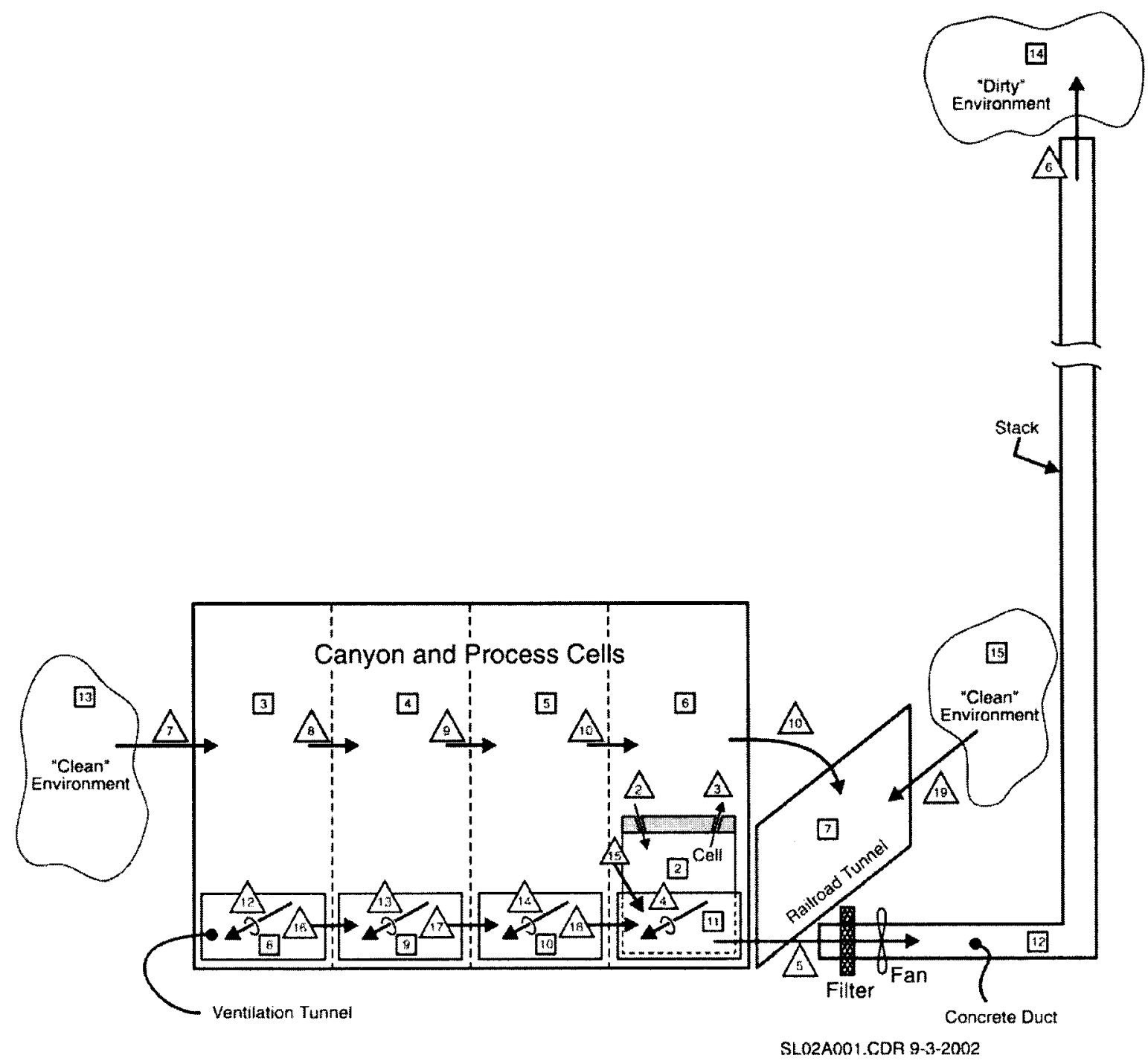




\subsection{CALCULATION}

\subsection{STSC Model Representation}

Figure 6-1 and Figure 6-2 show the FATE model for the STSC and sludge for the cases of settler sludge and container sludge respectively. Table 6-1 and Table 6-2 provide the corresponding list of regions, junctions, and heat sinks. For settler sludge, there is an annular insert that is water-filled in order to reduce the conduction length and the peak sludge temperature. The settler sludge volume is $0.5 \mathrm{~m}^{3}$ in all cases examined here, corresponding to one loaded batch. This insert is not necessary for other container sludge. A volume of $1.6 \mathrm{~m}^{3}$ of $\mathrm{KW}$ container sludge is loaded into the STSC, corresponding to two batches. Twodimensional axisymmetric heat conduction in sludge is modeled using 20 stacks of short disk heat conductors connected vertically for conduction, 10 in the cylindrical part and 10 in the bottom head of STSC. Each heat conductor has 20 radial nodes. Hence, each heat conductor node is approximately $3.7 \mathrm{~cm}$ in radial extent and $7.0 \mathrm{~cm}$ in height.

Corresponding to each sludge heat conductor layer, the STSC wall is modeled as separate heat conductors. Heat generated in the sludge is conducted radially out to the STSC wall, where it is lost by convection and radiation to the cell atmosphere. Heat is also conducted vertically upward to the sludge top, where it is removed by overlying water.

Convection and radiation beneath the skirt are modeled because the holes in the STSC skirt promote effective natural circulation, see Appendix $C$.

Sludge initial composition and properties are based on the assumption that materials stratify upon loading. In this case, sludge is modeled as a series of metal-bearing and metalfree layers, one pair of such layers per batch loaded. The elevations and volumes of the individual sludge heat conductors are selected so cases of varying numbers of batches may be exactly achieved, and so that the volumes of metal-bearing and metal-free layers indicated in Table 3-1 and Table 3-2 can be well-approximated.

Details of selected inputs are discussed in Appendix A. Input files that contain these inputs are listed in Appendix B. 
$\mathrm{FAl} / 10-83$

PRC-STP-00241, Rev 0

Rev. 0

Figure 6-1: FATE Model Representation for the STSC with Settler Sludge.

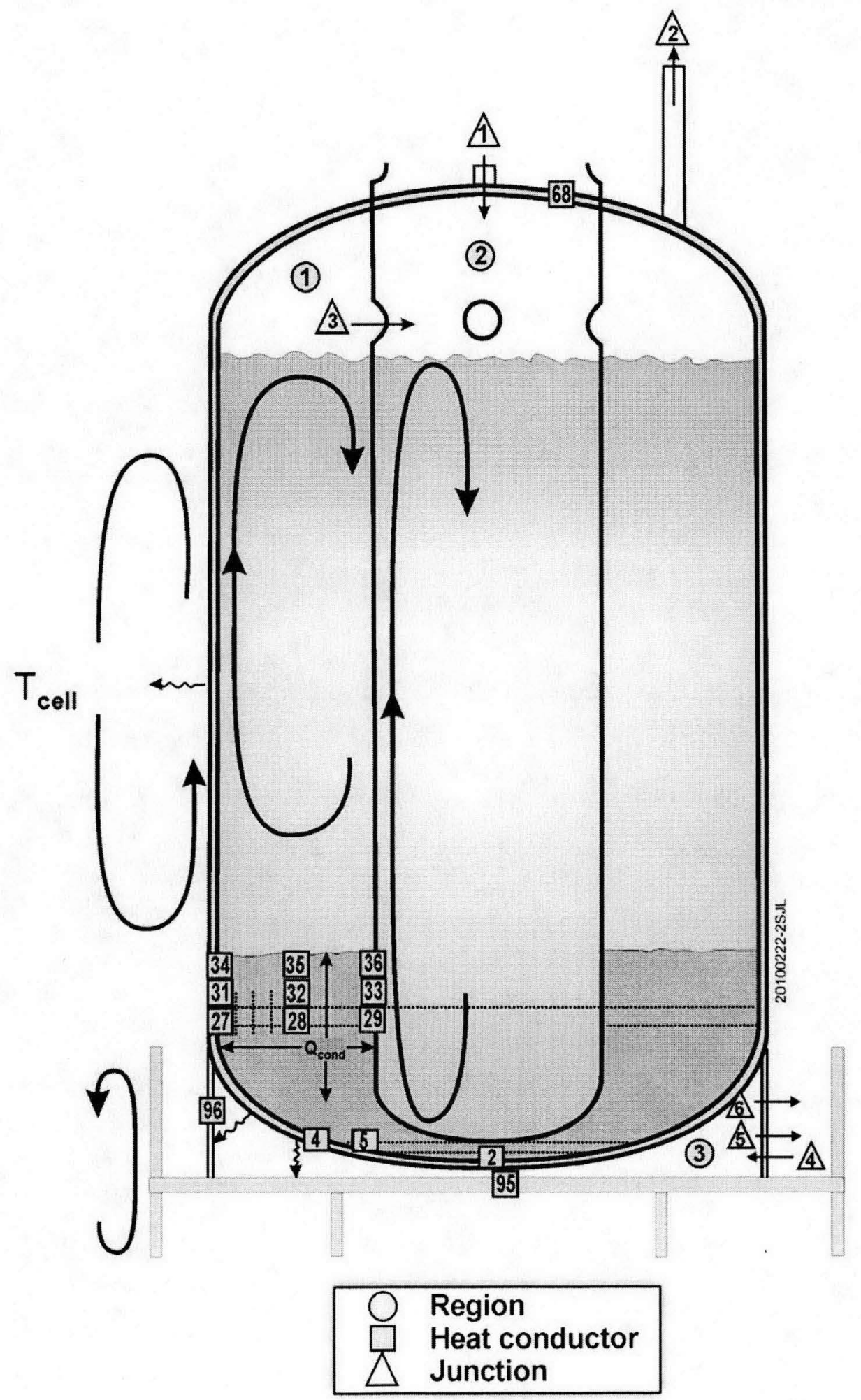


$\mathrm{FAl} / 10-83$

PRC-STP-00241, Rev 0

Rev. 0

Page 41 of 284

March, 2010

Figure 6-2: FATE Model Representation for the STSC with KW Container Sludge.

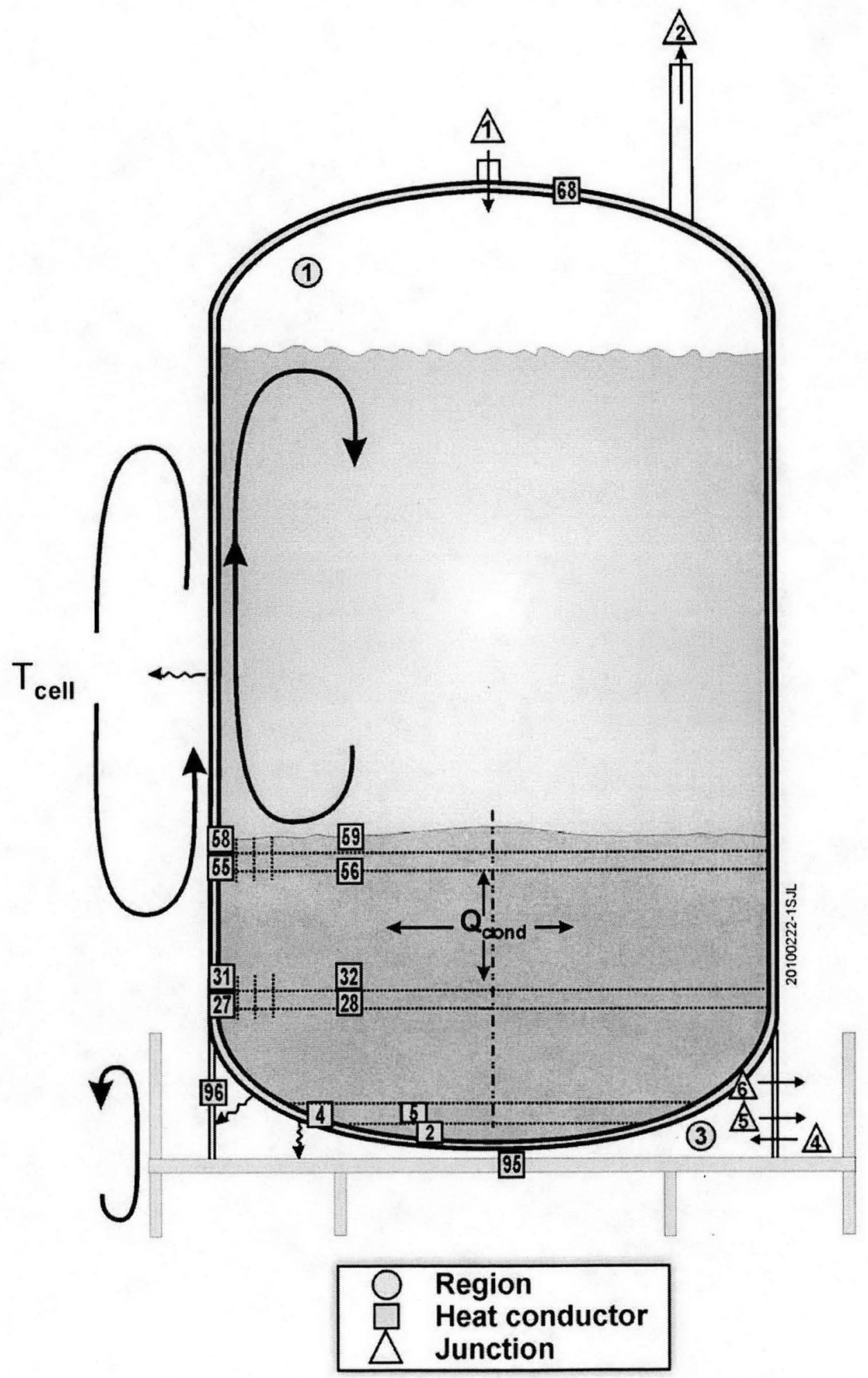


Table 6-1: FATE STSC Nodalization for Settler Sludge

\begin{tabular}{|l|l|}
\hline \multicolumn{2}{|l|}{ Regions } \\
\hline 1 & Main, annular section holding sludge \\
\hline 3 & Insert section \\
\hline \multicolumn{2}{|l|}{ Exterior, Inside Skirt } \\
\hline 1 & Open, unfiltered inlet, cell to insert section \\
\hline 2 & Open, unfiltered outlet, main section to cell \\
\hline 3 & Main to insert section \\
\hline 4 & Cell to inside skirt, bottom half-circular holes \\
\hline 5 & Cell to inside skirt, lower circular holes \\
\hline 6 & Inside skirt to cell, upper circular holes \\
\hline & \\
\hline $1,4,7, \ldots 34$ & STSC bottom head and cylindrical wall adjacent to sludge \\
\hline $2,5,8, \ldots 35$ & Sludge \\
\hline $7,10,13, \ldots 36$ & Insert wall adjacent to sludge \\
\hline 61 & Insert wall above sludge in contact with water and gas \\
\hline 63 & STSC wall above sludge in contact with water and gas \\
\hline 68 & STSC top head \\
\hline 95 & Secondary containment structure in cell \\
\hline 96 & STSC support skirt \\
\hline
\end{tabular}


Table 6-2: FATE STSC Nodalization for KW Floor Sludge

\begin{tabular}{|l|l|}
\hline \multicolumn{2}{|l|}{ Regions } \\
\hline 1 & STSC interior \\
\hline 3 & Exterior, Inside Skirt \\
\hline 1 & Open, unfiltered inlet, cell to STSC interior \\
\hline 2 & Open, unfiltered outlet, STSC interior to cell \\
\hline 4 & Cell to inside skirt, bottom half-circular holes \\
\hline 5 & Cell to inside skirt, lower circular holes \\
\hline 6 & Inside skirt to cell, upper circular holes \\
\hline $1,4,7, \ldots 58$ & STSC bottom head and cylindrical wall adjacent to sludge \\
\hline $2,5,8, \ldots 59$ & Sludge \\
\hline 63 & STSC wall above sludge in contact with water and gas \\
\hline 68 & STSC top head \\
\hline 95 & Secondary containment structure in cell \\
\hline 96 & STSC support skirt \\
\hline
\end{tabular}




\subsection{T Plant Model Representation}

The T Plant model representation is designed to allow cases with and without active ventilation, cases with the detailed STSC model residing in a standard cell or cell $2 R$, and cases with a variable number of cells containing STSCs. In particular, the model is designed to represent the potential for natural convection loops between cells and the canyon in the absence of ventilation. The region and junction nodalization is shown in Figure 6-3 and listed in Table 6-3: FATE T Plant Nodalization, Regions and Junctions. Heat sinks are listed in Table 6-4. Details of selected inputs are discussed in Appendix A. With respect to flow paths (junctions), please note that the direction indicated by arrow heads in figures is nominal, and that the FATE program mechanistically determines not only the direction of flow but whether or not countercurrent flow occurs along the path.

As mentioned above, one STSC is modeled in detail. This STSC may be placed in either a standard cell, Region 6 in Figure 6-3, or cell 2R, Region 11 in Figure 6-3. Sources of heat and hydrogen gas from other STSC are approximated by constant values, see Appendix $A$. The STSC loses heat by convection and radiation to the cell gas, which in turn transfers heat to the walls and cover blocks modeled as one-dimensional heat conductors. Since the floor is cooler, it can be neglected.

Except for cell 2L, each cell region has a cover block flow path to the canyon, and the pipe trench also has a cover block flow path. Standard cells and the pipe trench have 10" flow paths to the ventilation duct. Cells $2 \mathrm{~L}$ and $2 \mathrm{R}$ have 10 " flow paths to a 24 " buried pipe external to the plant. For cases with ventilation, the flows into cell regions and the pipe trench depend upon the cover block resistance input value. For cases without ventilation, the model will automatically calculate flow direction and whether or not there can be countercurrent flow.

Heat sinks assigned to each region are of greater importance in cases without ventilation than with ventilation because heat transfer from air to walls affects the gas density. Cell walls are modeled with external insulated boundary conditions as an approximation. The same applies to the ventilation duct and pipe trench. The wall between cells $2 \mathrm{~L}$ and $2 \mathrm{R}$ is modeled with convection to both cells. The 24 " pipe wall and surrounding ground are represented. 
PRC-STP-00241, Rev 0

FAl/10-83

Rev. 0

Page 45 of 284

March, 2010

Figure 6-3: T Plant Model Representation, Regions and Junctions.

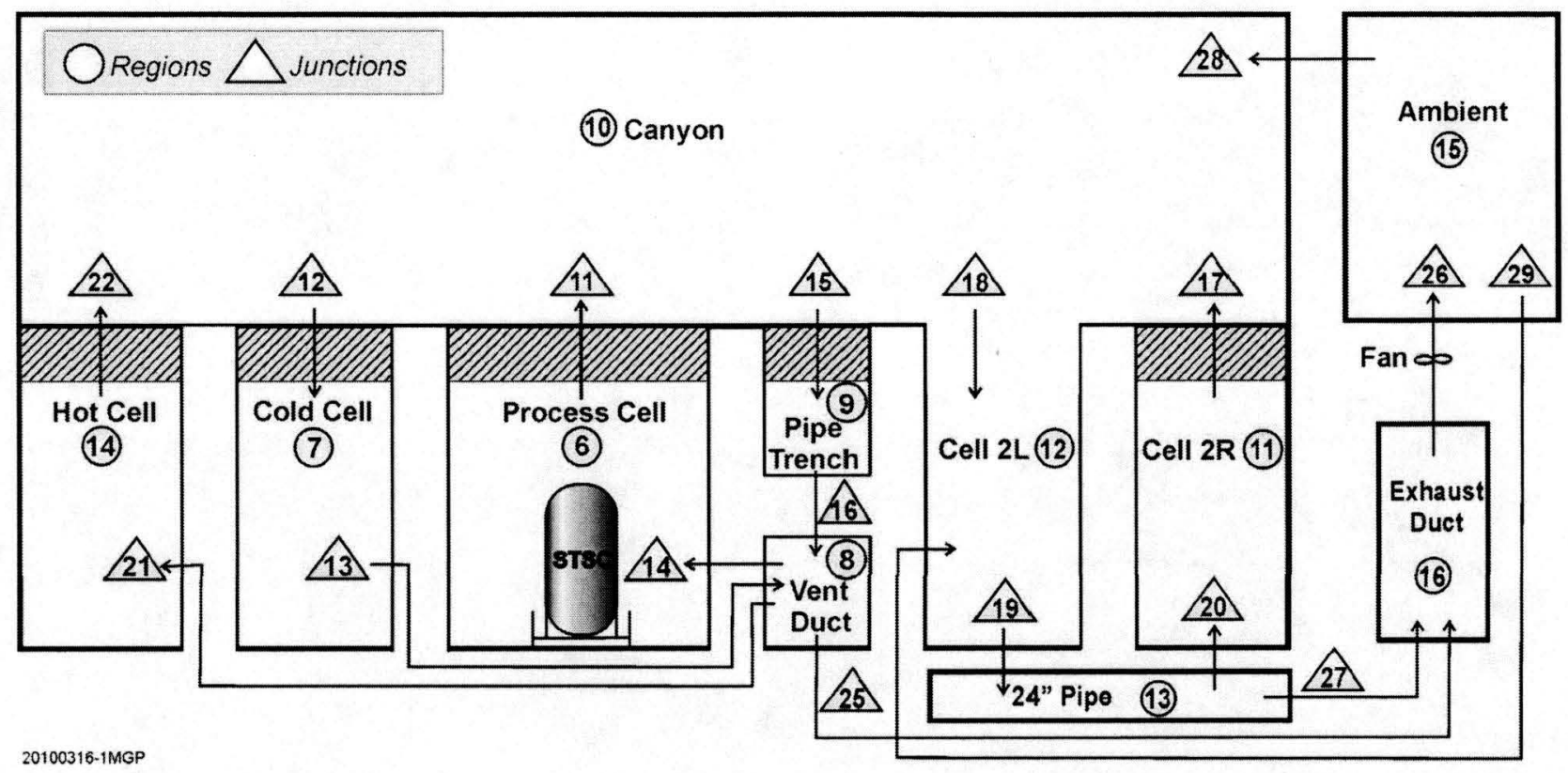

A-45 
Table 6-3: FATE T Plant Nodalization, Regions and Junctions

\begin{tabular}{|c|c|}
\hline \multicolumn{2}{|r|}{ Regions } \\
\hline 6 & Standard process cell, holds "active" STSCs for standard cell cases \\
\hline 7 & Cold (empty) standard process cells \\
\hline 8 & Ventilation duct \\
\hline 9 & Pipe trench \\
\hline 10 & Canyon \\
\hline 11 & Cell $2 \mathrm{R}$, holds STSCs for long cell cases \\
\hline 12 & Cell 2L \\
\hline 13 & 24 " duct segment connecting cells $2 \mathrm{~L}$ and $2 \mathrm{R}$ \\
\hline 14 & Hot (holding other STSCs) standard process cells \\
\hline 15 & Ambient \\
\hline 16 & Exhaust duct used for cases with ventilation \\
\hline \multicolumn{2}{|r|}{ Junctions } \\
\hline 11 & Process cell to canyon, cover block gaps \\
\hline 12 & Canyon to cold cells, cover block gaps \\
\hline 13 & Cold cells to ventilation duct, $10^{\prime \prime}$ path \\
\hline 14 & Ventilation duct to process cell, 10 " path \\
\hline 15 & Canyon to pipe trench, cover block gaps \\
\hline 16 & Pipe trench to ventilation duct, 10 " path \\
\hline 17 & Cell $2 R$ to canyon, cover block gaps \\
\hline 18 & Canyon to cell $2 \mathrm{~L}$, open area \\
\hline 19 & Cell $2 \mathrm{~L}$ to 24 " duct segment, 10 " path \\
\hline 20 & 24 " duct segment 10 cell $2 \mathrm{R}, 10$ " path \\
\hline 21 & Ventilation duct to hot standard cells \\
\hline 22 & Hot standard cells to canyon \\
\hline 25 & Ventilation duct to exhaust duct \\
\hline 26 & Exhaust duct to ambient, fan junction \\
\hline 27 & 24 " duct segment to exhaust duct \\
\hline 28 & Leakage from ambient to canyon \\
\hline 29 & Leakage from ambient to cell $2 \mathrm{~L}$ through railroad tunnel \\
\hline
\end{tabular}


Table 6-4: FATE T Plant Nodalization, Heat Sinks

\begin{tabular}{|l|l|}
\hline \multicolumn{2}{|l|}{ Heat Sinks } \\
\hline 101 & Process cell (6) "long side" walls to neighbor cells (insulated) \\
\hline 102 & Process cell (6) "short side" walls to galleries and trenches (insulated) \\
\hline 103 & Process cell (6) cover blocks, convects to canyon \\
\hline 106 & Cold cell (7) "long side" walls to neighbor cells (insulated) \\
\hline 107 & Cold cell (7) "short side" walls to galleries and trenches (insulated) \\
\hline 108 & Cold cell (7) cover blocks, convects to canyon \\
\hline 111 & Cell 2R (11) "long side" wall to standard cells (insulated) \\
\hline 112 & Cell 2R (11) "short side" walls to galleries and ground (insulated) \\
\hline 113 & Cell 2R (11) cover blocks, convects to canyon \\
\hline 114 & Cell 2R (11) "long side" wall to cell 2L, convects to 2L \\
\hline 116 & Cell 2L (12) "long side" wall to cell 1L (insulated) \\
\hline 117 & Cell 2L (12) "short side" walls to galleries and ground (insulated) \\
\hline 121 & Ventilation duct (8) lengthwise walls (insulated) \\
\hline 122 & Pipe trench (9) lengthwise walls (insulated) \\
\hline 123 & Pipe trench (9) cover blocks, convects to canyon \\
\hline 124 & Wall of 24" pipe connecting 2L and 2R, sandwiched to ground \\
\hline 125 & Ground outside 24" pipe \\
\hline 126 & Hot cell (14) "long side" walls to neighbor cells (insulated) \\
\hline 127 & Hot cell (14) "short side" walls to galleries and trenches (insulated) \\
\hline 128 & Hot cell (14) cover blocks, convects to canyon \\
\hline 131 & Canyon (10) lower section lengthwise exterior wall, convects to ambient \\
\hline 132 & Canyon (10) upper section lengthwise exterior walls, convects to ambient \\
\hline
\end{tabular}




\subsection{Sludge Interim Storage Cases}

Table 6-5 lists the cases calculated. There are three main attributes distinguishing the cases:

1. Sludge type, volume, and STSC geometry. For settler sludge the volume is always $0.5 \mathrm{~m}^{3}$ and the STSC geometry includes the insert per Figure 6-1. For KW container sludge the volume is always $1.6 \mathrm{~m}^{3}$ and the STSC does not have an insert, Figure 6-2.

2. Cell containing the STSC. The STSC is placed in either a standard cell from the cell range 3 through 20 inclusive (region 6 of Figure 6-3), or else in cell 2R (region 11 of Figure 6-3). There are always 6 STSCs in a standard cell and 8 STSCs in a long cell.

3. I Plant Ventilation. Cases with and without $T$ Plant ventilation are considered. With ventilation, the ventilation rate per cell is determined by the relative flow resistances as discussed in Appendix $A$. With no ventilation, the stack effect for $T$ Plant is conservatively ignored, so that there is no overall inflow to the canyon, through the cells, and up the stack. While this is conservative, it is also a potentially real situation depending upon the relative ambient and interior temperatures and pressures. The model will predict natural circulation flows between cells and the canyon based upon input flow resistances and elevations, and density differences that evolve during the calculation.

In all cases, the following attributes are identical:

1. Sludge is stratified into metal-bearing and metal-free layers per added batch.

2. Safety basis sludge properties are used.

3. Overlying water is filled to the level given in Figure 3-1.

4. The $\mathrm{U}-\mathrm{H}_{2} \mathrm{O}$ rate law multiplier is set to the safety basis value of 3.0 .

5. Sources of heat and hydrogen generation from additional STSCs in a process cell are approximated by constant values, see Appendix A. 


\subsection{RESULTS AND CONCLUSIONS}

\subsection{Results Description}

Calculation results are summarized in Table 7-1. Transient results plots provide histories of process variables, with three pages per case as listed in the table. Comparisons between peak quantities are shown in Figure 7-1 through Figure 7-3.

In all cases the transient duration simulated is 20 days. This duration is sufficient to allow maxima in sludge temperature, hydrogen generation rate, and STSC and cell hydrogen concentrations. Transient plots per case, listed in Table 7-1, present the following general information, and case-specific comments will follow this list:

Page 1, Upper Left: Gas concentration in the STSC.

Page 1, Upper Right: Sludge temperature, ${ }^{\circ} \mathrm{C}$.

Page 1, Lower Left: Gas, water, and cell wall temperatures, ${ }^{\circ} \mathrm{C}$.

Page 1, Lower Right: Gas flow through the STSC vent, $\mathrm{kg} / \mathrm{s}$. Since the gas density is about $1 \mathrm{~kg} / \mathrm{m}^{3}$, this is numerically about the volumetric flow rate in $\mathrm{m}^{3} / \mathrm{s}$.

Page 2, Upper Left: Sludge heat source, W.

Page 2, Upper Right: Cases with ventilation, canyon pressure, $\mathrm{Pa}$ (to convert to inches water gage, divide by 249). Cases without ventilation, gas flow rate through cover blocks, $\mathrm{kg} / \mathrm{s}$ (to convert to $\mathrm{cfm}$, multiply by approximately 2100 ).

Page 2, Lower Left: Hydrogen source rate, L/day. The STSC headspace is about $470 \mathrm{~L}$, and cell free volume is about $114 \mathrm{~m}^{3}$.

Page 2, Lower Right: Cell gas concentrations.

Page 3, Upper Left: Gas temperatures in canyon and cells.

Page 3, Upper Right: Gas flows within T-Plant.

Page 3, Lower Left: Gas temperatures in ambient and vent paths.

Page 3, Lower Right: Gas flow between T-Plant and environment (e.g. air infiltration). 
$\mathrm{FAl} / 10-83$

Rev. 0
PRC-STP-00241, Rev 0

Page 51 of 284

March, 2010

Table 7-1: Transient Results Summary for KW Floor Sludge Shipping in an STSC.

\begin{tabular}{|c|c|c|c|c|c|c|c|c|}
\hline Case & Name & $\begin{array}{l}\text { Thermal } \\
\text { Stability }\end{array}$ & $\begin{array}{c}\text { Peak Sludge } \\
\text { Temperature }\left[{ }^{\circ} \mathrm{C}\right]\end{array}$ & $\begin{array}{c}\text { Peak Power } \\
\text { [W] }\end{array}$ & $\begin{array}{c}\text { Peak } \mathrm{H}_{2} \text { Rate } \\
\text { [liter/day] }\end{array}$ & $\begin{array}{c}\text { Peak } \mathrm{H}_{2} \\
\text { Concentration } \\
\text { in Cell [\%] }\end{array}$ & $\begin{array}{c}\text { Peak } \mathrm{H}_{2} \\
\text { Concentration in } \\
\text { STSC }[\%]\end{array}$ & Figures \\
\hline $1 a$ & CONTRF1 & Stable & $60^{\circ} \mathrm{C}$ at $16 \mathrm{~d}$ & 195 & 830 & $<0.1$ & 1.6 & $7-4,5,6$ \\
\hline $1 \mathrm{~b}$ & CONTLF1 & Stable & $58^{\circ} \mathrm{C}$ at $16 \mathrm{~d}$ & 190 & 770 & $<0.1$ & 1.5 & $7-7,8,9$ \\
\hline $2 a$ & CONTRN1 & Stable & $72^{\circ} \mathrm{C}$ at $15 \mathrm{~d}$ & 270 & 1300 & 1.0 & 3.3 & $7-10,11,12$ \\
\hline $2 b$ & CONTLN1 & Stable & $67^{\circ} \mathrm{C}$ at $16 \mathrm{~d}$ & 240 & 1150 & 1.5 & 3.1 & $7-13,14,15$ \\
\hline $3 a$ & SETTRF1 & Stable & $53^{\circ} \mathrm{C}$ at $8 \mathrm{~d}$ & 190 & 670 & $<0.1$ & 1.3 & $7-16,17,18$ \\
\hline $3 b$ & SETTLF1 & Stable & $52^{\circ} \mathrm{C}$ at $8 \mathrm{~d}$ & 190 & 640 & $<0.1$ & 1.4 & $7-19,20,21$ \\
\hline $4 a$ & SETTRN1 & Stable & $61^{\circ} \mathrm{C}$ at $9 \mathrm{~d}$ & 230 & 960 & 1.0 & 2.8 & $7-22,23,24$ \\
\hline $4 b$ & SETTLN1 & Stable & $57^{\circ} \mathrm{C}$ at $10 \mathrm{~d}$ & 210 & 830 & 1.5 & 3.0 & $7-25,26,27$ \\
\hline
\end{tabular}


FAl/10-83

PRC-STP-00241, Rev 0

Rev. 0

Page 52 of 284

March, 2010

Figure 7-1: Peak Hydrogen Concentration in Cell

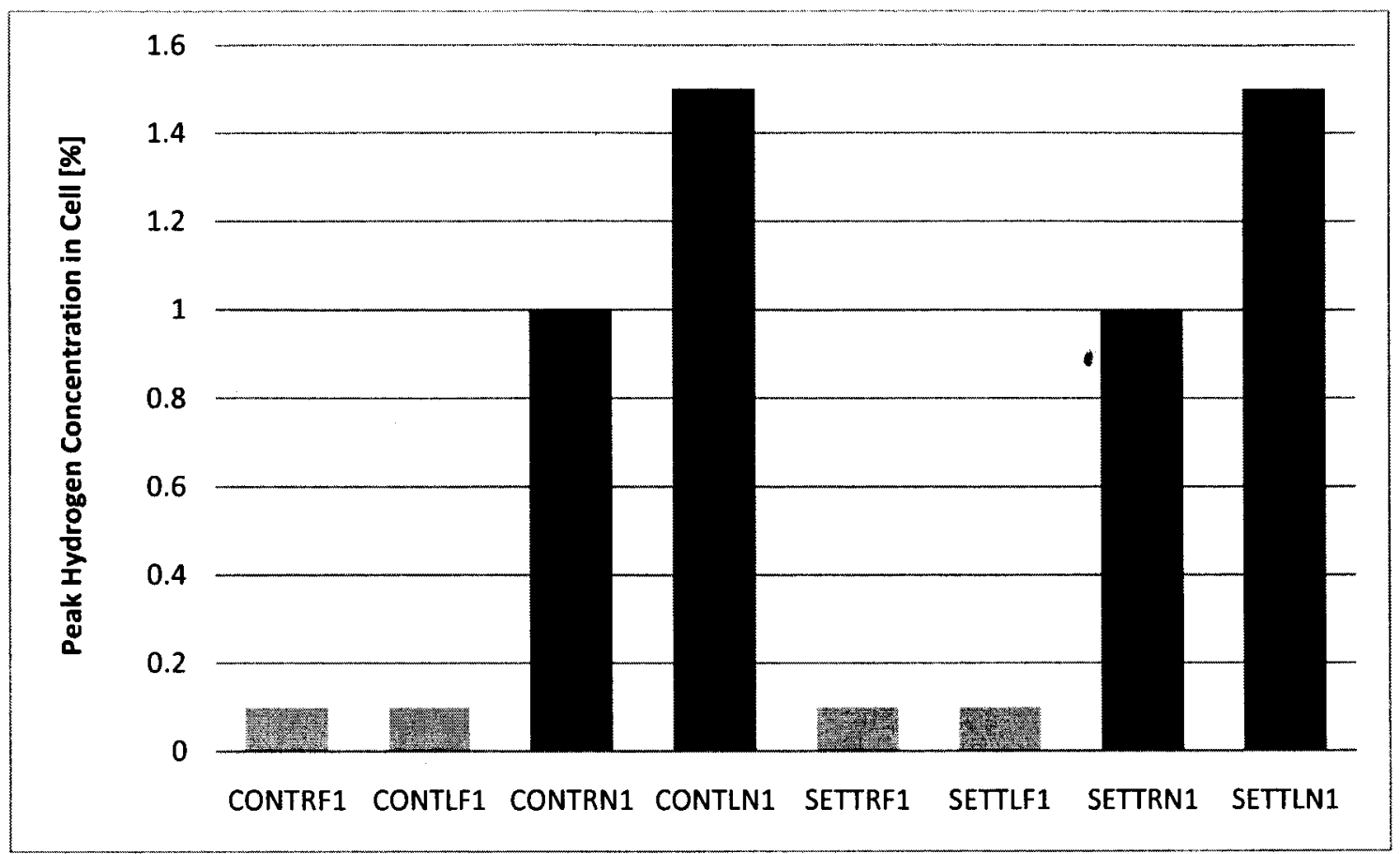

Figure 7-2: Peak Sludge Temperature

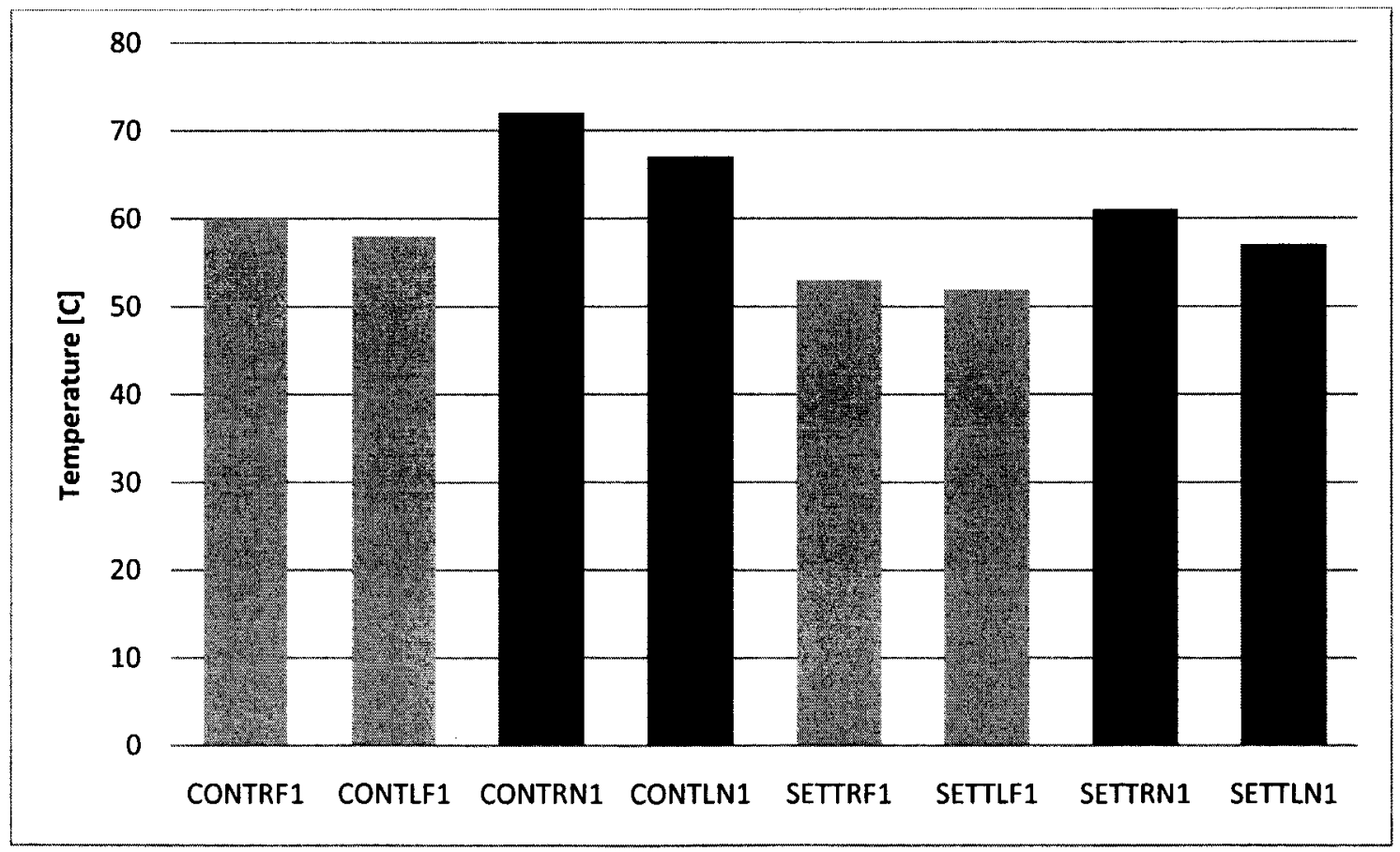


Figure 7-3: Peak Total Power in STSC

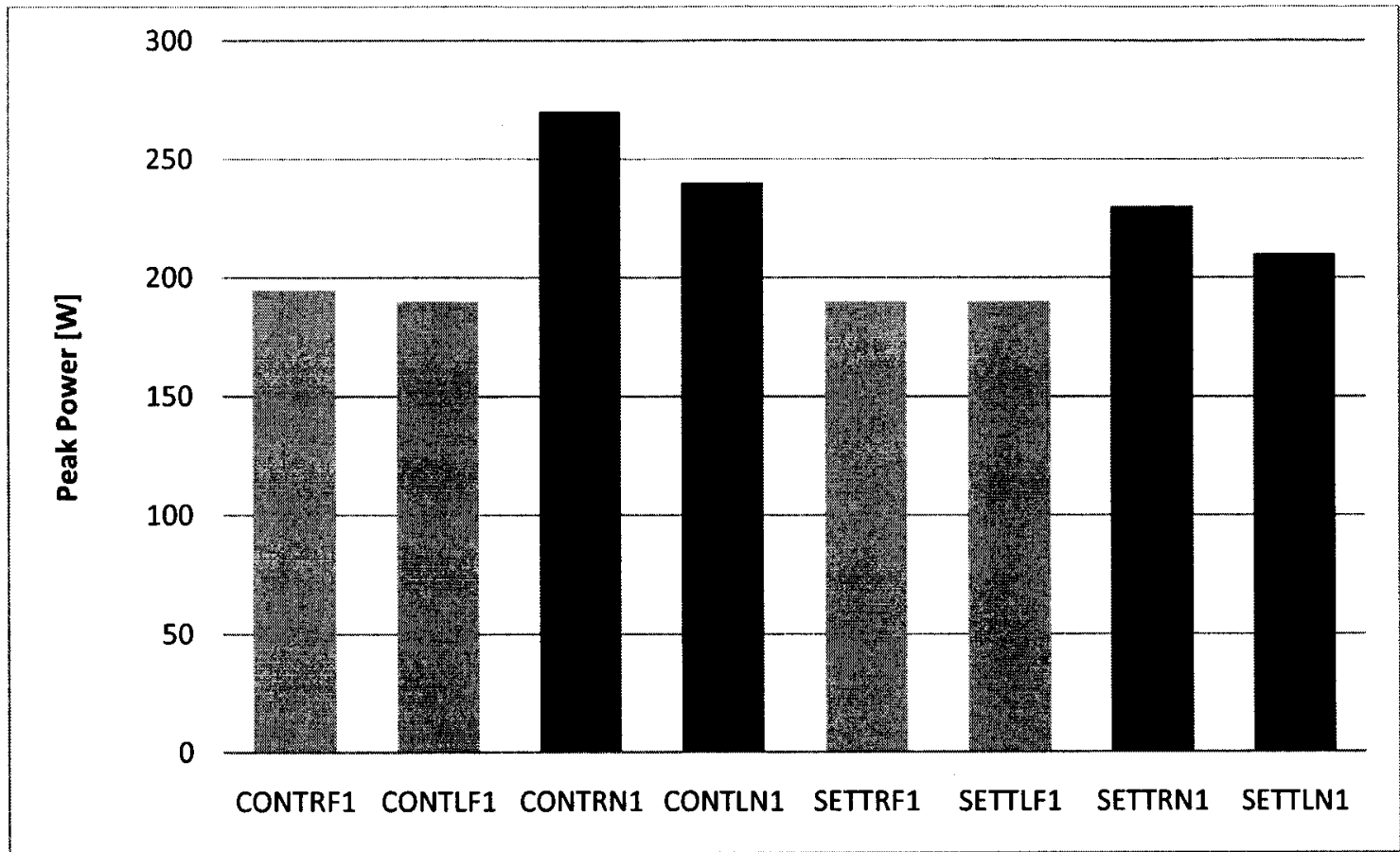

KW container sludge cases with ventilation CONTRF1 (standard cell) and CONTLF1 (long cell) progress in virtually the same manner, differing only slightly in absolute quantities (temperature, hydrogen concentration, etc.); see Figure 7-4 through Figure 7-9. Temperatures slowly rise with peak sludge temperature peaking at $60^{\circ} \mathrm{C}$ at around 16 days. The hydrogen generation rate peaks at about 15 days, and the hydrogen concentration in the STSC peaks around $1.6 \%$. The reason for maxima in temperatures and hydrogen concentrations is that uranium metal is consumed by the oxidation reaction. Reaction rates increase with temperature but decrease as metal is consumed.

Hydrogen does not accumulate in the cell in any appreciable amount for these cases with ventilation. The ventilation flow is about $450 \mathrm{cfm}$ per cell. This ventilation rate may be somewhat overestimated, because the pipe trench flow should be about half the total flow into the standard cells, but it is lower than expected. This is likely due to the given the cover block gap assumptions, but revising the relative flow resistances will not influence the overall conclusions. Gas and water temperatures exhibit periodic variation due to ambient diurnal temperature variation. A similar but lesser variation occurs in STSC gas concentrations. After 15 days, the water temperature sometimes exceeds the gas temperature, so that increased evaporation affects the steam concentration. 
The corresponding cases without ventilation CONTRN1 and CONTLN1 are also very similar to each other; see Figure 7-10 through Figure 7-15. The main differences between these "fans off" cases and the previous "fans on" cases (CONTRF1 and CONTLF1) are the accumulation of steam and hydrogen in the cell (up to $1.5 \% \mathrm{H}_{2}$ ) and the earlier, higher peaks in temperature, power, and hydrogen generation rate. The sludge temperature in fans off cases is about $10^{\circ} \mathrm{C}$ higher than in fans on cases.

In these cases without ventilation, hydrogen generated in the process cell and the other hot cells containing STSCs is lost by upflow to the canyon (see for example Figure 7-12, upper right). This flow is partially supplied by downflow from the canyon to cold standard cells and then into the ventilation duct, and partially by downflow through cell $2 \mathrm{~L}$ and via the 24 inch pipe and exhaust duct to the ventilation duct. The contribution from cell $2 \mathrm{~L}$ is comparable to that of all the cold standard cells combined because cell $2 \mathrm{~L}$ has no cover block resistance. It is interesting to note that exchange flow between the canyon and ambient through infiltration paths has no net effect on internal circulation in these fans-off cases.

Settler sludge cases with ventilation SETTRF1 (standard cell) and SETTLF1 (long cell) exhibit peak sludge temperatures about $10^{\circ} \mathrm{C}$ lower than in the $\mathrm{KW}$ container sludge cases, and peaking at earlier at around 8 days at $52-53^{\circ} \mathrm{C}$ (see Figure $7-16$ through Figure 7-21.) Fans provide adequate ventilation to prevent an appreciable quantity of hydrogen from building up in the cell. The two cases are very similar in progression and timing. As with container sludge cases, diurnal ambient temperature variation influences the gas and water temperatures, and the STSC steam concentration is affected by evaporation as well.

Corresponding cases without ventilation SETTRN1 and SETTLN1 (see Figure 7-22 through Figure $7-27$ ) show temperatures rising about $10^{\circ} \mathrm{C}$ higher than in fans on cases, also at around 8 days. The hydrogen concentration in the STSC peaks at about the same time ranging between $2.8 \%$ and $3.0 \%$, depending on cell size. Due to the insert, there is in general more heat transfer from sludge to water in settler sludge cases than in $\mathrm{KW}$ container cases, and without ventilation the water temperature exceeds the STSC gas temperature after about 8 days, leading to increased evaporation.

Ventilation availability plays the largest role in STSC thermal response. T-Plant ventilation is capable of cooling STSCs and removing hydrogen from the cell atmosphere. Without ventilation, the STSCs heat up more, and natural circulation through cover blocks is required to remove it from the cell.

The character of the sludge - volume, number of batches loaded, and material composition - plays the next most significant role in determining the thermal behavior of an STSC. The single-batch loading of settler sludge concentrates uranium metal in the lower head of the STSC where heat transfer is the lowest.

Cell size has the least effect on STSC thermal stability. Larger cells have more heat transfer area to the T-Plant's thick concrete walls which tends to remove more heat in cases without ventilation. The increased cell volume dilutes hydrogen released from the STSC, leading to a denser atmosphere than the standard cells in no ventilation cases. In the cases 
with ventilation, the heat load from the additional older STSCs tends to slightly increase the cell and sludge temperature.

This is the first calculation of sludge behavior at T Plant to employ a detailed building model that considers standard cells in various states, the long cells, and the pipe trench, and allows for natural circulation between the canyon and groups of cells. Actual flow and pressure balance conditions used at $T$ Plant during contemporary operation may differ from what is documented in earlier references. Cover block gap resistances are based upon old specifications and selected field measurements of gaps at deck level. The flow split between cells with fans on and the circulation patterns and rates with fans off are affected by assumptions that underlie the flow resistance values input to the model. Also, circulation patterns and hydrogen concentrations with fans off are affected by the assumed number of STSCs in a given cell and the number of cells containing STSCs, because these affect cell gas densities via their heat and hydrogen sources. It is also possible that the initial cell conditions, reflecting time of year and the thermal lag between the ambient, canyon, and cells, could influence the flow pattern for fans-off cases. The assumptions built into the T Plant model and fans-off scenarios require further review to ensure that conservative selections have been made.

\subsection{Conclusions}

Conclusions of from the discussion of results are:

1. Sludge is thermally stable in all cases considered.

2. The cell and STSC hydrogen concentrations never exceed $4 \%$ for all cases.

3. The most important effect on results is ventilation versus no ventilation.

4. Results are nearly identical for standard cell and long cell cases; this is the least significant effect.

5. The worst cases examined are for container sludge with no ventilation, cases $2 a$ and $2 b$, CONTRN1 and CONTLN1. For CONTRN1 the peak hydrogen concentration is $1.0 \%$ in the cell and $3.3 \%$ inside the STSC, and the peak sludge temperature is $72^{\circ} \mathrm{C}$ which occurs at day 15 of the scenario. The cell hydrogen concentration is slightly higher for CONTLN1, about $1.5 \%$.

6. T plant flow conditions, flow resistances, and assumptions for fans-off scenarios should be reviewed to ensure that the contemporaneous configuration is correctly represented and that conservative scenarios have been identified.

\subsection{Transient Results Figures}

Transient results figures appear on the following pages. 
FAl/10-83

Rev. 0
PRC-STP-00241, Rev 0

Page 56 of 284

March, 2010

Figure 7-4: Case CONTRF1 Transient Results History (1 of 3)
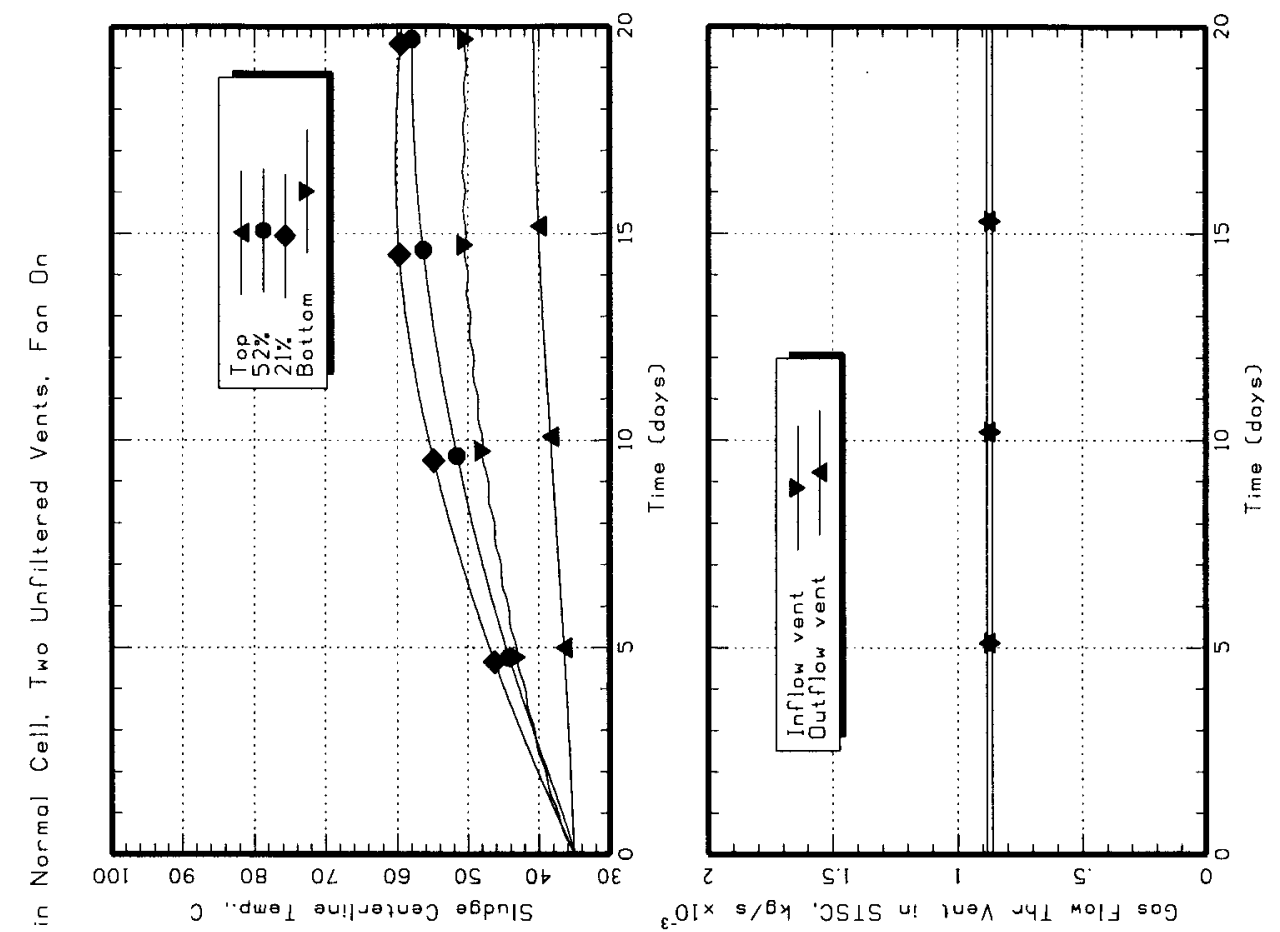

o
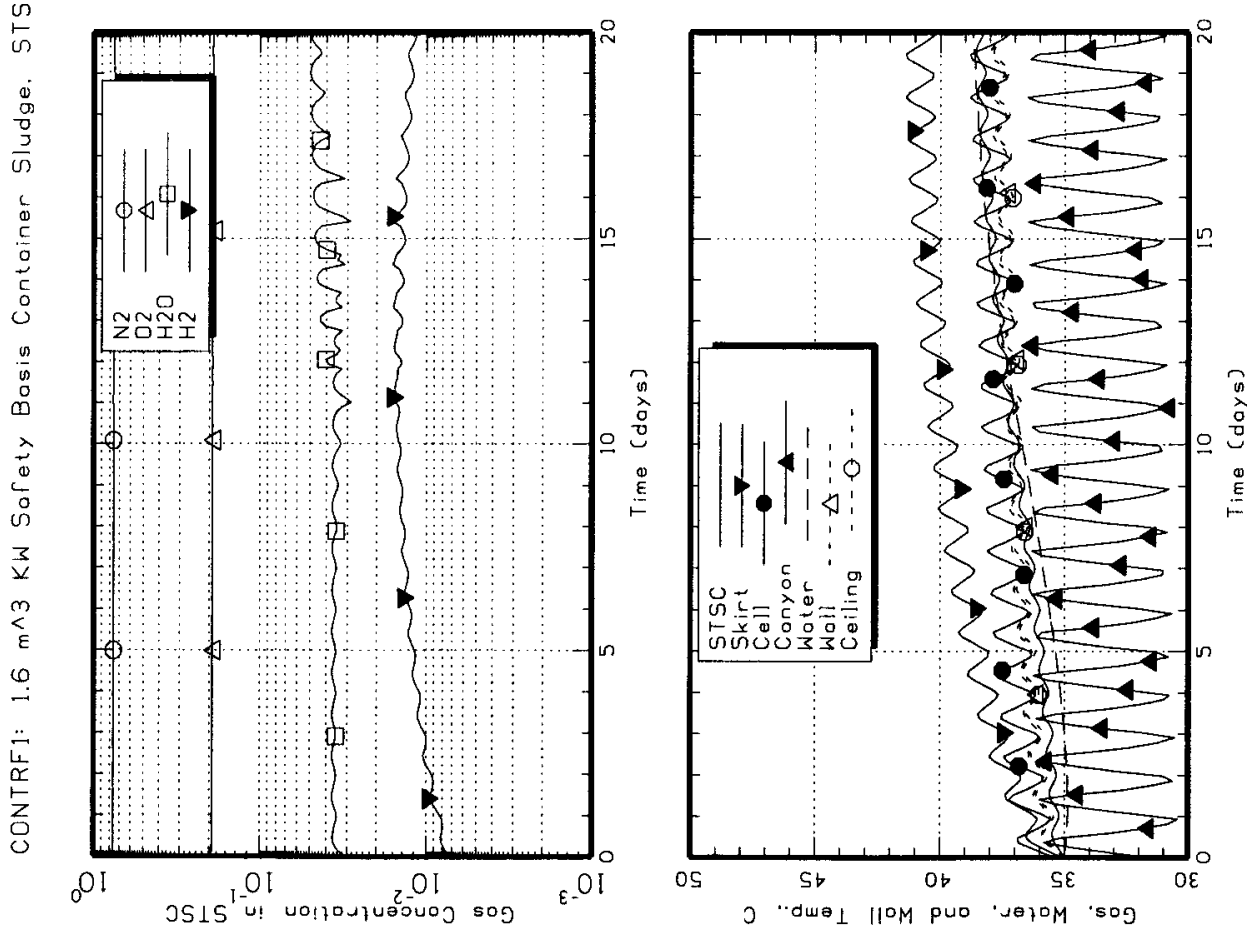
FAl/10-83

PRC-STP-00241, Rev 0

Rev. 0

Page 57 of 284

March, 2010

Figure 7-5: Case CONTRF1 Transient Results History (2 of 3)
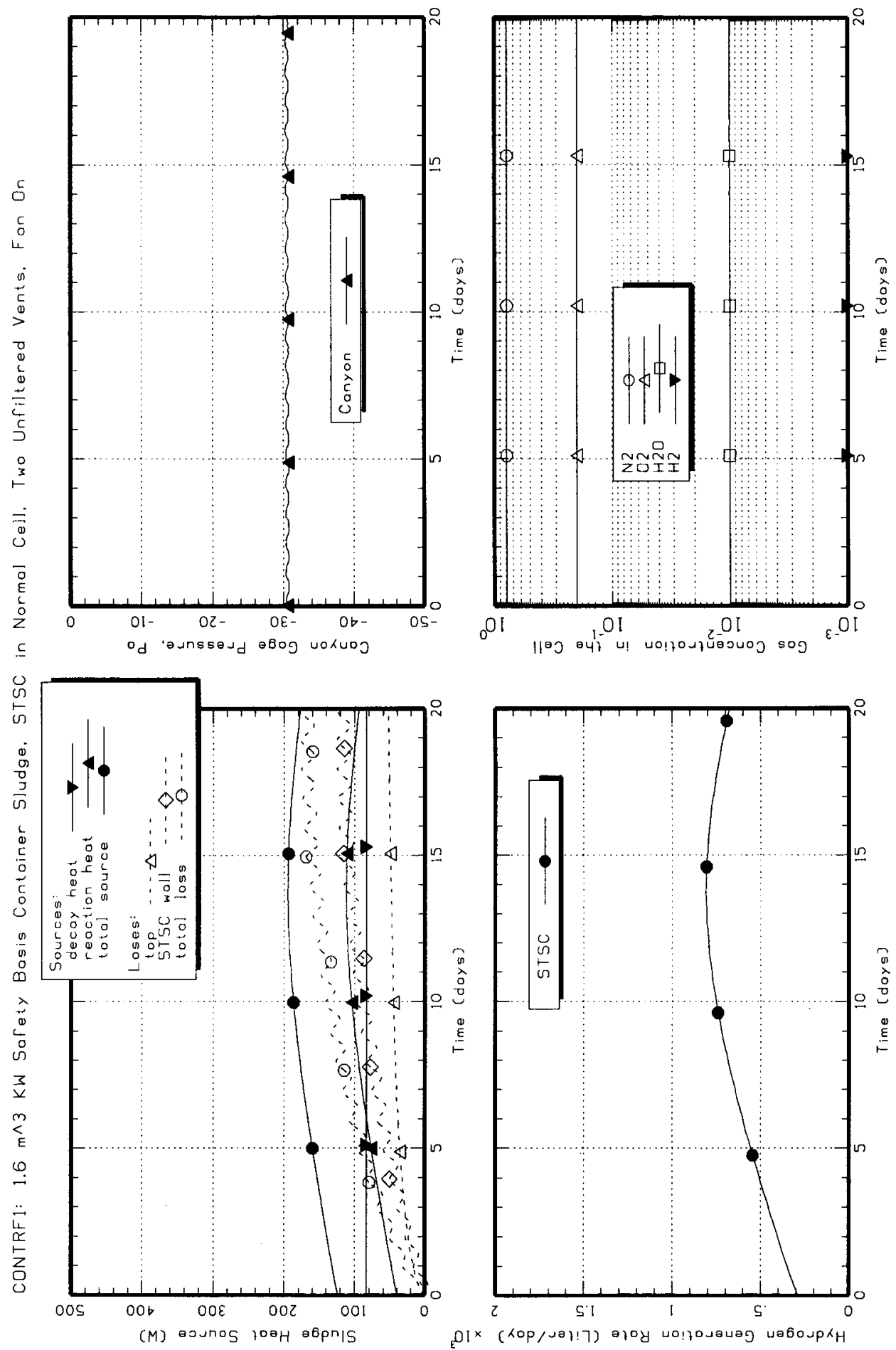
CONTRF1: $1.6 m^{\wedge} 3 \mathrm{KW}$ Safety Bosis Contoiner Sludge. STSC in Normal Cell. Two Unfiltered Vents. Fon On
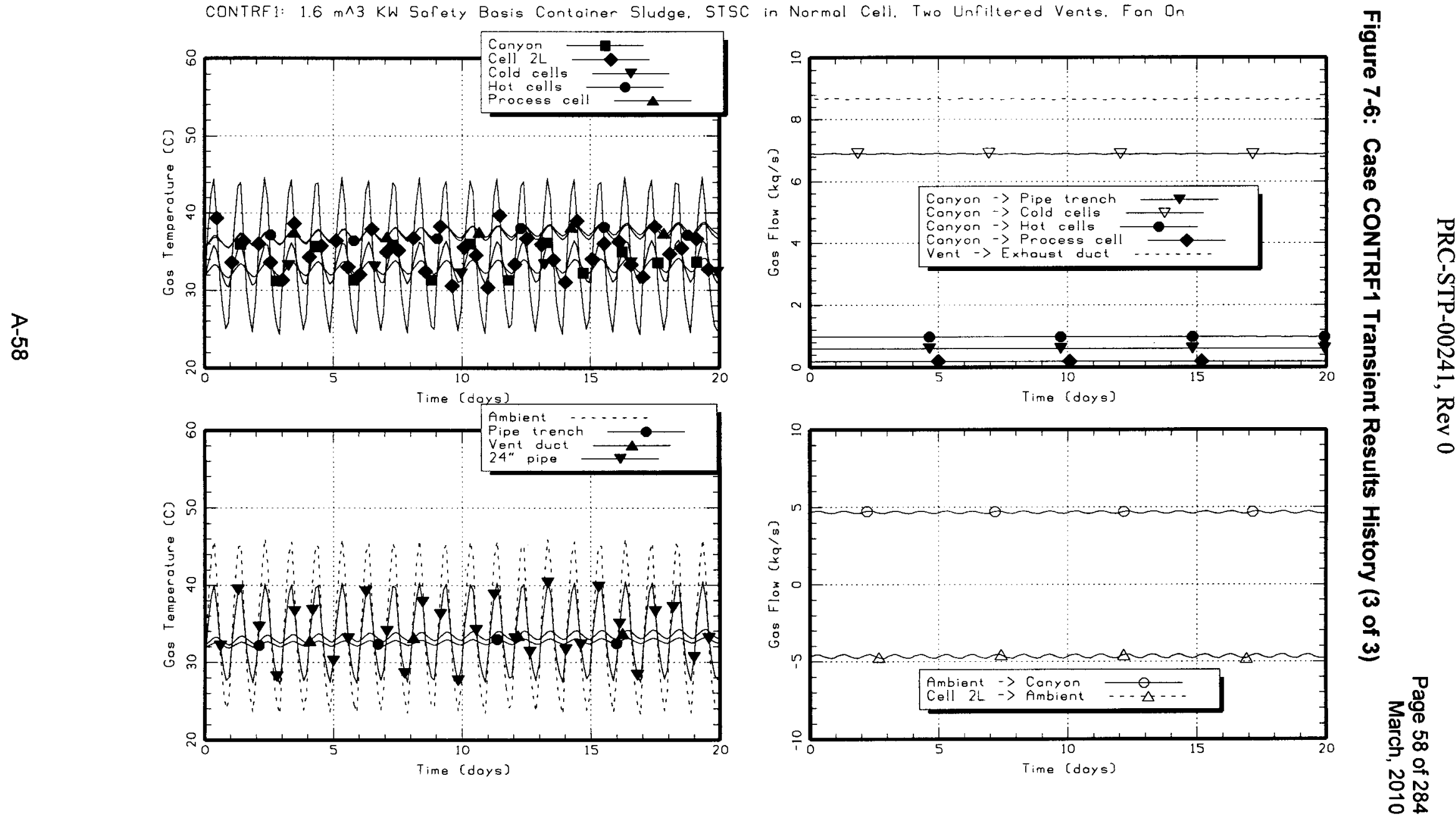
Figure 7-7: Case CONTLF1 Transient Results History (1 of 3)

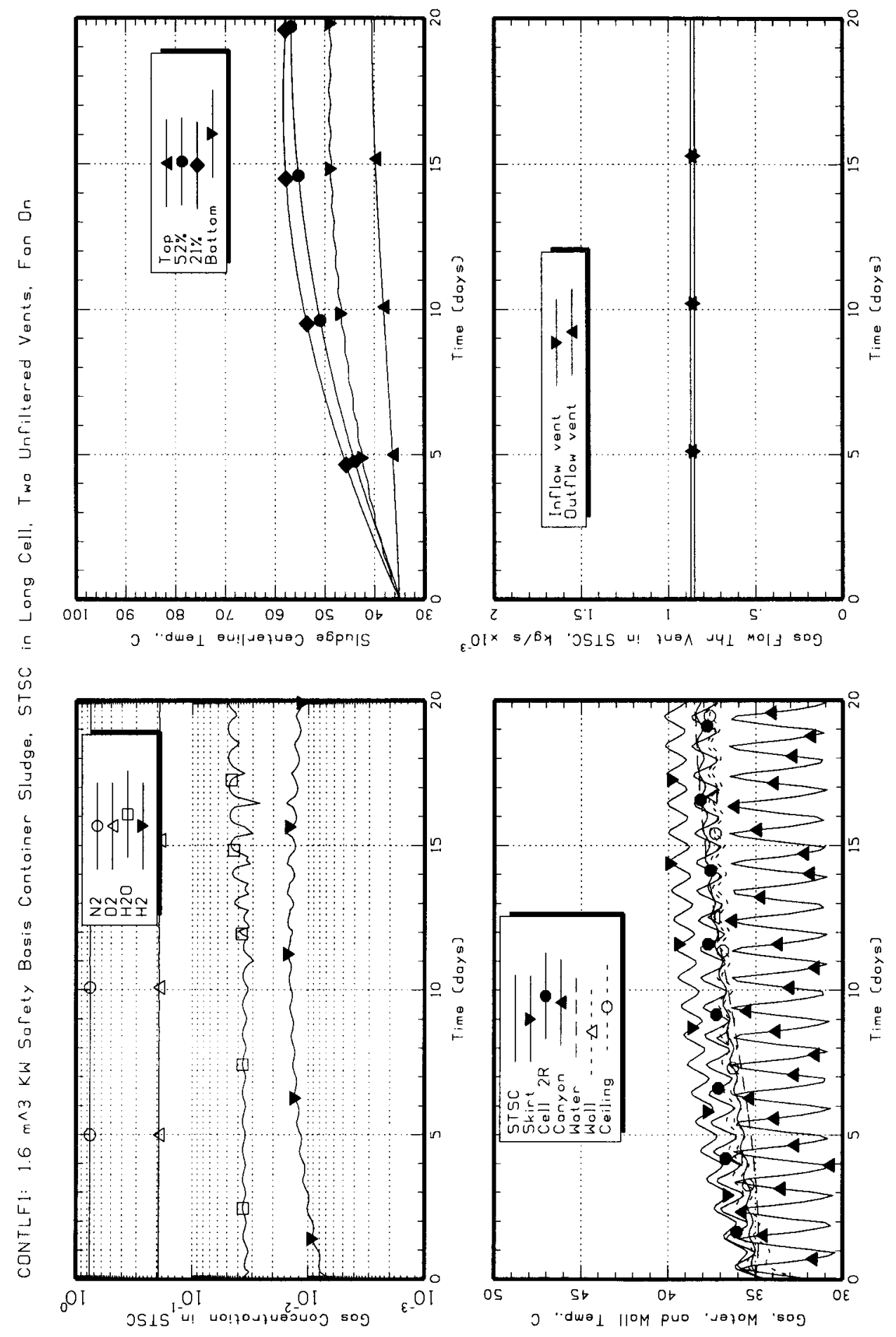



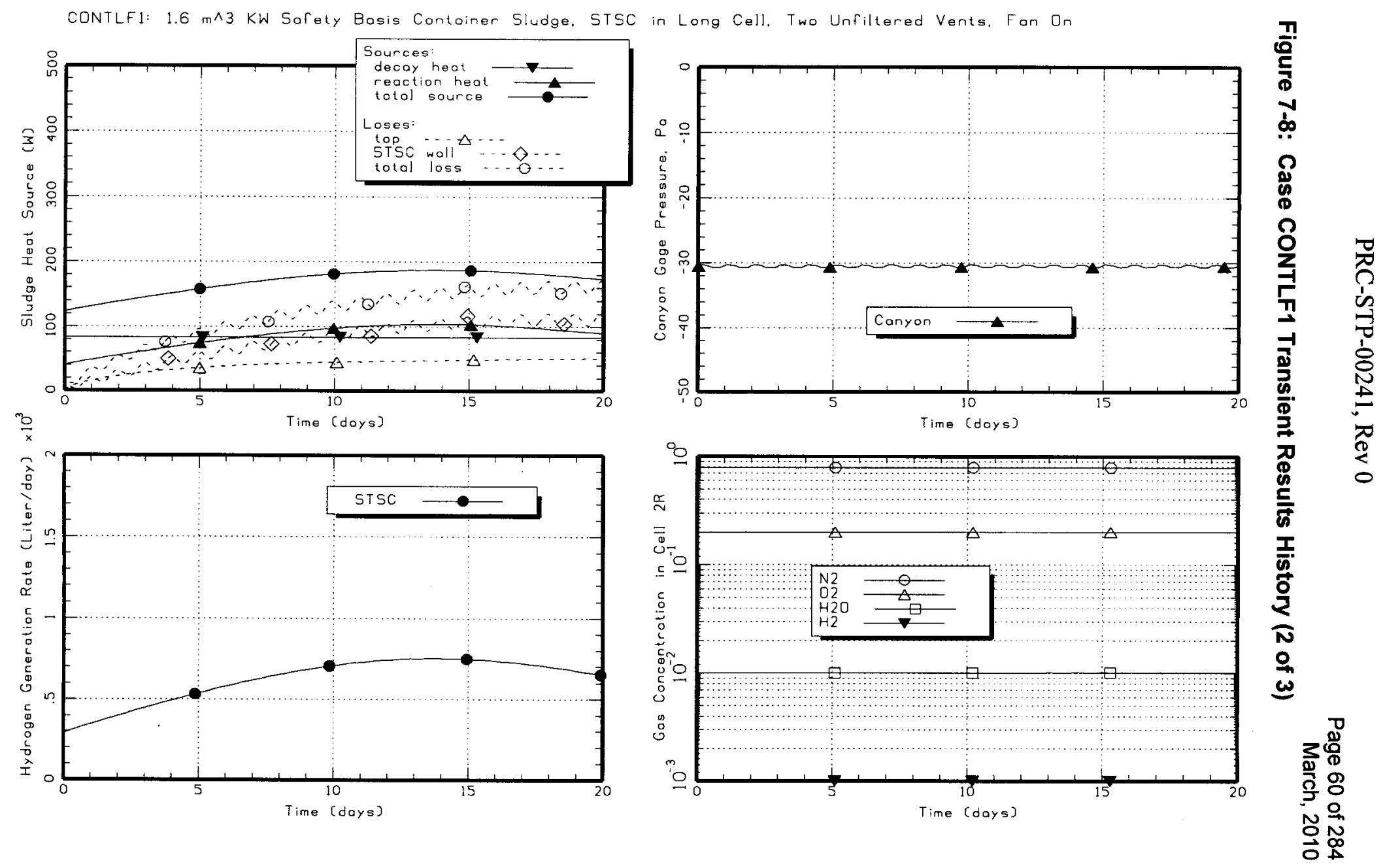
CONTLF1: 1.6 m^3 KW Sofety Bosis Container Sludge, STSC in Long Cell, Two Unfiltered Vents. Fan Dn
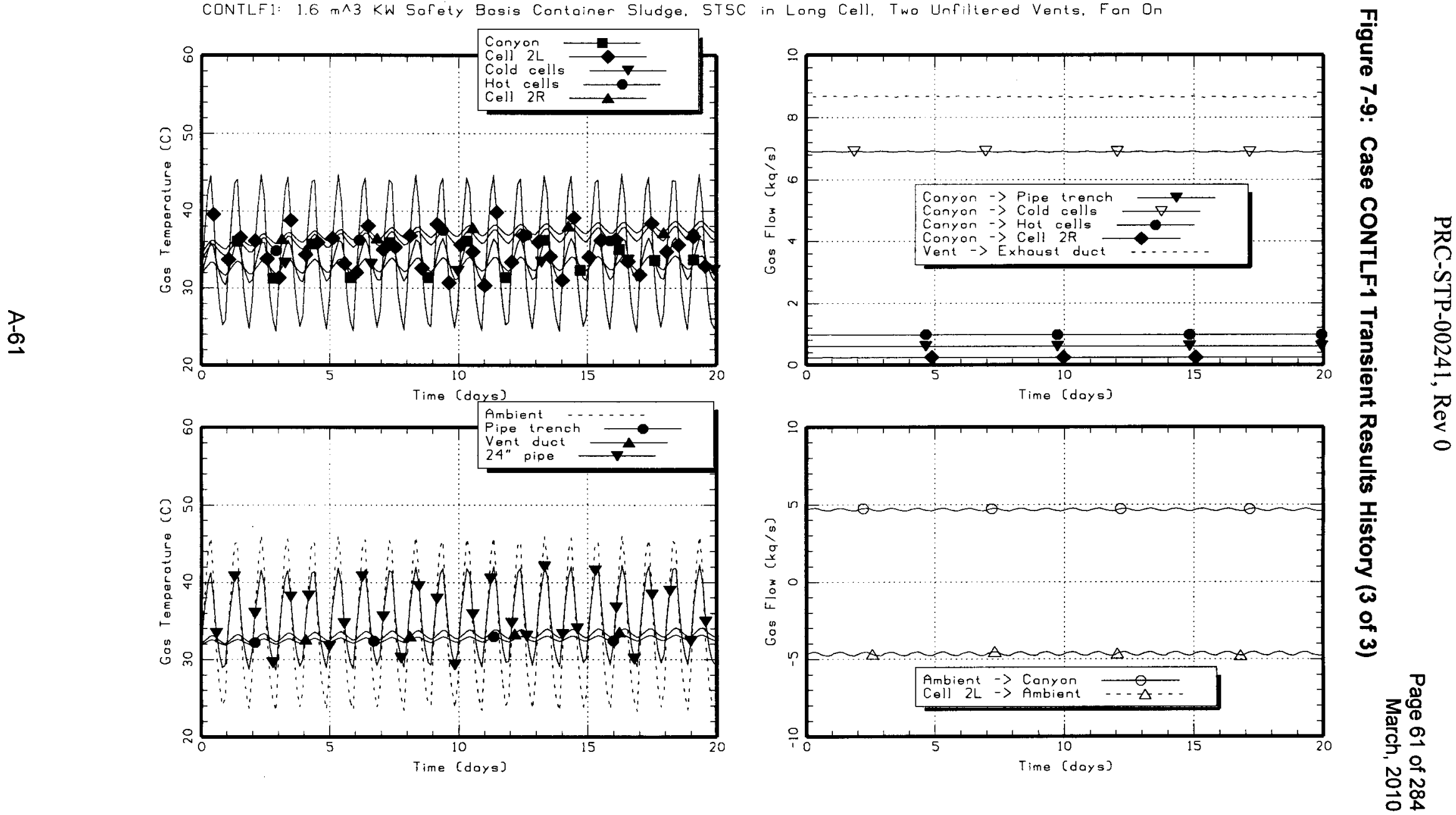
Rev. 0

Figure 7-10: Case CONTRN1 Transient Results History (1 of 3)
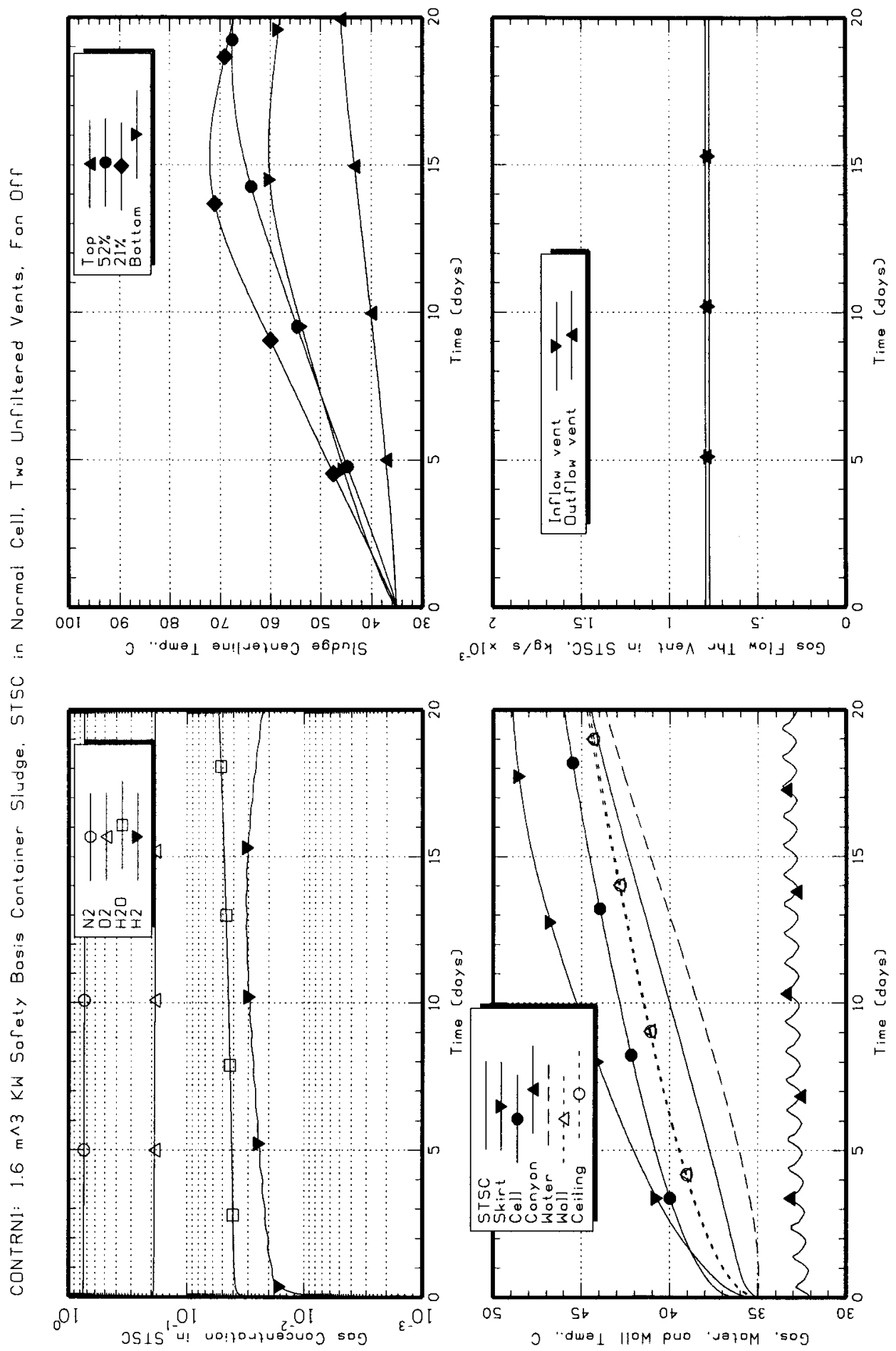
$\mathrm{FAl} / 10-83$

PRC-STP-00241, Rev 0

Rev. 0

Page 63 of 284

March, 2010

Figure 7-11: Case CONTRN1 Transient Results History (2 of 3)
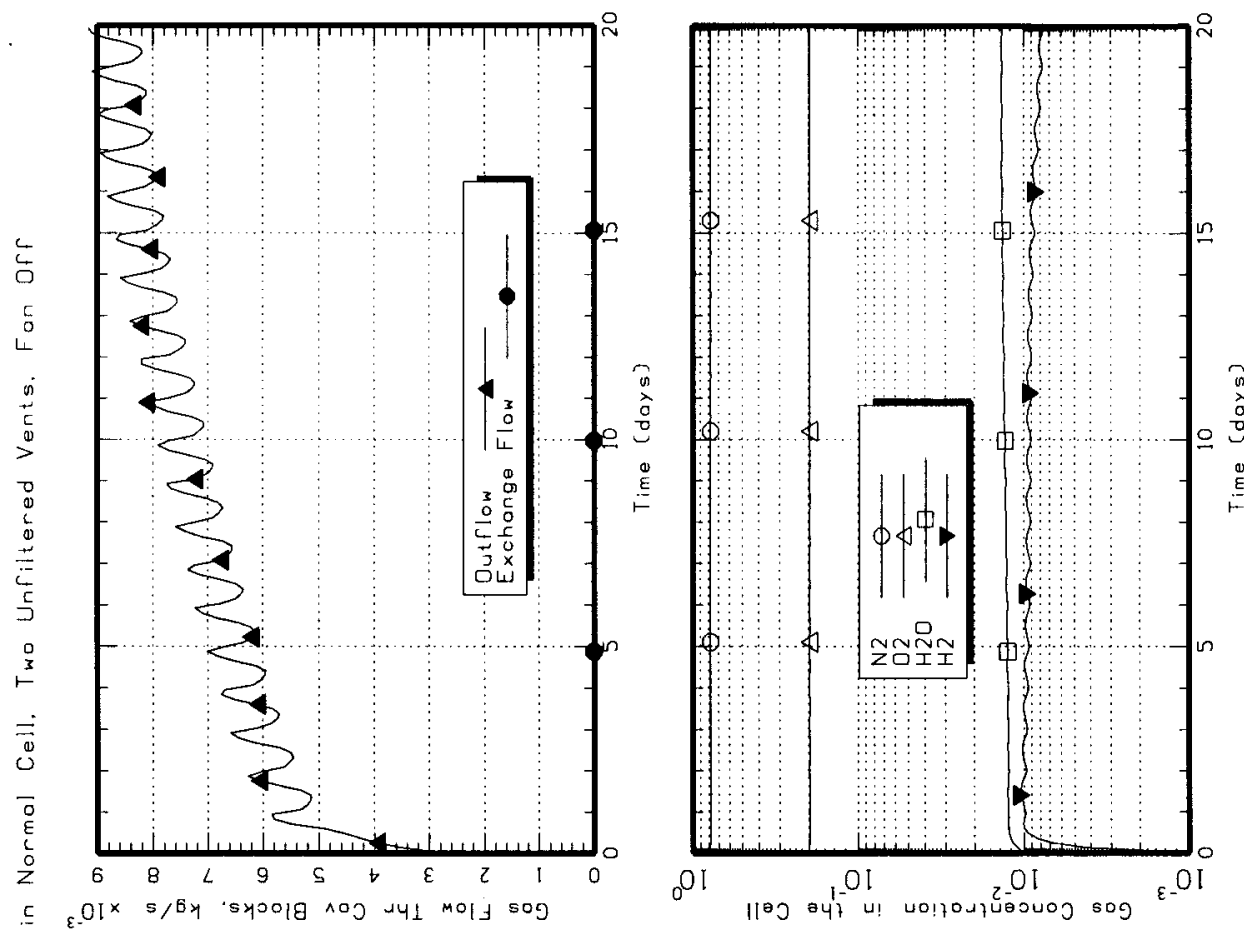

唄
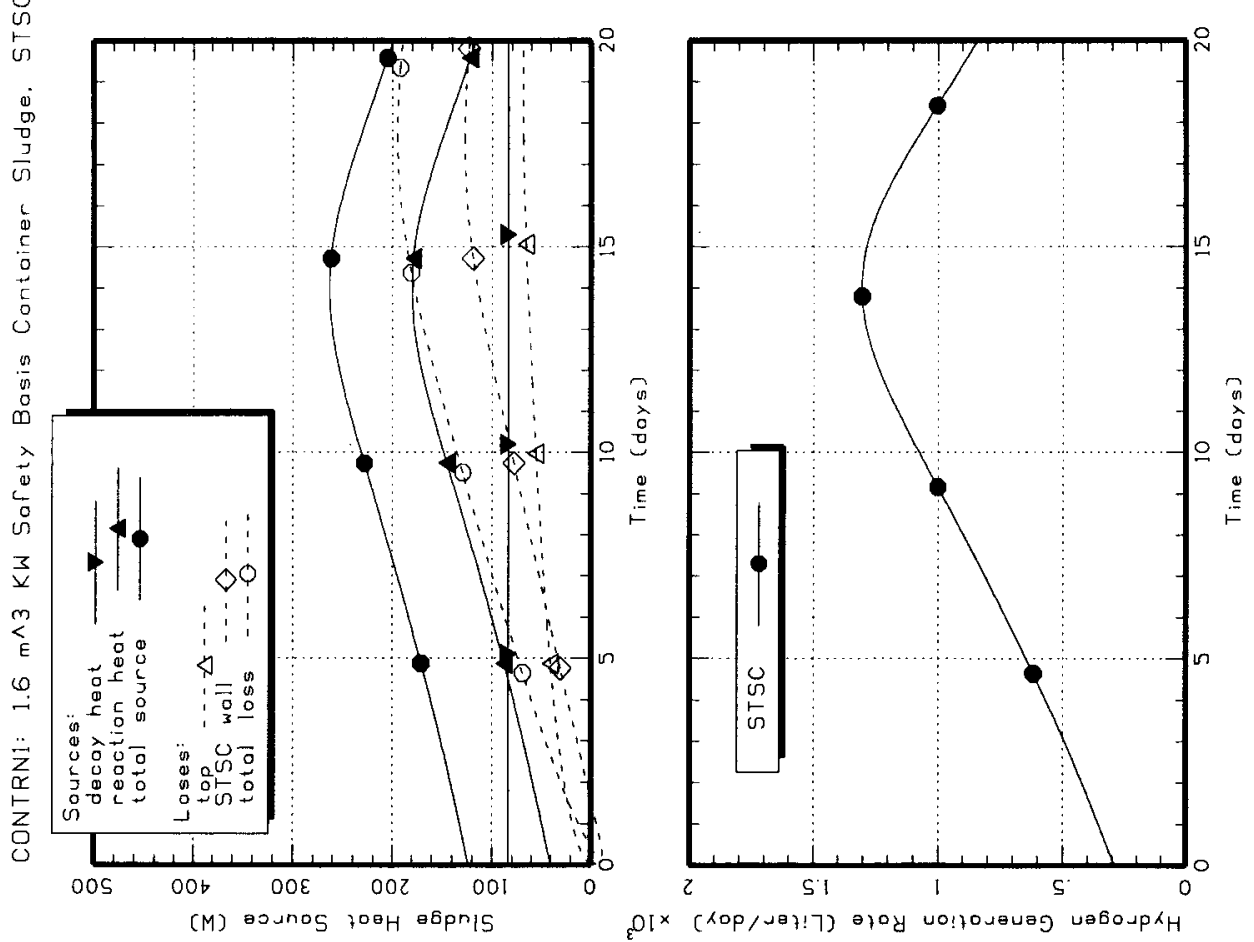
FAl/10-83

PRC-STP-00241, Rev 0

Rev. 0

Page 64 of 284

March, 2010

Figure 7-12: Case CONTRN1 Transient Results History (3 of 3)
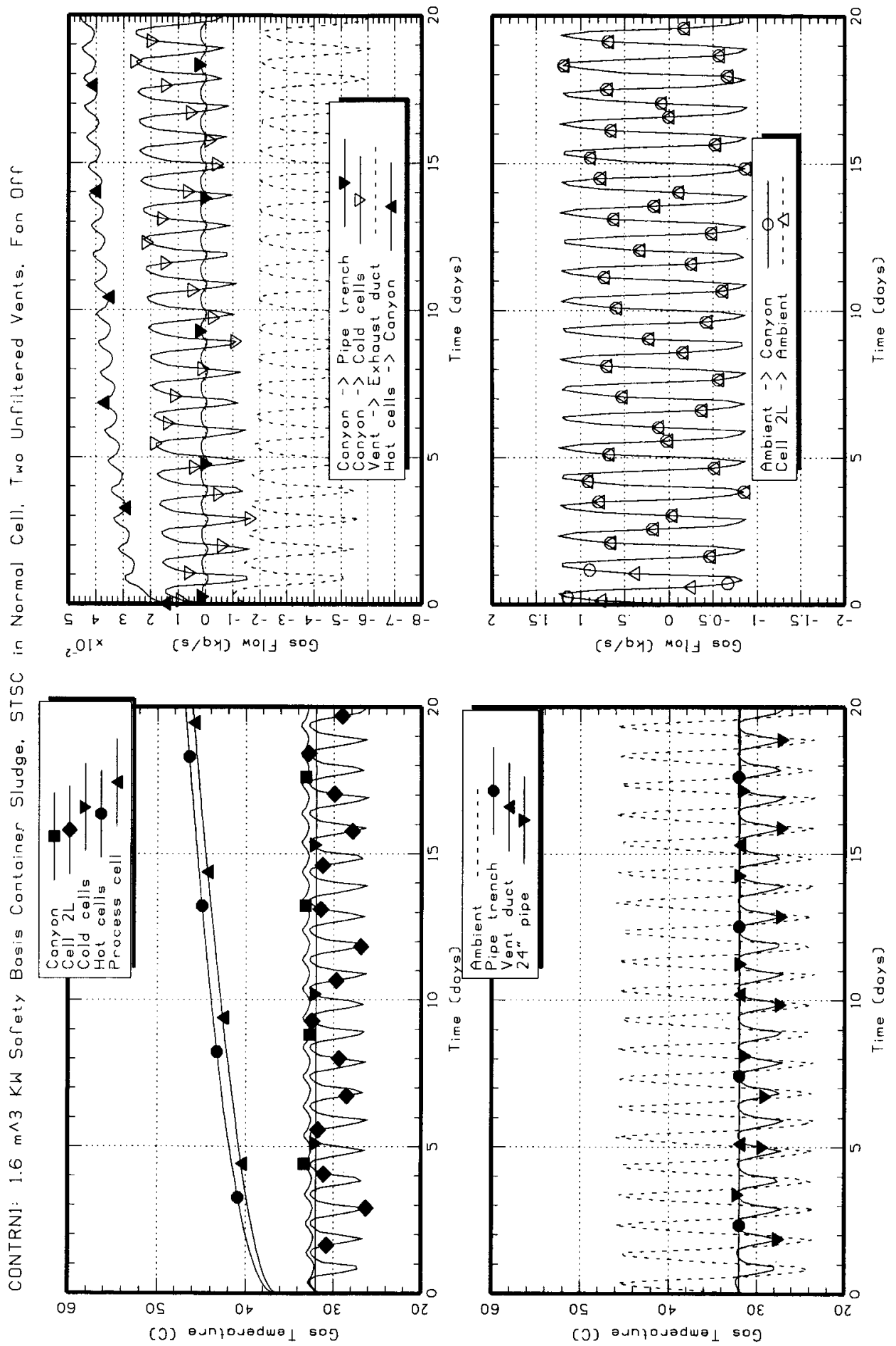
CONTLN1: $1.6 \mathrm{~m}^{\wedge} 3 \mathrm{KW}$ Sofety Basis Container Sludge. STSC in Long Cell. Two Unfiltered Vents, Fon Off
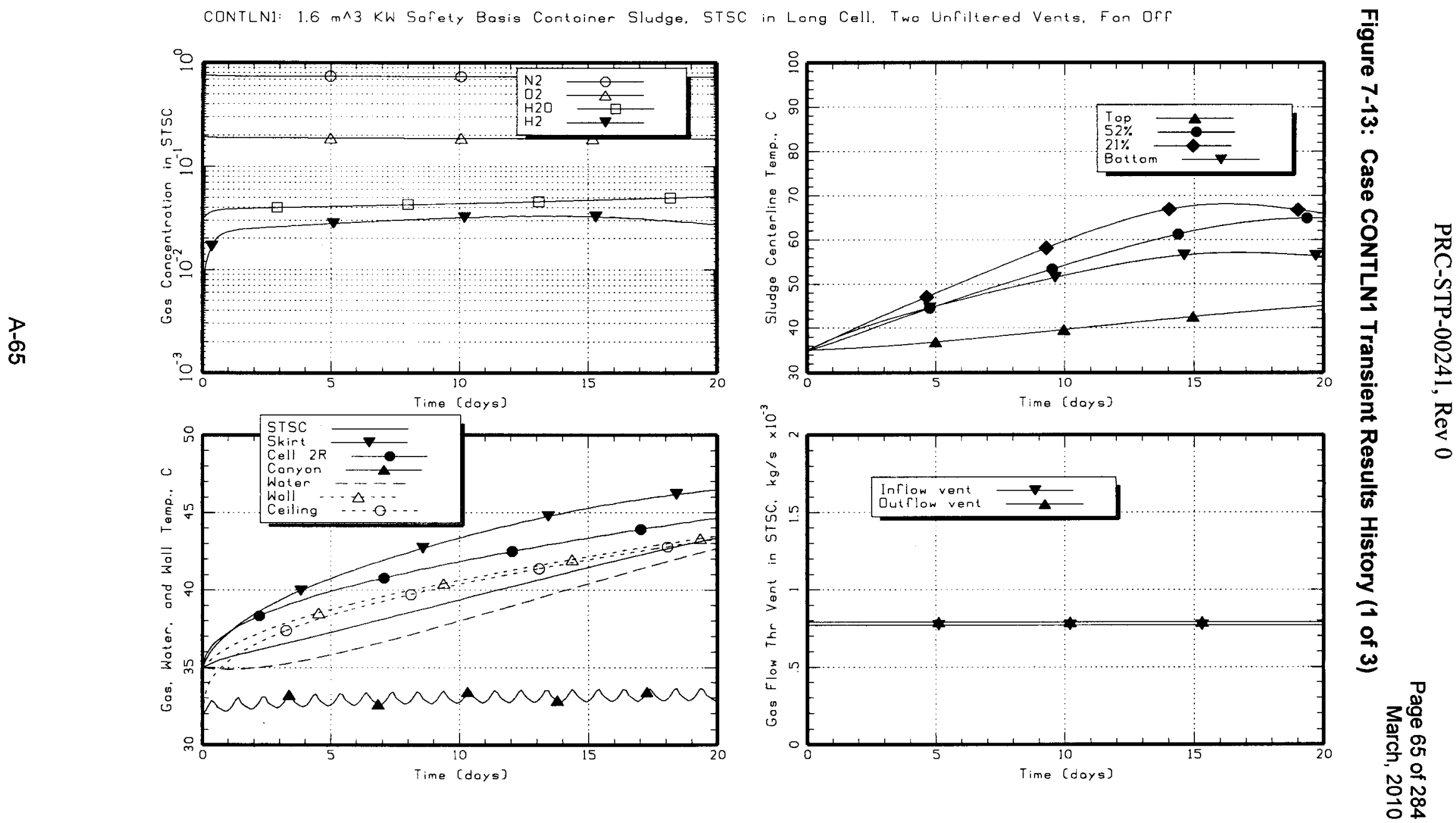
CONTLN1: $1.6 \mathrm{~m} \wedge 3 \mathrm{KW}$ Sofety Bosis Container Sludge, STSC in Long Cell, Two Unfiltered Vents. Fon Off
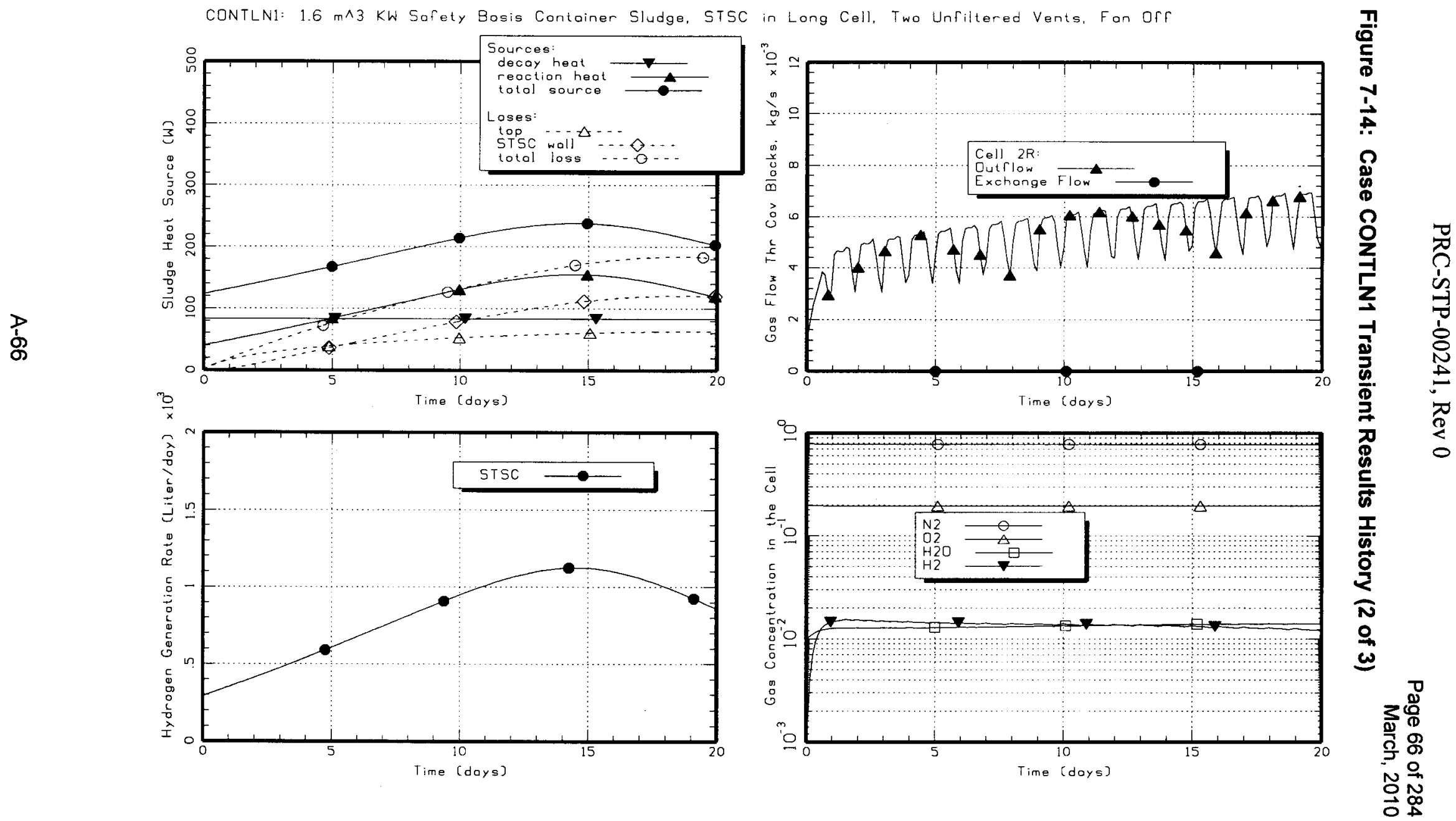
FAl/10-83

PRC-STP-00241, Rev 0
Rev. 0
Page 67 of 284

March, 2010

Figure 7-15: Case CONTLN1 Transient Results History (3 of 3)
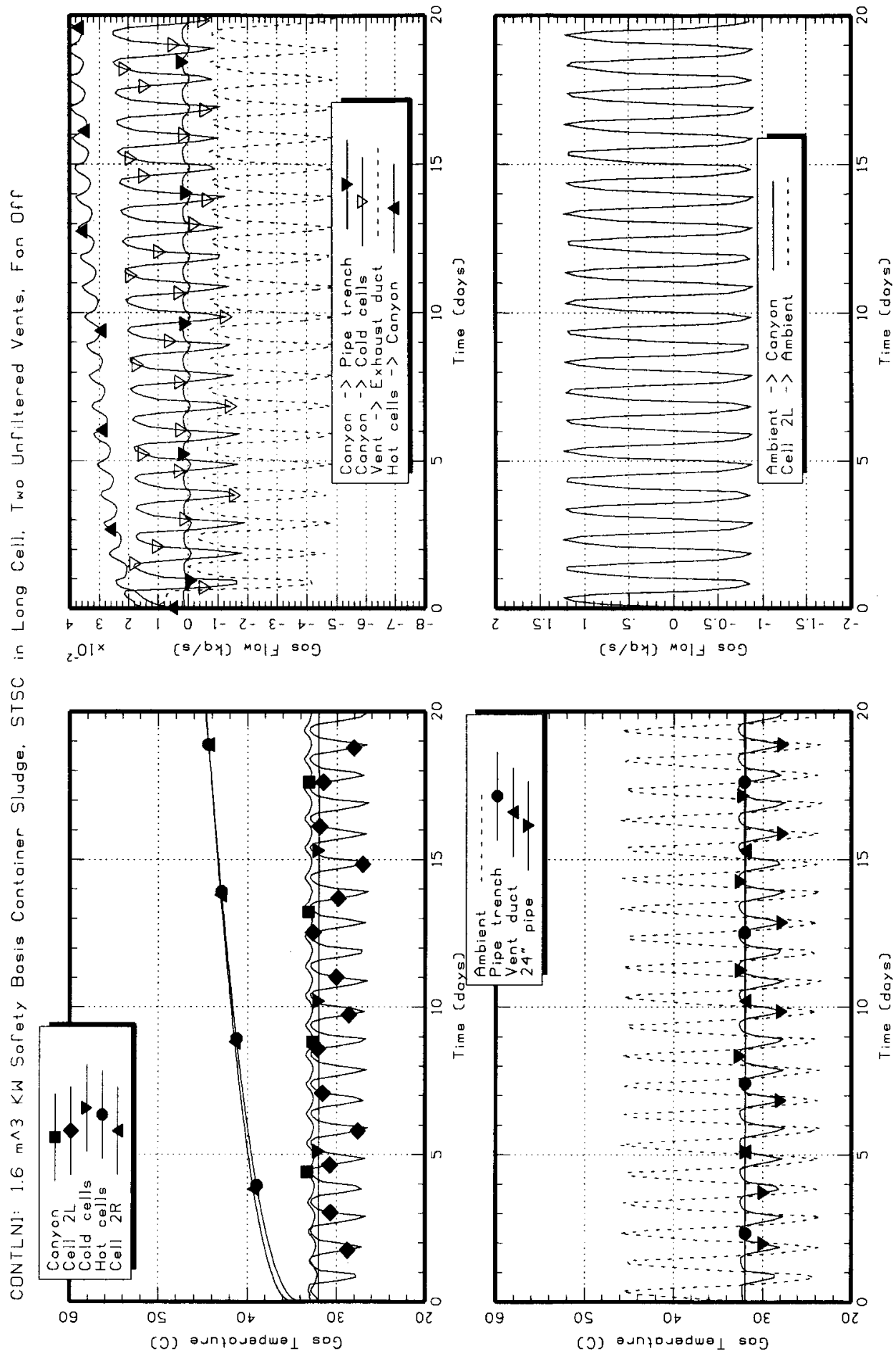
Figure 7-16: Case SETTRF1 Transient Results History (1 of 3)
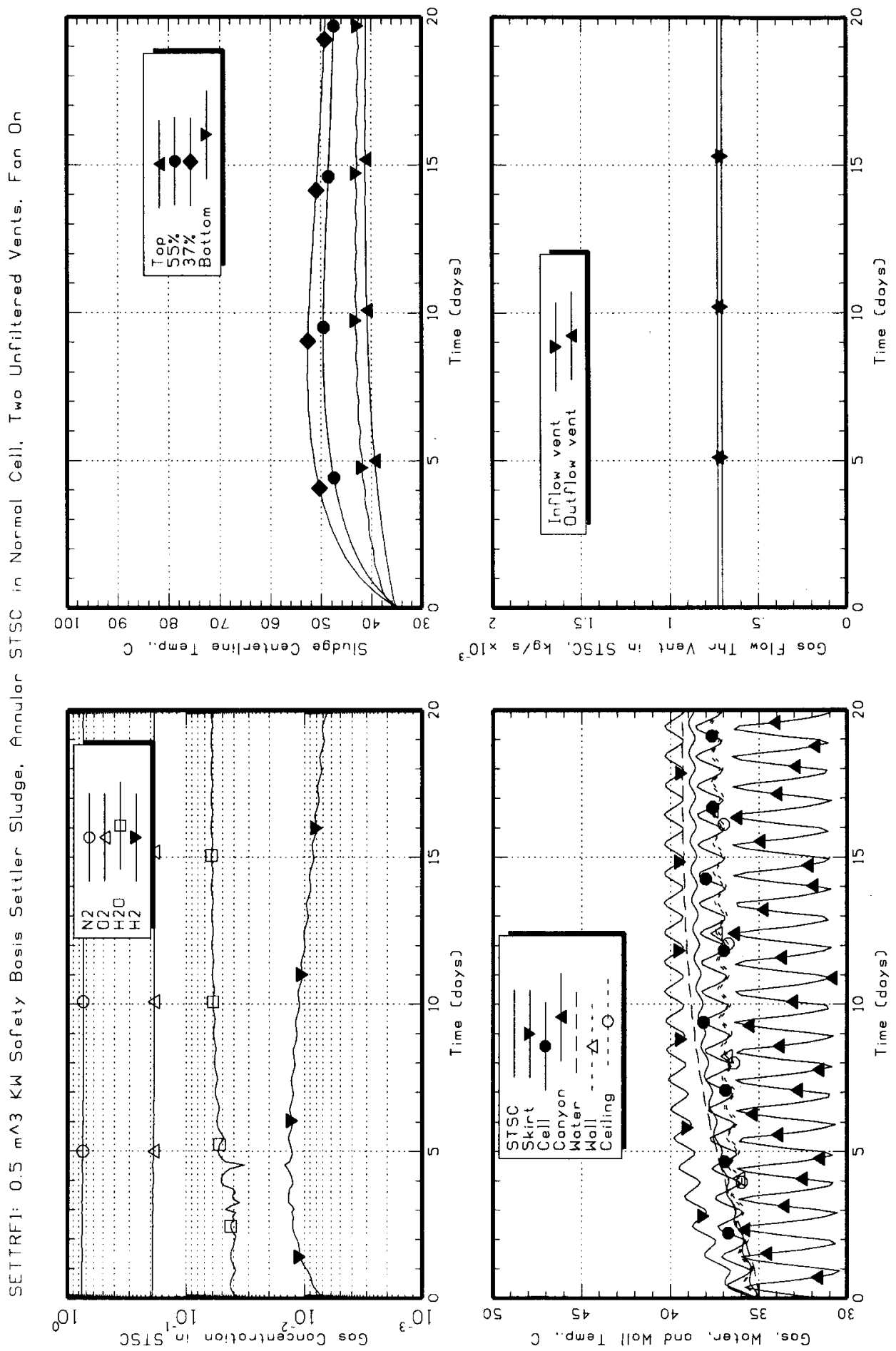
FAl/10-83

PRC-STP-00241, Rev 0

Rev. 0

Page 69 of 284

March, 2010

Figure 7-17: Case SETTRF1 Transient Results History (2 of 3)
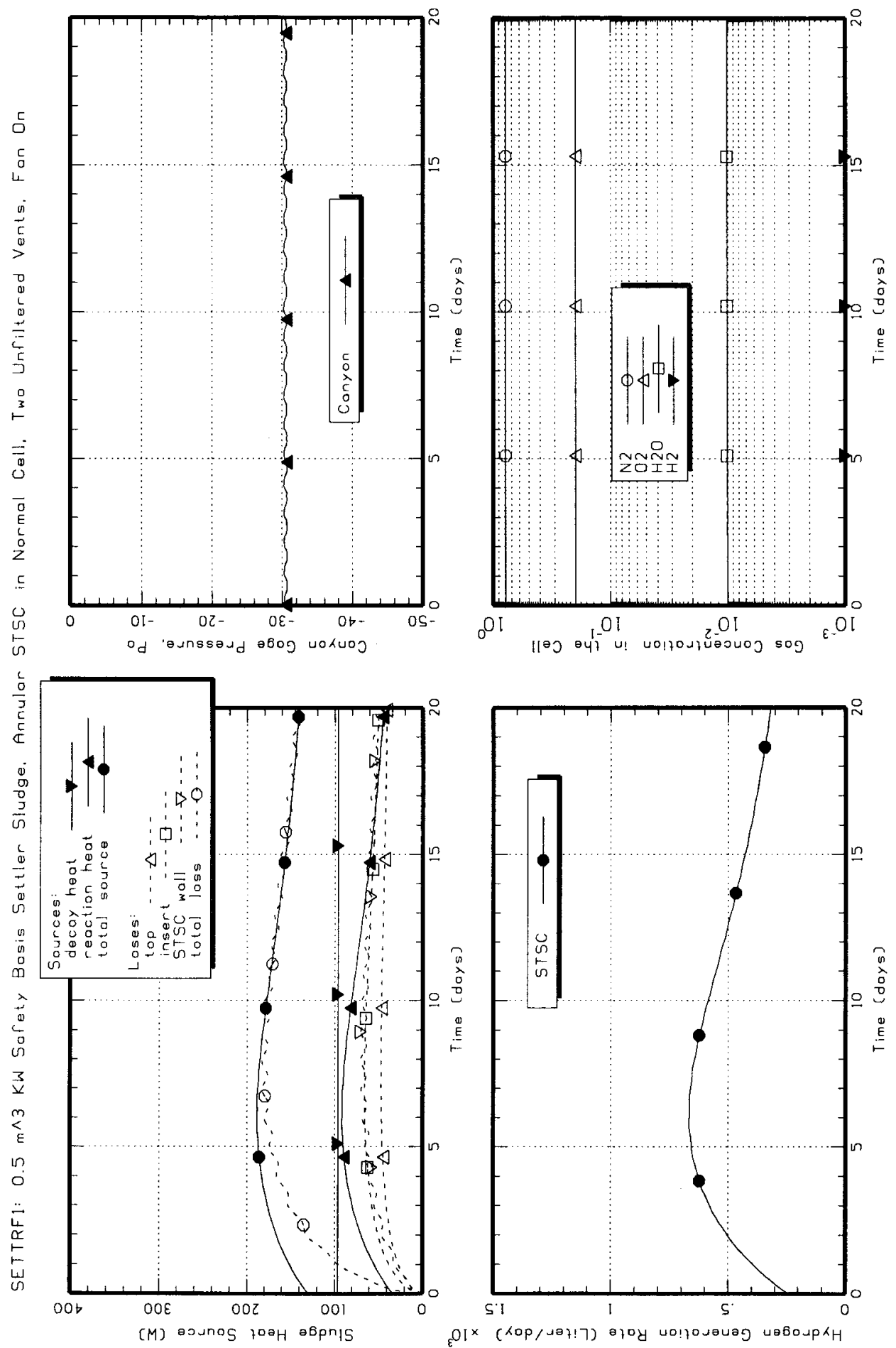
SETTRF1: $0.5 \mathrm{~m} \wedge 3 \mathrm{KW}$ Sofety Basis Settler Sludge. Annular STSC in Normal Cell. Two Unfiltered Vents. Fan On
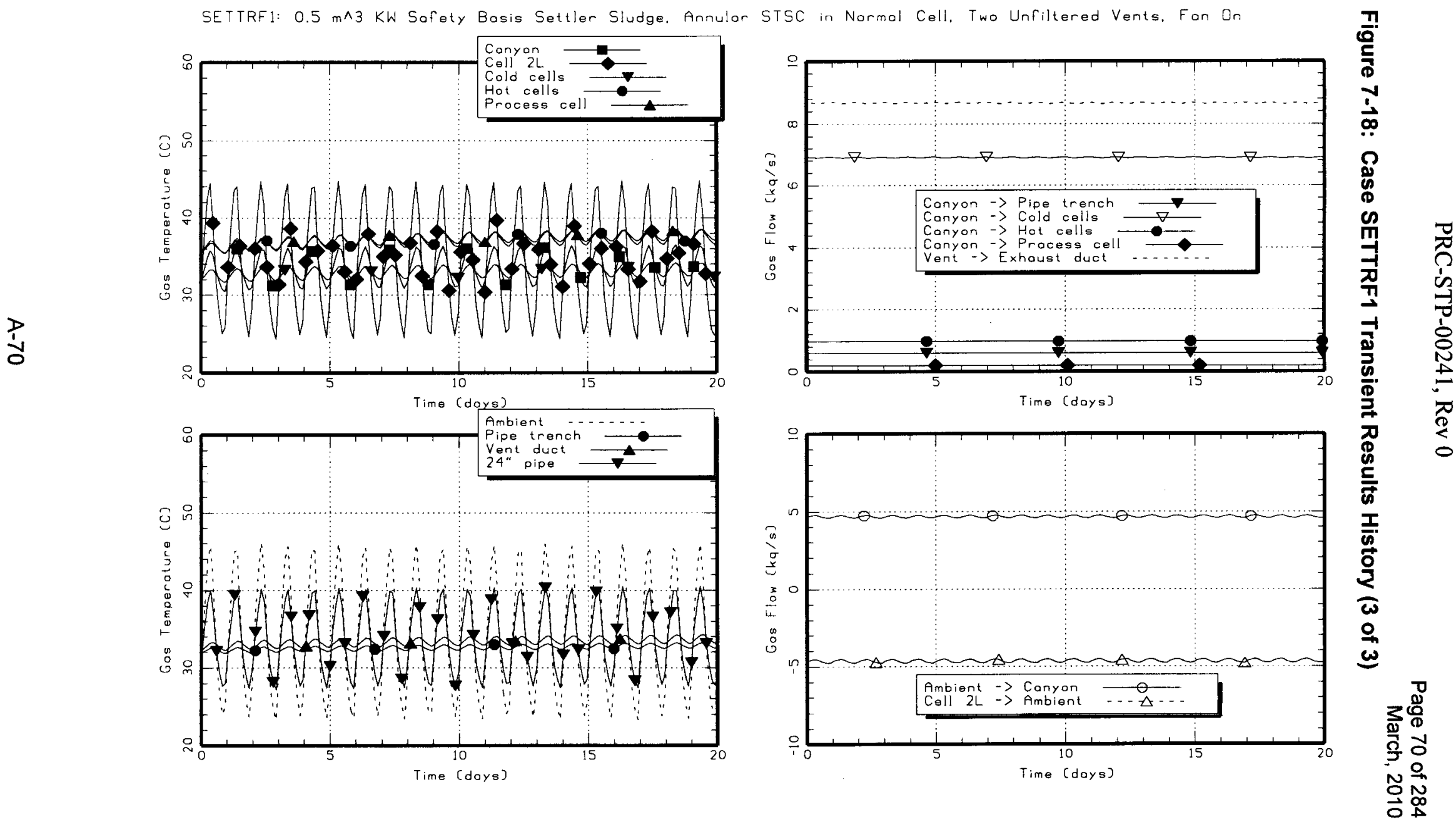
FAl/10-83

PRC-STP-00241, Rev 0
Page 71 of 284

March, 2010

Figure 7-19: Case SETTLF1 Transient Results History (1 of 3)
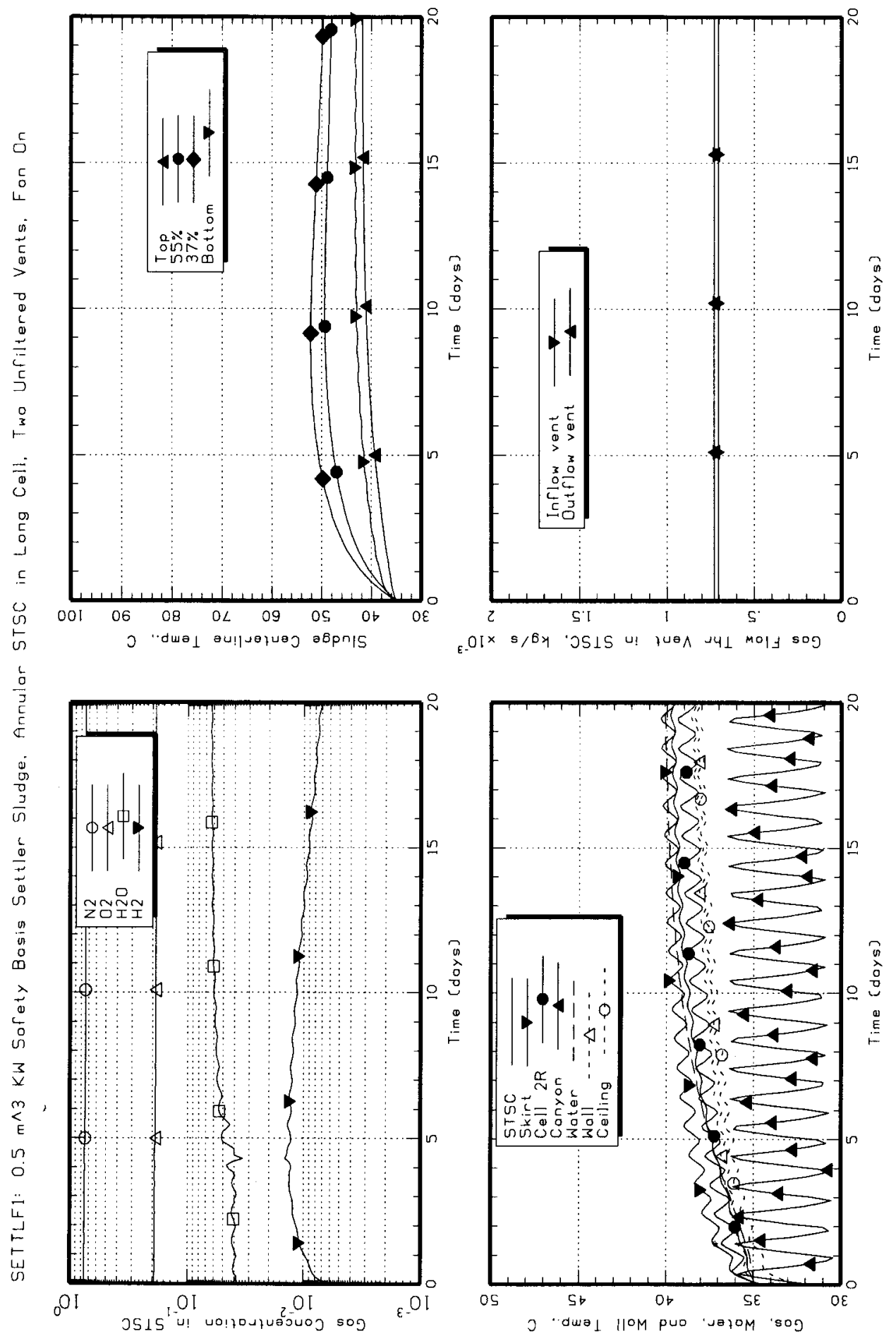
FAl/10-83

Rev. 0
PRC-STP-00241, Rev 0

Page 72 of 284

March, 2010

Figure 7-20: Case SETTLF1 Transient Results History (2 of 3)
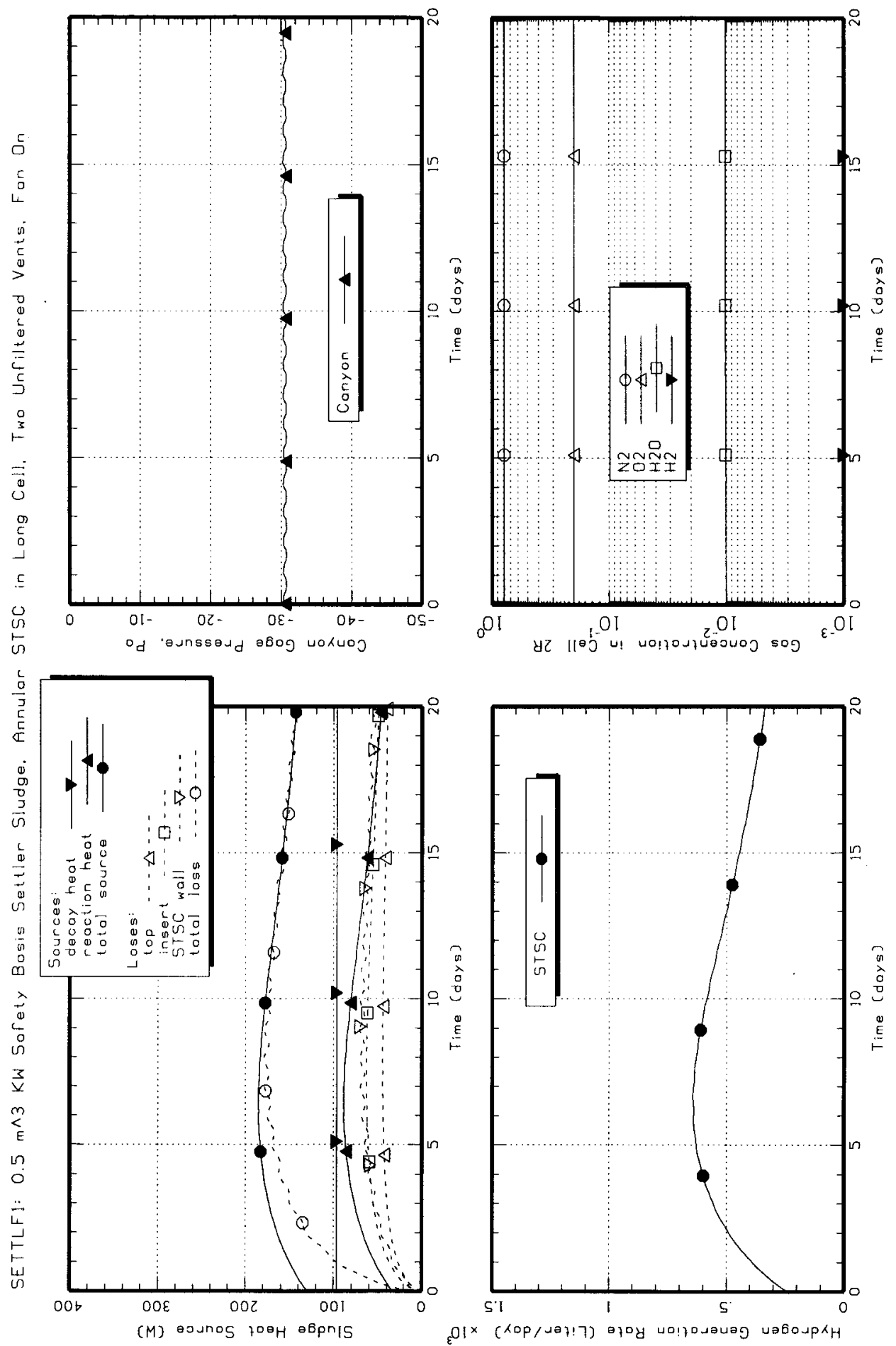
SETTLF]: $0.5 \mathrm{~m} \wedge 3 \mathrm{KW}$ Sofety Basis Settler Sludge. Annulor STSC in Long Cell, Two Unfiltered Vents. Fan On
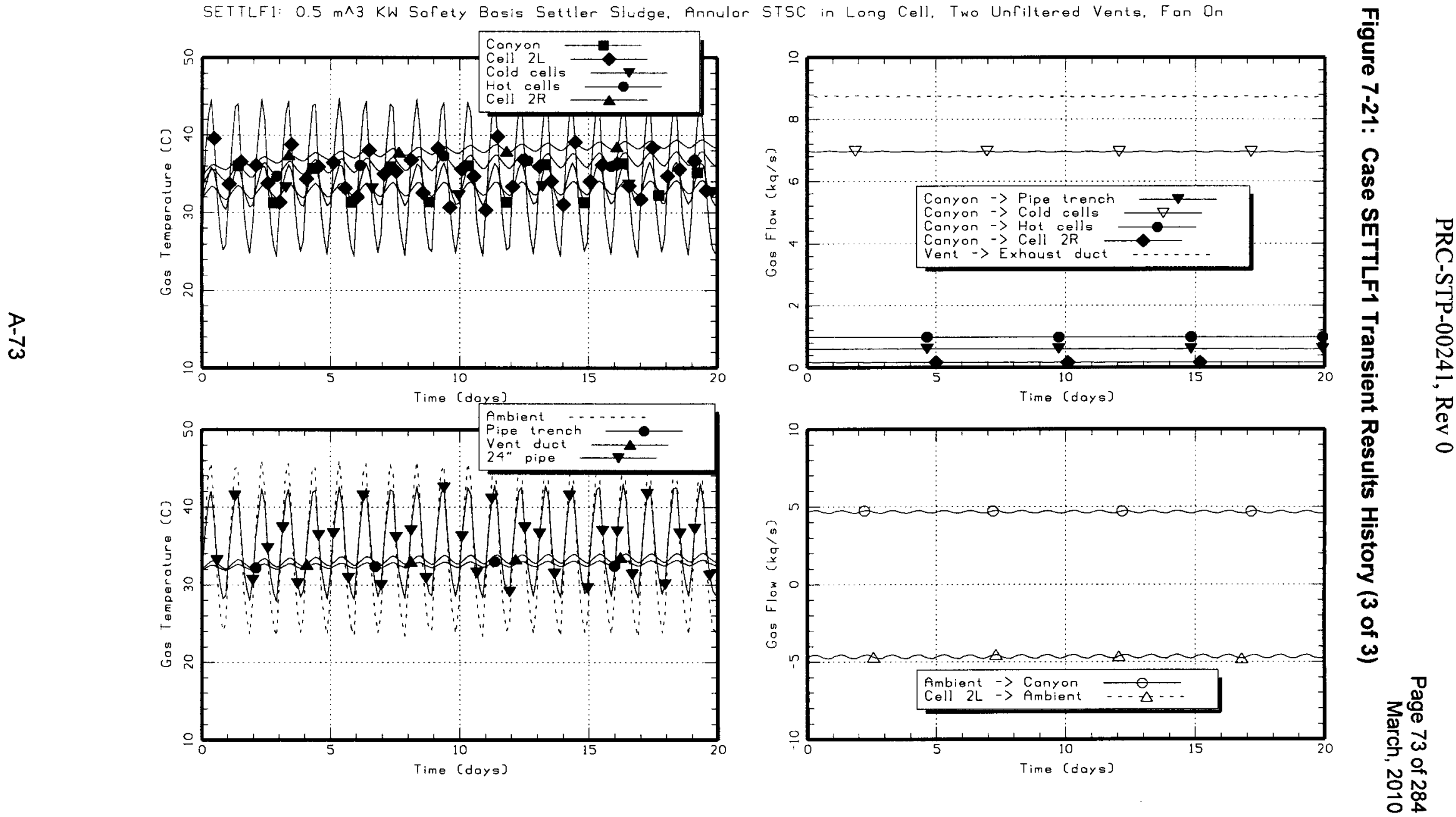
Figure 7-22: Case SETTRN1 Transient Results History (1 of 3)
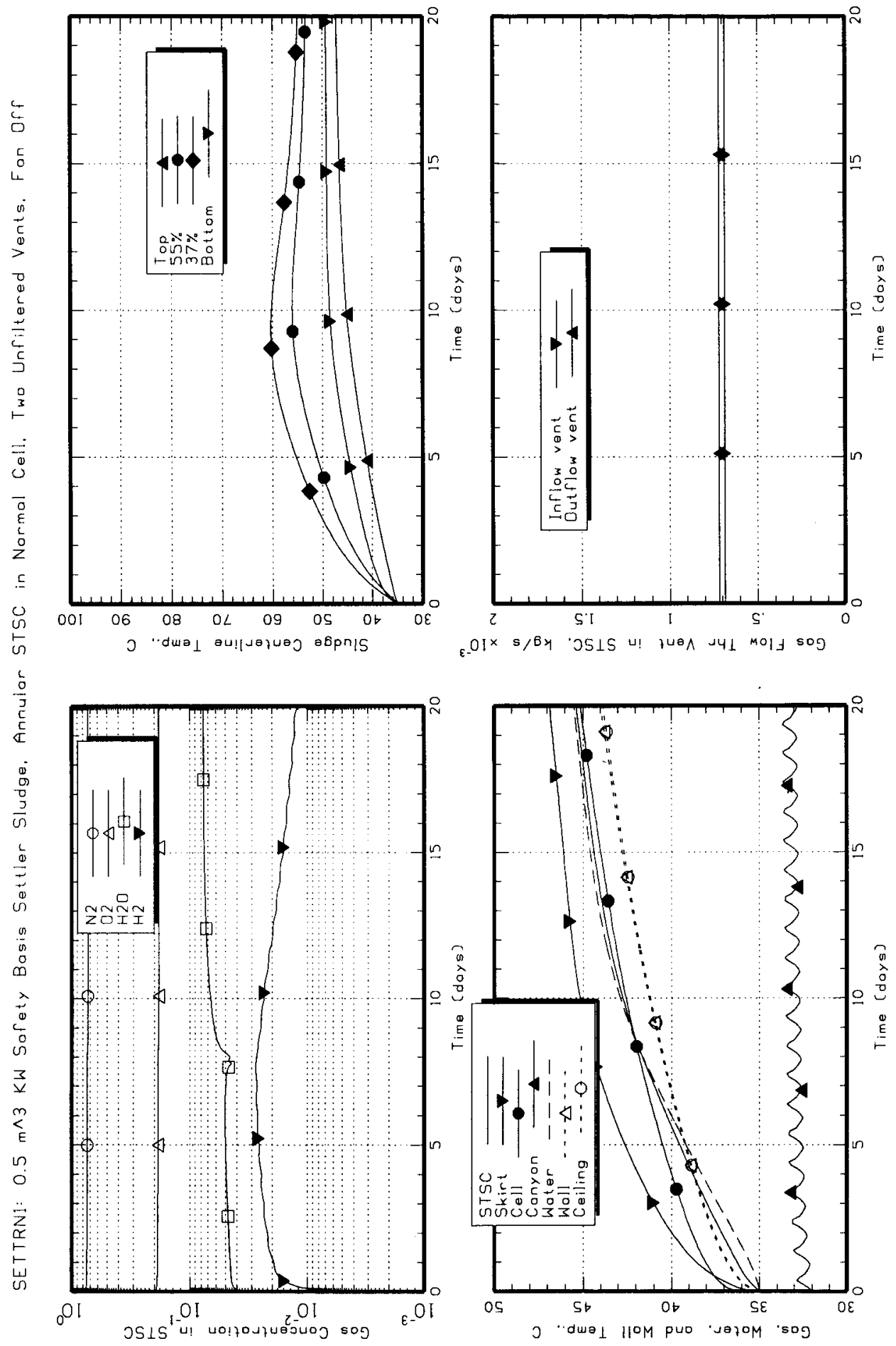
Figure 7-23: Case SETTRN1 Transient Results History (2 of 3)
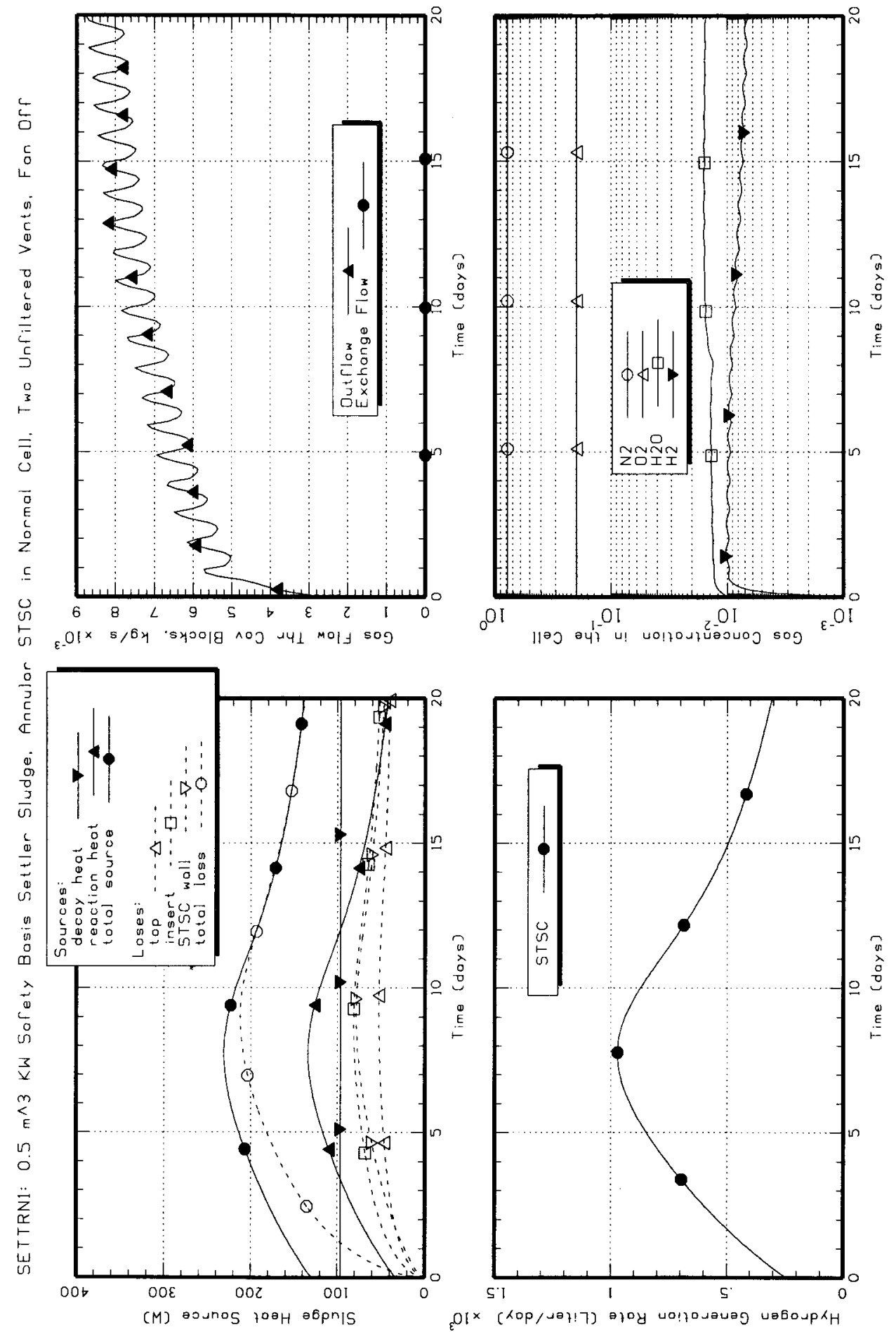
SETTRN1: $0.5 \mathrm{~m} \wedge 3 \mathrm{KW}$ Safety Basis Settler Sludge. Annular STSC in Normal Cell. Two Unfiltered Vents. Fan Off
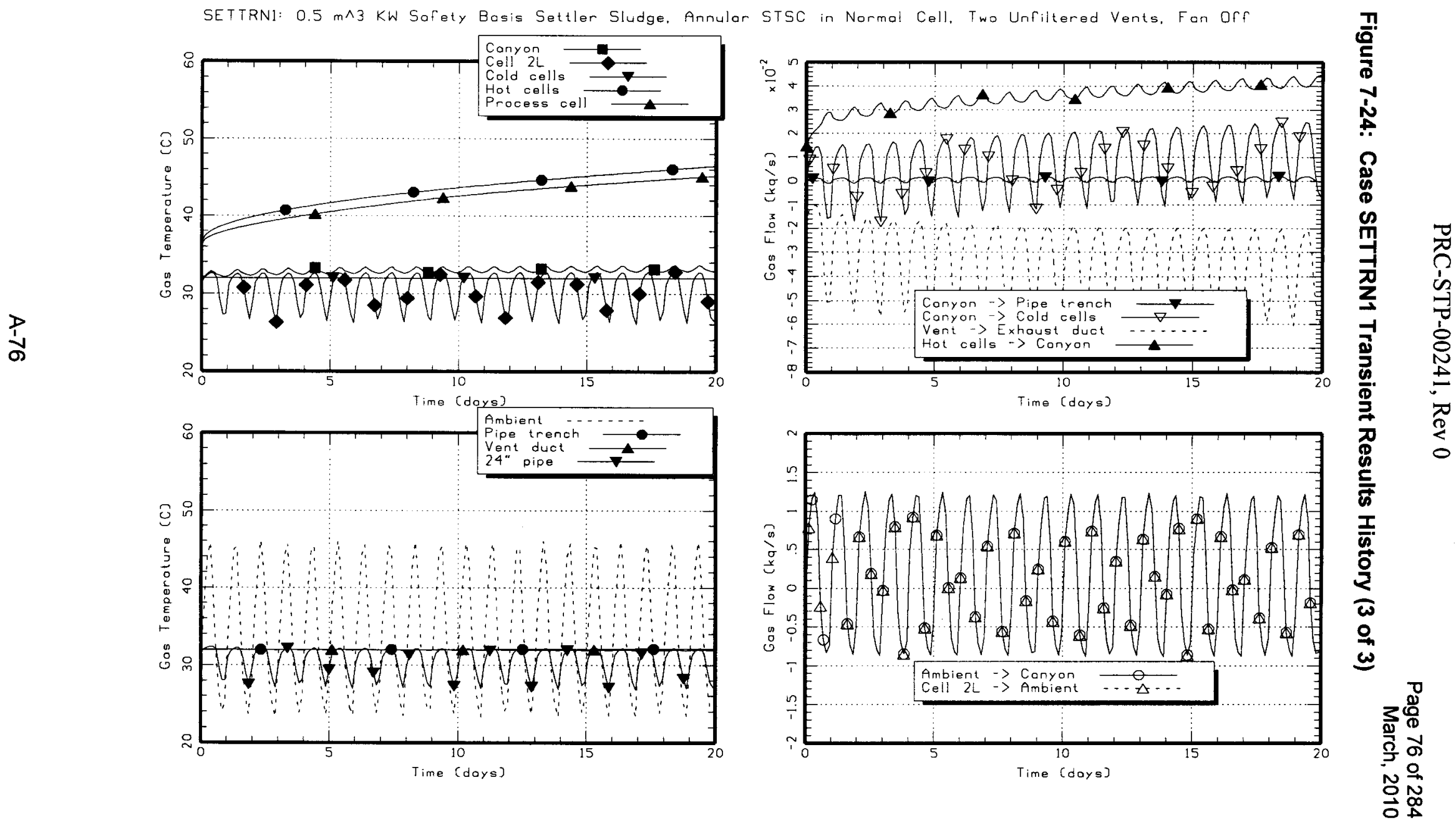
FAl $/ 10-83$

Rev. 0
PRC-STP-00241, Rev 0

Page 77 of 284

March, 2010

Figure 7-25: Case SETTLN1 Transient Results History (1 of 3)
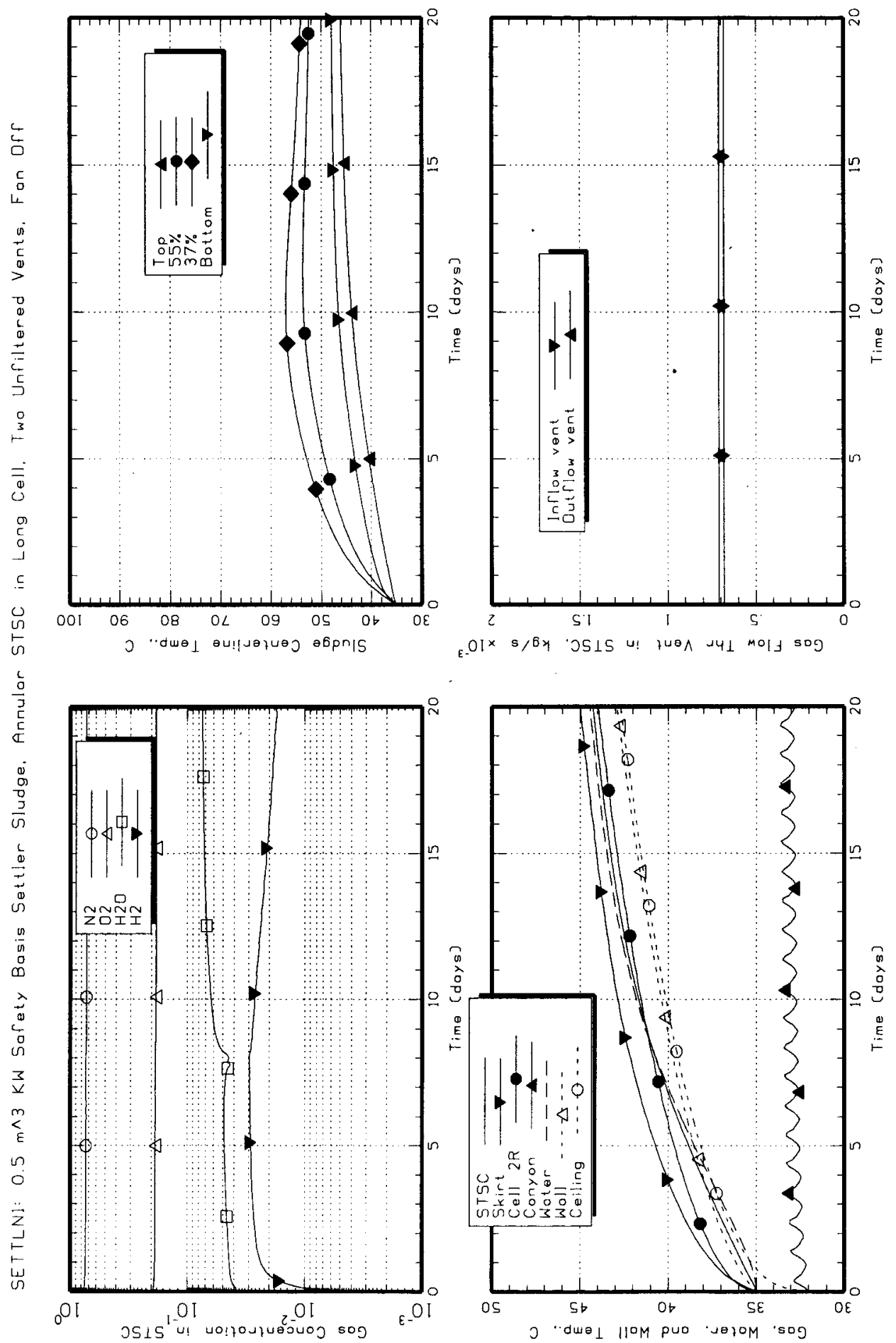
SETTLN1: $0.5 \mathrm{~m}^{\wedge} 3 \mathrm{KW}$ Safety Basis Settler Sludge. Annular STSC in Long Cell. Two Unfiltered Vents, Fan Orf
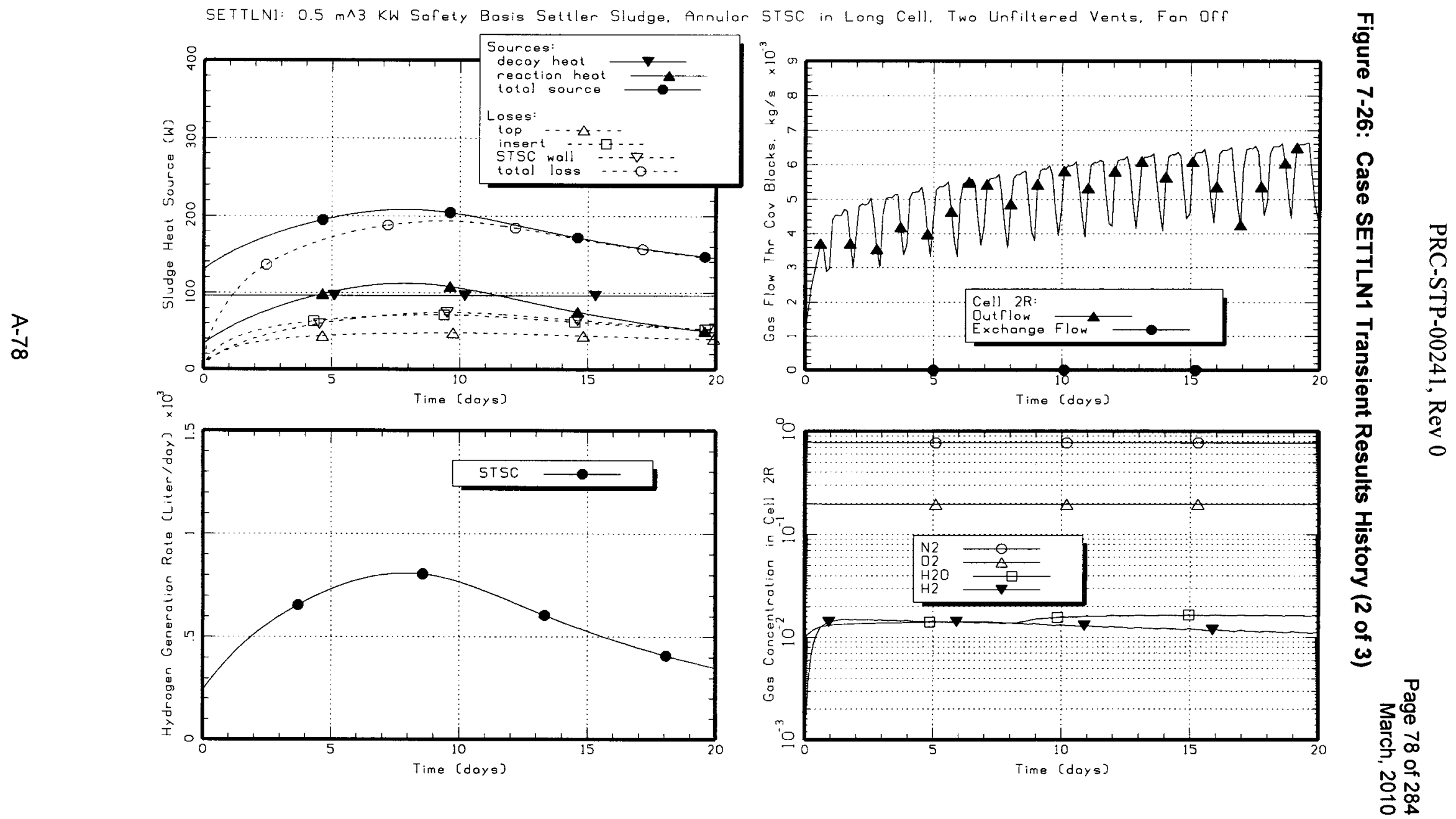
SETTLN1: $0.5 \mathrm{~m} \wedge 3$ KW Sofety Bosis Settler Sludge. Annular STSC in Long Cell. Two Unfiltered Vents. Fan Off
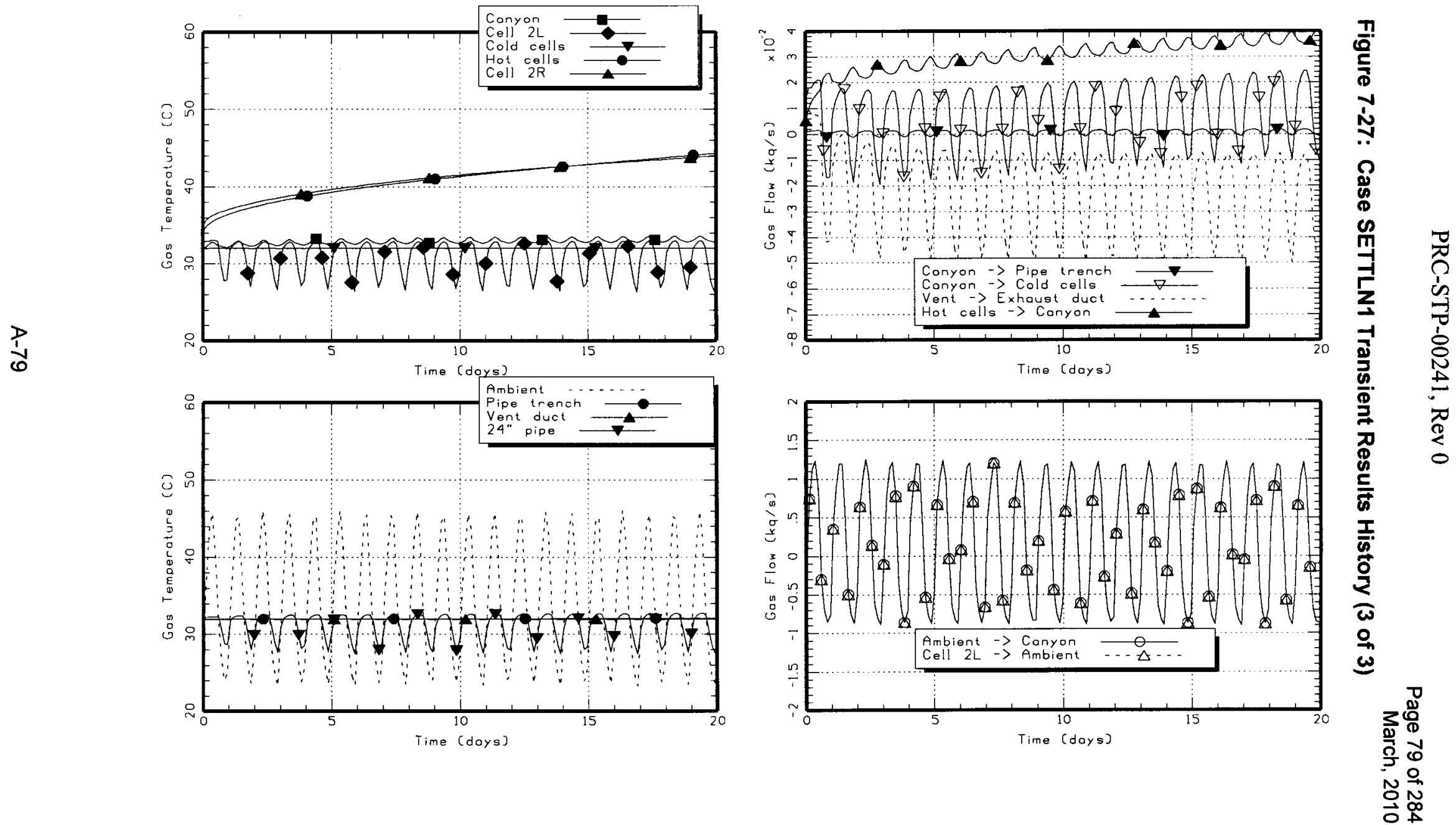


\subsection{REFERENCES}

Epstein, M., and M.G. Plys,. 2002, "A Study of Dryout Heat Fluxes in Liquid Saturated Sludge," FAl/02-63, September.

Lee, S.J., and M.G. Plys, 2006, "FATE 2.057 Software Change Specification and Testing Generic Models," FAI memorandum, August 25.

Lee, S.J., and J. Conzen, 2009, "On-Site Sludge Transportation and Storage Thermal and Gas Scoping Calculations," FAl/09-261, October.

Loscoe, P.G., 2003, "Accident and Thermal Analysis for Storing K East Basin Sludge at T Plant, HNF-12563, Rev. 2, Fluor Hanford, Richland, WA, November.

Johnson, M.E, CHPRC, e-mail dated Dec. 7, 2009, "Additional Cases for Thermal and Gas Analyses."

Johnson, M.E., 2009, "Preliminary STP Container and Settler Sludge Process System Description and Material Balance," HNF-41051, revision 4, CH2MHILL Plateau Remediation Company, Richland, WA, November.

Plys, M.G., S.J. Lee, and B. Malinovic, 2002, "HANSF/SLUDGE Computer Program User's Manual," Fauske \& Associates, Inc., Burr Ridge, IL, August.

Plys, M.G., and S.J. Lee, 2004, "FATE 2.0: Facility Flow, Aerosol, Thermal, and Explosion Model (Improved and Combined HANSF and HADCRT Models)," SNF-23281, FAl/0471, Two Volumes, Fluor Hanford, Inc., Richland, WA, November.

Plys, M.G., et al, 2006. "Hot Loss of Power (LOP) Scenarios and Flammability Potential for the BNG Corrosion Process," FAl/06-35, Rev. 0, Submitted to the Fluor Hanford K Basins Closure Project, Richland, WA, April.

Plys, M.G., and S.J. Lee, 2006, "K Basins Sludge Treatment Corrosion Process Analysis Using FATE," FAl/06-44, Rev. 1, Submitted to BNG America, Richland, WA, November.

Plys, M.G, 2007, "System Response to a Spray Release in the Shielded Vessel Enclosure," FAI/07-47, Rev. 0, Submitted to the Fluor Hanford Sludge Treatment Project, April.

Plys, M.G, 2008, "KOP Sludge Retrieval Tank Design Technical Basis," FAl/08-56, Rev. 0, Submitted to the Fluor Hanford, May.

Plys, M.G., et al, 2008, "Scoping Thermal and Gas Calculations for KW Container Sludge Retrieval," FAI/08-32, Rev. 0, Submitted to Fluor Hanford K Basins Closure Project, Richland, WA, March.

Plys, M.G., S.J. Lee, and M. Epstein, 2009, "Settler Sludge Behavior During Retrieval," HNF37009, Rev. 1, FAl/08-30, Rev. 2, Fluor Hanford, Inc., Richland, WA, February.

Plys, M.G., S.J. Lee, and R.A. Apthorpe, 2009, "Sludge Process Design Guidance and Conceptual Design Thermal \& Gas Analysis," FAl/09-065, Rev. 1, Fauske \& Associates, LLC, Burr Ridge, IL, April. 
Plys, M.G, and M. Johnson, 2009, "Thermal and Gas Analyses for an STSC Loaded with Settler Sludge," PRC-STP-00162, CH2M HILL Plateau Remediation Company, Richland, WA, December.

Plys, M.G., R.A. Apthorpe, S.J. Lee, and M. Johnson, 2010, "Sludge Treatment Project Engineered Container Retrieval and Transfer System - Thermal and Gas Analyses for an STSC KW Engineered Container Sludge, PRC-STP-00220, CH2M HILL Plateau Remediation Company, Richland, WA, March.

Schmidt, A.J., 2009, "Spent Nuclear Fuel Project Technical Databook, Vol. 2, Sludge," HNF-SDSNF-TI-015, Revision 14A, CH2MHILL Plateau Remediation Company, Richland, WA, March.

USDOE, 2004, "KE-Basin STS Cask, Cask Assembly", Drawing H-1-87445, Sheet 2, Revision 0. 
Rev. 0

\section{APPENDIX A: FATE ${ }^{T M}$ INPUT values}

This Appendix presents the derivation of selected input values to FATE for analysis of an STSC at T Plant. Parameters considered are:

1. Region volume and elevation inputs,

2. Junction inputs for STSC vent paths to the cell,

3. Junction inputs for cell cover blocks,

4. Heat sink inputs for cell heat conductors,

5. Heat sink inputs for sludge and STSC wall conductors,

6. Heat and hydrogen sources, and

7. Sludge radiolysis inputs.

\section{A.1 Region Volume and Elevation Inputs}

Typical cell dimensions are $13 \mathrm{ft}(3.96 \mathrm{~m})$ wide, $17 \mathrm{ft} 8$ in long $(5.38 \mathrm{~m})$, and $22 \mathrm{ft}$ $(6.71 \mathrm{~m})$ deep. The free volume in the normal cell, represented by Region 2 in the FATE model, is obtained by subtracting the approximate volume of six STSCs and $1.0 \mathrm{~m}^{3}$ for other structures in the cell. That is, for the normal cell, the region volume is given by $3.9624 \times 5.3848 \times$ $6.7056-6 \times 2.5941 \times \pi(1.4986)^{2} / 4-1.0=114.63 \mathrm{~m}^{3}$. Without STSCs and internal structures, the cell volume is $143.08 \mathrm{~m}^{3}$.

Cell $2 R$ differs only in its length with respect to the other cells, $27 \mathrm{ft} 6$ in $(8.38 \mathrm{~m})$ instead of $17 \mathrm{ft} 8$ in $(5.38 \mathrm{~m})$. The free volume I the long cell is obtained by subtracting the approximate volume of eight STSCs and $1.0 \mathrm{~m}^{3}$ for other structures in the cell. That is, for the long cell, the region volume is given by $3.9624 \times 8.3820 \times 6.7056-8 \times 2.5941 \times \pi(1.4986)^{2} / 4-1.0$ $=185.11 \mathrm{~m}^{3}$. Without STSCs and internal structures, the volume of cell $2 \mathrm{R}$ is $222.71 \mathrm{~m}^{3}$.

Since the cell floor elevation is defined with respect to the bottom of the sludge, and the drip pan is located 38 in $(0.9652 \mathrm{~m})$ off the floor, the region floor elevation is given by $0.9652-0.0254=-0.9906 \mathrm{~m}$. Note that there is a 0.5 in $(0.0127 \mathrm{~m}) \mathrm{STSC}$ bottom wall thickness and another 0.5 in $(0.0127 \mathrm{~m})$ gap between the STSC bottom and the drip pan.

The height of the cell is $22 \mathrm{ft}(6.7056 \mathrm{~m})$.

The canyon is modeled as a very large volume to which the cell exchange air through the gap in concrete cover blocks. The floor elevation of the canyon volume is $28 \mathrm{ft}(8.5344 \mathrm{~m})$ above the cell floor, or $-0.9906+8.5344=7.5438 \mathrm{~m}$. Table A-1 summarizes the key region inputs for the cell and canyon volume. 
FAl $/ 10-83$

PRC-STP-00241, Rev 0

Rev. 0

Page 83 of 284

March, 2010

Table A-1: Region Inputs for Cell Volumes

\begin{tabular}{|l|l|l|l|l|l|}
\hline FATE Inputs & $\begin{array}{l}\text { Standard } \\
\text { Cell }\end{array}$ & $\begin{array}{l}\text { Cold } \\
\text { Cells }\end{array}$ & $\begin{array}{l}\text { Hot } \\
\text { Cells }\end{array}$ & Cell 2L & Cell 2R \\
\hline Region Index & 6 & 7 & 14 & 12 & 11 \\
\hline VOLUME & $\begin{array}{l}143.08 \mathrm{~m}^{3} \\
\left(114.63 \mathrm{~m}^{3}\right. \\
\text { with 6 STSCs } \\
\text { \& internals) }\end{array}$ & $4435.48 \mathrm{~m}^{3}$ & $458.52 \mathrm{~m}^{3}$ & $251.39 \mathrm{~m}^{3}$ & $\begin{array}{l}222.71 \mathrm{~m}^{3} \\
\left(185.11 \mathrm{~m}^{3} \text { with }\right. \\
8 \text { STSCs \& } \\
\text { internals })\end{array}$ \\
\hline ELEVATION & $-0.9906 \mathrm{~m}$ & $-0.9906 \mathrm{~m}$ & $-0.9906 \mathrm{~m}$ & $-1.8542 \mathrm{~m}$ & $-0.9906 \mathrm{~m}$ \\
\hline ZTOP & $6.7056 \mathrm{~m}$ & $6.7056 \mathrm{~m}$ & $6.7056 \mathrm{~m}$ & $7.5692 \mathrm{~m}$ & $6.7056 \mathrm{~m}$ \\
\hline
\end{tabular}

Table A-2: Region Inputs for Other Volumes

\begin{tabular}{|l|l|l|l|l|l|}
\hline FATE Inputs & $\begin{array}{l}\text { Vent } \\
\text { Duct }\end{array}$ & $\begin{array}{l}\text { Pipe } \\
\text { Trench }\end{array}$ & Canyon & $\begin{array}{l}24 " \\
\text { Pipe }\end{array}$ & $\begin{array}{l}\text { Exhaust } \\
\text { Duct }\end{array}$ \\
\hline Region Index & 8 & 9 & 10 & 13 & 16 \\
\hline VOLUME & $2023.0 \mathrm{~m}^{3}$ & $951.45 \mathrm{~m}^{3}$ & $40818 \mathrm{~m}^{3}$ & $2.9357 \mathrm{~m}^{3}$ & $115 \mathrm{~m}^{3}$ \\
\hline ELEVATION & $-0.9906 \mathrm{~m}$ & $4.3434 \mathrm{~m}$ & $7.5438 \mathrm{~m}$ & $1.7526 \mathrm{~m}$ & $-0.9906 \mathrm{~m}$ \\
\hline ZTOP & $6.7056 \mathrm{~m}$ & $1.83 \mathrm{~m}$ & $14.9352 \mathrm{~m}$ & $0.6096 \mathrm{~m}$ & $2.1336 \mathrm{~m}$ \\
\hline
\end{tabular}

\section{A.2 Lunction Inputs for STSC Vent Paths}

One 2 in $(0.0508 \mathrm{~m})$ inlet vent and one 4 in $(0.1016 \mathrm{~m})$ outlet vent with $2 \mathrm{ft}(0.6096 \mathrm{~m})$ chimney in the STSC are modeled. Both vents have no filter, flow restriction, or bend. $A$ discharge coefficient of 0.6 is assumed, which corresponds to a FATE loss coefficient CJN of $1 / 0.6^{2}=2.8$. Pertinent junction inputs for STSC vent paths to the cell are summarized in Table A-3. 
FAl/10-83

PRC-STP-00241, Rev 0

Rev. 0

Page 84 of 284

March, 2010

Table A-3: Junction Inputs for STSC Vent Paths to the Cell

\begin{tabular}{|c|c|c|}
\hline \multirow[t]{2}{*}{ FATE Inputs } & \multicolumn{2}{|c|}{ Junction } \\
\hline & Inlet Vent & Outlet Vent \\
\hline Junction Index & 1 & 5 \\
\hline IR1, upstream node index & 2 & 1 \\
\hline IR2, downstream node index & $\begin{array}{l}6 \text { for settler sludge } \\
1 \text { for container sludge }\end{array}$ & 2 \\
\hline $\begin{array}{l}\text { OHORIZ, orientation } \\
=0, \text { vertical flow } \\
=1, \text { horizontal flow }\end{array}$ & 0 & 0 \\
\hline AJN, flow area & 2.03E-3 & $8.11 \mathrm{E}-3$ \\
\hline Z1JN, inlet height from floor & 3.8148 & $\begin{array}{l}2.1732 \text { for settler sludge } \\
1.5929 \text { for container sludge }\end{array}$ \\
\hline Z2JN, outlet height from floor & $\begin{array}{l}2.6035 \text { for settler sludge } \\
1.5929 \text { for container sludge }\end{array}$ & 4.4244 \\
\hline CJN, loss coefficient & 2.8 & 2.8 \\
\hline $\begin{array}{l}\text { FGAS1JN, fraction of junction } \\
\text { length occupied by donor gas }\end{array}$ & 1.0 & 1.0 \\
\hline
\end{tabular}

\section{A.3 Junction Inputs for Cell Cover Blocks}

The worst case gap widths for cell 3L cover blocks shown in Figure A-1 (HNF-12563, Rev. 2) are modeled using two junctions, one for upward and one for downward flow. Half the gap area is assumed to participate in upward flow and the other half in downward flow. In (HNF-12563, Rev. 2) the FATE input KFILTER, which characterizes the gap resistance by the relationship $\triangle P=K F I L T E R \times Q$, where $Q$ is the volumetric flow rate, is determined for cell $3 L$ cover blocks as following. The value of KFILTER for the three wider gaps is

$$
\mathrm{KFILTER}{ }_{3}=786.8 \mathrm{~Pa}-\mathrm{sec} / \mathrm{m}^{3},
$$

While for the two narrow gaps

$$
\text { KFILTER } 2=2.673 \times 10^{4} \mathrm{~Pa}-\mathrm{sec} / \mathrm{m}^{3} .
$$

The parallel combination of the two yields an effective value of KFILTER given by

$$
\begin{aligned}
& \text { KFILTER }=\left(\text { KFILTER }_{2} \times \text { KFILTER }_{3}\right) /\left(\text { KFILTER }_{2}+\text { KFILTER }_{3}\right) \\
& \text { KFILTER }=764.3 \mathrm{~Pa}-\mathrm{sec} / \mathrm{m}^{3} .
\end{aligned}
$$


In the current analysis, the gaps are modeled using a single junction. The countercurrent exchange of flow in the gaps is quantified by the exchange flowrate of the junction. Therefore, the KFILTER corresponding to the entire gap area is given by $764.3 / 2=382.15 \mathrm{~Pa}$ $\mathrm{sec} / \mathrm{m}^{3}$.

For cell 2R, a long cell, there are two more cover blocks for a total of six cover blocks. Hence there are five wider gaps and three narrow gaps. Assuming the size of the wider gaps in cell $2 R$ is same as that in cell $3 L$, the value of KFILTER for the five wider gaps can be easily obtained by

$\mathrm{KFILTER}_{5}=3 / 5 \times \mathrm{KFILTER}_{3}$

$\mathrm{KFILTER}_{5}=472.1 \mathrm{~Pa}-\mathrm{sec} / \mathrm{m}^{3}$.

The parallel combination of the two yields an effective value of KFILTER given by

KFILTER $=\left(K_{\text {KFILTER }} \times\right.$ KFILTER $\left._{5}\right) /\left(\right.$ KFILTER $_{2}+$ KFILTER $\left._{5}\right)$

KFILTER $=463.9 \mathrm{~Pa}-\mathrm{sec} / \mathrm{m}^{3}$.

Again the KFILTER corresponding to the entire gap area is given by $463.9 / 2=231.95$ $\mathrm{Pa}-\mathrm{sec} / \mathrm{m}^{3}$.

Pertinent junction inputs for the cover block gaps are summarized in Table A-4. 
FAl/10-83

PRC-STP-00241, Rev 0

Rev. 0

Page 86 of 284

Figure A-1: Worst Case Gap Widths for Cell 3L Cover Blocks.

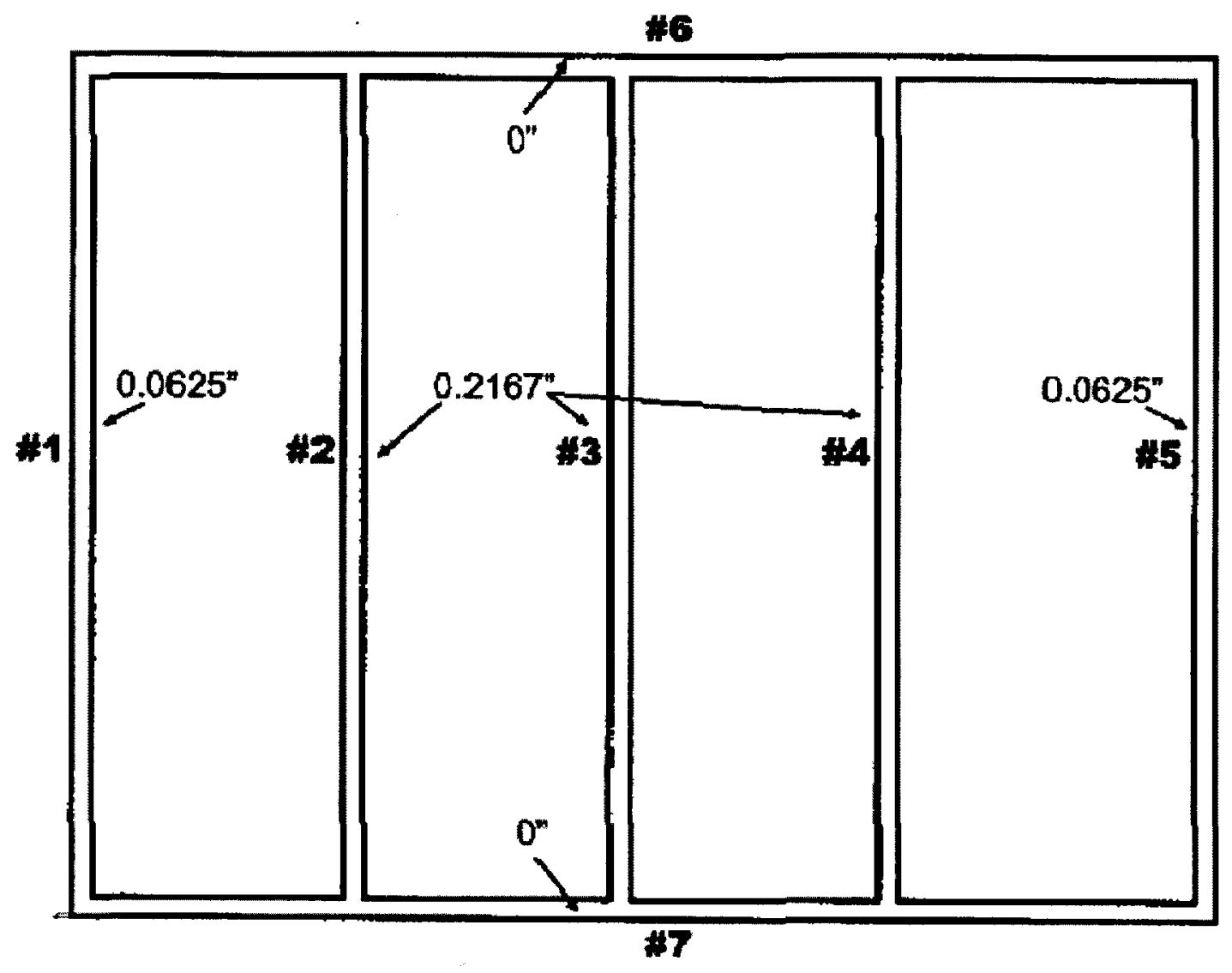


FAl/10-83

PRC-STP-00241, Rev 0

Rev. 0

Table A-4: Junction Inputs for Cover Block Gaps

\begin{tabular}{|l|l|l|}
\hline \multirow{2}{*}{ FATE Inputs } & \multicolumn{2}{|c|}{ Junction } \\
\cline { 2 - 4 } & \multicolumn{1}{|c|}{ Normal Process Cell } & \multicolumn{1}{c|}{ Long Process Cell (2R) } \\
\hline Junction Index & 11 & 17 \\
\hline IR1, upstream node index & 6 & 11 \\
\hline IR2, downstream node index & 10 & 10 \\
\hline $\begin{array}{l}\text { OHORIZ, orientation } \\
=0, \text { horizontal flow } \\
=1, \text { vertical flow }\end{array}$ & 1 & 1 \\
\hline AJN, flow area & $1.1^{1}$ & $1.0^{1}$ \\
\hline Z1JN, inlet height from floor & 0.0 & 0.0 \\
\hline Z2JN, outlet height from floor & 6.7056 & 6.7056 \\
\hline CJN, loss coefficient & 1. E-5 & 1. E-5 \\
\hline KFILTER & 382.15 & 231.95 \\
\hline $\begin{array}{l}\text { FGAS1JN, fraction of junction } \\
\text { length occupied by donor gas }\end{array}$ & 1.0 & 1.0 \\
\hline $\begin{array}{l}1 \text { For junctions with KFILTER }>0 \text { the junction flow area does not affect the flow rate. However, } \\
\text { a non-zero junction flow area has to be specified to make it an active junction. }\end{array}$ &
\end{tabular}


$\mathrm{FAl} / 10-83$

PRC-STP-00241, Rev 0

Rev. 0

Page 88 of 284

March, 2010

\section{A.4 Heat Sink Inputs for Cell Heat Conductors}

The two long side walls are represented by a heat conductor and the two short side walls are represented by a second heat conductor. One side of each heat conductor faces the cell and the other side is insulated. The characteristic height of each heat conductor for natural convection heat transfer is $6.7056 \mathrm{~m}$.

The cover block is represented as a $6 \mathrm{ft}(1.8288 \mathrm{~m})$ thick concrete heat conductor. Its one-sided area is given by $5.3848 \times 3.9624=21.337 \mathrm{~m}^{2}$ for normal cell and $8.3820 \times 3.9624$ $=33.21 \mathrm{~m}^{2}$ for long cell. The characteristic height of the heat conductor for natural convection heat transfer is $3.9624 \mathrm{~m}$. Note that the cell concrete floor is not represented since it is normally cooler than the cell gas and very little heat transfer is expected between the two. The heat sink inputs for cell heat conductors are summarized in Table A-5.

Table A-5: Heat Sink Inputs for Normal Cell Heat Conductors

\begin{tabular}{|l|l|l|l|}
\hline \multirow{2}{*}{ FATE Inputs } & \multicolumn{3}{c|}{ Heat Sink } \\
\cline { 2 - 4 } & \multicolumn{1}{|c|}{ Long Side Wall } & \multicolumn{1}{c|}{ Short Side Wall } & \multicolumn{1}{c|}{ Cover Block } \\
\hline Heat Sink Index & 101 & 102 & 103 \\
\hline $\begin{array}{l}\text { IORIHS, orientation } \\
=0 \text { for vertical } \\
=1 \text { for horizontal }\end{array}$ & 0 & 0 & 1 \\
\hline XRO, thickness & 1.067 & 1.372 & 1.829 \\
\hline AHS, one-sided area & 72.217 & 53.141 & 21.337 \\
\hline $\begin{array}{l}\text { IREGI, region inner } \\
\text { surface faces }\end{array}$ & 6 & 6 & 10 \\
\hline $\begin{array}{l}\text { IREGO, region outer } \\
\text { surface faces }\end{array}$ & 0 & 0 & 6 \\
\hline $\begin{array}{l}\text { XLHS, characteristic } \\
\text { height }\end{array}$ & 6.7056 & 6.7056 & 3.9624 \\
\hline ZTHS, top elevation & 5.7150 & 5.7150 & 7.5438 \\
\hline ZBHS, bottom elevation & -0.9906 & -0.9906 & 5.7150 \\
\hline IMATHS, material type ${ }^{1}$ & 3 & 3 & 3 \\
\hline $\begin{array}{l}\text { I Material type 3 represents concrete with density, thermal conductivity, specific heat, and } \\
\text { emissivity of 1850 kg/m }{ }^{3}, 0.6 \mathrm{~W} / \mathrm{m} / \mathrm{K}, 960 \mathrm{~J} / \mathrm{kg} / \mathrm{K}, \text { and } 0.75, \text { respectively. }\end{array}$ \\
\hline
\end{tabular}


FAl/10-83

PRC-STP-00241, Rev 0

Rev. 0

Page 89 of 284

March, 2010

Table A-6: Heat Sink Inputs for Long Cell Heat Conductors

\begin{tabular}{|l|l|l|l|}
\hline \multirow{2}{*}{ FATE Inputs } & \multicolumn{3}{|c|}{ Heat Sink } \\
\cline { 2 - 4 } & \multicolumn{1}{|c|}{ Long Side Wall } & \multicolumn{1}{c|}{ Short Side Wall } & \multicolumn{1}{c|}{ Cover Block } \\
\hline Heat Sink Index & 111 & 112 & 113 \\
\hline $\begin{array}{l}\text { IORIHS, orientation } \\
=0 \text { for vertical } \\
=1 \text { for horizontal }\end{array}$ & 0 & 0 & 1 \\
\hline XRO, thickness & 1.067 & 1.372 & 1.829 \\
\hline AHS, one-sided area & $56.206^{2}$ & 53.141 & 33.21 \\
\hline $\begin{array}{l}\text { IREGI, region inner } \\
\text { surface faces }\end{array}$ & 11 & 11 & 10 \\
\hline $\begin{array}{l}\text { IREGO, region outer } \\
\text { surface faces }\end{array}$ & 0 & 0 & 11 \\
\hline $\begin{array}{l}\text { XLHS, characteristic } \\
\text { height }\end{array}$ & 6.7056 & 6.7056 & 3.9624 \\
\hline ZTHS, top elevation & 5.7150 & 5.7150 & 7.5438 \\
\hline \begin{tabular}{l} 
ZBHS, bottom elevation \\
\hline IMATHS, material type
\end{tabular} & -0.9906 & -0.9906 & 5.7150 \\
\hline $\begin{array}{l}1 \\
\text { Material type 3 represents concrete with density, thermal conductivity, specific heat, and } \\
\text { emissivity of 1850 kg/m }{ }^{3}, 0.6 \mathrm{~W} / \mathrm{m} / \mathrm{K}, 960 \mathrm{~J} / \mathrm{kg} / \mathrm{K}, \text { and } 0.75, \text { respectively } \\
\text { Represents only one long side. The other long side is represented by heat sink } 114 \text { which is } \\
\text { between Cell 2R and Cell 2L. }\end{array}$ & 3 \\
\hline
\end{tabular}




\section{A.5 Heat Sink Inputs for Sludge}

The sludge in the elliptical bottom head of STSC is axially nodalized using 10 short annular disks as shown in Figure 6-1. Table A-7 summarizes the dimensions of the sludge nodes in the bottom head. There are two rows given per heat sink, and the meaning of each row and column is described next.

Table A-7: Sludge Node Dimensions in Elliptical Bottom Head

\begin{tabular}{|c|c|c|c|c|c|c|c|c|}
\hline & $\mathrm{Y}$ & RI & VI & SI & RO & vo & So & VO-VI \\
\hline & 0.3683 & 0.30480 & 0.07783 & & 0.73660 & 0.41853 & & \\
\hline \multirow[t]{2}{*}{ LAYER - 10} & & & 0.01205 & 0.07909 & & 0.07011 & 0.19175 & 0.05806 \\
\hline & 0.3270 & 0.30480 & 0.06578 & & 0.73195 & 0.34842 & & \\
\hline \multirow[t]{2}{*}{ LAYER - 9} & & & 0.01202 & 0.07890 & & 0.06817 & 0.19830 & 0.05615 \\
\hline & 0.2858 & 0.30480 & 0.05376 & & 0.71788 & 0.28025 & & \\
\hline \multirow[t]{2}{*}{ LAYER - 8} & & & 0.01197 & 0.07852 & & 0.06435 & 0.21056 & 0.05238 \\
\hline & 0.2448 & 0.30480 & 0.04179 & & 0.69395 & 0.21590 & & \\
\hline \multirow[t]{2}{*}{ LAYYER - 7} & & & 0.01214 & 0.07967 & & 0.05995 & 0.23238 & 0.04781 \\
\hline & 0.2032 & 0.30480 & 0.02965 & & 0.65844 & 0.15595 & & \\
\hline \multirow[t]{2}{*}{ LAYER - 6} & & & 0.01489 & 0.11669 & & 0.06595 & 0.33085 & 0.05106 \\
\hline & 0.1500 & 0.26766 & 0.01476 & & 0.59326 & 0.09000 & & \\
\hline \multirow[t]{2}{*}{ LAYER- 5} & & & 0.01162 & 0.10230 & & 0.04791 & 0.35101 & 0.03629 \\
\hline & 0.1000 & 0.22428 & 0.00314 & & 0.50462 & 0.04209 & & \\
\hline \multirow{2}{*}{ LAYER - 4} & & & 0.00208 & 0.07886 & & 0.01782 & 0.19157 & 0.01574 \\
\hline & 0.0750 & 0.16481 & 0.00106 & & 0.44551 & 0.02427 & & \\
\hline \multirow[t]{2}{*}{ LAYYER - 3} & & & 0.00106 & 0.08625 & & 0.01288 & 0.19590 & 0.01182 \\
\hline & 0.0508 & 0.0000 & 0.00000 & & 0.37330 & 0.01139 & & \\
\hline \multirow[t]{2}{*}{ LAYER - 2} & & & 0.00000 & 0.00000 & & 0.00847 & 0.21692 & 0.00847 \\
\hline & 0.0254 & 0.0000 & 0.00000 & & 0.26881 & 0.00292 & & \\
\hline \multirow[t]{2}{*}{ LAYER - 1} & & & 0.00000 & 0.00000 & & 0.00292 & 0.22802 & 0.00292 \\
\hline & 0.0 & 0.0000 & 0.00000 & & 0.00000 & 0.00000 & & \\
\hline
\end{tabular}

Each column in the table is defined either at the node center or at node boundaries, and is determined as follows.

$\mathrm{Y}$ - axial node boundary elevation, $\mathrm{m}$.

$\mathrm{RI}$ - inner radius at axial node boundaries, $\mathrm{m}$. The inner radius of the sludge is determined by

$$
R I=R_{\text {insert }} \sqrt{1-\frac{\left(Y-0.0508-\frac{R_{\text {insert }}}{2}\right)^{2}}{\left(\frac{R_{\text {insert }}}{2}\right)^{2}}}, \mathrm{Y} \geq 0.0508
$$

$0.0, Y<0.0508$

where $R_{\text {insert }}$ is the major radius of the insert $(0.3048 \mathrm{~m})$.

$\mathrm{VI}$ - cumulative volume of the elliptical insert at node boundaries, $\mathrm{m}$. VI is determined by 
$V I=4 \pi\left(\frac{R_{\text {insert }}}{2}(Y-0.0508)^{2}-\frac{(Y-0.0508)^{3}}{3}\right), Y \geq 0.0508$

$0.0, Y<0.0508$

$\mathrm{VI}$ is determined at axial node boundaries. Then, the difference between node boundary values is taken as the node value in Table A-7. This quantity is used later to determine the sludge volume in the annular disk.

$\mathrm{SI}$ - inner surface area of the sludge node in contact with insert, $\mathrm{m}$. SI is estimated by $S I=2 \pi\left(\frac{R I_{\text {top }}+R I_{\text {botom }}}{2}\right) \sqrt{\left(Y_{\text {top }}-Y_{\text {bottom }}\right)^{2}+\left(R I_{\text {top }}-R I_{\text {botom }}\right)^{2}}$

where the subscripts "top" and "bottom" refer to the node top and bottom boundary values.

RO - outer radius at axial node boundaries, $m$. The outer radius of the sludge is determined by

$$
R O=R_{S T S C} \sqrt{1-\frac{\left(Y-\frac{R_{S T S C}}{2}\right)^{2}}{\left(\frac{R_{S T S C}}{2}\right)^{2}}}
$$

where $R_{\text {STSC }}$ is the radius of the STSC $(0.73428 \mathrm{~m})$.

VO - cumulative volume of the elliptical STSC at node boundaries, $\mathrm{m}$. VO is determined by

$$
V O=4 \pi\left(\frac{R_{S T S C}}{2} Y^{2}-\frac{Y^{3}}{3}\right)
$$

VO is determined at axial node boundaries. The difference between node boundary values is taken as the node value in Table A-7. This quantity is used later to determine the sludge volume in the annular disk.

SO - outer surface area of sludge node in contact with STSC, $\mathrm{m}$. SO is estimated by

$S O=2 \pi\left(\frac{R O_{t o p}+R O_{\text {botom }}}{2}\right) \sqrt{\left(Y_{\text {top }}-Y_{\text {bottom }}\right)^{2}+\left(R O_{\text {top }}-R O_{\text {botom }}\right)^{2}}$

where the subscripts "top" and "bottom" refer to the node top and bottom boundary values.

$\mathrm{VO}-\mathrm{VI}$ - the difference between nodal-VO and nodal-VI gives the annular disk sludge volume. 
The insert wall, sludge, and STSC heat conductors at each row in the STSC bottom head are normally treated as an annular composite heat sink. To consider the curvature of surface, following approximation are used for FATE sludge heat conductor inputs.

$X R I$, inner radius,

$X R O$, outer radius,

$X Z H S$, conduction distance,

AHS, one-sided area,

ASHSI, inner surface area,

ASHSO, outer surface area,

VOLHS, volume,
$\left(\mathrm{RI}_{\text {top }}+\mathrm{RI}_{\text {bottom }}\right) / 2$

$\left(\mathrm{RO}_{\text {top }}+\mathrm{RO}_{\text {bottom }}\right) / 2$

$\left(Y_{\text {top }}+Y_{\text {bottom }}\right) / 2$

$\pi \times(X R I+X R O) \times X Z H S$

SI

so

VO-VI

The sludge heat sink conducts heat to the adjacent insert and STSC walls. Therefore, AHS of the insert and STSC walls are set to ASHSI and ASHSO of the sludge, respectively. Also, the conduction distance XZHS of the insert and STSC walls are set to $\sqrt{\left(Y_{\text {top }}-Y_{\text {bottom }}\right)^{2}+\left(R I_{\text {top }}-R I_{\text {bottom }}\right)^{2}}$ and $\sqrt{\left(Y_{\text {top }}-Y_{\text {bottom }}\right)^{2}+\left(R O_{\text {top }}-R O_{\text {bottom }}\right)^{2}}$, respectively.

The STSC bottom head is cooled by the air in the support skirt enclosure. The STSC bottom head surface is vertical at the top but progressively becomes flat near the bottom. Therefore, the orientation of the STSC wall flag, IORIHS, is set to "0" for the top three layers but "1" for the bottom seven layers. In FATE, heat transfer due to laminar boundary layer underside of a hot plate is modeled.

For the third row, the insert wall is not modeled. Instead, the sludge is exposed to water on the top using the "fin" feature of FATE. The exposed portion of the third row corresponds to $\mathrm{RI}_{\text {top }}$ of the sludge heat conductor, $0.16481 \mathrm{~m}$. The exposed area corresponds to SI, 0.08625 $\mathrm{m}^{2}$.

The resistance in the 0.25 inch insert wall is considered by increasing the conduction distance in the sludge by the equivalent distance. That is,

$$
\frac{\left(\frac{X Z H S_{\text {effective }}}{2}\right)}{k_{\text {sludge }}}=\frac{\left(\frac{X Z H S}{2}\right)}{k_{\text {sludge }}}+\frac{X_{\text {insert }}}{k_{\text {ss }}}
$$

Where $k_{\text {sludge }}$ is the thermal conductivity of sludge $\left(0.7 \mathrm{~W} \mathrm{~m}^{-1} \mathrm{~K}^{-1}\right), k_{s s}$ is the thermal conductivity of stainless steel $\left(16 \mathrm{~W} \mathrm{~m}^{-1} \mathrm{~K}^{-1}\right), X_{\text {insert }}$ is the insert wall thickness $(0.00635 \mathrm{~m}), X Z H S$ is the conduction distance, or height, of the sludge node $(0.0242 \mathrm{~m})$, and $X Z H S_{\text {effective }}$ is the effective conduction distance to be determined. The above equation can be easily solved to yield $X Z H S_{\text {effective }}=0.0248 \mathrm{~m}$. Note that this estimate is conservative because the actual conduction distance in the third row is smaller than the node height. 
Similarly, the STSC wall is not modeled for the first row. Instead, the sludge is exposed to air on the bottom. The exposed area corresponds to SO, $0.22802 \mathrm{~m}^{2}$.

The resistance in the 0.5 inch STSC wall is considered by increasing the conduction distance in the sludge by the equivalent distance. That is,

$$
\frac{\left(\frac{X Z H S_{\text {effective }}}{2}\right)}{k_{\text {sludge }}}=\frac{\left(\frac{X Z H S}{2}\right)}{k_{\text {sludge }}}+\frac{X_{S T S C}}{k_{s s}}
$$

Where $k_{\text {sludge }}$ is the thermal conductivity of sludge $\left(0.7 \mathrm{~W} \mathrm{~m}^{-1} \mathrm{~K}^{-1}\right), k_{s s}$ is the thermal conductivity of stainless steel $\left(16 \mathrm{~W} \mathrm{~m}^{-1} \mathrm{~K}^{-1}\right), X_{\text {STSC }}$ is the STSC wall thickness $(0.0127 \mathrm{~m}), X Z H S$ is the conduction distance of the sludge node $(0.0254 \mathrm{~m})$, and $X Z H S_{\text {effective }}$ is the effective conduction distance to be determined. The above equation can be easily solved to yield $X Z H S_{\text {effective }}=0.0265 \mathrm{~m}$.

\section{A.6 Heat and Hydrogen Sources}

Only one STSC is analyzed in detail within the process cell or the cell $2 \mathrm{R}$. To simulate the other STSCs in the hot cells or the cell of interest, the decay power, peak reaction power, and peak hydrogen generation rate for a single STSC was used.

Decay power in one STSC loaded with container sludge is given by $1.6 \mathrm{~m}^{\wedge} 3^{*} 590 \mathrm{Kg}$ $\mathrm{U} / \mathrm{m}^{\wedge} 3^{*} 0.08814 \mathrm{~W} / \mathrm{kg}-\mathrm{U}=83.2 \mathrm{~W}$. Oxidation power of $116 \mathrm{~W}$ was estimated from a FATE run analyzing a container sludge STSC in conditions similar to the T-Plant model. Similarly, the peak hydrogen generation rate was found to be $838 \mathrm{l} / \mathrm{day}$ * $1 / 86400 \mathrm{day} / \mathrm{s}$ * $0.07598 \mathrm{~kg} / \mathrm{m}^{\star \star} 3$ * $1 / 1000 \mathrm{~m} * * 3 / \mathrm{l}=7.37 \mathrm{E}-7 \mathrm{~kg} / \mathrm{s}$. Similar estimates were made for settler sludge.

Table A-8: Heat and Hydrogen Generation of Typical STSCs

\begin{tabular}{|l|l|l|}
\hline & Settler Sludge STSC & Container Sludge STSC \\
\hline Decay Power [W] & 96.5 & 83.2 \\
\hline Reaction Power [W] & 96 & 116 \\
\hline $\mathrm{H}_{2}$ Generation Rate $[\mathrm{kg} / \mathrm{s}]$ & $7.0 \mathrm{E}-7$ & $7.37 \mathrm{E}-7$ \\
\hline
\end{tabular}

\section{A.7 Sludge Radiolysis Inputs}

The best available calculation for sludge radiolysis is contained in SNF-22059, Revision 0 , Attachment 12 . The rate of hydrogen production from radiolysis $W_{\mathrm{H} 2}, \mathrm{~kg} / \mathrm{s}$, is

$$
\mathrm{W}_{\mathrm{H} 2}=\mathrm{CQ}\left[\mathrm{f}_{\mathrm{q} \alpha} \mathrm{e}_{\alpha} \mathrm{g}_{\alpha}+\mathrm{f}_{\mathrm{q} \beta} \mathrm{e}_{\beta} \mathrm{g}_{\beta}+\mathrm{f}_{\mathrm{q} \gamma} \mathrm{e}_{\gamma} \mathrm{g}_{\gamma}\right]
$$

where

$$
\mathrm{C}=\text { Units conversion factor, }
$$


Rev. 0

$\mathrm{C}=\frac{1}{100 \mathrm{eV}} \times \frac{1 \mathrm{eV}}{1.602 \times 10^{-19} \mathrm{~J}} \times \frac{0.002 \mathrm{~kg}}{6.02 \times 10^{23} \text { molecules }}=2.07 \times 10^{-10}$

$Q=$ Decay power, $W$,

$f_{q}=$ Fraction of decay power for the given radiation type,

$e=$ Fraction of power absorbed by water for the given radiation type, and

$g=g\left(\mathrm{H}_{2}\right)$, molecules $\mathrm{H}_{2}$ per $100 \mathrm{eV}$ absorbed by water,

and alpha, beta, and gamma radiation are respectively considered. An average $g$ value $G$ may be defined for convenience;

$$
G=f_{q \alpha} e_{\alpha} g_{\alpha}+f_{q \beta} e_{\beta} g_{\beta}+f_{q \gamma} e_{\gamma} g_{\gamma}
$$

which results in a simplified version of the equation,

$$
\mathrm{W}_{\mathrm{H} 2}=\mathrm{CQG}
$$

Invoking the standard molar volume of $22.4 \mathrm{~L} / \mathrm{gram}-\mathrm{mole}$, the rate of gas generation may be expressed in standard $\mathrm{L} / \mathrm{hr}$ as:

$$
\mathrm{Q}_{\mathrm{H} 2}=\mathrm{C}_{1} \mathrm{QG}
$$

SNF-22059 provides a calculation for the fraction of power absorbed by water for each radiation type, whose results are provided in Table 1 of its Attachment 12. Note that $g\left(\mathrm{H}_{2}\right)$ values are defined on the basis of energy absorbed by water alone.

FATE requires inputs for the $\mathrm{g}\left(\mathrm{H}_{2}\right)$ values and for the associated fraction of decay power. Therefore, to apply the SNF-22059 method using the FATE inputs, $g\left(\mathrm{H}_{2}\right)$ values are input for water as used in SNF-22059, and the associated fraction of decay power is the fraction for each radiation type deposited in water (the complementary fraction of the decay power is deposited in solids). So, FATE requires the products $\mathrm{f}_{\mathrm{q \alpha}} \mathrm{e}_{\alpha}, \mathrm{f}_{\mathrm{q} \beta} \mathrm{e}_{\beta}$, and $\mathrm{f}_{\mathrm{q \gamma}} \mathrm{e}_{\gamma}$. These products will be found by obtaining appropriate values for the current sludge type power fractions $f_{q a}, f_{q \beta}$, and $\mathrm{f}_{\mathrm{qY}}$, and choosing appropriate values of $\mathrm{e}_{\alpha}, \mathrm{e}_{\beta}$, and $\mathrm{e}_{\mathrm{Y}}$ from SNF-22059.

The alpha, beta, and gamma decay power fractions for each sludge type are given by decay corrected to October 2013 in the spreadsheet alpha beta and gamma decay fractions for sludge Rev 1.x/sx by Michael E. Johnson, dated February 23, 2010. The decay fractions are summarized in Table A-9. In future work, this spreadsheet will be validated and the results will be combined with a revised calculation of the power deposition to water as mentioned above. 
FAl/10-83

PRC-STP-00241, Rev 0

Rev. 0

Page 95 of 284

March, 2010

Table A-9: Fraction of Total Decay Energy, Reproduced from Michael E. Johnson, alpha beta and gamma decay fractions for sludge Rev 1.xIsx, February 23, 2010.

\begin{tabular}{|l|c|c|c|}
\hline \multirow{2}{*}{ Sludge Type } & \multicolumn{3}{|c|}{ Fraction of Total Decay Power } \\
\cline { 2 - 4 } & Alpha $\mathrm{f}_{\mathrm{qa}}$ & Beta $\mathrm{f}_{\mathrm{q} \beta}$ & Gamma $\mathrm{f}_{\mathrm{qV}}$ \\
\hline Settler & 0.34 & 0.47 & 0.19 \\
\hline KW Container & 0.36 & 0.43 & 0.21 \\
\hline
\end{tabular}

The calculation of SNF-22059 was for different sludge types than those considered in this work. The reference sludge types whose properties match most closely those of the settler and container sludge are chosen. For settler sludge, SB canister sludge is chosen. For container sludge, $\mathrm{N}$ canister sludge is chosen. The comparison between the sludge properties of sludge of interest and matching sludge types is shown in Table A-10. As indicated in the main body of the report, this assumption will be relaxed in the future, and an exact calculation following the SNF-22059 method will be followed for the sludge types considered in this work.

Table A-10: Sludge Properties of Closest Match to SNF-22059 Reference Types

\begin{tabular}{|l|c|c|c|}
\hline \multirow{2}{*}{ Sludge Type } & \multicolumn{3}{|c|}{ Sludge Properties } \\
\cline { 2 - 4 } & $\begin{array}{c}\text { Sludge Density } \\
\text { g/cc }\end{array}$ & $\begin{array}{c}\text { Total U } \\
\text { g/cc }\end{array}$ & $\begin{array}{c}\text { U metal } \\
\text { g/cc }\end{array}$ \\
\hline Settler (this work) & 3.25 & 2.050 & 0.1625 \\
\hline SB Canister (SNF-22059) & 2.50 & 1.400 & 0.125 \\
\hline KW Container (this work) & 1.8 & 0.59 & 0.082 \\
\hline N Canister (SNF-22059) & 1.90 & 0.770 & 0.0399 \\
\hline
\end{tabular}

Table A-11 lists the fraction of energy deposited to water for alpha, beta, and gamma radiation for different sludge types taken from SNF-22059, Attachment 12, Table 1.

Table A-11: Fraction of Energy Deposited to Water from SNF-22059

\begin{tabular}{|l|l|c|c|c|}
\hline \multirow{2}{*}{ Sludge Type } & Sludge Type in & \multicolumn{3}{|c|}{ Fraction of Energy Deposited to Water } \\
\cline { 3 - 5 } & & Alpha $e_{\alpha}$ & Beta $e_{\beta}$ & Gamma $_{Y}$ \\
\hline Settler & SB Canister & 0.320 & 0.191 & 0.0253 \\
\hline KW Container & N Canister & 0.329 & 0.251 & 0.0423 \\
\hline
\end{tabular}


Finally, the fraction of total decay energy attributed to alpha, beta, and gamma in Table A-9 is multiplied by the fraction of energy deposited to water in Table A-11 to obtain the FATE radiolysis inputs as shown inTable A-12.

Table A-12: FATE Radiolysis Inputs - Fraction of Power Deposited to Water

\begin{tabular}{|l|c|c|c|}
\hline \multirow{2}{*}{ Sludge Type } & \multicolumn{3}{|c|}{ FATE Radiolysis Inputs } \\
\cline { 2 - 4 } & $\begin{array}{c}\text { Alpha } \\
\mathrm{f}_{\mathrm{qq}} \mathrm{e}_{\alpha} \\
\text { FALPSG }\end{array}$ & $\begin{array}{c}\text { Beta } \\
\mathrm{f}_{\mathrm{q} \beta} \mathrm{e}_{\beta} \\
\text { FBETSG }\end{array}$ & $\begin{array}{c}\text { Gamma } \\
\mathrm{f}_{\mathrm{q \gamma}} \mathrm{e}_{\mathrm{Y}} \\
\text { FGAMSG }\end{array}$ \\
\hline Settler & 0.109 & 0.090 & 0.005 \\
\hline KW Container & 0.118 & 0.108 & 0.009 \\
\hline
\end{tabular}

The $g$ value for each radiation type for radiolytic generation of hydrogen is input to FATE and is summarized in Table A-13. Consistent with SNF-22059, these are the values for pure water.

Table A-13: FATE Radiolysis Inputs - G Values

\begin{tabular}{|l|c|c|c|}
\hline & \multicolumn{3}{|c|}{ FATE G Value Inputs, molecule $\mathrm{H}_{2} / 100 \mathrm{eV}$ absorbed in water } \\
\hline Radiation & Alpha $\mathrm{g}_{\alpha}$ & Beta $\mathrm{g}_{\beta}$ & Gamma $\mathrm{g}_{\gamma}$ \\
\hline FATE parameter & GH2ALPSG & GH2BETSG & GH2GAMSG \\
\hline Value & 1.5 & 0.5 & 0.5 \\
\hline
\end{tabular}




\section{APPENDIX B: Appendix B; FATETM INPUT FILES}

\section{B.1 Base File: CON2STSC1.dat}

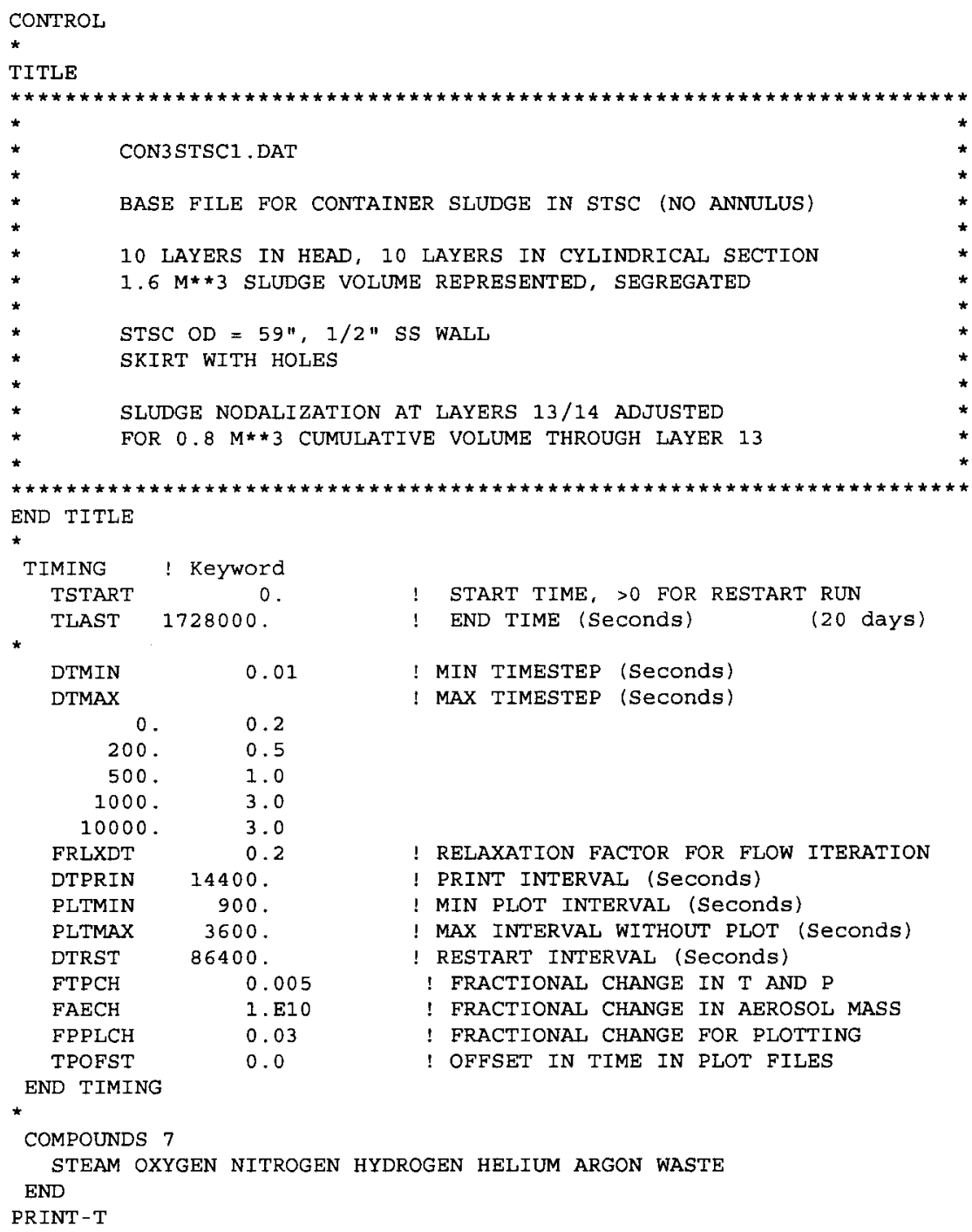

68,1

$\begin{array}{llllll}59,20 & 59,15 & 59,10 & 59,5 & 59,1 & 58,1 \\ 56,20 & 56,15 & 56,10 & 56,5 & 56,1 & 55,1 \\ 53,20 & 53,15 & 53,10 & 53,5 & 53,1 & 52,1 \\ 50,20 & 50,15 & 50,10 & 50,5 & 50,1 & 49,1 \\ 47,20 & 47,15 & 47,10 & 47,5 & 47,1 & 46,1\end{array}$


FAl/10-83

PRC-STP-00241, Rev 0

Rev. 0

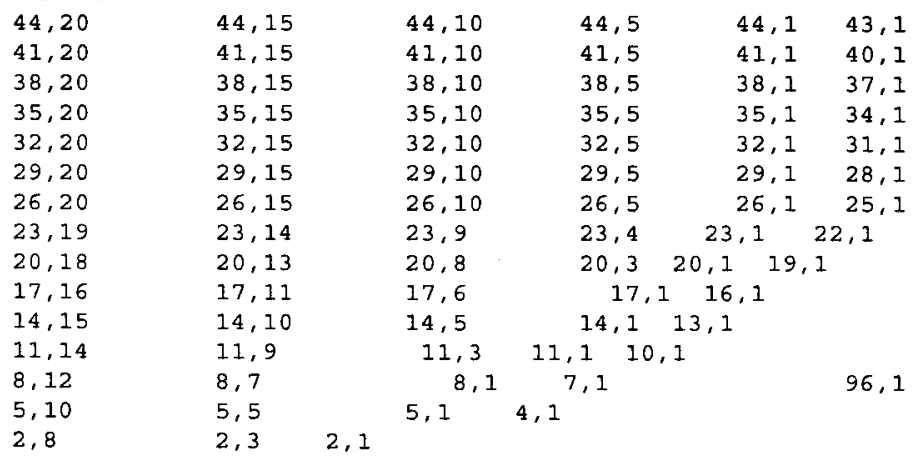

95,1

END PRINT-T

CELSIUS

PLOT 1

$\begin{array}{llll}\text { PRESSURE } & 2 & 1 & 3\end{array}$

GAS-T 2113

LIQ-T 1

HS-TI

HS -TI

HS - TI

QLIQ-HSI

QLIQ-HSI

QGAS - HSO

QGAS-HSO

QGAS-HSO

QFIN

OSW

QSW

$\begin{array}{lllllllll}4 & 7 & 10 & 13 & 16 & 19 & 22 & 25 & 28\end{array}$

$\begin{array}{llllllllll}31 & 34 & 37 & 40 & 43 & 46 & 49 & 52 & 55 & 58\end{array}$

$\begin{array}{llll}61 & 68 & 95 & 96\end{array}$

$\begin{array}{lllllll}12 & 15 & 18 & 21 & 24 & 27 & 30\end{array}$

$\begin{array}{llllllllll}33 & 36 & 39 & 42 & 45 & 48 & 51 & 54 & 57 & 60\end{array}$

$\begin{array}{lllllllll}4 & 7 & 10 & 13 & 16 & 19 & 22 & 25 & 28\end{array}$

$\begin{array}{llllllllll}31 & 34 & 37 & 40 & 43 & 46 & 49 & 52 & 55 & 58\end{array}$

$\begin{array}{llll}61 & 68 & 95 & 96\end{array}$

2859

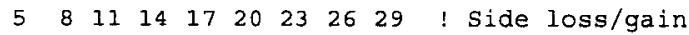
$\begin{array}{llllllllll}32 & 35 & 38 & 41 & 44 & 47 & 50 & 53 & 56 & 59\end{array}$

$\begin{array}{lllllll} & & & \end{array}$

GAS-X OXYGEN $2 \quad 1 \quad 3 \quad$ ! $02 \frac{\circ}{6}$

GAS-X STEAM $\quad 2 \quad 1103 \quad$ ! H2O

GAS - X HYDROGEN $2 \quad 1 \quad 3 \quad$ ! H2

GAS $-W$

GAS -WX

HS - T 59

HS-T 56

HS - T 53

HS - T 50

HS-T 47

HS - T 44

HS-T 41

HS $-\mathrm{T} \quad 38$

HS - T 35

HS-T 32

HS - T 29

HS - T 26

HS $-\mathrm{T} 23$

HS - T 20

HS-T 17

HS $-\mathrm{T} \quad 14$

HS $-\mathrm{T} \quad 11$

HS-T 8

HS - T 52

HS-T 22

WCOND-PL STEAM

WCOND-HSI STEAM

WCOND-HSO STEAM

SPECIAL-R

SPECIAL - R

456 ! vent flow

2456 ! vent cc flow

QGAS-HSI 29596

! Condensation rate of steam on pool

! Condensation rate of steam on STSC

! Condensation rate of steam on STSC

301302303304305309 ! Energy Balance Terms

$306 \quad 307 \quad 312$

! Watch radiation \& convection to skirt 
FAl/10-83

PRC-STP-00241, Rev 0

\section{Rev. 0}

QGAS-HSO $9 \quad \begin{array}{llllllllll}4 & 7 & 10 & 13 & 16 & 19 & 22 & 25 & 28\end{array}$

QGAS-HSO $29596 \quad$ ! Watch radiation \& convection to skirt

QRAD-HSI 29596

$\begin{array}{lllllllllll}\text { QRAD-HSO } & 9 & 4 & 7 & 10 & 13 & 16 & 19 & 22 & 25 & 28\end{array}$

QRAD-HSO 29596

END PLOT ! PLOT is a comment

ACTIVE MODELS ! Keyword; MODELS is a comment; $1=$ on, $0=$ off

IJUNC 1 ! Junction flow

ICCFLW 1 ! Counter-current flow

IDIFLW 0 ! Diffusional transport

IHSINK 1 ! Heat sinks

IHXPOL 1 ! POOl-gas heat/mass transfer

IHSBOIL 1 ! Boiling heat transfer

ICNDS 1 ! Condensation

IASED 0 ! Aerosol sedimentation

IALEAK 0 ! Aerosol Leakage

IFOG 0 ! Fog formation

IAEB 0 ! Aerosol release via sparging/boiling

ISRC 1 ! User-defined sources

IQDECAY 0 ! Assign decay power to compounds

ILXFER 0 ! Liquid transfers

IDCRT $0 \quad$ ! DCRT

ISLUDGE 1 ! Sludge

IPLTYP 2 ! 1=wrap around, 2=no wrap (spreadsheet format)

END ACTIVE MODELS

END CONTROL

*

VOLUMES

*

* UPPER OR LOWER hEAD

* ASSUME 1/2" WALL THICKNESS

* VOLUME OF ELLIPTICAL HEAD $=1 / 3 * \mathrm{PI} *(58 / 2)^{\wedge} 3=25540.1 \mathrm{IN}^{\wedge} 3$

$\star=0.41853 \mathrm{M}^{\wedge} 3$

* MIDDLE SECTION

$\star P I *(58 / 2)^{\wedge} 2 * 72.63=191894 \mathrm{IN}^{\wedge} 3=3.14458 \mathrm{M}^{\wedge} 3$

* Volume of SLUDGe in the LOWER heAd

$\star=0.41853 \mathrm{M}^{\wedge}$

* HEIGHT OF $1.6 \mathrm{M}^{\wedge} 3$ SLUDGE IN THE CYLINDRICAL SECTION

$\star=(1.6-0.41853) /\left(\mathrm{PI} * 1.4732^{\wedge} 2 / 4\right)$

$\star=0.69312 \mathrm{M}$

* INPUTS FOR REGION 1:

$\star$ VOLUME $=2 \star 0.41853+3.14458-1.6$

* $\quad=2.38164 \mathrm{M}^{\wedge} 3$

* elevation $=0.3683+0.69312=1.0614 \mathrm{M}$

* SED AREA $=\mathrm{PI} * 1.4732^{\wedge} 2 / 4=1.7046 \mathrm{M}^{\wedge} 2$

* Z LIQ $=2.1750(85.63$ IN $)-1.0614=1.1136 \mathrm{M}$

* VOLUME of water in Region 1

$\star \quad=1.1136 \star \mathrm{PI} * 1.4732^{\wedge} 2 / 4=1.8982 \mathrm{M}^{\wedge} 3$

$\star \quad Z T O P=1.1136 \star 2.38164 / 1.8982=1.3972 \mathrm{M}$

REGIONS 1106

LABEL STSC PROCESS-CELL SKIRT

$\begin{array}{llll}\text { VOLUME } & 1.8982 & 1 . E 9 & 0.2203\end{array}$

SED_AREA $\quad 1.7046 \quad 1 . E 6 \quad 1.76$

ELEVATION $\quad 1.0614 \quad-0.0254 \quad-0.0254$

TEMP GAS $35.0 \quad 35.00 \quad 35.0$

PRESSURE $\quad 1.01334 \mathrm{E5} \quad 1.0 \mathrm{E} 5 \quad 1.0 \mathrm{E} 5$

$\begin{array}{llll}\text { ZTOP } & 1.3972 & 1 . \mathrm{E} 3 & 0.3747\end{array}$

$\begin{array}{llll}\text { Z_LIQ } & 1.1136 & 0.0 & 0.0\end{array}$

TEMP_LIQ $35.0 \quad 35.0 \quad 35.0$

END REGIONS

*

* Gas composition of each region; specify mole fraction of each gas

GASES

1

6

3 
FAl/10-83

PRC-STP-00241, Rev 0

\section{Rev. 0}

$\begin{array}{llll}\text { STEAM } & 0.01 & 0.01 & 0.01 \\ \text { OXYGEN } & 0.20 & 0.20 & 0.20 \\ \text { NITROGEN } & 0.79 & 0.79 & 0.79\end{array}$

END GASES

0.79

0.79

0.20

*

* Liquid composition of each region; specify mass fractions

LIQUIDS

STEAM

1

6

3

END LIQUIDS

* Aerosol concentration of each region $\left(\mathrm{kg} / \mathrm{m}^{\wedge} 3\right)$

* aERosols $\quad 1 \quad 2$

* STEAm $0.0001 \quad 0.0 \quad 0.0$

* PART DIA $1.0 \mathrm{E}-6$ 1.0E-6 $1.0 \mathrm{E}-6$ - optional

1.4E0 $\quad \cdots$ optional

* END AEROSOLS

* offset_timetg

$1.4 \mathrm{E} 0$

50 .

LAST

timetg 10.0 100. 200.

* TGFIX $130.00 \quad 30.00 \quad 30.00$

* OFFSET TIMEPG 30.

* extrapollation_timepg extrap

* timer $10.0^{-} 100.200$.

* PRFIX 1 1.E5 1.2E5 1.4E5

END VOLUMES

JUNCTIONS

* 2 " INLET VENT

* 4" OUTLET VENT WITH 2 FOOT $(0.6096$ M) CHIMNEY

* ASSUME DISCharge COEFFICIENT OF 0.6 , OR CuN=2,8

PATHS

$\begin{array}{lll}\text { ITABEL } & 1 & 2 \\ \text { IJTYP } & 1 & \text { VENT-OUT } \\ \text { IRI } & 6 & 1 \\ \text { IR2 } & 1 & 1 \\ \text { IHORIZ } & 0 & 6 \\ \text { XWJN } & 0.05080 & 0.1016 \\ \text { XHJN } & 0.05080 & 0.1016 \\ \text { XIJN } & 0.1699 & 0.7795 \\ \text { AJN } & 2.03 E-3 & 8.11 E-3 \\ \text { Z1JN } & 3.8148 & 1.5929 \\ \text { Z2JN } & 1.5929 & 4.4244 \\ \text { CJN } & 2.8 & 2.8 \\ \text { FGAS1JN } & 1.0 & 1.0\end{array}$

END PATHS

* hOles IN THE SKIRT

* 11 half-holes at the bottom

* 12 holes AT 3 INCH heIght

* 12 holes at 9.5 INCH height

* holes are 4 inch in Diameter

$\begin{array}{lccc}\text { PATHS } & 4 & 5 & 5 \\ \text { LABEL } & \text { HOLE-BOT } & \text { HOLE-MID } & \text { HOLE-TOP } \\ \text { IJTYP } & 1 & 1 & 1 \\ \text { IR1 } & 6 & 6 & 3 \\ \text { IR2 } & 3 & 3 & 6 \\ \text { IHORIZ } & 1 & 1 & 1 \\ \text { XLJN } & 0.0127 & 0.0127 & 0.0127 \\ \text { XHJN } & 0.1016 & 0.1016 & 0.1016 \\ \text { XWJN } & 0.1016 & 0.1016 & 0.1016 \\ \text { AJN } & 0.0446 & 0.0973 & 0.0973\end{array}$


FAl/10-83

PRC-STP-00241, Rev 0

Rev. 0

$\begin{array}{llll}\text { Z1JN } & 0.9906 & 1.0414 & 0.2413 \\ \text { Z2JN } & 0.0254 & 0.0762 & 1.2065 \\ \text { CJN } & 2.8 & 2.8 & 2.8\end{array}$

Page 101 of 284

March, 2010

END JUNCTIONS

HEAT_SINKS

* SET ZTHS TO REgION 1 TOP ELEVATION, $2.43327 \mathrm{M}$

SINKS 68

LABEL

IORIHS TOP

$\begin{array}{ll}\text { IGEOM } & 1 \\ \text { IMATHS } & 2\end{array}$

IMSLAB

IREGI 1

XRI $\quad 0.0$

XRO $\quad 0.01905$

AHS 2.380

XLHS 1.524

XZHS $\quad 1.524$

ZTHS 2.4586

ZBHS 2.2131

EHSO $\quad 0.30$

TIINIT $\quad 35.00$

TOINIT $\quad 35.00$

END

*

* uncovered portion of STSC CYLINDER

${ }^{*} \mathrm{XZHS}=2.2131-2.1750=0.0381$

$\star A H S=P I *(0.73660+0.74930) * 0.0381=0.17785 \mathrm{M}^{\wedge} 2$

* Assign STSC outer emissivities because STSC wall "sees"

* other STSC's. Cut radiation down by $50 \%$.

* Baseline overall value is $1 /(1 / 0.44+1 / 0.6-1)=0.34$

* So desire overall $=0.17,1 /(1 / x+1 / 0.6-1)=0.17, x=0.192$

*

*

SINKS 63

LABEL WALLI -22

IORIHS 0

IGEOM 0

IMATHS 2

IMSLAB

IREGI 1

XRI $\quad 0.73660$

XRO $\quad 0.74930$

AHS $\quad 0.17785$

XLHS $\quad 1.38$

XZHS $\quad 0.0381$

ZTHS 2.2131

ZBHS 2.1750

EHSO $\quad 0.192$

TIINIT $\quad 35.0$

TOINIT $\quad 35.0$

END

$\star$

* COVERED PORTION OF STSC CYLINDER

$\star$ XZHS $=$ Z_LIQ $=1.1136$

$\star$ AHS $=P I *(0.73660+0.74930) * 1.1136=5.1984 \mathrm{M}^{\wedge} 2$

*

SINKS

Layer 21

SAME_AS

62 
FAl/10-83

PRC-STP-00241, Rev 0

Rev. 0

$\begin{array}{ll}\text { LABEL } & \text { WALLI -21 } \\ \text { AHS } & 5.1984 \\ \text { XZHS } & 1.1136 \\ \text { ZTHS } & 2.1750 \\ \text { ZBHS } & 1.0614 \\ \text { END } & \end{array}$

* 10 Layers in the sludge in cylinderical section

$\star \mathrm{XZHS}=0.69312 / 10=0.069312$

$\star$ AHS $=P I \star(0.0+0.73660) \star 0.069312=0.16039$ FOR SLUDGE

$\star$ AHS $=P I *(0.73660+0.74930) * 0.069312=0.32355$ FOR STSC WALL

$\star \mathrm{AHHS} 1=\mathrm{PI} \star 1.4732^{\wedge} 2 / 4$

* $\quad=1.7046 \mathrm{M}^{\wedge} 2$

* Sludge volume per layer in cylindrical section

$\star=P I * 0.7366^{\star} 2 * 0.069312=0.11815 \mathrm{M}^{\wedge} 3$

*

* cumulative volume in the original 20 layers is as follows:

* LAYER-20 0.11815 $\quad 1.60003$

* LAYER-19 0.11815 1.48188

* LAYER-18 0.11815 1.36373

* LAYER-17 0.11815 1.24558

*

* layer-16 $0.11815 \quad 1.12743$

* LAYER-15 0.11815 1.00928

* LAYER-14 0.11815 0.89113

* LAYER-13 $0.11815 \quad 0.77298$

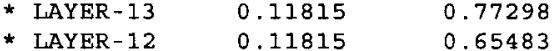

* LAYER-11 $0.11815 \quad 0.53668$

* LAYER-10 $0.07011 \quad 0.41853$

* - .

* LAYER-9 $0.05817 \quad 0.34842$

* Layer-8 0.064350 .28025

* LAYER-7 $0.05995 \quad 0.21590$

* LAYER-6 $0.06595 \quad 0.15595$

* LAYER-5 $0.04791 \quad 0.09000$

* LAyer-4 $0.01782 \quad 0.04209$

* LAYER-3 $0.01288 \quad 0.02427$

* LAYER-2 $0.00847 \quad 0.01139$

* Layer-1 $\quad 0.00292 \quad 0.00292$

* for metal segregation as 40\% of batch volume,

* aDJUSt layers $9 / 10$ So that layer 9 atTains

* $0.32 \mathrm{M} * \star 3$ CUMULATIVE VOLUME

$\star$ VHS OF LAYER-9 $=0.06817-(0.34842-0.32)=0.03975$

$\star$ AHS OF LAYER-9 $=0.14443 *(0.03975 / 0.06817)=0.08422$

$\star$ ASHSO OF LAYER- $9=0.19830 *(0.03975 / 0.06817)=0.11563$

* VHS OF LAYER-10 $=0.07011+(0.34842-0.32)=0.09853$

* AHS OF LAYER-10 $=0.09527 *(0.09853 / 0.07011)=0.13389$

$\star$ ASHSO OF LAYER-10 $=0.19175 *(0.09853 / 0.07011)=0.26948$

* adjust layers $13 / 14$ so that layer 13 atTains

* $0.80 \mathrm{M} * * 3$ CUMULATIVE VOLUME

* XZHS OF LAYER-13=0.069312*(0.80-0.65483)/(0.77298-0.65483)

* $=0.085163$

$\star$ XZHS OF LAYER-14=2*0.069312 $-0.085163=0.053461$

* scale ahs accordingly.

* For LAYER-13, AHS $=0.16039 * 0.085163 / 0.069312=0.19707$ FOR SLUDGE

$\star \quad$ AHS $=0.32355 * 0.085163 / 0.069312=0.39754$ FOR WALL

* For LAYER-14, AHS $=0.16039 * 0.053461 / 0.069312=0.12371$ FOR SLUDGE

* AHS $=0.32355 * 0.053461 / 0.069312=0.24956$ FOR WALL

* revised layers now are:

* Volume Cumulative volume 
FAl/10-83

PRC-STP-00241, Rev 0

\section{Rev. 0}

* IAYYER-14

$4 \quad 0.09113 \quad 0.89113$

Page 103 of 284

March, 2010

* LAYER-13 $0.14517 \quad 0.80000$

$\star$

$\star$

* LAAYER-10 $0.32000 \quad 0.41853$

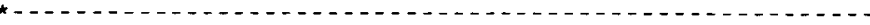

* LAYER-9 $0.03975 \quad 0.32$

$\star$

* Layer 20

SINKS $\quad 59 \quad 58$

LABEL SL-20 WALLO-20

IORIHS $\quad 0 \quad 0$

IGEOM 00

IMATHS $\quad 1 \quad 2$

IMSLAB $\quad 20 \quad 3$

$\begin{array}{ll}\text { IREGI } & 0 \\ \text { IREGO } & 0\end{array}$

$\begin{array}{lll}\text { XRI } & 0.0 & 0.73660\end{array}$

XRO $\quad 0.73660 \quad 0.74930$

AHS $0.16039 \quad 0.32355$

XIHS $\quad 0.0 \quad 0.84$

$\begin{array}{lll}X Z H S & 0.069312 & 0.0693120\end{array}$

$\begin{array}{lll}\text { ZTHS } & 1.0614 & 1.0614\end{array}$

ZBHS $\quad 0.99209 \quad 0.99209$

$\begin{array}{lll}\text { EHSO } & 0 & 0.192\end{array}$

$\begin{array}{lll}\text { IREGSI } & 1 & 0 \\ \text { AHSS 1 } & 1.7046 & 0.0\end{array}$

TIINIT $\quad 35.0 \quad 35.0$

$\begin{array}{lll}\text { TOINIT } & 35.0 & 35.0\end{array}$

END

*

SINKS

$\begin{array}{lll} & 56 & 55 \\ \text { SAME_AS } & 59 & 58\end{array}$

LABEL SL-19 WALLO-19

ZTHS $0.99209 \quad 0.99209$

$\begin{array}{lll}\text { ZBHS } & 0.92278 & 0.92278\end{array}$

IREGS $1 \quad 0 \quad 0$

END

*

SINKS
SAME AS

LABEL

ZTHS

ZBHS

END

*

SINKS

SAME_AS

LABEL

ZTHS

Layer 18

(n)

$53 \quad 52$

$56 \quad 55$

SL-18 WALLO-18

$0.92278 \quad 0.92278$

0.85346

0.85346

Layer 17

$50 \quad 49$

$56 \quad 55$

SL-17 WALLO- 17

ZBHS $\quad 0.78415 \quad 0.78415$

END

* SINKS

$\begin{array}{lll}\text { SAME_AS } & 56 & 55 \\ \text { LABEL } & \text { SL-16 } & \text { WAL }\end{array}$

ZTHS $\quad 0.78415 \quad 0.78415$

ZBHS $\quad 0.71484 \quad 0.71484$

END

SINKS

SAME AS

LABEI

Layer 15

$44 \quad 43$

$56 \quad 55$

SL-15 WALLO-15

$0.71484 \quad 0.71484$

$0.64553 \quad 0.64553$

ZBHS

END

SINKS

SAME_AS

Layer 14

41

$56 \quad 55$

SL-14 WALLO-14 
FAl $/ 10-83$

PRC-STP-00241, Rev 0

Rev. 0

$\begin{array}{lll}\text { ZTHS } & 0.64553 & 0.64553 \\ \text { ZBHS } & 0.59206 & 0.59206 \\ \text { XZHS } & 0.053461 & 0.053461 \\ \text { AHS } & 0.12371 & 0.24956 \\ \text { END } & & \\ \text { * } & \text { Layer } 13 & \\ \text { SINKS } & 38 & 37 \\ \text { SAME_AS } & 56 & 55 \\ \text { LABEL_ } & \text { SL-13 } & \text { WALLO-13 } \\ \text { ZTHS } & 0.59206 & 0.59206 \\ \text { ZBHS } & 0.50690 & 0.50690 \\ \text { XZHS } & 0.085163 & 0.085163 \\ \text { AHS } & 0.19707 & 0.39754 \\ \text { END } & & \\ \text { \# } & \text { Layer } 12 & \\ \text { SINKS } & 35 & 34 \\ \text { SAME_AS } & 56 & 55 \\ \text { LABEL } & \text { SL-12 } & \text { WALLO-12 } \\ \text { ZTHS } & 0.50690 & 0.50690 \\ \text { ZBHS } & 0.43759 & 0.43759 \\ \text { XZHS } & 0.06609 & 0.06609 \\ \text { END } & & \\ \text { * } & \text { LaYer } 11 & \\ \text { SINKS } & 32 & 31 \\ \text { SAME_AS } & 56 & \text { WALLO-11 } \\ \text { LABEL } & \text { SL-11 } & 0.43759 \\ \text { ZTHS } & 0.43759 & \\ \text { ZBHS } & 0.36830 & 0.36830 \\ \text { END } & & \end{array}$

Page 104 of 284

March, 2010

* elliptical section

* RADIUS R = RO*SQRT $\left(1-(Y-R 0 / 2)^{\wedge} 2 /(\mathrm{RO} / 2)^{\wedge} 2\right)$

* where ro is the major radius of the elliptical head

* AND Y IS THE HEIGHT

* VOLUME $\mathrm{V}=4 * \mathrm{PI} *\left(\mathrm{R} 0 / 2 * \mathrm{Y}^{\wedge} 2-\mathrm{Y}^{\wedge} 3 / 3\right)$

$\star$

$\star$

*

* LAYER-10

Y

RO

Vo

so

$\begin{array}{llll}0.3683 & 0.73660 & 0.41853\end{array}$

$\begin{array}{lll}0.3270 & 0.73195 & 0.34842\end{array}$

* LAYER- 9

0.06817

$\begin{array}{llll}0.2858 & 0.71788 & 0.28025\end{array}$

* LAYER- 8

* LAYYER- 7

$\begin{array}{llll}0.2448 & 0.69395 & 0.21590\end{array}$

0.06435

* LAYER- 6

$\begin{array}{llll}0.2032 & 0.65844 & 0.15595\end{array}$

$0.06595 \quad 0.33085$

* LAYYER - 5

* LAYER- 4

$\begin{array}{llll}0.1500 & 0.59326 & 0.09000\end{array}$

0.047910 .35101

$\begin{array}{lll}0.1000 & 0.50462 & 0.04209\end{array}$

$0.01782 \quad 0.19157$

* LAYER-3

*

$0.0750 \quad 0.44551 \quad 0.02427$

$0.02427 \quad 01288 \quad 0.19590$

* LAYYER-2

*

* LAYER- 1

$\begin{array}{lll}0.0508 & 0.37330 & 0.01139\end{array}$

$0.00847 \quad 0.21692$

$\begin{array}{lll}0.0254 & 0.26881 & 0.00292\end{array}$

$0.00292 \quad 0.22802$

* STSC bottom head radiates to skirt or drip pan

* reset emissivity to 0.44

SINKS

SAME_AS

LABEI

IMSLAB

IREGO

$X R I$

29

56

28

WALLO- 10

20

0.00000

3

0.73428

$X R O$

0.73428

0.74698 
FAl/10-83

PRC-STP-00241, Rev 0

\section{Rev. 0}

\begin{tabular}{|c|c|c|}
\hline AHS & 0.13389 & 0.19175 \\
\hline ASHSO & 0.26948 & 0.19175 \\
\hline VHS & 0.09853 & -1 \\
\hline XZHS & 0.04130 & 0.04130 \\
\hline ZTHS & 0.3683 & 0.3683 \\
\hline ZBHS & 0.3270 & 0.3270 \\
\hline EHSO & 0.7 & 0.44 \\
\hline \multicolumn{3}{|l|}{ END } \\
\hline$\star$ & Layer 9 & \\
\hline SINKS & 26 & 25 \\
\hline SAME_AS & 29 & 28 \\
\hline LABEL & $S L-9$ & WALLO - 9 \\
\hline IMSLAB & 20 & 3 \\
\hline $\mathrm{XRI}$ & 0.00000 & 0.73485 \\
\hline XRO & 0.73485 & 0.74755 \\
\hline AHS & 0.08422 & 0.19830 \\
\hline ASHSO & 0.11563 & 0.19830 \\
\hline VHS & 0.03975 & -1 \\
\hline $\mathrm{XZHS}$ & 0.04120 & 0.04120 \\
\hline ZTHS & 0.3270 & 0.3270 \\
\hline ZBHS & 0.2858 & 0.2858 \\
\hline \multicolumn{3}{|l|}{ END } \\
\hline$\star$ & Layer 8 & \\
\hline SINKS & 23 & 22 \\
\hline SAME_AS & 29 & 28 \\
\hline LABE $\bar{L}$ & $S L-8$ & WALLO - 8 \\
\hline IMSLAB & 19 & 3 \\
\hline $\mathrm{XRI}$ & 0.00000 & 0.70592 \\
\hline XRO & 0.70592 & 0.71862 \\
\hline AHS & 0.09093 & 0.21056 \\
\hline ASHSO & 0.21056 & 0.21056 \\
\hline VHS & 0.06435 & -1 \\
\hline XZHS & 0.041 & 0.04747 \\
\hline ZTHS & 0.2858 & 0.2858 \\
\hline ZBHS & 0.2448 & 0.2448 \\
\hline
\end{tabular}

\section{END}

* wall for Layer 7 and below is considered horizontal;

* heat transfer due to laminar boundary layer underside

* of a hot plate is modeled in FATE

$$
\star
$$

*

SINKS Layer 7

INKS $20 \quad 19$

SAME_AS $29 \quad 28$

LABEL SL-7 WALLO-7

$\begin{array}{lll}\text { IORIHS } & 0 & 1\end{array}$

$\begin{array}{lll}\text { IMSLAB } & 18 & 3 \\ \text { XRI } & 0.00000 & 0.67620\end{array}$

$\begin{array}{lll}\text { XRI } & 0.00000 & 0.67620 \\ \text { XRO } & 0.67520 & 0.68890\end{array}$

$\begin{array}{lll}\text { AHS } & 0.08837 & 0.23238\end{array}$

$\begin{array}{lll}\text { ASHSO } & 0.23238 & 0.23238\end{array}$

VHS $\quad 0.05995 \quad-1$

$\begin{array}{lll}\text { XZHS } & 0.04160 & 0.05469\end{array}$

$\begin{array}{lll}\text { ZTHS } & 0.2448 & 0.2448\end{array}$

$\begin{array}{lll}\text { ZBHS } & 0.2032 & 0.2032\end{array}$

END

SINKS

SAME AS

LABEL

IMSLAB

Layer 6

17

29
SL -6

16

XRI $\quad 0.00000$

XRO $\quad 0.62585$

AHS $\quad 0.10460$

ASHSO $\quad 0.33083$

VHS $\quad 0.06595$

XZHS $\quad 0.05320$

ZTHS $\quad 0.2032$

0.1500

16

19

WALIO - 6

0.62585

0.63855

0.33083

0.33083

$-1$

0.08413

0.2032

0.1500

Layer 5 
FAl/10-83

PRC-STP-00241, Rev 0

Rev. 0

SINKS

SAME_AS

14

29

LABEL

SL- 5

IMSLAB

XRI

$\mathrm{XRO}$

AHS

ASHSO

VHS

XZHS

ZTHS

ZBHS

END

SINKS

SAME_AS

LABEL

IMSLAB

XRI

XRO

AHS

ASHSO

VHS

XZHS

ZTHS

ZBHS

END

*

SAME_AS

LABEL

IMSLAB

XRI

XRO

AHS

ASHSO

VHS

XZHS

ZBHS

ZBHS

END

*

SINKS

SAME_AS

LABEL

IMSLAB

XRI

$\mathrm{XRO}$

AHS

ASHSO

VHS

15

0.00000

0.54894

0.08623

0.35507

0.04791

0.0500

0.1500

0.100

13

19

WALLO - 5

3

0.54894

0.56164

0.35507

0.35507

$-1$

0.10177

0.1500

0.100

Layer 4

11
29

SL-4 WALLO-4

143

$0.00000 \quad 0.47507$

$0.47507 \quad 0.48777$

$0.03731 \quad 0.19413$

$0.19413 \quad 0.19413$

$0.01782 \quad-1$

$0.025 \quad 0.06418$

$0.100 \quad 0.100$

$0.075 \quad 0.075$

Layer 3

8

29

SL -3

12

0.00000

0.40941

0.03113

0.19895

0.01288

0.02420

0.075

19

WALLO - 3

3

0.40941

0.42211

0.19895

0.19895

$-1$

0.07616

$\begin{array}{ll}0.0508 & 0.075\end{array}$

Layer 2

5

29

SL-2

10

0.0

19

WALLO- 2

0

$0.32105 \quad 0.32106$

$0.02562 \quad 0.22121$

$0.22121 \quad 0.22121$

$0.00847 \quad-1$

$0.0254 \quad 0.10753$

$\begin{array}{lll}\text { ZTHS } & 0.0508 & 0.0508 \\ \text { ZBHS } & 0.0254 & 0.0254\end{array}$

END

* For layer 1, where STSC bottom head is nearly horizontal,

* set XRI of the bottom head to RO at the top of layer 1

* and expose underside of the sludge to gas

* AHSS2 $=\mathrm{pi} \star^{\star} 0.26881^{\wedge} 2=0.22701$

*

*

SINKS

Layer 1

SAME AS

LABEL $\quad$ SL-

IMSLAB 8

XRI $\quad 0.0$

XRO 0.26881

AHS $\quad 0.02145$

VHS $\quad 0.00292$

XZHS $\quad 0.0265$ 
FAl/10-83

PRC-STP-00241, Rev 0

Rev. 0

$\begin{array}{ll}\text { ZTHS } & 0.0254 \\ \text { ZBHS } & 0.0 \\ \text { IREGS2 } & 3 \\ \text { AHSS2 } & 0.22802 \\ \text { END } & \end{array}$

END

* SKIRT AND DRIP PAN

* MODEL DRIP-PAN AS VERTICAL HS TO ALLOW CONVECTIVE HT TO CELL

SINKS

LABEL

IORIHS

IGEOM

IMATHS

IMSLAB

IREGI

IREGO

$X R I$

$\mathrm{XRO}$

AHS

XIHS

XZHS

ZTHS

ZBHS

EHSO

TIINIT

TOINIT

$96 \quad 95$

SKIRT DRIP-PAN

END

* MATERIAL LIBRARY - specify material properties for material 'imaths'

* up to 20 (INMAT) materials can be specified

* the sludge properties (excluding EHSI \& EHSO) are specified in the

* SLUDGE section

* syNTAX:

MATERIAL IIBRARY

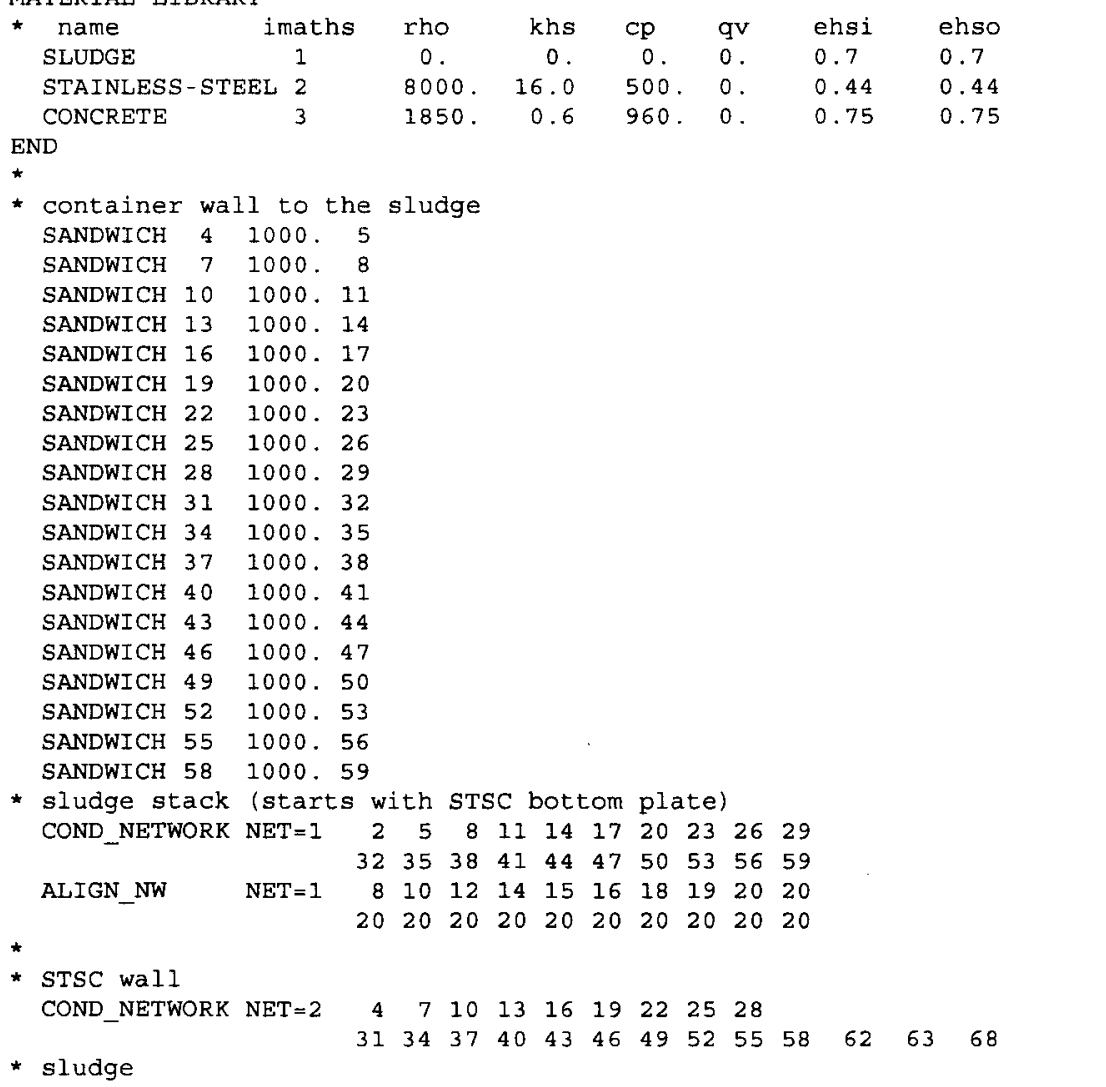

1

6

$0.74930 \quad 0.0127$

$\begin{array}{ll}0.83783 & 2.246\end{array}$

$-0.0254 \quad-0.0381$

1920.44

$35.0 \quad 35.0$

$5.0 \quad 35.0$ 
FAl/10-83

PRC-STP-00241, Rev 0

Rev. 0

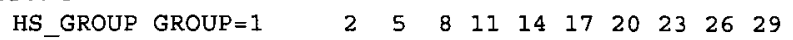

$\begin{array}{llllllllll}32 & 35 & 38 & 41 & 44 & 47 & 50 & 53 & 56 & 59\end{array}$

* between drip pan and STSC bottom head

* (layer 2, 3, and 4) RAD NETWORK NET $=195$ FVIEWHS

$\begin{array}{ccc}-4 & -7 & -10 \\ -1 & -1 & -1 \\ 0.0 & 0.0 & 0.0 \\ 0.0 & 0.0 & 0.0 \\ 0.0 & 0.0 & 0.0\end{array}$

* between drip pan and STSC bottom head - continue

* (layer 5, 6, and 7)

RAD_NETWORK NET $=2 \quad 95 \quad-13 \quad-16 \quad-19$

$\begin{array}{lllll}\text { FVIEWHS } & 0.1 & -1 & -1 & -1\end{array}$

$\begin{array}{llll}1.0 & 0.0 & 0.0 & 0.0\end{array}$

$\begin{array}{llll}1.0 & 0.0 & 0.0 & 0.0\end{array}$

* between skirt and STSC wall

* (layer 8, 9, and 10)

RAD_NETWORK NET $=396$

FVIEWHS

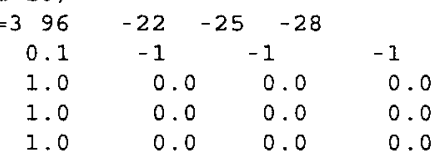

END HEAT SINKS

*

SLUDGE

*

* KW Container sludge

* Segregated into metal-bearing and non-metal layers

* metal is $40 \%$ the volume of a $0.8 \mathrm{~m} * \star 3$ batch

* Top-down by elevation:

* Layers 17-20 non-metal

* Layers 14-16 metal

* Layers 10-13 non-metal

* Layers 1-9 metal

ISTOP $1 \quad !=0$, continue even if negative non-U density

$!=1$, stop if negative non-U density

IPRX $1 \quad !=0$, constant particle size

$!=1$, shrinking core model for depletion of area

IWSTRIP 2 ! vapor stripping model choice

$!=0$, no vapor stripping

! = 1 , sparging bubbles bypass the water pool

! = 2, partial equilibrium if pool less than ZLBEQ deep

$!=3$, Eull equilibrium with the pool

ILAWSG 5 ! Reaction rate model flag:

! = 0, MCGillivrary/Ritchie

$!=1$, Pearce

$!=2$, Trimble

$!=3$, Databook (default)

$!=4$, Databook + Oxygen Free Trimble

$!=5$, New

! list of heat sinks comprising sludge

IHSSG $59 \quad 56 \quad 53 \quad 50$

$\begin{array}{lll}47 & 44 & 41\end{array}$

$\begin{array}{llll}38 & 35 & 32 & 29\end{array}$

$\begin{array}{lllllllll}26 & 23 & 20 & 17 & 14 & 11 & 8 & 5 & 2\end{array}$

! region containing each sludge heat sink

$\begin{array}{lllll}\text { IRSLDG } & 1 & 1 & 1 & 1\end{array}$

$\begin{array}{lll}1 & 1 & 1\end{array}$

$\begin{array}{llll}1 & 1 & 1 & 1\end{array}$

$\begin{array}{lllllllll}1 & 1 & 1 & 1 & 1 & 1 & 1 & 1 & 1\end{array}$

! wet sludge density, $\mathrm{kg} / \mathrm{m}^{\wedge} 3$ wet sludge

RHOSG $\quad \begin{array}{lllllll}1793.7 & 1793.7 & 1793.7 & 1793.7\end{array}$

$1809.4 \quad 1809.4 \quad 1809.4$

$1793.7 \quad 1793.7 \quad 1793.7 \quad 1793.7$

$1809.4 \quad 1809.4 \quad 1809.4 \quad 1809.4 \quad 1809.4 \quad 1809.4 \quad 1809.4 \quad 1809.4 \quad 1809.4$

! void fraction of the sludge 
FAl/10-83

PRC-STP-00241, Rev 0

\section{Rev. 0}

$\begin{array}{llllllllll}\text { FPORSG } & 0.74 & 0.74 & 0.74 & 0.74 & & & & & \\ & 0.74 & 0.74 & 0.74 & & & & & & \\ & 0.74 & 0.74 & 0.74 & 0.74 & & & & & \\ & 0.74 & 0.74 & 0.74 & 0.74 & 0.74 & 0.74 & 0.74 & 0.74 & 0.74\end{array}$

! Density of $U$ metal, $\mathrm{kg} \mathrm{U}$ metal/m^3 wet sludge

! Optionally, user may specify TABLE-n or FIT-n for position dependent

! density; for this option, specify:

! XRHOUM table\# enumeration of $x$-positions of the node

! YRHOUM table\# enumeration of metal concentrations

! or

! YRHOUM fit\# min-x max-x coeffo coeffl coeff2 coeff3 coeff4

RHOUM $\begin{array}{rrrr}0.0 & 0.0 & 0.0 & 0.0\end{array}$

205.0205 .0205 .0

$\begin{array}{llll}0.0 & 0.0 & 0.0 & 0.0\end{array}$

205.0205 .0205 .0205 .0205 .0205 .0205 .0205 .0205 .0

! density of all $\mathrm{U}, \mathrm{kg} \mathrm{U}$ in any chemical form $/ \mathrm{m}^{\wedge} 3$ wet sludge

RHOUT $584.2 \quad 584.2 \quad 584.2 \quad 584.2$

$598.7 \quad 598.7 \quad 598.7$

$584.2 \quad 584.2 \quad 584.2 \quad 584.2$

$\begin{array}{llllllllll}598.7 & 598.7 & 598.7 & 598.7 & 598.7 & 598.7 & 598.7 & 598.7 & 598.7\end{array}$

! gas (h2) void fraction in the sludge

FGASSG $0.00 \quad 0.00 \quad 0.00 \quad 0.00$

$0.00 \quad 0.00 \quad 0.00$

$0.00 \quad 0.00 \quad 0.00 \quad 0.00$

$\begin{array}{lllllllllll}0.00 & 0.00 & 0.00 & 0.00 & 0.00 & 0.00 & 0.00 & 0.00 & 0.00\end{array}$

$\begin{array}{lllll}\text { KSLDG } & 0.7 & 0.7 & 0.7 & 0.7\end{array}$

$\begin{array}{lll}0.7 & 0.7 & 0.7\end{array}$

$\begin{array}{llll}0.7 & 0.7 & 0.7 & 0.7\end{array}$

$\begin{array}{lllllllll}0.7 & 0.7 & 0.7 & 0.7 & 0.7 & 0.7 & 0.7 & 0.7 & 0.7\end{array}$

KGSG 0.17 ! thermal conductivity of the gas in the sludge

XDSG

FOXSG

0.17 ! thermal conductivity of the gas in the sludge

0.000500 ! particle diameter, m

3 ! oxidation rate multiplier

FKSG 1 ! sludge thermal conductivity multiplier

! (not applied to user specified KSLDG)

$\begin{array}{lll}\text { QSG } & 0.08814 & \text { ! decay power, } W / \mathrm{kg}-\mathrm{U}, 52 \mathrm{~W} / \mathrm{m}^{\wedge} 3 \star 1 \mathrm{~m}^{\wedge} 3 / 590 \mathrm{~kg}-\mathrm{U}=0.08814 \mathrm{~W} / \mathrm{kg}-\mathrm{U} \\ \text { DUOX } & 7500 & \text { ! true density of U oxide compounds, } \mathrm{kg} / \mathrm{m}^{\wedge} 3\end{array}$

DUOX $\quad 7500$ ! true density of $U$ oxide compounds, $\mathrm{kg} / \mathrm{m}^{\wedge} 3$

FWUOX 272.0 ! formula weight of $\mathrm{U}$ oxide compounds, $\mathrm{kg} / \mathrm{kg}$-mole

KUSG $\quad 3.90$ ! thermal conductivity of $U$ in sludge, $\mathrm{W} / \mathrm{m}-\mathrm{C}$

KUO2SG $\quad 1.80$ ! thermal conductivity of UO2 in sludge, $\mathrm{W} / \mathrm{m}-\mathrm{C}$

KH2OSG $\quad 0.6$ ! thermal conductivity of $\mathrm{H} 2 \mathrm{O}$ in sludge, $\mathrm{W} / \mathrm{m}-\mathrm{C}$

KNONUSG $\quad 1.3$ ! thermal conductivity of non-U in $s l u d g e, W / m-C$

CPUSG $\quad 120.0 \quad$ ! specific heat of $\mathrm{U}$ in sludge, J/kg-C

CPUO2SG 240.0 ! specific heat of UO2 in sludge, J/kg-C

CPH2OSG $4180.0 \quad !$ specific heat of $\mathrm{H} 2 \mathrm{O}$ in sludge, J/kg-C

CPNONUSG 700.0 ! specific heat of non-U in sludge, $\mathrm{J} / \mathrm{kg}-\mathrm{C}$

ZLBEQ $\quad 0.10 \quad$ ! pool depth for equilibrium of sludge offgas

FRADIOLY 1.0 ! radiolysis rate multiplier

! FROM SNF-22059, REVISION 0, ATTACHMENT 12, TABLE 1, N CANISTER

AND 'ALPHA BETA AND GAMMA DECAY FRACTIONS FOR SLUDGE REV 1.XLSX'

BY MICHAEL E. JOHNSON, 23-FEB-10, KW Engineered Container Sludge

FALPSG $\quad 0.118$ ! fraction of decay power from alpha dep. in water

! $0.329 * 0.36=0.118$

FBETSG 0.108 : fraction of decay power from beta dep. in water

! $0.251 * 0.43=0.108$

FGAMSG 0.009 ! Eraction of decay power from gamma dep. in water

! $0.0423 * 0.21=0.009$

GH2ALPSG $\quad 1.5 \quad \mathrm{~g}(\mathrm{H} 2)$ molecules $\mathrm{H} 2 / 100 \mathrm{eV}$ alpha dep. in water

GH2BETSG $\quad 0.5$ ! $g(\mathrm{H} 2)$ molecules $\mathrm{H} 2 / 100 \mathrm{eV}$ beta dep. in water

GH2GAMSG $\quad 0.5 \quad \mathrm{~g}(\mathrm{H} 2)$ molecules $\mathrm{H} 2 / 100 \mathrm{eV}$ gamma dep. in water

! User specified format for U-metal concentration in the sludge

! output. Each pair of integers designates the heat sink number

! followed by its node index. Note that the node index starts from

! the outer surface of the heat sink and ends at the inner surface.

! For example, "4,5" designates the concentration in the innermost 
FAl/10-83

PRC-STP-00241, Rev 0

Rev. 0

! node of heat sink \#4.

!

PRINT -M

59,20

56,20

53,20

50,20

47,20

44,20

41,20

38,20

35,20

32,20

29,20

23,19

17,16

11,14

8,12

5,10

2,8

END PRINT - M

END SLUDGE

$\begin{array}{rr}59,10 & 59,1 \\ 56,10 & 56,1 \\ 53,10 & 53,1 \\ 50,10 & 50,1 \\ 47,10 & 47,1 \\ 44,10 & 44,1 \\ 41,10 & 41,1 \\ 38,10 & 38,1 \\ 35,10 & 35,1 \\ 32,10 & 32,1 \\ 29,10 & 29,1 \\ 23,8 & 23,1 \\ 17,1 & \\ & \end{array}$

Page 110 of 284

March, 2010 
FAl/10-83

PRC-STP-00241, Rev 0

Rev. 0

B.2 Base File: SET1STSC1,dat

Page 111 of 284

March, 2010

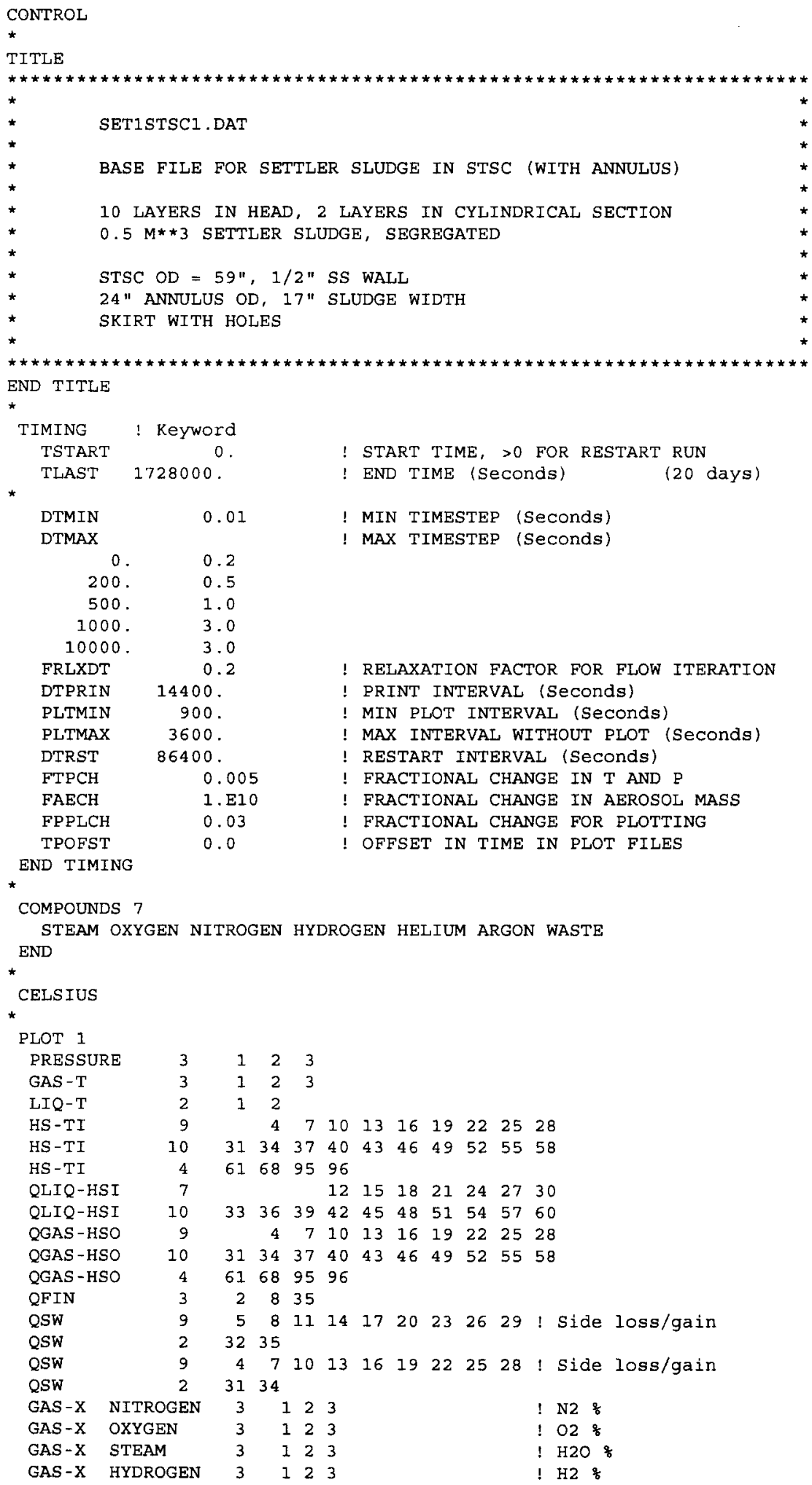


FAl/10-83

PRC-STP-00241, Rev 0

Rev. 0

\begin{tabular}{|c|c|c|c|c|c|c|c|c|c|c|}
\hline \multicolumn{4}{|c|}{ GAS-W } & & 2 & 12 & & & $!$ & vent flow \\
\hline \multicolumn{4}{|c|}{ GAS-WX } & & 2 & 12 & & & $!$ & vent $\mathrm{cc}$ flow \\
\hline \multicolumn{4}{|c|}{ GAS-W } & & 3 & 45 & 6 & & ! & skirt hole flow \\
\hline \multicolumn{4}{|c|}{ GAS-WX } & & 3 & 45 & 6 & & ! & skirt hole cc flow \\
\hline HS - T & 35 & & 5 & & 6 & 7 & 8 & 9 & 10 & \\
\hline $\mathrm{HS}-\mathrm{T}$ & 32 & & 5 & & 6 & 7 & 8 & 9 & 10 & \\
\hline$H S-T$ & 29 & & 5 & & 6 & 7 & 8 & 9 & 10 & \\
\hline $\mathrm{HS}-\mathrm{T}$ & 26 & & 5 & & 6 & 7 & 8 & 9 & 10 & \\
\hline HS $-T$ & 23 & & 5 & & 6 & 7 & 8 & 9 & 10 & \\
\hline HS $-T$ & 20 & & 5 & & 5 & 6 & 7 & 8 & 9 & \\
\hline $\mathrm{HS}-\mathrm{T}$ & 17 & & 5 & & 4 & 5 & 6 & 7 & 8 & \\
\hline $\mathrm{HS}-\mathrm{T}$ & 14 & & 5 & & 3 & 4 & 5 & 6 & 7 & \\
\hline HS $-\mathrm{T}$ & 11 & & 5 & & 3 & 4 & 5 & 6 & 7 & \\
\hline HS $-\mathrm{T}$ & 2 & & 5 & & 2 & 3 & 4 & 5 & 6 & \\
\hline \multicolumn{3}{|c|}{ SPECIAL-R } & & & 6 & 301 & 302 & 3033 & 304305309 & ! Energy Balance Terms \\
\hline \multicolumn{3}{|c|}{ SPECIAL-R } & & & 3 & 306 & 307 & 312 & & \\
\hline \multicolumn{3}{|c|}{ QGAS-HSI 2} & 95 & 96 & & & ! & Watch & h radiation & \& convection to skirt \\
\hline \multicolumn{3}{|c|}{ QRAD-HSI 2} & 95 & 96 & & & & & & \\
\hline \multicolumn{3}{|c|}{ QRAD-HSO 9} & 4 & 71 & $0 \quad 13$ & 316 & 19 & $22 \quad 25$ & 28 & \\
\hline \multicolumn{3}{|c|}{ QRAD-HSO 2} & 95 & 96 & & & & & & \\
\hline END PI & OT & $!$ & PLOT & ris & $a c$ & comme & ent & & & \\
\hline
\end{tabular}

PRINT-T

68,1
Page 112 of 284

March, 2010

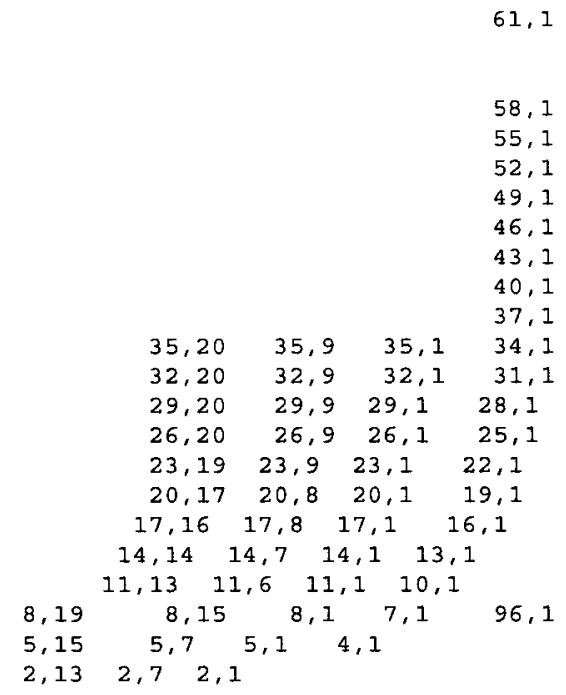

95,1

END PRINT-T

ACTIVE MODELS : Keyword; MODELS is a comment; $1=$ on, $0=$ off

IJUNC 1 : Junction flow

ICCFLW 1 ! Counter-current flow

IDIELW 0 : Diffusional transport

IHSINK 1 ! Heat sinks

IHXPOL 1 ! Pool-gas heat/mass transfer

IHSBOIL 0 ! Boiling heat transfer

ICNDS 1 ! Condensation

IASED 0 ! Aerosol sedimentation

IALEAK 0 ! Aerosol Leakage

IFOG 0 ! Fog formation

IAEB 0 ! Aerosol release via sparging/boiling

ISRC 1 ! User-defined sources

IQDECAY 0 ! Assign decay power to compounds

ILXEER 0 : Liquid transfers

IDCRT 0 : DCRT 
FAI/10-83

PRC-STP-00241, Rev 0

\section{Rev. 0}

$\begin{array}{lll}\text { ISLUDGE } 1 & \text { ! Sludge } \\ \text { IPLTYP } 2 & \text { ! } 1 \text { =wrap }\end{array}$

IPLTYP 2 ! 1 =wrap around, $2=$ no wrap (spreadsheet format) END ACTIVE MODELS

END CONTROL

VOLUMES

$\star$

* upper or lower head

* asSUME 1/2" WALL tHickNESS

* VOLUME OF ELLIPTiCAL HEAD $=1 / 3 * \mathrm{PI} \star(58 / 2)^{\wedge} 3=25540.1 \mathrm{IN}^{\wedge} 3$

$\star=0.41853 \mathrm{M}^{\wedge} 3$

*

* VOLUME OF INTERNAL CYLINDER IN UPPER hEAD

* (IGNORE 0.25" WALL THICKNESS) $=P I * 24 \wedge 2 / 4 *(58 / 4)=6559.5 \mathrm{IN}^{\wedge} 3$

* $=0.10749 \mathrm{M}^{\wedge} 3$

* MIDDLE SECTION

$\star \mathrm{PI} *(58 / 2)^{\wedge} 2 * 72.63=191894 \mathrm{IN}^{\wedge} 3=3.14458 \mathrm{M}^{\wedge} 3$

* Volume of internal cylinder in middle section

* (IGNORE $0.25^{\prime \prime}$ WALL THICKNESS $)=\mathrm{PI} * 24^{\wedge} 2 / 4 * 72.63=32857.0 \mathrm{IN}^{\wedge} 3$

* $=0.53843 \mathrm{M}^{\wedge} 3$

*

* VOLUME OF INTERNAI CYLINDER IN LOWER HEAD

$\star=1 / 3 * P I \star 12 \wedge 3+P I \star 24 \wedge 2 / 4 *(14.5-2-6)=4750 \operatorname{IN}^{\wedge} 3$

$*=0.07784 \mathrm{M}^{\wedge} 3$

*

* VOLUMe OF SLUDGE IN THE LOWER HEAD

* $=0.41853-0.07784=0.34069 \mathrm{M}^{\wedge} 3$

*

* HEIGHT OF $1 \mathrm{M}^{\wedge} 3$ SLUDGE IN THE CYLINDRICAL SECTION

* $=(1-0.34069) /\left(\mathrm{PI} *\left(1.4732^{\wedge} 2-0.6096^{\wedge} 2\right) / 4\right)$

* $=0.46670 \mathrm{M}$

* INPUTS FOR REGION 1:

$\star$ VOLUME $=2 * 0.41853+3.14458-0.72376$ (VOLUME OF REGION 3 ) -1

$\quad=2.25788 \mathrm{M}^{\wedge} 3$
$*$

* Elevation $=0.3683+0.46670=0.8350 \mathrm{M}$

$\star \quad S E D$ AREA $=P I *\left(1.4732^{\wedge} 2-0.6096^{\wedge} 2\right) / 4=1.4127 \mathrm{M}^{\wedge} 2$

* ZLLIQ $=2.175(85.63$ IN $)-0.8350=1.340 \mathrm{M}$

VOLUME OF WATER IN REGION 1

$=1.340 * \mathrm{PI} *\left(1.4732^{\wedge} 2-0.6096^{\wedge} 2\right) / 4=1.89302 \mathrm{M}^{\wedge} 3$

ZTOP $=1.340 * 2.25788 / 1.89302=1.59827 \mathrm{M}$

* changed for setstsci.dat:

* MODIFY REgION 1 INPUTS FOR $0.50 \mathrm{M} *$ *3 SLUDGE REMOVED

FROM ORIGINAL $1.0 \mathrm{M} * 3$ SLUDGE:

VOLUME INCREASES BY $2.25788+0.50$

elevation top OF LAYER 120.48106 , WAS 0.8350

* $\quad \mathrm{ZLIQ}=2.175-0.48106=1.694$

* WATER VOLUME $=1.893+0.50=2.393$

* $\quad$ ZTOP $=1.694 \star 2.75788 / 2.393=1.952$

* REGION 3 - SKIRT

* $\quad$ VOLUME $=P I * 59^{\wedge} 2 / 4 *(59 / 4)-1 / 3 * P I *(59 / 2)^{\wedge} 3=1.344 \mathrm{E} 4 \mathrm{IN}^{\wedge} 3=0.2203 \mathrm{M}^{\wedge} 3$

* $\mathrm{ZTOP}=59 / 4=14.75 \mathrm{IN}=0.3747 \mathrm{M}$

* ASED $=\mathrm{PI} * 59^{\wedge} 2 / 4 *=1.76 \mathrm{M}^{\wedge} 2$

\begin{tabular}{lllll} 
REGIONS & \multicolumn{1}{c}{1} & \multicolumn{1}{c}{6} & \multicolumn{1}{c}{2} & 3 \\
LABEL & STSC-OUTER & PROCESS-CELL & STSC-INNER & \multicolumn{1}{c}{ SKIRT } \\
VOLUME & 2.75788 & 1. E9 & 0.72376 & 0.2203 \\
SED_AREA & 1.4127 & $1 . E 6$ & 0.29186 & 1.76 \\
ELEVATION & 0.48106 & -0.0254 & 0.0508 & -0.0254 \\
TEMP_GAS & 35.0 & 35.00 & 35.0 & 35.0 \\
PRESSURE & $1.0 \mathrm{E} 5$ & $1.0 \mathrm{E} 5$ & $1.0 \mathrm{E} 5$ & $1.0 \mathrm{E} 5$ \\
ZTOP & 1.952 & $1 . \mathrm{E} 3$ & 2.47978 & 0.3747 \\
Z_LIQ & 1.694 & 0.0 & 2.1242 & 0.0 \\
TEMP_LIQ & 35.0 & 35.0 & 35.0 & 35.0
\end{tabular}


FAl/10-83

PRC-STP-00241, Rev 0

Rev. 0

* Gas composition of each region; specify mole fraction of each gas

$\begin{array}{lcccc}\text { GASES } & 1 & 6 & 2 & 3 \\ \text { STEAM } & 0.01 & 0.01 & 0.01 & 0.01 \\ \text { OXYGEN } & 0.20 & 0.20 & 0.20 & 0.20 \\ \text { NITROGEN } & 0.79 & 0.79 & 0.79 & 0.79\end{array}$

END GASES

* Liquid composition of each region; specify mass fractions

$\begin{array}{ccccc}\text { LIQUIDS } & 1 & 6 & 2 & 3 \\ \text { STEAM } & 1.0 & 1.0 & 1.0 & 1.0\end{array}$

END LIQUIDS

$\star$

* Aerosol concentration of each region $\left(\mathrm{kg} / \mathrm{m}^{\wedge} 3\right)$

* aerosols

* STEAM

1

23

$\begin{array}{lllll}\text { * PART_DIA } & 1.0 \mathrm{E}-6 & 1.0 \mathrm{E}-6 & 1.0 \mathrm{E}-6 & \text { - }- \text { optional } \\ \text { * LOG_STD } & 1.4 \mathrm{EO} & 1.4 \mathrm{E} 0 & 1.4 \mathrm{EO} & \text { - - optional }\end{array}$

* END AEROSOLS

* ofFSET TIMETG

* TIMETg $10.0 \quad 100 . \quad 200$

* TGFIX $130.00 \quad 30.00 \quad 30.00$

* offset timepg 30.

* EXTRAPOLATION TIMEPG EXTRAP

* TIMEP $10.0 \quad 100.200$.

* PRFIX 1 1.E5 1.2E5 $1.4 \mathrm{E} 5$

END VOLUMES

JUNCTIONS

* 2 " INLET VENT

* 4" OUTLet Vent With 2 FOOT (0.6096 M) Chimney

* assume discharge coefficient of 0.6 , or CJN=2.8

$\begin{array}{lll}\text { PATHS } & 1 & 2 \\ \text { LABEL } & \text { VENT-IN } & \text { VENT-OUT } \\ \text { IJTYP } & 1 & 1 \\ \text { IR1 } & 6 & 1 \\ \text { IR2 } & 2 & 6 \\ \text { IHORIZ } & 0 & 0 \\ \text { XWJN } & 0.05080 & 0.1016 \\ \text { XHJN } & 0.05080 & 0.1016 \\ \text { XLJN } & 0.1699 & 0.7795 \\ \text { AJN } & 2.03 \mathrm{E}-3 & 8.11 \mathrm{E}-3 \\ \text { Z1JN } & 3.8148 & 2.1732 \\ \text { Z2JN } & 2.6035 & 4.4244 \\ \text { CJN } & 2.8 & 2.8 \\ \text { FGASIJN } & 1.0 & 1.0 \\ \text { END PATHS } & & \end{array}$

END PATHS

* JUNCTION 3 REPRESENTS THE OPENING BETWEEN THE INNER CYLINDER AND STSC

* NeEded for pREssure equalization

* actual junction area and resistance are not important

$\begin{array}{lc}\text { PATHS } & 3 \\ \text { LABEL } & 1-2 \\ \text { IJTYP } & 1 \\ \text { IR1 } & 1 \\ \text { IR2 } & 2 \\ \text { IHORIZ } & 0 \\ \text { XLJN } & 0.01 \\ \text { XHJN } & 0.025 \\ \text { XWJN } & 0.025\end{array}$


FAl $/ 10-83$

PRC-STP-00241, Rev 0

Rev. 0

$\begin{array}{ll}\text { AJN } & 2.027 \mathrm{E}-3 \\ \text { Z1JN } & 1.8189 \\ \text { Z2JN } & 2.249 \\ \text { CJN } & 2.8 \\ \text { ND PATHS } & \end{array}$

* holes IN THE SKIRT

* 11 haLF-HOLES AT THE BOTTOM

* 12 holes AT 3 INCH height

* 12 holes at 9.5 inch height

* HOLES ARE 4 INCH IN DIAMETER

*

$\begin{array}{lccc}\text { PATHS } & 4 & 5 & 6 \\ \text { LABEL } & \text { HOLE-BOT } & \text { HOLE-MID } & \text { HOLE-TOP } \\ \text { IJTYP } & 1 & 1 & 1 \\ \text { IR1 } & 6 & 6 & 3 \\ \text { IR2 } & 3 & 3 & 6 \\ \text { IHORIZ } & 1 & 1 & 1 \\ \text { XLJN } & 0.0127 & 0.0127 & 0.0127 \\ \text { XHJN } & 0.1016 & 0.1016 & 0.1016 \\ \text { XWJN } & 0.1016 & 0.1016 & 0.1016 \\ \text { AJN } & 0.0446 & 0.0973 & 0.0973 \\ \text { ZIJN } & 0.9906 & 1.0414 & 0.2413 \\ \text { Z2JN } & 0.0254 & 0.0762 & 1.2065 \\ \text { CJN } & 2.8 & 2.8 & 2.8\end{array}$

\# END JUNCTIONS

HEAT_SINKS

* SET zTHS TO REgion 1 TOP ELEVATION, $2.43327 \mathrm{M}$

*

SINKS $\quad 68$

*

IABEL TOP

IORIHS 2

IGEOM 1

IMATHS 2

IMSLAB

IREGI 1

XRI 0.0

XRO $\quad 0.01905$

AHS 2.380

XLHS 1.524

$\mathrm{XZHS} \quad 1.524$

ZTHS 2.43327

ZBHS 2.2131

EHSO $\quad 0.30$

TIINIT $\quad 35.00$

TOINIT $\quad 35.00$

END

* inNer cylinder and stsc wall adjacent to water and gas

* neglect inNer cylinder wall in the upper elliptical head

$\star \mathrm{XZHS}=2.2131-0.8350=1.37810$

$\star$ AHS $=P I *(0.29845+0.30480) * 1.37810=2.61173 \mathrm{M}^{\wedge} 2$ FOR INNER CYLINDER WALL

$\star \mathrm{AHS}=\mathrm{PI} *(0.73660+0.74930) * 1.37810=6.43310 \mathrm{M}^{\wedge} 2$ FOR STSC WALL

*

Layer 21

INKS 63

LABEL WALLI-21

IORIHS 0

IGEOM 0

IMATHS 2

IMSLAB 3

IREGI 2

61
WALLO-21
0
0
2
3
1


FAl/10-83

\section{PRC-STP-00241, Rev 0}

\section{Rev. 0}

$\begin{array}{lll}\text { IREGO } & 1 & 6 \\ \text { XRI } & 0.29845 & 0.73660 \\ \text { XRO } & 0.30480 & 0.74930 \\ \text { AHS } & 2.61173 & 6.43310 \\ \text { XLHS } & 1.38 & 1.38 \\ \text { XZHS } & 1.3781 & 1.3781 \\ \text { ZTHS } & 2.2131 & 2.2131 \\ \text { ZBHS } & 0.8350 & 0.8350 \\ \text { EHSO } & 0.30 & 0.30 \\ \text { TIINIT } & 35.0 & 35.0 \\ \text { TOINIT } & 35.0 & 35.0\end{array}$

END

$\star$ XZHS $=0.46670 / 10=0.046670$

$\star$ AHS $=\mathrm{PI} *(0.29845+0.30480) * 0.046670=0.08845$ FOR INNER CYLINDER WALL

$\star$ AHS $=P I *(0.30480+0.73660) * 0.046670=0.15269$ FOR SLUDGE

$\star$ AHS $=P I *(0.73660+0.74930) * 0.046670=0.21786$ FOR STSC WALL

* AHHS1 $=\mathrm{PI} *\left(1.4732^{\wedge} 2-0.6096^{\wedge} 2\right) / 4$

* $\quad=1.4127 \mathrm{M}^{\wedge} 2$

* SLUdGe VOlume PER LAYer IN CYLINDRICAL SECTION

* $=P I *\left(0.7366^{\wedge} 2-0.3048^{\wedge} 2\right) \star 0.046670=0.06593 \mathrm{M}^{\wedge} 3$

*

* CUMUlative Volume IN THE ORIgINAL 20 LAYERS IS AS FOLLOWS:

* Volume Cumulative volume

* LAYER-20 $0.06593 \quad 1.0000$

* LAYER-19 $0.06593 \quad 0.93407$

* LAYER-18 $0.06593 \quad 0.86814$

* LAYER-17 $0.06593 \quad 0.80221$

* LAYER-16 $0.06593 \quad 0.73628$

*...

* LAYER-15 $0.06593 \quad 0.67035$

* Layer-14 $0.06593 \quad 0.60442$

* LAYER-13 $0.06593 \quad 0.53849$

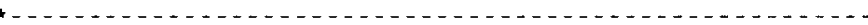

* Layer-12 $0.06593 \quad 0.47256$

* LAYER-11 $0.06593 \quad 0.40663$

* Layer-10 $0.05806 \quad 0.34070$

* LaYer-9 0.056150 .28264

* LAYER-8 $0.05238 \quad 0.22649$

* LAYER $7 \quad 0.04781 \quad 0.17411$

* LAYER-6 $0.05106 \quad 0.12630$

* LAYER-5 $0.03629 \quad 0.07524$

* LAYER-4 $0.01574 \quad 0.03895$

* LAYER-3 $0.01182 \quad 0.02321$

* Layer-2 $0.00847 \quad 0.01139$

* LAYER-1 $0.00292 \quad 0.00292$

* For metal segregation as 1/3 of batch Volume,

* ADJUST LAYERS $12 / 13$ SO THAT LAYER 12 AT"TAINS

* $0.50 \mathrm{M} * * 3$ CUMULATIVE VOLUME

* THEN, LOWER METAL IS $0.17411 / 0.50=0.348$ CLOSE

* also, upper metal is $0.17035 / 0.50$, closer.

* SLUdge CROSS-SECTIONAL AREA

$\star \mathrm{AXS}=\mathrm{PI} *(0.73660 * \star 2-0.30480 * \star 2)=1.412700 \mathrm{M} * 2$

* Face areas ahs of inNer wall, sLUdge, outer wall are:

*0.08845, $0.15269,0.21786 \mathrm{M} * * 2$ RESPECTIVELY

* volume V-12=0.50-0.40663=0.09337

* height XzHS-12=V12/AXS $=0.06609$

* elevation ZTHS-12=0.41497+0.06609=0.48106

* area = old area * new height/old height

* height ratio $=0.06609 / 0.046670=1.41611$

* so for sinks $36,35,34$ new areas are: 
FAI $/ 10-83$

PRC-STP-00241, Rev 0

Rev. 0

Page 117 of 284

$\star$ AHS $=0.12526,0.21623,0.30851$

March, 2010

* volume $\mathrm{V}-13=0.53849-0.50=0.03849$

* height XzHS $-13=2 * 0.04667-0.06609=0.02725$

* elevation zBHS-13=ZTHS-12=0.48106

* height ratio $=0.02725 / 0.04657=0.58389$

* so for sinks 39, 38, 37 new areas are:

$\star$ AHS $=0.05164,0.08915,0.12721$

* REVised LAYERS NOW ARE:

* Volume Cumulative volume

* LAYER-13 $0.03849 \quad 0.53849$

*

* LAYER-12 0.09337 0.50000

*

$\begin{array}{lll}* & \text { Layer } 20 \\ \text { SINKS } & 60 & 59 \\ \text { LABEL } & \text { WALLI }-20 & \text { SL-20 }\end{array}$

$S L-20$

58

IORIHS

IGEOM

IMATHS

IMSLAB

IREGI

IREGO

$\mathrm{XRI}$

0

0

2

3

0

0.29845

0.30480

0.08845

0.78

0.046670

0.8350

0.78833

0.30

0

0.0

35.0

35.0

0

20

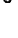

0.30480

0.73660

0.15269

0.0

0.046670

0.8350

0.78833

1

1. 4127

35.0

TIINIT

TOINIT

35.0

WALLO - 20

*INKS

Layer 19

SAME AS

57

60

56

59

WALLI-19 SL-19

0.78833

0.78833

0.74166

0.74166

ZBHS

IREGS 1

END

*

SAME_AS

LABEL

ZTHS

ZBHS

0

0

2

0

0.73660

0.74930

0.21786

0.84

0.046670

0.8350

0.78833

0.30

0

0.0

35.0

35.0

Layer 18

54

56

WALLI - 18 SL-18

$0.74166 \quad 0.74166$

$0.69499 \quad 0.69499$

55

WALLO - 19

0.78833

0.74166

0

END

SINKS

SAME_AS

LABEL

ZTHS

ZBHS

END

औ

SAME AS

$\triangle A B E \bar{L}$

ZTHS

ZBHS

END

SINKS

SAME_AS

LABEL

Layer 17

51

57

WALLI -17

50

SL -17

$0.69499 \quad 0.69499$

0.64832

0.64832

52

WALLO- 18

0.74166

0.69499

Layer 16

$48 \quad 47$

$57 \quad 56$

WALLI-16 SL-16

$0.64832 \quad 0.64832$

0.60165

0.60165

49

WALLO - 17

0.69499

0.64832

Layer 15

$\begin{array}{lll}45 & 44 & 43 \\ 57 & 56 & 55 \\ \text { WALLI-15 } & \text { SL-15 } & \text { WALLO-15 } \\ 0.60165 & 0.60165 & 0.60165\end{array}$

46

55

WALLO- 16

0.64832

0.60165

WALLO -15 
FAl/10-83

PRC-STP-00241, Rev 0

Rev. 0

\begin{tabular}{|c|c|c|c|}
\hline ZBHS & 0.55498 & 0.55498 & 0.55498 \\
\hline \multicolumn{4}{|l|}{ END } \\
\hline * & Layer 14 & & \\
\hline SINKS & 42 & 41 & 40 \\
\hline SAME_AS & 57 & 56 & 55 \\
\hline LABEL & WALLI - 14 & $S L-14$ & WALLO- 14 \\
\hline ZTHS & 0.55498 & 0.55498 & 0.55498 \\
\hline ZBHS & 0.50831 & 0.50831 & 0.50831 \\
\hline \multicolumn{4}{|l|}{ END } \\
\hline * & Layer 13 & & \\
\hline SINKS & 39 & 38 & 37 \\
\hline SAME_AS & 57 & 56 & 55 \\
\hline IJABEL & WALLI - 13 & $S L-13$ & WALLO-13 \\
\hline ZTHS & 0.50831 & 0.50831 & 0.50831 \\
\hline ZBHS & 0.48106 & 0.48106 & 0.48106 \\
\hline $\mathrm{XZHS}$ & 0.02725 & 0.02725 & 0.02725 \\
\hline AHS & 0.05164 & 0.08915 & 0.12721 \\
\hline * ZBHS & 0.46164 & 0.46164 & 0.46164 \\
\hline \multicolumn{4}{|l|}{ END } \\
\hline * & Layer 12 & & \\
\hline SINKS & 36 & 35 & 34 \\
\hline SAME_AS & 57 & 56 & 55 \\
\hline LABEL & WALLI - 12 & $\mathrm{SL}-12$ & WALLO- 12 \\
\hline * ZTHS & 0.46164 & 0.46164 & 0.46164 \\
\hline zTHS & 0.48106 & 0.48106 & 0.48106 \\
\hline $\mathrm{ZBHS}$ & 0.41497 & 0.41497 & 0.41497 \\
\hline XZHS & 0.06609 & 0.06609 & 0.06609 \\
\hline AHS & 0.12526 & 0.21623 & 0.30851 \\
\hline \multicolumn{4}{|l|}{ END } \\
\hline * & Layer 11 & & \\
\hline SINKS & 33 & 32 & 31 \\
\hline SAME_AS & 57 & 56 & 55 \\
\hline LABEL & WALLI - 11 & SL-11 & WALLO- 11 \\
\hline ZTHS & 0.41497 & 0.41497 & 0.41497 \\
\hline ZBHS & 0.36830 & 0.36830 & 0.36830 \\
\hline
\end{tabular}

END

elliptical section

RADIUS $R=R 0 * \operatorname{SQRT}\left(1-(Y-R O / 2)^{\wedge} 2 /(\mathrm{RO} / 2)^{\wedge} 2\right)$

WHERE RO IS THE MAJOR RADIUS OF THE ELIIPTICAL HEAD

AND $Y$ IS THE HEIGHT

* VOLUME $\mathrm{V}=4 * \mathrm{PI} *\left(\mathrm{RO} / 2 * \mathrm{Y}^{\wedge} 2-\mathrm{Y}^{\wedge} 3 / 3\right)$

PI* $\left(\mathrm{RO} / 2 * \mathrm{Y}^{\wedge} 2-\mathrm{Y}^{\wedge} 3 / 3\right)$

$\star$

$\star$

SI

RO

so

VO-VI

* Layer-10

$\begin{array}{llll}0.3683 & 0.30480 & 0.07783\end{array}$

$0.73660 \quad 0.41853$

$\begin{array}{lllll}0.07909 & 0.07011 & 0.19175 & 0.05806\end{array}$

* LAYER- 9

$\begin{array}{llll}0.3270 & 0.30480 & 0.06578\end{array}$

0.01202

* LAYER- 8

* LAYER-7

$\star$

* LAYER- 6

$0.2858 \quad 0.30480 \quad 0.05376$

$\begin{array}{lll}0.2448 & 0.30480 & 0.01197 \\ & 0.04179\end{array}$

$\begin{array}{lll}0.2032 & 0.30480 & 0.02965\end{array}$

0.02965
0.01489

* LAYER- 5

$\begin{array}{lll}0.1500 & 0.26766 & 0.01476\end{array}$

0.01162

$\begin{array}{llll}0.1000 & 0.22428 & 0.00314\end{array}$

0.00208

* LAYER-4

*

* LAYER-3

$\star$

* IAYYER-2

$\begin{array}{llll}0.0750 & 0.16481 & 0.00106\end{array}$

$\begin{array}{lll}0.0508 & 0.0000 & 0.00106 \\ & 0.00000\end{array}$

$0.73195 \quad 0.34842$

$\begin{array}{lll}0.07890 & 0.06817\end{array}$

$0.71788 \quad 0.28025$

0.07852

0.07967

0.69395

0.06435

$0.19830 \quad 0.05615$

$0.21056 \quad 0.05238$

0.11669

0.65844

0.21590

$0.23238 \quad 0.04781$

0.593260 .09000

0.04791

0.504620 .04209

0.01782

0.07886

$0.44551 \quad 0.02427$

$\begin{array}{lll}0.08625 & & 0.01288 \\ & 0.37330 & 0.01139\end{array}$

0.00000

0.00847

$\begin{array}{lll}0.0254 & 0.0000 \quad 0.00000\end{array}$

* LAYER- 1

$\begin{array}{lll}0.0 & 0.0000 & 0.00000 \\ 0.00000\end{array}$

0.00000

$\begin{array}{ll}0.26881 & 0.00292\end{array}$

0.00292

$0.00000 \quad 0.00000$

0.330850 .05106

0.351010 .03629

$0.19157 \quad 0.01574$

$0.19590 \quad 0.01182$

$0.21692 \quad 0.00847$

$0.22802 \quad 0.00292$

Page 118 of 284

March, 2010

* lower head exterior sees atmosphere in the skirt enclosure

Layer 10 
FAl/10-83

PRC-STP-00241, Rev 0

\section{Rev. 0}

SINKS

SAME_AS

LABEL

IMSLAB

IREGO

$X R I$

XRO

AHS

ASHSI

ASHSO

VHS

XZHS

ZTHS

ZBHS

END

*

SINKS

SAME_AS

LABEL

IMSLAB

XRI

XRO

AHS

ASHSI

ASHSO

VHS

XZHS

ZTHS

ZBHS

END

¿

SAME_AS

LABEI.

IMSLAB

XRI

XRO

AHS

ASHSI

ASHSO

VHS

XZHS

ZTHS

ZBHS

END

*

* wall for Layer 7 and below is considered horizontal;

* heat transfer due to laminar boundary layer underside

* of a hot plate is modeled in FATE

*

SINKS

SAME_AS

LABEL

IORIHS

IMSLAB

XRI

XRO

AHS

ASHSI

ASHSO

VHS

XZHS

ZTHS

ZBHS

END

SINKS

SAME_AS

LABEL

IMSLAB
30
57
WALL

$I-10$

3

0.29845

0.30480

0.07909

0.07909

$-1$

0.04130

0.3683

0.3270

Layer 9

27
30

WALLI - 9

3

0.29845

0.3048

0.07890

0.07890

0.07890

0.04120

0.3270

0.2858

Layer 8

24

30

WALLI - 8

3

0.29845

0.30480

0.07852

0.07852

0.07852

$-1$

0.041

0.2858

0.2448
0.07909
29

56

SL- 10

0

0.30480

0.73428

0.13482

0.07909

0.19175

0.05806

0.04130

0.3683

0.3270

26

29

0.30480

0.73485

0.14443

0.07890

0.19830

0.05615

0.04120

0.3270

0.2858

23

SL- 8

19

0.30480

0.70592

0.17215

0.07852

0.21056

0.05238

0.041

0.2858

0.2448
28

55

WALLO - 9

0.73428

0.74698

0. 19175

0.19175

0.19175

$-1$

0.04130

0.3683

0.3270

25

28

WALLO - 9

3

0.73485

0.74755

0.19830

0.19830

0.19830

$-1$

0.04120

0.3270

0.2858

22

28

WALLO - 8

0.70592

0.71862

0.21056

0.21056

o. 21056

$-1$

0.04747

0. 2858

0.2448
Page 119 of 284

March, 2010 
FAl/10-83

PRC-STP-00241, Rev 0

Rev. 0

\begin{tabular}{|c|c|c|c|}
\hline$X R I$ & 0.27988 & 0.28623 & 0.62585 \\
\hline XRO & 0.28623 & 0.62585 & 0.63855 \\
\hline AHS & 0.11672 & 0.15244 & 0.33083 \\
\hline ASHSI & 0.11672 & 0.11672 & 0.33083 \\
\hline ASHSO & 0.11672 & 0.33083 & 0.33083 \\
\hline VHS & -1 & 0.05106 & -1 \\
\hline XZHS & 0.06490 & 0.05320 & 0.08413 \\
\hline ZTHS & 0.2032 & 0.2032 & 0.2032 \\
\hline ZBHS & 0.1500 & 0.1500 & 0.1500 \\
\hline \multicolumn{4}{|l|}{ END } \\
\hline * & Layer 5 & & \\
\hline SINKS & 15 & 14 & 13 \\
\hline SAME_AS & 30 & 29 & 19 \\
\hline LABEL & WALLI - 5 & $S L-5$ & WALLO - 5 \\
\hline IMSLAB & 3 & 14 & 3 \\
\hline$X R I$ & 0.23962 & 0.24597 & 0.54894 \\
\hline XRO & 0.24597 & 0.54894 & 0.56164 \\
\hline AHS & 0.10099 & 0.12486 & 0.35507 \\
\hline ASHSI & 0.10099 & 0.10099 & 0.35507 \\
\hline ASHSO & 0.10099 & 0.35507 & 0.35507 \\
\hline VHS & -1 & 0.03629 & -1 \\
\hline XZHS & 0.06620 & 0.0500 & 0.10177 \\
\hline ZTHS & 0.1500 & 0.1500 & 0.1500 \\
\hline ZBHS & 0.100 & 0.100 & 0.100 \\
\hline \multicolumn{4}{|l|}{ END } \\
\hline * & Layer 4 & & \\
\hline SINKS & 12 & 11 & 10 \\
\hline SAME_AS & 30 & 29 & 19 \\
\hline$\triangle A B E \bar{L}$ & WALLI - 4 & $\mathrm{SL}-4$ & WALLO - 4 \\
\hline IMSIAB & 3 & 13 & 3 \\
\hline $\mathrm{XRI}$ & 0.18820 & 0.19455 & 0.47507 \\
\hline XRO & 0.19455 & 0.47507 & 0.48777 \\
\hline AHS & 0.07757 & 0.05259 & 0.19413 \\
\hline ASHSI & 0.07757 & 0.07757 & 0.19413 \\
\hline ASHSO & 0.07757 & 0.19413 & 0.19413 \\
\hline VHS & -1 & 0.01574 & -1 \\
\hline XZHS & 0.06451 & 0.025 & 0.06418 \\
\hline ZTHS & 0.100 & 0.100 & 0.100 \\
\hline ZBHS & 0.075 & 0.075 & 0.075 \\
\hline
\end{tabular}

Page 120 of 284

March, 2010

$+$

* For layer 3, whose insert wall is nearly horizontal.

* do not model the inset waill. Instead, expose top

* of layer 3 to water, to $0.16481 \mathrm{~m}$.

* AHSS1 = SI of third row $=0,08625 \mathrm{~m}^{\wedge} 2$

* IBSS1, beginning node to expose =

$\star(1+(0.40941-0.16481-0.01137) / 0.02275)+1=12$

* IESSI, end node to expose $=19$

* use effective xzHS considering 0.25 inch insert wall

*

*

SINKS

SAME_AS

LABEL

IMSLAB

XRI

XRO

AHS

ASHSI

ASHSO

VHS

XZHS

ZTHS

ZBHS

IREGS I

AHSS1

IBSS 1

IESSI

END

Layer 3

*

$\begin{array}{ll}8 & 7 \\ 29 & 19 \\ \text { SL-3 } & \text { WALLO-3 } \\ 19 & 3 \\ 0.0 & 0.40941 \\ 0.40941 & 0.42211 \\ 0.03113 & 0.19895 \\ 0.0 & 0.19895 \\ 0.19895 & 0.19895 \\ 0.01182 & -1 \\ 0.0248 & 0.07616 \\ 0.075 & 0.075 \\ 0.0508 & 0.0508 \\ 2 & 0 \\ 0.08625 & 0.0 \\ 12 & 0 \\ 19 & 0\end{array}$


FAl/10-83

PRC-STP-00241, Rev 0

\section{Rev. 0}

* below the inner eliptical head

SINKS

SAME_AS

LABEL

IMS LAB

XRI

$\mathrm{XRO}$

AHS

ASHSI

ASHSO

Layer 2

VHS

XZHS

ZTHS

ZBHS

END

*

* For layer 1, where STSC bottom head is nearly horizontal,

* set XRI of the bottom head to Ro at the top of layer 1

* and expose underside of the sludge to gas

$\star$ AHSS $2=\mathrm{pi} * 0.2688 \mathrm{I}^{\wedge} 2=0.22701$

*

SINKS

LABEL

IMSLAB 13

XRI 0.0

XRO $\quad 0.26881$

AHS $\quad 0.02145$

VHS $\quad 0.00292$

XZHS 0.0265

ZTHS 0.0254

ZBHS 0.0

$\begin{array}{ll}\text { IREGS2 } & 3 \\ \text { AHSS2 } & 0.22802\end{array}$

END

* skirt and dRip pan

* MODEL DRIP-PAN As VERTICAL hS TO ALLOW CONVECTIVE ht to CELL

$\begin{array}{lll} & \text { SINKS } & 96\end{array}$

LABEL SKIRT DRIP-PAN

IORIHS $\quad 0 \quad 1$

IGEOM $\quad 0 \quad 1$

$\begin{array}{lll}\text { IMATHS } & 2 & 2 \\ & 3 & 3\end{array}$

IREGI

IREGO

$\mathrm{XRI}$

3

XRO

AHS

XLHS

$\mathrm{XZHS}$

ZTHS

ZBHS

EHSO

TIINIT

TOINIT

WALLO - 2

0.32106

0.33376

0.22121

2121

0.0508

0.0254

March, 2010

END

* Material library - specify material properties for material 'imaths'

* up to 20 (INMAT) materials can be specified

* the sludge properties (excluding EHSI \& EHSO) are specified in the

* SLudge section

* SYNTAX:

MATERIAL LIBRARY

$\begin{array}{lcccccll}\text { * name } & \text { imaths } & \text { rho } & \text { khs } & \text { cp } & \text { qv } & \text { ehsi } & \text { ehso } \\ \text { SLUDGE } & 1 & 0 . & 0 . & 0 . & 0 . & 0.7 & 0.7 \\ \text { STAINLESS-STEEL } 2 & 8000 & 16.0 & 500 & 0 . & 0.3 & 0.44\end{array}$


FAl/10-83

PRC-STP-00241, Rev 0

Rev. 0

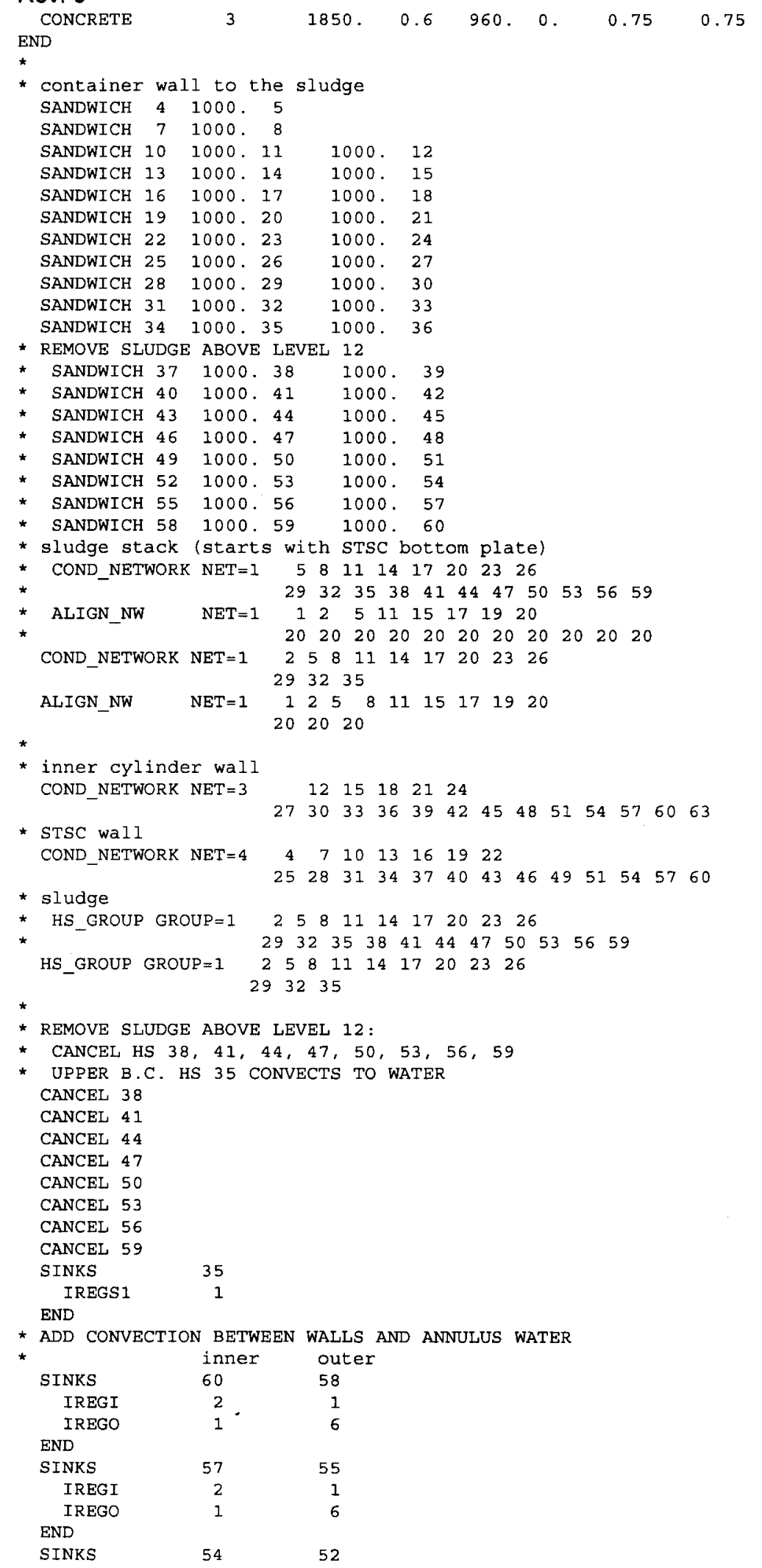


FAl/10-83

\section{PRC-STP-00241, Rev 0}

Rev. 0

$\begin{array}{lrr}\text { IREGI } & 2 & 1 \\ \text { IREGO } & 1 & 6 \\ \text { END } & 51 & 49 \\ \text { SINKS } & 2 & 1 \\ \quad \text { IREGI } & 1 & 6 \\ \text { IREGO } & & \\ \text { END } & 48 & 46 \\ \text { SINKS } & 2 & 1 \\ \text { IREGI } & 1 & 6 \\ \text { IREGO } & & \\ \text { END } & 45 & 43 \\ \text { SINKS } & 2 & 1 \\ \text { IREGI } & 1 & 6 \\ \text { IREGO } & & \\ \text { END } & 42 & 40 \\ \text { SINKS } & 2 & 1 \\ \text { IREGI } & 1 & 6 \\ \text { IREGO } & & 1 \\ \text { END } & 39 & \\ \text { SINKS } & 1 & \\ \text { IREGI } & & \end{array}$

* between drip pan and STSC bottom head

* (layer 2, 3, and 4) RAD NETWORK NET $=1 \quad 95 \quad-4 \quad-7 \quad-70$ FVIËWHS

$\begin{array}{cccc}95 & -4 & -7 & -10 \\ 0.1 & -1 & -1 & -1 \\ 1.0 & 0.0 & 0.0 & 0.0 \\ 1.0 & 0.0 & 0.0 & 0.0 \\ 1.0 & 0.0 & 0.0 & 0.0\end{array}$

* between drip pan and STSC bottom head - continue

* (layer 5, 6, and 7) RAD_NETWORK NET $=2$ 2 $95 \quad-13 \quad-16 \quad-19$

$\begin{array}{cccc}0.1 & -1 & -1 & -1 \\ 1.0 & 0.0 & 0.0 & 0.0 \\ 1.0 & 0.0 & 0.0 & 0.0 \\ 1.0 & 0.0 & 0.0 & 0.0\end{array}$

* between skirt and STSC wall

* (layer 8, 9, and 10) RAD NETWORK NET $=396$ EVIEWHS

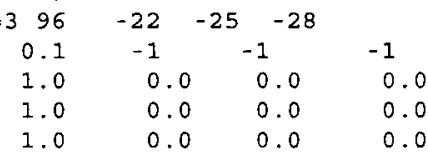

END HEAT_SINKS

\footnotetext{
SLUDGE

$\star \ldots$

* $50 / 50 \mathrm{KE} / \mathrm{KW}$ settler sludge

* Segregated into metal-bearing and non-metal layers

* metal is $1 / 3$ the volume of a $0.5 \mathrm{~m} * * 3$ batch

* Top-down by elevation:

* Layers 8-12 non-metal

* Layers $1-7$ metal

ISTOP 1 ! = 0 , continue even if negative non-U density

$!=1$, stop if negative non-U density

IPRX $1 \quad !=0$, constant particle size

$!=1$, shrinking core model for depletion of area

IWSTRIP 2 ! vapor stripping model choice

$!=0$, no vapor stripping

! = 1, sparging bubbles bypass the water pool

$!=2$, partial equilibrium if pool less than ZLBEQ deep

$!=3$, full equilibrium with the pool

ILAWSG 5 ! Reaction rate model flag:

$1=0$, McGillivrary/Ritchie

$!=1$, Pearce

! 2, Trimble
} 
FAl/10-83

PRC-STP-00241, Rev 0

Rev. 0

! list of heat sinks compri

IHSSG $\begin{array}{lllll}35 & 32 & 29 & 26 & 23\end{array}$

$\begin{array}{llllllll}20 & 17 & 14 & 11 & 8 & 5 & 2\end{array}$

! region containing each sludge heat sink

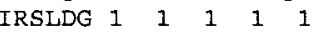

$\begin{array}{lllllll}1 & 1 & 1 & 1 & 1 & 1 & 1\end{array}$

! wet sludge density, $\mathrm{kg} / \mathrm{m}^{\wedge} 3$ wet sludge

RHOSG $\quad 2954.12954 .12954 .12954 .12954 .1$

$\begin{array}{llllllll}3822.6 & 3822.6 & 3822.6 & 3822.6 & 3822.6 & 3822.6 & 3822.6\end{array}$

1 void fraction of the sludge

$\begin{array}{llllll}\text { FPORSG } & 0.70 & 0.70 & 0.70 & 0.70 & 0.70\end{array}$

$\begin{array}{lllllll}0.70 & 0.70 & 0.70 & 0.70 & 0.70 & 0.70 & 0.70\end{array}$

1 Density of U metal, $\mathrm{kg} \mathrm{U}$ metal/m^3 wet sludge

! Optionally, user may specify TABLE-n or FIT-n for position dependent

! density; for this option, specify:

! XRHOUM table\# enumeration of $x$-positions of the node

! YRHOUM table\# enumeration of metal concentrations

! or

YRHOUM fit\# min-x max-x coeffo coeff1 coeff 2 coeff 3 coeff 4

RHOUM $\quad \begin{array}{llllll}0.0 & 0.0 & 0.0 & 0.0 & 0.0\end{array}$

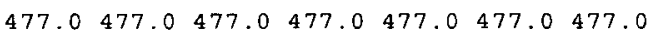

1 density of all $\mathrm{U}, \mathrm{kg} U$ in any chemical form $/ \mathrm{m}^{\wedge} 3$ wet sludge

RHOUT $\quad 1716.4 \quad 1716.4 \quad 1716.4 \quad 1716.4 \quad 1716.4$

2695.52695 .52695 .52695 .52695 .52695 .52695 .5

! gas (h2) void fraction in the sludge

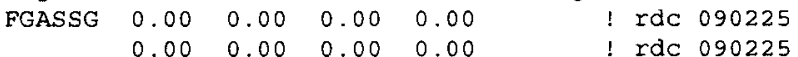

$0.00 \quad 0.00 \quad 0.00 \quad 0.00 \quad 1 \operatorname{rdc} 090225$

$\begin{array}{lllll}\text { KSLDG } & 0.7 & 0.7 & 0.7 & 0.7\end{array}$

$\begin{array}{llll}0.7 & 0.7 & 0.7 & 0.7\end{array}$

$\begin{array}{llll}0.7 & 0.7 & 0.7 & 0.7\end{array}$

KGSG

XDSG

FOXSG

0.17 ! thermal conductivity of the gas in the sludge

0.000375 ! particle diameter, m

3 : oxidation rate multiplier

FKSG 1 : sludge thermal conductivity multiplier

! (not applied to user specified KSLDG)

QSG $\quad 0.09378$ ! decay power, W/ $\mathrm{kg}-\mathrm{U}$

DUOX 11100 ! true density of $\mathrm{U}$ oxide compounds, $\mathrm{kg} / \mathrm{m}^{\wedge} 3$

FWUOX 272.0 ! formula weight of U oxide compounds, $\mathrm{kg} / \mathrm{kg}$-mole

KUSG $\quad 3.90 \quad$ thermal conductivity of $\mathrm{U}$ in sludge, $\mathrm{w} / \mathrm{m}-\mathrm{C}$

KUO2SG $\quad 1.80$ ! thermal conductivity of UO2 in sludge, $\mathrm{W} / \mathrm{m}-\mathrm{C}$

KH2OSG $\quad 0.6$ ! thermal conductivity of $\mathrm{H} 20$ in sludge, $\mathrm{w} / \mathrm{m}-\mathrm{C}$

KNONUSG $\quad 1.3$ : thermal conductivity of non-U in sludge, $w / m-C$

CPUSG $\quad 120.0$ ! specific heat of $U$ in sludge, $\mathrm{J} / \mathrm{kg}-\mathrm{C}$

CPUO2SG 240.0 ! specific heat of UO2 in sludge, J/kg-C

CPH2OSG 4180.0 ! specific heat of $\mathrm{H} 2 \mathrm{O}$ in sludge, $\mathrm{J} / \mathrm{kg}-\mathrm{C}$

CPNONUSG 700.0 ! specific heat of non-U in sludge, J/kg-C

ZLBEQ $\quad 0.10$ ! pool depth for equilibrium of sludge offgas

FRADIOLY $\quad 1.0$ ! radiolysis rate multiplier

FROM SNF-22059, REVISION 0, ATTACHMENT 12, TABLE 1, SB CANISTER

AND 'ALPHA BETA AND GAMMA DECAY FRACTIONS FOR SLUDGE REV 1.XLSX'

BY MICHAEL E. JOHNSON, 23-FEB-10, Settler sludge

FALPSG $\quad 0.109$ ! fraction of decay power from alpha dep. in water

$0.320 * 0.34=0.109$

FBETSG $\quad 0.090$ ! fraction of decay power from beta dep. in water

$0.191 * 0.47=0.090$

FGAMSG $\quad 0.005$ ! fraction of decay power from gamma dep. in water

! $0.0253 * 0.19=0.005$

GH2ALPSG $\quad 1.5$ ! $\mathrm{g}(\mathrm{H} 2)$ molecules $\mathrm{H} 2 / 100 \mathrm{eV}$ alpha dep. in water

GH2BETSG $\quad 0.5$ ! $\mathrm{g}(\mathrm{H} 2)$ molecules $\mathrm{H} 2 / 100 \mathrm{eV}$ beta dep. in water

GH2GAMSG $\quad 0.5 \quad \mathrm{~g}(\mathrm{H} 2)$ molecules $\mathrm{H} 2 / 100 \mathrm{eV}$ gamma dep. in water 
FAl/10-83

PRC-STP-00241, Rev 0

Rev. 0

! User specified format for U-metal concentration in the sludge

! output. Each pair of integers designates the heat sink number

! followed by its node index. Note that the node index starts from

! the outer surface of the heat sink and ends at the inner surface.

! For example, "4,5" designates the concentration in the innermost

! node of heat sink \#4.

PRINT - M

$$
\begin{array}{rcr}
35,20 & 35,10 & 35,1 \\
29,20 & 29,10 & 29,1 \\
23,16 & 23,8 & 23,1 \\
17,8 & 17,1 & \\
11,3 & & \\
8,3 & & \\
5,15 & &
\end{array}
$$

END PRINT-M

2,7

END SLUDGE 
$\mathrm{FAl} / 10-83$

PRC-STP-00241, Rev 0

Rev. 0

B.3 Case File: CONTRF1.dat

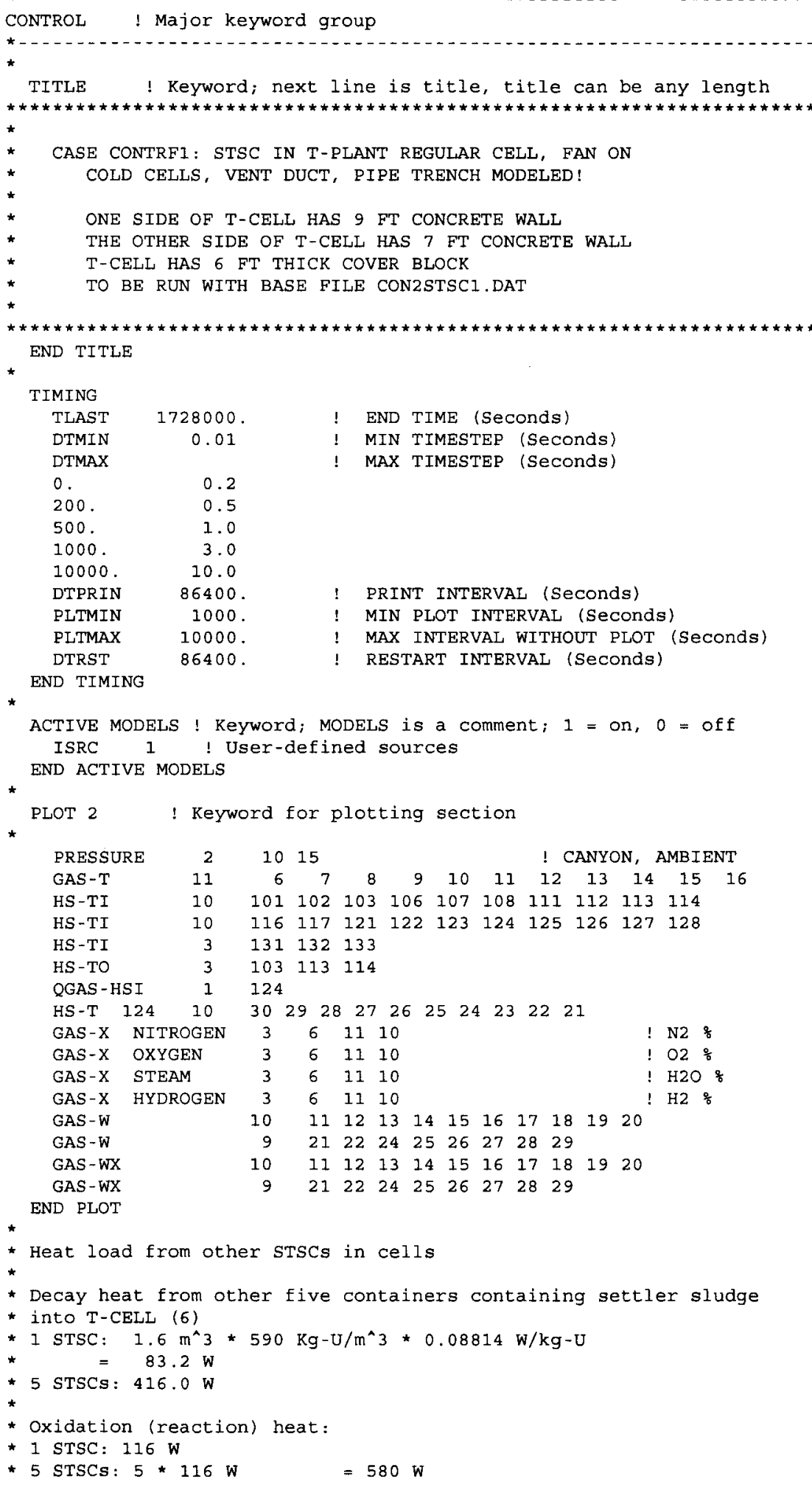


* Total heat load for 5 STSCs: $996 \mathrm{~W}$

*

* H2 Generation Rate:

* $1 \mathrm{STSC}=8381 /$ day

* $\quad=838 \mathrm{l} / \mathrm{day} * 1 / 86400 \mathrm{day} / \mathrm{s} * 0.07598 \mathrm{~kg} / \mathrm{m} * 3 * 1 / 1000 \mathrm{~m} * 3 / 1$

* $\quad=7.37 \mathrm{E}-7 \mathrm{~kg} / \mathrm{s}$

* 5 STSCs: $\quad 3.69 \mathrm{E}-6 \mathrm{~kg} / \mathrm{s}$

SOURCES 2

REGION 6 GASES 1 PHASE 1 HYDROGEN

$\begin{array}{llll}0 & 50.0 & 3.69 \mathrm{E}-6 & 996.0 \\ 1 . \mathrm{E} 9 & 50.0 & 3.69 \mathrm{E}-6 & 996.0\end{array}$

END REGION

* Decay heat from six containers of container sludge in each of four

* cells in the Hot Cell (14)

*4*6*83.2W=

$1996.8 \mathrm{~W}$

* Oxidation (reaction) heat:

* 1 STSC : $116 \mathrm{~W}$

*24 STSCS : 4 * 6 * $116 \mathrm{~W}=2784.0 \mathrm{~W}$

* Total heat load for 5 STSCs: $4780.8 \mathrm{~W}$

* H2 Generation Rate:

* $1 \mathrm{STSC}=7.37 \mathrm{E}-7 \mathrm{~kg} / \mathrm{s}$

$* 24 \mathrm{STSCs}=1.77 \mathrm{E}-5 \mathrm{~kg} / \mathrm{s}$ REGION 14 GASES 1 PHASE 1 HYDROGEN
$0 \quad 50.0$
$1.77 \mathrm{E}-5 \quad 4780.8$
1.E9 $50.0 \quad 1.77 \mathrm{E}-5 \quad 4780.8$

END REGION

END SOURCES

END CONTROL

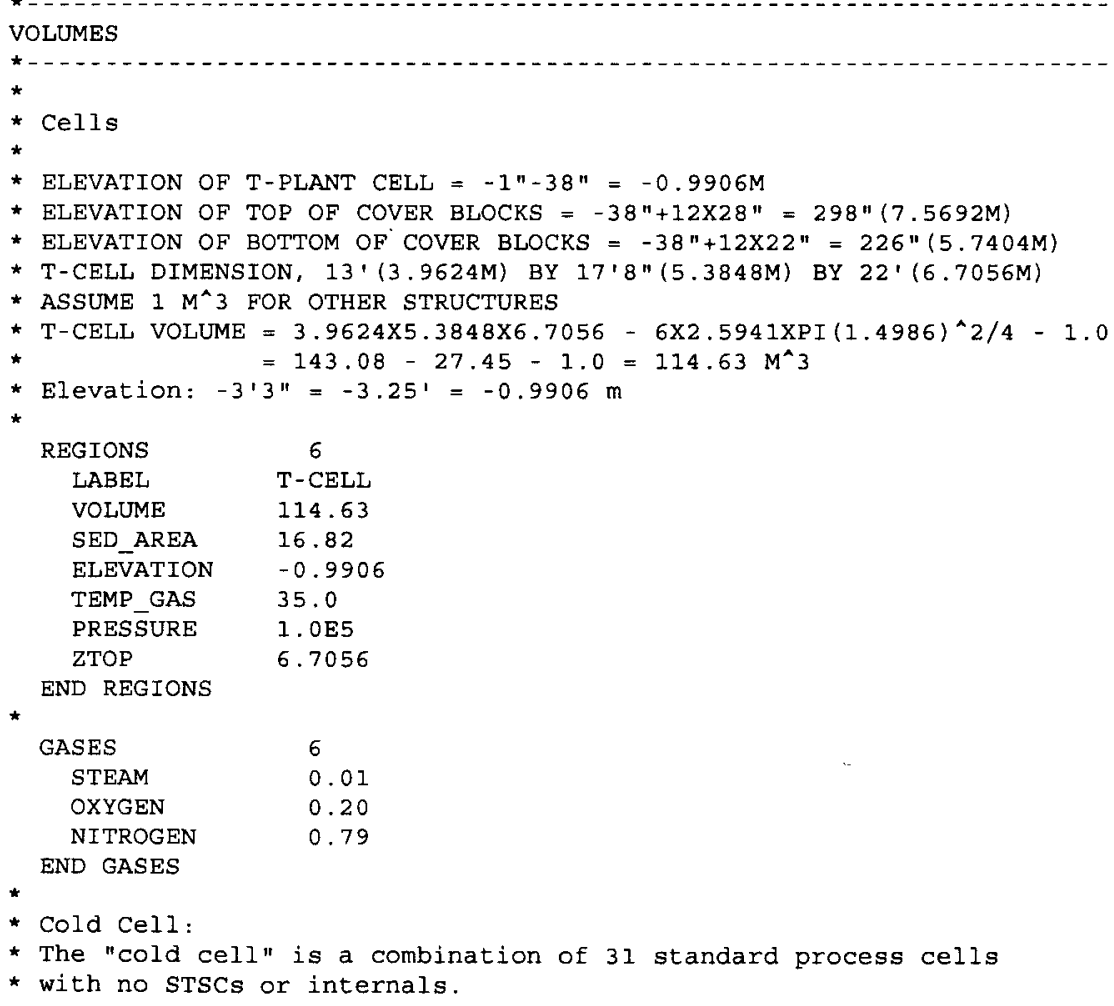




\section{Rev. 0}

$\star$ Volume: $31 \star 143.08 \mathrm{~m} \star \star 3=4435.48 \mathrm{~m} * \star 3$

* Sed. Area: $31 * 16.82 \mathrm{~m} \star 22=521.42 \mathrm{~m} \star 2$

* Elevation: -3.25 '

* Cell 2R:

*Volume: $\quad \mathrm{L}=27^{\prime} 6^{\prime \prime} \mathrm{W}=13^{\prime} \mathrm{H}=22^{\prime} \mathrm{V}=7865 \mathrm{ft} \star \star 3=222.71 \mathrm{~m} \star \star 3$

* Sed. Area: $L=27^{\prime} 6^{\prime \prime} W=13^{\prime} A=357.5 \mathrm{ft} \star \star 2=33.21 \mathrm{~m} * 2$

* Elevation: $-3.25^{\prime}$

* Cell 2L:

* Cell 2L is slightly deeper than $2 \mathrm{R}$ due to train tracks, plus has no cover

* blocks. This adds another $6^{\prime}$ of height to the cell

*Volume: $\quad L=27^{\prime} 6^{\prime \prime} \mathrm{W}=13^{\prime} \mathrm{H}=30^{\prime} 10^{\prime \prime} \mathrm{V}=11022.92 \mathrm{ft} * \star 3=312.13 \mathrm{~m} * * 3$

* Sed. Area: $L=27 \cdot 6$ " $W=13$ ' $A=357.5 \mathrm{ft} * \star 2=33.21 \mathrm{~m} * 2$

* Z-top: $H=30^{\prime} 10^{\prime \prime}=9.398 \mathrm{~m}$

* Elevation: $-3 \cdot 3 "+28^{\prime}-30^{\prime} 10^{\prime \prime}=-6^{\prime} 1^{\prime \prime}=-1.8542 \mathrm{~m}$

* Hot Cell:

* The "hot cell" is a combination of 4 standard process cells.

* including STSCs and internals.

*Volume: $4 * 114.63 \mathrm{~m} * * 3=458.52 \mathrm{~m} * \star 3$

* Sed. Area: $4 \star 16.82 \mathrm{~m} * \star 2=67.28 \mathrm{~m} * * 2$

* Elevation: $-3.25^{\circ}$

REGIONS

SAME_AS

LABEL

VOLUME

SED_AREA

ELEVATION

7
6
COLD-CELL
4435.48
521.42
-0.9906
32.0
$1.0 \mathrm{E} 5$
6.7056

11
6
CELL-2R

12

14

TEMP GAS

222.71

CELI-2I

251.39

$\begin{array}{lll}33.21 & 33.21 & 67.28\end{array}$

PRESSURE

$-0.9906$

$-1.8542$

32.0

$-0.9906$

32.0

ZTOP

6.7056

1. $0 \mathrm{E5}$

$1.0 \mathrm{E5}$

$1.0 \mathrm{E} 5$

END REGIONS

GASES

SAME_AS

END GASES

* VENTS AND DUCTING

* Vent duct (runs along the face of 40 standard cells, each 18' wide):

* Volume: $\quad L=36 * 18^{\prime}, W=10.5 \cdot \mathrm{H}=10.5^{\prime} \mathrm{V}=71442 \mathrm{ft} * 3=2023.0 \mathrm{~m} * 3$

* Sed. Area: $\mathrm{L}=36 \star 18, \mathrm{~W}=10.5, \mathrm{~A}=6804 \mathrm{ft} * * 2=632.1 \mathrm{~m} * * 2$

* Z-top: $\quad \mathrm{H}=10.5^{\prime}=3.2 \mathrm{~m}$

* Elevation: $-3.25^{\prime}=-0.9906 \mathrm{~m}$

REGIONS

SAME_AS

LABEL

VOLUME

SED AREA

7

11

12

14

ELEVATION

TEMP_GAS

PRESSURE

ZTOP

8
6

VENT

2023.0

632.1

$-0.9906$

32.0

1. $0 \mathrm{E} 5$

END REGIONS

GASES

SAME_AS

*

* Pipe Trench:

* Sed. Area: $L=\left(35 \times 20^{\prime}\right) \quad W=81 A=5600 \mathrm{ft} \star \star 2=520.26 \mathrm{~m} * \star 2$

* Volume: $\quad \mathrm{L}=\left(35 \times 20^{\prime}\right) \mathrm{W}=8^{\prime} \mathrm{H}=6^{\prime} \mathrm{V}=33600 \mathrm{ft} * \star 3=951.45 \mathrm{~m} \star \star 3$

* Z-top: $\quad \mathrm{H}=6^{\prime}=1.83 \mathrm{~m}$

* Elevation: 10.5' below canyon deck $\left(14.25^{\prime}=28^{\prime}-3.25^{\prime}-10.5^{\prime}=\right.$ )

* STSC bottom elevation: 0 '

* T-Cell floor elevation: -3.25 '

* Canyon deck elevation: $28^{\prime}-3.25^{\prime}=24.75^{\prime}$

* Pipe trench cover block depth: 4.5' 
FAl/10-83

PRC-STP-00241, Rev 0

Rev. 0

Page 129 of 284

* Pipe trench floor elevation: $24.75^{\prime}-4.5^{\prime}-6^{\prime}=14.25^{\prime}=4.3434 \mathrm{~m}$

$\begin{array}{lc}\text { REGIONS } & 9 \\ \text { LABEL } & \text { PTRENCH } \\ \text { VOLUME } & 951.45 \\ \text { SED_AREA } & 520.26 \\ \text { ELEVATION } & 4.3434 \\ \text { ZTOP } & 1.83 \\ \text { TEMP_GAS } & 23.0 \\ \text { PRESSURE } & 1.0 \mathrm{E} 5\end{array}$

GASES

SAME AS

END GASES

* 24" Pipe:

* Sed. Area: $D=2^{\prime} \mathrm{L}=7^{\prime}+2 \star 13^{\prime} \mathrm{A}=\mathrm{D}=\mathrm{L}=66 \mathrm{ft} \star \star 2=6.1316 \mathrm{~m} * 2$

* Volume: $D=2$ ' $I=71+2 \star 13{ }^{\prime} \mathrm{V}=103.67 \mathrm{ft} * 3=2.9357 \mathrm{~m} \star * 3$

* Z-top: $\mathrm{D}=\mathbf{2}^{\prime}=0.6096 \mathrm{~m}$

* Elevation: $-3.25^{\prime}+28^{\prime}-19^{\prime}=5.75^{\prime}=1.7526 \mathrm{~m}$

* Exhaust duct:

* Sed. Area: $L=145, \mathrm{~W}=4, \mathrm{~A}=580 \mathrm{ft} \star \star 2=53.88 \mathrm{~m} \star \star 2$

*Volume: $\quad \mathrm{L}=145^{\prime} \mathrm{W}=4, \mathrm{H}=7, \mathrm{~V}=4060 \mathrm{ft} * 22=115.0 \mathrm{~m} * \star 2$

* Z-top: $\quad \mathrm{H}=7$

* Elevation: $-3.25^{\prime}=-0.9906 \mathrm{~m}$

REGIONS

SAME_AS

LABEL

VOLUME

SED_AREA

ELEVATION

ZTOP

TEMP_GAS

PRESSTURE

END REGIONS

*

GASES

SAME_AS

$=7$ '

END GAS̄ES

$\begin{array}{cc}13 & 16 \\ 8 & 8 \\ \text { PIPE-24 } & \text { EXH-DUCT } \\ 2.9357 & 115.0 \\ 6.1316 & 53.88 \\ 1.7526 & -0.9906 \\ 0.6096 & 2.1336 \\ 32.0 & 32.0 \\ 1.0 \mathrm{E} 5 & 1.0 \mathrm{E} 5\end{array}$

* AtMospheres

* Canyon Length $=43^{\prime}+680^{\prime}+38.5^{\prime}=761.5 \mathrm{ft}=232.1 \mathrm{~m}$

* Lower $\mathrm{H}=25^{\prime} \mathrm{g}^{\prime \prime}=7.85 \mathrm{~m}, \mathrm{~W}=37^{\prime} \mathrm{2}^{\prime \prime}, \mathrm{AXI}=88.96 \mathrm{~m} * 2$

* Upper $\mathrm{H}=14^{\prime}=4.27 \mathrm{~m}, \mathrm{~W}=60.2 ", \mathrm{AX} 2=78.30 \mathrm{~m} \star \star 2$

* Crane $\mathrm{H}=9^{\prime 3}, \quad, W=10^{\prime}, \mathrm{AX} 3=8.60 \mathrm{~m} * 2$

* Canyon total height $=25^{\prime} 9^{\prime \prime}+144^{\prime}+9 \cdot 3 "=49^{\prime}=14.9352 \mathrm{~m}$

* volume $=232.1 \times(88.96+78.30+8.60)=40,818 \mathrm{~m} * * 3$

* Sed area $232.1 \mathrm{~m} \times 60 \mathrm{ft}=4245 \mathrm{~m} * \star 2$

REGIONS

LABEL

VOLUME

SED_AREA

ELEVTATION

TEMP GAS

PRESSURE

ZTOP

ZTOP

END REGIONS

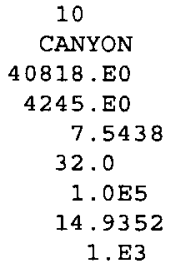

15

AMBIENT

1.E9

1. $\mathrm{E} 6$

7.5438

25.0

1. $0 \mathrm{E} 5$

1. E3

1. $\mathrm{E3}$

GASES

STEAM

OXYGEN

10

0.01

0.20

0.79

15

0.01

0.20

NITROGEN

* control boundary pressure 
FAl/10-83

PRC-STP-00241, Rev 0

\section{Rev. 0}

*

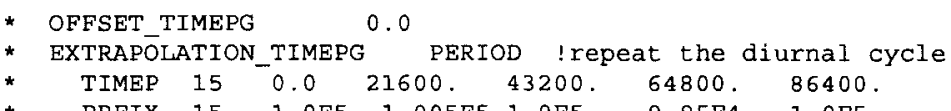

* PRFIX 15 1.0E5 1.005E5 $1.0 \mathrm{E} 5 \quad 9.95 \mathrm{E} 4$ 1.0E5

OFFSET_TIMETG 28800

EXTRAPOLATION_TIMETG PERIOD

TIMETG $15 \quad 0.7200 .0 \quad 14400.0 \quad 21600.0 \quad 28800.0 \quad 36000.0 \quad 43200.0$ $50400.0 \quad 57600.0 \quad 64800.0 \quad 72000.0 \quad 79200.0 \quad 86400.0$

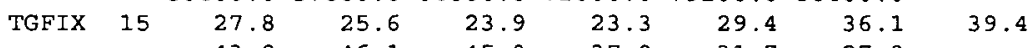

END VOLUME

$\begin{array}{llllll}43.9 & 46.1 & 45.0 & 37.8 & 31.7 & 27.8\end{array}$

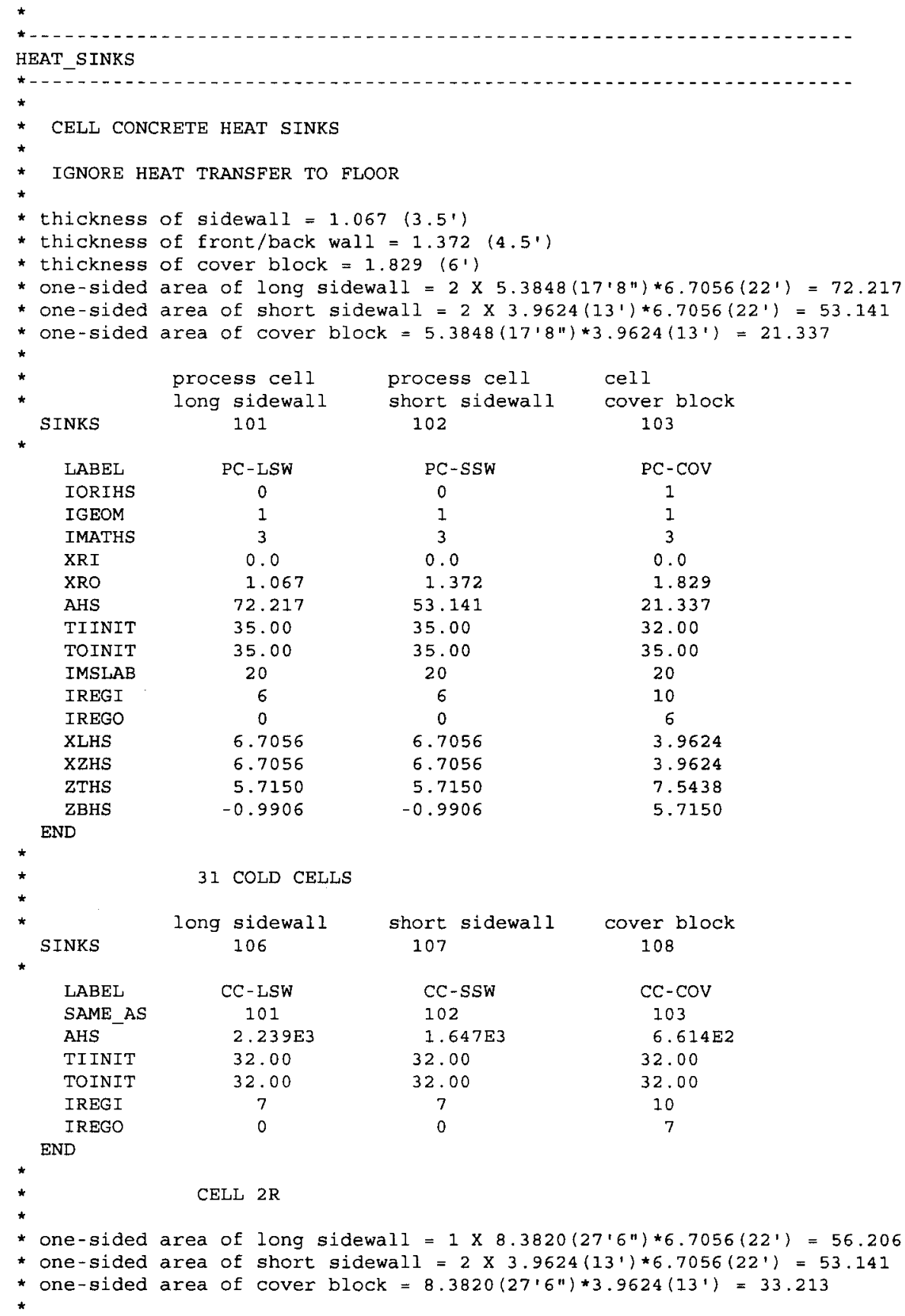


FAI $/ 10-83$

PRC-STP-00241, Rev 0

Rev. 0

$$
\text { * }
$$

SINKS

$\bullet$

$\begin{array}{lcl}\text { LABEL } & 2 R-L S W & 2 \mathrm{R}-2 \mathrm{~L} \\ \text { SAME_AS } & 101 & 101 \\ \text { AHS } & 56.206 & 56.206 \\ \text { TIINIT } & 32.00 & 32.00 \\ \text { TOINIT } & 32.00 & 32.00 \\ \text { IREGI } & 11 & 11\end{array}$

IREGO 0

END

$\star$

$\star$

*

SINKS

*

LABEL SAME AS

IREG $\bar{I}$

IREGO

END

*

*

SINKS

LABEL

SAME AS

AHS

IREGI

IREGO

END

$\star$

$\star$

$\star 2 \times 10.5 \times$

SINKS

\section{IORIHS}

IGEOM

IMATHS

XRI

$X R O$

AHS

TIINIT

TOINIT

IMSLAB

IREGI

IREGO

XLHS

$\mathrm{XZHS}$

ZTHS

ZBHS

END

*

*

* Lower canyon walls: $5 \mathrm{ft}$ thick, $7.85 \mathrm{~m}$ high, $260.5 \mathrm{~m}$ long, x2

* upper canyon walls: $3 \mathrm{ft}$ thick, $4.27 \mathrm{~m}$ high, $\mathrm{x} 2$

SINKS

IORIHS

IGEOM

IMATHS

XRI

131

132

0
1
3
0.0

0.0

CC-LSW

101

14

VENT DUCT

121

0

3

1.52

1405.4

20

8

3.20

3.20

2.21

$-0.9906$

short sidewall

127

cover block

128

CC-SSW

102

212.6

14

$\mathrm{CC}-\mathrm{COV}$

103

85.35

10

14

short sidewall

117

2L-SSW

0
Page 131 of 284

March, 2010

cover

113

$2 \mathrm{R}-\mathrm{COV}$

103

33.213

32.0

32.0

10

11 
FAl/10-83

PRC-STP-00241, Rev 0

Rev. 0

$\begin{array}{lcc}\text { XRO } & 1.52 & 0.915 \\ \text { AHS } & 4090.0 & 222.7 \\ \text { TIINIT } & 32.00 & 32.00 \\ \text { TOINIT } & 32.00 & 35.00 \\ \text { IMSLAB } & 20 & 20 \\ \text { IREGI } & 10 & 10 \\ \text { IREGO } & 0 & 0 \\ \text { XLHS } & 12.0 & 12.0 \\ \text { XZHS } & 12.0 & 12.0 \\ \text { ZTHS } & 15.394 & 19.664 \\ \text { ZBHS } & 7.5438 & 15.394\end{array}$

Page 132 of 284

March, 2010

PIPE TRENCH

* PIPE TRENCH WALL IS $2 \times 6 \times(35 \times 20) \quad F T * * 2$

COVER IS $8 \times(35 \times 20) \quad F T \star \star 2$

$\star$

SINKS

cover

$\begin{array}{lcc}\text { IORIHS } & 0 & 1 \\ \text { IGEOM } & 1 & 1 \\ \text { IMATHS } & 3 & 3 \\ \text { XRI } & 0.0 & 0.0 \\ \text { XRO } & 1.52 & 1.37 \\ \text { AHS } & 781.0 & 520.5 \\ \text { TIINIT } & 32.00 & 32.00 \\ \text { TOINIT } & 32.00 & 32.00 \\ \text { IMSLAB } & 20 & 20 \\ \text { IREGI } & 9 & 10 \\ \text { IREGO } & 0 & 9 \\ \text { XLHS } & 1.83 & 1.83 \\ \text { XZHS } & 1.83 & 1.83 \\ \text { ZTHS } & 6.1710 & 7.5438 \\ \text { ZBHS } & 4.3426 & 6.1710\end{array}$

END

* 24 INCH PIPE

$\star$ length $=2.1336+2 * 3.9624=10.0584$

$\begin{array}{lll}\text { SINKS } & 124 & 125\end{array}$

$\begin{array}{lll}\text { IORIHS } & 0 & 0 \\ \text { IGEOM } & 0 & 0 \\ \text { IMATHS } & 3 & 3 \\ \text { XRI } & 0.6096 & 0.3048 \\ \text { XRO } & 5.0 & 0.6096 \\ \text { AHS } & 177.3 & 2.8727 \\ \text { TIINIT } & 32.00 & 32.00 \\ \text { TOINIT } & 32.00 & 32.00 \\ \text { IMSLAB } & 30 & 20 \\ \text { IREGI } & 0 & 13 \\ \text { IREGO } & 0 & 0 \\ \text { XLHS } & 12.0 & 0.6096 \\ \text { XZHS } & 10.1 & 10.1 \\ \text { ZTHS } & ? & ? \\ \text { ZBHS } & ? & ? \\ \text { END } & & \end{array}$

END HEAT SINKS

-

JUNCTIONS

* Canyon to cells \& pipe trench through cover block gaps

* Path 11: Process cell to canyon via gap

* [References needed for CJN, KFILTER]

* IRI $=6=\mathrm{T}-\mathrm{Cell}$ 


\section{Rev. 0}

$\star \mathrm{ZIJN}=$ Cell height $=$ ZTOP $=6.7056 \mathrm{~m}$

* IR2 $=10$ = Canyon

$\star \mathrm{Z2JN}=$ Canyon $\mathrm{Eloor}=0.0 \mathrm{~m}$

PATHS 11

LABEL TCELL-GAP

$\begin{array}{ll}\text { IJTYP } & 8 \\ \text { ICCJN } & 0\end{array}$

IRI $\quad 6$

IR2 10

IHORIZ 1

AJN $\quad 1.0$

ZIJN $\quad 6.7056$

Z2JN $\quad 0.0$

CJN $\quad 1 . \mathrm{E}-5$

KFILTER 382.15

FGASIJN 1.0

XLJN $\quad 1.0$

XWJN $\quad 1.0$

XHJN $\quad 1.0$

END PATHS

* Path 12: Canyon to cold cells via cover block gaps

* [References needed for CJN]

* IRI = $10=$ Canyon

* Z1JN = Canyon floor $=0.0 \mathrm{~m}$

* IR2 = 7 = cold cells

* $\mathrm{Z} 2 \mathrm{JN}=\mathrm{Cell}$ height $=\mathrm{ZTOP}=6.7056 \mathrm{~m}$

* $\operatorname{KFILTER}=1 /(\operatorname{sum}[i=1.35](1 / \operatorname{KFILTER}$ tceli) $)$

* $\quad$ KFILTER_tcel1 / 35

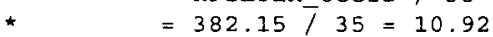

* Path 15: Canyon to pipe trench via cover block gaps

* [References needed for CJN, KFILTER]

* IR $1=10=$ Canyon

$\star$ ZIJN $=$ Canyon floor $=0.0 \mathrm{~m}$

* IR2 = $9=$ Pipe trench

* $\mathrm{Z2JN}=$ Trench height $=$ ZTOP $=1.83 \mathrm{~m}$

* KFILTER $=($ Kwidth * Klength $) /(2 *($ Kwidth + Klength $))$

* $\quad=(389.7 * 1781.1) /(2 *(389.7+1781.1))$

$\star \quad=159.87$

* Path 17: Cell 2R to canyon via cover block gaps

* [References needed for CJN, KFILTER]

* IR1 = II = Cell 2R

$\star$ ZIJN $=$ Cell $2 \mathrm{R}$ height $=$ ZTOP $=6.7056 \mathrm{~m}$

* IR2 = $10=$ Canyon

$\star \mathrm{Z} 2 \mathrm{JN}=$ Canyon floor $=0.0 \mathrm{~m}$

* Path 22: Hot cells to canyon via cover block gaps

* [References needed for CJN]

* IRI $=14=$ Hot cells

$\star \mathrm{ZIJN}=$ Cell height $=$ ZTOP $=6.7056 \mathrm{~m}$

* IR2 $=10=$ Canyon

* $\mathrm{z} 2 \mathrm{JN}=$ Canyon floor $=0.0 \mathrm{~m}$

* $\operatorname{KFILTER}=1 /(\operatorname{sum}[i=1.5](1 / \operatorname{KFILTER}$ tcell $))$

* $\quad=$ KFILTER_tcell / 5

* $\quad 382.15 / 5=76.43$

$\begin{array}{lllll}\text { PATHS } & 12 & 15 & 17 & 22 \\ \text { SAME_AS } & 11 & 11 & 11 & 11 \\ \text { LABEL } & \text { GAP-COLD } & \text { GAP-PIPE } & \text { C2R-GAP } & \text { HOT-GAP } \\ \text { IJTYP } & 8 & 8 & 8 & 8 \\ \text { IRI } & 10 & 10 & 11 & 14 \\ \text { IR2 } & 7 & 9 & 10 & 10 \\ \text { IHORIZ } & 1 & 1 & 1 & 1 \\ \text { AJN } & 1.0 & 1.0 & 1.0 & 1.0 \\ \text { Z1JN } & 0.0 & 0.0 & 6.7056 & 6.7056 \\ \text { Z2JN } & 6.7056 & 1.83 & 0.0 & 0.0 \\ \text { CJN } & 1 . E-5 & 1 . E-5 & 1 . \mathrm{E}-5 & 1 . \mathrm{E}-5 \\ \text { KFILTER } & 10.92 & 159.87 & 231.95 & 76.43\end{array}$


FAI/10-83

PRC-STP-00241, Rev 0

Rev. 0

$\begin{array}{lllll}\text { FGASIJN } & 1.0 & 1.0 & 1.0 & 1.0 \\ \text { XLJN } & 1.0 & 1.0 & 1.0 & 1.0 \\ \text { XWJN } & 1.0 & 1.0 & 1.0 & 1.0 \\ \text { XHJN } & 1.0 & 1.0 & 1.0 & 1.0\end{array}$

* Path 18: Canyon to Cell 2L

* [References needed for CJN]

* IRI = 10 = Canyon

* $\mathrm{ZIJN}=$ Canyon floor $=0.0 \mathrm{~m}$

* IR2 = $12=\operatorname{Cell} 2 \mathrm{~L}$

* $22 \mathrm{JN}=$ Full cell $2 \mathrm{I}$ height $=30.10 "=9.397 \mathrm{~m}$

*AJN $=$ SED_AREA $=33.21 \mathrm{~m} * \star 2$

$\star X L J N=L=27.5^{\prime}=8.3820 \mathrm{~m}$

$\star X W J N=W=13^{\prime}=3.9624 \mathrm{~m}$

$\star$ XHJN $=0.001 \mathrm{~m}=$ thin

LABEL CANYON-C2L

IJTYP 1

IR1 10

IR2 12

IHORIZ 1

AJN $\quad 33.21$

ZIJN 0.0

Z2JN $\quad 9.397$

CJN 2.8

FGASIJN 1.0

XLJN $\quad 8.3820$

XWJN $\quad 3.9624$

XHJN $\quad 0.001$

* Celis to ventilation duct

* Path 13: Cola cells to ventilation duct via 10"-dia pipe.

* [Reference needed for CJN]

* IRI = $7=$ Cold cells

* ZlJN $=9^{\prime}=2.7432 \mathrm{~m}$

* IR2 = 8 = Ventilation duct

* $22 \mathrm{JN}=$ top of duct $=$ ZTOP $=10.5^{\prime}=3.2004 \mathrm{~m}$

$\star \mathrm{CJN}=(1 / 0.6) \star \star 2=2.8$

* Consider 35 pipes for 35 cold cells:

$\star \mathrm{AJN}=35 \star \mathrm{pi} / 4 \star(\mathrm{D} * 2)$

$\star \quad \quad=19.1 \mathrm{ft} \star \star 2$

$\star \quad \quad=1.7735 \mathrm{~m} * \star 2$

$\star X L J N=10^{\prime}=2.5 \mathrm{~m}$

* $\mathrm{XWJN}=10^{\prime \prime}=0.254 \mathrm{~m}$

$\star \mathrm{XHJN}=10 "=0.254 \mathrm{~m}$

* Path 14: Ventilation duct to process cell via 10"-dia pipe.

* [References needed for CJN]

* IRI = 8 = Ventilation duct

$\star \mathrm{ZIJN}=$ top of duct $=\mathrm{ZTOP}=10.5^{\prime}=3.2004 \mathrm{~m}$

* IR2 $=6=\mathrm{T}$ cell

$\star \mathrm{Z} 2 \mathrm{JN}=9^{\prime}=2.7432 \mathrm{~m}$

$\star C J N=(1 / 0.6) * \star 2=2.8$

$\star \mathrm{AJN}=\mathrm{pi} / 4 *(\mathrm{D} * \star 2)$

$\star \quad=0.5454 \mathrm{ft} \star \star 2$

$\star \quad \quad=0.05067 \mathrm{~m} \star \star 2$

$\star X L J N=10^{1}=2.5 \mathrm{~m}$

* $\mathrm{XWJN}=10^{\prime \prime}=0.254 \mathrm{~m}$

$\star \mathrm{XHJN}=10^{n}=0.254 \mathrm{~m}$

* Path 21: Ventilation duct to hot cells via 10"-dia pipe.

* [References needed for CJN]

* IRI = 8 = Ventilation duct

$\star \mathrm{ZIJN}=$ top of duct $=\mathrm{ZTOP}=10.5^{\prime}=3.2004 \mathrm{~m}$

* IR2 = $14=$ Hot cells

$\star \mathrm{Z} 2 \mathrm{JN}=9^{\prime}=2.7432 \mathrm{~m}$

$\star \mathrm{CJN}=(1 / 0.6) * 2=2.8$ 


\section{Rev. 0}

* Consider 5 pipes for 5 hot cells:

$\star \mathrm{AJN}=5 \star \mathrm{pi} / 4 \star(\mathrm{D} * \star 2)$

$\star \quad=2.7271 \mathrm{ft} * \star 2$

* $\quad=0.25335 \mathrm{~m} \star \star 2$

$\star X \mathrm{XLJN}=10^{\prime}=2.5 \mathrm{~m}$

$\star X W J N=10^{\prime \prime}=0.254 \mathrm{~m}$

$\star \mathrm{XHJN}=10^{\prime \prime}=0.254 \mathrm{~m}$

$\begin{array}{llll}\text { PATHS } & 13 & 14 & 21 \\ \text { LAABL } & \text { COLD-VENT } & \text { VENT-TCELL } & \text { VENT-HOT } \\ \text { IJTYP } & 1 & 1 & 1 \\ \text { ICCJN } & 0 & 0 & 0 \\ \text { IR1 } & 7 & 8 & 8 \\ \text { IR2 } & 8 & 6 & 14 \\ \text { IHORIZ } & 0 & 0 & 0 \\ \text { AJN } & 1.7735 & 0.05067 & 0.25335 \\ \text { Z1JN } & 2.7432 & 3.2004 & 3.2004 \\ \text { Z2JN } & 3.2004 & 2.7432 & 2.7432 \\ \text { CJN } & 2.8 & 2.8 & 2.8 \\ \text { KFILTER } & 0.0 & 0.0 & 0.0 \\ \text { FGAS1JN } & 1.0 & 1.0 & 1.0 \\ \text { XLUN } & 2.5 & 2.5 & 2.5 \\ \text { XWJN } & 0.254 & 0.254 & 0.254 \\ \text { XHJN } & 0.254 & 0.254 & 0.254\end{array}$

END PATHS

*? Single cell pair $\mathrm{K}=160$; divide by 17.5

* Pipe trench to ventilation duct

* Path 16: Pipe trench to ventilation duct via 18 10"-dia pipes.

* [Reference needed for CJN]

* $\operatorname{IR} 1=9=$ Pipe trench

* $\mathrm{Z} 1 \mathrm{JN}=\mathrm{Pipe}$ trench floor $=0 \mathrm{~m}$

* IR2 = 8 = Ventilation duct

$\star$ Z2JN $=$ top of duct $=$ ZTOP $=10.5^{\prime}=3.2004 \mathrm{~m}$

$\star C J N=(1 / 0.6) * * 2=2.8$

* Consider 18 pipes for 18 cold cells:

* $\mathrm{AJN}=18 * \mathrm{pi} / 4 *\left(\mathrm{D}^{*} * 2\right)$

$\star \quad=9.8229 \mathrm{ft} * \star 2$

* $\quad=0.9121 \mathrm{~m} * * 2$

$\star X L J N=10^{\circ}=2.5 \mathrm{~m}$

$*$ XWJN $=10^{\prime \prime}=0.254 \mathrm{~m}$

$\star \mathrm{XHJN}=10^{\prime \prime}=0.254 \mathrm{~m}$

PATHS 16

IUTYP $I$

ICCJN 0

IR2 8

IHORIZ 1

AJN 0.9121

ZIJN 0.0

Z2JN $\quad 3.2004$

CJN 2.8

FGAS1JN 1.0

XLJN 2.5

XWJN $\quad 0.254$

XHUN $\quad 0.254$

*

* Long cells to $24 "$ pipe

* Path 19: Cell 2L to 24" vent pipe via 10"-dia pipes.

* [Reference needed for CJN]

* IRI $=12=\operatorname{Cell} 2 \mathrm{~L}$

* ZlJN $=6.9 "$ below canyon deck (note: 5'8" is at cover block level)

* = ZTOP 12 - 6'9"

* $\quad=7.56 \overline{9} 2 \mathrm{~m}-2.0574 \mathrm{~m}$

$\star \quad=5.5118 \mathrm{~m}$ 
FAl/10-83

PRC-STP-00241, Rev 0

Rev. 0

* IR2 = $13=24 "$ pipe

Page 136 of 284

March, 2010

$\star \mathrm{Z} 2 \mathrm{JN}=0 \mathrm{~m}$

$\star \mathrm{CJN}=(1 / 0.6) * * 2=2.8$

$\star \mathrm{AJN}=\mathrm{pi} / 4 \star(\mathrm{D} * \star 2)$

$\star \quad=0.5454 \mathrm{ft} * * 2$

* $\quad=0.05067 \mathrm{~m} * * 2$

$\star X L J N=10^{\prime}=2.5 \mathrm{~m}$

$\star \mathrm{XWJN}=10^{\prime \prime}=0.254 \mathrm{~m}$

$\star \mathrm{XHJN}=10^{\prime \prime}=0.254 \mathrm{~m}$

* Path 20: Cell 2R to 24" vent pipe via 10"-dia pipes.

* [Reference needed for CJN]

* IR1 = $13=24$ " pipe

* $\mathrm{ZIJN}=0 \mathrm{~m}$

* IR2 = $11=\operatorname{Cell} 2 \mathrm{R}$

* Z2JN = 6'9" below canyon deck

* $\quad$ ZTOP $12-6.9 "$

* $\quad=7.56 \overline{9} 2 \mathrm{~m}-2.0574 \mathrm{~m}$

$\star \quad \quad=5.5118 \mathrm{~m}$

$\star \operatorname{CJN}=(1 / 0.6) * * 2=2.8$

* AJN $=p i / 4 *(D * * 2)$

$\star \quad \quad=0.5454 \mathrm{ft} * \star 2$

* $\quad=0.05067 \mathrm{~m} * \star 2$

$\star X L J N=10^{\circ}=2.5 \mathrm{~m}$

$\star X W J N=10^{\prime \prime}=0.254 \mathrm{~m}$

$\star \mathrm{XHJN}=10 "=0.254 \mathrm{~m}$

$\begin{array}{llr}\text { IJTYP } & 1 & 1\end{array}$

ICCJN 00

IR1 $12 \quad 13$

IR2 $13 \quad 11$

$\begin{array}{lll}\text { IHORIZ } & 0 & 0 \\ & 0.05067 & 0.05067\end{array}$

$\begin{array}{lll}\text { AJN } & 0.05067 & 0.050 \\ \text { ZIJN } & 5.5118 & 0.0\end{array}$

$\begin{array}{lll}\text { Z2JN } & 0.0 & 5.5118\end{array}$

$\begin{array}{lll}\text { CJN } & 2.8 & 2.8\end{array}$

FGASIJN $1.0 \quad 1.0$

$\begin{array}{lll}\text { XWJN } & 0.254 & 0.254\end{array}$

$\begin{array}{lll}\text { XHJN } & 0.254 & 0.254\end{array}$

END PATHS

*

* 24 " Pipe and vent duct to exhaust duct

* Path 25: Ventilation duct to exhaust duct

* [Reference needed for CJN]

* IR1 $=8$ = Ventilation duct

* $\mathrm{ZlJN}=$ Vent duct floor $=0.0 \mathrm{~m}$

* IR2 = 16 = Exhaust duct

$\star$ Z2JN $=$ Exhaust duct floor $=0.0 \mathrm{~m}$

$\star \mathrm{AJN}=5^{\prime} \star 4^{\prime}=20.0 \mathrm{ft} * 2=1.8581 \mathrm{~m} * 2$

$\star$ XLJN $=$ thin $=0.001 \mathrm{~m}$

$\star \mathrm{XWJN}=4^{\prime}=1.2192 \mathrm{~m}$ (est.)

$\star \mathrm{XHJN}=5^{\prime}=1.5240 \mathrm{~m}$

$\star$

* Path 27: 24" vent pipe to exhaust duct

* [Reference needed for CJN]

* $\operatorname{IRI}=13=24 "$ pipe

* ZIJN $=0 \mathrm{~m}$

* IR2 = 16 = Exhaust duct

$\star \mathrm{Z} 2 \mathrm{JN}=$ vent duct floor +4 ,

$\star \quad=4$.

$\star \quad=1.2192 \mathrm{~m}$

$* \mathrm{CJN}=(1 / 0.6) * \star 2=2.8$

$\star \mathrm{AJN}=\mathrm{pi} / 4 \star(\mathrm{D} * \star 2)$

* $\quad=3.1416 \mathrm{ft} * \star 2$

* $\quad=0.2919 \mathrm{~m} * * 2$

* $\mathrm{XLJN}=10^{\circ}=3.048 \mathrm{~m}$ (est.)

* $\mathrm{XWJN}=24 "=0.6096 \mathrm{~m}$ 
FAl/10-83

PRC-STP-00241, Rev 0

Rev. 0

$\star$ XHJN $=24 " / \sin (45)=0.8621 \mathrm{~m}$

$\begin{array}{lcc}\text { PATHS } & 25 & 27 \\ \text { LABEL } & \text { VENT-EXH } & \text { PIPE-EXH } \\ \text { IJTYP } & 1 & 1 \\ \text { ICCJN } & 0 & 0 \\ \text { IRI } & 8 & 13 \\ \text { IR2 } & 16 & 16 \\ \text { IHORIZ } & 0 & 0 \\ \text { AJN } & 1.8581 & 0.2919 \\ \text { ZIJN } & 0.0 & 0.0 \\ \text { Z2JN } & 0.0 & 1.2192 \\ \text { CJN } & 1.8-5 & 2.8 \\ \text { KFILTER } & 0.0 & 0.0 \\ \text { FGASIJN } & 1.0 & 1.0 \\ \text { XIJN } & 0.001 & 3.048 \\ \text { XWJN } & 1.2192 & 0.6096 \\ \text { XHJN } & 1.5240 & 0.8621\end{array}$

* Fan from exhaust duct to ambient

* Ean flow rate $=17500 \mathrm{cfm}=8.2591 \mathrm{~m}^{\wedge} 3 / \mathrm{s}$

* fan flow rate $=0 \mathrm{~m}^{\wedge} 3 / \mathrm{s}$

* Path 26: Exhaust duct to ambient

* CJN not used, constant volumetric flow rate

* Set AJN to an arbitrary positive value

* so code does not bypass the junction

* IRI = $16=$ Exhaust duct

* ZIJN $=0 \mathrm{~m}$

* IR2 = 15 = Ambient (atmosphere)

* Z2JN = $15 \mathrm{~m}$ (est.; stack height = 200'?)

PATHS 26

LABEL FAN

IJTYP 1

ICCJN 1

IR1 16

IR2 15

AJN $\quad 1.0$

ZIJN $\quad 0.0$

Z2JN $\quad 15.0$

CJN 1.0

KFILTER 0.0

FGASIJN 1.0

IFAN 1

WVFAN 8.2591

END PATHS

* Cell 2L and canyon to ambient

* Path 28: Ambient to Canyon

* Leakage modeled using KFILTER

* $17500 \mathrm{cfm}\left(82.6 \mathrm{~m}^{\wedge} 3 / \mathrm{s}\right)$ at 0.15 in w.g. (35.9 Pa)

* Assume equal split between canyon leakage and

* access tunnel leakage.

* Hence, KFILTER=35.9; $(82.6 / 2)=0.870$

* IRI = 15 = Ambient (atmosphere)

* Z1JN = ELEVATION_10+ZTOP_10/2 - ELEVATION 15

* $\quad=7.5438 \mathrm{~m}+14.9352 \mathrm{~m}^{-} / 2-7.5438 \mathrm{~m}$

* $\quad=7.4676 \mathrm{~m}$

* IR2 $=10=$ Canyon

$\star \mathrm{Z} 2 \mathrm{JN}=\mathrm{ZTOP} 10 / 2$

$\star \quad \quad=7.46 \overline{7} 6 \mathrm{~m}$

* Path 29: Ambient to Cell 2I

* Leakage modeled using KFILTER

* $17500 \mathrm{cmf}\left(82.6 \mathrm{~m}^{\wedge} 3 / \mathrm{s}\right)$ at $0.15 \mathrm{in} w .9 .(35.9 \mathrm{~Pa})$

* Assume equal split between canyon leakage and 
FAl $/ 10-83$

PRC-STP-00241, Rev 0

\section{Rev. 0}

* access tunnel leakage.

* Hence, KFILTER $=35.9 /(82.6 / 2)=0.870$

$\star$ IR1 = 15 = Ambient (atmosphere)

* ZIJN = ELEVATION $12+$ ZTOP $12 / 2$ - ELEVATION 15

* $\quad=-1.8542 \mathrm{~m}+7.5692 \overline{\mathrm{m}} / 2-7.5438 \mathrm{~m}$

$\star \quad=-5.6134 \mathrm{~m}$

* IR2 = $12=\operatorname{Cell} 2 \mathrm{~L}$

* Z2JN $=$ ZTOP $12 / 2$

$\star \quad \quad=7.56 \overline{9} 2 \mathrm{~m} / 2$

* $\quad=3.7846 \mathrm{~m}$

PATHS LABEL AMB-CANYON AMB-C2L

IJTYP

ICCJN

IRI

IR2

IHORIZ

AJN

ZIJN

$\mathrm{Z} 2 \mathrm{JN}$

$\mathrm{CJN}$

8

88

$15 \quad 15$

$10 \quad 12$

11

$1.0 \quad 1.0$

$\begin{array}{ll}7.4676 & -5.6134\end{array}$

$\begin{array}{ll}7.4676 & 3.7846\end{array}$

$\begin{array}{lll}\text { KFILTER } & 0.870 & 0.870\end{array}$

FGASIJN $1.0 \quad 1.0$

XLJN $1.0 \quad 1.0$

XWJN $1.0 \quad 1.0$

$\begin{array}{lll}X H J N & 1.0 & 1.0\end{array}$

END PATHS

END JUNCTIONS 
FAl/10-83

PRC-STP-00241, Rev 0

Rev. 0

B.4 Case File: CONTLF1.dat

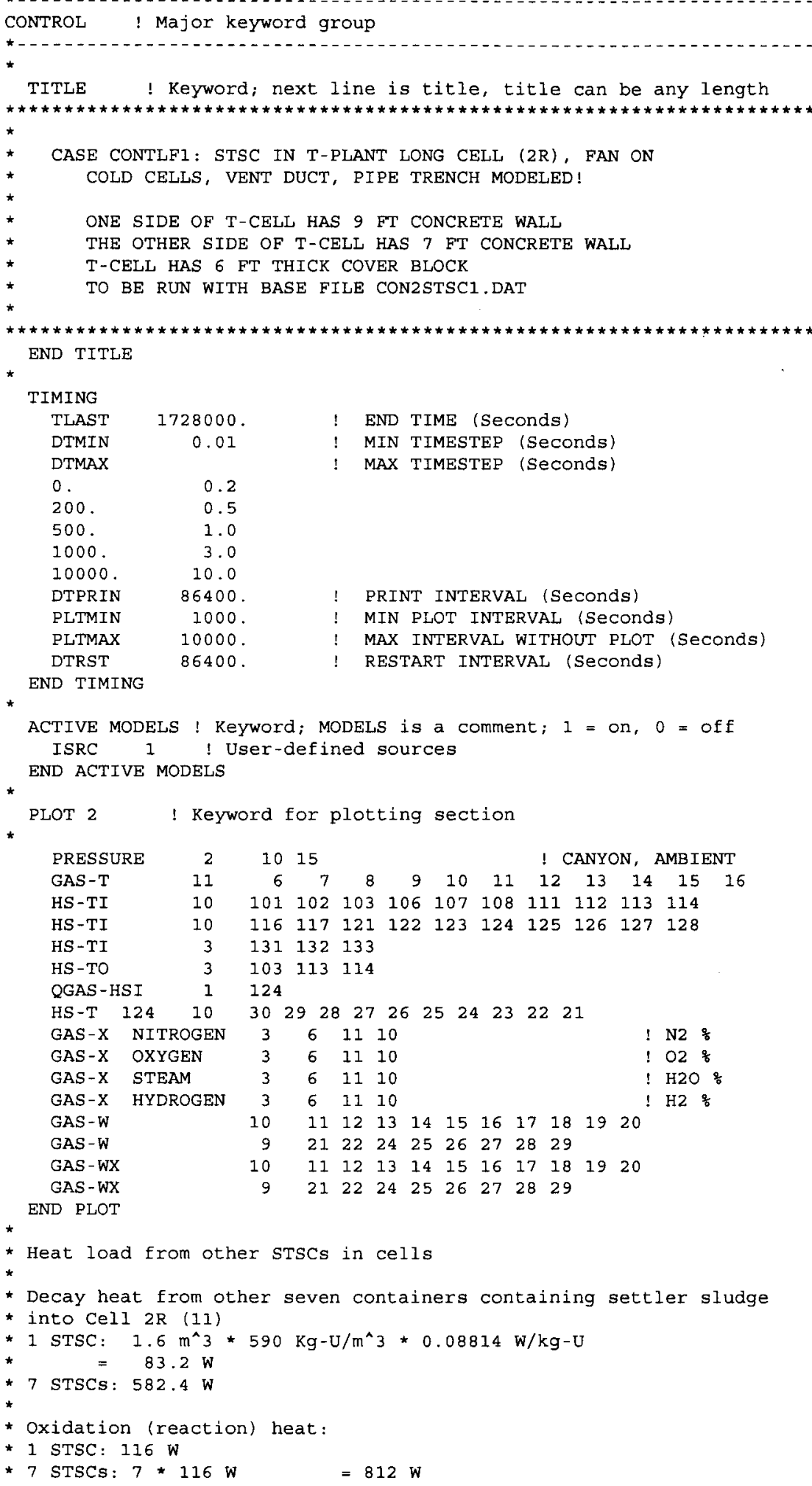


*

* Total heat load for 7 STSCs: $1394.4 \mathrm{~W}$

* H2 Generation Rate:

* 1 STsC $=8381 / \mathrm{day}$

* $\quad=838 \mathrm{l} / \mathrm{day} \star 1 / 86400 \mathrm{day} / \mathrm{s} * 0.07598 \mathrm{~kg} / \mathrm{m} * 3 * 1 / 1000 \mathrm{~m} * 3 / 1$

* $\quad=7.37 \mathrm{E}-7 \mathrm{~kg} / \mathrm{s}$

* 7 STSCs: $5.159 \mathrm{E}-6 \mathrm{~kg} / \mathrm{s}$

SOURCES 2

REGION 11 GASES 1 PHASE 1

HYDROGEN

$\begin{array}{llll}0 & 50.0 & 5.159 \mathrm{E}-6 & 1394.4\end{array}$

1.E9 $50.0 \quad 5.159 \mathrm{E}-6 \quad 1394.4$

END REGION

* Decay heat from six containers of container sludge in each of four

* cells in the Hot Cell (14)

$\star 4 \star 6 \star 83.2 \mathrm{~W}=$

$1996.8 \mathrm{~W}$

* Oxidation (reaction) heat:

* 1 STSC: $116 \mathrm{~W}$

* 24 STSCs : $4 * 6 * 116 \mathrm{~W} \quad=2784.0 \mathrm{~W}$

* Total heat load for 5 STSCs: 4780.8 W

* H2 Generation Rate:

* 1 STSC $=7.37 \mathrm{E}-7 \mathrm{~kg} / \mathrm{s}$

$\star 24 \mathrm{STSCs}=1.77 \mathrm{E}-5 \mathrm{~kg} / \mathrm{s}$

REGION 14 GASES 1 PHASE 1 HYDROGEN

$\begin{array}{llll}0 & 50.0 & 1.77 \mathrm{E}-5 & 4780.8\end{array}$

$\begin{array}{llll}1 . \mathrm{Eg} & 50.0 & 1.77 \mathrm{E}-5 & 4780.8\end{array}$

END REGION

END SOURCES

END CONTROL

VOLUMES

*

* Cells

* elevation of T-PLANT CELL $=-1 "-38 "=-0.9906 \mathrm{M}$

* ELEVATION OF TOP OF COVER BLOCKS $=-38 "+12 \times 28 "=298 "(7.5692 \mathrm{M})$

* ELEVATION OF BOTTOM OF COVER BLOCKS $=-38 "+12 \times 22^{\prime \prime}=226 "(5.7404 \mathrm{M})$

* T-CELl DIMENSION, 13'(3.9624M) BY $17 \cdot 8 "(5.3848 \mathrm{M})$ BY $22 \cdot(6.7056 \mathrm{M})$

* ASSUME 1 M^3 FOR OTHER STRUCTURES

* T-CELL VOLUME $=3.9624 \times 5.3848 \times 6.7056-6 \times 2.5941 X P I(1.4986)^{\wedge} 2 / 4-1.0$

*

* Elevation: $-3.3^{\prime \prime}=-3.25^{\prime}=-0.9906 \mathrm{~m}$

REGIONS

IABEL T-CELL

VOLUME $\quad 143.08$

SED AREA $\quad 16.82$

ELEVEATION $\quad-0.9906$

TEMP GAS 35.0

PRESSURE $\quad 1.0 E 5$

ZTOP $\quad 6.7056$

GASES

STEAM 0.01

OXYGEN $\quad 0.20$

NITROGEN $\quad 0.79$

END GASES

* Cola celi:

* The "cold cell" is a combination of 31 standard process cells

* with no STSCs or internals. 
* Pipe trench floor elevation: $24.75^{\prime}-4.5^{\prime}-6^{\prime}=14.25^{\prime}=4.3434 \mathrm{~m}$

REGIONS

LABEL

$\begin{array}{lr}\text { VOLUME } & 951.45\end{array}$

SED AREA $\quad 520.26$

ELEVATION $\quad 4.3434$

ZTOP 1.83

TEMP GAS 23.0

PRESSTRE $\quad 1.0 \mathrm{E} 5$

GASES

SAMEAS $\quad 9$

*

* 24" Pipe:

* Sed. Area: $D=21 \quad L=7 \cdot+2 * 13^{\prime} A=D * L=66 \mathrm{ft} * * 2=6.1316 \mathrm{~m} * * 2$

* Volume: $\mathrm{D}=21 \mathrm{~L}=7 \mathrm{\prime}+2 * 13{ }^{\prime} \mathrm{V}=103.67 \mathrm{ft} * 3=2.9357 \mathrm{~m} * * 3$

* Z-top: $D=2^{\prime}=0.6096 \mathrm{~m}$

* Elevation: $-3.25^{\prime}+28^{\prime}-19^{\prime}=5.75^{\prime}=1.7526 \mathrm{~m}$

* Exhaust duct:

* Sed. Area: $L=145, W=4, A=580 \mathrm{ft} * * 2=53.88 \mathrm{~m} * * 2$

*Volume: $\quad L=145^{\prime}, W=4, H=7, V=4050 \mathrm{ft} * \star 2=115.0 \mathrm{~m} * \star 2$

* Z-top: $\quad \mathrm{H}=7^{\prime}$

* Elevation: $-3.25^{\prime}=-0.9906 \mathrm{~m}$

REGIONS

SAME_AS

LABEL

VOLUME

SED_AREA

ELEVATION

ZTOP

TEMP_GAS

PRESSTURE

END REGIONS

*

GASES

SAME_AS

$\begin{array}{cc}13 & 16 \\ 8 & 8 \\ \text { PIPE-24 } & \text { EXH-DUCT } \\ 2.9357 & 115.0 \\ 6.1316 & 53.88 \\ 1.7526 & -0.9906 \\ 0.6096 & 2.1336 \\ 32.0 & 32.0 \\ 1.0 \mathrm{E} 5 & 1.0 \mathrm{E} 5\end{array}$

END GASES

* atmospheres

* Canyon Length $=43^{\prime}+680^{\prime}+38.5^{\prime}=761.5 \mathrm{ft}=232.1 \mathrm{~m}$

* Lower $\mathrm{H}=2519 "=7.85 \mathrm{~m}, \mathrm{~W}=37.2 ", \operatorname{AX1}=88.96 \mathrm{~m} \star 2$

* Upper $\mathrm{H}=14 \mathrm{\prime}=4.27 \mathrm{~m}, \mathrm{~W}=60.2 \mathrm{\prime}, \mathrm{AX2}=78.30 \mathrm{~m} * \star 2$

* Crane $\mathrm{H}=9.3 " \quad, \mathrm{~W}=10^{\prime}, \mathrm{AX} 3=8.60 \mathrm{~m} * 2$

* Canyon total height $=2519 "+141+913 "=491=14.9352 \mathrm{~m}$

* Volume $=232.1 \times(88.96+78.30+8.60)=40,818 \mathrm{~m} * * 3$

* Sed area $232.1 \mathrm{~m} \times 60 \mathrm{ft}=4245 \mathrm{~m} * \star 2$

REGIONS

LABEL

VOLUME

SED_AREA

ELEVATION

TEMP_GAS

PRESSURE

ZTOP

ZTOP

10

CANYON

40818 . EO

4245 . EO

GASES

STEAM

OXYGEN

NITROGEN

END GASES

* control boundary pREsSURe
7.5438

32.0

1. $0 \mathrm{E} 5$

14.9352

1. $\mathrm{E} 3$

15

AMBIENT

1.E9

1. E6

7.5438

25.0

1. $0 \mathrm{E} 5$

$1 . \mathrm{E} 3$

1. E3

10

0.01

0.20

0.01

0.20

0.79 
FAll10-83

\section{PRC-STP-00241, Rev 0}

Rev. 0

* offSET_timePG 0.0

* extrapótation timerg period irepeat the diurnal cycle

* TIMEP 15 0.0 21600. 43200. 64800. 86400.

* PRFIX $15 \quad 1.0 \mathrm{E5} \quad 1.005 \mathrm{E} 51.0 \mathrm{E} 5 \quad 9.95 \mathrm{E} 4 \quad 1.0 \mathrm{E5}$

OFFSET TIMETG 28800

EXTRAPOLATION_TIMETG PERIOD

TIMETG $15 \quad 0.7200 .0 \quad 14400.0 \quad 21600.028800 .0 \quad 36000.0 \quad 43200.0$ $\begin{array}{rrrrrr}50400.0 & 57600.0 & 64800.0 & 72000.0 & 79200.0 & 86400.0\end{array}$

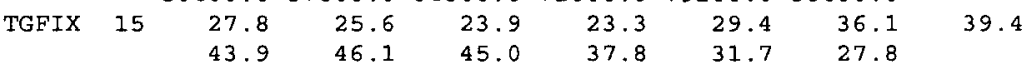

END VOLUME

HEAT_SINKS

* CELl concrete heat sinks

* ignore heat transfer to floor

* thickness of sidewall $=1.067$ (3.5')

* thickness of front/back wall = 1.372 (4.51)

* thickness of cover block $=1.829(61)$

* one-sided area of long sidewall $=2 \times 5.3848(17 \cdot 8 \prime) \star 6.7056\left(22^{\prime}\right)=72.217$

* one-sided area of short sidewall $=2 \times 3.9624\left(13^{\prime}\right) * 6.7056\left(22^{\prime}\right)=53.141$

* one-sided area of cover block $=5.3848\left(17^{\prime} 8^{\prime \prime}\right) \star 3.9624\left(13^{\prime}\right)=21.337$

SINKS

process cell process cell cell

long sidewall short sidewall cover block

$102 \quad 103$

$\begin{array}{lccc}\text { LABEL } & \text { PC-LSW } & \text { PC-SSW } & \text { PC-COV } \\ \text { IORIHS } & 0 & 0 & 1 \\ \text { IGEOM } & 1 & 1 & 1 \\ \text { IMATHS } & 3 & 3 & 3 \\ \text { XRI } & 0.0 & 0.0 & 0.0 \\ \text { XRO } & 1.067 & 1.372 & 1.829 \\ \text { AHS } & 72.217 & 53.141 & 21.337 \\ \text { TIINIT } & 32.00 & 32.00 & 32.00 \\ \text { TOINIT } & 32.00 & 32.00 & 35.00 \\ \text { IMSLAB } & 20 & 20 & 20 \\ \text { IREGI } & 6 & 6 & 10 \\ \text { IREGO } & 0 & 0 & 6 \\ \text { XLHS } & 6.7056 & 6.7056 & 3.9624 \\ \text { XZHS } & 6.7056 & 6.7056 & 3.9624 \\ \text { ZTHS } & 5.7150 & 5.7150 & 7.5438 \\ \text { ZBHS } & -0.9906 & -0.9906 & 5.7150\end{array}$

END

$\star$

SINKS

long sidewall 106

short sidewall 107

cover block

108

LABEL

SAME_AS

AHS

CC-LSW

101

$2.239 \mathrm{E3}$

CC-SSW

102

$1.647 \mathrm{E} 3$

32.00

32.00

7
0

$\mathrm{CC}-\mathrm{COV}$

103

$6.614 \mathrm{E} 2$

32.00

32.00

10

IREGI

IREGO

0

END

CELL 2R

* one-sided area of long sidewall $=1 \times 8.3820\left(27^{\prime} 6^{\prime \prime}\right) * 6.7056\left(22^{\prime}\right)=56.206$

* one-sided area of short sidewall $=2 \times 3.9624\left(13^{\prime}\right) * 6.7056\left(22^{\prime}\right)=53.141$

* one-sided area of cover block $=8.3820\left(27^{\prime} 6^{\prime \prime}\right) * 3.9624\left(13^{\prime}\right)=33.213$ 
FAl/10-83

PRC-STP-00241, Rev 0

Rev. 0

*

SINKS

$$
\text { LABEL }
$$

SAME_AS

AHS

TIINIT

TOINIT

IREGI

IREGO

END

*

*

*

*

SINKS

*

SAME_AS

IREGI

IREGO

- END

*

*

*

SINKS

* LABEL

SAME_AS

AHS

IREGI

IREGO

END

$\star$

*

*2 2 x $10.5 \times$

SINKS

IORIHS

IGEOM

IMATHS

XRI

XRO

AHS

TIINIT

TOINIT

IMSLAB

IREGI

IREGO

XLHS

XZHS

ZTHS

ZBHS

END

*

*

* lower canyon walls: $5 \mathrm{ft}$ thick, $7.85 \mathrm{~m}$ high, $260.5 \mathrm{~m}$ long, x2

* upper canyon walls: $3 \mathrm{ft}$ thick, $4.27 \mathrm{~m}$ high, x2

*

SINKS

IORIHS

IGEOM

IMATHS

XRI

long sidewall
block
111
2 R-LSW
101
56.206
35.00
35.00
11
0

CELL 2 I

116

2L-ISW

111

12
0

4 HOT CELLS

long sidewall

126

CC-LSW

101

288.9

14

VENT DUCT

$(18 \times 40) F T * * 2$

121

0

3

0.0

1. 52

1405.4

32.0

32.0

0

3.20

3.20

2.21

$-0.9906$ long sidewall long sidewall

114

$2 \mathrm{R}-2 \mathrm{~L}$

101

56.206

35.00

35.00

11

12

short sidewall

127

CC-SSW

212.6

14 short sidewall

112

$2 \mathrm{R}-\mathrm{SSW}$

102

53.141

32.00

32.00

11

short sidewall

117

$2 \mathrm{~L}-\mathrm{SSW}$

112

12
0

128

CC-COV

103

85.35

10

14 cover block
Page 144 of 284

March, 2010 
FAl/10-83

PRC-STP-00241, Rev 0

Rev. 0

$\begin{array}{lcc}\text { XRO } & 1.52 & 0.915 \\ \text { AHS } & 4090.0 & 2224.7 \\ \text { TIINIT } & 32.00 & 32.00 \\ \text { TOINIT } & 32.00 & 35.00 \\ \text { IMSLAB } & 20 & 20 \\ \text { IREGI } & 10 & 10 \\ \text { IREGO } & 0 & 0 \\ \text { XLHS } & 12.0 & 12.0 \\ \text { XZHS } & 12.0 & 12.0 \\ \text { ZTHS } & 15.394 & 19.664 \\ \text { ZBHS } & 7.5438 & 15.394\end{array}$

Page 145 of 284

March, 2010

END

*

* pipe trench wall is $2 \times 6 \times(35 \times 20)$ FT**2

COVER IS $8 \times(35 \times 20) \quad F T \star \star 2$

SINKS

122

cover

IORIHS

IGEOM

IMATHS

XRI

XRO

AHS

TIINIT

TOINIT

IMSLAB

IREGI

IREGO

XLHS

XZHS

ZTHS

ZBHS

END

0

0

$\begin{array}{ll}1 & 1 \\ 3 & 3\end{array}$

$0.0 \quad 0.0$

$1.52 \quad 1.37$

$781.0 \quad 520.5$

$32.00 \quad 32.00$

$32.00 \quad 32.00$

2020

910

9

$\begin{array}{ll}1.83 & 1.83 \\ 1.83 & 1.83\end{array}$

$6.1710 \quad 7.5438$

$4.3426 \quad 6.1710$

$\star$

$\star$ length $=2.1336+2 * 3.9624=10.0584$

*

$\begin{array}{lll}\text { SINKS } & 124 & 125\end{array}$

* IORIHS

IGEOM

IMATHS

XRI

XRO

AHS

TIINIT

TOINIT

IMSIAB

IREGI

IREGO

XLHS

$X 2 \mathrm{HS}$

24 INCH PIPE

! ZTHS

END

0

0

0

$0.6096 \quad 0.3048$

$\begin{array}{ll}5.0 & 0.6096\end{array}$

$\begin{array}{ll}177.3 & 2.8727\end{array}$

$32.00 \quad 32.00$

$32.00 \quad 32.00$

$30 \quad 20$

013

$0 \quad 0$

$12.0 \quad 0.6096$

$10.1 \quad 10.1$

? ?

?

*

*

* SET ZTHS TO REgion I TOP ELEVATION, $2.43327 \mathrm{M}$

SINKS $\quad 68$

IREGO $\quad 11$

END

* inner cylinder and stsc wall adjacent to water and gas 
FAl/10-83

PRC-STP-00241, Rev 0

Rev. 0

Page 146 of 284

*

* SINKS

Layer 21

61

LABEL WALLO-2I

IREGO 11

END

* LAYER - 13

Volume

Cumulative volume

* LAYER-12 $0.09337 \quad 0.50000$

Layer 20

IREGO 11

END

$\begin{array}{lc} & \text { Layer } 19 \\ \text { SINKS } & 55\end{array}$

*

SINKS Layer 18

END

SINKS

IREGO

END

SINKS

IREGO

*

END

SINKS

IREGO

END

*

Layer 14

INKS
IREGO

END

Layer 17

Layer 16

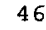

Layer 13

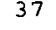

IREGO 11

END

* Layer 12

$\begin{array}{ll}\text { SINKS } & 34 \\ \text { IREGO } & 11\end{array}$

END

* Layer 11

31

END

*

ELLIPTICAL SECTION

* lower head exterior sees atmosphere in the skirt enclosure

SINKS 28

END

Layer

25

END

Layer 8

SINKS 22

REGO

*

* wall for Layer 7 and below is considered horizontal; 
FAl/10-83

PRC-STP-00241, Rev 0

Rev. 0

* heat transfer due to laminar boundary layer underside

* of a hot plate is modeled in FATE

*

* Layer ?

$\begin{array}{ll}\text { SINKS } & 19\end{array}$

END

*

SINKS

IREGO 11

END

SINKS Layer 5

IREGO 11

END

Layer 4

$\begin{array}{ll} & 10 \\ \text { IREGO } & 11\end{array}$

END

SINKS Layer 3

IREGO 11

END

* below the inner eliptical head

* Layer 2

SINKS 4

END

*

* skirt and dRIP pan

* MODEL DRIP-PAN AS VERTiCAL hS TO ALLOW CONVECTIVE HT TO CELL
SINKS
96
95
LABEL
SKIRT
DRIP-PAN

END

END HEAT SINKS

JUNCTIONS

$\star$

* Move STSC from region 6 to region 11

* 2" INLET VENT

* 4" OUTLet VENT With 2 fOOT $(0.6096$ M) ChIMnEy

! LABEL $\quad$ VENT-IN $\quad$ VENT-OUT

IRI 11 I

END PATHS

* holes in the skirt

* Redirect from typical cell (6) to cell 2R (1l)

$\begin{array}{cccc}\text { PATHS } & 4 & 5 & 6 \\ \text { LABEL } & \text { HOLE-BOT } & \text { HOLE-MID } & \text { HOLE-TOP } \\ \text { IRI } & 11 & 11 & 3\end{array}$

$\begin{array}{rrrr}\text { IR2 } & 3 & 3 & 11\end{array}$

END PATHS

*

*

* Canyon to cells \& pipe trench through cover block gaps

* Path 11: Process cell to canyon via gap

* [References needed for CJN, KFILTER] 
FAl/10-83

PRC-STP-00241, Rev 0

Rev. 0

* IRI $=6=\mathrm{T}$-Cell

March, 2010

$\star$ ZlJN $=$ Cell height $=$ ZTOP $=6.7056 \mathrm{~m}$

* IR2 = 10 = Canyon

* Z2JN $=$ Canyon floor $=0.0 \mathrm{~m}$

PATHS 1

LABEL TCELL-GAP

IJTYP 8

ICCJN $\quad 0$

IRI 6

IR2 10

AJN 1.0

Z1JN $\quad 6.7056$

Z2JN $\quad 0.0$

CJN 1.E-5

KFILTER 382.15

FGASIJN $\quad 1.0$

XLJN 1.0

XWJN $\quad 1.0$

XHJN $\quad 1.0$

END PATHS

* Path 12: Canyon to cold cells via cover block gaps

* [References needed for CJN]

* IR $1=10$ = Canyon

$*$ ZlJN $=$ Canyon floor $=0.0 \mathrm{~m}$

$\star$ IR2 $=7$ = Cold cells

* $\mathrm{Z2JN}=$ Cell height $=$ ZTOP $=6.7056 \mathrm{~m}$

* KFILTER $=1 /($ sum $[i=1.35]$ ( $1 /$ KFILTER tcell $)$

* $\quad=$ KFILTER_tcell / 35

* $\quad=382.15 / 35=10.92$

* Path 15: Canyon to pipe trench via cover block gaps

* [References needed for CJN, KFILTER]

* $\operatorname{IR} 1=10$ = Canyon

* ZlJN $=$ Canyon floor $=0.0 \mathrm{~m}$

$\star$ IR2 = 9 = Pipe trench

$\star$ Z2JN $=$ Trench height $=$ ZTOP $=1.83 \mathrm{~m}$

* KFILTER $=($ Kwidth * Klength $) /(2 *$ (Kwidth + Klength $))$

$\star \quad=(389.7 * 1781.1) /(2 *(389.7+1781.1))$

$\star \quad=159.87$

* Path 17: Cell 2R to canyon via cover block gaps

* [References needed for CJN, KFILTER]

* IRI $=11=$ Cell $2 R$

$*$ ZlJN $=$ Cell 2R height $=$ ZTOP $=6.7056 \mathrm{~m}$

* $\mathrm{IR} 2=10$ = Canyon

* Z2JN $=$ Canyon floor $=0.0 \mathrm{~m}$

* Path 22: Hot cells to canyon via cover block gaps

* [References needed for CJN]

* IRI $=14=$ Hot cells

$*$ ZIJN $=$ Cell height $=$ ZTOP $=6.7056 \mathrm{~m}$

* IR2 = 10 = Canyon

* Z2JN = Canyon floor $=0.0 \mathrm{~m}$

* KFILter $=1 /(\operatorname{sum}[i=1.5](1 /$ KFILTER_tcell $))$

* $\quad=$ KFILTER tcell / 5

$=382.15 / 5=76.43$

$\begin{array}{lllll}\text { PATHS } & 12 & 15 & 17 & 22 \\ \text { SAME_AS } & 11 & 11 & 11 & 11 \\ \text { LABEL } & \text { GAP-COLD } & \text { GAP-PIPE } & \text { C2R-GAP } & \text { HOT-GAP } \\ \text { IJTYP } & 8 & 8 & 8 & 8 \\ \text { IRI } & 10 & 10 & 11 & 14 \\ \text { IR2 } & 7 & 9 & 10 & 10 \\ \text { IHORIZ } & 1 & 1 & 1 & 1 \\ \text { AJN } & 1.0 & 1.0 & 1.0 & 1.0 \\ \text { Z1JN } & 0.0 & 0.0 & 6.7056 & 6.7056 \\ \text { Z2JN } & 6.7056 & 1.83 & 0.0 & 0.0 \\ \text { CJN } & 1 . E-5 & 1 . E-5 & 1 . E-5 & 1 . E-5\end{array}$


FAl/10-83

Rev. 0

KFILTER
FGASIJN
XLJN
XWJN

10.9
1.0
1.0
1.0
1.0

END PATHS

\section{PRC-STP-00241, Rev 0}

* Path 18: Canyon to Cell 2L

* [References needed for CJN]

* IRI = $10=$ Canyon

* ZlJN = Canyon floor $=0.0 \mathrm{~m}$

* $\operatorname{IR} 2=12=\operatorname{cell} 2 \mathrm{~L}$

$* \mathrm{Z} 2 \mathrm{JN}=$ Full cell $2 \mathrm{~L}$ height $=30110 "=9.397 \mathrm{~m}$

$\star \mathrm{AJN}=$ SED AREA $=33.21 \mathrm{~m} * \star 2$

$\star \mathrm{XLJN}=\mathrm{L}=27.5^{\prime}=8.3820 \mathrm{~m}$

$\star \mathrm{XWJN}=\mathrm{W}=131=3.9624 \mathrm{~m}$

$\star$ XHJN $=0.001 \mathrm{~m}=$ thin

$\begin{array}{ll}\text { PATHS } & 18 \\ \text { LABEL } & \text { CA }\end{array}$

IR $1 \quad 10$

IR2 12

IHORIZ 1

AJN $\quad 33.21$

ZIJN $\quad 0.0$

Z2JN $\quad 9.397$

CJN 2.8

FGAS1JN 1.0

XIJN $\quad 8.3820$

XWJN $\quad 3.9624$

XHJN 0.001

END PATHS

* Cells to ventilation duct

* Path 13: Cold cells to ventilation duct via 10"-dia pipe.

* [Reference needed for CJN]

* IRI $=7=$ Cold cells

* ZIJN $=9^{\prime}=2.7432 \mathrm{~m}$

* IR2 = $8=$ Ventilation duct

$\star \mathrm{Z} 2 \mathrm{JN}=$ top of duct $=\mathrm{ZTOP}=10.5^{\prime}=3.2004 \mathrm{~m}$

$\star \mathrm{CJN}=(1 / 0.6) \star \star 2=2.8$

* Consider 35 pipes for 35 cold cells:

$\star \mathrm{AJN}=35 \star \mathrm{pi} / 4 \star(\mathrm{D} \star 2)$

$\star \quad \quad=19.1 \mathrm{ft} * * 2$

$\star \quad \quad=1.7735 \mathrm{~m} * \star 2$

$\star X L J N=10^{\prime}=2.5 \mathrm{~m}$

$\star X W J N=10^{\prime \prime}=0.254 \mathrm{~m}$

$\star \mathrm{XHJN}=10^{\prime \prime}=0.254 \mathrm{~m}$

* Path 14: Ventilation duct to process cell via 10"-dia pipe.

* [References needed for CJN]

* IRI $=8$ = Ventilation duct

$* \mathrm{zIJN}=$ top of duct $=\mathrm{zTOP}=10.5^{\prime}=3.2004 \mathrm{~m}$

* IR2 = $6=\mathrm{T}$ cell

$\star \mathrm{Z} 2 \mathrm{JN}=9^{\prime}=2.7432 \mathrm{~m}$

$* \mathrm{CJN}=(1 / 0.6) * * 2=2.8$

* $\mathrm{AJN}=\mathrm{pi} / 4 *(\mathrm{D} * \star 2)$

$\star \quad=0.5454$ ft $t * 2$

* $\quad=0.05067 \mathrm{~m} * * 2$

$\star X I J N=10^{\circ}=2.5 \mathrm{~m}$

* XWJN $=10^{\prime \prime}=0.254 \mathrm{~m}$

$\star \mathrm{XHJN}=10 "=0.254 \mathrm{~m}$

* Path 21: Ventilation duct to hot cells via 10"-dia pipe.

* [References needed for CJN]

* IRI $=8=$ Ventilation duct

$\star \mathrm{ZIJN}=$ top of duct $=\mathrm{ZTOP}=10.5^{\prime}=3.2004 \mathrm{~m}$

* IR2 = I4 = Hot cells

* Z2JN $=9^{\prime}=2.7432 \mathrm{~m}$ 
Rev. 0

* $\operatorname{CJN}=(1 / 0.6) * \star 2=2.8$

March, 2010

* Consider 5 pipes for 5 hot cells:

* $\mathrm{AJN}=5 * \mathrm{pi} / 4 *(\mathrm{D} * * 2)$

* $\quad=2.7271 \mathrm{ft} * * 2$

* $\quad=0.25335 \mathrm{~m} * \star 2$

$\star X I J N=10^{\circ}=2.5 \mathrm{~m}$

$\star X W J N=10^{\prime \prime}=0.254 \mathrm{~m}$

$\star \mathrm{XHJN}=10^{\prime \prime}=0.254 \mathrm{~m}$

$\begin{array}{llll}\text { PATHS } & 13 & 14 & 21\end{array}$

LABEL COLD-VENT VENT-TCELL VENT-HOT

IJTYP

ICCJN

IRI

IR 2

IHORIZ

AJN

11

1

0

1. 7735

8

0

$0.05067 \quad 0.25335$

Z2JN $\quad 3.2004$

3. 2004

3.2004

CJN 2.8

7432

2.7432

KFILTER 0.0

FGASIJN 1.0

XLUN 2.5

2.8

2.8

1.0

0.0

1.0

XWJN $\quad 0.254$

2.5

2.5

XHJN $\quad 0.254$

0.254

0.254

END PATHS

0.254

0.254

*? Single cell pair $\mathrm{K}=160$; divide by 17.5

* Pipe trench to ventilation duct

* Path 16: Pipe trench to ventilation duct via 18 10"-dia pipes.

* [Reference needed for CJN]

* $\operatorname{IRl}=9=$ Pipe trench

* ZlJN = Pipe trench floor $=0 \mathrm{~m}$

* IR2 $=8=$ ventilation duct

$\star \mathrm{Z} 2 \mathrm{JN}=$ top of duct $=\mathrm{ZTOP}=10.5^{\prime}=3.2004 \mathrm{~m}$

*CJN $=(1 / 0.6) * * 2=2.8$

* Consider 18 pipes for 18 cold cells:

* $\mathrm{AJN}=18 \star \mathrm{pi} / 4 \star(\mathrm{D} * \star 2)$

$\star \quad \quad=9.8229 \mathrm{ft} \star \star 2$

* $\quad=0.9121 \mathrm{~m} * \star 2$

$\star \mathrm{XLJN}=10^{\prime}=2.5 \mathrm{~m}$

$\star X W J N=10^{\prime \prime}=0.254 \mathrm{~m}$

* $\mathrm{XHJN}=10^{\prime \prime}=0.254 \mathrm{~m}$

PATHS 16

LABEL PTRENCH-VENT

IJTYP 1

ICCJN 0

IRI 9

IR2 8

IHORIZ 1

AJN $\quad 0.9121$

ZIJN 0.0

$\mathrm{Z2JN} \quad 3.2004$

CJN 2.8

FGASIJN 1.0

XLJN 2.5

XWJN 0.254

XHJN $\quad 0.254$

END PATHS

* Long cells to $24 "$ pipe

* Path 19: Cell 2L to 24" vent pipe via 10"-dia pipes.

* [Reference needed for CJN]

* IR1 = $12=\operatorname{cell} 2 \mathrm{~L}$

* ZlJN = 6'9" below canyon deck (note: 5.8" is at cover block level)

* $\quad$ ZTOP $12-6 \cdot 9 "$

* $\quad=7.56 \overline{9} 2 \mathrm{~m}-2.0574 \mathrm{~m}$ 
FAl/10-83

PRC-STP-00241, Rev 0

Rev. 0

* $\quad=5.5118 \mathrm{~m}$

* IR2 $=13=24 "$ pipe

* $\mathrm{Z} 2 \mathrm{JN}=0 \mathrm{~m}$

$\star \operatorname{CJN}=(1 / 0.6) * * 2=2.8$

$\star \mathrm{AJN}=\mathrm{pi} / 4 \star(\mathrm{D} * \star 2)$

$\star \quad \quad=0.5454 \mathrm{ft} * \star 2$

$\star \quad \quad=0.05067 \mathrm{~m} * \star 2$

$\star X L J N=10^{\circ}=2.5 \mathrm{~m}$

$\star X W J N=10^{\prime \prime}=0.254 \mathrm{~m}$

$\star \mathrm{XHJN}=10^{\prime \prime}=0.254 \mathrm{~m}$

*

* Path 20: Cell 2R to 24" vent pipe via 10"-dia pipes.

* [Reference needed for CJN]

* $\operatorname{IR} 1=13=24 "$ pipe

* Z1JN $=0 \mathrm{~m}$

* IR2 = II = Cell $2 \mathrm{R}$

* $\mathrm{Z2JN}=6.9 "$ below canyon deck

* $\quad$ ZTOP_12 - 619"

* $\quad=7.56 \overline{9} 2 \mathrm{~m}-2.0574 \mathrm{~m}$

* $\quad=5.5118 \mathrm{~m}$

$\star \mathrm{CJN}=(1 / 0.6) * \star 2=2.8$

* $\mathrm{AJN}=\mathrm{pi} / 4 *(\mathrm{D} * * 2)$

$\star \quad \quad=0.5454 \mathrm{Et} * \star 2$

* $\quad=0.05067 \mathrm{~m} * \star 2$

$\star X L J N=101=2.5 \mathrm{~m}$

$\star X W J N=10^{\prime \prime}=0.254 \mathrm{~m}$

$\star \mathrm{XHJN}=10^{\prime \prime}=0.254 \mathrm{~m}$

$\begin{array}{clc}\text { PATHS } & 19 & 20 \\ \text { LABEL } & \text { C2L-PIPE } & \text { PIPE-C2R }\end{array}$

$\begin{array}{lll}\text { IJTYP } & 1 & 1 \\ \text { ICCJN } & 0 & 0\end{array}$

IRI $\quad 12 \quad 13$

IR2 $13 \quad 11$

$\begin{array}{lll}\text { IHORIZ } & 0 & 0 \\ \text { AJN } & 0.05067 & 0.05067\end{array}$

$\begin{array}{lll}\text { AJN } & 0.05067 & 0.050 \\ \text { Z1JN } & 5.5118 & 0.0\end{array}$

$\begin{array}{lll}\mathrm{Z} 2 \mathrm{JN} & 0.0 & 5.5118\end{array}$

$\begin{array}{lll}\text { CJN } & 2.8 & 2.8\end{array}$

FGASIJN $1.0 \quad 1.0$

$\begin{array}{lll}X L J N & 2.5 & 2.5\end{array}$

$\begin{array}{lll}\text { XWJN } & 0.254 & 0.254\end{array}$

$\begin{array}{lll}\text { XHJN } & 0.254 & 0.254\end{array}$

END PATHS

*

* 24" Pipe and vent duct to exhaust duct

* Path 25: Ventilation duct to exhaust duct

* [Reference needed for CJN]

* IRI = $8=$ ventilation duct

* ZlJN $=$ Vent duct floor $=0.0 \mathrm{~m}$

* IR2 = $16=$ Exhaust duct

* $\mathrm{Z} 2 \mathrm{JN}=$ Exhaust duct floor $=0.0 \mathrm{~m}$

$\star \mathrm{AJN}=5^{\prime} * 4^{\prime}=20.0 \mathrm{ft} * 2_{2}=1.8581 \mathrm{~m} \star 22$

$\star$ XLUN $=$ thin $=0.001 \mathrm{~m}$

$\star$ XWJN $=4^{\prime}=1.2192 \mathrm{~m}$ (est.)

$\star X H J N=5^{\prime}=1.5240 \mathrm{~m}$

* Path 27: 24 " vent pipe to exhaust duct

* [Reference needed for CJN]

* IRI $=13=24$ " pipe

* ZIJN $=0 \mathrm{~m}$

* IR2 = $16=$ Exhaust duct

* $\mathrm{Z} 2 \mathrm{JN}=$ Vent duct floor +4 '

$\star \quad=4$ '

$\star \quad \quad=1.2192 \mathrm{~m}$

$\star \mathrm{CJN}=(1 / 0.6) \star \star 2=2.8$

$\star A J N=p i / 4 *(D * \star 2)$

* $\quad=3.1416 \mathrm{ft} * \star 2$

* $\quad=0.2919 \mathrm{~m} * * 2$

$\star$ XLJN $=10^{\circ}=3.048 \mathrm{~m}$ (est.) 
FAl/10-83

PRC-STP-00241, Rev 0

\section{Rev. 0}

$\star$ XWJN $=24 "=0.6096 \mathrm{~m}$

$\star$ XHJN $=24 " / \sin (45)=0.8621 \mathrm{~m}$

*

$\begin{array}{lcc}\text { PATHS } & 25 & 27 \\ \text { LABEL } & \text { VENT-EXH } & \text { PIPE-EXH } \\ \text { IJTYP } & 1 & 1 \\ \text { ICCJN } & 0 & 0 \\ \text { IR1 } & 8 & 13 \\ \text { IR2 } & 16 & 16 \\ \text { IHORIZ } & 0 & 0 \\ \text { AJN } & 1.8581 & 0.2919 \\ \text { Z1JN } & 0.0 & 0.0 \\ \text { Z2JN } & 0.0 & 1.2192 \\ \text { CJN } & 1 . E-5 & 2.8 \\ \text { KFILTER } & 0.0 & 0.0 \\ \text { FGAS1JN } & 1.0 & 1.0 \\ \text { XLJN } & 0.001 & 3.048 \\ \text { XWJN } & 1.2192 & 0.6096 \\ \text { XHJN } & 1.5240 & 0.8621\end{array}$

$\star$ END PATHS

* Fan from exhaust duct to ambient

* fan flow rate $=17500 \mathrm{cfm}=8.2591 \mathrm{~m}^{\wedge} 3 / \mathrm{s}$

* fan flow rate $=0 \mathrm{~m}^{\wedge} 3 / \mathrm{s}$

* Path 26: Exhaust duct to ambient

* CJN not used, constant volumetric flow rate

* Set AJN to an arbitrary positive value

* so code does not bypass the junction

* IRI $=16=$ Exhaust duct

* ZIJN $=0 \mathrm{~m}$

* $\mathrm{IR2}=15=$ Ambient (atmosphere)

* $\mathrm{Z} 2 \mathrm{JN}=15 \mathrm{~m}$ (est.; stack height = 200'?)

PATHS 26

LABEL FAN

IJTYP 1

ICCJN 1

IR $1 \quad 16$

IR2 15

IHORIZ 0

AJN $\quad 1.0$

ZIJN $\quad 0.0$

Z2JN $\quad 15.0$

CJN 1.0

KFILTER 0.0

FGAS1JN 1.0

IFAN 1

WVFAN 8.2591

END PATHS

* Cel1 2L and canyon to ambient

* Path 28: Ambient to Canyon

* Leakage modeled using KFILTER

* $17500 \mathrm{cfm}\left(82.6 \mathrm{~m}^{\wedge} 3 / \mathrm{s}\right)$ at $0.15 \mathrm{in} \mathrm{w.g.} \mathrm{(35.9} \mathrm{Pa)}$

* Assume equal split between canyon leakage and

* access tunnel leakage.

* Hence, KFILTER $=35.9 /(82.6 / 2)=0.870$

* IRI = $15=$ Ambient (atmosphere)

* Z1JN $=$ ELEVATION_10 + ZTOP_10/2 - ELEVATION_15

* $\quad=7.5438 \mathrm{~m}+14.9352 \mathrm{~m}^{-} / 2-7.5438 \mathrm{~m}$

* $\quad=7.4676 \mathrm{~m}$

* IR2 = $10=$ Canyon

* Z2JN $=$ ZTOP $10 / 2$

* $\quad=7.46 \overline{7} 6 \mathrm{~m}$

* Path 29: Ambient to Cell 2L

* Leakage modeled using KFILTER

* $17500 \mathrm{cmf}\left(82.6 \mathrm{~m}^{\wedge} 3 / \mathrm{s}\right)$ at 0.15 in w.g. (35.9 Pa) 
* Assume equal split between canyon leakage and

* access tunnel leakage.

* Hence, KFILTER $=35.9 /(82.6 / 2)=0.870$

* IRI = 15 = Ambient (atmosphere)

* $\mathrm{ZIJN}=$ ELEVATION_12+ZTOP_12/2 - ELEVATION_15

$\star \quad=-1.8542 \mathrm{~m}^{-}+7.5692 \overline{\mathrm{m}} / 2-7.5438 \mathrm{~m}$

* $\quad=-5.6134 \mathrm{~m}$

* IR2 = $12=\operatorname{cell} 2 \mathrm{~L}$

* $\mathrm{Z} 2 \mathrm{JN}=\mathrm{ZTOP} 12 / 2$

* $\quad=7.56 \overline{9} 2 \mathrm{~m} / 2$

* $\quad=3.7846 \mathrm{~m}$

PATHS

LABEL AMB-CANYON AMB-C2L

$\begin{array}{lll}\text { IJTYP } & 8 & 8\end{array}$

ICCJN 00

IRI $15 \quad 15$

IR2 $10 \quad 12$

IHORIZ 11

$\begin{array}{lll}A J N & 1.0 & 1.0\end{array}$

$\begin{array}{lll}Z I J N & 7.4676 & -5.6134\end{array}$

$\begin{array}{lll}Z 2 J N & 7.4676 & 3.7846\end{array}$

$\begin{array}{lll}\text { CJN } & 2.8 & 2.8\end{array}$

KFILTER $\quad 0.870 \quad 0.870$

FGASIJN 1.0

$\begin{array}{lll}X L J N & 1.0 & 1.0\end{array}$

XWJN $1.0 \quad 1.0$

XHJN $1.0 \quad 1.0$

END PATHS

END JUNCTIONS 
FAl/10-83

PRC-STP-00241, Rev 0

Rev. 0

\section{B.5 Case File: CONTRN1.dat}

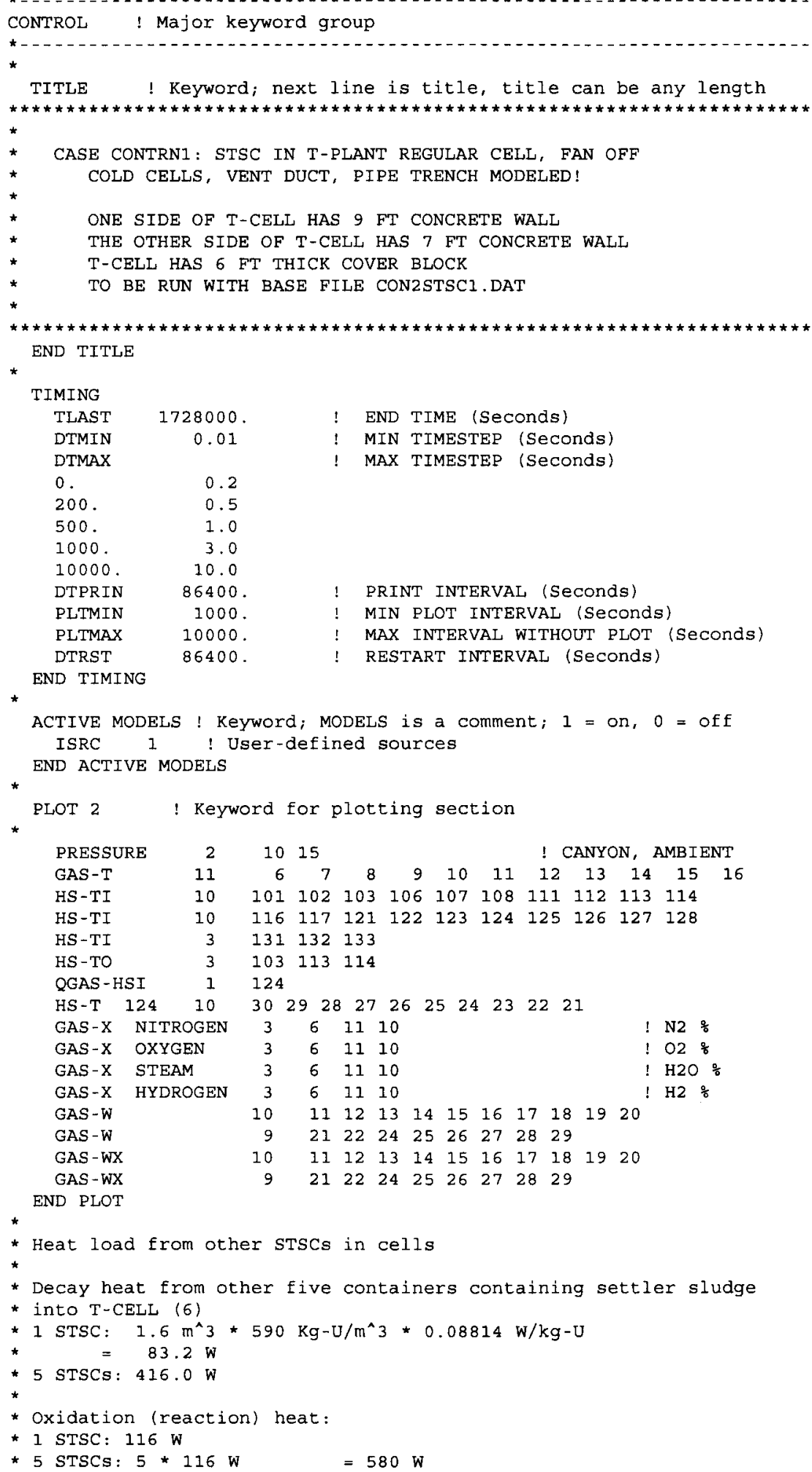


* Total heat load for 5 STSCs: $996 \mathrm{~W}$

* H2 Generation Rate:

* $1 \mathrm{STSC}=8381 /$ day

* $\quad=838 \mathrm{l} / \mathrm{day} * 1 / 86400 \mathrm{day} / \mathrm{s} * 0.07598 \mathrm{~kg} / \mathrm{m} \star 3 * 3 / 1000 \mathrm{~m} \star 3 / 1$

$\star \quad=7.37 \mathrm{E}-7 \mathrm{~kg} / \mathrm{s}$

* 5 STSCs: $3.69 \mathrm{E}-6 \mathrm{~kg} / \mathrm{s}$

SOURCES 2

REGION 6 GASES 1 PHASE 1 HYDROGEN

\begin{tabular}{llll}
0 & 50.0 & $3.69 \mathrm{E}-6$ & 996.0 \\
\hline
\end{tabular}

END REGION

*

* Decay heat from six containers of container sludge in each of four

* cells in the Hot Cell (14)

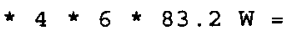

$1996.8 \mathrm{~W}$

* Oxidation (reaction) heat:

* 1 STSC : $116 \mathrm{~W}$

*24 STSCs : $4 * 6 * 116 \mathrm{~W}=2784.0 \mathrm{~W}$

* Total heat load for 5 STSCS: $4780.8 \mathrm{~W}$

* H2 Generation Rate:

* 1 STSC $=7.37 \mathrm{E}-7 \mathrm{~kg} / \mathrm{s}$

*24 STSCs $=1.77 \mathrm{E}-5 \mathrm{~kg} / \mathrm{s}$

REGION 14 GASES 1 PHASE 1 HYDROGEN

$\begin{array}{llll}0 & 50.0 & 1.77 \mathrm{E}-5 & 4780.8\end{array}$

$\begin{array}{llll}1 . \mathrm{E} 9 & 50.0 & 1.77 \mathrm{E}-5 & 4780.8\end{array}$

END REGION

END SOURCES

END CONTROL

VOLUMES

$\star-$

* Cells

* ELEVATion OF T-PLANT CELL $=-1 "-38 "=-0.9906 \mathrm{M}$

* ELEVATion OF TOP OF COVER BLOCKS $=-38 "+12 \times 28 "=298 "(7.5692 \mathrm{M})$

* ELEVATION OF BOTTOM OF COVER BLOCKS $=-38 "+12 \times 22 "=226 "(5.7404 \mathrm{M})$

* T-CELL DIMENSION, $13^{\prime}(3.9624 \mathrm{M})$ BY $17^{\prime} \mathrm{B}^{\prime \prime}(5.3848 \mathrm{M})$ BY $22^{\prime}(6.7056 \mathrm{M})$

* ASSUME $1 \mathrm{M}^{\wedge} 3$ FOR OTHER STRUCTURES

$\star \mathrm{T}$-CELL VOLUME $=3.9624 \times 5.3848 \times 6.7056-6 \times 2.5941 \mathrm{XPI}(1.4986)^{\wedge} 2 / 4-1.0$

$\star \quad=143.08-27.45-1.0=114.63 \mathrm{M}^{\wedge} 3$

$\star$ Elevation: $-3^{\prime} 3^{\prime \prime}=-3.25^{\prime}=-0.9906 \mathrm{~m}$

REGIONS

LABEL T-CELI

VOLUME $\quad 114.63$

SED_AREA $\quad 16.82$

ELEVATION $\quad-0.9906$

TEMP_GAS 35.0

PRESSURE $\quad 1.0 \mathrm{E} 5$

ZTOP $\quad 6.7056$

REGIONS

GASES 6

STEAM $\quad 0.01$

OXYGEN $\quad 0.20$

NITROGEN $\quad 0.79$

* Cola cell:

* The "cold cell" is a combination of 31 standard process cells

* with no STSCs or internals. 
*Volume: $31 * 143.08 \mathrm{~m} * 3=4435.48 \mathrm{~m} * * 3$

March, 2010

* Sed. Area: $31 \star 16.82 \mathrm{~m} * * 2=521.42 \mathrm{~m} * * 2$

* Elevation: -3.25 .

* Cell 2R:

* Volume:

$\mathrm{L}=27^{\prime} \mathrm{6}^{\prime \prime} \mathrm{W}=13^{\prime} \mathrm{H}=22^{\prime} \mathrm{V}=7865 \mathrm{ft} \star \star 3=222.71 \mathrm{~m} \star \star 3$

* Sed. Area: $L=27^{\prime} 6^{\prime \prime} W=13^{\prime} A=357.5 \mathrm{ft} \star \star 2=33.21 \mathrm{~m} \star 2$

* Elevation: -3.25 '

* Cell 2L:

* Cell 2L is slightly deeper than 2R due to train tracks, plus has no cover

* blocks. 'This adds another 6' of height to the cell

*Volume: $\quad \mathrm{L}=27 \cdot 6 " \mathrm{~W}=13^{\prime} \mathrm{H}=30^{\prime} 10^{\prime \prime} \mathrm{V}=11022.92 \mathrm{ft} \star \star 3=312.13 \mathrm{~m} \star * 3$

* Sed. Area: $L=27 \cdot 6 " W=13$ ' $A=357.5 \mathrm{ft} * 2=33.21 \mathrm{~m} * 2$

* Z-top: $\mathrm{H}=30 \cdot 10^{\prime \prime}=9.398 \mathrm{~m}$

* Elevation: $-3 \cdot 3 "+28^{\prime}-30^{\prime} 10 "=-6 \cdot 1 "=-1.8542 \mathrm{~m}$

* Hot Cell:

* The "hot cell" is a combination of 4 standard process cells.

* including STSCs and internals.

*Volume: $4 * 114.63 \mathrm{~m} * * 3=458.52 \mathrm{~m} * * 3$

* Sed. Area: $4 \star 16.82 \mathrm{~m} * \star 2=67.28 \mathrm{~m} * * 2$

* Elevation: $-3.25^{\prime}$

REGIONS

LABEL

VOLUME

$S E D$ AREA

ELEVATION

7
6
COLD-CELI

11
6

$\frac{1}{6}$

$4435.48 \quad 222.71$

222.71
33.21

$-0.9906$

$-0.9906$

32.0

32.0

PRESSURE

1. $0 \mathrm{E} 5$

1. $0 \mathrm{E} 5$

12
6

14

CELL-2L HOT-CELI

$251.39 \quad 458.52$

$33.21 \quad 67.28$

ZTOP

6.7056

6. 7056

$-1.8542$

$-0.9906$

$32.0 \quad 32.0$

$1.0 \mathrm{E} 5 \quad 1.0 \mathrm{E} 5$

END REGIONS

GASES

SAME_AS

$7 \quad 11$

7.5692

6.7056

END GASESE

* VENTS AND DUCTING

* Vent duct (runs along the face of 40 standard cells, each 18' wide):

*Volume: $\quad \mathrm{L}=36 * 18^{\prime} \mathrm{W}=10.5^{\prime} \mathrm{H}=10.5, \mathrm{~V}=71442 \mathrm{ft} * 3=2023.0 \mathrm{~m} * 3$

* Sed. Area: $L=36 * 18^{\prime}, W=10.5^{\prime} A=6804 \mathrm{ft} * \star 2=632.1 \mathrm{~m} * \star 2$

* Z-top: $\quad \mathrm{H}=10.5^{\prime}=3.2 \mathrm{~m}$

* Elevation: $-3.251=-0.9906 \mathrm{~m}$

REGIONS

SAME_AS

LABEL

VOLUME

SED_AREA

ELEVTATION

TEMP_GAS

PRESSURE

ZTOP

11
6

12
6

14
6

END REGIONS

GASES

SAME_AS

* Pipe Trench:

* Sed. Area : $L=\left(35 \times 20^{\prime}\right) \quad W=81 A=5600 \mathrm{ft} \star \star 2=520.26 \mathrm{~m} * \star 2$

* Volume: $\quad \mathrm{L}=\left(35 \times 20^{\prime}\right) \mathrm{W}=8^{\prime} \mathrm{H}=6^{\prime} \mathrm{V}=33600 \mathrm{ft} \star \star 3=951.45 \mathrm{~m} \star \star 3$

* Z-top: $\quad \mathrm{H}=6^{\prime}=1.83 \mathrm{~m}$

* Elevation: $10.5^{\prime}$ below canyon deck $\left(14.25^{\prime}=28^{\prime}-3.25^{\prime}-10.5^{\prime}=\right.$ )

* STSC bottom elevation: 0 .

* T-Cell floor elevation: -3.25

* Canyon deck elevation: $28^{\prime}-3.25^{\prime}=24.75^{\prime}$

* Pipe trench cover block depth: $4.5^{\prime}$ 
FAl/10-83

PRC-STP-00241, Rev 0

Rev. 0

Page 157 of 284

* Pipe trench floor elevation: $24.75^{\prime}-4.5^{\prime}-6^{\prime}=14.25^{\prime}=4.3434 \mathrm{~m}$

REGION

LABEL PTRENCH

VOLUME $\quad 951.45$

SED AREA $\quad 520.26$

ELEVATION $\quad 4.3434$

ZTOP 1.83

TEMP GAS

PRESSURE $\quad 1.0 \mathrm{E} 5$

GASES

9

SAME_AS 6

END GASES

* 24 " Pipe:

* Sed. Area: $D=2, \quad L=7 \cdot+2 * 13 \prime A=D * L=66 \mathrm{ft} * * 2=6.1316 \mathrm{~m} * * 2$

* Volume: $\mathrm{D}=22^{\prime} \mathrm{L}=7 \mathrm{\prime}^{\prime}+2 * 13^{\prime} \mathrm{V}=103.67 \mathrm{ft} * \star 3=2.9357 \mathrm{~m} * * 3$

* Z-top: $D=2 '=0.6095 \mathrm{~m}$

* Elevation: $-3.25^{\prime}+28^{\prime}-19^{\prime}=5.75^{\prime}=1.7526 \mathrm{~m}$

* Exhaust duct:

* Sed. Area; $L=145^{\prime}, \mathrm{W}=4, \mathrm{~A}=580 \mathrm{ft} * * 2=53.88 \mathrm{~m} * * 2$

*Volume: $\quad \mathrm{L}=145, \mathrm{~W}=4, \mathrm{H}=7, \mathrm{~V}=4060 \mathrm{ft} \star \star 2=115.0 \mathrm{~m} \star 2$

* Z-top: $\quad \mathrm{H}=7$

* Elevation: $-3.25^{\prime}=-0.9906 \mathrm{~m}$

REGIONS

SAME_AS

LABEL

VOLUME

SED AREA

ELEVATION

ZTOP

TEMP_GAS

PRESSURE

END REGIONS

gases

SAME_AS

$13 \quad 16$

PIPE-24 EXH-DUCT

$2.9357 \quad 115.0$

$6.1316 \quad 53.88$

$\begin{array}{ll}1.7526 & -0.9906\end{array}$

$0.6095 \quad 2.1336$

$32.0 \quad 32.0$

$1.0 \mathrm{E5} \quad 1.0 \mathrm{E5}$

END GAS $E S$

* atmospheres

* Canyon Length $=43^{\prime}+680^{\prime}+38.5^{\prime}=761.5 \mathrm{ft}=232.1 \mathrm{~m}$

* Lower $\mathrm{H}=25^{\prime} \mathrm{g}^{\prime \prime}=7.85 \mathrm{~m}, \mathrm{~W}=37^{\prime} \mathrm{2}^{\prime \prime}, \mathrm{AXI}=88.96 \mathrm{~m} \star 2$

$\star$ Upper $\mathrm{H}=14^{\prime} \mathrm{\prime}=4.27 \mathrm{~m}, \mathrm{~W}=60^{\prime} 2^{\prime \prime}, \mathrm{AX} 2=78.30 \mathrm{~m} \star \star 2$

* Crane $\mathrm{H}=913 \mathrm{~N}, \mathrm{~W}=10^{1}, \mathrm{AX} 3=8.60 \mathrm{~m} * 2$

* Canyon total height $=25^{\prime} 9^{\prime \prime}+14^{\prime}+9^{\prime} 3^{\prime \prime}=49^{\prime}=14.9352 \mathrm{~m}$

* Volume $=232.1 \times(88.96+78.30+8.60)=40,818 \mathrm{~m} * * 3$

* Sed area $232.1 \mathrm{~m} \mathrm{x} 60 \mathrm{ft}=4245 \mathrm{~m} * * 2$

REGIONS

LABEL

VOLUME

SED AREA

ELEVATION

TEMP GAS

PRESSTURE

ZTOP

ZTOP

13
8

END REGIONS

$\begin{array}{lcc}\text { GASES } & 10 & 15 \\ \text { STEAM } & 0.01 & 0.01 \\ \text { OXYGEN } & 0.20 & 0.20 \\ \text { NITROGEN } & 0.79 & 0.79\end{array}$

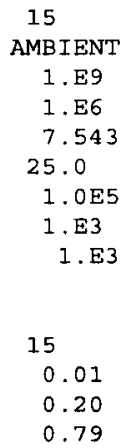

* control boundary pressure 
$\mathrm{FAl} / 10-83$

PRC-STP-00241, Rev 0

\section{Rev. 0}

*

* OFFSET_TIMEPG

* EXTRAPólation_timepg PERIOD !repeat the diurnal cycle

* TIMEF 15 0.0 21600. 43200. 64800. 86400.

* PRFIX 15 1.0E5 1.005E5 1.0E5 9.95E4 1.0E5

OFFSET TIMETG 28800

EXTRAPOLATION_TIMETG PERIOD

TIMETG $15 \quad 0 . \quad 7200.0 \quad 14400.0 \quad 21600.0 \quad 28800.0 \quad 36000.0 \quad 43200.0$ $50400.0 \quad 57600.064800 .072000 .079200 .0 \quad 86400.0$

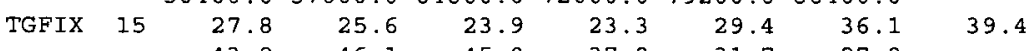

END VOLUME

$\begin{array}{llllll}43.9 & 46.1 & 45.0 & 37.8 & 31.7 & 27.8\end{array}$

March, 2010

HEAT_SINKS

* CELI CONCRETE HEAT SINKS

* ignore heat transfer to floor

* thickness of sidewall = 1.067 (3.5')

* thickness of front/back wall $=1.372\left(4.5^{\prime}\right)$

* thickness of cover block $=1.829$ (6')

* one-sided area of long sidewall $=2 \times 5.3848\left(17 \cdot 8^{\prime \prime}\right) \star 6.7056\left(22^{\prime}\right)=72.217$

* one-sided area of short sidewall $=2 \times 3.9624\left(13^{\prime}\right) * 6.7056\left(22^{\prime}\right)=53.141$

* one-sided area of cover block $=5.3848\left(17^{\prime} 8^{\prime \prime}\right) * 3.9624\left(13^{\prime}\right)=21.337$

SINKS

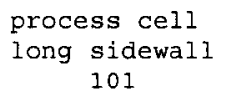

process cell cell

short sidewall cover block

102

103

\section{LABEL}

IORIHS

IGEOM

IMATHS

XRI

XRO

AHS

PC - LSW

0

1

(1)

0.0

1.067

72.217

TIINIT $\quad 35.00$

TOINIT $\quad 35.00$

IMSLAB 20

IREGI

IREGO

XLHS

XZHS

ZTHS

ZBHS

END

20
6

6

6.7056

6.7056

5.7150

PC-SSW

0

1

3

0.0
1.372

53.141

35.00

35.00

20

6

6.7056

6.7056

5.7150

$-0.9906$

$\mathrm{PC}-\mathrm{COV}$

$-0.9906$

31 COLD CELLS

*

SINKS

long sidewall

106

short sidewall

cover block

107

108

IABEL

SAME_AS

CC-LSW

101

$2.239 \mathrm{E} 3$

CC-SSW

102

$1.647 \mathrm{E} 3$

$\mathrm{CC}-\mathrm{COV}$

AHS

32.00

32.00

$6.614 \mathrm{E} 2$

TOINIT $\quad 32.00$

IREGI

7
0

32.00

7
0

32.00

32.00

10
7

END

*

*

* one-sided area of long sidewall $=1 \times 8.3820\left(27^{\prime} 6^{\prime \prime}\right) \star 6.7056\left(22^{\prime}\right)=56.206$

* one-sided area of short sidewall $=2 \times 3.9624\left(13^{\prime}\right) * 6.7056\left(22^{\prime}\right)=53.141$

* one-sided area of cover block $=8.3820\left(27^{\prime} 6^{\prime \prime}\right) * 3.9624\left(13^{\prime}\right)=33.213$ 
FAl/10-83

PRC-STP-00241, Rev 0

Rev. 0

*

^ SINKS

*

*

LABEL
SAME_AS

$$
\text { AHS }
$$

TIINIT

TOINIT

IREGI

END

long sidewall block

111

2R-LSW

101

56.206

32.00

32.00

11
0

CELL 2L

long sidewall

116

SINKS

*

LABEL

111

IREGO

END

$\star$

$\star$

*

SINKS

LABEL

SAME_AS

AHS

IREGI

IREGO

END

*

*

*2 $2 \times 10.5 \times(18 \times 40) \quad F T * * 2$

SINKS

.*

IORIHS

IGEOM

IMATHS

XRI

XRO

AHS

TI INIT

TOINIT

IMSLAB

IREGI

IREGO

XLHS

XZHS

ZTHS

END

ZBHS

*

* lower canyon walls: $5 \mathrm{ft}$ thick, $7.85 \mathrm{~m}$ high, $260.5 \mathrm{~m}$ long, x2

* upper canyon walls: $3 \mathrm{ft}$ thick, $4.27 \mathrm{~m}$ high, $\times 2$

SINKS

131

0
1
3
0.0

long sidewall

114

$2 \mathrm{R}-2 \mathrm{~L}$

101

56.206

32.00

12

short sidewall

127

CC-SSW

102

212.6

0 short sidewall cover

112

2R-SSW

102

53.141

32.00

32.00

11

short sidewall

117

2L-SSW

112

12
0

cover block

128

$\mathrm{CC}-\mathrm{COV}$

103

85.35

10
Page 159 of 284

March, 2010

IORIHS
IGEOM
IMATHS
XRI

XRI

0.0 
FAl/10-83

PRC-STP-00241, Rev 0

Rev. 0

$\begin{array}{lcc}\text { XRO } & 1.52 & 0.915 \\ \text { AHS } & 4090.0 & 2224.7 \\ \text { TIINIT } & 32.00 & 32.00 \\ \text { TOINIT } & 32.00 & 35.00 \\ \text { IMSLAB } & 20 & 20 \\ \text { IREGI } & 10 & 10 \\ \text { IREGO } & 0 & 0 \\ \text { XLHS } & 12.0 & 12.0 \\ \text { XZHS } & 12.0 & 12.0 \\ \text { ZTHS } & 15.394 & 19.664 \\ \text { ZBHS } & 7.5438 & 15.394 \\ \text { END } & & \end{array}$

PIPE TRENCH

* PIPE tRench Wall IS $2 \times 6 \times(35 \times 20) \quad F T \star \star 2$

* COVER IS $8 \times(35 \times 20) \quad F T \star \star 2$

SINKS

wall

cover

IORIHS

IGEOM

IMATHS

XRI

XRO

AHS

TIINIT

TOINIT

IMSLAB

IREGI

IREGO

XLHS

XZHS

ZTHS

ZBHS

*

END

* 24 INCH PIPE

$\star$ length $=2.1336+2 * 3.9624=10.0584$

SINKS $\quad 124$

$\star$

$\begin{array}{lll}\text { IORIHS } & 0 & 0 \\ \text { IGEOM } & 0 & 0 \\ \text { IMATHS } & 3 & 3 \\ \text { XRI } & 0.6096 & 0.3048 \\ \text { XRO } & 5.0 & 0.6096 \\ \text { AHS } & 177.3 & 2.8727 \\ \text { TIINIT } & 32.00 & 32.00 \\ \text { TOINIT } & 32.00 & 32.00 \\ \text { IMSLAB } & 30 & 20 \\ \text { IREGI } & 0 & 13 \\ \text { IREGO } & 0 & 0 \\ \text { XLHS } & 12.0 & 0.6096 \\ \text { XZHS } & 10.1 & 10.1 \\ \text { ZTHS } & ? & ? \\ \text { ZBHS } & ? & ?\end{array}$

END

END HEAT SINKS

औU.

JUNCTIONS

$\star$

* Canyon to cells \& pipe trench through cover block gaps

* Path 1l: Process cell to canyon via gap

* [References needed for CJN, KFILTER]

* $\operatorname{IRI}=6=\mathrm{T}$-Cell 
FAl/10-83

\section{PRC-STP-00241, Rev 0}

Rev. 0

$\star$ ZIJN $=$ Cell height $=$ ZTOP $=6.7056 \mathrm{~m}$

* IR2 = $10=$ Canyon

* Z2JN $=$ Canyon floor $=0.0 \mathrm{~m}$

PATHS 11

LABEL TCELL-GAP

$\begin{array}{ll}\text { IJTYP } & 8 \\ \text { ICCJN } & 0\end{array}$

IRI 6

IR2 10

IHORIZ 1

AJN 1.0

Z1JN $\quad 6.7056$

Z2JN 0.0

CJN 1.E-5

KFILTER 382.15

FGASIJN 1.0

XLJN 1.0

XWJN $\quad 1.0$

XHJN 1.0

END PATHS

* Path 12: Canyon to cold cells via cover block gaps

* [References needed for CJN]

* IRI = $10=$ Canyon

* $\mathrm{ZlJN}=$ Canyon floor $=0.0 \mathrm{~m}$

* IR2 = $7=$ Cold cells

$\star \mathrm{Z2JN}=\operatorname{Cell}$ height $=$ ZTOP $=6.7056 \mathrm{~m}$

* $\operatorname{kFILTER}=1 /(\operatorname{sum}[i=1.35](1 / \operatorname{kFILTER}$ tcell $)$ )

* $\quad=$ KFILTER tcell / 35

$\star \quad=382.15 \bar{T} 35=10.92$

* Path 15: Canyon to pipe trench via cover block gaps

* [References needed for CJN, KFILTER]

$\star$ IR1 $1=10$ = Canyon

* ZlJN = Canyon floor $=0.0 \mathrm{~m}$

* IR2 $=9=$ Pipe trench

* $\mathrm{Z} 2 \mathrm{JN}=$ Trench height $=\mathrm{ZTOP}=1.83 \mathrm{~m}$

* KFILTER $=($ Kwidth * Klength $) /(2 *$ (Kwidth + Klength $)$ )

* $\quad=(389.7 * 1781.1) /(2 *(389.7+1781.1))$

* $\quad=159.87$

* Path 17: Cell 2R to canyon via cover block gaps

* [References needed for CJN, KFILTER]

* IRI = $11=\operatorname{CelI} 2 \mathrm{R}$

$\star \mathrm{ZlJN}=\operatorname{Cell} 2 \mathrm{R}$ height $=\mathrm{ZTOP}=6.7056 \mathrm{~m}$

* IR2 $=10=$ Canyon

$\star \mathrm{Z} 2 \mathrm{JN}=$ Canyon floor $=0.0 \mathrm{~m}$

* Path 22: Hot cells to canyon via cover block gaps

* [References needed for CJN]

* IRI $=14=$ Hot cells

* $\mathrm{zlJN}=$ Cell height $=\mathrm{ZTOP}=6.7056 \mathrm{~m}$

* IR2 $=10=$ Canyon

* Z2JN = Canyon floor $=0.0 \mathrm{~m}$

* $\operatorname{KFILTER}=1 /(\operatorname{sum}[i=1.5](1 /$ KFILTER tcell $)$ )

* $\quad=$ KFILTER_tcell / 5

* $\quad 382.15 / 5=76.43$

PATHS

SAME_AS

SAME_AS 11

LABEL $\quad$ GAP-COLD

IR 1

IR2

IHORIZ

AJN

ZIJN

$\mathrm{Z} 2 \mathrm{JN}$

CJN

8
10

7

1

1.0

0.0

6.7056

1. $\mathrm{E}-5$

15

11

$17 \quad 22$

KFILTER

10.92

GAP-PIPE

C2R-GAP

C2R-GA
8

8
11
10

9

1.0

1.0

0.0

1. $E-5$

159.87

1

1. 0

6.7056

0.0

I. E- 5

231.95

22
11
HOT-GAP
8
14
10
1
1.0
6.7056
0.0
$1 . E-5$
76.43


FAl/10-83

PRC-STP-00241, Rev 0

Rev. 0

$\begin{array}{lllll}\text { FGAS1JN } & 1.0 & 1.0 & 1.0 & 1.0 \\ \text { XLJN } & 1.0 & 1.0 & 1.0 & 1.0 \\ \text { XWJN } & 1.0 & 1.0 & 1.0 & 1.0 \\ \text { XHJN } & 1.0 & 1.0 & 1.0 & 1.0\end{array}$

Page 162 of 284

March, 2010

* Path 18: Canyon to Cell 2L

* [References needed for CJN]

* $\operatorname{IR} 1=10$ = Canyon

* $\mathrm{Z} 1 \mathrm{JN}=$ Canyon floor $=0.0 \mathrm{~m}$

* $\operatorname{IR} 2=12=\operatorname{cel} 12 \mathrm{~L}$

$\star \mathrm{Z} 2 \mathrm{JN}=\mathrm{Full}$ cell $2 \mathrm{~L}$ height $=30.10 "=9.397 \mathrm{~m}$

$\star$ AJN $=$ SED_AREA $=33.21 \mathrm{~m} \star \star 2$

$\star X L J N=L=27.51=8.3820 \mathrm{~m}$

$\star X W J N=W=131=3.9624 \mathrm{~m}$

$\star$ XHJN $=0.001 \mathrm{~m}=$ thin

$\star$

PATHS 18

LABEL CANYON-C2I

IJTYP 1

IR1 10

IR2 12

IHORIZ 1

AJN $\quad 33.21$

ZIJN $\quad 0.0$

Z2JN $\quad 9.397$

CJN 2.8

FGASIJN 1.0

XLJN $\quad 8.3820$

XWJN $\quad 3.9624$

XHJN $\quad 0.001$

* Cells to ventilation duct

* Path 13: Cold cells to ventilation duct via 10"-dia pipe.

* [Reference needed for CJN]

* $\operatorname{IRI}=7=$ Cold cells

* $\mathrm{ZIJN}=9^{\prime}=2.7432 \mathrm{~m}$

* IR2 = 8 = Ventilation duct

$\star \mathrm{Z} 2 \mathrm{JN}=$ top of duct $=\mathrm{ZTOP}=10.5^{1}=3.2004 \mathrm{~m}$

* $\mathrm{CJN}=(1 / 0.6) \star \star 2=2.8$

* Consider 35 pipes for 35 cold cells:

* $\mathrm{AJN}=35 \star \mathrm{pi} / 4 *(\mathrm{D} * \star 2)$

* $\quad=19.1 \mathrm{ft} \star \star 2$

$\star \quad=1.7735 \mathrm{~m} \star \star 2$

$\star X L J N=10^{\circ}=2.5 \mathrm{~m}$

* XWJN $=10^{\prime \prime}=0.254 \mathrm{~m}$

$\star \mathrm{XHJN}=10^{\prime \prime}=0.254 \mathrm{~m}$

* Path 14: Ventilation duct to process cell via 10"-dia pipe.

* [References needed for CJN]

* IR1 = 8 = Ventilation duct

$\star \mathrm{Z} 1 \mathrm{JN}=\mathrm{tOp}$ of duct $=\mathrm{ZTOP}=10.5^{\prime}=3.2004 \mathrm{~m}$

* IR2 $=6=\mathrm{T}$ cell

$\star \mathrm{Z} 2 \mathrm{JN}=9^{\prime}=2.7432 \mathrm{~m}$

* $\mathrm{CJN}=(1 / 0.6) * * 2=2.8$

* AJN $=p i / 4 \star(D * * 2)$

$\star \quad=0.5454 \mathrm{ft} * \star 2$

* $\quad=0.05067 \mathrm{~m} \star \star 2$

$\star \mathrm{XLJN}=10^{1}=2.5 \mathrm{~m}$

$\star X W J N=10^{\prime \prime}=0.254 \mathrm{~m}$

$\star \mathrm{XHJN}=10 "=0.254 \mathrm{~m}$

* Path 21: Ventilation duct to hot cells via 10"-dia pipe.

* [References needed for CJN]

* IRI = 8 = Ventilation duct

$\star \mathrm{Z} 1 \mathrm{JN}=\mathrm{tOp}$ of duct $=\mathrm{ZTOP}=10.5^{\prime}=3.2004 \mathrm{~m}$

* $\operatorname{IR2}=14=$ Hot cells

$\star$ Z2JN $=9^{\prime}=2.7432 \mathrm{~m}$

$\star \mathrm{CJN}=(1 / 0.6) \star \star 2=2.8$ 
$\mathrm{FAl} / 10-83$

PRC-STP-00241, Rev 0

Rev. 0

* Consider 5 pipes for 5 hot cells:

$\star \mathrm{AJN}=5 \star \mathrm{pi} / 4 \star(\mathrm{D} * \star 2)$

* $\quad=2.7271 \mathrm{ft} \star \star 2$

$\star \quad=0.25335 \mathrm{~m} \star \star 2$

$\star X L J N=10^{\prime}=2.5 \mathrm{~m}$

$*$ XWJN $=10^{\prime \prime}=0.254 \mathrm{~m}$

$\star \mathrm{XHJN}=10 "=0.254 \mathrm{~m}$

$\begin{array}{llll}\text { PATHS } & 13 & 14 & 21 \\ \text { LABEL } & \text { COLD-VENT } & \text { VENT-TCELL } & \text { VENT-HOT } \\ \text { IJTYP } & 1 & 1 & 1 \\ \text { ICCJN } & 0 & 0 & 0 \\ \text { IRI } & 7 & 8 & 8 \\ \text { IR2 } & 8 & 6 & 14 \\ \text { IHORIZ } & 0 & 0 & 0 \\ \text { AJN } & 1.7735 & 0.05067 & 0.25335 \\ \text { ZIJN } & 2.7432 & 3.2004 & 3.2004 \\ \text { Z2JN } & 3.2004 & 2.7432 & 2.7432 \\ \text { CJN } & 2.8 & 2.8 & 2.8 \\ \text { KFILTER } & 0.0 & 0.0 & 0.0 \\ \text { FGAS1JN } & 1.0 & 1.0 & 1.0 \\ \text { XLJN } & 2.5 & 2.5 & 2.5 \\ \text { XWJN } & 0.254 & 0.254 & 0.254 \\ \text { XHJN } & 0.254 & 0.254 & 0.254\end{array}$

END PATHS

*? Single cell pair $K=160$; divide by 17.5

* Pipe trench to ventilation duct

* Path 16: Pipe trench to ventilation duct via 18 10"-dia pipes.

* [Reference needed for CJN]

* IRI = 9 = Pipe trench

* $\mathrm{ZIJN}=$ Pipe trench floor $=0 \mathrm{~m}$

* IR2 = $8=$ Ventilation duct

$\star \mathrm{Z} 2 \mathrm{JN}=$ top of duct $=\mathrm{ZTOP}=10.5^{1}=3.2004 \mathrm{~m}$

$\star \mathrm{CJN}=(1 / 0.6) \star \star 2=2.8$

* Consider 18 pipes for 18 cold cells:

* $\mathrm{AJN}=18 \star \mathrm{pi} / 4 \star(\mathrm{D} \star \star 2)$

$\star \quad=9.8229 \mathrm{ft} * \star 2$

$=0.9121 \mathrm{~m} * \star 2$

* XLJN $=10^{\prime}=2.5 \mathrm{~m}$

$\star X W J N=10 "=0.254 \mathrm{~m}$

$*$ XHJN $=10^{\prime \prime}=0.254 \mathrm{~m}$

PATHS 16

LABEL PTRENCH - VENT

IJTYP 1

ICCJN 0

IRI

IR2 8

IHORIZ 1

AJN $\quad 0.9121$

ZIJN 0.0

Z2JN $\quad 3.2004$

CJN 2.8

FGAS1JN 1.0

XLJN 2.5

XWJN $\quad 0.254$

XHJN $\quad 0.254$

END PATHS

* Long cells to $24 "$ pipe

* Path 19: Cell 2L to 24" vent pipe via 10"-dia pipes.

* [Reference needed for CJN]

* IR1 = $12=\operatorname{cel} 12 \mathrm{~L}$

* $\mathrm{ZlJN}=6$ 6' below canyon deck (note: 5'8" is at cover block level)

* $\quad$ ZTOP_12 - 6.9"

* $\quad=7.56 \overline{9} 2 \mathrm{~m}-2.0574 \mathrm{~m}$

* $\quad=5.5118 \mathrm{~m}$ 
Rev. 0

* IR2 $=13=24 "$ pipe

¿ Z2JN $=0 \mathrm{~m}$

$\star \mathrm{CJN}=(1 / 0.6) \star \star 2=2.8$

$\star A J N=p i / 4 \star(D * \star 2)$

$\star \quad \quad=0.5454 \mathrm{ft} \star \star 2$

$\star \quad \quad=0.05067 \mathrm{~m} \star \star 2$

$\star \mathrm{XLJN}=10^{\prime}=2.5 \mathrm{~m}$

$\star X W J N=10^{\prime \prime}=0.254 \mathrm{~m}$

$\star \mathrm{XHJN}=10^{\prime \prime}=0.254 \mathrm{~m}$

* Path 20: Cell 2R to 24" vent pipe via 10"-dia pipes.

* [Reference needed for CJN]

* IR1 = $13=24$ " pipe

$\star \mathrm{ZIJN}=0 \mathrm{~m}$

* IR2 $=11=\operatorname{Cell} 2 \mathrm{R}$

* $\mathrm{Z2JN}=6$ '9" below canyon deck

* $\quad$ ZTOP $12-6 \cdot 9 "$

* $\quad=7.56 \overline{9} \mathrm{~m}-2.0574 \mathrm{~m}$

* $\quad=5.5118 \mathrm{~m}$

* $\mathrm{CJN}=(1 / 0.6) * \star 2=2.8$

* AJN $=p i / 4 *(D * * 2)$

* $\quad=0.5454 \mathrm{ft} * * 2$

* $\quad=0.05067 \mathrm{m**2}$

$\star X L J N=10^{\circ}=2.5 \mathrm{~m}$

* XWJN $=10 "=0.254 \mathrm{~m}$

* $\mathrm{XHJN}=10^{\prime \prime}=0.254 \mathrm{~m}$

PATHS $19 \quad 20$

LABEL C2L-PIPE PIPE-C2R

$\begin{array}{lll}\text { IJTYP } & 1 & 1 \\ \text { ICCJN } & 0 & 0\end{array}$

IRI $12 \quad 13$

IR2 $13 \quad 11$

$\begin{array}{lll}\text { IHORIZ } & 0 & 0 \\ \text { AJN } & 0.05067 & 0.05067\end{array}$

Z1JN $\quad 5.5118 \quad 0.0$

$\begin{array}{lll}\mathrm{Z} 2 \mathrm{JN} & 0.0 & 5.5118\end{array}$

$\begin{array}{lll}\text { CJN } & 2.8 & 2.8\end{array}$

FGASIJN $1.0 \quad 1.0$

XLJN $2.5 \quad 2.5$

XWJN $\quad 0.254 \quad 0.254$

END PATHS

*

* 24" Pipe and vent duct to exhaust duct

* Path 25: Ventilation duct to exhaust duct

* [Reference needed for CJN]

* $\operatorname{IR} \mathbf{1}=\mathbf{8}=$ Ventilation duct

* $\mathrm{ZlJN}=$ Vent duct floor $=0.0 \mathrm{~m}$

* IR2 = 16 = Exhaust duct

* $\mathrm{Z} 2 \mathrm{JN}=$ Exhaust duct floor $=0.0 \mathrm{~m}$

$\star \mathrm{AJN}=5^{\prime} \star 4^{\prime}=20.0 \mathrm{ft} \star \star 2=1.8581 \mathrm{~m} * \star 2$

$\star$ XLJN $=$ thin $=0.001 \mathrm{~m}$

${ }^{\star}$ XWJN $=4^{\prime}=1.2192 \mathrm{~m}$ (est.)

$\star X H J N=5^{\prime}=1.5240 \mathrm{~m}$

* Path 27: 24" vent pipe to exhaust duct

* [Reference needed for CJN]

* $I R 1=13=24$ " pipe

* ZIJN $=0 \mathrm{~m}$

* IR2 = 16 = Exhaust duct

* Z2JN = Vent duct floor +4 '

$\star \quad=4$

$\star \quad \quad=1.2192 \mathrm{~m}$

* CJN $=(1 / 0.6) \star \star 2=2.8$

$\star \mathrm{AJN}=\mathrm{pi} / 4 \star(\mathrm{D} \star \star 2)$

$\star \quad \quad=3.1416 \mathrm{ft} * \star 2$

$\star \quad \quad=0.2919 \mathrm{~m} \star \star 2$

$\star \mathrm{XLJN}=10^{\circ}=3.048 \mathrm{~m}$ (est.)

$\star X W J N=24 "=0.6096 \mathrm{~m}$ 
FAl/10-83

PRC-STP-00241, Rev 0

Rev. 0

$\star$ XHJN $=24 " / \sin (45)=0.8621 \mathrm{~m}$

Page 165 of 284

PATHS

LABEL VENT-EXH PIPE-EXH

$\begin{array}{lll}\text { IJTYP } & I & 1 \\ \text { ICCJN } & 0 & 0\end{array}$

$\begin{array}{lll}\text { IR1 } 13 & 8\end{array}$

IR2 $16 \quad 16$

$\begin{array}{lll}\text { IHORIZ } & 0 & 0 \\ \text { AJN } & 1.8581 & 0.2919\end{array}$

ZIJN $\quad 0.0 \quad 0.0$

$\begin{array}{lll}\text { Z2JN } & 0.0 & 1.2192\end{array}$

$\begin{array}{lll}\text { CJN } & 1 . E-5 & 2.8\end{array}$

KFILTER $0.0 \quad 0.0$

FGASIJN $1.0 \quad 1.0$

$\begin{array}{lll}\text { XLJN } & 0.001 & 3.048\end{array}$

$\begin{array}{lll}\text { XWJN } & 1.2192 & 0.6096\end{array}$

$\begin{array}{lll}\text { XHJN } & 1.5240 & 0.8621\end{array}$

*

* Fan from exhaust duct to ambient

* fan flow rate $=17500 \mathrm{cfm}=8.2591 \mathrm{~m}^{\wedge} 3 / \mathrm{s}$

* fan flow rate $=0 \mathrm{~m}^{\wedge} 3 / \mathrm{s}$

* Path 26: Exhaust duct to ambient

* CJN not used, constant volumetric flow rate

* Set AuN to an arbitrary positive value

* so code does not bypass the junction

* IR1 = $16=$ Exhaust duct

* $\mathrm{Z} 1 \mathrm{JN}=0 \mathrm{~m}$

* IR2 = 15 = Ambient (atmosphere)

* $\mathrm{z} 2 \mathrm{JN}=15 \mathrm{~m}$ (est.; stack height = 200'?)

PATHS 26

LABEL FAN

IJTYP 1

ICCJN

IR1 16

IR2 15

IHORIZ 0

AJN 0.0

ZIJN $\quad 0.0$

Z2JN 15.0

CJN I.O

KFILTER 0.0

FGAS1JN 1.0

IFAN 1

WVFAN 8.2591

END PATHS

* Cell 2L and canyon to ambient

* Path 28: Ambient to Canyon

* Leakage modeled using KFILTER

* $17500 \mathrm{cfm}\left(82.6 \mathrm{~m}^{\wedge} 3 / \mathrm{s}\right)$ at 0.15 in w.g. (35.9 Pa)

* Assume equal split between canyon leakage and

* access tunnel leakage.

* Hence, KFILTER $=35.9 /(82.6 / 2)=0.870$

* $\operatorname{IR} 1=15=$ Ambient (atmosphere)

* $\mathrm{ZIJN}=$ ELEVATION_10 + ZTOP_10/2 - ELEVATION_15

$\star \quad=7.5438 \mathrm{~m}+14.9352 \mathrm{~m} / 2-7.5438 \mathrm{~m}$

* $\quad=7.4676 \mathrm{~m}$

* $\mathrm{IR} 2=10=$ Canyon

* $\mathrm{Z} 2 \mathrm{JN}=\mathrm{ZTOP} 10 / 2$

* $\quad=7.46 \overline{7} 6 \mathrm{~m}$

* Path 29: Ambient to Cell 2L

* Leakage modeled using KFILTER

* $17500 \mathrm{cmf}\left(82.6 \mathrm{~m}^{\wedge} 3 / \mathrm{s}\right)$ at 0.15 in w.g. (35.9 Pa)

* Assume equal split between canyon leakage and 
FAl/10-83

PRC-STP-00241, Rev 0

Rev. 0

Page 166 of 284

* access tunnel leakage.

* Hence, KFILTER $=35.9 /(82.6 / 2)=0.870$

* IRI = $15=$ Ambient (atmosphere)

* Z1JN = ELEVATION $12+$ ZTOP $12 / 2$ - ELEVATION 15

* $\quad=-1.8542 \mathrm{~m}+7.5692 \overline{\mathrm{m}} / 2-7.5438 \mathrm{~m}$

$\star \quad=-5.6134 \mathrm{~m}$

$\star$ IR2 $=12=\operatorname{cell} 2 \mathrm{~L}$

* $\mathrm{Z} 2 \mathrm{JN}=$ ZTOP_12/2

$\star \quad=7.56 \overline{9} 2 \mathrm{~m} / 2$

* $\quad=3.7846 \mathrm{~m}$

$\begin{array}{ccc}\text { PATHS } & 28 & 29 \\ \text { LABEL } & \text { AMB-CANYON } & \text { AMB-C2 }\end{array}$

LABEL AMB-CANYON AMB-C2

$\begin{array}{lll}\text { IJTYP } & 8 & 8 \\ \text { ICCJN } & 0 & 0\end{array}$

IRI $15 \quad 15$

IR2 $10 \quad 12$

IHORIZ 11

1.0

ZIJN $\quad 7.4676 \quad-5.6134$

Z2JN $\quad 7.4676 \quad 3.7846$

$\begin{array}{lll}\text { CJN } & 2.8 & 2.8\end{array}$

KFILTER $0.870 \quad 0.870$

FGAS1JN $1.0 \quad 1.0$

$\begin{array}{lll}X L J N & 1.0 & 1.0\end{array}$

XWJN $1.0 \quad 1.0$

$\begin{array}{lll}X H J N & 1.0 & 1.0\end{array}$

END PATHS

END JUNCTIONS 
FAl/10-83

PRC-STP-00241, Rev 0

Rev. 0

\section{B.6 Case File: CONTLN1.dat}

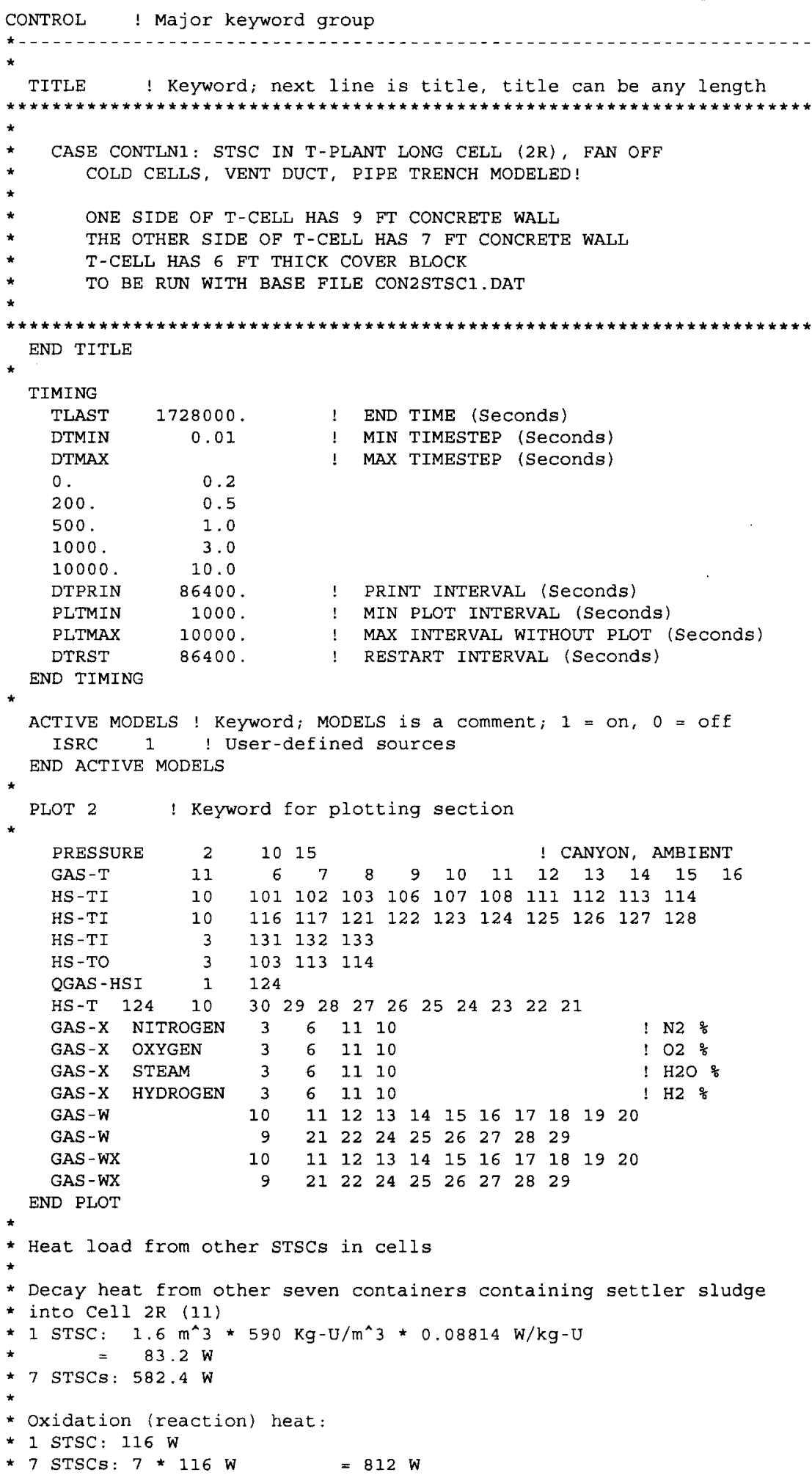


FAl/10-83

PRC-STP-00241, Rev 0

Rev. 0

* Total heat load for 7 STSCs: $1394.4 \mathrm{~W}$

* H2 Generation Rate:

* 1 STSC $=8381 /$ day

* $\quad=838 \mathrm{l} /$ day * $1 / 86400 \mathrm{day} / \mathrm{s} * 0.07598 \mathrm{~kg} / \mathrm{m} * 3 * 1 / 1000 \mathrm{~m} * 3 / \mathrm{l}$

* $\quad=7.37 \mathrm{E}-7 \mathrm{~kg} / \mathrm{s}$

* 7 STSCs: $5.159 \mathrm{E}-6 \mathrm{~kg} / \mathrm{s}$

SOURCES 2

REGION 11 GASES 1 PHASE 1

HYDROGEN

$\begin{array}{llll}0 & 50.0 & 5.159 \mathrm{E}-6 & 1394.4\end{array}$

1.E9 $\quad 50.0 \quad 5.159 \mathrm{E}-6 \quad 1394.4$

END REGION

* Decay heat from six containers of container sludge in each of four

* cells in the Hot cell (14)

$\star 4 \star 6 \star 83.2 W=$

$1996.8 \mathrm{~W}$

* Oxidation (reaction) heat:

* 1 STSC : $116 \mathrm{~W}$

$\star 24$ STSCs: 4 * 6 *116 W $=2784.0 \mathrm{~W}$

* Total heat load for 5 STSCs: $4780.8 \mathrm{~W}$

* H2 Generation Rate:

* $1 \mathrm{STSC}=7.37 \mathrm{E}-7 \mathrm{~kg} / \mathrm{s}$

*24 STSCs $=1.77 \mathrm{E}-5 \mathrm{~kg} / \mathrm{s}$

REGION 14 GASES 1 PHASE 1

HYDROGEN

$\begin{array}{llll}0 & 50.0 & 1.77 \mathrm{E}-5 & 4780.8\end{array}$

$\begin{array}{llll}1 . E 9 & 50.0 & 1.77 E-5 & 4780.8\end{array}$

END REGION

END SOURCES

END CONTROL

VOLUMES

$\star \ldots+\cdots$

* Cells

" elevation of T-Plant Cell $=-1 "-38 "=-0.9906 \mathrm{M}$

* ELEVATION OF TOP OF COVER BLOCKS $=-38 "+12 \times 28 "=298 "(7.5692 \mathrm{M})$

* ELEVATION OF BOTTOM OF COVER BLOCKS $=-38 "+12 \times 22 "=226 "(5.7404 \mathrm{M})$

* T-CELL DIMENSION, $13 \cdot(3.9624 \mathrm{M})$ BY $17 \cdot 8 "(5.3848 \mathrm{M})$ BY $22 \cdot(6.7056 \mathrm{M})$

* ASSUME $1 \mathrm{M} \wedge 3$ FOR OTHER STRUCTURES

* T-CELL VOLUME $=3.9624 \times 5.3848 \times 6.7056-6$ X2.5941XPI $(1.4986)^{\wedge} 2 / 4-1.0$

$\star \quad=143.08-27.45-1.0=114.63 \mathrm{M}^{\wedge} 3$

* Elevation: $-3 \cdot 3 "=-3.25^{\prime}=-0.9906 \mathrm{~m}$

\begin{tabular}{ll} 
REGIONS & \multicolumn{1}{c}{6} \\
LABEL & T-CELL \\
VOLUME & 143.08 \\
SED_AREA & 16.82 \\
ELEVATION & -0.9906 \\
TEMP_GAS & 35.0 \\
PRESSURE & $1.0 \mathrm{E} 5$ \\
ZTOP & 6.7056
\end{tabular}

ND REGIONS

$\begin{array}{ll}\text { GASES } & 6 \\ \text { STEAM } & 0.01 \\ \text { OXYGEN } & 0.20 \\ \text { NITROGEN } & 0.79\end{array}$

GASES

* Cold cell.

* The "cold cell" is a combination of 31 standard process cells

* with no STSCs or internals. 
* Pipe trench cover block depth: 4.5' 
FAl/10-83

PRC-STP-00241, Rev 0

Rev. 0

Page 170 of 284

* Pipe trench floor elevation: $24.75^{\prime}-4.5^{\prime}-6^{\prime}=14.25^{\prime}=4.3434 \mathrm{~m}$

REGIONS

9

VOLUME $\quad 951.45$

SED AREA $\quad 520.26$

ELEVATION $\quad 4.3434$

ZTOP 1.83

TEMP GAS 23.0

PRESSURE $\quad 1.0 \mathrm{E} 5$

GASES

SAME_AS

END GASES

* 24 " Pipe:

* Sed. Area: $D=2+L=71+2 * 131 A=D * L=66 \mathrm{ft} * \star 2=6.1316 \mathrm{~m} * * 2$

*Volume: $D=2, \quad L=71+2 * 13 \prime \mathrm{V}=103.67 \mathrm{ft} * * 3=2.9357 \mathrm{~m} * * 3$

* Z-top: $\mathrm{D}=2^{\prime}=0.6096 \mathrm{~m}$

* Elevation: $-3.25^{\prime}+28^{\prime}-19^{\prime}=5.75^{\prime}=1.7526 \mathrm{~m}$

* Exhaust duct:

* Sed. Area: $L=145^{\prime} W=4, A=580 \mathrm{ft} * * 2=53.88 \mathrm{~m} * * 2$

*Volume: $\quad \mathrm{L}=145^{\prime} \mathrm{W}=4, \mathrm{H}=7, \mathrm{~V}=4060 \mathrm{ft} * 2=115.0 \mathrm{~m} \star 2$

* Z-top: $\quad \mathrm{H}=7$

* Elevation: $-3.25^{\prime}=-0.9906 \mathrm{~m}$

REGIONS

SAME_AS

LABE $\bar{L}$

VOLUME

SED AREA

ELEVATTION

ZTOP

TEMP_GAS

PRESSURE

END REGIONS

$\begin{array}{cc}13 & 16 \\ 8 & 8 \\ \text { PIPE-24 } & \text { EXH-DUCT } \\ 2.9357 & 115.0 \\ 6.1316 & 53.88 \\ 1.7526 & -0.9906 \\ 0.6096 & 2.1336 \\ 32.0 & 32.0 \\ 1.0 \mathrm{E} 5 & 1.0 \mathrm{E} 5\end{array}$

$\begin{array}{lrr}\text { GASES } & 13 & 16 \\ \text { SAME_AS } & 8 & 8\end{array}$

* atmospheres

* Canyon Length $=43^{\prime}+680^{\prime}+38.5^{\prime}=761.5 \mathrm{ft}=232.1 \mathrm{~m}$

* Lower $\mathrm{H}=25^{\prime} \mathrm{g}^{\prime \prime}=7.85 \mathrm{~m}, \mathrm{~W}=37 \mathrm{\prime}^{\prime \prime} ", \mathrm{AX1}=88.96 \mathrm{~m} \star 2$

* Upper $\mathrm{H}=14 \mathrm{\prime}=4.27 \mathrm{~m}, \mathrm{~W}=60^{\prime} \mathrm{2}^{\prime \prime}, \mathrm{AX} 2=78.30 \mathrm{~m} * \star 2$

* Crane $\mathrm{H}=9^{\prime} 3^{\prime \prime} \quad, \mathrm{W}=10^{\prime}, \mathrm{AX} 3=8.60 \mathrm{~m} * 2^{\prime}$

* Canyon total height $=25^{\prime} 9^{\prime \prime}+14^{\prime}+9^{\prime} 3^{\prime \prime}=49^{\prime}=14.9352 \mathrm{~m}$

* Volume $=232.1 \times(88.96+78.30+8.60)=40,818 \mathrm{~m} * 3$

* Sed area $232.1 \mathrm{~m} \mathrm{x} 60 \mathrm{ft}=4245 \mathrm{~m} * 2$

REGIONS

LABEL

VOLUME

10

CANYON

ELEVATION $\quad 4245.50$

PRESSURE

ZTOP

ZTOP

32.0

$1.0 \mathrm{E} 5$

14.9352

1.E3

15

AMBIENT

1.E9

$1 . \mathrm{E} 6$

7.5438

25.0

$1.0 \mathrm{E5}$

$1 . \mathrm{E} 3$

1. E3

END REGIONS

* GASES

STEAM

OXYGEN

NITROGEN

10

0.01

0.20

0.79

15

0.01

0.20

0.79

* control boundary fRESSuRe 
FAl/10-83

\section{PRC-STP-00241, Rev 0}

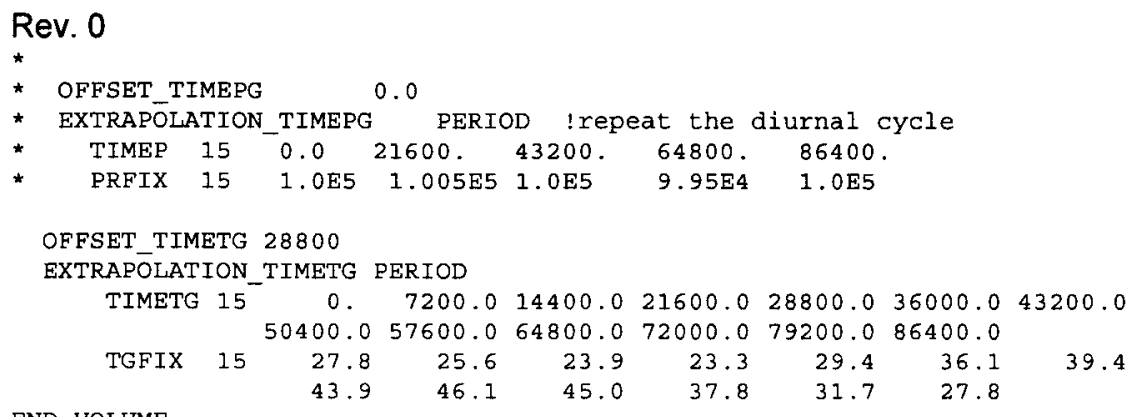

END VOLUME

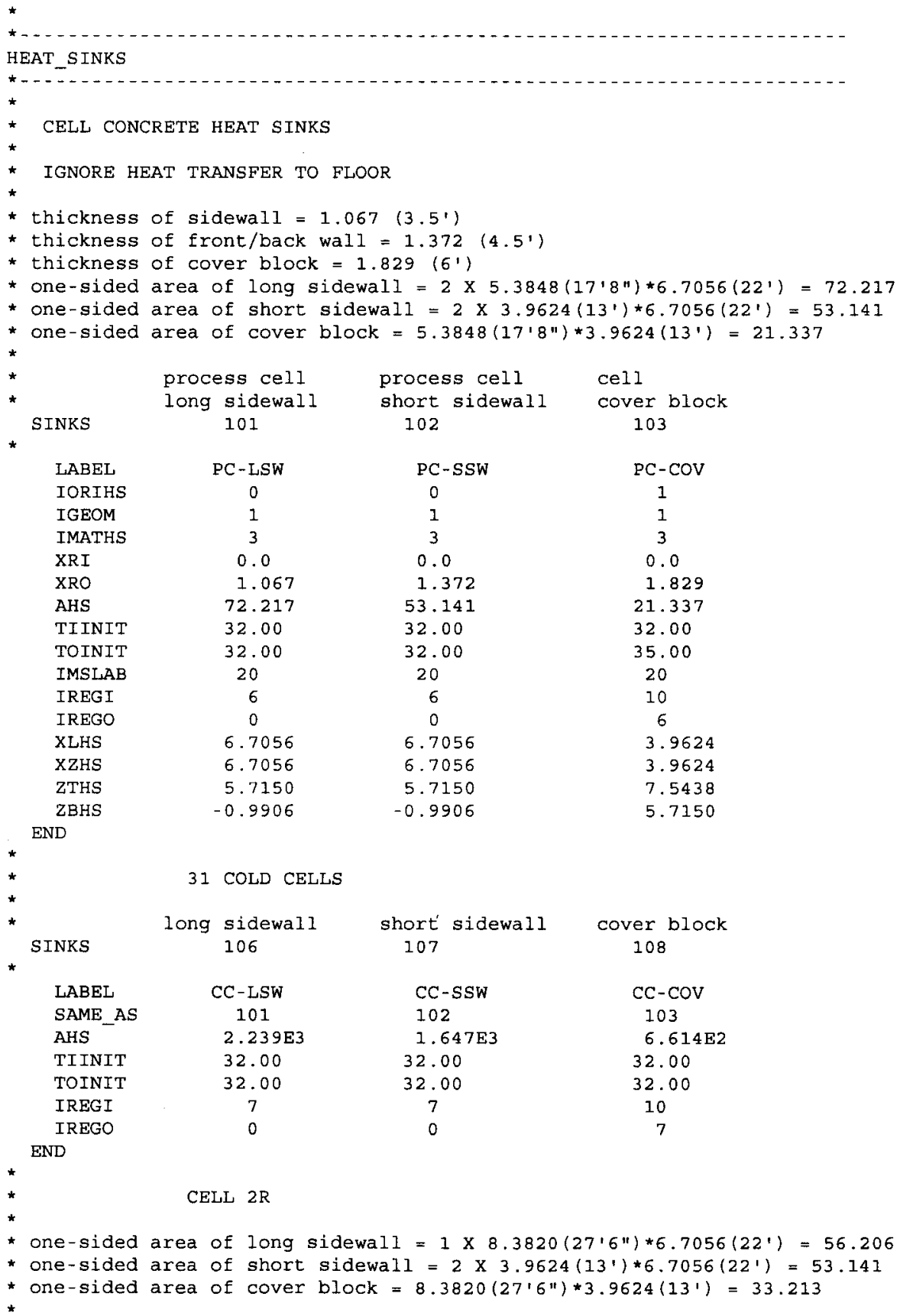


FAl/10-83

PRC-STP-00241, Rev 0

Rev. 0

*

*

SINKS

LABEL

SAME_AS

AHS

TIINIT

TOINIT

IREGI

END

*

*

*

SINKS

LABEL SAME_AS

IREGI

I REGO

END

$$
\text { * }
$$$$
\text { * }
$$

$$
\text { SINKS }
$$

* SINRS

IABEL

SAME_AS

AHS

IREGI

I REGO

END

*

*

* $2 \times 10.5 \mathrm{x}$

SINKS

* IORIHS

IGEOM

IMATHS

XRI

XRO

AHS

TIINIT

TOINIT

IMSLAB

IREGI

IREGO

XLHS

$\mathrm{XZHS}$

ZTHS

ZBHS

END

*

*

$\star$

lower canyon walls: $5 \mathrm{ft}$ thick, $7.85 \mathrm{~m}$ high, $260.5 \mathrm{~m}$ long, $\mathrm{x} 2$

* upper canyon walls: 3 ft thick, $4.27 \mathrm{~m}$ high, x2

SINKS

131

132

IORIHS

IGEOM

IMATHS

XRI long sidewall

111

$2 \mathrm{R}-\mathrm{LSW}$

101

56.206

11

0

CELL 2L

long sidewall

116

2L-LSW

0

4 HOT CELLS

long sidewall short sidewall

127

CC-SSW

212.6

14 short sidewall

112

2R-SSW

102

53.141

32.00

2.00

11

short sidewall

117

2L-SSW

112

12
0

cover block

128

$\mathrm{CC}-\mathrm{COV}$

103

85.35

10

14
VENT DUCT

121

0

3

32.0

0

3.20

3.20

2.21

$-0.9906$

CANYON

0
1
3
0.0

0
1
3
0.0
Page 172 of 284

March, 2010 
FAl/10-83

PRC-STP-00241, Rev 0

Rev. 0

$\begin{array}{lcc}\text { XRO } & 1.52 & 0.915 \\ \text { AHS } & 4090.0 & 2224.7 \\ \text { TIINIT } & 32.00 & 32.00 \\ \text { TOINIT } & 32.00 & 35.00 \\ \text { IMSLAB } & 20 & 20 \\ \text { IREGI } & 10 & 10 \\ \text { IREGO } & 0 & 0 \\ \text { XLHS } & 12.0 & 12.0 \\ \text { XZHS } & 12.0 & 12.0 \\ \text { ZTHS } & 15.394 & 19.664 \\ \text { ZBHS } & 7.5438 & 15.394\end{array}$

END

PIPE TRENCH

* PIPE trench WALl IS $2 \times 6 \times(35 \times 20) \quad F T * * 2$

* COVER IS $8 \times(35 \times 20) \quad F T * \star 2$

* wall cover

$\begin{array}{lll}\text { SINKS } & 122 & 123\end{array}$

$\begin{array}{lcc}\text { IORIHS } & 0 & 1 \\ \text { IGEOM } & 1 & 1 \\ \text { IMATHS } & 3 & 3 \\ \text { XRI } & 0.0 & 0.0 \\ \text { XRO } & 1.52 & 1.37 \\ \text { AHS } & 781.0 & 520.5 \\ \text { TIINIT } & 32.00 & 32.00 \\ \text { TOINIT } & 32.00 & 32.00 \\ \text { IMSLAB } & 20 & 20 \\ \text { IREGI } & 9 & 10 \\ \text { IREGO } & 0 & 9 \\ \text { XLHS } & 1.83 & 1.83 \\ \text { XZHS } & 1.83 & 1.83 \\ \text { ZTHS } & 6.1710 & 7.5438 \\ \text { ZBHS } & 4.3426 & 6.1710\end{array}$

* inner cylinder and stsc wall adjacent to water and gas 
FAl/10-83

PRC-STP-00241, Rev 0

Rev. 0

Page 174 of 284

$\star$

Layer 21

61

LABEL WALLO-21

IREGO 11

END

$\star$

* Volume Cumulative volume

* Layer-13 $0.03849 \quad 0.53849$

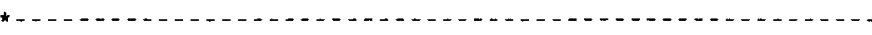

* LAYER-12 $0.09337 \quad 0.50000$

*

Layer

IREGO

END

SINKS

Layer 19

IREGO

END

SINKS

Layer 18

END

SINKS

IREGO

END

SINKS

END

SINKS

IREGO

END

SINKS

IREGO

END

*

SINKS

IREGO

END

* SINKS

IREGO

END

$\begin{array}{cc} & \text { Layer } 11 \\ \text { SINKS } & 31 \\ \text { IREGO } & 11\end{array}$

END

* elliptical Section

* lower head exterior sees atmosphere in the skirt enclosure

SINKS

IREGO $\quad 11$

END

* Layer 9

IREGO 11

END

Layer 8

22

END

*

* wall for Layer 7 and below is considered horizontal; 
Rev. 0

* heat transfer due to laminar boundary layer underside

* of a hot plate is modeled in FATE

* Layer 7

SINKS 19

IREGO 11

END

Layer 6

IREGO 11

END

* Layer 5

SINKS 13

END

* Layer 4

SINKS 10

IREGO 11

END

SINKS $\quad$ Layer 3

IREGO

END

* below the inner eliptical head

*

Layer 2

$\begin{array}{cl}\text { SINKS } & 4 \\ \text { IREGO } & 11\end{array}$

END

*

* skirt and drif pan

* model drip-pan as vertical hs to allow convective ht to cell

SINKS 96

1 LABEL SKIRT DRIP-PAN

IREGO 11

END

END HEAT SINKS

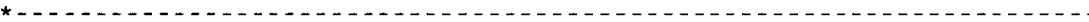

JUNCTIONS

* Move STSC from region 6 to region 11

* 2" INLET VENT

* 4" OUTLET VENT WITH 2 FOOT (0.6096 M) CHIMNEY

PATH

$\begin{array}{llc}\text { PATHS } & 1 & 2 . \\ \text { LABEL } & \text { VENT-IN } & \text { VENT-OUT } \\ \text { IR1 } & 11 & 1 \\ \text { IR2 } & 1 & 11\end{array}$

END PATHS

* HOLES IN THE SKIRT

* Redirect from typical cell (6) to cell 2R (11)

$\begin{array}{llll}\text { PATHS } & 4 & 5 & 6\end{array}$

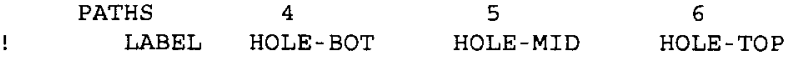

$\begin{array}{rrrr}I R 1 & 11 & 11 & 3\end{array}$

END PATHS

*

* Canyon to cells \& pipe trench through cover block gaps

* Path 11: Process cell to canyon via gap

* [References needed for CJN, KFILTER] 


\section{FAl/10-83}

PRC-STP-00241, Rev 0

Rev. 0

* IRI $1=6=\mathrm{T}$-Cell

$*$ ZlJN $=$ Cell height $=$ ZTOP $=6.7056 \mathrm{~m}$

* IR2 = 10 = Canyon

* $\mathrm{Z2JN}=$ Canyon floor $=0.0 \mathrm{~m}$

$\begin{array}{lc}\text { PATHS } & 11 \\ \text { LABEL } & \text { TCELL-GAP } \\ \text { IJTYP } & 8 \\ \text { ICCJN } & 0 \\ \text { IRI } & 6 \\ \text { IR2 } & 10 \\ \text { IHORIZ } & 1 \\ \text { AJN } & 1.0 \\ \text { Z1JN } & 6.7056 \\ \text { Z2JN } & 0.0 \\ \text { CJN } & 1 . \text { E-5 } \\ \text { KFILTER } & 382.15 \\ \text { FGASIJN } & 1.0 \\ \text { XIJN } & 1.0 \\ \text { XWJN } & 1.0 \\ \text { XHJN } & 1.0 \\ \text { END PATHS } & \end{array}$

*

* Path 12: Canyon to cold cells via cover block gaps

* [References needed for CJN]

* IRI $=10=$ Canyon

* Z1JN $=$ Canyon floor $=0.0 \mathrm{~m}$

* IR2 $=7=$ Cold cells

$\star \mathrm{Z} 2 \mathrm{JN}=$ Cell height $=$ ZTOP $=6.7056 \mathrm{~m}$

* $\operatorname{KFILTER}=1 /(\operatorname{sum}[i=1.35](1 / \mathrm{KFILTER} t c e 11))$

* $\quad$ KFILTER_tcell / 35

$\star \quad \quad 382.15 \bar{T} 35=10.92$

* Path 15: Canyon to pipe trench via cover block gaps

* [References needed for CJN, KFILTER]

* IRI = 10 = Canyon

* ZlJN = Canyon floor $=0.0 \mathrm{~m}$

* IR2 $=9$ = Pipe trench

* Z2JN $=$ Trench height $=$ ZTOP $=1.83 \mathrm{~m}$

* KFILTER $=($ Kwidth * Klength $) /(2 *($ Kwidth + Klength $))$

* $\quad=(389.7 * 1781.1) /(2 \star(389.7+1781.1))$

* $\quad=159.87$

* Path 17: Cell 2R to canyon via cover block gaps

* [References needed for CJN, KFILTER]

* $\operatorname{IR} 1=11=\operatorname{Cell} 2 \mathrm{R}$

* $\mathrm{zlJN}=\operatorname{Cell} 2 \mathrm{R}$ height $=$ ZTOP $=6.7056 \mathrm{~m}$

* IR2 = $10=$ Canyon

* Z2JN $=$ Canyon floor $=0.0 \mathrm{~m}$

* Path 22: Hot cells to canyon via cover block gaps

* [References needed for CJN]

* IRl $=14=$ Hot cells

* $\mathrm{z} 1 \mathrm{JN}=$ Cell height $=$ ZTOP $=6.7056 \mathrm{~m}$

* $\mathrm{IR} 2=10=$ Canyon

* Z2JN = Canyon floor $=0.0 \mathrm{~m}$

* KFILTER $=1 /(\operatorname{sum}[i=1.5](1 / \mathrm{KFILTER} t c e l 1))$

* $\quad$ KFILTER tcell/5

$\star \quad=382.15 \overline{/} 5=76.43$

$\begin{array}{lllll}\text { PATHS } & 12 & 15 & 17 & 22 \\ \text { SAME_AS } & 11 & 11 & 11 & 11 \\ \text { LABEL } & \text { GAP-COLD } & \text { GAP-PIPE } & \text { C2R-GAP } & \text { HOT-GAP } \\ \text { IJTYP } & 8 & 8 & 8 & 8 \\ \text { IR1 } & 10 & 10 & 11 & 14 \\ \text { IR2 } & 7 & 9 & 10 & 10 \\ \text { IHORIZ } & 1 & 1 & 1 & 1 \\ \text { AJN } & 1.0 & 1.0 & 1.0 & 1.0 \\ \text { Z1JN } & 0.0 & 0.0 & 6.7056 & 6.7056 \\ \text { Z2JN } & 6.7056 & 1.83 & 0.0 & 0.0 \\ \text { CJN } & 1 . E-5 & 1 . \mathrm{E}-5 & 1 . \mathrm{E}-5 & 1 . \mathrm{E}-5\end{array}$


FAl/10-83

PRC-STP-00241, Rev 0

\section{Rev. 0}

$\begin{array}{lcccc}\text { KFILTER } & 10.92 & 159.87 & 231.95 & 76.43 \\ \text { FGASIJN } & 1.0 & 1.0 & 1.0 & 1.0 \\ \text { XLJN } & 1.0 & 1.0 & 1.0 & 1.0 \\ \text { XWJN } & 1.0 & 1.0 & 1.0 & 1.0 \\ \text { XHJN } & 1.0 & 1.0 & 1.0 & 1.0\end{array}$

* Path 18: Canyon to Cell 2L

* [References needed for CJN]

* IRI = $10=$ Canyon

* ZlJN = Canyon floor $=0.0 \mathrm{~m}$

* IR2 = $12=\operatorname{cell} 2 \mathrm{~L}$

* $\mathrm{Z} 2 \mathrm{JN}=\mathrm{Full}$ cell $2 \mathrm{~L}$ height $=30 \cdot 10^{\prime \prime}=9.397 \mathrm{~m}$

$\star$ AJN $=$ SED AREA $=33.21 \mathrm{~m} * * 2$

$\star X L J N=L=27.5^{1}=8.3820 \mathrm{~m}$

$\star \mathrm{XWJN}=\mathrm{W}=13^{\circ}=3.9624 \mathrm{~m}$

$\star$ XHJN $=0.001 \mathrm{~m}=$ thin

*

$\begin{array}{ll}\text { PATHS } & 18 \\ \text { LABEL } & \text { CAN }\end{array}$

IJTYP 1

IRI $\quad 10$

IR2 12

IHORIZ 1

AJN $\quad 33.21$

ZIJN $\quad 0.0$

Z2JN $\quad 9.397$

CJN 2.8

FGASIJN 1.0

XLJN 8.3820

XWJN $\quad 3.9624$

XHJN $\quad 0.001$

END PATHS

* Cells to ventilation duct

* Path 13: Cold cells to ventilation duct via 10"-dia pipe.

* [Reference needed for CJN]

* IRI $=7=$ Cold cells

$\star \mathrm{ZIJN}=91=2.7432 \mathrm{~m}$

* IR2 $=8$ = ventilation duct

$\star \mathrm{Z2JN}=$ top of duct $=\mathrm{ZTOP}=10.5^{\prime}=3.2004 \mathrm{~m}$

$\star \mathrm{CJN}=(1 / 0.6) * \star 2=2.8$

* Consider 35 pipes for 35 cola cells:

$\star \mathrm{AJN}=35 * \mathrm{pi} / 4 *(\mathrm{D} \star \star 2)$

* $\quad=19.1 \mathrm{ft} * 2$

* $\quad=1.7735 \mathrm{~m} * \star 2$

* XLJN $=10^{\prime}=2.5 \mathrm{~m}$

$\star X W J N=10^{\prime \prime}=0.254 \mathrm{~m}$

$\star \mathrm{XHJN}=10^{\prime \prime}=0.254 \mathrm{~m}$

* Path 14: Ventilation duct to process cell via 10"-dia pipe.

* [References needed for CJN]

* IRI = 8 = Ventilation duct

$\star \mathrm{ZIJN}=$ top of duct $=\mathrm{ZTOP}=10.5^{\prime}=3.2004 \mathrm{~m}$

* IR2 $=6=T$ cell

* Z2JN $=9^{\prime}=2.7432 \mathrm{~m}$

* $\mathrm{CJN}=(1 / 0.6) * * 2=2.8$

* AJN $=\mathrm{pi} / 4 *(\mathrm{D} * * 2)$

* $\quad=0.5454 \mathrm{ft} * \star 2$

* $\quad=0.05067 \mathrm{~m} * * 2$

$\star X L J N=10^{\prime}=2.5 \mathrm{~m}$

$\star \mathrm{XWJN}=10^{\prime \prime}=0.254 \mathrm{~m}$

$\star \mathrm{XHJN}=10^{\prime \prime}=0.254 \mathrm{~m}$

* Path 21: Ventilation duct to hot cells via 10"-dia pipe.

* [References needed for CJN]

* IR $1=8$ = Ventilation duct

$\star \mathrm{ZIJN}=$ top of duct $=\mathrm{ZTOP}=10.5^{\prime}=3.2004 \mathrm{~m}$

* IR2 = $14=$ Hot cells

$\star \mathrm{Z} 2 \mathrm{JN}=9^{\prime}=2.7432 \mathrm{~m}$ 
FAl/10-83

\section{PRC-STP-00241, Rev 0}

\section{Rev. 0}

$*$ CJN $=(1 / 0.6) * * 2=2.8$

* Consider 5 pipes for 5 hot cells:

* $\mathrm{AJN}=5 * \mathrm{pi} / 4 *(\mathrm{D} * * 2)$

* $\quad=2.7271 \mathrm{ft} * * 2$

$\star \quad=0.25335 \mathrm{~m} * \star 2$

$\star X L J N=10^{\prime}=2.5 \mathrm{~m}$

$\star \mathrm{XWJN}=10^{\prime \prime}=0.254 \mathrm{~m}$

$\star \mathrm{XHJN}=10^{\prime \prime}=0.254 \mathrm{~m}$

$\begin{array}{llll}\text { PATHS } & 13 & 14 & 2\end{array}$

LABEL COLD-VENT VENT-TCELL VENT-HOT

$\begin{array}{llll}\text { IJTYP } & 1 & 1 & 1 \\ \text { ICCJN } & 0 & 0 & 0\end{array}$

$\begin{array}{llll}\text { IR1 } & 7 & 8 & 8\end{array}$

$\begin{array}{llll}\text { IR2 } & 8 & 6 & 14\end{array}$

$\begin{array}{llll}\text { AJN } & 1.7735 & 0.05067 & 0.25335\end{array}$

$\begin{array}{llll}\mathrm{Z} 1 \mathrm{JN} & 2.7432 & 3.2004 & 3.2004\end{array}$

$\begin{array}{llll}\text { Z2JN } & 3.2004 & 2.7432 & 2.7432\end{array}$

$\begin{array}{llll}\text { CJN } & 2.8 & 2.8 & 2.8\end{array}$

$\begin{array}{llll}\text { KFILTER } & 0.0 & 0.0 & 0.0\end{array}$

FGASIJN $1.0 \quad 1.0 \quad 1.0$

XIJN $2.5 \quad 2.5 \quad 2.5$

$\begin{array}{llll}\text { XWJN } & 0.254 & 0.254 & 0.254\end{array}$

XHJN $\quad 0.254 \quad 0.254 \quad 0.254$

$\star$ END PATHS

*? Single cell pair $\mathrm{K}=160$; divide by 17.5

* Pipe trench to ventilation duct

* Path 16: Pipe trench to ventilation duct via 18 10"-dia pipes.

* [Reference needed for CJN]

* IRI = $9=$ Pipe trench

* ZlJN $=$ Pipe trench floor $=0 \mathrm{~m}$

* IR2 = 8 = Ventilation duct

$\star \mathrm{Z} 2 \mathrm{JN}=$ top of duct $=\mathrm{ZTOP}=10.5^{\prime}=3.2004 \mathrm{~m}$

* $C J N=(1 / 0.6) * * 2=2.8$

* Consider 18 pipes for 18 cold cells:

* AJN $=18 * \mathrm{pi} / 4 *(\mathrm{D} * \star 2)$

$\star \quad=9.8229 \mathrm{ft} \star \star 2$

$\star \quad \quad=0.9121 \mathrm{~m} * \star 2$

$\star X \mathrm{XJN}=10^{\prime}=2.5 \mathrm{~m}$

$\star X W J N=10^{\prime \prime}=0.254 \mathrm{~m}$

$\star X H J N=10^{\prime \prime}=0.254 \mathrm{~m}$

$\begin{array}{ll}\text { PATHS } & 16 \\ \text { LABEL } & \text { PTRE }\end{array}$

IJTYP 1

ICCJN 0

IRI 9

IR2 8

IHORIZ 1

AJN $\quad 0.9121$

ZIJN 0.0

Z2JN $\quad 3.2004$

CJN 2.8

FGASIJN 1.0

XLJN 2.5

XWJN $\quad 0.254$

XHJN $\quad 0.254$

END PATHS

* Long cells to 24 " pipe

* Path 19: Cell 2L to 24" vent pipe via 10"-dia pipes.

* [Reference needed for CJN]

* IRI = $12=\operatorname{cell} 2 \mathrm{~L}$

* Z1JN = 6'9" below canyon deck (note: 5.8" is at cover block level)

* $\quad=$ ZTOP_12 - 6.9"

* $\quad=7.56 \overline{9} 2 \mathrm{~m}-2.0574 \mathrm{~m}$ 
FAl/10-83

PRC-STP-00241, Rev 0

Rev. 0

* $\quad=5.5118 \mathrm{~m}$

* IR2 $=13=24 "$ pipe

* $\mathrm{Z} 2 \mathrm{JN}=0 \mathrm{~m}$

$*$ CJN $=(1 / 0.6) * \star 2=2.8$

*AJN $=\mathrm{pi} / 4 *(\mathrm{D} * \star 2)$

* $\quad=0.5454 \mathrm{ft} * \star 2$

* $\quad=0.05067 \mathrm{~m} * \star 2$

* $\mathrm{XLJN}=10^{\circ}=2.5 \mathrm{~m}$

$*$ XWJN $=10 "=0.254 \mathrm{~m}$

$\star \mathrm{XHJN}=10 "=0.254 \mathrm{~m}$

* Path 20: Cell 2R to 24" vent pipe via 10"-dia pipes.

* [Reference needed for CJN]

* IR1 $=13=24 "$ pipe

* $\mathrm{Z} 1 \mathrm{JN}=0 \mathrm{~m}$

* IR2 = $11=\operatorname{Cell} 2 \mathrm{R}$

* $\mathrm{Z} 2 \mathrm{JN}=619 "$ below canyon deck

* $\quad$ ZTOP_12 - 6.9"

* $\quad=7.56 \overline{9} 2 \mathrm{~m}-2.0574 \mathrm{~m}$

* $=5.5118 \mathrm{~m}$

$\star \mathrm{CJN}=(1 / 0.6) \star \star 2=2.8$

$\star \mathrm{AJN}=\mathrm{pi} / 4 *(\mathrm{D} * \star 2)$

$\star \quad \quad=0.5454 \mathrm{ft} * \star 2$

$\star \quad=0.05067 \mathrm{~m} \star \star 2$

$\star X L J N=10^{\prime}=2.5 \mathrm{~m}$

$\star$ XWJN $=10^{\prime \prime}=0.254 \mathrm{~m}$

$\star \mathrm{XHJN}=10^{\prime \prime}=0.254 \mathrm{~m}$

$\begin{array}{lll}\text { PATHS } & 19 & 20\end{array}$

PIPE-C2R

$\begin{array}{lll}\text { IJTYP } & 1 & 1 \\ \text { ICCJN } & 0 & 0\end{array}$

IR1 $12 \quad 13$

$\begin{array}{lrr}\text { IR2 } & 13 & 11\end{array}$

$\begin{array}{lll}\text { IHORIZ } & 0 & 0 \\ \text { AJN } & 0.05067 & 0.05067\end{array}$

$\begin{array}{lll}\text { ZIJN } & 5.5118 & 0.0\end{array}$

Z2JN $\quad 0.0 \quad 5.5118$

$\begin{array}{lll}\text { CJN } & 2.8 & 2.8\end{array}$

FGASIJN $1.0 \quad 1.0$

$\begin{array}{lll}X L J N & 2.5 & 2.5\end{array}$

$\begin{array}{lll}\text { XWJN } & 0.254 & 0.254\end{array}$

$\begin{array}{lll}\text { XHJN } & 0.254 & 0.254\end{array}$

END PATHS

*

* 24" Pipe and vent duct to exhaust duct

* Path 25: Ventilation duct to exhaust duct

* [Reference needed for CJN]

* IRI = 8 = ventilation duct

* $\mathrm{z} 1 \mathrm{JN}=$ Vent duct floor $=0.0 \mathrm{~m}$

* IR2 = 16 = Exhaust duct

* $\mathrm{Z2JN}=$ Exhaust duct floor $=0.0 \mathrm{~m}$

$\star \mathrm{AJN}=5^{\prime} \star 4^{\prime}=20.0 \mathrm{ft} * * 2=1.8581 \mathrm{~m} * 2$

$\star$ XLJN $=$ thin $=0.001 \mathrm{~m}$

$\star X W J N=4^{\prime}=1.2192 \mathrm{~m}$ (est.)

$\star \mathrm{XHJN}=5^{\prime}=1.5240 \mathrm{~m}$

* Path 27: 24" vent pipe to exhaust duct

* [Reference needed for CJN]

* $\operatorname{IR} 1=13=24 "$ pipe

* $\mathrm{ZIJN}=0 \mathrm{~m}$

* IR2 = 16 = Exhaust duct

* $\mathrm{Z} 2 \mathrm{JN}=$ Vent duct floor +4 '

$\star \quad \quad=4^{\prime}$

$\star \quad \quad=1.2192 \mathrm{~m}$

$* \operatorname{CJN}=(1 / 0.6) * * 2=2.8$

* AJN $=p i / 4 *\left(D^{*} * 2\right)$

* $\quad=3.1416 \mathrm{ft} * \star 2$

* $\quad=0.2919 \mathrm{~m} * * 2$

$\star \mathrm{XLJN}=10^{1}=3.048 \mathrm{~m}$ (est.) 
FAl/10-83

PRC-STP-00241, Rev 0

Rev. 0

$\star X W J N=24 "=0.6096 \mathrm{~m}$

${ }^{*}$ XHJN $=24 " / \sin (45)=0.8621 \mathrm{~m}$

$\begin{array}{lcc}\text { PATHS } & 25 & 27 \\ \text { LABEL } & \text { VENT-EXH } & \text { PIPE-EXH } \\ \text { IJTYP } & 1 & 1 \\ \text { ICCJN } & 0 & 0 \\ \text { IRI } & 8 & 13 \\ \text { IR2 } & 16 & 16 \\ \text { IHORIZ } & 0 . & 0 \\ \text { AJN } & 1.8581 & 0.2919 \\ \text { ZIJN } & 0.0 & 0.0 \\ \text { Z2JN } & 0.0 & 1.2192 \\ \text { CJN } & 1 . E-5 & 2.8 \\ \text { KFILTER } & 0.0 & 0.0 \\ \text { FGASIJN } & 1.0 & 1.0 \\ \text { XLJN } & 0.001 & 3.048 \\ \text { XWJN } & 1.2192 & 0.6096 \\ \text { XHJN } & 1.5240 & 0.8621 \\ \text { END PATHS } & & \end{array}$

* Fan from exhaust duct to ambient

* fan flow rate $=17500 \mathrm{cfm}=8.2591 \mathrm{~m}^{\wedge} 3 / \mathrm{s}$

* fan flow rate $=0 \mathrm{~m}^{\wedge} 3 / \mathrm{s}$

* Path 26: Exhaust duct to ambient

* CJN not used, constant volumetric flow rate

* Set AJN to an arbitrary positive value

* so code does not bypass the junction

* IRI $=16=$ Exhaust duct

* $\mathrm{Z} 1 \mathrm{JN}=0 \mathrm{~m}$

* IR2 = 15 = Ambient (atmosphere)

* $\mathrm{Z} 2 \mathrm{JN}=15 \mathrm{~m}$ (est.; stack height = 200'?)

PATHS

LABEL FAN

IJTYP 1

ICCJN I

IRI $\quad 16$

IR2 15

IHORIZ 0

AJN $\quad 0.0$

ZIJN $\quad 0.0$

Z2JN $\quad 15.0$

CJN 1.0

KFILTER 0.0

FGASIJN 1.0

IFAN 1

WVFAN 8.2591

END PATHS

* cell 2l and canyon to ambient

* Path 28: Ambient to Canyon

* Leakage modeled using KFILTER

* $17500 \mathrm{cfm}\left(82.6 \mathrm{~m}^{\wedge} 3 / \mathrm{s}\right)$ at 0.15 in w.g. (35.9 Pa)

* Assume equal split between canyon leakage and

* access tunnel leakage.

* Hence, KFILTER=35.9/(82.6/2) $=0.870$

* IR1 = $15=$ Ambient (atmosphere)

* ZIJN = ELEVATION $10+$ ZTOP $10 / 2$ - ELEVATION 15

* $\quad=7.5438 \mathrm{~m}+14.9352 \mathrm{~m}^{-1} / 2-7.5438 \mathrm{~m}$

$=7.4676 \mathrm{~m}$

* IR2 = 10 = Canyon

* $\mathrm{Z} 2 \mathrm{JN}=\mathrm{ZTOP} 10 / 2$

* $\quad=7.46 \overline{7} 6 \mathrm{~m}$

* Path 29: Ambient to Cell 2L

* Leakage modeled using KFILTER

* $17500 \mathrm{cmf}\left(82.6 \mathrm{~m}^{\wedge} 3 / \mathrm{s}\right)$ at $0.15 \mathrm{in}$ w.g. (35.9 Pa) 
FAl/10-83

PRC-STP-00241, Rev 0

Rev. 0

* Assume equal split between canyon leakage and

Page 181 of 284

* access tunnel leakage.

* Hence, KFILTER $=35.9 /(82.6 / 2)=0.870$

* IRI = 15 = Ambient (atmosphere)

$\star \mathrm{Z} 1 \mathrm{JN}=$ ELEVATION_12 + ZTOP_12/2 - ELEVATION_15

$\star \quad=-1.8542 \mathrm{~m}+7.5692 \mathrm{~m} / 2-7.5438 \mathrm{~m}$

$\star \quad=-5.6134 \mathrm{~m}$

* IR2 = $12=\operatorname{Cell} 2 \mathrm{~L}$

* Z2JN $=$ ZTOP $12 / 2$

* $\quad=7.56 \overline{9} 2 \mathrm{~m} / 2$

$\star \quad \quad=3.7846 \mathrm{~m}$

PATHS

LABEL AMB-CANYON AMB-C2I

$\begin{array}{lll}\text { IJTYP } & 8 & 8\end{array}$

ICCJN 0

IRI $\quad 15 \quad 15$

IR2 $10 \quad 12$

IHORIZ 11

AJN $1.0 \quad 1.0$

$\begin{array}{lll}\text { ZIJN } & 7.4676 & -5.6134\end{array}$

Z2JN $\quad 7.4676 \quad 3.7846$

$\begin{array}{lll}\text { CJN } & 2.8 & 2.8\end{array}$

KFILTER $0.870 \quad 0.870$

FGASIJN $1.0 \quad 1.0$

$\begin{array}{lll}\text { XLJN } & 1.0 & 1.0\end{array}$

$\begin{array}{lll}X W J N & 1.0 & 1.0\end{array}$

$\begin{array}{lll}X H J N & 1.0 & 1.0\end{array}$

END PATHS

END JUNCTIONS 
FAl/10-83

PRC-STP-00241, Rev 0

Rev. 0

B.7 Case File: SETTRF1.dat

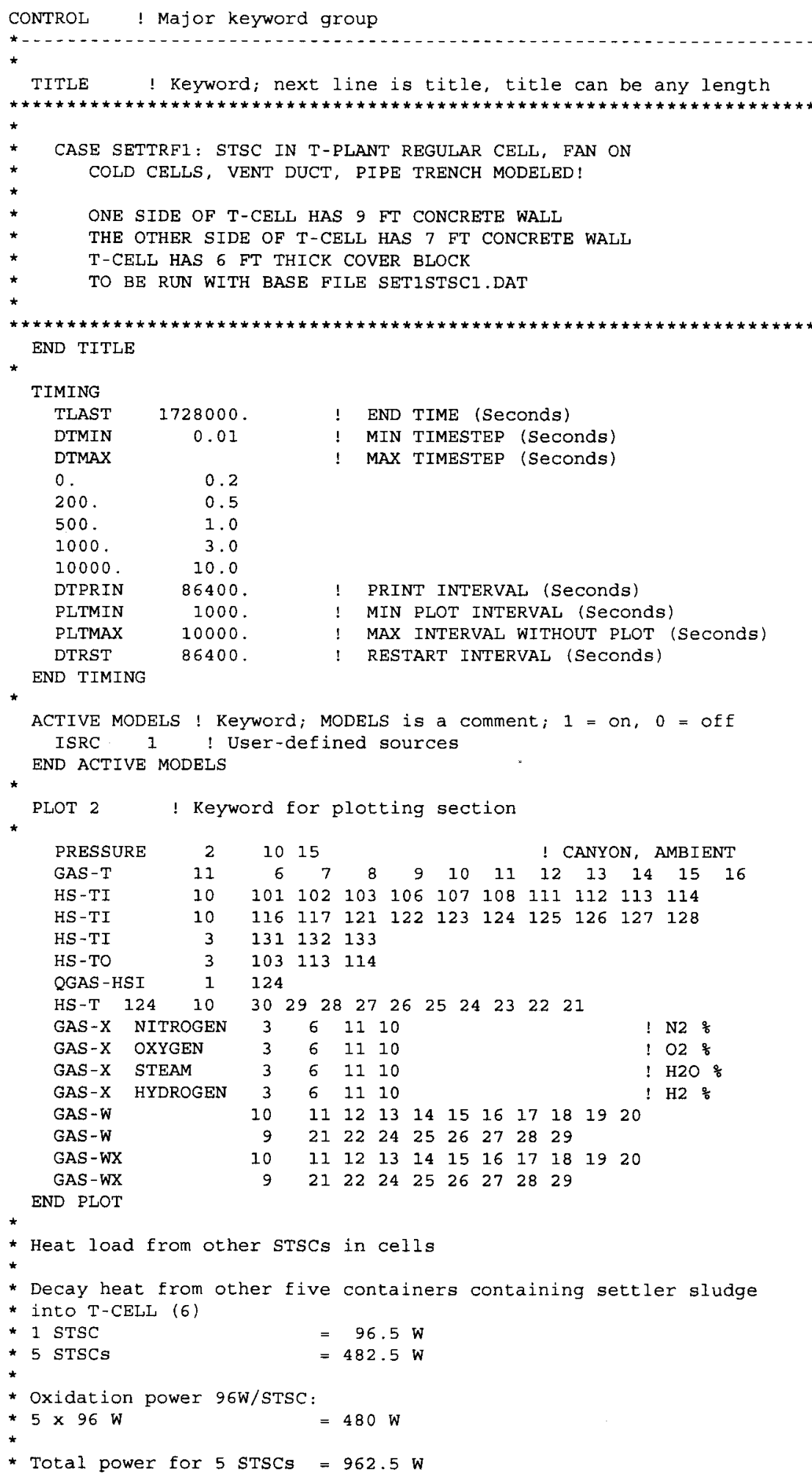


* H2 generation rate for $1 \mathrm{STSC}=7.0 \mathrm{E}-7 \mathrm{~kg} / \mathrm{s}$

* H2 generation rate for 5 STSCs $=3.5 \mathrm{E}-6 \mathrm{~kg} / \mathrm{s}$

* H2 released at $50 \mathrm{C}$

SOURCES 2

REGION 6 GASES 1 PHASE 1 HYDROGEN

$\begin{array}{llll}0 & 50.0 & 3.5 E-6 & 962.5 \\ \text { 1.E9 } & 50.0 & 3.5 E-6 & 962.5\end{array}$

END REGION

* Decay heat from six containers containing settler sludge in each of

* four cells in the Hot Cell (14)

* 1 STSC $=96.5 \mathrm{~W}$

$\star 24$ STSCS $\quad=2316.0 \mathrm{~W}$

* Oxidation power $96 \mathrm{~W} / \mathrm{STSC}$ :

$\star 4 \times 6 \times 96 \mathrm{~W} \quad=2304.0 \mathrm{~W}$

*

* Total power for $4 \times 6$ STSCs $=4620.0 \mathrm{~W}$

* H2 generation rate for 1 STSC $=7.00 \mathrm{E}-7 \mathrm{~kg} / \mathrm{s}$

* H2 generation rate for $24 \mathrm{STSCs}=1.68 \mathrm{E}-5 \mathrm{~kg} / \mathrm{s}$

* $\mathrm{H} 2$ released at $50 \mathrm{C}$

REGION 14 GASES 1 PHASE 1 HYDROGEN

$0 \quad 50.0 \quad 1.68 \mathrm{E}-5 \quad 4620.0$

1.E9 $50.0 \quad 1.68 \mathrm{E}-5 \quad 4620.0$

END REGION

END SOURCES

END CONTROI

VOLUMES

*

* Cells

* ELEVATION OF T-PLANT CELL $=-1 "-38 "=-0.9905 \mathrm{M}$

* ELEVATION OF TOP OF COVER BLOCKS $=-38 "+12 \times 28 "=298 "(7.5692 \mathrm{M})$

* ELEVATION OF BOTTOM OF COVER BLOCKS $=-38 "+12 \times 22 "=226 "(5.7404 \mathrm{M})$

* T-CELL DIMENSION, $13 \cdot(3.9624 \mathrm{M})$ BY $17 \cdot 8 "(5.3848 \mathrm{M})$ BY $22^{\prime}(6.7056 \mathrm{M})$

* ASSUME 1 M^3 FOR OTHER STRUCTURES

* T-CELL VOLUME $=3.9624 \times 5.3848 \times 6.7056-6 \times 2.5941 \times P I(1.4986)^{\wedge} 2 / 4-1.0$

*

* Elevation: $-313 "=-3.251=-0.9906 \mathrm{~m}$

REGIONS

LABEL T-CELI

VOLUME $\quad 114.63$

SED AREA $\quad 16.82$

ELEVATION $\quad-0.9906$

TEMP_GAS 35.0

PRESSURE $\quad 1.0 E 5$

ZTOP $\quad 6.7056$

END REGIONS

GasEs 6

STEAM 0.01

OXYGEN $\quad 0.20$

NITROGEN $\quad 0.79$

END GASES

* Cold cell :

* The "cold cell" is a combination of 31 standard process cells

* with no stscs or internals.

*Volume: $31 * 143.08 \mathrm{~m} * * 3=4435.48 \mathrm{~m} * * 3$

* Sed. Area: $31 \star 16.82 \mathrm{~m} \star 2=521.42 \mathrm{~m} * * 2$ 
FAl/10-83

PRC-STP-00241, Rev 0

Rev. 0

Page 184 of 284

$\star$ Elevation: $-3.25^{\prime}$

March, 2010

$\star$

$\star$ Cell 2R:

* Volume: $\quad L=27 \prime^{\prime \prime} \mathrm{W}=13^{\prime} \mathrm{H}=22^{\prime} \mathrm{V}=7865 \mathrm{ft} \star \star 3=222.71 \mathrm{~m} \star \star 3$

* Sed. Area: $L=27 \cdot 6^{\prime \prime} W=13^{\prime} A=357.5 \mathrm{ft} \star \star 2=33.21 \mathrm{~m} \star 2$

* Elevation: $-3.25^{\prime}$

* Cel1 2L:

* Cell 2L is slightly deeper than 2R due to train tracks, plus has no cover

* blocks. This adds another 6 ' of height to the cell

* Volume: $\quad \mathrm{L}=27^{\prime} 6^{\prime \prime} \mathrm{W}=13^{\prime} \mathrm{H}=30^{\prime} 10^{\prime \prime} \mathrm{V}=11022.92 \mathrm{ft} *{ }^{*}=312.13 \mathrm{~m} \mathrm{~m}^{*}$

* Sed. Area: $L=27 \cdot 6 " W=13^{\prime} A=357.5 \mathrm{ft} \star \star 2=33.21 \mathrm{~m} \star \star 2$

* Z-top: H=30'10" $=9.398 \mathrm{~m}$

*Elevation: $-3 \cdot 3 "+28^{\prime}-30^{\prime} 10^{\prime \prime}=-6^{\prime} 1 "=-1.8542 \mathrm{~m}$

* Hot Cell:

* The "hot cell" is a combination of 4 standard process cells.

* including STSCs and internals.

* Volume: $4 \star 114.63 \mathrm{~m} * 3=458.52 \mathrm{~m} * \star 3$

* Sed. Area: $4 * 16.82 \mathrm{~m} * \star 2=67.28 \mathrm{~m} \mathrm{~m}^{\star} 2$

* Elevation: -3.25 '

REGIONS

SAME AS

LABEL

VOLUME

SED AREA

ELEVATION

TEMP GAS

PRESSURE

7
6
COLD-CELL
4435.48
521.42
-0.9906
32.0
1.055
6.7056

11
6
CELL-2R

222.71

33.21

$-0.9906$

32.0

12
6

CELL-2L

251.39

33.21

$-1.8542$

32.0

$1.0 \mathrm{E} 5$

$1.0 \mathrm{E} 5$

7.5692

14

6

HOT-CELL

458.52

67.28

$-0.9906$

32.0

ND REGIONS

GASES

SAME AS

END GASES

* VENTS AND DUCTING

$\star$

* Vent duct (runs along the face of 40 standard cells, each 18' wide):

*Volume: $\quad \mathrm{L}=36 * 18^{\prime} \mathrm{W}=10.5^{\prime} \mathrm{H}=10.5^{\prime} \mathrm{V}=71442 \mathrm{ft} * \star 3=2023.0 \mathrm{~m} * * 3$

* Sed. Area: $L=36 * 18, W=10.5$ ' $A=6804 \mathrm{ft} \star \star 2=632.1 \mathrm{~m} * \star 2$

* Z-top: $\quad \mathrm{H}=10.5^{\prime}=3.2 \mathrm{~m}$

* Elevation: $-3.25^{\prime}=-0.9906 \mathrm{~m}$

REGIONS

SAME_AS 6

LABEL VENT

VOLUME 2023.0

SED_AREA 632.1

ELEVATION $\quad-0.9906$

TEMP_GAS 32.0

PRESSEURE 1.OE5

ZTOP

3.2

END REGIONS

GASES

SAME_AS

END GASES

* Pipe Trench:

* Sed. Area: $L=\left(35 \times 20^{\prime}\right) \quad W=8^{\prime} A=5600 \mathrm{ft} * \star 2=520.26 \mathrm{~m} * * 2$

* Volume: $\quad \mathrm{H}=\left(35 \times 20^{\prime}\right) \mathrm{W}=8^{\prime}, \mathrm{H}=6^{\prime} \mathrm{V}=33600 \mathrm{ft} * * 3=951.45 \mathrm{~m} * * 3$

* Z-top: $\quad \mathrm{H}=6^{\prime}=1.83 \mathrm{~m}$

* Elevation: $10.5^{\prime}$ below canyon deck $\left(14.25^{\prime}=28^{\prime}-3.25^{\prime}-10.5^{\prime}=\right.$ )

* STSC bottom elevation: 0 '

* T-Cell floor elevation: -3.25 '

* Canyon deck elevation: $28^{\prime}-3.25^{\prime}=24.75^{\prime}$

* Pipe trench cover block depth: 4.5'

* Pipe trench floor elevation: $24.75^{\prime}-4.5^{\prime}-6^{\prime}=14.25^{\prime}=4.3434 \mathrm{~m}$ 
FAl/10-83

PRC-STP-00241, Rev 0

Rev. 0

$$
\begin{aligned}
& \text { REGIONS } \\
& \text { LABEL } \\
& \text { VOLUME } \\
& \text { SED_AREA } \\
& \text { ELEVATION } \\
& \text { ZTOP } \\
& \text { TEMP_GAS } \\
& \text { PRESSURE }
\end{aligned}
$$

Page 185 of 284

March, 2010

SAME_AS $\quad 9$

END GASES

* 24 " Pipe:

* Sed. Area: $D=2^{\prime} \quad \mathrm{L}=7^{\prime}+2 * 13^{\prime} \mathrm{A}=\mathrm{D}=\mathrm{L}=66 \mathrm{ft} \star \star 2=6.1316 \mathrm{~m} * 2$

* Volume: $\mathrm{D}=2 \mathrm{I}^{\prime} \mathrm{L}=7 \mathrm{\prime}+2 * 13 \mathrm{I}^{\prime} \mathrm{V}=103.67 \mathrm{ft} \star * 3=2.9357 \mathrm{~m} * 3$

* Z-top: $D=21=0.6096 \mathrm{~m}$

* Elevation: $-3.25^{\prime}+28^{\prime}-19^{\prime}=5.75^{\prime}=1.7526 \mathrm{~m}$

* Exhaust duct :

* Sed. Area: $L=145^{\prime}, W=4, A=580 \mathrm{ft} * \star 2=53.88 \mathrm{~m} * \star 2$

* Volume: $\quad L=145^{\prime} W=4, H=7, V=4060 \mathrm{ft} * \star 2=115.0 \mathrm{~m} * \star 2$

* Z-top: $\quad \mathrm{H}=7$

* Elevation: $-3.25^{\prime}=-0.9906 \mathrm{~m}$

REGIONS

SAME_AS

VOLUME

SED AREA

ELEVATION

ZTOP

TEMP_GAS

PRESSTURE

END REGIONS

$\begin{array}{rr}13 & 16 \\ 8 & 8\end{array}$

PIPE-24 EXH-DUCT

$2.9357 \quad 115.0$

$6.1316 \quad 53.88$

$1.7526 \quad-0.9906$

$0.6096 \quad 2.1336$

$32.0 \quad 32.0$

$1.0 \mathrm{E} 5 \quad 1.0 \mathrm{E} 5$

GASES

SAME_AS

$\begin{array}{rr}13 & 16 \\ 8 & 8\end{array}$

* ATMOSPHERES

* Canyon Length $=43^{\prime}+680^{\prime}+38.5^{\prime}=761.5 \mathrm{ft}=232.1 \mathrm{~m}$

* Lower H $=25^{\prime} \mathrm{g}^{\prime \prime}=7.85 \mathrm{~m}, \mathrm{~W}=37^{\prime} \mathrm{2}^{\prime \prime}, \mathrm{AXI}=88.96 \mathrm{~m} * \star 2$

* Upper $\mathrm{H}=14 \mathrm{\prime}^{\prime}=4.27 \mathrm{~m}, \mathrm{~W}=6012 \mathrm{\prime}, \mathrm{AX} 2=78.30 \mathrm{~m} * \star 2$

* Crane $\mathrm{H}=9 \cdot 3 " \quad, \mathrm{~W}=10^{\prime}, \mathrm{Ax} 3=8.60 \mathrm{~m} * \star 2$

* Canyon total height $=25^{\prime} 9^{\prime \prime}+14^{\prime}+9^{\prime} 3^{\prime \prime}=49^{\prime}=14.9352 \mathrm{~m}$

* Volume $=232.1 \times(88.96+78.30+8.60)=40,818 \mathrm{~m} * * 3$

* Sed area $232.1 \mathrm{~m} \times 60 \mathrm{ft}=4245 \mathrm{~m} \star 22$

REGIONS

LABEL

VOLUME

10

SED_AREA

ELEVATION

TEMP_GAS

PRESSURE

ZTOP

ZTOP

CANYON

40818 . EO

4245 . E0

7.5438

32.0

1. $0 \mathrm{E} 5$

14.9352

1. $\mathrm{E} 3$

15

AMBIENT

1.E9

1. $\mathrm{E} 6$

7.5438

25.0

1. $0 \mathrm{E} 5$

1. E3

1.E3

END REGIONS

* GASES

STEAM

OXYGEN

10

0.01

0.20

0.79

15

0.01

0.20

0.79

* control boundary pRessure

OFFSET_TIMEPG $\quad 0.0$ 
FAl/10-83

\section{PRC-STP-00241, Rev 0}

Rev. 0

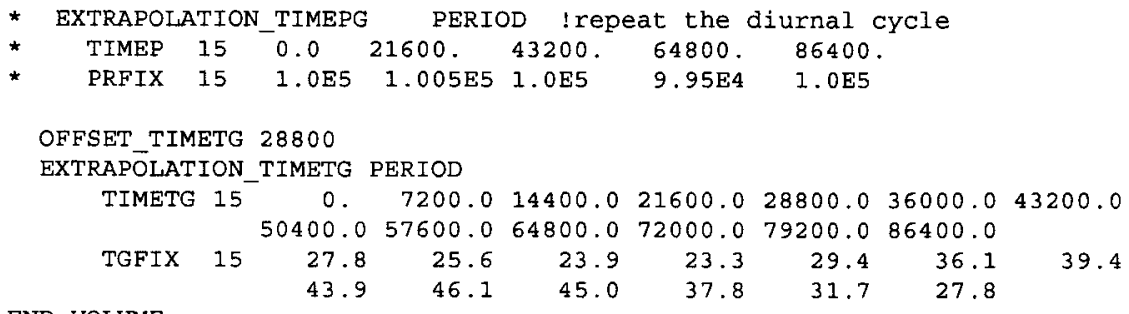

END VOLUME

HEAT SINKS

*

* Cell concrete heat sinks

* ignore heat transfer to fLoor

* thickness of sidewall $=1.067$ (3.5')

* thickness of front/back wall $=1.372\left(4.5^{\prime}\right)$

* thickness of cover block $=1.829\left(6^{1}\right)$

* one-sided area of long sidewall $=2 \times 5.3848(17 \cdot 8 ") * 6.7056\left(22^{\prime}\right)=72.217$

* one-sided area of short sidewall $=2 \times 3.9624\left(13^{\prime}\right) * 6.7056\left(22^{\prime}\right)=53.141$

* one-sided area of cover block $=5.3848\left(17^{\prime} 8^{\prime \prime}\right) * 3.9624\left(13^{\prime}\right)=21.337$

* process cell process cell cell

* long sidewall short sidewall cover block

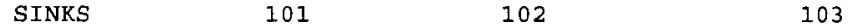

*

$\begin{array}{lccc}\text { LABEL } & \text { PC-LSW } & \text { PC-SSW } & \text { PC-COV } \\ \text { IORIHS } & 0 & 0 & 1 \\ \text { IGEOM } & 1 & 1 & 1 \\ \text { IMATHS } & 3 & 3 & 3 \\ \text { XRI } & 0.0 & 0.0 & 0.0 \\ \text { XRO } & 1.067 & 1.372 & 1.829 \\ \text { AHS } & 72.217 & 53.141 & 21.337 \\ \text { TIINIT } & 35.00 & 35.00 & 32.00 \\ \text { TOINIT } & 35.00 & 35.00 & 35.00 \\ \text { IMSLAB } & 20 & 20 & 20 \\ \text { IREGI } & 6 & 6 & 10 \\ \text { IREGO } & 0 & 0 & 6 \\ \text { XLHS } & 6.7056 & 6.7056 & 3.9624 \\ \text { XZHS } & 6.7056 & 6.7056 & 3.9624 \\ \text { ZTHS } & 5.7150 & 5.7150 & 7.5438 \\ \text { ZBHS } & -0.9906 & -0.9906 & 5.7150\end{array}$

END

31 COLD CELLS

long sidewall

$\begin{array}{lccc}\text { LABEL } & \text { CC-LSW } & \text { CC-SSW } & \text { CC-COV } \\ \text { SAME_AS } & 101 & 102 & 103 \\ \text { AHS } & 2.239 E 3 & 1.647 \mathrm{E} 3 & 6.614 \mathrm{E2} \\ \text { TIINIT } & 32.00 & 32.00 & 32.00 \\ \text { TOINIT } & 32.00 & 32.00 & 32.00 \\ \text { IREGI } & 7 & 7 & 10 \\ \text { IREGO } & 0 & 0 & 7\end{array}$

END

CELL 2R

* one-sided area of long sidewall $=1 \times 8.3820\left(27^{\prime} 6^{\prime \prime}\right) * 6.7056(221)=56.206$

* one-sided area of short sidewall $=2 \times 3.9624\left(13^{\prime}\right) \star 6.7056\left(22^{\prime}\right)=53.141$

* one-sided area of cover block $=8.3820\left(27^{\prime} 6^{\prime \prime}\right) * 3.9624\left(13^{\prime}\right)=33.213$

* long sidewall long sidewall short sidewall cover block 
FAl/10-83

Rev. 0

SINKS

* LABEL

SAME AS

AHS

TIINIT

TOINIT

IREGI

IREGO

END

*

*

$\star$

*

SINKS

LABEL

SAME_AS

IREGI

IREGO

END

$$
\text { * }
$$

*

*

SINKS

*

LABEL
SAME AS

AHS

IREGI

IREGO

END

*

*

$\star 2 \times 10.5 \times$

SINKS

\section{IORIHS}

IGEOM

IMATHS

XRI

XRO

AHS

TI INIT

TOINIT

IMSLAB

IREG I

IREGO

XLHS

$X Z H S$

ZTHS

ZBHS

END

$\star$

$\star$

* lower canyon walls: $5 \mathrm{ft}$ thick, $7.85 \mathrm{~m}$ high, $260.5 \mathrm{~m}$ long, x2

* upper canyon walls: 3 ft thick, $4.27 \mathrm{~m} \mathrm{high,} \mathrm{x2}$

औ SINKS

*

SINKS

IORIHS

IGEOM

IMATHS

XRI

XRO

AHS
111

$2 \mathrm{R}-\mathrm{LSW}$

101

56.206

32.00

32.00

11

CELL 2L

long sidewall

116

2L-LSW

111

12
0

4 HOT CELLS

long sidewall short sidewall

127

CC-SSW

102

212.6

14
112

2R-SSW

102

53.141

32.00

32.00

11
0

short sidewall

$$
117
$$

$2 \mathrm{~L}-\mathrm{SSW}$

112

12
0

cover block

128

$\mathrm{CC}-\mathrm{COV}$

103

85.35

10
VENT DUCT

121

0

0.0

1.52

1405.4

2.0

2. 0

20

3.20

3.20

2.21

$-0.9906$

CANYON
131

0
1
3
0.0
1.52
4090.0

4090.0
132

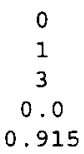

2224.7
Page 187 of 284

March, 2010
113

$2 \mathrm{R}-\mathrm{COV}$

103

33.213

32.0

32.0

10 
FAl/10-83

PRC-STP-00241, Rev 0

Rev. 0

$\begin{array}{lcc}\text { TIINIT } & 32.00 & 32.00 \\ \text { TOINIT } & 32.00 & 35.00 \\ \text { IMSLAB } & 20 & 20 \\ \text { IREGI } & 10 & 10 \\ \text { IREGO } & 0 & 0 \\ \text { XLHS } & 12.0 & 12.0 \\ \text { XZHS } & 12.0 & 12.0 \\ \text { ZTHS } & 15.394 & 19.664 \\ \text { ZBHS } & 7.5438 & 15.394\end{array}$

$\mathrm{ZBH}$

* $\quad$ PIPE TRENCH

* PIPE TRENCH WALI IS $2 \times 6 \times(35 \times 20) \quad F T * * 2$

* COVER IS $8 \times(35 \times 20) \quad F T * \star 2$

* wall cover

SINKS 122

*

IORIHS 0

IGEOM 1

$\begin{array}{lll}\text { XRI } & 0.0 & 0.0\end{array}$

$\begin{array}{lll}X R O & 1.52 & 1.37\end{array}$

AHS $\quad 781.0 \quad 520.5$

TIINIT $\quad 32.00 \quad 32.00$

$\begin{array}{lll}\text { TOINIT } & 32.00 & 32.00\end{array}$

IMSLAB $\quad 20 \quad 20$

IREGI 90

$\begin{array}{lll}\text { XLHS } & 1.83 & 1.83\end{array}$

XZHS $1.83 \quad 1.83$

$\begin{array}{lll}\text { ZTHS } & 6.1710 & 7.5438\end{array}$

$\begin{array}{lll}\text { ZBHS } & 4.3426 & 6.1710\end{array}$

END

*

* length $=2.1336+2 * 3.9624=10.0584$

$\begin{array}{lll}\text { SINKS } & 124 & 125\end{array}$

IORIHS $\quad 0$

$\begin{array}{lll}\text { IGEOM } & 0 & 0\end{array}$

IMATHS 3

$X R T$

$\mathrm{XRO}$

AHS

0.6096

5.0

177.3

32.00

32.00

30

IREGI

IREGO

XLHS

0

0

12.0

10.1

$?$

$! \quad$ ZTHS

END

END HEAT_SINKS

JUNCTIONS

\#-1.-1...

* Canyon to cells \& pipe trench through cover block gaps

* Path 11: Process cell to canyon via gap

* [References needed for CJN, KFILTER]

$\star \mathrm{IRI}=6=\mathrm{T}-\mathrm{Cel} \mathrm{I}$

$\star \mathrm{zIJN}=$ Cell height $=$ ZTOP $=6.7056 \mathrm{~m}$

* IR2 = 10 = Canyon 
FAl $/ 10-83$

PRC-STP-00241, Rev 0

Rev. 0

$\star$ z2JN $=$ Canyon floor $=0.0 \mathrm{~m}$

Page 189 of 284

*

PATHS 11

LABEL TCELL-GAP

IJTYP 8

ICCJN 0

IRI

IR2

IHORIZ

AJN 1.0

ZIJN $\quad 6.7056$

Z2JN 0.0

CJN 1.E-5

KFILTER 382.15

FGASIJN 1.0

XLJN 1.0

XWJN 1.0

XHJN 1.0

PATHS

* Path 12: Canyon to cold cells via cover block gaps

* [References needed for CJN]

* IRI = $10=$ Canyon

* $\mathrm{ZlJN}=$ Canyon floor $=0.0 \mathrm{~m}$

* IR2 = $7=$ cold cells

* $\mathrm{Z2JN}=\mathrm{Cell}$ height $=\mathrm{ZTOP}=6.7056 \mathrm{~m}$

* $\operatorname{kFILTER}=1 /(\operatorname{sum}[i=1.35](1 / \operatorname{KFILTER}$ tcell $))$

* $\quad$ KFILTER_tcell / 35

* $\quad 382.15 / 35=10.92$

* Path 15: Canyon to pipe trench via cover block gaps

* [References needed for CJN, KFILTER]

* IRl = $10=$ Canyon

* ZlJN = Canyon floor $=0.0 \mathrm{~m}$

* $\operatorname{IR2}=9$ = Pipe trench

* $\mathrm{Z2JN}=$ Trench height $=\mathrm{ZTOP}=1.83 \mathrm{~m}$

* KFILTER $=($ Kwidth * Klength $) /(2 *($ Kwidth + Klength $))$

$\star \quad=(389.7 * 1781.1) /(2 *(389.7+1781.1))$

$\star \quad \quad=159.87$

* Path 17: Cell 2R to canyon via cover block gaps

* [References needed for CJN, KFILTER]

$\star$ IRI $=11=\operatorname{Cell} 2 \mathrm{R}$

* $\mathrm{ZlJN}=$ Cell $2 \mathrm{R}$ height $=$ ZTOP $=6.7056 \mathrm{~m}$

* IR2 = 10 = Canyon

$\star \mathrm{Z} 2 \mathrm{JN}=$ Canyon floor $=0.0 \mathrm{~m}$

* Path 22: Hot cells to canyon via cover block gaps

* [References needed for CJN]

* IRI = $14=$ Hot cells

* $\mathrm{ZIJN}=$ Cell height $=\mathrm{ZTOP}=6.7056 \mathrm{~m}$

* IR2 = $10=$ Canyon

^ $\mathrm{Z} 2 \mathrm{JN}=$ Canyon floor $=0.0 \mathrm{~m}$

* KFILTER $=1 /(\operatorname{sum}[i=1.5](1 /$ KFILTER_tcell $))$

$\star \quad=$ KFILTER_tcell / 5

* $\quad 382.15 \% 5=76.43$

$\begin{array}{lcccc}\text { PATHS } & 12 & 15 & 17 & 22 \\ \text { SAME_AS } & 11 & 11 & 11 & 11 \\ \text { LABEL } & \text { GAP-COLD } & \text { GAP-PIPE } & \text { C2R-GAP } & \text { HOT-GAP } \\ \text { IJTYP } & 8 & 8 & 8 & 8 \\ \text { IRI } & 10 & 10 & 11 & 14 \\ \text { IR2 } & 7 & 9 & 10 & 10 \\ \text { IHORIZ } & 1 & 1 & 1 & 1 \\ \text { AJN } & 1.0 & 1.0 & 1.0 & 1.0 \\ \text { ZIJN } & 0.0 & 0.0 & 6.7056 & 6.7056 \\ \text { Z2JN } & 6.7056 & 1.83 & 0.0 & 0.0 \\ \text { CJN } & 1 . E-5 & 1 . E-5 & 1 . E-5 & 1 . E-5 \\ \text { KFILTER } & 10.92 & 159.87 & 231.95 & 76.43 \\ \text { FGASIJN } & 1.0 & 1.0 & 1.0 & 1.0 \\ \text { XLJN } & 1.0 & 1.0 & 1.0 & 1.0\end{array}$


FAl/10-83

PRC-STP-00241, Rev 0

Rev. 0

XWJN

$$
1.0
$$

1.0

$$
\begin{aligned}
& 1.0 \\
& 1.0
\end{aligned}
$$

1.0

1.0

1.0

* Path 18: Canyon to Cell 2L

* [References needed for CJN]

* IRI = 10 = Canyon

* $\mathrm{ZlJN}=$ Canyon floor $=0.0 \mathrm{~m}$

- $\operatorname{IR} 2=12=\operatorname{cell} 2 \mathrm{~L}$

$* \mathrm{Z} 2 \mathrm{JN}=\mathrm{Full}$ cell $2 \mathrm{~L}$ height $=30110 "=9.397 \mathrm{~m}$

$\star \mathrm{AJN}=\mathrm{SED}$ AREA $=33.21 \mathrm{~m} \star \star 2$

$* \mathrm{XLJN}=\mathrm{L}=27.5^{\prime}=8.3820 \mathrm{~m}$

$\star X W J N=W=13^{\prime}=3.9624 \mathrm{~m}$

* XHJN $=0.001 \mathrm{~m}=$ thin

$\begin{array}{ll}\text { PATHS } & 18 \\ \text { LABEL } & \text { CANYON } \\ \text { IJTYP } & 1 \\ \text { IR1 } & 10 \\ \text { IR2 } & 12 \\ \text { IHORIZ } & 1 \\ \text { AJN } & 33.21 \\ \text { ZIJN } & 0.0 \\ \text { Z2JN } & 9.397 \\ \text { CJN } & 2.8 \\ \text { FGAS1JN } & 1.0 \\ \text { XLJN } & 8.3820 \\ \text { XWJN } & 3.9624 \\ \text { XHJN } & 0.001\end{array}$

* Cells to ventilation duct

* Path 13: Cold cells to ventilation duct via 10"-dia pipe.

* [Reference needed for CJN]

* IRI $=7=$ cold cells

* ZIJN $=9^{\prime}=2.7432 \mathrm{~m}$

* IR2 = 8 = Ventilation duct

$\star \mathrm{Z} 2 \mathrm{JN}=$ top of duct $=\mathrm{ZTOP}=10.5^{\prime}=3.2004 \mathrm{~m}$

$\star$ CJN $=(1 / 0.6) * \star 2=2.8$

* Consider 35 pipes for 35 cold cells:

$\star \mathrm{AJN}=35 * \mathrm{pi} / 4 *(\mathrm{D} * \star 2)$

* $\quad=19.1 \mathrm{Et} * * 2$

* $\quad=1.7735 \mathrm{~m} * * 2$

$\star$ XLJN $=10^{\circ}=2.5 \mathrm{~m}$

* XWJN $=10 "=0.254 \mathrm{~m}$

$\star X H J N=10^{n}=0.254 \mathrm{~m}$

* Path 14: Ventilation duct to process cell via 10"-dia pipe.

* [References needed for CJN]

* IRI = 8 = Ventilation duct

$\star \mathrm{ZlJN}=$ top of duct $=\mathrm{ZTOP}=10.5^{\prime}=3.2004 \mathrm{~m}$

* IR2 $=6=T$ cell

$\star \mathrm{Z} 2 \mathrm{JN}=9^{\prime}=2.7432 \mathrm{~m}$

$\star C J N=(1 / 0.6) \star \star 2=2.8$

$\star \mathrm{AJN}=\mathrm{pi} / 4 *(\mathrm{D} * * 2)$

* $\quad=0.5454 \mathrm{ft} * * 2$

* $\quad=0.05067 \mathrm{~m} * * 2$

$\star X L J N=10^{\prime}=2.5 \mathrm{~m}$

* XWJN $=10^{\prime \prime}=0.254 \mathrm{~m}$

$\star X H J N=10^{\prime \prime}=0.254 \mathrm{~m}$

* Path 21: Ventilation duct to hot cells via 10"-dia pipe.

* [References needed for CJN]

* IRI = 8 = ventilation duct

$\star \mathrm{ZIJN}=$ top of duct $=$ ZTOP $=10.5^{\prime}=3.2004 \mathrm{~m}$

* IR2 $=14=$ Hot cells

* $\mathrm{Z} 2 \mathrm{JN}=9^{\circ}=2.7432 \mathrm{~m}$

* $\mathrm{CJN}=(1 / 0.6) \star \star 2=2.8$

* Consider 5 pipes for 5 hot cells:

* $\mathrm{AJN}=5 * \mathrm{pi} / 4 *\left(\mathrm{D}^{*} * 2\right)$ 
$\star X W J N=10^{\prime \prime}=0.254 \mathrm{~m}$

$\star \mathrm{XHJN}=10 "=0.254 \mathrm{~m}$

$\begin{array}{llll}\text { PATHS } & 13 & 14 & 21 \\ \text { LABEL } & \text { COLD-VENT } & \text { VENT-TCELL } & \text { VENT-HOT } \\ \text { IJTYP } & 1 & 1 & 1 \\ \text { ICCJN } & 0 & 0 & 0 \\ \text { IR1 } & 7 & 8 & 8 \\ \text { IR2 } & 8 & 6 & 14 \\ \text { IHORIZ } & 0 & 0 & 0 \\ \text { AJN } & 1.7735 & 0.05067 & 0.25335 \\ \text { Z1JN } & 2.7432 & 3.2004 & 3.2004 \\ \text { Z2JN } & 3.2004 & 2.7432 & 2.7432 \\ \text { CJN } & 2.8 & 2.8 & 2.8 \\ \text { KFILTER } & 0.0 & 0.0 & 0.0 \\ \text { FGAS1JN } & 1.0 & 1.0 & 1.0 \\ \text { XLJN } & 2.5 & 2.5 & 2.5 \\ \text { XWJN } & 0.254 & 0.254 & 0.254 \\ \text { XHJN } & 0.254 & 0.254 & 0.254\end{array}$

END PATHS

*? Single cell pair $\mathrm{K}=160$; divide by 17.5

* Pipe trench to ventilation duct

* Path 16: Pipe trench to ventilation duct via 18 10"-dia pipes.

* [Reference needed for CJN]

* IRI = $9=$ Pipe trench

* $\mathrm{ZIJN}=$ Pipe trench floor $=0 \mathrm{~m}$

* IR2 = 8 = Ventilation duct

* $\mathrm{Z} 2 \mathrm{JN}=$ top of duct $=\mathrm{ZTOP}=10.5^{\prime}=3.2004 \mathrm{~m}$

$\star \mathrm{CJN}=(1 / 0.6) \star \star 2=2.8$

* Consider 18 pipes for 18 cold cells:

* $\mathrm{AJN}=18 * \mathrm{pi} / 4 *(\mathrm{D} * * 2)$

* $\quad=9.8229 \mathrm{ft} * * 2$

* $\quad=0.9121 \mathrm{~m} * 2$

$\star X L J N=10^{\circ}=2.5 \mathrm{~m}$

* XWJN $=10^{\prime \prime}=0.254 \mathrm{~m}$

$\star \mathrm{XHJN}=10^{\prime \prime}=0.254 \mathrm{~m}$

PATHS 16

LABEL PTRENCH-VENT

IJTYP 1

ICCJN 0

IRI

IHORIZ 1

AJN $\quad 0.9121$

ZIJN $\quad 0.0$

Z2JN $\quad 3.2004$

CJN 2.8

FGAS1JN 1.0

XLJN 2.5

XWJN $\quad 0.254$

XHJN $\quad 0.254$

END PATHS

* Long cells to $24 "$ pipe

* Path 19: Cell 2L to 24" vent pipe via 10"-dia pipes.

* [Reference needed for CJN]

* IRI = $12=\operatorname{cell} 2 \mathrm{~L}$

* $\mathrm{zlJN}=6.9 "$ below canyon deck (note: 5'8" is at cover block level)

* $\quad$ ZTOP $12-6.9 "$

* $\quad=7.56 \overline{9} 2 \mathrm{~m}-2.0574 \mathrm{~m}$

* $\quad=5.5118 \mathrm{~m}$

* IR2 $=13=24 "$ pipe

$\star \mathrm{Z} 2 \mathrm{JN}=0 \mathrm{~m}$ 
FAl/10-83

\section{PRC-STP-00241, Rev 0}

Rev. 0

$\star \mathrm{CJN}=(1 / 0.6) * 22=2.8$

$\star \mathrm{AJN}=\mathrm{pi} / 4 *(\mathrm{D} * * 2)$

$\star \quad \quad=0.5454 \mathrm{ft} \star \star 2$

$\star \quad \quad=0.05067 \mathrm{~m} \star \star 2$

$\star X \mathrm{XJNN}=10^{\prime}=2.5 \mathrm{~m}$

* $\mathrm{XWJN}=10^{\prime \prime}=0.254 \mathrm{~m}$

$\star \mathrm{XHJN}=10 "=0.254 \mathrm{~m}$

* Path 20: Cell 2R to 24" vent pipe via 10"-dia pipes.

* [Reference needed for CJN]

* IRI = $13=24 "$ pipe

* ZIJN $=0 \mathrm{~m}$

* IR2 = $11=\mathrm{Cell} 2 \mathrm{R}$

* Z2JN $=6.9 "$ below canyon deck

* $\quad$ ZTOP_12 - 6.9"

* $\quad=7.56 \overline{92} \mathrm{~m}-2.0574 \mathrm{~m}$

* $\quad=5.5118 \mathrm{~m}$

* $\operatorname{CJN}=(1 / 0.6) * * 2=2.8$

*AJN $=p i / 4 *(D * * 2)$

* $\quad=0.5454 \mathrm{ft} * * 2$

* $\quad=0.05067 \mathrm{~m} * \star 2$

$\star X \mathrm{XJJN}=10^{\circ}=2.5 \mathrm{~m}$

$\star X W J N=10^{\prime \prime}=0.254 \mathrm{~m}$

$\star \mathrm{XHJN}=10^{\prime \prime}=0.254 \mathrm{~m}$

PATHS $19 \quad 20$

LABEL C2L-PIPE PIPE-C2R

IJTYP

ICCJN

IRI

IR2

IHORIZ

$\begin{array}{lll}\text { AJN } & 0.05067 & 0.05067\end{array}$

$\begin{array}{lll}Z 1 \mathrm{JN} & 5.5118 & 0.0\end{array}$

$\begin{array}{lll}Z 2 . J N & 0.0 & 5.5118\end{array}$

$\begin{array}{lll}\text { CJN } & 2.8 & 2.8\end{array}$

FGASIJN $1.0 \quad 1.0$

$\begin{array}{lll}X L J N & 2.5 & 2.5\end{array}$

$\begin{array}{lll}X W U N & 0.254 & 0.254\end{array}$

$\begin{array}{lll}\text { XHJN } & 0.254 & 0.254\end{array}$

END PATHS

* 24" pipe and vent duct to exhaust duct

* Path 25: Ventilation duct to exhaust duct

* [Reference needed for CJN]

* IRI = 8 = Ventilation duct

* ZlJN = Vent duct floor $=0.0 \mathrm{~m}$

* IR2 = 16 = Exhaust duct

$\star$ Z2JN $=$ Exhaust duct floor $=0.0 \mathrm{~m}$

$\star A J N=5^{\prime} \star 4^{\prime}=20.0 \mathrm{ft} *{ }^{\prime} 2=1.8581 \mathrm{~m} * 2$

$\star$ XLJN $=$ thin $=0.001 \mathrm{~m}$

$\star$ XWJN $=4^{\prime}=1.2192 \mathrm{~m}$ (est.)

$\star \mathrm{XHJN}=5^{\prime}=1.5240 \mathrm{~m}$

* Path 27: 24" vent pipe to exhaust duct

* [Reference needed for CJN]

* IR1 = $13=24$ " pipe

* ZIJN $=0 \mathrm{~m}$

* IR2 = $16=$ Exhaust duct

* Z2JN = Vent duct floor $+4^{\prime}$

$\star \quad=4^{\prime}$

$\star \quad \quad=1.2192 \mathrm{~m}$

$\star \mathrm{CJN}=(1 / 0.6) \star \star 2=2.8$

$\star \mathrm{AJN}=\mathrm{pi} / 4 \star(\mathrm{D} \star 2)$

$\star \quad \quad=3.1416 \mathrm{ft} \star \star 2$

$\star \quad=0.2919 \mathrm{~m} \star \star 2$

$\star X L J N=10^{\prime}=3.048 \mathrm{~m}$ (est.)

$\star X W J N=24 "=0.6096 \mathrm{~m}$

* $\mathrm{XHJN}=24 \mathrm{n} / \sin (45)=0.8621 \mathrm{~m}$ 
FAl/10-83

PRC-STP-00241, Rev 0

Rev. 0

PATHS

LABEL VENT-EXH

IJTYP

ICCJN

IRI

IR2

IHORIZ

AJN

Z1JN

Z2JN

CJN

KFILTER

FGASIJN

XLJN

XWJN

XHJN

END PATHS

1
0
8

$1 . \pm-5$

27

PIPE-EXH

1

13

16

0

0.2919

0.0

1. 2192

2.8

0.0

1.0

$\begin{array}{ll}0.001 & 3.048 \\ 1.2192 & 0.6096\end{array}$

*

* Fan from exhaust duct to ambient

* fan flow rate $=17500 \mathrm{cfm}=8.2591 \mathrm{~m}^{\wedge} 3 / \mathrm{s}$

* fan flow rate $=0 \mathrm{~m}^{\wedge} 3 / \mathrm{s}$

* Path 26: Exhaust duct to ambient

* CJN not used, constant volumetric flow rate

* Set AJN to an arbitrary positive value

* so code does not bypass the junction

* IRI = 16 = Exhaust duct

$\star \mathrm{ZlJN}=0 \mathrm{~m}$

* IR2 = 15 = Ambient (atmosphere)

* $22 \mathrm{JN}=15 \mathrm{~m}$ (est.; stack height = 200'?)

PATHS 26

LABEL FAN

IJTYP 1

ICCJN

IRI $\quad 16$

IR2 15

IHORIZ 0

AJN $\quad 1.0$

Z1JN $\quad 0.0$

Z2JN 15.0

CJN $\quad 1.0$

KFILTER 0.0

FGASIJN 1.0

IFAN 1

WVFAN 8.2591

END PATHS

* Cell 2l and canyon to ambient

* Path 28: Ambient to Canyon

* Leakage modeled using KFILTER

* $17500 \mathrm{cfm}\left(82.6 \mathrm{~m}^{\wedge} 3 / \mathrm{s}\right)$ at 0.15 in $\mathrm{w} . \mathrm{g} .(35.9 \mathrm{~Pa})$

* Assume equal split between canyon leakage and

* access tunnel leakage.

* Hence, KFILTER $=35.9 /(82.6 / 2)=0.870$

* IRI = $15=$ Ambient (atmosphere)

* ZIJN $=$ ELEVATION_10 + ZTOP_10/2 - ELEVATION_15

$\star \quad=7.5438 \mathrm{~m}+14.9352 \mathrm{~m} / 2-7.5438 \mathrm{~m}$

* $\quad=7.4676 \mathrm{~m}$

* $\mathrm{IR} 2=10=$ Canyon

* Z2JN $=$ ZTOP_10/2

* $\quad=7.46 \overline{7} 6 \mathrm{~m}$

* Path 29: Ambient to Cell 2L

* Leakage modeled using KFILTER

* $17500 \mathrm{cmf}\left(82.6 \mathrm{~m}^{\wedge} 3 / \mathrm{s}\right)$ at $0.15 \mathrm{in} \mathrm{w.g.}(35.9 \mathrm{~Pa})$

* Assume equal split between canyon leakage and

* access tunnel leakage.

* Hence, KFILTER $=35.9 /(82.6 / 2)=0.870$ 
FAl/10-83

PRC-STP-00241, Rev 0

Rev. 0

^ $\mathrm{IRI}=15=$ Ambient (atmosphere)

$\star$ ZIJN $=$ ELEVATION_12 + ZTOP $12 / 2-$ ELEVATION 15

* $\quad=-1.8542 \mathrm{~m}+7.5692 \mathrm{~m} / 2-7.5438 \mathrm{~m}$

$\star \quad=-5.6134 \mathrm{~m}$

* IR2 $=12=\operatorname{Cell} 2 \mathrm{~L}$

* Z2JN $=$ ZTOP_12/2

$\star \quad=7.5692 \mathrm{~m} / 2$

* $\quad=3.7846 \mathrm{~m}$

PATHS

LABEL AMB-CANYON AMB-C2L

$\begin{array}{lll}\text { IJTYP } & 8 & 8 \\ \text { ICCJN } & 0 & 0\end{array}$

IRI $15 \quad 15$

IR2 $10 \quad 12$

$\begin{array}{lll}\text { IHORIZ } & 1 & 1 \\ \text { AJN } & 1.0 & 1.0\end{array}$

$\begin{array}{lll}\text { ZIJN } & 1.0 & 1.0 \\ \text { ZIJN } & 7.4676 & -5.6134\end{array}$

$\begin{array}{lll}Z 2 J N & 7.4676 & 3.7846\end{array}$

$\begin{array}{lll}\text { CJN } & 2.8 & 2.8\end{array}$

KFILTER $\quad 0.870 \quad 0.870$

FGASIJN $1.0 \quad 1.0$

$\begin{array}{lll}X L J N & 1.0 & 1.0\end{array}$

$\begin{array}{lll}\text { XWJN } & 1.0 & 1.0\end{array}$

$\begin{array}{lll}\text { XHJN } 1.0 & 1.0\end{array}$

END PATHS

END JUNCTIONS 
FAl/10-83

PRC-STP-00241, Rev 0

Rev. 0

B.8 Case File: SETTLF1.dat

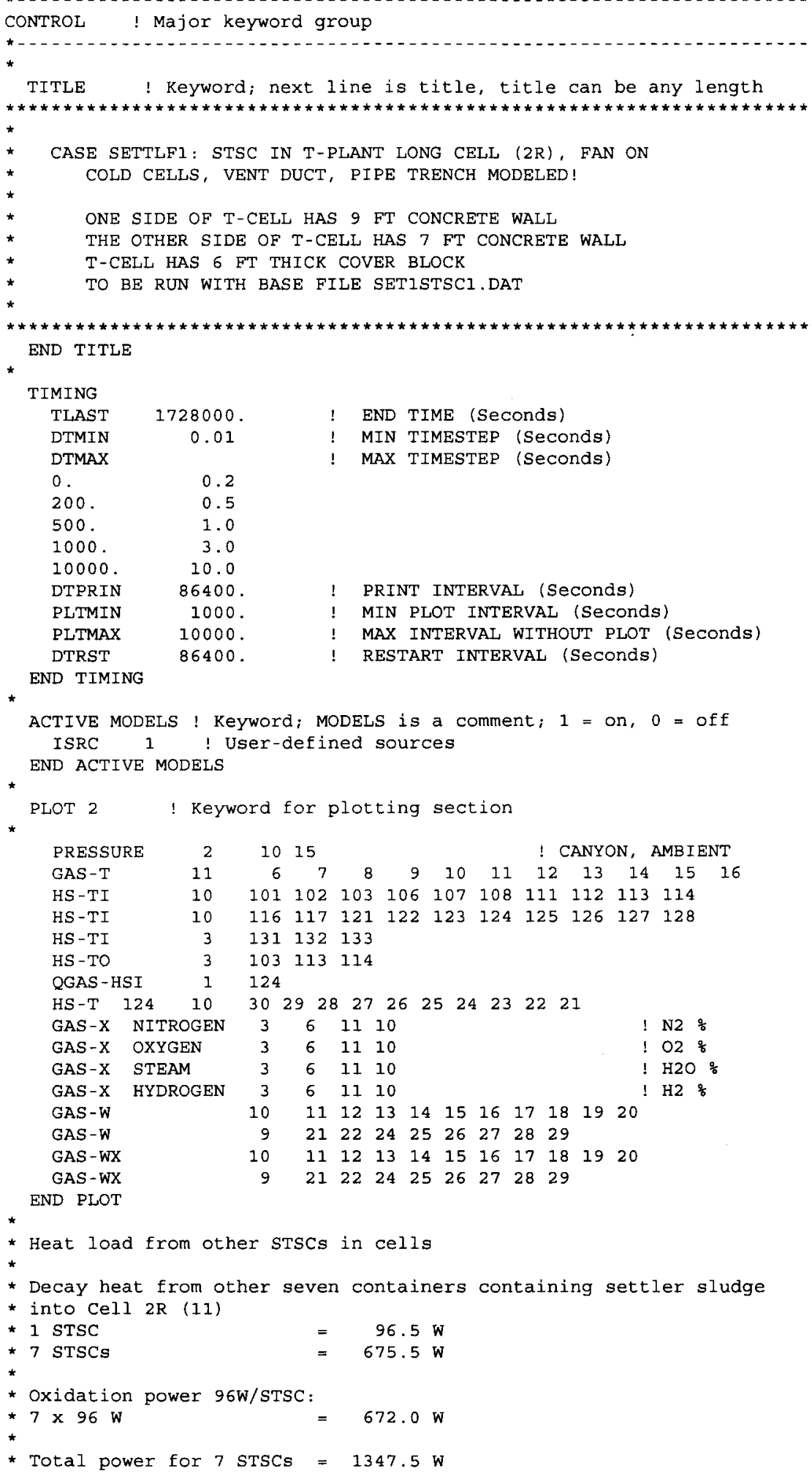


* H2 generation rate for $1 \mathrm{STSC}=7.0 \mathrm{E}-7 \mathrm{~kg} / \mathrm{s}$

* H2 generation rate for $7 \mathrm{STSCs}=4.9 \mathrm{E}-6 \mathrm{~kg} / \mathrm{s}$

* H2 released at $50 \mathrm{C}$

SOURCES 2

REGION 11 GASES 1 PHASE 1

HYDROGEN

$\begin{array}{llll}0 & 50.0 & 4.9 \mathrm{E}-6 & 1347.5 \\ 1 . \mathrm{E} 9 & 50.0 & 4.9 \mathrm{E}-6 & 1347.5\end{array}$

END REGION

* Decay heat from six containers containing settler sludge in each of

* Eour cells in the Hot Cell (14)

* 1 STSC

* Oxidation power $96 \mathrm{~W} / \mathrm{STSC}$.

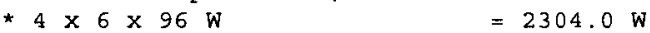

*

* Total power for $4 \times 6$ STSCs $=4620.0 \mathrm{~W}$

* H2 generation rate for 1 STSC $=7.00 \mathrm{E}-7 \mathrm{~kg} / \mathrm{s}$

* H2 generation rate for $24 \mathrm{STSCs}=1.68 \mathrm{E}-5 \mathrm{~kg} / \mathrm{s}$

* $\mathrm{H} 2$ released at $50 \mathrm{C}$

REGION 14 GASES 1 PHASE 1

HYDROGEN

$\begin{array}{llll}0 & 50.0 & 1.68 \mathrm{E}-5 & 4620.0\end{array}$

END REGION

END SOURCES

END CONTROL

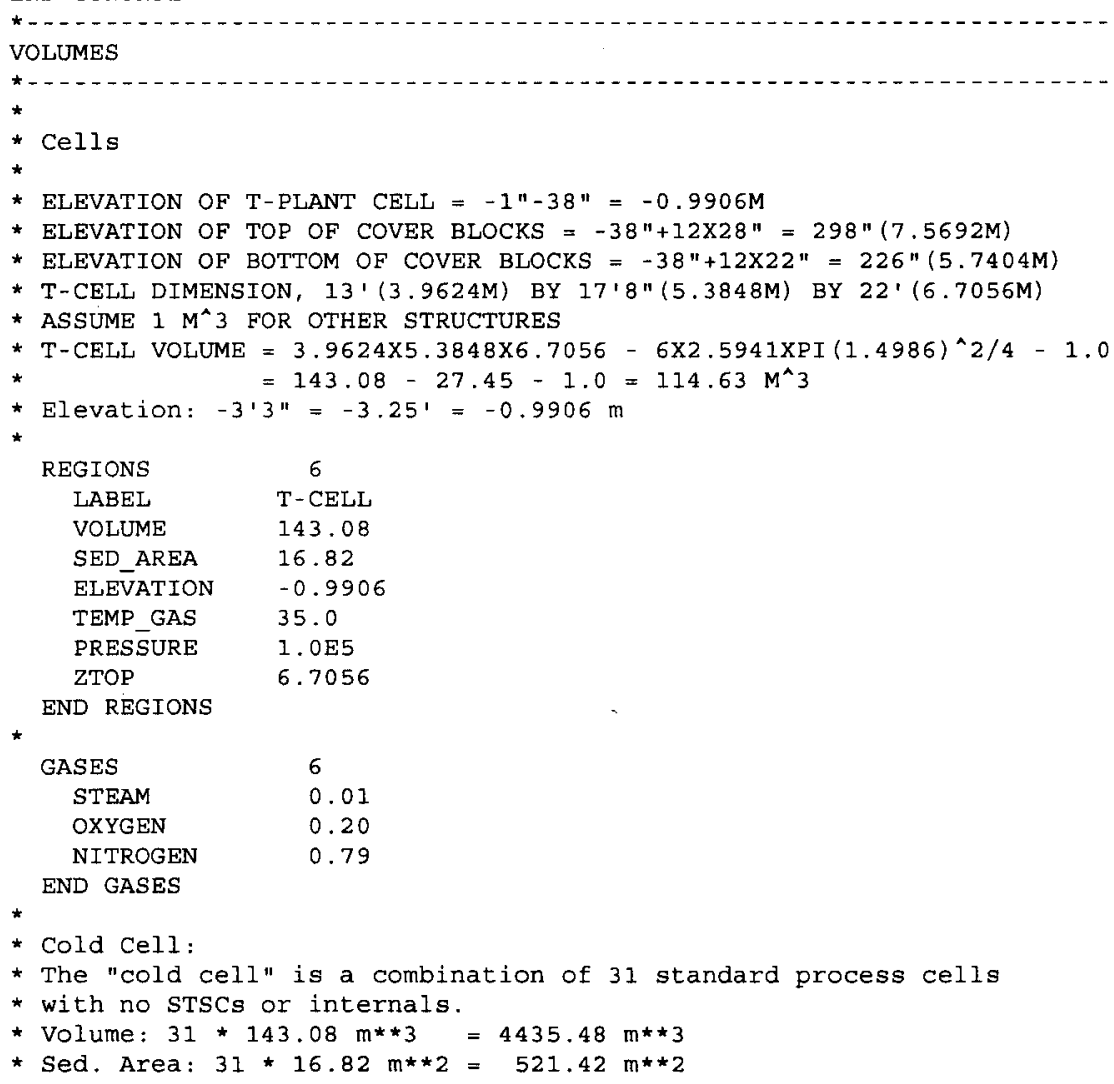


FAl/10-83

\section{PRC-STP-00241, Rev 0}

\section{Rev. 0}

* Elevation: $-3.25^{\prime}$

* Cell 2R:

* Volume: $\quad \mathrm{L}=27^{\prime} 6^{\prime \prime} \mathrm{W}=13^{\prime} \mathrm{H}=22^{\prime} \mathrm{V}=7865 \mathrm{ft} \star * 3=222.71 \mathrm{~m} * \star 3$

* Sed. Area: $L=27 \cdot 6 " W=13$, $A=357.5 \mathrm{ft} * \star 2=33.21 \mathrm{~m} * \star 2$

* Elevation: $-3.25^{\prime}$

* Cell 2L:

* Cell 2L is slightly deeper than $2 \mathrm{R}$ due to train tracks, plus has no cover

* blocks. This adds another 6 ' of height to the cell

*Volume: $\quad L=27^{\prime} 6^{\prime \prime} \mathrm{W}=13^{\prime} \mathrm{H}=30^{\prime} 10^{\prime \prime} \mathrm{V}=11022.92 \mathrm{ft} * \star 3=312.13 \mathrm{~m} * 3$

* Sed. Area: $L=27^{\prime} 6^{\prime \prime} \mathrm{W}=13^{\prime} \mathrm{A}=357.5 \mathrm{ft} \star \star 2=33.21 \mathrm{~m} \star \star 2$

* Z-top: H=30'10" = $9.398 \mathrm{~m}$

t Elevation: $-3 \cdot 3 \prime+28^{\prime}-30^{\prime} 10^{\prime \prime}=-6^{\prime} 1^{\prime \prime}=-1.8542 \mathrm{~m}$

* Hot Cell:

* The "hot cell" is a combination of 4 standard process cells.

* including STSCs and internals.

* Volume: $4 \star 114.63 \mathrm{~m} \star \star 3=458.52 \mathrm{~m} \star \star 3$

* Sed. Area: $4 \star 16.82 \mathrm{~m} \star 2=67.28 \mathrm{~m} \star \star 2$

* Elevation: -3.25 '

REGIONS

SAME_AS

LABEL

VOLUME

SED AREA

ELEVATION

TEMP GAS

PRESSURE

7

COLD-CELL

4435.48

521.42

$-0.9906$

32.0

1. $0 \mathrm{E} 5$

11

CELL-2R

12
6
CELL -2

185.11

33.21

$-0.9906$

32.0

251.39

33.21

$-1.8542$

32.0

$1.0 \mathrm{E} 5$
6.7056

1. $0 \mathrm{E} 5$

7.5692

14
6
HOT-CELI
458.52
67.28
-0.9906
32.0
$1.0 \mathrm{E} 5$
6.7056

END REGIONS

$\begin{array}{crrrr}\text { GASES } & 7 & 11 & 12 & 14 \\ \text { SAME_AS } & 6 & 6 & 6 & 6\end{array}$

END GASSES

* VENTS AND DUCTING

* Vent duct (runs along the face of 40 standard cells, each 18 ' wide):

* Volur

$\mathrm{L}=366^{\prime} 8^{\prime} \mathrm{W}=10.5^{\prime} \mathrm{H}=10.5^{\prime} \mathrm{V}=71442 \mathrm{ft} \star \star 3=2023.0 \mathrm{~m} \star \star 3$

* Sed. Arer

$\mathrm{L}=36$ * 18 ' $\mathrm{W}=10.5^{\prime} \mathrm{A}=6804 \mathrm{ft} \star \star 2=632.1 \mathrm{~m} \star \star 2$

* Z-top:

$\mathrm{H}=10.5^{\prime}=3.2 \mathrm{~m}$

* Elevation: $-3.25^{\prime}=-0.9906 \mathrm{~m}$

REGIONS

SAME AS

LABEL

8

VOLUME

VENT

SED AREA 632.1

ELEVATION $\quad-0.9906$

TEMP_GAS 32.0

PRESSURE $1.0 \mathrm{E} 5$

ZTOP 3.2

GASES

SAME AS

END GASES

* Pipe Trench.

* Sed. Area: $L=\left(35 \times 20^{\prime}\right), W=8, A=5600 \mathrm{ft} \star \star 2=520.26 \mathrm{~m} * 2$

* Volume: $\quad L=\left(35 \times 20^{\prime}\right) \mathrm{W}=8, \mathrm{H}=6^{\prime} \mathrm{V}=33600 \mathrm{ft} * \star 3=951.45 \mathrm{~m} * \star 3$

* Z-tOp: $\quad \mathrm{H}=6^{\prime}=1.83 \mathrm{~m}$

* Elevation: $10.5^{\prime}$ below canyon deck $\left(14.25^{\prime}=28^{\prime}-3.25^{\prime}-10.5^{\prime}=\right.$ )

* STSC bottom elevation: 01

* T-Cell floor elevation: -3.25 '

* Canyon deck elevation: $28^{\prime}-3.25^{\prime}=24.75^{\prime}$

* Pipe trench cover block depth: 4.5'

* Pipe trench floor elevation: $24.75^{\prime}-4.5^{\prime}-6^{\prime}=14.25^{\prime}=4.3434 \mathrm{~m}$ 
FAl/10-83

PRC-STP-00241, Rev 0

Rev. 0

REGIONS

LABEL

VOLUME

SED AREA

ELEVATION

ZTOP

TEMP GAS

PRESSURE

END REGIONS

GASES
SAME_AS

END GASES

* 24 " Pipe:

* Sed. Area: $\mathrm{D}=2^{\prime} \mathrm{L}=7^{\prime}+2 * 13^{\prime} \mathrm{A}=\mathrm{D} \star \mathrm{L}=66 \mathrm{ft} \star * 2=6.1316 \mathrm{~m} \star 2$

*Volume: $\mathrm{D}=2, \mathrm{~L}=7$ ' $+2 * 13^{\prime} \mathrm{V}=103.67 \mathrm{ft} * * 3=2.9357 \mathrm{~m} * 3$

* Z-top: D=2' $=0.6096 \mathrm{~m}$

* Elevation: $-3.25^{\prime}+28^{\prime}-19^{\prime}=5.75^{\prime}=1.7526 \mathrm{~m}$

* Exhaust duct :

* Sed. Area: $L=145^{\prime}, W=4, A=580 \mathrm{ft} * * 2=53.88 \mathrm{~m} * \star 2$

*Volume: $L=145^{\circ} \mathrm{W}=4^{\prime} \mathrm{H}=7^{\prime} \mathrm{V}=4060 \mathrm{ft} \star 2=115.0 \mathrm{~m} * * 2$

* Z-top: $\quad \mathrm{H}=7$

$\star$ Elevation: $-3.25^{\prime}=-0.9906 \mathrm{~m}$

REGIONS

SAME_AS

VOLUME

SED_AREA

ELEVATION

ZTOP

TEMP GAS

PRESSURE

END REGIONS

GASES

SAME_AS

END GASES

$\begin{array}{cc}13 & 16 \\ 8 & 8 \\ \text { PIPE-24 } & \text { EXH-DUCT } \\ 2.9357 & 115.0 \\ 6.1316 & 53.88 \\ 1.7526 & -0.9906 \\ 0.6096 & 2.1336 \\ 32.0 & 32.0 \\ 1.0 \mathrm{E} 5 & 1.0 \mathrm{E} 5\end{array}$

* atmospheres

* Canyon Length $=43^{\prime}+680^{\prime}+38.5^{\prime}=761.5 \mathrm{ft}=232.1 \mathrm{~m}$

* Lower $\mathrm{H}=25^{\prime} \mathrm{g}^{\prime \prime}=7.85 \mathrm{~m}, \mathrm{~W}=37.2 ", \mathrm{AXI}=88.96 \mathrm{~m} * 2$

$\star$ Upper $\mathrm{H}=14^{\prime}=4.27 \mathrm{~m}, \mathrm{~W}=60^{\prime} 2^{\prime \prime}, \mathrm{Ax} 2=78.30 \mathrm{~m} \star \star 2$

* Crane $\mathrm{H}=9.3 " \quad, \mathrm{~W}=10^{\prime}, \mathrm{Ax} 3=8.60 \mathrm{~m} * 2$

* Canyon total height $=25^{\prime} 9^{\prime \prime}+14^{\prime}+93^{\prime \prime}=49^{\prime}=14.9352 \mathrm{~m}$

* Volume $=232.1 \times(88.96+78.30+8.60)=40,818 \mathrm{~m} \star * 3$

* Sed area $232.1 \mathrm{~m} \times 60 \mathrm{ft}=4245 \mathrm{~m} * \star 2$

REGIONS

LABEL

VOLUME

SED AREA

ELEVATION

TEMP GAS

PRESS̄URE

ZTOP

ZTOP

END REGIONS

GASES

STEAM

OXYGEN

NITROGEN

END GASES

* control boundary pREssure

* OffSET_tIMEPG 0.0
Page 198 of 284

March, 2010 
$\mathrm{FAl} / 10-83$

PRC-STP-00241, Rev 0

Rev. 0

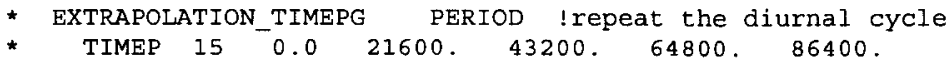

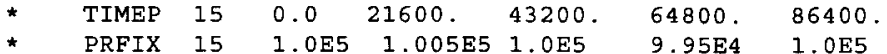

OFFSET_TIMETG 28800

EXTRAPOLATION_TIMETG PERIOD

TIMETG $15^{-} \quad 0.7200 .0 \quad 14400.0 \quad 21600.0 \quad 28800.0 \quad 36000.0 \quad 43200.0$

$50400.0 \quad 57600.0 \quad 64800.0 \quad 72000.0 \quad 79200.0 \quad 86400.0$

$\begin{array}{lllllllll}\text { TGFIX } & 15 & 27.8 & 25.6 & 23.9 & 23.3 & 29.4 & 36.1 & 39.4\end{array}$

END VOLUME

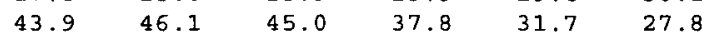

HEAT SINKS

* CELl concREte heat sinks

* ignore heat transfer to floor

* thickness of sidewall $=1.067$ (3.5')

* thickness of front/back wall = 1.372 (4.5')

* thickness of cover block $=1.829$ (6')

* one-sided area of long sidewall $=2 \times 5.3848\left(17^{\prime} 8^{\prime \prime}\right) * 6.7056\left(22^{\prime}\right)=72.217$

* one-sided area of short sidewall $=2 \times 3.9624\left(13^{\prime}\right) * 6.7056\left(22^{\prime}\right)=53.141$

* one-sided area of cover block $=5.3848\left(17^{\prime} 8^{\prime \prime}\right) * 3.9624\left(13^{\prime}\right)=21.337$

SINKS

process cell

process cell

cell short sidewall

cover block

$\begin{array}{lccc}\text { LABEL } & \text { PC-LSW } & \text { PC-SSW } & \text { PC-COV } \\ \text { IORIHS } & 0 & 0 & 1 \\ \text { IGEOM } & 1 & 1 & 1 \\ \text { IMATHS } & 3 & 3 & 3 \\ \text { XRI } & 0.0 & 0.0 & 0.0 \\ \text { XRO } & 1.067 & 1.372 & 1.829 \\ \text { AHS } & 72.217 & 53.141 & 21.337 \\ \text { TIINIT } & 32.00 & 32.00 & 32.00 \\ \text { TOINIT } & 32.00 & 32.00 & 35.00 \\ \text { IMSLAB } & 20 & 20 & 20 \\ \text { IREGI } & 6 & 6 & 10 \\ \text { IREGO } & 0 & 0 & 6 \\ \text { XLHS } & 6.7056 & 6.7056 & 3.9624 \\ \text { XZHS } & 6.7056 & 6.7056 & 3.9624 \\ \text { ZTHS } & 5.7150 & 5.7150 & 7.5438 \\ \text { ZBHS } & -0.9906 & -0.9906 & 5.7150\end{array}$

END

*

*

SINKS

long sidewall

106

short sidewall

cover block

LABEL

SAME_AS

CC-LSW

101

108

AHS

2. $239 \mathrm{E} 3$

CC-SSW

102

$\mathrm{CC}-\mathrm{COV}$

TIINIT

32.00

1. $647 \mathrm{E3}$

32.00

103

TOINIT

32.00

32.00

$6.614 \mathrm{E} 2$

IREGI

7
0

7

END

CELL 2R

* one-sided area of long sidewall $=1 \times 8.3820\left(27^{\prime} 6^{\prime \prime}\right) * 6.7056\left(22^{\prime}\right)=56.206$

* one-sided area of short sidewall $=2 \times 3.9624\left(13^{\prime}\right) * 6.7056\left(22^{\prime}\right)=53.141$

* one-sided area of cover block $=8.3820\left(27^{\prime} 6^{\prime \prime}\right) * 3.9624\left(13^{\prime}\right)=33.213$

* long

long sidewall

short sidewall cover 
FAl/10-83

Rev. 0

SINKS

PRC-STP-00241, Rev 0

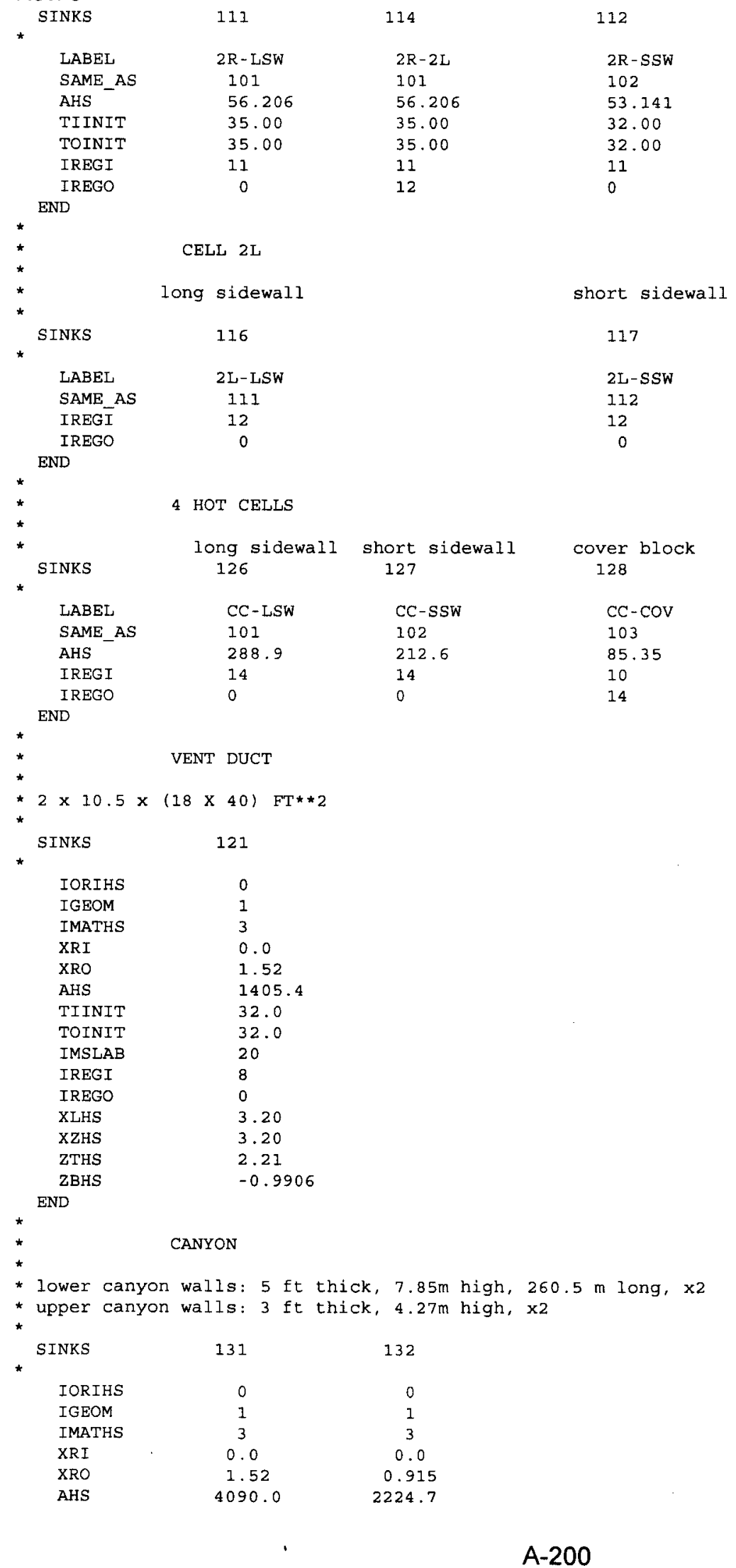


FAl/10-83

PRC-STP-00241, Rev 0

Rev. 0

$\begin{array}{lcc}\text { TIINIT } & 32.00 & 32.00 \\ \text { TOINIT } & 32.00 & 35.00 \\ \text { IMSLAB } & 20 & 20 \\ \text { IREGI } & 10 & 10 \\ \text { IREGO } & 0 & 0 \\ \text { XLHS } & 12.0 & 12.0 \\ \text { XZHS } & 12.0 & 12.0 \\ \text { ZTHS } & 15.394 & 19.664 \\ \text { ZBHS } & 7.5438 & 15.394 \\ \text { END } & & \end{array}$

* PIPE TRENCH

* PIPE TRENCH WALl IS $2 \times 6 \times(35 \times 20)$ FT**2

* COVER IS 8 X (35X 20) FT**2

* wall cover

$\begin{array}{lll}\text { SINKS } & 122 & 123\end{array}$

*

IORIHS 0

IGEOM

IMATHS

XRI

$\begin{array}{ll}1 & 1 \\ 3 & 3\end{array}$

$\begin{array}{ll}1.52 & 1.37\end{array}$

AHS $\quad 781.0 \quad 520.5$

TIINIT $\quad 32.00 \quad 32.00$

TOINIT $\quad 32.00 \quad 32.00$

IMSLAB $20 \quad 20$

IREGI 9210

IREGO 009

$\begin{array}{lll}\text { XLHS } & 1.83 & 1.83\end{array}$

XZHS 1.83

ZTHS $\quad 6.1710 \quad 7.5438$

ZBHS $\quad 4.3426 \quad 6.1710$

END

24 INCH PIPE

* length $=2.1336+2 \star 3.9624=10.0584$

SINKS

124

125

IORIHS

IGEOM

IMATHS

$X R I$

XRO

AHS

TIINIT

TOINIT

IMSLAB

IREGI

IREGO

XLHS

XZHS

! ZTHS

ZBHS

$\begin{array}{ll}0 & 0 \\ 0 & 0\end{array}$

3

$0.6096 \quad 0.3048$

$5.0 \quad 0.6096$

$177.3 \quad 2.8727$

$32.00 \quad 32.00$

$32.00 \quad 32.00$

$30 \quad 20$

00

$12.0 \quad 0.6096$

$10.1 \quad 10.1$

$\begin{array}{ll}? & \text { ? }\end{array}$

END

*

*-

* SET zTHS TO REgiON 1 TOP ELEVATION, $2.43327 \mathrm{M}$

SINKS 68

IABEL TOP

IREGO 11

END

* inNer cylinder and stsc wall adjacent to water and gas

* Layer 21 
FAl/10-83

PRC-STP-00241, Rev 0

Rev. 0

SINKS

61

! LABEL WALLO-21

END

11

Volume Cumulative volume

* LAYER-13 $0.03849 \quad 0.53849$

* LAYER-12 $0.09337 \quad 0.50000$

* Layer 20

SINKS $\quad 58$

IREGO 11

END

SINKS Layer 19

IREGO 11

END

* Layer 18

$\begin{array}{cc}\text { SINKS } & 52 \\ \text { IREGO } & 11\end{array}$

END

49

END

Layer 16

SINKS 46

END

Layer 15

IREGO

END

SINKS

Layer 14

IREGO $\quad 11$

END

Layer 13

37

END

*

Layer 12

INKS $\quad 34$

END

IREGO 11

END

* elliptical section

* lower head exterior sees atmosphere in the skirt enclosure

Layer 1

IREGO 28

END

*

Layer

IREGO

END

* Layer 8

SINKS 22

IREGO 11

TND

* wall for Layer 7 and below is considered horizontal,

* heat transfer due to laminar boundary layer underside

* of a hot plate is modeled in FATE 
FAl/10-83

PRC-STP-00241, Rev 0

Rev. 0

*

* $\begin{array}{cc} & \text { Layer } 7 \\ \text { SINKS } & 19\end{array}$

IREGO 11

END

Layer 6

$\begin{array}{cc}\text { SINKS } & 16 \\ \text { IREGO } & 11\end{array}$

END

* Layer 5

IREGO 11

END

* Layer 4

SINKS 10

IREGO

END

SINKS Layer 3

IREGO $\quad 11$

END

* below the inner eliptical head

* LINKS Layer 2 IREGO $\quad 11$

END

*

* skirt and dRip pan

* model drip-pan as vertical hs to allow convective ht to cell $\begin{array}{lll}\text { SINKS } & 96 & 95\end{array}$

! LABEL SKIRT DRIP-PAN IREGO 11

END

END HEAT SINKS

«

JUNCTIONS

*

* Move STSC from region 6 to region 11

* 2" INLET VENT

* 4" OUTLET VenT WITH 2 FOOT (0.6096 M) CHIMNEY

$\begin{array}{lccc} & \text { PATHS } & 1 & 2 \\ \text { LABEL } & \text { VENT-IN } & \text { VENT-OUT }\end{array}$

$\begin{array}{lll}\text { IRI } & 11 & 1\end{array}$

$\begin{array}{lrr}\text { IR2 } & 11 & 11\end{array}$

END PATHS

* HOLES IN THE SKIRT

* Redirect from typical cell (6) to cell 2R (11)

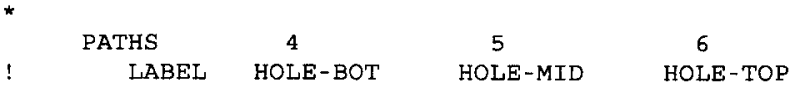

$\begin{array}{lrrr}I R 1 & 11 & 11 & 3 \\ \text { IR2 } & 3 & 3 & \end{array}$

END PATHS

$\star$

*

* Canyon to cells \& pipe trench through cover block gaps

* Path 11: Process cell to canyon via gap

* [References needed for CJN, KFILTER]

* IRI = $6=\mathrm{T}-\mathrm{Cell}$

$\star \mathrm{ZlJN}=$ Cell height $=$ ZTOP $=6.7056 \mathrm{~m}$ 
FAl/10-83

PRC-STP-00241, Rev 0

Rev. 0

Page 204 of 284

* IR2 = $10=$ Canyon

March, 2010

* $\mathrm{z2JN}=$ Canyon floor $=0.0 \mathrm{~m}$

$\begin{array}{ll}\text { PATHS } & 11 \\ \text { LABEL } & \text { TC }\end{array}$

ICCJN 0

IRI 6

IR2 $\quad 10$

IHORIZ 1

AJN 1.0

ZIJN $\quad 6.7056$

Z2JN $\quad 0.0$

CJN I.E-5

KFILTER 382.15

FGASIJN 1.0

XLJN 1.0

XWJN $\quad 1.0$

XHJN 1.0

END PATHS

* Path 12 : Canyon to cold cells via cover block gaps

* [References needed for CJN]

* IR1 = 10 = Canyon

* $\mathrm{z} 1 \mathrm{JN}=$ Canyon floor $=0.0 \mathrm{~m}$

* IR2 $=7$ = Cold cells

* $\mathrm{Z2JN}=$ Cell height $=$ ZTOP $=6.7056 \mathrm{~m}$

* KFILTER $=1 /(\operatorname{sum}[i=1.35](1 /$ KFILTER_tcell $))$

* $\quad$ a kilter tcell / 35

* $=382.15 / 35=10.92$

* Path 15: Canyon to pipe trench via cover block gaps

* [References needed for CJN, KFILTER]

* $\operatorname{IRI}=10$ = Canyon

* ZIJN $=$ Canyon floor $=0.0 \mathrm{~m}$

$\star$ IR2 $=9$ = Pipe trench

* Z2JN $=$ Trench height $=$ ZTOP $=1.83 \mathrm{~m}$

$\star$ KFILTER $=($ Kwidth $*$ Klength $) /(2 *($ Kwidth + Klength $))$

* $\quad=(389.7 * 1781.1) /(2 *(389.7+1781.1))$

$=159.87$

* Path 17: Cell 2R to canyon via cover block gaps

* [References needed for CJN, KFILTER]

* IRI $=11=$ Cell $2 R$

$\star \mathrm{ZIJN}=\mathrm{Cell} 2 \mathrm{R}$ height $=$ ZTOP $=6.7056 \mathrm{~m}$

* IR2 = 10 = Canyon

* Z2JN $=$ Canyon floor $=0.0 \mathrm{~m}$

* Path 22: Hot cells to canyon via cover block gaps

* [References needed for CJN]

$\star$ IRI $=14=$ Hot cells

$\star$ ZlJN $=$ Cell height $=$ ZTOP $=6.7056 \mathrm{~m}$

* IR2 $=10$ = Canyon

* Z2JN $=$ Canyon floor $=0.0 \mathrm{~m}$

* KFILTER $=1 /(\operatorname{sum}[i=1.5]$ (1 / KFILTER_tcell) )

* $\quad$ KFILTER tcell / 5

* $\quad=382.15 / 5=76.43$

PATHS SAME_AS

LABEL

12

IJTYP

IRI

IR2

IHORIZ

AJN

Z1JN

Z2JN

CJN

KFILTER

11

GAP - COLD

1

10

10
7

1.0

0.0

6.7056

1.E- 5

FGASIJN

10.92

1.0

15
11
GAP-PIPE
8
10
9
1
1.0
0.0
1.83
$1.8-5$
59.87
1.0

$\begin{array}{ll}17 & 22 \\ 11 & 11 \\ \text { C2R-GAP } & \text { HOT-GAP } \\ 8 & 8 \\ 11 & 14 \\ 10 & 10 \\ 1 & 1 \\ 1.0 & 1.0 \\ 6.7056 & 6.7056 \\ 0.0 & 0.0 \\ 1 . E-5 & 1 . E-5 \\ 463.9 & 76.43 \\ 1.0 & 1.0 \\ & \end{array}$


$\mathrm{FAl} / 10-83$

\section{PRC-STP-00241, Rev 0}

Rev. 0

\section{XLJN \\ XWJN \\ XHJN}

* Path 18: Canyon to Cell 2L

* [References needed for CJN]

* IRI = 10 = Canyon

* ZlJN $=$ Canyon floor $=0.0 \mathrm{~m}$

* IR2 = $12=\operatorname{cell} 2 \mathrm{~L}$

$*$ Z2JN $=$ Full cell 2L height $=30.10 "=9.397 \mathrm{~m}$

* AJN $=$ SED_AREA $=33.21 \mathrm{~m} * \star 2$

$* \mathrm{XLJN}=\mathrm{L}=27.5^{\prime}=8.3820 \mathrm{~m}$

$\star X W J N=W=13^{\prime}=3.9624 \mathrm{~m}$

$\star$ XHJN $=0.001 \mathrm{~m}=$ thin

PATHS 18

LABEL CANYON-C2L

IJTYP 1

IR $1 \quad 10$

IR2 12

IHORIZ 1

AJN $\quad 33.21$

Z1JN $\quad 0.0$

Z2JN $\quad 9.397$

CJN 2.8

FGASIJN 1.0

XLJN $\quad 8.3820$

XWJN $\quad 3.9624$

XHJN $\quad 0.001$

END PATHS

* Cells to ventilation duct

* Path 13: Cold cells to ventilation duct via 10"-dia pipe.

* [Reference needed for CJN]

* IRI = 7 = cold cells

* ZIJN $=9^{\prime}=2.7432 \mathrm{~m}$

* IR2 $=8$ = ventilation duct

$\star \mathrm{Z2JN}=$ top of duct $=\mathrm{ZTOP}=10.5^{\prime}=3.2004 \mathrm{~m}$

* $\mathrm{CJN}=(1 / 0.6) * * 2=2.8$

* Consider 35 pipes for 35 cold cells:

* AJN $=35 * \mathrm{pi} / 4 *(\mathrm{D} * * 2)$

* $\quad=19.1 \mathrm{ft} * * 2$

* $\quad=1.7735 \mathrm{~m} * \star 2$

$\star X L J N=10^{\prime}=2.5 \mathrm{~m}$

$\star X W J N=10^{\prime \prime}=0.254 \mathrm{~m}$

$\star \mathrm{XHJN}=10^{\prime \prime}=0.254 \mathrm{~m}$

* Path 14: Ventilation duct to process cell via 10"-dia pipe

* [References needed for CJN]

* IR1 = 8 = Ventilation duct

$\star$ ZlJN $=$ top of duct $=$ ZTOP $=10.5^{\prime}=3.2004 \mathrm{~m}$

$\star \operatorname{IR2}=6=\mathrm{T}$ cell

$\star \mathrm{Z} 2 \mathrm{JN}=9^{1}=2.7432 \mathrm{~m}$

$\star \mathrm{CJN}=(1 / 0.6) \star \star 2=2.8$

$\star \mathrm{AJN}=\mathrm{pi} / 4 \star(\mathrm{D} \star \star 2)$

* $\quad=0.5454 \mathrm{ft} * \star 2$

$=0.05067 \mathrm{~m} * * 2$

$\star \mathrm{XIJN}=10^{\circ}=2.5 \mathrm{~m}$

* XWJN $=10^{\prime \prime}=0.254 \mathrm{~m}$

$\star \mathrm{XHJN}=10^{\prime \prime}=0.254 \mathrm{~m}$

* Path 21: Ventilation duct to hot cells via 10"-dia pipe.

* [References needed for CJN]

* IRI = 8 = Ventilation duct

$\star$ ZIJN $=$ top of duct $=$ ZTOP $=10.5^{\prime}=3.2004 \mathrm{~m}$

$\star$ IR2 $=14=$ Hot cells

$\star \mathrm{Z} 2 \mathrm{JN}=9^{\circ}=2.7432 \mathrm{~m}$

* $\mathrm{CJN}=(1 / 0.6) *{ }^{2}=2.8$

* Consider 5 pipes for 5 hot cells: 
$\mathrm{FAl} / 10-83$

PRC-STP-00241, Rev 0

Rev. 0

* $\mathrm{AJN}=5 * \mathrm{pi} / 4 *(\mathrm{D} * 2)$

$\star \quad \quad=2.7271 \mathrm{ft} * \star 2$

* $\quad=0.25335 \mathrm{~m} * \star 2$

* XIJN $=10^{\circ}=2.5 \mathrm{~m}$

* XWJN $=10^{\prime \prime}=0.254 \mathrm{~m}$

$\star X H J N=10^{\prime \prime}=0.254 \mathrm{~m}$

PATHS $13 \quad 14$

LABEL COLD-VENT VENT-TCELL VENT-HOT

IJTYP

ICCJN

IRI

IR2

IHORIZ

AJN $\quad 1.7735$

ZIJN 2.7432

Z2JN $\quad 3.2004$

CJN 2.8

KFILTER 0.0

FGASIJN 1.0

XLJN 2.5

XWJN $\quad 0.254$

XHJN $\quad 0.254$

END PATHS

1

8

$0 \quad 14$

$0.05067 \quad 0.25335$

$3.2004 \quad 3.2004$

$2.7432 \quad 2.7432$

$2.8 \quad 2.8$

$0.0 \quad 0.0$

$1.0 \quad 1.0$

$2.5 \quad 2.5$

$0.254 \quad 0.254$

*? Single cell pair $\mathrm{K}=160$; divide by 17.5

* Pipe trench to ventilation duct

* Path 16: Pipe trench to ventilation duct via 18 10"-dia pipes.

* [Reference needed for CJN]

* IRI = $9=$ Pipe trench

$\star \mathrm{Z} 1 \mathrm{JN}=$ Pipe trench floor $=0 \mathrm{~m}$

* IR2 = 8 = Ventilation duct

$\star \mathrm{Z2JN}=$ top of duct $=\mathrm{ZTOP}=10.5^{\prime}=3.2004 \mathrm{~m}$

$\star \operatorname{CJN}=(1 / 0.6) \star \star 2=2.8$

* Consider 18 pipes for 18 cold cells:

$\star \mathrm{AJN}=18 * \mathrm{pi} / 4 *(\mathrm{D} * \star 2)$

$\star \quad=9.8229 \mathrm{ft} * \star 2$

$\star \quad \quad=0.9121 \mathrm{~m} * * 2$

$\star X L J N=10^{\circ}=2.5 \mathrm{~m}$

$\star X W J N=10^{\prime \prime}=0.254 \mathrm{~m}$

$\star \mathrm{XHJN}=10 "=0.254 \mathrm{~m}$

PATHS 16

LABEL PTRENCH-VENT

IJTYP 1

ICCJN 0

IR1 9

IR2 8

IHORIZ 1

AJN $\quad 0.9121$

Z1JN 0.0

ZJN $\quad 3.2004$

CJN 2.8

FGASIJN 1.0

XLJN 2.5

XWJN $\quad 0.254$

XHJN $\quad 0.254$

END PATHS

* Long cells to $24 "$ pipe

* Path 19: Cell 2L to 24" vent pipe via 10"-dia pipes.

* [Referencè needed for CJN]

* IRI = $12=\operatorname{Cell} 2 \mathrm{~L}$

* Z1JN $=6.9 "$ below canyon deck (note: 5.8" is at cover block level)

* $\quad$ ZTOP 12 - 619"

$\star \quad \quad=7.56 \overline{9} 2 \mathrm{~m}-2.0574 \mathrm{~m}$

$=5.5118 \mathrm{~m}$

* IR2 = $13=24 "$ pipe 
Rev. 0

* $\mathrm{Z} 2 \mathrm{JN}=0 \mathrm{~m}$

* $\mathrm{CJN}=(1 / 0.6) \star * 2=2.8$

* AJN $=\mathrm{pi} / 4 *(\mathrm{D} * \star 2)$

* $\quad=0.5454 \mathrm{ft} * * 2$

* $\quad=0.05067 \mathrm{~m} * 2$

$\star X L J N=10^{\prime}=2.5 \mathrm{~m}$

* XWJN $=10^{\prime \prime}=0.254 \mathrm{~m}$

$*$ XHJN $=10^{\prime \prime}=0.254 \mathrm{~m}$

* Path 20: Cell 2R to 24" vent pipe via 10"-dia pipes.

* [Reference needed for CJN]

* IRI $=13=24$ " pipe

* ZIJN $=0 \mathrm{~m}$

* IR2 = $11=\operatorname{Cell} 2 \mathrm{R}$

* Z2JN $=6 \cdot 9 "$ below canyon deck.

* $\quad$ ZTOP_12 - 6'9"

* $\quad=7.56 \overline{9} \mathrm{~m}-2.0574 \mathrm{~m}$

* $\quad=5.5118 \mathrm{~m}$

* $\mathrm{CJN}=(1 / 0.6) * \star 2=2.8$

$\star \mathrm{AJN}=\mathrm{pi} / 4 *(\mathrm{D} * * 2)$

* $\quad=0.5454 \mathrm{ft} * \star 2$

$\star \quad \quad=0.05067 \mathrm{~m} * \star 2$

$\star \mathrm{XLJN}=10^{\prime}=2.5 \mathrm{~m}$

$\star X W J N=10^{\prime \prime}=0.254 \mathrm{~m}$

$\star \mathrm{XHJN}=10 "=0.254 \mathrm{~m}$

PATHS $19 \quad 20$

LABEL C2L-PIPE PIPE-C2R

IJTYP 11

ICCJN 0

$\begin{array}{lll}\text { IR1 } & 12 & 13 \\ \text { IR2 } & 13 & 11\end{array}$

IHORIZ 00

$\begin{array}{lll}\mathrm{AJN} & 0.05067 & 0.05067\end{array}$

$\begin{array}{lll}\text { ZlJN } & 5.5118 & 0.0\end{array}$

Z2JN $\quad 0.0 \quad 5.5118$

$\begin{array}{lll}\text { CJN } & 2.8 & 2.8\end{array}$

FGASIJN $1.0 \quad 1.0$

$\begin{array}{lll}X L J N & 2.5 & 2.5\end{array}$

XWJN $\quad 0.254 \quad 0.254$

$\begin{array}{lll}\text { XHJN } & 0.254 & 0.254\end{array}$

END PATHS

* 24" Pipe and vent duct to exhaust duct

* Path 25: Ventilation duct to exhaust duct

* [Reference needed for CJN]

* IRI = $8=$ Ventilation duct

* Z1JN $=$ Vent duct floor $=0.0 \mathrm{~m}$

* IR2 = 16 = Exhaust duct

* $\mathrm{Z2JN}=$ Exhaust duct floor $=0.0 \mathrm{~m}$

$\star \mathrm{AJN}=5^{\prime} \star 4^{\prime}=20.0 \mathrm{ft} \star \star 2=1.8581 \mathrm{~m} \star \star 2$

* XLJN $=$ thin $=0.001 \mathrm{~m}$

$\star$ XWJN $=4^{\prime}=1.2192 \mathrm{~m}$ (est.)

$\star \mathrm{XHJN}=5^{\prime}=1.5240 \mathrm{~m}$

* Path 27: 24" vent pipe to exhaust duct

* [Reference needed for CJN]

* IRI = $13=24$ " pipe

* ZIJN $=0 \mathrm{~m}$

* IR2 $=16=$ Exhaust duct

* $\mathrm{Z2JN}=$ Vent duct floor $+4^{\prime}$

$\star \quad \quad=4$,

$\star \quad \quad=1.2192 \mathrm{~m}$

$\star \mathrm{CJN}=(1 / 0.6) * \star 2=2.8$

* $\mathrm{AJN}=\mathrm{pi} / 4 \star(\mathrm{D} * \star 2)$

$\star \quad=3.1416 \mathrm{ft} * \star 2$

$\star \quad=0.2919 \mathrm{~m} * \star 2$

$\star$ XLJN $=10^{\prime}=3.048 \mathrm{~m}$ (est.)

$\star \mathrm{XWJN}=24 "=0.6096 \mathrm{~m}$

$\star \mathrm{XHJN}=24 " / \sin (45)=0.8621 \mathrm{~m}$ 
FAl/10-83

PRC-STP-00241, Rev 0

Rev. 0

Page 208 of 284

$\begin{array}{lcc}\text { PATHS } & 25 & 27 \\ \text { LABEL } & \text { VENT-EXH } & \text { PIPE-EXH } \\ \text { IJTYP } & 1 & 1 \\ \text { ICCJN } & 0 & 0 \\ \text { IR1 } & 8 & 13 \\ \text { IR2 } & 16 & 16 \\ \text { IHORIZ } & 0 & 0 \\ \text { AJN } & 1.8581 & 0.2919 \\ \text { Z1JN } & 0.0 & 0.0 \\ \text { Z2JN } & 0.0 & 1.2192 \\ \text { CJN } & 1.5-5 & 2.8 \\ \text { KFILTER } & 0.0 & 0.0 \\ \text { FGAS1JN } & 1.0 & 1.0 \\ \text { XLJN } & 0.001 & 3.048 \\ \text { XWJN } & 1.2192 & 0.6096 \\ \text { XHJN } & 1.5240 & 0.8621\end{array}$

March, 2010

* Fan from exhaust duct to ambient

* fan flow rate $=17500 \mathrm{cfm}=8.2591 \mathrm{~m}^{\wedge} 3 / \mathrm{s}$

* fan flow rate $=0 \mathrm{~m}^{\wedge} 3 / \mathrm{s}$

* Path 26: Exhaust duct to ambient

* CJN not used, constant volumetric flow rate

* Set AJN to an arbitrary positive value

* so code does not bypass the junction

* IRI $=16=$ Exhaust duct

* ZIJN $=0 \mathrm{~m}$

* IR2 = 15 = Ambient (atmosphere)

* $\mathrm{Z} 2 \mathrm{JN}=15 \mathrm{~m}$ (est.; stack height $=200^{\prime}$ ?)

PATHS 26

TATYP

$\begin{array}{ll}\text { IJTYP } & 1 \\ \text { ICCJN } & 1\end{array}$

IR1 16

IR2 15

IHORIZ 0

AJN $\quad 1.0$

$\mathrm{Z} 1 \mathrm{JN} \quad 0.0$

Z2JN $\quad 15.0$

CJN I.0

KFILTER 0.0

FGASIJN 1.0

IFAN 1

WVFAN 8.2591

END PATHS

* Cell 2L and canyon to ambient

* Path 28: Ambient to Canyon

* Leakage modeled using KFILTER

* $17500 \mathrm{cfm}\left(82.6 \mathrm{~m}^{\wedge} 3 / \mathrm{s}\right)$ at 0.15 in $w . g .(35.9 \mathrm{~Pa})$

* Assume equal split between canyon leakage and

* access tunnel leakage.

* Hence, KFILTER $=35.9 /(82.6 / 2)=0.870$

* IRI = $15=$ Ambient (atmosphere)

* $\mathrm{ZIJN}=$ ELEVATION_10+ZTOP_10/2 - ELEVATION_15

* $\quad=7.5438 \mathrm{~m}+14.9352 \mathrm{~m}^{-} / 2-7.5438 \mathrm{~m}$

$\quad=7.4676 \mathrm{~m}$

* IR2 = $10=$ Canyon

* Z2JN $=$ ZTOP $10 / 2$

* $\quad=7.46 \overline{7} 6 \mathrm{~m}$

* Path 29: Ambient to Cell 2L

* Leakage modeled using KFILTER

$\star 17500 \mathrm{cmf}\left(82.6 \mathrm{~m}^{\wedge} 3 / \mathrm{s}\right)$ at 0.15 in w.g. (35.9 Pa)

* Assume equal split between canyon leakage and

* access tunnel leakage. 
* Hence, KFILTER $=35.9 /(82.6 / 2)=0.870$

* IRI = $15=$ Ambient (atmosphere)

$\star$ ZIJN $=$ ELEVATION_12 + ZTOP_12 $/ 2$ - ELEVATION_15

$\star \quad=-1.8542 \mathrm{~m}+7.5692 \mathrm{~m} / 2-7.5438 \mathrm{~m}$

* $\quad=-5.6134 \mathrm{~m}$

* $\mathrm{IR} 2=12=\mathrm{Cell} 2 \mathrm{~L}$

* Z2JN = ZTOP $12 / 2$

* $\quad=7.5692 \mathrm{~m} / 2$

$* \quad=3.7846 \mathrm{~m}$

PATHS $28 \quad 29$

LABEL AMB-CANYON AMB-C2I

$\begin{array}{lll}\text { IJTYP } & 8 & 8\end{array}$

ICCJN 000

IRI $15 \quad 15$

IR2 $10 \quad 12$

$\begin{array}{lll}\text { IHORIZ } & 1 & 1 \\ \text { AJN } & 1.0 & 1.0\end{array}$

Z1JN $\quad 7.4676 \quad-5.6134$

$\begin{array}{lll}Z 2 J N & 7.4676 & 3.7846\end{array}$

$\begin{array}{lll}\text { CJN } & 2.8 & 2.8\end{array}$

KFILTER $\quad 0.870 \quad 0.870$

FGAS1JN $1.0 \quad 1.0$

$\begin{array}{lll}\text { XLJN } & 1.0 & 1.0\end{array}$

$\begin{array}{lll}\text { XWJN } 1.0 & 1.0\end{array}$

$\begin{array}{lll}\text { XHJN } & 1.0 & 1.0\end{array}$

END JUNCTIONS 
FAl/10-83

PRC-STP-00241, Rev 0

Rev. 0

\section{B.9 Case File: SETTRN1,dat}

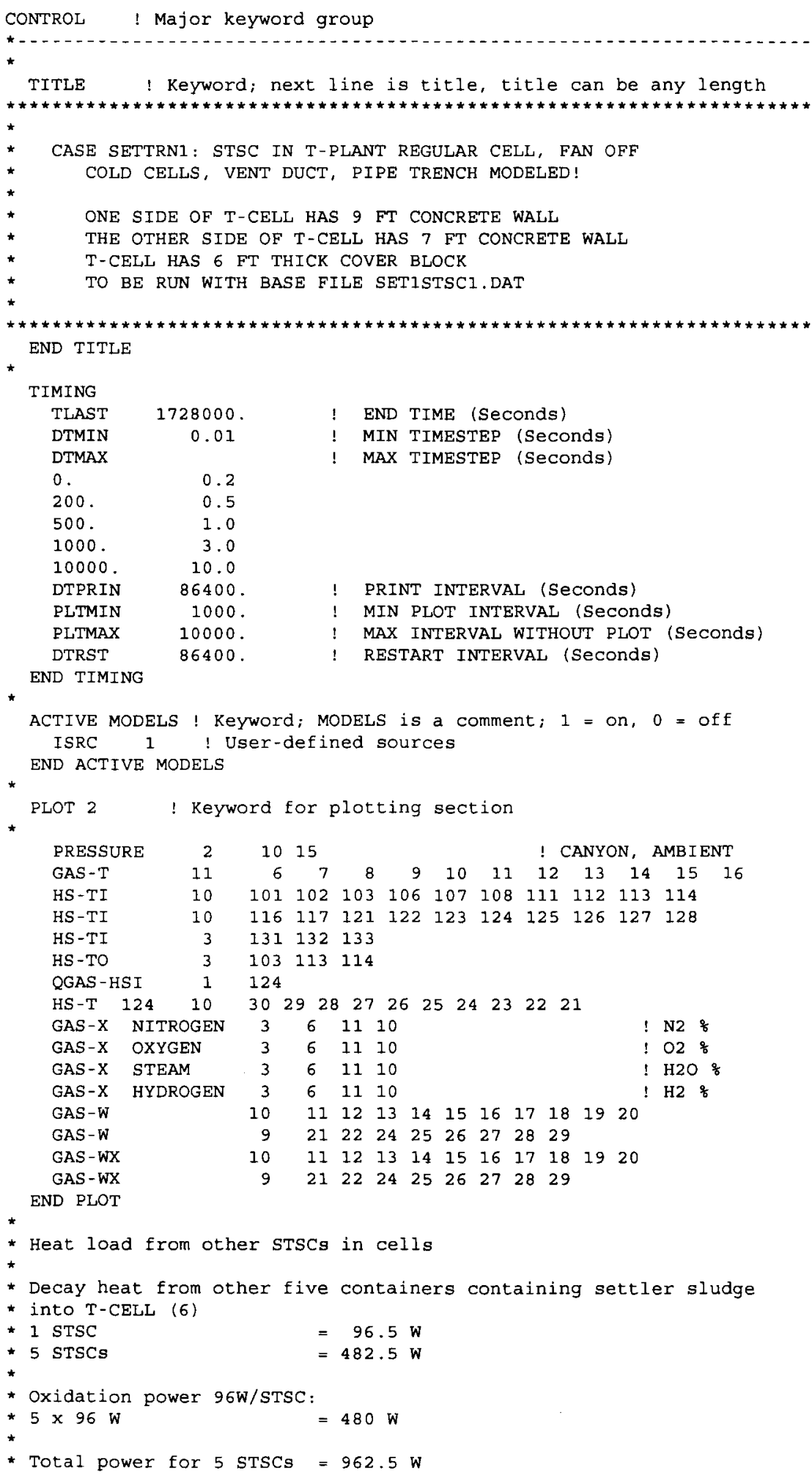


* H2 generation rate for $1 \mathrm{STSC}=7.0 \mathrm{E}-7 \mathrm{~kg} / \mathrm{s}$

* H2 generation rate for $5 \mathrm{STSCs}=3.5 \mathrm{E}-6 \mathrm{~kg} / \mathrm{s}$

* H2 released at $50 \mathrm{C}$

SOURCES 2

REGION 6 GASES 1 PHASE 1

HYDROGEN

$\begin{array}{llll}0 & 50.0 & 3.5 \mathrm{E}-6 & 962.5 \\ 1 . \mathrm{E9} & 50.0 & 3.5 \mathrm{E}-6 & 962.5\end{array}$

* END REGION

* Decay heat from six containers containing settler sludge in each of

* four cells in the Hot Cell (14)

* 1 STSC

* Oxidation power $96 \mathrm{~W} / \mathrm{STSC}$ :

$\star 4 \times 6 \times 96 \mathrm{~W}=2304.0 \mathrm{~W}$

* Total power for $4 \times 6$ STSCs $=4620.0 \mathrm{~W}$

* H2 generation rate for I STSC $=7.00 \mathrm{E}-7 \mathrm{~kg} / \mathrm{s}$

$\star$ H2 generation rate for $24 \mathrm{STSCs}=1.68 \mathrm{E}-5 \mathrm{~kg} / \mathrm{s}$

* H2 released at $50 \mathrm{C}$

REGION 14 GASES 1 PHASE 1 HYDROGEN

$\begin{array}{llll}0 & 50.0 & 1.68 \mathrm{E}-5 & 4620.0\end{array}$

1.E9 $50.0 \quad 1.68 \mathrm{E}-5 \quad 4620.0$

END REGION

END SOURCES

END CONTROL

VOLUMES

*--

* Cells

* elevation of T-plant Cell $=-1 "-38 "=-0.9906 \mathrm{M}$

* ELEVATION OF TOP OF COVER BLOCKS $=-38 "+12 \times 28 "=298 "(7.5692 \mathrm{M})$

* ELEVATION OF BOTTOM OF COVER BLOCKS $=-38 "+12 \times 22 "=226 "(5.7404 \mathrm{M})$

* T-CELL DIMENSION, $13 \cdot(3.9624 \mathrm{M})$ BY $17 \cdot 8 "(5.3848 \mathrm{M})$ BY $22 \cdot(6.7056 \mathrm{M})$

* ASSUME 1 M^3 FOR OTHER STRUCTURES

^ T-CELL VOLUME $=3.9624 \times 5.3848 \times 6.7056-6 \times 2.5941$ XPI $(1.4986)^{\wedge} 2 / 4-1.0$

$\star \quad=143.08-27.45-1.0=114.63 \mathrm{M}^{\wedge} 3$

* Elevation: $-3 \cdot 3^{\prime \prime}=-3.25^{\prime}=-0.9906 \mathrm{~m}$

REGIONS

LABEL T-CELL

VOLUME $\quad 114.63$

SED AREA $\quad 16.82$

ELEVATION $\quad-0.9906$

TEMP_GAS 35.0

PRESSURE $\quad 1.0 \mathrm{E} 5$

ZTOP $\quad 6.7056$

GASES 6

STEAM 0.01

OXYGEN $\quad 0.20$

NITROGEN $\quad 0.79$

END GASES

* Cold cell.

* The "cold cell" is a combination of 31 standard process cells

* with no STSCs or internals.

* Volume: $31 * 143.08 \mathrm{~m} * * 3=4435.48 \mathrm{~m} * \star 3$

* Sed. Area: $31 \star 16.82 \mathrm{~m} * * 2=521.42 \mathrm{~m} * \star 2$ 
FAl/10-83

PRC-STP-00241, Rev 0

Rev. 0

* Elevation: $-3.25^{\prime}$

* Cell 2R:

* Volume: $\quad \mathrm{L}=27 \mathrm{6}^{\prime \prime} \mathrm{W}=133^{\prime} \mathrm{H}=22^{\prime} \mathrm{V}=7865 \mathrm{ft} \star \star 3=222.71 \mathrm{~m} \star \star 3$

* Sed. Area: $L=27 \cdot 6 " W=13$ ' $A=357.5$ ft $* \star 2=33.21 \mathrm{~m} \star \star 2$

* Elevation: -3.25

* Cell 2L:

* Cell 2L is slightly deeper than $2 \mathrm{R}$ due to train tracks, plus has no cover

* blocks. This adds another $6^{\prime}$ of height to the cell

* Volume: $L=27^{\prime} 6^{\prime \prime} \mathrm{W}=13^{\prime} \mathrm{H}=30^{\prime} 10^{\prime \prime} \mathrm{V}=11022.92 \mathrm{ft} * * 3=312.13 \mathrm{~m} * * 3$

* Sed. Area: $L=27^{\prime} 6 " W=13$ ' $A=357.5 \mathrm{ft} * * 2=33.21 \mathrm{~m} * \star 2$

* Z-top: $\mathrm{H}=30 \cdot 10^{\prime \prime}=9.398 \mathrm{~m}$

* Elevation: $-3 \cdot 3^{\prime \prime}+28^{\prime}-30^{\prime} 10^{\prime \prime}=-6 \cdot 1^{\prime \prime}=-1.8542 \mathrm{~m}$

* Hot Cell :

* The "hot cell" is a combination of 4 standard process cells.

* including STSCs and internals.

* Volume: $4 * 114.63 \mathrm{~m} * * 3=458.52 \mathrm{~m} * * 3$

* Sed. Area : 4 * $16.82 \mathrm{~m} * \star 2=67.28 \mathrm{~m} * \star 2$

* Elevation: -3.25 '

REGIONS

SAME_AS

LABEL

VOLUME

SED_AREA

ELEVATION

TEMP GAS

PRESSURE

ZTOP

7
6
COLD-CELL
4435.48
521.42
-0.9906
32.0
1.055
6.7056

11
6

CELL - 2R

222.71

33.21

$-0.9906$

32.0

$1.0 \mathrm{E} 5$

6.7056

12
6
CELL-2L
251.39
33.21
-1.8542
32.0
$1.0 \mathrm{E} 5$
7.5692

14
6

HOT-CELL

458.52

67.28

$-0.9906$

END REGIONS

GASES

SAME AS

END GASESS

* VENTS AND DUCTING

* Vent duct (runs along the face of 40 standard cells, each 18' wide):

* Volume: $\quad \mathrm{L}=36 * 18^{\prime} \mathrm{W}=10.5{ }^{\prime} \mathrm{H}=10.5{ }^{\prime} \mathrm{V}=71442 \mathrm{ft} * * 3=2023.0 \mathrm{~m} * * 3$

* Sed. Area: $L=36 * 18, W=10.5, A=6804 \mathrm{ft} * \star 2=632.1 \mathrm{~m} * 2$

* Z-top: $\quad \mathrm{H}=10.5^{\prime}=3.2 \mathrm{~m}$

* Elevation: $-3.25^{\prime}=-0.9906 \mathrm{~m}$

REGIONS

SAME_AS

LABEL

VOLUME

SED AREA

ELEVTATION

TEMP GAS

PRESSURE

ZTOP

11
6

12
6

14
6

END REGIONS

GASES

SAME_AS

END GASESS

* Pipe Trench.

* Sed. Area: $L=\left(35 \times 20^{\prime}\right) \quad W=8^{\prime} A=5600 \mathrm{ft} \star \star 2=520.26 \mathrm{~m} * \star 2$

*Volume: $\quad L=\left(35 \times 20^{\prime}\right) \quad W=8^{\prime} \quad H=6^{\prime} V=33600 \mathrm{ft} * * 3=951.45 \mathrm{~m} * 3$

* z-top: $\quad \mathrm{H}=6^{\prime}=1.83 \mathrm{~m}$

* Elevation: $10.5^{\prime}$ below canyon deck $\left(14.25^{\prime}=28^{\prime}-3.25^{\prime}-10.5^{\prime}=\right.$ )

* STSC bottom elevation: 0 '

* T-Cell floor elevation: -3.25 '

* Canyon deck elevation: $28^{\prime}-3.25^{\prime}=24.75^{\prime}$

* Pipe trench cover block depth: $4.5^{\circ}$

* Pipe trench floor elevation: $24.75^{\prime}-4.5^{\prime}-6^{\prime}=14.25^{\prime}=4.3434 \mathrm{~m}$ 
FAl $10-83$

PRC-STP-00241, Rev 0

Rev. 0

$\begin{array}{lc}\text { REGIONS } & 9 \\ \text { LABEL } & \text { PTRENCH } \\ \text { VOLUME } & 951.45 \\ \text { SED_AREA } & 520.26 \\ \text { ELEVATION } & 4.3434 \\ \text { ZTOP } & 1.83 \\ \text { TEMP_GAS } & 23.0 \\ \text { PRESSURE } & 1.0 \mathrm{E} 5\end{array}$

*

GASES 9

END GASES

* 24 " Pipe:

* Sed. Area: $\mathrm{D}=2^{\prime} \mathrm{L}=7^{\prime}+2 \star 13^{\prime} \mathrm{A}=\mathrm{D} * \mathrm{~L}=66 \mathrm{ft} \star \star 2=6.1316 \mathrm{~m} \star 2$

*Volume: $\mathrm{D}=2, \mathrm{~L}=71+2 \star 13, \mathrm{~V}=103.67 \mathrm{ft} \star \star 3=2.9357 \mathrm{~m} \star \star 3$

* Z-top: $D=21=0.6096 \mathrm{~m}$

$\star^{*}$ Elevation: $-3.25^{\prime}+28^{\prime}-19^{\prime}=5.75^{\prime}=1.7526 \mathrm{~m}$

* Exhaust duct:

* Sed. Area: $L=145^{\prime}, W=4, A=580 \mathrm{ft} * \star 2=53.88 \mathrm{~m} * \star 2$

* Volume: $\quad L=145^{\prime}, W=4, \quad H=7, \quad V=4060 \mathrm{ft} * \star 2=115.0 \mathrm{~m} \star \star 2$

* Z-top: $\quad \mathrm{H}=7$

* Elevation: $-3.25^{\prime}=-0.9906 \mathrm{~m}$

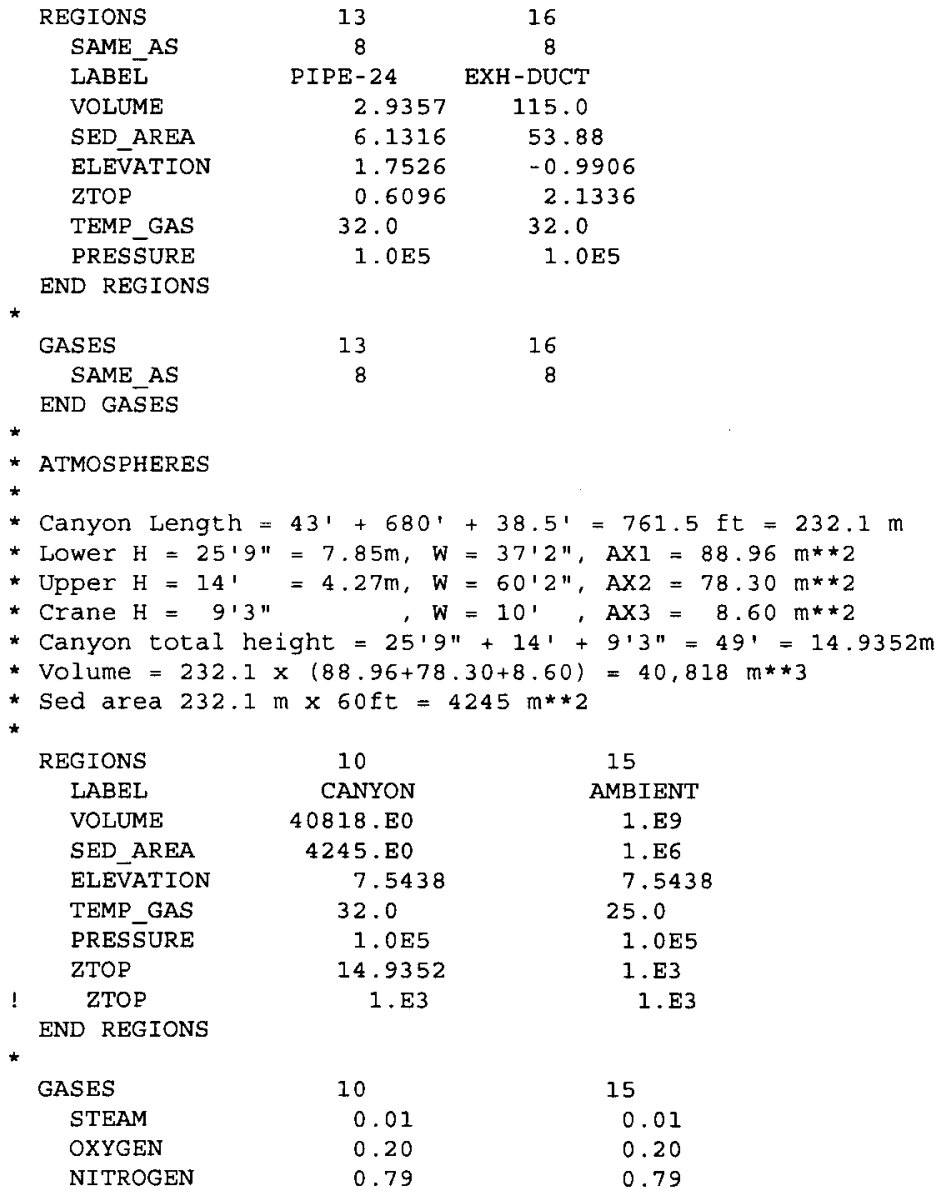


FAl/10-83

PRC-STP-00241, Rev 0

Rev. 0

* EXTRAPOLATION_TIMEPG PERIOD irepeat the diurnal cycle
* TIMEP 15 0.0 21600. 43200. 64800. 86400.

* PRFIX 15 1.0E5 1.005E5 1.0E5 $9.95 \mathrm{E} 4 \quad 1.0 \mathrm{E} 5$

OFFSET_TIMETG 28800

EXTRAPOLATION_TIMETG PERIOD

TIMETG $15-0.7200 .0 \quad 14400.0 \quad 21600.0 \quad 28800.0 \quad 36000.0 \quad 43200.0$

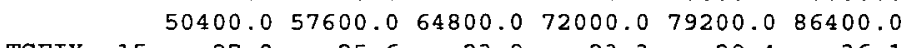

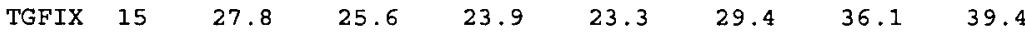

END VOLUME

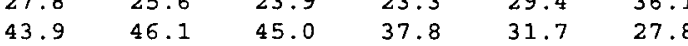

\footnotetext{
HEAT_SINKS

*-

* cell concrete heat sinks

* ignore heat transfer to floor

* thickness of sidewall = 1.067 (3.5')

* thickness of front/back wall = 1.372 (4.5')

* thickness of cover block $=1.829$ (6')

* one-sided area of long sidewall $=2 \mathrm{x} 5.3848\left(17^{\prime} 8^{\prime \prime}\right) * 6.7056\left(22^{\prime}\right)=72.217$

* one-sided area of short sidewall $=2 \times 3.9624\left(13^{\prime}\right) \star 6.7056\left(22^{\prime}\right)=53.141$

* one-sided area of cover block $=5.3848\left(17^{\prime} 8^{\prime \prime}\right) * 3.9624\left(13^{\prime}\right)=21.337$

*

process cell process cell

cell

SINKS

101

short sidewall

cover block

$\begin{array}{lccc}\text { LABEL } & \text { PC-LSW } & \text { PC-SSW } & \text { PC-COV } \\ \text { IORIHS } & 0 & 0 & 1 \\ \text { IGEOM } & 1 & 1 & 1 \\ \text { IMATHS } & 3 & 3 & 3 \\ \text { XRI } & 0.0 & 0.0 & 0.0 \\ \text { XRO } & 1.067 & 1.372 & 1.829 \\ \text { AHS } & 72.217 & 53.141 & 21.337 \\ \text { TIINIT } & 35.00 & 35.00 & 32.00 \\ \text { TOINIT } & 35.00 & 35.00 & 35.00 \\ \text { IMSLAB } & 20 & 20 & 20 \\ \text { IREGI } & 6 & 6 & 10 \\ \text { IREGO } & 0 & 0 & 6 \\ \text { XLHS } & 6.7056 & 6.7056 & 3.9624 \\ \text { XZHS } & 6.7056 & 6.7056 & 3.9624 \\ \text { ZTHS } & 5.7150 & 5.7150 & 7.5438 \\ \text { ZBHS } & -0.9906 & -0.9906 & 5.7150\end{array}$

END

*

SINKS long sidewall short sidewall cover block

*

$\begin{array}{lclc}\text { LABEL } & \text { CC-LSW } & \text { CC-SSW } & \text { CC-COV } \\ \text { SAME_AS } & 101 & 102 & 103 \\ \text { AHS } & 2.239 E 3 & 1.647 \mathrm{E} 3 & 6.614 \mathrm{E2} \\ \text { TIINIT } & 32.00 & 32.00 & 32.00 \\ \text { TOINIT } & 32.00 & 32.00 & 32.00 \\ \text { IREGI } & 7 & 7 & 10 \\ \text { IREGO } & 0 & 0 & 7\end{array}$

END

CELL $2 R$

* one-sided area of long sidewall $=1 \times 8.3820\left(27^{\prime} 6^{\prime \prime}\right) \star 6.7056\left(22^{\prime}\right)=56.206$

* one-sided area of short sidewall $=2 \times 3.9624\left(13^{\prime}\right) \star 6.7056\left(22{ }^{\prime}\right)=53.141$

* one-sided area of cover block $=8.3820\left(27^{\prime} 6^{\prime \prime}\right) * 3.9624\left(13^{\prime}\right)=33.213$

* long sidewall long sidewall short sidewall cover

long sidewall long sidewall short sidewall cover
block
}


FAl/10-83

PRC-STP-00241, Rev 0

Rev. 0

SINKS *

LABEL

SAME_AS

AHS

TIINIT

TOINIT

IREGI

IREGO

END

$\star$

*

*

SINKS

LABEL

SAME AS 111

IREGI

IREGO

END

*

$\star$

*

SINKS

LABEL

SAME_AS

AHS

IREGI

IREGO

END

*

*2x $10.5 \times$

SINKS

IORIHS

IGEOM

IMATHS

XRI

XRO

AHS

TIINIT

TOINIT

IMSLAB

IREGI

IREGO

$X$ LHS

$\mathrm{XZHS}$

ZTHS

ZBHS

END

*

*

* lower canyon walls: $5 \mathrm{ft}$ thick, $7.85 \mathrm{~m}$ high, $260.5 \mathrm{~m}$ long, x2

* upper canyon walls: 3 ft thick, $4.27 \mathrm{~m}$ high, x2

SINKS

IORIHS

IGEOM

IMATHS

XRI

$X R O$

AHS
111

101

32.00

32.00

11
0

CELL 2L

long sidewall

116

12

4 HOT CELLS

long sidewall

126

CC-LSW

101

288.9

14

VENT DUCT

121

0

0.0

1. 52

1405.4

32.0

32.0

20

0

3.20

3.20

2.21

$-0.9906$
112

2R-SSW

102

53.141

32.00

32.00

11

11

short sidewall

127

CC-SSW

102

212.6

0

117
$2 \mathrm{~L}-\mathrm{SSW}$
112
12
0

128

$\mathrm{CC}-\mathrm{COV}$

103

85.35

10 short sidewall

cover block
Page 215 of 284

March, 2010
113

$2 \mathrm{R}-\mathrm{COV}$

103

33.213

32.0

32.0

10

11 
FAl/10-83

PRC-STP-00241, Rev 0

Rev. 0

$\begin{array}{lcc}\text { TIINIT } & 32.00 & 32.00 \\ \text { TOINIT } & 32.00 & 35.00 \\ \text { IMSLAB } & 20 & 20 \\ \text { IREGI } & 10 & 10 \\ \text { IREGO } & 0 & 0 \\ \text { XLHS } & 12.0 & 12.0 \\ \text { XZHS } & 12.0 & 12.0 \\ \text { ZTHS } & 15.394 & 19.664 \\ \text { ZBHS } & 7.5438 & 15.394\end{array}$

END

PIPE TRENCH

* PIPE tRenCh WALL IS $2 \times 6 \times(35 \times 20) \quad F T * 2$

* COVER IS $8 \times(35 \times 20)$ FT**2

* wall cover

SINKS $122 \quad 123$

$\begin{array}{lcc}\text { IORIHS } & 0 & 1 \\ \text { IGEOM } & 1 & 1 \\ \text { IMATHS } & 3 & 3 \\ \text { XRI } & 0.0 & 0.0 \\ \text { XRO } & 1.52 & 1.37 \\ \text { AHS } & 781.0 & 520.5 \\ \text { TIINIT } & 32.00 & 32.00 \\ \text { TOINIT } & 32.00 & 32.00 \\ \text { IMSLAB } & 20 & 20 \\ \text { IREGI } & 9 & 10 \\ \text { IREGO } & 0 & 9 \\ \text { XLHS } & 1.83 & 1.83 \\ \text { XZHS } & 1.83 & 1.83 \\ \text { ZTHS } & 6.1710 & 7.5438 \\ \text { ZBHS } & 4.3426 & 6.1710\end{array}$

END

24 INCH PIPE

* length $=2.1336+2 * 3.9624=10.0584$

SINKS

124

125

\section{IORIHS}

IGEOM

IMATHS

$\mathrm{XRI}$

XRO

AHS

TIINIT

TOINIT

IMSLAB

IREGI

IREGO

XLHS

XZHS

! ZTHS

1 ZBHS

$\begin{array}{ll}0 & 0 \\ 0 & 0\end{array}$

3

$0.6096 \quad 0.3048$

$\begin{array}{ll}5.0 & 0.6096\end{array}$

$177.3 \quad 2.8727$

$32.00 \quad 32.00$

$32.00 \quad 32.00$

$30 \quad 20$

$\begin{array}{ll}30 & 20 \\ 0 & 13\end{array}$

$0 \quad 0$

$12.0 \quad 0.6096$

$10.1 \quad 10.1$

? ?

END HEAT_SINKS

JUNCTIONS

๓-

* Canyon to cells \& pipe trench through cover block gaps

* Path 11: Process cell to canyon via gap

* [References needed for CJN, KFILTER]

* IRI $=6=\mathrm{T}$-Cell

$\star$ ZIJN $=$ Cell height $=$ ZTOP $=6.7056 \mathrm{~m}$

* IR2 = 10 = Canyon 
FAI/10-83

PRC-STP-00241, Rev 0

Rev. 0

$*$ Z2JN $=$ Canyon floor $=0.0 \mathrm{~m}$

Page 217 of 284

PATHS 1

LABEL TCELL-GAP

IJTYP 8

ICCJN 0

IRI 6

IR2 10

$\begin{array}{ll}\text { AJN } & 1 \\ & 1.0\end{array}$

Z1JN $\quad 6.7056$

Z2JN 0.0

CJN $1 . \mathrm{E}-5$

KFILTER 382.15

FGASIJN 1.0

XIJN 1.0

XWJN 1.0

XHJN 1.0

$\star$

* Path 12: Canyon to cold cells via cover block gaps

* [References needed for CJN]

* IRI = $10=$ Canyon

* $\mathrm{ZlJN}=$ Canyon floor $=0.0 \mathrm{~m}$

* IR2 $=7=$ Cold cells

* $\mathrm{Z} 2 \mathrm{JN}=\mathrm{Cell}$ height $=$ ZTOP $=6.7056 \mathrm{~m}$

* $\operatorname{KFILTER}=1 /(\operatorname{sum}[i=1.35](1 / \operatorname{KFILTER}$ tcel1)

* $\quad$ KeILTER_tcell / 35

* $\quad 382.15 / 35=10.92$

* Path 15: Canyon to pipe trench via cover block gaps

* [References needed for CJN, KFILTER]

* IR1 $=10=$ Canyon

* ZlJN = Canyon floor $=0.0 \mathrm{~m}$

* IR2 = 9 = Pipe trench

* $\mathrm{Z} 2 \mathrm{JN}=$ Trench height $=\mathrm{ZTOP}=1.83 \mathrm{~m}$

* KFILTER $=($ Kwidth * Klength $) /(2 *($ Kwidth + Klength $))$

$\star \quad=(389.7 * 1781.1) /(2 *(389.7+1781.1))$

$\star \quad=159.87$

* Path 17: Cell 2R to canyon via cover block gaps

* [References needed for CJN, KFILTER]

* IRI = II = Cell 2R

$\star$ ZlJN $=$ Cell 2R height $=$ ZTOP $=6.7056 \mathrm{~m}$

* IR2 = I0 = Canyon

* Z2JN $=$ Canyon floor $=0.0 \mathrm{~m}$

* Path 22: Hot cells to canyon via cover block gaps

* [References needed for CJN]

- IRI = $14=$ Hot cells

* ZluN $=$ Cell height $=$ ZTOP $=6.7056 \mathrm{~m}$

* IR2 = $10=$ Canyon

* $\mathrm{Z} 2 \mathrm{JN}=$ Canyon floor $=0.0 \mathrm{~m}$

* KFILTER $=1 /(\operatorname{sum}[i=1.5](1 /$ KFILTER tcell) $)$

* $\quad$ KFILTER_tcell / 5

* $\quad=382.15 / 5=76.43$

PATHS

$\begin{array}{lcccc}\text { STHS } & 12 & 15 & 17 & 22 \\ \text { SAME_AS } & 11 & 11 & 11 & 11 \\ \text { LABEL } & \text { GAP-COLD } & \text { GAP-PIPE } & \text { C2R-GAP } & \text { HOT-GAP } \\ \text { IJTYP } & 8 & 8 & 8 & 8 \\ \text { IR1 } & 10 & 10 & 11 & 14 \\ \text { IR2 } & 7 & 9 & 10 & 10 \\ \text { IHORIZ } & 1 & 1 & 1 & 1 \\ \text { AJN } & 1.0 & 1.0 & 1.0 & 1.0 \\ \text { ZIJN } & 0.0 & 0.0 & 6.7056 & 6.7056 \\ \text { Z2JN } & 6.7056 & 1.83 & 0.0 & 0.0 \\ \text { CJN } & 1.5-5 & 1 . E-5 & 1 . E-5 & 1 . E-5 \\ \text { KFILTER } & 10.92 & 159.87 & 231.95 & 76.43 \\ \text { FGASIJN } & 1.0 & 1.0 & 1.0 & 1.0 \\ \text { XLJN } & 1.0 & 1.0 & 1.0 & 1.0\end{array}$

A-217 
FAl $10-83$

PRC-STP-00241, Rev 0

Rev. 0

XWJN

XHJN

1.0

1.0

1. 0

1.0

1.0

1. 0

* Path 18: Canyon to Cell 2L

* [References needed for CJN]

* IRI = 10 = Canyon

* ZIJN = Canyon floor $=0.0 \mathrm{~m}$

* IR2 = $12=\operatorname{cell} 2 \mathrm{~L}$

$*$ Z2JN $=$ Full cell 2L height $=30.10 "=9.397 \mathrm{~m}$

* AJN $=$ SED_AREA $=33.21 \mathrm{~m} * 2$

$\star X L J N=I=27.5^{\circ}=8.3820 \mathrm{~m}$

$\star X W J N=W=13^{\prime}=3.9624 \mathrm{~m}$

$\star$ XHJN $=0.001 \mathrm{~m}=$ thin

PATHS 18

LABEL CANYON-C2L

IJTYP 1

IRI 10

IR2 12

IHORIZ 1

AJN $\quad 33.21$

ZIJN $\quad 0.0$

Z2JN $\quad 9.397$

CJN 2.8

FGASIJN 1.0

XLJN $\quad 8.3820$

XWJN $\quad 3.9624$

XHJN $\quad 0.001$

END PATHS

* Cells to ventilation duct

* Path 13: Cold cells to ventilation duct via 10"-dia pipe.

* [Reference needed for CJN]

* IRI = $7=$ Cold cells

$\star \mathrm{Z} 1 \mathrm{JN}=9^{\circ}=2.7432 \mathrm{~m}$

* IR2 $=8$ = Ventilation duct

$\star \mathrm{Z} 2 \mathrm{JN}=$ top of duct $=\mathrm{ZTOP}=10.5^{\prime}=3.2004 \mathrm{~m}$

$\star \mathrm{CJN}=(1 / 0.6) \star \star 2=2.8$

* Consider 35 pipes for 35 cold cells:

$\star \mathrm{AJN}=35 \star \mathrm{pi} / 4 \star(\mathrm{D} * \star 2)$

$\star \quad=19.1 \mathrm{ft} \star \star 2$

* $\quad=1.7735 \mathrm{~m} * \star 2$

* XLJN $=10^{\prime}=2.5 \mathrm{~m}$

$\star X W J N=10^{\prime \prime}=0.254 \mathrm{~m}$

$\star \mathrm{XHJN}=10^{\prime \prime}=0.254 \mathrm{~m}$

* Path 14: Ventilation duct to process cell via 10"-dia pipe.

* [References needed for CJN]

* IR1 = 8 = Ventilation duct

$\star \mathrm{ZlJN}=$ top of duct $=\mathrm{ZTOP}=10.5^{\prime}=3.2004 \mathrm{~m}$

* IR2 = $6=\mathrm{T}$ cell

$\star \mathrm{Z} 2 \mathrm{JN}=9^{\prime}=2.7432 \mathrm{~m}$

$\star C J N=(1 / 0.6) * * 2=2.8$

* AJN $=p i / 4 *\left(D^{*} * 2\right)$

$\star \quad=0.5454 \mathrm{ft} \star \star 2$

* $\quad=0.05067 \mathrm{~m} \star \star 2$

$\star X L J N=10^{\circ}=2.5 \mathrm{~m}$

* XWJN $=10 "=0.254 \mathrm{~m}$

$\star \mathrm{XHJN}=10^{\prime \prime}=0.254 \mathrm{~m}$

* Path 21: Ventilation duct to hot cells via 10"-dia pipe.

* [References needed for CJN]

* IR1 = $8=$ Ventilation duct

* Z1JN $=$ top of duct $=\mathrm{ZTOP}=10.5^{1}=3.2004 \mathrm{~m}$

* IR2 = $14=$ Hot cells

$\star \mathrm{Z} 2 \mathrm{JN}=9^{1}=2.7432 \mathrm{~m}$

* $\mathrm{CJN}=(1 / 0.6) \star \star 2=2.8$

* Consider 5 pipes for 5 hot cells:

* $\mathrm{AJN}=5 \star \mathrm{pi} / 4 \star(\mathrm{D} * 2)$ 
$\mathrm{FAl} / 10-83$

\section{PRC-STP-00241, Rev 0}

\section{Rev. 0}

$* \quad=2.7271 \mathrm{ft} * * 2$

$* \quad=0.25335 \mathrm{~m} * * 2$

$* X L J N=10^{\prime}=2.5 \mathrm{~m}$

$* X W J N=10^{\prime \prime}=0.254 \mathrm{~m}$

$* \mathrm{XHJN}=10^{\prime \prime}=0.254 \mathrm{~m}$

$\begin{array}{llll}\text { PATHS } & 13 & 14 & 21 \\ \text { LABEL } & \text { COLD-VENT } & \text { VENT-TCELL } & \text { VENT-HOT } \\ \text { IJTYP } & 1 & 1 & 1 \\ \text { ICCJN } & 0 & 0 & 0 \\ \text { IRI } & 7 & 8 & 8 \\ \text { IR2 } & 8 & 6 & 14 \\ \text { IHORIZ } & 0 & 0 & 0 \\ \text { AJN } & 1.7735 & 0.05067 & 0.25335 \\ \text { ZIJN } & 2.7432 & 3.2004 & 3.2004 \\ \text { Z2JN } & 3.2004 & 2.7432 & 2.7432 \\ \text { CJN } & 2.8 & 2.8 & 2.8 \\ \text { KFILTER } & 0.0 & 0.0 & 0.0 \\ \text { FGASIJN } & 1.0 & 1.0 & 1.0 \\ \text { XLJN } & 2.5 & 2.5 & 2.5 \\ \text { XWJN } & 0.254 & 0.254 & 0.254 \\ \text { XHJN } & 0.254 & 0.254 & 0.254\end{array}$

END PATHS

*? Single cell pair $\mathrm{K}=160$; divide by 17.5

* Pipe trench to ventilation duct

* Path 16: Pipe trench to ventilation duct via 18 10"-dia pipes.

* [Reference needed for CJN]

* IR1 $=9=$ Pipe trench

* $\mathrm{ZlJN}=$ Pipe trench floor $=0 \mathrm{~m}$

* $\mathrm{IR2}=8$ = Ventilation duct

* $\mathrm{Z2JN}=$ top of duct $=$ ZTOP $=10.5^{\prime}=3.2004 \mathrm{~m}$

$\star \operatorname{CJN}=(1 / 0.6) \star 2=2.8$

* Consider 18 pipes for 18 cold cells:

* $\mathrm{AJN}=18 * \mathrm{pi} / 4 *(\mathrm{D} * 2)$

* $\quad=9.8229 \mathrm{ft} * * 2$

* $\quad=0.9121 \mathrm{~m} * * 2$

$\star X \mathrm{XLJN}=10^{\prime}=2.5 \mathrm{~m}$

$*$ XWJN $=10^{\prime \prime}=0.254 \mathrm{~m}$

$\star \mathrm{XHJN}=10^{\prime \prime}=0.254 \mathrm{~m}$

PATHS

16

LABEL PTRENCH - VENT

IJTYP 1

ICCJN 0

IRI 9

$\begin{array}{ll}\text { IR2 } & 8 \\ \text { IHORIZ } & 1\end{array}$

AJN $\quad 0.9121$

ZIJN $\quad 0.0$

Z2JN $\quad 3.2004$

CJN 2.8

FGASIJN 1.0

XLJN 2.5

XWJN $\quad 0.254$

XHJN $\quad 0.254$

eND paths

*

* Long cells to $24 "$ pipe

* Path 19: Cell 2L to $24 "$ vent pipe via 10"-dia pipes.

* [Reference needed for CJN]

* IR1 = $12=\operatorname{Cell} 2 \mathrm{~L}$

* ZlJN = 6'9" below canyon deck (note: 5'8" is at cover block level)

* $\quad$ ZTOP $12-619 "$

* $\quad=7.56 \overline{9} 2 \mathrm{~m}-2.0574 \mathrm{~m}$

* $\quad=5.5118 \mathrm{~m}$

* IR2 = $13=24 "$ pipe

* $\mathrm{Z} 2 \mathrm{JN}=0 \mathrm{~m}$ 


\section{$\mathrm{FAl} / 10-83$}

PRC-STP-00241, Rev 0

Rev. 0

* $\operatorname{CJN}=(1 / 0.6) * \star 2=2.8$

* $A J N=p i / 4 *(D * * 2)$

* $\quad=0.5454 \mathrm{ft} * * 2$

* $\quad=0.05067 \mathrm{~m} * * 2$

$\star \mathrm{XLJN}=10^{\prime}=2.5 \mathrm{~m}$

$\star X W J N=10^{\prime \prime}=0.254 \mathrm{~m}$

$\star \mathrm{XHJN}=10 "=0.254 \mathrm{~m}$

* Path 20: Cell 2R to 24" vent pipe via 10"-dia pipes.

* [Reference needed for CJN]

* $I R I=13=24 "$ pipe

* ZlJN $=0 \mathrm{~m}$

* IR2 = $11=\operatorname{cell} 2 \mathrm{R}$

* Z2JN = 6'9" below canyon deck

* $\quad$ ZTOP_12 - 6.9"

* $\quad=7.56 \overline{9} 2 \mathrm{~m}-2.0574 \mathrm{~m}$

$=5.5118 \mathrm{~m}$

* $\mathrm{CJN}=(1 / 0.6) * * 2=2.8$

* AJN $=p i / 4 *(D * * 2)$

$\star \quad \quad=0.5454 \mathrm{ft} * \star 2$

* $\quad=0.05067 \mathrm{m**2}$

$*$ XLJN $=10^{\circ}=2.5 \mathrm{~m}$

$*$ XWJN $=10^{\prime \prime}=0.254 \mathrm{~m}$

$* \mathrm{XHJN}=10^{\prime \prime}=0.254 \mathrm{~m}$

PATHS $19 \quad 20$

LABEL C2L-PIPE PIPE-C2R

$\begin{array}{lll}\text { IJTYP } & 1 & 1 \\ \text { ICCJN } & 0 & 0\end{array}$

IR1 12

IR2 $13 \quad 11$

IHORIZ 0 O

$\begin{array}{lll}\text { AJN } & 0.05067 & 0.05067\end{array}$

ZIJN $\quad 5.5118 \quad 0.0$

$\begin{array}{lll}Z 2 J N & 0.0 & 5.5118\end{array}$

$\begin{array}{lll}\text { CJN } & 2.8 & 2.8\end{array}$

FGASIJN $1.0 \quad 1.0$

XLJN $2.5 \quad 2.5$

$\begin{array}{lll}\text { XWJN } & 0.254 & 0.254\end{array}$

$\begin{array}{lll}X H J N & 0.254 & 0.254\end{array}$

END PATHS

* 24" Pipe and vent duct to exhaust duct

* Path 25: Ventilation duct to exhaust duct

* [Reference needed for CJN]

* IRI $=8$ = Ventilation duct

$\star \mathrm{zIJN}=$ Vent duct floor $=0.0 \mathrm{~m}$

* IR2 = 16 = Exhaust duct

* $\mathrm{Z} 2 \mathrm{JN}=$ Exhaust duct floor $=0.0 \mathrm{~m}$

$\star \mathrm{AJN}=5^{\prime} \star 4^{\prime}=20.0 \mathrm{ft} * 2=1.8581 \mathrm{~m} * \star 2$

$\star X L J N=\operatorname{thin}=0.001 \mathrm{~m}$

$\star$ XWJN $=4^{\prime}=1.2192 \mathrm{~m}$ (est.)

$\star \mathrm{XHJN}=5^{\prime}=1.5240 \mathrm{~m}$

* Path 27: 24" vent pipe to exhaust duct

* [Reference needed for CJN]

* $\operatorname{IRI}=13=24$ " pipe

* $\mathrm{Z} 1 \mathrm{JN}=0 \mathrm{~m}$

* IR2 = 16 = Exhaust duct

* Z2JN $=$ Vent duct floor +4 '

$\star \quad=4$ '

* $\quad=1.2192 \mathrm{~m}$

* $\mathrm{CJN}=(1 / 0.6) \star \star 2=2.8$

$\star \mathrm{AJN}=\mathrm{pi} / 4 \star(\mathrm{D} \star \star 2)$

* $\quad=3.1416 \mathrm{ft} \star \star 2$

$=0.2919 \mathrm{~m} * * 2$

$\star \mathrm{XLJN}=10^{1}=3.048 \mathrm{~m}$ (est.)

$\star$ XWJN $=24 "=0.6096 \mathrm{~m}$

* $\mathrm{XHJN}=24 " / \sin (45)=0.8621 \mathrm{~m}$

* 
FAl/10-83

PRC-STP-00241, Rev 0

Rev. 0

$\begin{array}{lcc}\text { PATHS } & 25 & 27 \\ \text { LABEL } & \text { VENT-EXH } & \text { PIPE-EXH } \\ \text { IJTYP } & 1 & 1 \\ \text { ICCJN } & 0 & 0 \\ \text { IRI } & 8 & 13 \\ \text { IR2 } & 16 & 16 \\ \text { IHORIZ } & 0 & 0 \\ \text { AJN } & 1.8581 & 0.2919 \\ \text { Z1JN } & 0.0 & 0.0 \\ \text { Z2JN } & 0.0 & 1.2192 \\ \text { CJN } & 1.5-5 & 2.8 \\ \text { KFILTER } & 0.0 & 0.0 \\ \text { FGASIJN } & 1.0 & 1.0 \\ \text { XLJN } & 0.001 & 3.048 \\ \text { XWJN } & 1.2192 & 0.6096 \\ \text { XHJN } & 1.5240 & 0.8621 \\ \text { END PATHS } & & \end{array}$

$\star$

* Fan from exhaust duct to ambient

* fan flow rate $=17500 \mathrm{cfm}=8.2591 \mathrm{~m} \wedge 3 / \mathrm{s}$

* fan flow rate $=0 \mathrm{~m}^{\wedge} 3 / \mathrm{s}$

* Path 26: Exhaust duct to ambient

* CJN not used, constant volumetric flow rate

* Set AJN to an arbitrary positive value

* so code does not bypass the junction

* IRI = 16 = Exhaust duct

* ZIJN $=0 \mathrm{~m}$

* $\mathrm{IR} 2=15=$ Ambient (atmosphere)

* $\mathrm{Z} 2 \mathrm{JN}=15 \mathrm{~m}$ (est.; stack height = 200'?)

PATHS 26

LABEL FAN

IUTYP 1

ICCJN

IR1 16

IR2 15

IHORIZ 0

AJN $\quad 0.0$

ZIJN $\quad 0.0$

Z2JN 15.0

CJN 1.0

KFILTER 0.0

FGASIJN 1.0

IFAN

WVFAN 8.2591

END PATHS

* cell 2L and canyon to ambient

* Path 28: Ambient to Canyon

* Leakage modeled using KFILTER

* $17500 \mathrm{cfm}\left(82.6 \mathrm{~m}^{\wedge} 3 / \mathrm{s}\right)$ at 0.15 in w.g. $(35.9 \mathrm{~Pa})$

* Assume equal split between canyon leakage and

* access tunnel leakage.

* Hence, KFILTER $=35.9 /(82.6 / 2)=0.870$

* IR1 = 15 = Ambient (atmosphere)

* ZIJN = ELEVATION $10+$ ZTOP $10 / 2$ - ELEVATION 15

* $\quad=7.5438 \mathrm{~m}+14.9352 \mathrm{~m}^{-1} / 2-7.5438 \mathrm{~m}$

$\star \quad \quad=7.4676 \mathrm{~m}$

* IR2 $=10=$ Canyon

* Z2JN $=$ ZTOP_10/2

* $\quad=7.46 \overline{76} \mathrm{~m}$

* Path 29: Ambient to Cell 2L

* Leakage modeled using KFILTER

* $17500 \mathrm{cmf}\left(82.6 \mathrm{~m}^{\wedge} 3 / \mathrm{s}\right)$ at $0.15 \mathrm{in} \mathrm{w.g.} \mathrm{(35.9} \mathrm{Pa)}$

* Assume equal split between canyon leakage and

* access tunnel leakage.

* Hence, KFILTER $=35.9 /(82.6 / 2)=0.870$ 
FAl/10-83

PRC-STP-00241, Rev 0

Rev. 0

* IRI = 15 = Ambient (atmosphere)

* Z1JN = ELEVATION_12 + ZTOP_12/2 - ELEVATION_15

* $\quad=-1.8542 \mathrm{~m}+7.5692 \overline{\mathrm{m}} / 2-7.5438 \mathrm{~m}$

$\star \quad=-5.6134 \mathrm{~m}$

$\star$ IR2 $=12=\operatorname{Cell} 2 \mathrm{~L}$

* $\mathrm{Z} 2 \mathrm{JN}=\mathrm{ZTOP} 12 / 2$

$\star \quad=7.56 \overline{9} 2 \mathrm{~m} / 2$

ॠ $\quad=3.7846 \mathrm{~m}$

PATHS

$28 \quad 29$

LABEL AMB-CANYON AMB-C2L

$\begin{array}{lll}\text { IJTYP } & 8 & 8 \\ \text { ICCJN } & 0 & 0\end{array}$

IRI $15 \quad 15$

IR2 $10 \quad 12$

IHORIZ 11

$\begin{array}{llc}\text { AJN } & 1.0 & 1.0 \\ \text { Z1JN } & 7.4676 & -5.6134\end{array}$

$\begin{array}{lll}Z 2 J N & 7.4676 & 3.7846\end{array}$

$\begin{array}{lll}\text { CJN } & 2.8 & 2.8\end{array}$

KFILTER $0.870 \quad 0.870$

FGASIJN $1.0 \quad 1.0$

$\begin{array}{lll}X L J N & 1.0 & 1.0\end{array}$

$\begin{array}{lll}\text { XWJN } & 1.0 & 1.0\end{array}$

$\begin{array}{lll}X H J N & 1.0 & 1.0\end{array}$

END PATHS

END JUNCTIONS

Page 222 of 284

March, 2010 
FAl/10-83

PRC-STP-00241, Rev 0

Rev. 0

\section{B.10 Case File: SETTLN1,dat}

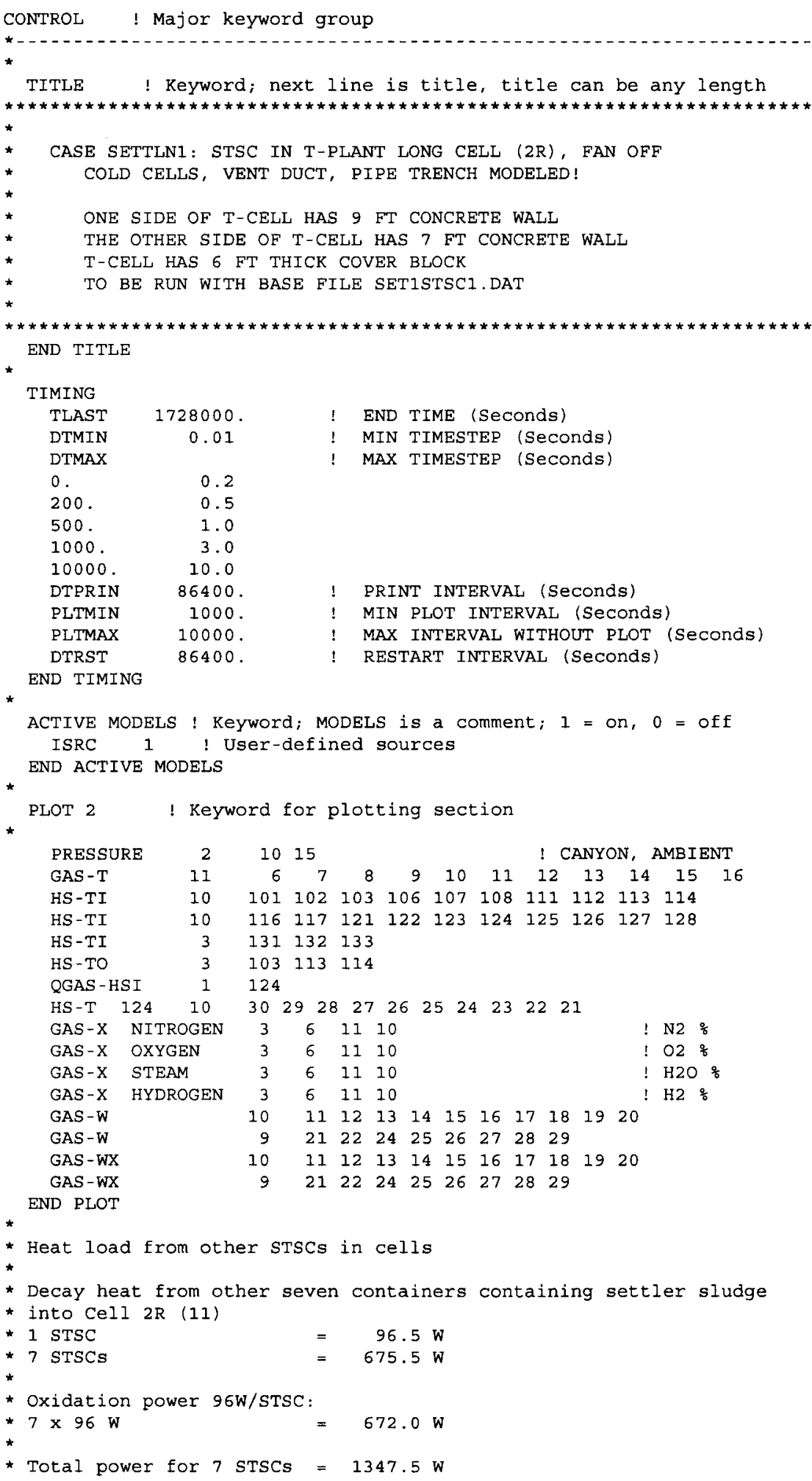


* $\mathrm{H} 2$ generation rate for $1 \mathrm{STSC}=7.0 \mathrm{E}-7 \mathrm{~kg} / \mathrm{s}$

* H2 generation rate for $7 \mathrm{STSCs}=4.9 \mathrm{E}-6 \mathrm{~kg} / \mathrm{s}$

* $\mathrm{H} 2$ released at $50 \mathrm{C}$

SOURCES 2

REGION 11 GASES 1 PHASE 1

HYDROGEN

$\begin{array}{llll}0 & 50.0 & 4.9 \mathrm{E}-6 & 1347.5 \\ 1 . \mathrm{E} 9 & 50.0 & 4.9 \mathrm{E}-6 & 1347.5\end{array}$

END REGION

*

* Decay heat from six containers containing settler sludge in each of

* four cells in the Hot Cell (14)

* 1 STSC

* 24 STSCs $\quad=2316.0 \mathrm{~W}$

* Oxidation power $96 \mathrm{~W} / \mathrm{STSC}$ :

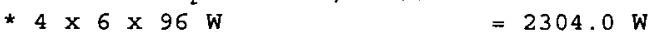

* Total power for $4 \times 6$ STsCs $=4620.0 \mathrm{~W}$

* $\mathrm{H} 2$ generation rate for $1 \mathrm{STSC}=7.00 \mathrm{E}-7 \mathrm{~kg} / \mathrm{s}$

* H2 generation rate for $24 \mathrm{STSCs}=1.68 \mathrm{E}-5 \mathrm{~kg} / \mathrm{s}$

* H2 released at $50 \mathrm{C}$

REGION 14 GASES 1 PHASE 1 HYDROGEN

$\begin{array}{llll}0 & 50.0 & 1.68 \mathrm{E}-5 & 4620.0\end{array}$

1.E9 $50.0 \quad 1.68 \mathrm{E}-5 \quad 4620.0$

END REGION

END SOURCES

END CONTROL

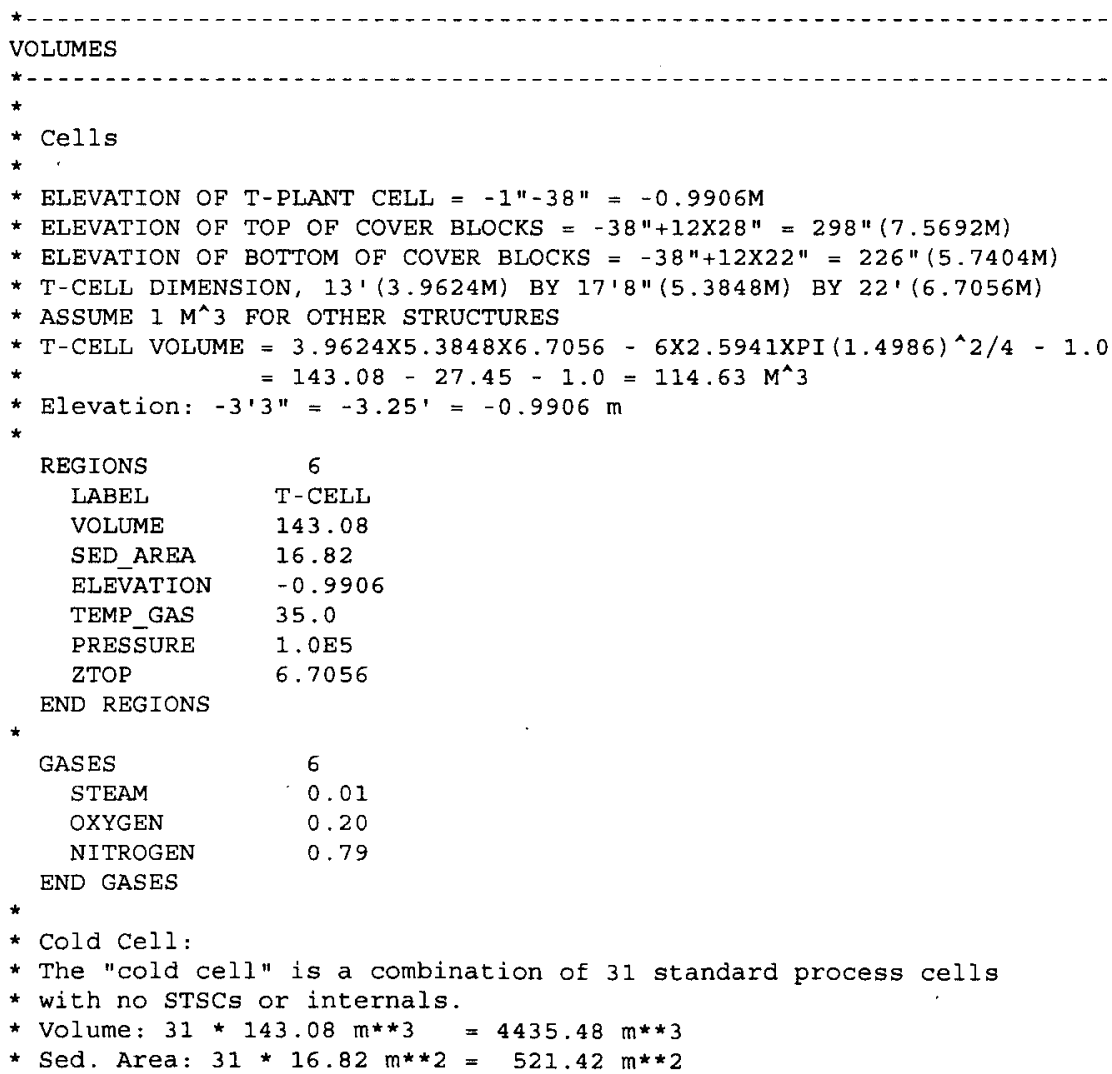


FAl/10-83

PRC-STP-00241, Rev 0

Rev. 0

* Elevation: -3.25 '

* Cell 2R:

*Volume: $\quad L=27^{\prime} 6^{\prime \prime} W=13^{\prime} \mathrm{H}=22^{\prime} \mathrm{V}=7865 \mathrm{ft} \star * 3=222.71 \mathrm{~m} * \star 3$

* Sed. Area: $L=27^{\prime} 6^{\prime \prime} W=13$ ' $A=357.5 \mathrm{ft} * * 2=33.21 \mathrm{~m} * 2$

* Elevation: -3.25 '

* Cell 2L:

* Cell 2L is slightly deeper than 2R due to train tracks, plus has no cover

* blocks. This adds another 6 ' of height to the cell

* Volume: $\quad L=27^{\prime} 6^{\prime \prime} \mathrm{W}=13^{\prime} \mathrm{H}=30^{\prime} 10^{\prime \prime} \mathrm{V}=11022.92 \mathrm{ft} * \star 3=312.13 \mathrm{~m} * \star 3$

* Sed. Area: $L=27^{\prime} 6^{\prime \prime} W=13^{\prime} A=357.5 \mathrm{ft} * * 2=33.21 \mathrm{~m} * 2$

* Z-top: $\mathrm{H}=30^{\prime} 10^{\prime \prime}=9.398 \mathrm{~m}$

* Elevation: $-3 \cdot 3^{\prime \prime}+28^{\prime}-30^{\prime} 10^{\prime \prime}=-6^{\prime} 1^{\prime \prime}=-1.8542 \mathrm{~m}$

* Hot Cell:

* The "hot cell" is a combination of 4 standard process cells.

* including STSCs and internals.

* Volume: $4 * 114.63 \mathrm{~m} * * 3=458.52 \mathrm{~m} * * 3$

* Sed. Area: $4 * 16.82 \mathrm{~m} * 2=67.28 \mathrm{~m} * * 2$

* Elevation: -3.25 '

REGIONS

SAME_AS

LABEL

VOLUME

SED_AREA

ELEVATION

TEMP GAS

PRESSURE

ZTOP

7
6
COLD-CELL
4435.48
521.42
-0.9906
32.0
$1.0 \mathrm{E} 5$
6.7056

11
6

CELL-2R

185.11

33.21

$-0.9906$

32.0

1. $0 \mathrm{E} 5$

$\begin{array}{cc}12 & 14 \\ 6 & 6 \\ \text { CELL-2L } & \text { HOT-CELL } \\ 251.39 & 458.52 \\ 33.21 & 67.28 \\ -1.8542 & -0.9906 \\ 32.0 & 32.0 \\ 1.0 \mathrm{E} 5 & 1.0 \mathrm{E} 5 \\ 7.5692 & 6.7056\end{array}$

$\star$

GASES

SAME AS

\section{7}

6. 7056

7. 5692

6. 7056

END GASSES

* VENTS AND DUCTING

* Vent duct (runs along the face of 40 standard cells, each 18' wide):

*Volume: $\quad \mathrm{L}=36 * 18^{\prime} \mathrm{W}=10.5^{\prime} \mathrm{H}=10.5^{\prime} \mathrm{V}=71442 \mathrm{ft} * \star 3=2023.0 \mathrm{~m} * \star 3$

* sed. Area : $L=36 * 18^{\prime}, W=10.5^{\prime} A=6804$ ft**2 $=632.1 \mathrm{~m} * * 2$

* Z-top: $\quad H=10.5^{\prime}=3.2 \mathrm{~m}$

* Elevation: $-3.25^{\prime}=-0.9906 \mathrm{~m}$

REGIONS

SAME_AS

LABEL

VOLUME

SED AREA

ELEVATION

TEMP_GAS

PRESSURE

ZTOP

11

12

14

Page 225 of 284

March, 2010

END REGIONS

GASES

SAME_AS

END GAS̄ES

* Pipe Trench:

* Sed. Area: I

$=\left(35 \times 20^{\prime}\right) W=8, A=5600 \mathrm{ft} \star \star 2=520.26 \mathrm{~m} \star \star 2$

* Z-top: $H=6^{\prime}=1.83 \mathrm{~m}$

* Elevation: 10.5' below canyon deck $\left(14.25^{\prime}=28^{\prime}-3.25^{\prime}-10.5^{\prime}=\right.$ )

* STSC bottom elevation: $0^{\prime}$

* T-Cell floor elevation: $-3.25^{\prime}$

* Canyon deck elevation: $28^{\prime}-3.25^{\prime}=24.75^{\prime}$

* Pipe trench cover block depth: 4.5'

* Pipe trench floor elevation: $24.75^{\prime}-4.5^{\prime}-6^{\prime}=14.25^{\prime}=4.3434 \mathrm{~m}$ 
FAI/10-83

PRC-STP-00241, Rev 0

Rev. 0

REGIONS

LABEL

VOLUME

SED AREA

ELEVATION

ZTOP

TEMP_GAS

PRESS̄URE

*

$\begin{array}{ll}\text { GASES } & 9 \\ \text { SAME_AS } & 6\end{array}$

Page 226 of 284

March, 2010

* 24 " Pipe:

* Sed. Area: $\mathrm{D}=2^{\prime} \mathrm{L}=7^{\prime}+2 * 13^{\prime} \mathrm{A}=\mathrm{D} * \mathrm{~L}=66 \mathrm{ft} \star 2=2=6.1316 \mathrm{~m} \star 2$

* Volume: $\mathrm{D}=2$ ' $\mathrm{L}=7 \mathrm{\prime}^{\prime}+2 * 13{ }^{\prime} \mathrm{V}=103.67 \mathrm{ft} * 3=2.9357 \mathrm{~m} \star 3$

* Z-top: $\mathrm{D}=2$ ' $=0.6096 \mathrm{~m}$

* Elevation: $-3.25^{\prime}+28^{\prime}-19^{\prime}=5.75^{\prime}=1.7526 \mathrm{~m}$

* Exhaust duct:

* Sed. Area: $L=145^{\prime} \mathrm{W}=4{ }^{\prime} \mathrm{A}=580 \mathrm{ft} \star * 2=53.88 \mathrm{~m} * \star 2$

*Volume: $\quad \mathrm{L}=145^{\prime} \mathrm{W}=4^{\prime} \mathrm{H}=7^{\prime} \mathrm{V}=4060 \mathrm{ft} \star * 2=115.0 \mathrm{~m} \star \star 2$

* Z-top: $\quad \mathrm{H}=7$

* Elevation: $-3.25^{\prime}=-0.9906 \mathrm{~m}$

REGIONS

SAME_AS

LABEL

VOLUME

SED AREA

ELEVTATION

ZTOP

TEMP GAS

PRESSURE

END REGIONS

$\begin{array}{cc}13 & 16 \\ 8 & 8 \\ \text { PIPE-24 } & \text { EXH-DUCT } \\ 2.9357 & 115.0 \\ 6.1316 & 53.88 \\ 1.7526 & -0.9906 \\ 0.6096 & 2.1336 \\ 32.0 & 32.0 \\ 1.0 \mathrm{E} 5 & 1.0 \mathrm{E} 5\end{array}$

GASES

SAME AS

END GASES

*

* atmospheres

* Canyon Length $=43^{\prime}+680^{\prime}+38.5^{\prime}=761.5 \mathrm{ft}=232.1 \mathrm{~m}$

* Lower $\mathrm{H}=25.9 "=7.85 \mathrm{~m}, \mathrm{~W}=37.2 ", \mathrm{AXI}=88.96 \mathrm{~m} * 2$

* Upper $\mathrm{H}=14^{\prime}=4.27 \mathrm{~m}, \mathrm{~W}=60^{\prime} 2^{\prime \prime}, \mathrm{Ax} 2=78.30 \mathrm{~m} * 2^{\prime}$

* Crane $\mathrm{H}=9.3 ", W=10^{\prime}, \mathrm{AX} 3=8.60 \mathrm{~m} * 2$

* Canyon total height $=25^{\prime} 9^{\prime \prime}+14^{\prime}+93^{\prime \prime}=49^{\prime}=14.9352 \mathrm{~m}$

* Volume $=232.1 \mathrm{x}(88.96+78.30+8.60)=40,818 \mathrm{~m} * * 3$

* Sed area $232.1 \mathrm{~m} \times 60 \mathrm{ft}=4245 \mathrm{~m} \star \star 2$

REGIONS

LABEL

VOLUME

SED_AREA

ELEVATION

TEMP GAS

PRESSURE

ZTOP

ZTOP

10

CANYON

40818 . EO

4245 .E0

7.5438

32.0

1. $0 \mathrm{E} 5$

14.9352

1. E3

15

AMB I ENT

1.E9

1.E6

7.5438

25.0

1. $0 \mathrm{E} 5$

1.E3

END REGIONS

GASES

STEAM

OXYGEN

NITROGEN

10

0.01

0.20

0.79

0.01

0.20

0.79

*

* control boundary pREssure

* OfFSET_TIMEPG 0.0 
FAl/10-83

PRC-STP-00241, Rev 0

Rev. 0

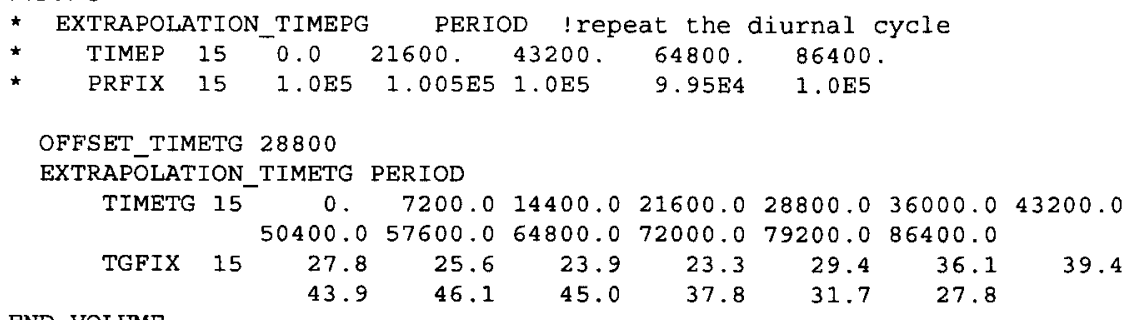

$\begin{array}{llllll}43.9 & 46.1 & 45.0 & 37.8 & 31.7 & 27.8\end{array}$

END VOLUME

HEAT SINKS

$\star-$

*

* CEll CONCRETe heat sinks

* ignore heat transfer to fLOOR

* thickness of sidewall $=1.067(3.51)$

* thickness of front/back wall $=1.372$ (4.5')

* thickness of cover block $=1.829$ (61)

* one-sided area of long sidewall $=2 \times 5.3848\left(178^{\prime \prime}\right) * 6.7056\left(22^{\prime \prime}\right)=72.217$

* one-sided area of short sidewall $=2 \times 3.9624\left(13^{\prime}\right) * 6.7056\left(22^{\prime}\right)=53.141$

* one-sided area of cover block $=5.3848\left(17^{\prime} 8^{\prime \prime}\right) * 3.9624\left(13^{\prime}\right)=21.337$

*

SINKS

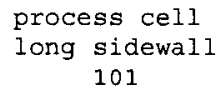

process cell

cell

cover block

102

103

$\begin{array}{lccc}\text { LABEL } & \text { PC-LSW } & \text { PC-SSW } & \text { PC-COV } \\ \text { IORIHS } & 0 & 0 & 1 \\ \text { IGEOM } & 1 & 1 & 1 \\ \text { IMATHS } & 3 & 3 & 3 \\ \text { XRI } & 0.0 & 0.0 & 0.0 \\ \text { XRO } & 1.067 & 1.372 & 1.829 \\ \text { AHS } & 72.217 & 53.141 & 21.337 \\ \text { TIINIT } & 32.00 & 32.00 & 32.00 \\ \text { TOINIT } & 32.00 & 32.00 & 35.00 \\ \text { IMSLAB } & 20 & 20 & 20 \\ \text { IREGI } & 6 & 6 & 10 \\ \text { IREGO } & 0 & 0 & 6 \\ \text { XLHS } & 6.7056 & 6.7056 & 3.9624 \\ \text { XZHS } & 6.7056 & 6.7056 & 3.9624 \\ \text { ZTHS } & 5.7150 & 5.7150 & 7.5438 \\ \text { ZBHS } & -0.9906 & -0.9906 & 5.7150\end{array}$

*

SINKS

31 COLD CELLS

long sidewall

106

short sidewall
107

cover block

108

LABEL

SAME_AS

CC-LSW

101

CC-SSW

102

$\mathrm{CC}-\mathrm{COV}$

AHS

2. $239 E 3$

$1.647 \mathrm{E3}$

32.00

103

TIINIT

32.00

32.00

$6.614 \mathrm{E} 2$

32.00

IREGI

7

7
0

32.00

10

END

*

$\star$

CELI 2R

* one-sided area of long sidewall $=1 \times 8.3820\left(27^{\prime} 6^{\prime \prime}\right) * 6.7056\left(22^{\prime}\right)=56.206$

* one-sided area of short sidewall $=2 \times 3.9624\left(13^{\prime}\right) * 6.7056\left(22^{\prime}\right)=53.141$

* one-sided area of cover block $=8.3820\left(27^{\prime} 6^{\prime \prime}\right) * 3.9624\left(13^{\prime}\right)=33.213$ long sidewall long sidewall short sidewall cover
block 
FAl/10-83

Rev. 0

SINKS

*

$\begin{array}{lc}\text { LABEL } & \text { 2R-LSW } \\ \text { SAME_AS } & 101 \\ \text { AHS } & 56.206 \\ \text { TIINIT } & 35.00 \\ \text { TOINIT } & 35.00 \\ \text { IREGI } & 11 \\ \text { IREGO } & 0\end{array}$

END

*

*

SINKS

$\begin{array}{lc}\text { LABEL } & 2 \text { L-LSW } \\ \text { SAME_AS } & 111 \\ \text { IREGI } & 12 \\ \text { IREGO } & 0\end{array}$

END

$$
\begin{aligned}
& \star \\
& \star \\
& \star
\end{aligned}
$$$$
\text { SINKS }
$$

*

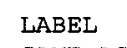

SAME_AS

AHS

IREGI

IREGO

END

$\star$

$\star 2 \times 10.5 \times(18 \times 40)$ FT**2

SINKS

IORIHS

IGEOM

XRI

$X R O$

AHS

TI INIT

TOINIT

IMSLAB

IREGI

IREGO

XIHS

XZHS

ZTHS

ZBHS

4 HOT CELLS

long sidewall short sidewall

127

CC-LSW

101

288.9

14

0

CC-SSW
102
212.6
14

0

VENT DUCT

121

0
1
3
0.0
1.52
1405.4
32.0
32.0
20
8
0
3.20
3.20
2.21
-0.9906

112

2R-SSW

102

53.141

32.00

32.00

11

11

12
Page 228 of 284

March, 2010
113

$2 \mathrm{R}-\mathrm{COV}$

103

33.213

32.0

32.0

10 cover block

128

$\mathrm{CC}-\mathrm{COV}$

103

85.35

10

* CANYON

* lower canyon walls: $5 \mathrm{ft}$ thick, $7.85 \mathrm{~m}$ high, $260.5 \mathrm{~m}$ long, x2

* upper canyon walls: 3 ft thick, $4.27 \mathrm{~m}$ high, x2

$\begin{array}{lcc}\text { SINKS } & 131 & 132 \\ \text { IORIHS } & 0 & 0 \\ \text { IGEOM } & 1 & 1 \\ \text { IMATHS } & 3 & 3 \\ \text { XRI } & 0.0 & 0.0 \\ \text { XRO } & 1.52 & 0.915 \\ \text { AHS } & 4090.0 & 2224.7\end{array}$


FAl/10-83

PRC-STP-00241, Rev 0

Rev. 0

TIINIT

TOINIT

IMSLAB

IREGI

IREGO

XLHS

XZHS

ZTHS

ZBHS

END

7.5438

32.00
32.00

32.00
20

0

12.0

12.0

32.00

35.00

20

10

12.0

12.0

19.664

15.394

PIPE TRENCH

* PIPE TRENCH WALL IS $2 \times 6 \times(35 \times 20) \quad F T * \star 2$

* COVER IS $8 \times(35 \times 20) \quad$ FT**2

* wall cover

SINKS $122 \quad 123$

*

IGEOM $\quad 11$

$\begin{array}{lll}\text { XRI } & 0.0 & 0.0\end{array}$

$\begin{array}{lll}X R O & 1.52 & 1.37\end{array}$

$\begin{array}{lll}\text { AHS } & 781.0 & 520.5\end{array}$

TIINIT $\quad 32.00 \quad 32.00$

TOINIT $\quad 32.00 \quad 32.00$

IMSLAB $20 \quad 20$

IREGI 90

$\begin{array}{lll}\text { XLHS } & 1.83 & 1.83\end{array}$

$\begin{array}{lll}X Z H S & 1.83 & 1.83\end{array}$

$\begin{array}{lll}\text { ZTHS } & 6.1710 & 7.5438\end{array}$

END

$\begin{array}{ll}6.1710 & 7.5438 \\ 4.3426 & 6.1710\end{array}$

*

* length $=2.1336+2 * 3.9624=10.0584$

$\begin{array}{lll}\text { SINKS } & 124 & 125\end{array}$

IORIHS

IGEOM

IMATHS

XRI

XRO

AHS

TIINIT

TOINIT

IMSLAB

IREGI

IREGO

XLHS

XZHS

Z ZTHS

ZBHS

0

$0 \quad 0$

$3 \quad 3$

$0.6096 \quad 0.3048$

$5.0 \quad 0.6096$

$177.3 \quad 2.8727$

$32.00 \quad 32.00$

$32.00 \quad 32.00$

$30 \quad 20$

$0 \quad 13$

$0 \quad 0$

$12.0 \quad 0.6096$

$10.1 \quad 10.1$

?

END

4. - - - -

* SET ZTHS TO REgION 1 TOP ELEVATION, $2.43327 \mathrm{M}$

$\begin{array}{cr}\text { SINKS } & 68 \\ \text { LABEL } & \text { TOP } \\ \text { IREGO } & 11\end{array}$

END

*

* inNer cylinder and stsc wall adjacent to water and gas

$\star \quad$ Layer 21 
FAl/10-83

PRC-STP-00241, Rev 0

Rev. 0

SINKS

1 LABEL

61

WALLO- 21

END

11

* Volume Cumulative volume

* LAYER-13 $0.03849 \quad 0.53849$

*-1.-.

$\begin{array}{lll}* \text { LAYER-12 } & 0.09337 & 0.50000\end{array}$

* Layer 20

SINKS $\quad 58$

IREGO 、 11

END

SINKS Layer 19

IREGO 11

END

* Layer 18

SINKS 52

IREGO 11

END

LINKS Layer 17

IREGO

*ND Layer 16

SINKS $\quad$ Layer 16

END

IREGO

END

SINKS

END

Layer 13

37

END

*

Layer 12

SINKS $\quad 34$

END

Layer 11

31

IREGO 11

END

* ELIIPTICAL SECTion

* lower head exterior sees atmosphere in the skirt enclosure

Layer 10

SINKS $\quad 28$

END

* Layer 9

SINKS 25

IREGO 11

END

* Layer 8

SINKS 22

IREGO 11

END

* wall for Layer 7 and below is considered horizontal;

* heat transfer due to laminar boundary layer underside

* of a hot plate is modeled in FATE 
FAl/10-83

PRC-STP-00241, Rev 0

Rev. 0

Page 231 of 284

*

$\begin{array}{lc}\text { * } & \text { Layer } 7 \\ \text { SINKS } & 19 \\ \text { IREGO } & 11 \\ \text { END } & \text { Layer } 6 \\ & \\ \text { SINKS } & 16 \\ \text { IREGO } & 11 \\ \text { END } & \text { Layer } 5 \\ \text { SINKS } & 13 \\ \text { IREGO } & 11 \\ \text { END } & \\ & \text { Layer } 4 \\ \text { SINKS } & 10 \\ \text { IREGO } & 11\end{array}$

*

SINKS

IREGO 11

END

* below the inner eliptical head

SINKS Layer 2

IREGO 4

END

* Skirt and dRip pan

*

* MODEL DRIP-PAN AS VERTICAL hS TO ALLOW CONVECTIVE HT TO CELL

$\begin{array}{lll}\text { SINKS } & 96 & 95 \\ \text { LABEL } & \text { SKIRT } & \text { DRIP-PAN }\end{array}$

$\begin{array}{ccc}\text { SINKS } & 96 & 95 \\ \text { LABEL } & \text { SKIRT } & \text { DRIP-PAN }\end{array}$

IREGO 11

END

END HEAT SINKS

\#--

JUNCTIONS

$\star--.--$

* Move STSC from region 6 to region 11

* 2" INLET VENT

* 4" OUTLET VENT WITH 2 FOOT $(0.6096 \mathrm{M})$ CHIMNEY

\begin{tabular}{|c|c|c|}
\hline PATHS & 1 & 2 \\
\hline LABEL & VENT - IN & VENT - OUT \\
\hline IRI & 11 & 1 \\
\hline IR2 & 2 & 11 \\
\hline
\end{tabular}

* holes IN THE SKIRT

* Redirect from typical cell (6) to cell 2R (11)

PATHS 405

LABEL HOLE-BOT HOLE-MID HOLE-TOP

$\begin{array}{lrrr}\text { IR1 } & 11 & 11 & 3 \\ \text { IR2 } & 3 & 3 & 11\end{array}$

END PATHS

$\star$

* Canyon to cells \& pipe trench through cover block gaps

* Path 11: Process cell to canyon via gap

* [References needed for CJN, KFILTER]

* IRI $=6=\mathrm{T}-\mathrm{Cell}$

$\star \mathrm{ZlJN}=$ Cell height $=$ ZTOP $=6.7056 \mathrm{~m}$ 
FAl/10-83

PRC-STP-00241, Rev 0

Rev. 0

* $\mathrm{IR2}=10=$ Canyon

$\star \mathrm{z} 2 \mathrm{JN}=$ Canyon floor $=0.0 \mathrm{~m}$

PATHS 11

LABEL TCELL-GAP

IJTYP 8

ICCJN

IRI

IR2

AJN 1

ZIJN $\quad 6.7056$

Z2JN $\quad 0.0$

CJN $\quad 1 . E-5$

KFILTER 382.15

FGASIJN 1.0

XLJN 1.0

XWJN $\quad 1.0$

XHJN 1.0

END PATHS

* Path 12: Canyon to cold cells via cover block gaps

* [References needed for CJN]

* IRI = 10 = Canyon

* $\mathrm{Z} 1 \mathrm{JN}=$ Canyon floor $=0.0 \mathrm{~m}$

* IR2 = 7 = Cold cells

* $\mathrm{z} 2 \mathrm{JN}=$ Cell height $=$ ZTOP $=6.7056 \mathrm{~m}$

* KFILTER $=1 /(\operatorname{sum}[i=1.35](1 /$ KFILTER_tcell) $)$

* $\quad$ KFILTER tcell / 35

$=382.15 / 35=10.92$

* Path 15: Canyon to pipe trench via cover block gaps

* [References needed for CJN, KFILTER]

* IR $1=10=$ Canyon

* $\mathrm{z} 1 \mathrm{JN}=$ Canyon floor $=0.0 \mathrm{~m}$

* IR2 = 9 = Pipe trench

* Z2JN $=$ Trench height $=$ ZTOP $=1.83 \mathrm{~m}$

* KFILTER $=($ Kwidth * Klength $) /(2 *($ Kwidth + Klength $))$

* $\quad=(389.7 * 1781.1) /(2 *(389.7+1781.1))$

$=159.87$

* Path 17: Cell 2R to canyon via cover block gaps

* [References needed for CJN, KFILTER]

* IRI $=11=\operatorname{cel} 12 \mathrm{R}$

* $\mathrm{ZlJN}=\mathrm{Cell} 2 \mathrm{R}$ height $=\mathrm{ZTOP}=6.7056 \mathrm{~m}$

* IR2 = $10=$ Canyon

* Z2JN $=$ Canyon floor $=0.0 \mathrm{~m}$

* Path 22: Hot cells to canyon via cover block gaps

* [References needed for CJN]

* IRI = $14=$ Hot cells

$\star \mathrm{ZIJN}=\mathrm{Cell}$ height $=$ ZTOP $=6.7056 \mathrm{~m}$

* IR2 = 10 = Canyon

* Z2JN = Canyon floor $=0.0 \mathrm{~m}$

* KFILTER $=1 /(\operatorname{sum}[i=1.5](1 /$ KFILTER_tcell $))$

$=$ KFILTER tcell / 5

$=382.15 \bar{T} 5=76.43$

PATHS SAME AS 11

LABEI

12

11

15
11

IJTYP

IRI

IR2

IHORIZ

AJN

ZIJN

$22 \mathrm{JN}$

CJN

8
10

7

1.0

0.0

6. 7056

1. E-5

KFILTER 10.92

1.0

GAP-PI PE

$17 \quad 22$

FGASIJN

8

9

1

1.0

0.0

1.83

1.E-5

159.87

1.0

C2R-GAP

11

HOT-GAP

8
11
10

10

1.01 .0

$6.7056 \quad 6.7056$

$0.0 \quad 0.0$

1.E-5 1.E-5

$231.95 \quad 76.43$

$\begin{array}{ll}1.95 & 16.0\end{array}$ 
FAl/10-83

PRC-STP-00241, Rev 0

Rev. 0

$\begin{array}{lllll}\text { XLJN } & 1.0 & 1.0 & 1.0 & 1.0 \\ \text { XWJN } & 1.0 & 1.0 & 1.0 & 1.0 \\ \text { XHJN } & 1.0 & 1.0 & 1.0 & 1.0\end{array}$

*

* Path 18: Canyon to Cell 2L

* [References needed for CJN]

* IRI = 10 = Canyon

* Z1JN = Canyon floor $=0.0 \mathrm{~m}$

* IR2 = $12=\operatorname{cell} 2 \mathrm{~L}$

$* \mathrm{Z} 2 \mathrm{JN}=$ Full cell $2 \mathrm{~L}$ height $=30.10 "=9.397 \mathrm{~m}$

* AJN = SED_AREA $=33.21 \mathrm{~m} * * 2$

$\star X L J N=L=27.5^{\prime}=8.3820 \mathrm{~m}$

$\star X W J N=W=13^{\prime}=3.9624 \mathrm{~m}$

$\star$ XHJN $=0.001 \mathrm{~m}=$ thin

PATHS 18

LABEL CANYON-C2L

IUTYP 1

IR1 10

IR2 12

IHORIZ 1

AJN $\quad 33.21$

Z1JN $\quad 0.0$

Z2JN $\quad 9.397$

CJN 2.8

FGASIJN 1.0

XLJN 8.3820

XWJN $\quad 3.9624$

XHJN $\quad 0.001$

END PATHS

* Cells to ventilation duct

* Path 13: Cold cells to ventilation duct via 10"-dia pipe.

* [Reference needed for CJN]

* IRI = 7 = Cold cells

* ZIJN $=9^{\prime}=2.7432 \mathrm{~m}$

* IR2 = 8 = ventilation duct

$\star \mathrm{Z} 2 \mathrm{JN}=$ top of duct $=\mathrm{ZTOP}=10.5^{\prime}=3.2004 \mathrm{~m}$

* $\mathrm{CJN}=(1 / 0.6) * \star 2=2.8$

* Consider 35 pipes for 35 cold cells:

* AJN $=35 \star p i / 4 \star(D * \star 2)$

* $\quad=19.1 \mathrm{ft} * 2$

* $\quad=1.7735 \mathrm{~m} * \star 2$

$* \mathrm{XLJN}=10^{\prime}=2.5 \mathrm{~m}$

* XWJN $=10^{\prime \prime}=0.254 \mathrm{~m}$

$\star \mathrm{XHJN}=10 "=0.254 \mathrm{~m}$

* Path 14: Ventilation duct to process cell via 10"-dia pipe.

* [References needed for CJN]

* IRI = 8 = Ventilation duct

$\star \mathrm{Z} 1 \mathrm{JN}=$ top of duct $=\mathrm{ZTOP}=10.5^{\prime}=3.2004 \mathrm{~m}$

$\star$ IR2 $=6=\mathrm{T}$ cell

$\star \mathrm{Z} 2 \mathrm{JN}=9^{\prime}=2.7432 \mathrm{~m}$

$\star \mathrm{CJN}=(1 / 0.6) \star * 2=2.8$

$\star \mathrm{AJN}=\mathrm{pi} / 4 *(\mathrm{D} * \star 2)$

* $\quad=0.5454 \mathrm{ft} * \star 2$

* $\quad=0.05067 \mathrm{~m} * \star 2$

$*$ XLJN $=10^{\prime}=2.5 \mathrm{~m}$

$\star X W J N=10^{\prime \prime}=0.254 \mathrm{~m}$

$* \mathrm{XHJN}=10^{\prime \prime}=0.254 \mathrm{~m}$

* Path 21: Ventilation duct to hot cells via 10"-dia pipe.

* [References needed for CJN]

* IR1 = 8 = Ventilation duct

$\star \mathrm{Z} 1 \mathrm{JN}=$ top of duct $=\mathrm{ZTOP}=10.5^{1}=3.2004 \mathrm{~m}$

* IR2 $=14=$ Hot cells

* $\mathrm{Z} 2 \mathrm{JN}=91=2.7432 \mathrm{~m}$

$\star C J N=(1 / 0.6) * \star 2=2.8$

* Consider 5 pipes for 5 hot cells: 
FAl/10-83

\section{PRC-STP-00241, Rev 0}

Rev. 0

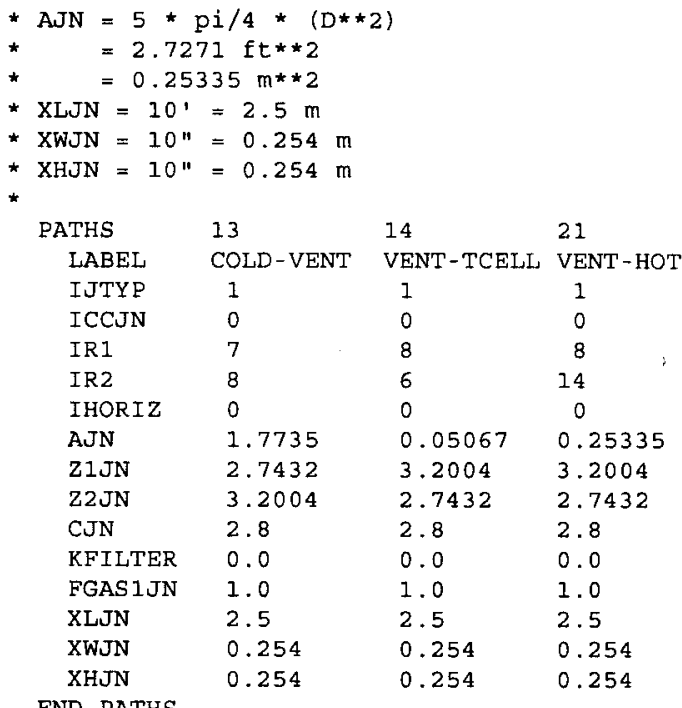

*

*? Single cell pair $\mathrm{K}=160$; divide by 17.5

* Pipe trench to ventilation duct

* Path 16: Pipe trench to ventilation duct via 18 10"-dia pipes.

* [Reference needed for CJN]

* IR1 = 9 = Pipe trench

$\star \mathrm{Z} 1 \mathrm{JN}=$ Pipe trench floor $=0 \mathrm{~m}$

* IR2 = 8 = Ventilation duct

$\star \mathrm{Z} 2 \mathrm{JN}=$ top of duct $=\mathrm{ZTOP}=10.5^{\prime}=3.2004 \mathrm{~m}$

$\star \mathrm{CJN}=(1 / 0.6) \star \star 2=2.8$

* Consider 18 pipes for 18 cold cells:

* $\mathrm{AJN}=18 * \mathrm{pi} / 4 \star(\mathrm{D} \star \star 2)$

$\star \quad \quad=9.8229 \mathrm{ft} * * 2$

* $\quad=0.9121 \mathrm{~m} * * 2$

$* X_{4} \mathrm{JN}=10^{\prime}=2.5 \mathrm{~m}$

$\star X W J N=10^{\prime \prime}=0.254 \mathrm{~m}$

$\star \mathrm{XHJN}=10 "=0.254 \mathrm{~m}$

*

PATHS 16

LABEL PTRENCH-VENT

IJTYP 1

ICCJN 0

IRI 9

IR2 8

$\begin{array}{ll}\text { IHORIZ } & 1 \\ \text { AJN } & 0.9121\end{array}$

ZIJN 0.0

Z2JN $\quad 3.2004$

CJN 2.8

FGASIJN 1.0

XLUN 2.5

XWJN $\quad 0.254$

XHJN 0.254

D PATHS

* Long cells to $24 "$ pipe

* Path 19: Cell 2l to $24 "$ vent pipe via 10"-dia pipes.

* [Reference needed for CJN]

* IRI = $12=\operatorname{Cell} 2 \mathrm{~L}$

* ZlJN = 6'9" below canyon deck (note: 5'8" is at cover block level)

* $\quad$ ZTOP_12-6.9"

* $\quad=7.56 \overline{9} 2 \mathrm{~m}-2.0574 \mathrm{~m}$

* $\quad=5.5118 \mathrm{~m}$

* IR2 $=13=24 "$ pipe 
* CJN $=(1 / 0.6) * \star 2=2.8$

* $\mathrm{AJN}=\mathrm{pi} / 4 *(\mathrm{D} * * 2)$

* $\quad=0.5454 \mathrm{ft} * * 2$

* $\quad=0.05067 \mathrm{~m} * \star 2$

$\star \mathrm{XLJN}=10^{\prime}=2.5 \mathrm{~m}$

* XWJN $=10 "=0.254 \mathrm{~m}$

$\star X H J N=10 "=0.254 \mathrm{~m}$

* Path 20: Cell 2R to $24 "$ vent pipe via 10"-dia pipes.

* [Reference needed for CJN]

* IRI = $13=24 "$ pipe

* $\mathrm{ZIJN}=0 \mathrm{~m}$

* IR2 = II = Cell 2R

* Z2JN = 6.9" below canyon deck

* $\quad$ ZTOP_12 - 6.9"

$\star \quad=7.56 \overline{9} 2 \mathrm{~m}-2.0574 \mathrm{~m}$

* $\quad=5.5118 \mathrm{~m}$

$\star \operatorname{CJN}=(1 / 0.6) \star \star 2=2.8$

* AJN $=p i / 4 *(D * * 2)$

$\star \quad=0.5454 \mathrm{ft} * \star 2$

$\star \quad=0.05067 \mathrm{~m} \star 2$

${ }^{*} \mathrm{XLJN}=10^{\prime}=2.5 \mathrm{~m}$

* $X$ WJN $=10^{\prime \prime}=0.254 \mathrm{~m}$

$\star \mathrm{XHJN}=10 "=0.254 \mathrm{~m}$

*

$\begin{array}{lll}\text { PATHS } & 19 & 20 \\ \text { LABEL } & \text { C2L-PIPE } & \text { PIPE-C2R } \\ \text { IJTYP } & 1 & 1 \\ \text { ICCJN } & 0 & 0 \\ \text { IR1 } & 12 & 13 \\ \text { IR2 } & 13 & 11 \\ \text { IHORIZ } & 0 & 0 \\ \text { AJN } & 0.05067 & 0.05067 \\ \text { Z1JN } & 5.5118 & 0.0 \\ \text { Z2JN } & 0.0 & 5.5118 \\ \text { CJN } & 2.8 & 2.8 \\ \text { FGAS1JN } & 1.0 & 1.0 \\ \text { XLJN } & 2.5 & 2.5 \\ \text { XWJN } & 0.254 & 0.254 \\ \text { XHJN } & 0.254 & 0.254\end{array}$

END PATHS

* 24" Pipe and vent duct to exhaust duct

* Path 25: Ventilation duct to exhaust duct

* [Reference needed for CJN]

* IRI = 8 = Ventilation duct

* ZIJN $=$ Vent duct floor $=0.0 \mathrm{~m}$

* IR2 $=16$ = Exhaust duct

* Z2JN = Exhaust duct floor $=0.0 \mathrm{~m}$

$*$ AJN $=5^{\prime} * 4^{\prime}=20.0 \mathrm{ft} * 2=1.8581 \mathrm{~m} * 2$

* XLJN $=$ thin $=0.001 \mathrm{~m}$

$\star$ XWJN $=4^{\prime}=1.2192 \mathrm{~m}$ (est.)

$\star \mathrm{XHJN}^{\prime}=5^{\circ}=1.5240 \mathrm{~m}$

* Path 27: 24" vent pipe to exhaust duct

* [Reference needed for CJN]

* $\mathrm{IR} 1=13=24 "$ pipe

* $\mathrm{ZIJN}=0 \mathrm{~m}$

* IR2 $=16$ = Exhaust duct

* Z2JN = vent duct floor +4

* $\quad=4^{\prime}$

* $\quad=1.2192 \mathrm{~m}$

* $\operatorname{CJN}=(1 / 0.6) * * 2=2.8$

* AJN $=p i / 4 *(D * * 2)$

$\star \quad=3.1416 \mathrm{ft} * \star 2$

* $\quad=0.2919 \mathrm{~m} * * 2$

${ }^{*} \mathrm{XLJN}=10^{\prime}=3.048 \mathrm{~m}$ (est.)

$\star$ XWJN $=24 "=0.6096 \mathrm{~m}$

$\star$ XHJN $=24 \mathrm{~N} / \sin (45)=0.8621 \mathrm{~m}$ 
FAl/10-83

PRC-STP-00241, Rev 0

Rev. 0

Page 236 of 284

$\begin{array}{lcc}\text { PATHS } & 25 & 27 \\ \text { LABEL } & \text { VENT-EXH } & \text { PIPE-EXH } \\ \text { IJTYP } & 1 & 1 \\ \text { ICCJN } & 0 & 0 \\ \text { IRI } & 8 & 13 \\ \text { IR2 } & 16 & 16 \\ \text { IHORIZ } & 0 & 0 \\ \text { AJN } & 1.8581 & 0.2919 \\ \text { ZIJN } & 0.0 & 0.0 \\ \text { Z2JN } & 0.0 & 1.2192 \\ \text { CJN } & 1 . E-5 & 2.8 \\ \text { KFILTER } & 0.0 & 0.0 \\ \text { FGASIJN } & 1.0 & 1.0 \\ \text { XLJN } & 0.001 & 3.048 \\ \text { XWJN } & 1.2192 & 0.6096 \\ \text { XHJN } & 1.5240 & 0.8621\end{array}$

*

* Fan from exhaust duct to ambient

$\star$

* far flow rate $=17500 \mathrm{cfm}=8.2591 \mathrm{~m}^{\wedge} 3 / \mathrm{s}$

* far flow rate $=0 \mathrm{~m}^{\wedge} 3 / \mathrm{s}$

* Path 26: Exhaust duct to ambient

* CJN not used, constant volumetric flow rate

* Set AJN to an arbitrary positive value

* so code does not bypass the junction

* IRI = $16=$ Exhaust duct

* ZIJN $=0 \mathrm{~m}$

* IR2 = 15 = Ambient (atmosphere)

- $\mathrm{Z} 2 \mathrm{JN}=15 \mathrm{~m}$ (est. ; stack height = 200'?)

$\begin{array}{lc}\text { PATHS } & 26 \\ \text { LABEL } & \text { FAN } \\ \text { IJTYP } & 1 \\ \text { ICCJN } & 1 \\ \text { IR1 } & 16 \\ \text { IR2 } & 15 \\ \text { IHORIZ } & 0 \\ \text { AJN } & 0.0 \\ \text { ZIJN } & 0.0 \\ \text { Z2JN } & 15.0 \\ \text { CJN } & 1.0 \\ \text { KFILTER } & 0.0 \\ \text { FGAS1JN } & 1.0 \\ \text { IFAN } & 1 \\ \text { WVFAN } & 8.2591 \\ \text { END PATHS } & \end{array}$

* Cell 2L and canyon to ambient

* Path 28: Ambient to Canyon

* Leakage modeled using KFILTER

* $17500 \mathrm{cfm}\left(82.6 \mathrm{~m}^{\wedge} 3 / \mathrm{s}\right)$ at $0.15 \mathrm{in} \mathrm{w.g.} \mathrm{(35.9} \mathrm{Pa)}$

* Assume equal split between canyon leakage and

* access tunnel leakage.

* Hence, KFILTER $=35.9 /(82.6 / 2)=0.870$

$\star$ IR1 = 15 = Ambient (atmosphere)

* ZIJN $=$ ELEVATION_10 + ZTOP_10/2 - ELEVATION_15

* $\quad=7.5438 \mathrm{~m}+14.9352 \mathrm{~m} / 2-7.5438 \mathrm{~m}$

$\star \quad=7.4676 \mathrm{~m}$

* IR2 = $10=$ Canyon

* $\mathrm{Z2JN}=\mathrm{ZTOP} 10 / 2$

* $\quad=7.46 \overline{7} 6 \mathrm{~m}$

* Path 29: Ambient to Cell 2L

* Leakage modeled using KFILTER

* $17500 \mathrm{cmf}\left(82.6 \mathrm{~m}^{\wedge} 3 / \mathrm{s}\right)$ at $0.15 \mathrm{in} \mathrm{w.g.} \mathrm{(35.9} \mathrm{Pa)}$

* Assume equal split between canyon leakage and

* access tunnel leakage. 
* Hence, KFILTER $=35.9 /(82.6 / 2)=0.870$

* IR1 $=15=$ Ambient (atmosphere)

* ZIJN = ELEVATION $12+$ ZTOP $12 / 2$ - ELEVATION_15

* $\quad=-1.8542 \mathrm{~m}+7.5692 \mathrm{~m} / 2-7.5438 \mathrm{~m}$

* $\quad=-5.6134 \mathrm{~m}$

$*$ IR2 $=12=\operatorname{Cell} 2 \mathrm{~L}$

$*$ Z2JN $=$ ZTOP_12/2

$* \quad=7.56 \overline{9} 2 \mathrm{~m} / 2$

* $\quad=3.7846 \mathrm{~m}$

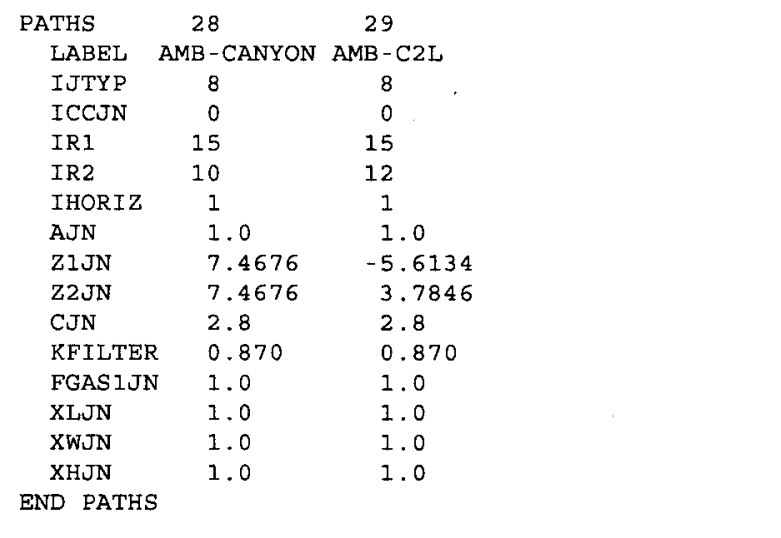

END JUNCTIONS

\section{APPENDIX C: SELECTED FATETM MODEL IMPROVEMENT MEMOS}

This Appendix contains five FAl memoranda describing improved FATE ${ }^{\mathrm{TM}}$ computer code models for modeling sludge behavior during transportation and storage.

Sections C. 1 through C.3 describe the theoretical basis for global natural circulation between standard cells and the canyon in T Plant, implementation and testing of the model for FATE Quality Assurance, and an example application demonstrating that the circulation flow predicted by FATE is in agreement with a simple hand calculation. The important conclusion of these memos is that such global circulation will exist, which is beneficial in achieving low hydrogen concentrations in a cell.

Sections C.4 and C.5 describe the theoretical basis for natural convection heat transfer around the bottom head of an STSC, and implementation and testing of the model in FATE for FATE Quality Assurance. The important conclusion is that the holes in the STSC skirt are sufficient to credit this heat removal process, which is beneficial for thermal stability of sludge.

Note that the individual memoranda are copied here verbatim, so that figure, table, equation, and section numbers are given as in the original work, as are references. 
DATE: March 1, 2010

TO: Michael E. Johnson

James P. Sloughter

Bob Apthorpe

Sung Jin Lee

Marty Plys

FROM: $\quad$ Michael Epstein Vice President, Consulting Services

SUBJECT: Buoyancy-Driven Flows in T Plant When the Ventilation System is Not Operating

\section{INTRODUCTION}

Previous analyses of sludge storage at $T$ Plant have conservatively assumed stagnant cell conditions (no $\mathrm{T}$ Plant ventilation) allowing only exchange flow between the cell of interest and the canyon via gaps in cover blocks. The general condition under which global natural circulation within $T$ Plant can enhance the ventilation rate within a process cell, relative to the local countercurrent flow ventilation rate presently used in the FATE T Plant calculations, is examined analytically. The results clearly show that global natural circulation is the dominant mode of process cell ventilation and that significant ventilation enhancement will likely be predicted once global circulation is incorporated into the FATE code.

A global T Plant stack effect is possible, but at the present time its potential magnitude is unknown, so that this work considers zero stack effect, which is conservative. Also, this work pertains to all the standard cells from sections 3 through 20 which are connected via a common manifold, the main ventilation duct. The other cells which are connected by an external clay pipe do not participate in this global natural circulation process, but may in principle create a similar flow pattern between themselves and the canyon. 
FAI/10-83

PRC-STP-00241, Rev 0

Rev. 0

Page 239 of 284

March, 2010

\section{CONDITION FOR COUNTERCURRENT COVER BLOCK FLOW}

Consider the process cell at T Plant illustrated in Fig. 1 whose air density $\rho$ is lower than that of neighbor cells and lower than the canyon air density $\rho_{\mathrm{cn}}$ due to heat, steam and hydrogen generation within the cell. Even if the T Plant vent fan system is not operating, a global natural convection pattern is established between the high-density-atmosphere cells (cold cells) that do not contain process material and the low-density-atmosphere cells that contain process material and generate heat (hot cells) or generate both heat and gas (process cell). Because of the global circulation pattern air is supplied to the process cell in Fig. 1 from the ventilation duct at a volumetric flow rate $\mathrm{Q}_{\mathrm{u}}$. The flow between the process cell and the canyon through the gaps in the cover blocks could be one way flow from cell to canyon. Alternatively, if the imposed global flow $Q_{u}$ is sufficiently weak, a countercurrent exchange flow between the cell and the canyon is established within the cover blocks passages. The countercurrent flow case is shown in Fig. 1, where $\mathrm{Q}_{\mathrm{BF}}$ is the buoyant down flow due to the density difference $\rho_{\mathrm{cn}}-\rho$.

The flow through the gaps in the cover blocks is laminar and the pressure drop $\Delta \mathrm{P}_{\mathrm{f}}$ over the vertical extent $\mathrm{H}$ of the blocks due to gas flow friction is well represented by the product of a known constant $\mathrm{K}$ ("filter constant") and the volumetric flow rate Q:

$$
\Delta \mathrm{P}_{\mathrm{f}}=\mathrm{KQ}
$$

where $\mathrm{K}$ is in units $\mathrm{Pa} \mathrm{s} \mathrm{m} \mathrm{m}^{-3}$ and is based on the total gap flow area. If $\mathrm{P}_{1}$ is the pressure in the cell just below the cover blocks and $P_{c n}$ is the pressure in the canyon just above the cover blocks (see Fig. 1), the momentum equation for the upward flow through the cover blocks is

$$
P_{1}-P_{c n}=\frac{K}{f} Q+\rho g H
$$

where $f$ is the fraction of the cover block flow area through which the upward flow from cell to canyon is transmitted. The momentum equation for the downward buoyant flow is 


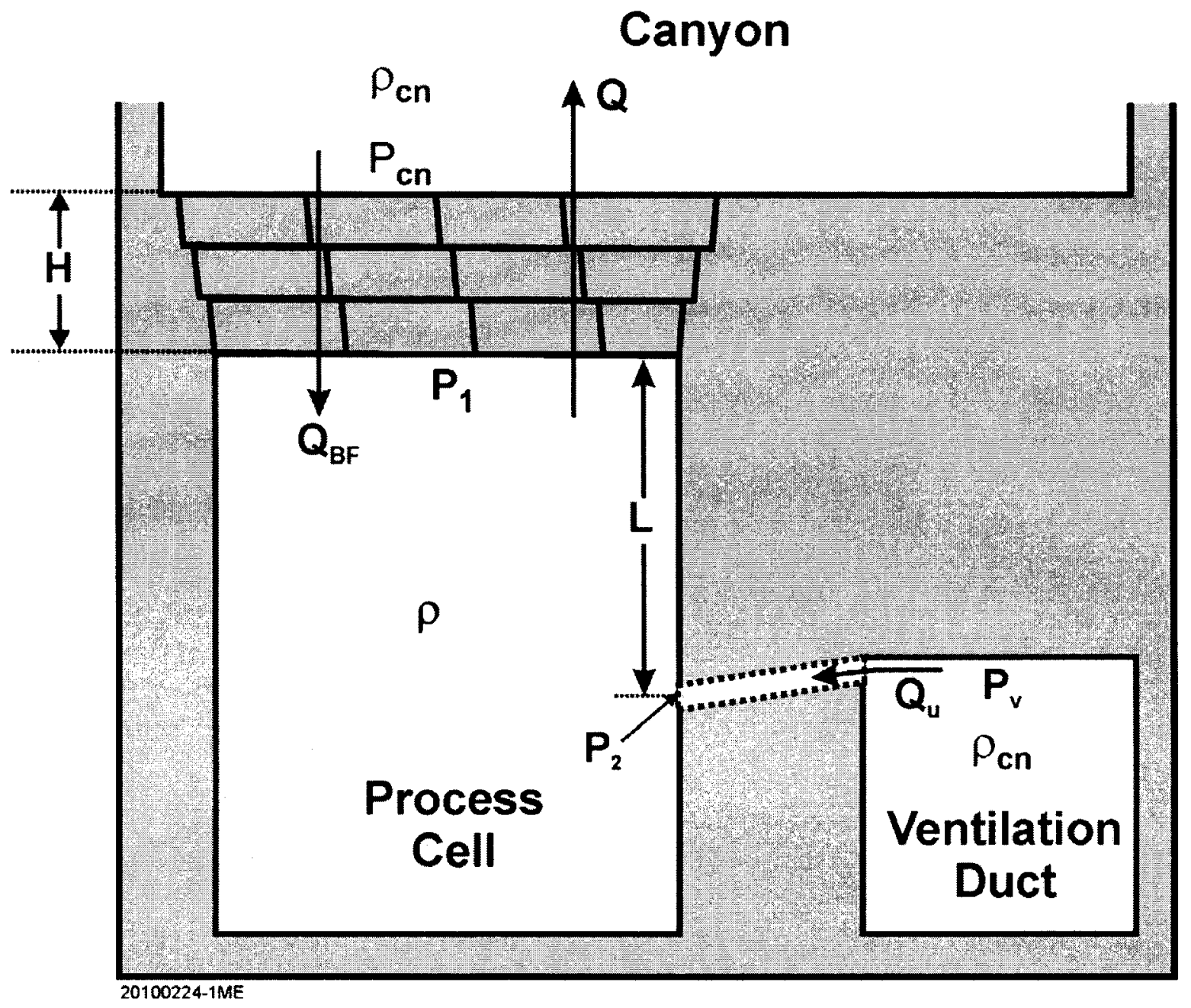

Figure 1 Countercurrent flow in cover blocks above process cell. Both heat and gas are generated in the process cell. In the case of unidirectional flow in cover blocks; $\mathrm{Q}_{\mathrm{BF}}=0, \mathrm{Q}=\mathrm{Q}_{\mathrm{u}}$. 
Rev. 0

$$
P_{c n}-P_{1}=\frac{K}{1-f} Q_{B F}-\rho_{c n} g H
$$

Adding Eqs. (2) and (3):

$$
\frac{K}{f} Q+\frac{K}{1-f} Q_{B F}=\left(\rho_{c n}-\rho\right) g H
$$

A volumetric flow balance on the cell requires that

$$
\mathrm{Q}=\mathrm{Q}_{\mathrm{u}}+\mathrm{Q}_{\mathrm{BF}}
$$

Replacing Q in Eq. (4) with Eq. (5) gives

$$
\frac{K}{f}\left(Q_{u}+Q_{B F}\right)+\frac{K}{1-f} Q_{B F}=\left(\rho_{c n}-\rho\right) g H
$$

Suppose the global flow imposed on the cell vanishes $\left(\mathrm{Q}_{u}=0\right)$ and the flow through the cover blocks is purely countercurrent $(\mathrm{cc})$ buoyant flow $\mathrm{Q}_{\mathrm{BF}}=\mathrm{Q}_{\mathrm{cc}}$. It is reasonable to assume that under purely buoyant flow conditions the upward and downward flows each occupy half of the available gap flow areas so that $\mathrm{f}=1 / 2$. From Eq. (6) the purely buoyant countercurrent volumetric flow rate is then

$$
\mathrm{Q}_{\mathrm{cc}}=\frac{\left(\rho_{\mathrm{cn}}-\rho\right) g H}{4 \mathrm{~K}}
$$

Equation (6) may be rewritten as

$$
\frac{Q_{u}+Q_{B F}}{f}+\frac{Q_{B F}}{1-f}=4 Q_{c c}
$$

The purging (or "flooding") flow rate $Q_{u}=q$ necessary to reduce $Q_{B F}$ to zero is achieved when all the flow through the cover blocks is upward. Thus in Eq. (8), setting $Q_{B F}=0$ and then setting $f=1.0$ (see Eq. 7):

$$
q=4.0 Q_{c c}=\frac{\left(\rho_{c n}-\rho\right) g H}{K}
$$

Dividing Eq. (8) by $q$ and using Eq. (9) where q divides $\mathrm{Q}_{\mathrm{BF}}$ results in 


$$
\frac{1}{f}\left(\frac{Q_{u}}{q}+\frac{Q_{B F}}{4.0 Q_{c c}}\right)+\frac{1}{1-f} \frac{Q_{B F}}{4.0 Q_{c c}}=1.0
$$

Solving for $\mathrm{Q}_{\mathrm{BF}} / \mathrm{Q}_{\mathrm{cc}}$ yields

$$
\frac{Q_{B F}}{Q_{c c}}=4.0 f(1-f)\left(1.0-\frac{Q_{u}}{q f}\right)
$$

We now desire to develop and interpolation formula for estimating the values of $Q_{B F}$ and $f$ between the limits of purely buoyant (countercurrent) flow through the cover blocks and one way flooding flow due to natural-convection-driven circulation within T Plant. In order to accomplish this another constraint must be imposed on the cover block flow. A physically meaningful constraint is to seek the value of the flow area fraction $f$ that maximizes $Q_{B F}$ in Eq. (11) for a fixed value of $Q_{u}$. Differentiating Eq. (11) with respect to $f$ and using the condition $\mathrm{dQ}_{\mathrm{BF}} / \mathrm{dx}=0$ yields

$$
\mathrm{f}=\frac{1}{2}+\frac{\mathrm{Q}_{\mathrm{u}}}{2 \mathrm{q}}
$$

Substituting this result into Eq. (11):

$$
\frac{Q_{B F}}{Q_{c c}}=\left(1-\frac{Q_{u}}{q}\right)^{2}
$$

Interestingly enough, the functional form of Eq. (13) is identical to available expressions for the actual combined free and forced convection through an opening in a wall or ceiling (Epstein and Kenton, 1989). In view of this finding the procedure recommended by Epstein and Kenton for dealing with exchange flow in a multicompartment system would appear valid for application to T Plant. The global circulation flow is calculated by first assuming one-way flow throughout the plant, including the process cell of interest. In this manner a $\mathrm{Q}_{\mathrm{u}}$ is calculated for the subject process cell. Then the cover block flow is checked for countercurrent natural convection flow by calculating $q$ (Eq. 9) and comparing it with $Q_{u}$. If the cover block flow above the process cell is such that $\mathrm{Q}_{\mathrm{u}}<\mathrm{q}$ then the exchange flow rate through the cover block is recomputed using Eq. (13). The $Q_{u}$ to be input in Eq. (13) is that already obtained from the 
FAll/10-83

PRC-STP-00241, Rev 0

Rev. 0

Page 243 of 284

March, 2010

one-way global circulation analysis of $T$ Plant. If $Q_{u}>q$ then one-way upward flow $Q_{u}$ through the cover blocks prevails $\left(\mathrm{Q}_{\mathrm{BF}}=0\right)$. The equation for $\mathrm{Q}_{\mathrm{u}}$ is derived in the next section.

\section{GLOBAL CIRCULATION CURRENT IN T PLANT}

As already indicated there are three types of cells. There is one process cell within which heat and gas is generated; it is illustrated in Fig. 1. For the purpose of estimating $Q_{u}, Q_{B F}=0$ and $Q=Q_{u}$. Figure 2 shows a "hot cell" within which only heat is generated. The density of the air in a hot cell is denoted by the symbol $\rho_{\mathrm{h}}$. There are about 4 or 5 hot cells. As part of the global circulation pattern and much like the process cell, the hot cells draw in air from the ventilation duct and supply air to the canyon, but at a different volumetric rate denoted by $\mathrm{Q}_{\mathrm{h}}$. The remaining cells of which there are many are called "cold cells". The temperature and density of a cold cell atmosphere is the same as those of the canyon atmosphere. The global circulation drives air into a cold cell from the canyon and out of the cold cell into the ventilation duct (see Fig. 3). Accordingly, the density of the air in the ventilation duct is taken to be the same as the density of the canyon atmosphere, namely $\rho_{\mathrm{cn}}$.

The following hydrostatic relations may be written for the cell atmosphere pressures shown in Figs. 1 to 3 
FAI/10-83

Rev. 0

PRC-STP-00241, Rev 0

Page 244 of 284

March, 2010

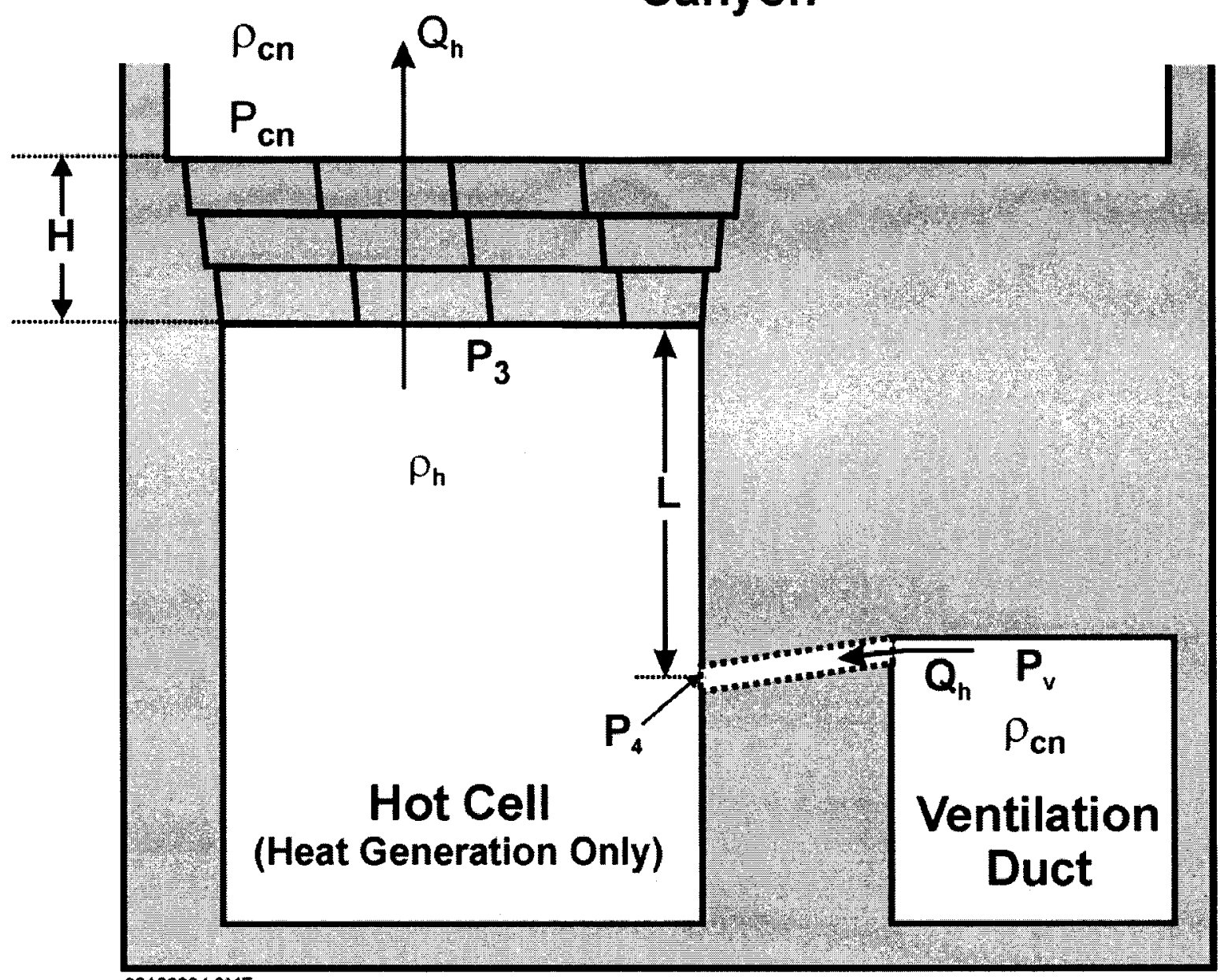

20100224-2ME

Figure 2 One-way buoyancy-driven flow through cell with heat generation. 


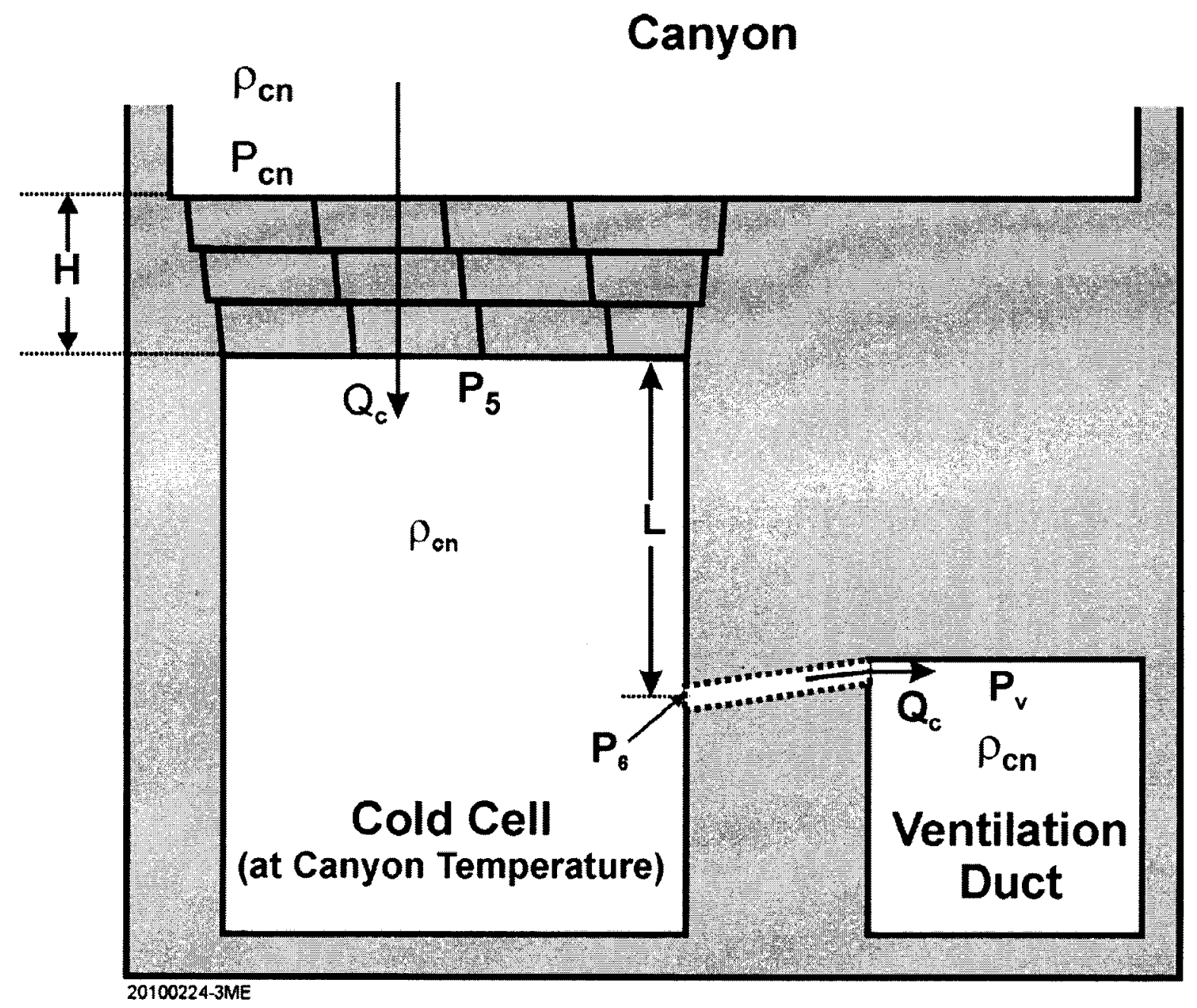

Figure 3 One-way buoyancy-driven flow through cold cell. The temperature and density of the cold cell atmosphere is the same as those of the canyon atmosphere. 
$\mathrm{FAl} / 10-83$

Rev. 0

$$
\begin{aligned}
& P_{2}=P_{1}+\rho g L \\
& P_{2}=P_{v}+\rho_{c n} g \delta \\
& P_{4}=P_{3}+\rho_{h} g L \\
& P_{4}=P_{v}+\rho_{c n} g \delta \\
& P_{6}=P_{5}+\rho_{c n} g L \\
& P_{6}=P_{v}+\rho_{c n} g \delta
\end{aligned}
$$

where $\mathrm{L}$ is the distance between the bottom of the cover blocks and the center of the ventilation pipe which connects the cell to the ventilation duct (see Figs. 1 to 3 ), $\mathrm{P}_{\mathrm{v}}$ is the pressure at the top of the ventilation duct, and $\delta$ is the vertical rise distance (not shown in the figures) of the ventilation pipe from the cell to the ventilation duct. In writing Eqs. (15), (17) and (19), flow frictional resistance in the ventilation pipe was ignored since it can be shown to be negligible compared with flow frictional resistance in the cover block gaps.

The momentum equations for the one-way flows through the blocks that cover the process cell, a hot cell and a cold cell are, respectively,

$$
\begin{aligned}
& P_{1}-P_{c n}=K Q_{u}+\rho g H \\
& P_{3}-P_{c n}=K Q_{h}+\rho_{h} g H \\
& P_{c n}-P_{5}+\rho_{c n g H} g K Q_{c}
\end{aligned}
$$

Eliminating $\mathrm{P}_{2}$ between Eqs. (14) and (15), $\mathrm{P}_{4}$ between Eqs. (16) and (17) and $\mathrm{P}_{6}$ between Eqs. (18) and (19):

$$
\begin{aligned}
& \mathrm{P}_{1}+\rho \mathrm{gL}=\mathrm{P}_{\mathrm{v}}+\rho_{\mathrm{cn}} \mathrm{g} \delta \\
& \mathrm{P}_{3}+\rho_{\mathrm{h}} \mathrm{gL}=\mathrm{P}_{\mathrm{v}}+\rho_{\mathrm{cn}} \mathrm{g} \delta \\
& \mathrm{P}_{5}+\rho_{\mathrm{cn}} \mathrm{gL}=\mathrm{P}_{\mathrm{v}}+\rho_{\mathrm{cn}} \mathrm{g} \delta
\end{aligned}
$$

Adding Eqs. (20) and (22) and adding Eqs. (21) and (22):

$$
P_{1}-P_{5}+\left(\rho_{c n}-\rho\right) g H=K\left(Q_{u}+Q_{c}\right)
$$


$\mathrm{FAl} / 10-83$

PRC-STP-00241, Rev 0

Rev. 0

$$
P_{3}-P_{5}+\left(\rho_{c n}-\rho_{h}\right) g H=K\left(Q_{h}+Q_{c}\right)
$$

Eliminating $P_{1}, P_{3}$, and $P_{5}$ between Eqs. (23) to (25) and Eqs. (26) and (27) gives

$$
\begin{aligned}
& \left(\rho_{c n}-\rho\right) g(L+H)=K\left(Q_{u}+Q_{c}\right) \\
& \left(\rho_{c n}-\rho_{h}\right) g(L+H)=K\left(Q_{h}+Q_{c}\right)
\end{aligned}
$$

The overall T Plant volumetric flow balance that includes the total number of cold and hot cells, denoted respectively by $N_{c}$ and $N_{h}$, is

$$
N_{c} Q_{c}=N_{h} Q_{h}+Q_{u}
$$

Equations (28) to (30) comprise a linear algebraic system for the volumetric flows $\mathrm{Q}_{c}, \mathrm{Q}_{\mathrm{b}}$ and $\mathrm{Q}_{\mathrm{u}}$. The solutions of this system are

$$
\begin{aligned}
& Q_{c}=\frac{g(L+H)}{K N_{t o t}}\left[N_{h}\left(\rho_{c n}-\rho_{h}\right)+\left(\rho_{c n}-\rho\right)\right] \\
& Q_{h}=\frac{g(L+H)}{K_{\text {tot }}}\left[N_{c}\left(\rho_{c n}-\rho_{h}\right)-\left(\rho_{h}-\rho\right)\right] \\
& Q_{u}=\frac{g(L+H)}{K N_{\text {tot }}}\left[N_{c}\left(\rho_{c n}-\rho\right)+N_{h}\left(\rho_{h}-\rho\right)\right]
\end{aligned}
$$

where $\mathrm{N}_{\text {tot }}$ is the total number of cells (cold + hot + process):

$$
N_{\text {tot }}=N_{c}+N_{h}+1
$$




\section{COUNTERCURRENT VERSUS UNIDIRECTIONAL FLOW}

\section{IN THE COVER BLOCKS ABOVE THE PROCESS CELL}

Recall that the condition for unidirectional flow through the blocks that cover the process cell is

$$
\frac{Q_{u}}{q}>1.0
$$

Using Eqs. (9) and (33) to evaluate the left-hand side of Eq. (35), the condition for unidirectional flow becomes

$$
\frac{N_{c}}{N_{\text {tot }}}\left(\frac{L}{H}+1\right)\left[1.0+\frac{N_{h}\left(\rho_{h}-\rho\right)}{N_{c}\left(\rho_{c n}-\rho\right)}\right]>1.0
$$

Since the process cell atmosphere is always less dense than the hot cell and canyon atmospheres the term in brackets on the left-hand side of the above inequality is always greater than unity. The total number of cells is $N_{\text {tot }}=36$ and the number of cold cells is $N_{c}=31$. The vertical extent of the cover blocks is $H=$ $1.83 \mathrm{~m}$ and the vent pipe is located a vertical distance $\mathrm{L}=3.96 \mathrm{~m}$ below the cover blocks. Therefore

$$
\frac{\mathrm{N}_{\mathrm{c}}}{\mathrm{N}_{\text {tot }}}\left(\frac{\mathrm{L}}{\mathrm{H}}+1\right)=2.72
$$

and Eq. (36) is always satisfied. This means that the countercurrent flow pattern through the cover blocks shown in Fig. 1 does not occur. Instead $\mathrm{Q}_{\mathrm{BF}}=0$ and $\mathrm{Q}=\mathrm{Q}_{\mathfrak{u}}$ where $\mathrm{Q}_{\mathrm{u}}$ is given by Eq. (33). In other words the global natural circulation in T Plant is always strong enough to prevent downward buoyant flow in the cover blocks above the process cell.

It is also instructive to evaluate the ratio of the unidirectional flow to the countercurrent flow (see Eqs. 7 and 33)

$$
\frac{\mathrm{Q}_{\mathrm{u}}}{\mathrm{Q}_{\mathrm{cc}}}=\frac{4.0 \mathrm{~N}_{\mathrm{c}}}{\mathrm{N}_{\text {tot }}}\left(\frac{\mathrm{L}}{\mathrm{H}}+1\right) \cong 10.9
$$

where the small term $N_{h}\left(\rho_{h}-\rho\right)$ in Eq. (33) was ignored. It follows from Eq. (38) that large enhancements in the process cell ventilation rate can be expected (although not as large as indicated by Eq. 38) by replacing the countercurrent flow model with the more realistic global circulation driven unidirectional flow model (Eq. 33). 
FAl/10-83

PRC-STP-00241, Rev 0

Rev. 0

Page 249 of 284

March, 2010

\section{REFERENCE}

Epstein, M. and Kenton, M. A., 1989, "Combined Natural Convection and Forced Flow Through Small Openings in a Horizontal Partition, With Special Reference to Flows in Multicompartment Enclosures," J. Heat Transfer 111, pp. 980-987.

ME:lak 
FAl/10-83

PRC-STP-00241, Rev 0

Rev. 0

Page 250 of 284

March, 2010

\section{C.2 FATE Ceiling Crack Flow Model and Testing}

DATE: March 4, 2010

TO: Bob Apthorpe, Sung Jin Lee, and Michael Epstein

FROM: $\quad$ Marty Plys; Desk 1-630-887-5207, Cell 1-312-953-7299, plys@fauske.com

SUBJECT: FATE Ceiling Crack Flow Model and Testing

The attached pages contain a section for FAI/10-93, the new FATE 2.061 Software Change Specification (SCS). The equation numbers will need to be revised to follow numbering in the SCS. The equations have been taken from "Buoyancy-Driven Flows in T Plant when the Ventilation System is Not Operating," FAl memorandum by M. Epstein to M.E. Johnson et al, March 1, 2010. 


\subsection{Ceiling Gap Flow Model}

Similar to the door gap configuration discussed above, a ceiling gap flow model has been added to consider the case where two regions can exchange flow via narrow gaps in a partition that forms the ceiling of the underlying region and the floor of the overlying region. This is a typical "cover block" configuration in which one or more cover blocks are used to close a hatch between two floor levels, or to cover a process cell. The key feature of this junction model is that the narrow gaps lead to laminar flow, so that the flow rate and pressure drop are linearly proportional. In FATE, this kind of flow characteristic is treated by using the filter resistance KFILTER, and setting a small value for the loss coefficient (which multiplies the square of the velocity). However, unlike a filter flow path, counter-current flow can occur through the gaps, in which some gaps carry flow upward and some carry flow downward. Therefore, a special junction type is required to account for the possibility of unidirectional and countercurrent flow.

A pressure difference will cause unidirectional flow through ceiling gaps in a manner identical to the flow through door gaps. The value of the filter resistance KFILTER, denoted by the symbol $\mathrm{K}$, is derived as shown in the discussion of the door gap model. The counter-current flow for ceiling gaps is derived next.

\subsubsection{Counter-Current Ceiling Gap Flow}

Consider the geometry shown in Figure 6-16 in which a region of relatively lower gas density $\rho$ is at lower elevation than another region of relatively higher gas density $\rho_{2}$. These regions communicate via gaps in the structure that forms the ceiling of the lower elevation region and the floor of the higher elevation region. In the absence of a ventilation flow, this is an unstable configuration, and high density air from the higher elevation region will circulate downward at a rate $Q\left(\mathrm{~m}^{3} / \mathrm{s}\right)$, and low density air from the lower elevation will circulate upward at a rate $Q_{B F}$, and these two rates will be equal, $Q=Q_{B F}$. This circulation pattern is called countercurrent flow. When the ventilation flow out from the lower elevation region $Q_{v}$ is sufficiently weak, countercurrent flow can still occur, but there must also be a net flow of equal magnitude into the lower region from the higher region. The analysis that follows will quantify the magnitude of the flow rates and identify the condition at which the countercurrent flow is prevented by a sufficiently high value of the ventilation flow.

\section{Momentum Balance}

The flow through the gaps is laminar and the pressure drop $\Delta P_{f}$ over the vertical extent $H$ of the gaps due to gas flow friction is well represented by the product of a known constant $K$ ("filter constant") and the volumetric flow rate $Q$ :

$$
\Delta P_{f}=\frac{12 \mu L}{\delta^{3} p} Q=K Q
$$


where $K$ is in units Pa $\mathrm{P} \mathrm{m}^{-3}, \mu$ is the gas viscosity, $L$ represents the length along the flow path through the gap which is approximately the same as $H, \delta$ is the width of the gap, and $p$ is the perimeter of the gap (so the gap cross-sectional area is the product $\delta \times p$ ). If $P_{1}$ is the pressure in the lower region just below the gaps and $P_{2}$ is the pressure in the upper region just above the gaps, the momentum equation for the downward flow through the gaps is

$$
P_{2}-P_{1}=\frac{K}{f} Q-\rho_{2} g H
$$

where $f$ is the fraction of the gap flow area through which the downward flow is transmitted. The momentum equation for the upward buoyant flow is

$$
P_{1}-P_{2}=\frac{K}{1-f} Q_{B F}+\rho g H
$$

Adding the two momentum equations,

$$
\frac{K}{f} Q+\frac{K}{1-f} Q_{B F}=\left(\rho_{2}-\rho\right) g H
$$

A volumetric flow balance on the lower region requires that

$$
Q=Q_{V}+Q_{B F}
$$

Eliminating $Q$ between these equations

$$
\frac{K}{f}\left(Q_{v}+Q_{B F}\right)+\frac{K}{1-f} Q_{B F}=\left(\rho_{2}-\rho\right) g H
$$

\section{Pure Countercurrent Flow Rate}

Suppose the ventilation flow vanishes $\left(Q_{V}=0\right)$ and the flow through the gaps is purely countercurrent (cc) buoyant flow $Q_{B F}=Q_{c c}$. It is reasonable to assume that under purely buoyant flow conditions the upward and downward flows each occupy half of the available gap flow areas so that $f=1 / 2$. From the preceding equation the purely buoyant countercurrent volumetric flow rate is then

$$
\mathrm{Q}_{\mathrm{cc}}=\frac{\left(\rho_{2}-\rho\right) \mathrm{gH}}{4 \mathrm{~K}}
$$


Purge Flow Rate

Next we seek the value of the vent flow that will cause the countercurrent flow to vanish, known as the purge flow. Combining the preceding two equations,

$$
\frac{Q_{v}+Q_{B F}}{f}+\frac{Q_{B F}}{1-f}=4 Q_{c c}
$$

The purging (or "flooding") flow rate $Q_{u}=q$ necessary to reduce $Q_{B F}$ to zero is achieved when all the flow through the gaps is downward. Thus in the preceding equation setting $Q_{B F}=0$ and then setting $f=1.0$ yields

$$
q=4.0 Q_{c c}=\frac{\left(\rho_{2}-\rho\right) g H}{K}
$$

\section{Combined Countercurrent and Unidirectional Flow}

We now desire to develop an interpolation formula for estimating the values of $Q_{B F}$ and $f$ between the limits of purely buoyant (countercurrent) flow and the unidirectional purge flow due to ventilation. We expect $Q_{B F}$ to vary in the range $0 \leq Q_{B F} \leq Q_{c c}$ as the ventilation flow varies over the range $q \geq Q_{v} \geq 0$. In order to accomplish this, another constraint must be imposed on the cover block flow. A physically meaningful constraint is to seek the value of the flow area fraction $f$ that maximizes $Q_{B F}$ for a fixed value of $Q_{v}$. Combining the preceding two equations to obtain the ratio $Q_{B F} / Q_{c c}$ results in

$$
\frac{1}{f}\left(\frac{Q_{v}}{q}+\frac{Q_{B F}}{4.0 Q_{c c}}\right)+\frac{1}{1-f} \frac{Q_{B F}}{4.0 Q_{c c}}=1.0
$$

Solving for $Q_{B F} / Q_{c c}$ yields

$$
\frac{Q_{B F}}{Q_{c c}}=4.0 f(1-f)\left(1.0-\frac{Q_{v}}{q f}\right)
$$

Differentiating this equation with respect to $f$ and using the condition $d Q_{B F} / d f=0$ yields

$$
\mathrm{f}=\frac{1}{2}+\frac{\mathrm{Q}_{\mathrm{v}}}{2 \mathrm{q}}
$$

Combining the preceding two equations yields the desired result for how the countercurrent flow rate $Q_{B F}$ is reduced from its maximum value $Q_{c c}$ due to a unidirectional flow $Q_{v}$ :

$$
\frac{Q_{B F}}{Q_{c c}}=\left(1-\frac{Q_{v}}{q}\right)^{2}
$$




\subsubsection{Model Implementation}

Interestingly enough, the functional form of this relationship is identical to available expressions for the actual combined free and forced convection through an opening in a wall or ceiling (Epstein and Kenton, 1989), and already implemented in FATE. First, the pressuredriven unidirectional flow through a flow path is calculated; this is the same as the parameter $Q_{v}$ used above. The purge flow $q$ is then calculated based upon geometry and current densities. If the unidirectional is less than the purge flow, $Q_{v}<q$ then the pure countercurrent exchange flow rate $Q_{c c}$ is calculated and the final relationship is used for the actual countercurrent flow in the presence of the unidirectional flow. Otherwise if $Q_{v}>q$ then there is no countercurrent flow, only a unidirectional flow.

The model is implemented in FATE by creating a new subroutine WJEXCHC which is similar to the existing routine WJEXCH for countercurrent flow, and simply implements the equations for $Q_{c c}, q$, and $Q_{B F}$ given above. The model is employed for a new junction type, IJTYP $=8$, which has a filter resistance characteristic.

\subsubsection{New Inputs}

The existing parameter IJTYP is now allowed a new value, IJTYP $=8$ for a ceiling gap junction. For this junction, the loss coefficient CJN and flow area AJN are not used. The flow resistance is input via KFILTER. The height $\mathrm{H}$ used in the preceding equations is derived by FATE from the existing inputs for junction elevation Z1JN and Z2JN.

\subsubsection{Test Requirements}

The ceiling crack flow model should be tested to demonstrate that it can reproduce the expected pure countercurrent flow rate, the quadratic decrease with increasing unidirectional flow, and zero countercurrent flow for a unidirectional flow exceeding the purge flow.

\subsubsection{Test Description}

The test geometry consists of a lower region of $10 \mathrm{~m}^{3}$ volume whose atmosphere consists of oxygen and nitrogen at $25^{\circ} \mathrm{C}$, and an upper region of very large volume whose atmosphere consists of pure argon at $25^{\circ} \mathrm{C}$. The height of the lower region is $10 \mathrm{~m}$, and the bottom elevation of the upper region is $12 \mathrm{~m}$, so that the gap height is $\mathrm{H}=2 \mathrm{~m}$. The regions are connected by a junction with IJTYP $=8$ with a resistance KFILTER $=\mathrm{K}=764.3$, which is taken from an application of interest. The entire system is adiabatic. 
For the first $100 \mathrm{~s}$, pure countercurrent flow is expected to be observed. Starting at 100 $s$, an air source is introduced into the lower region. The magnitude of the air source flow rate ramps up linearly from $0 \mathrm{~kg} / \mathrm{s}$ at $100 \mathrm{~s}$ to a value equal to the purge rate at $200 \mathrm{~s}$, and double the purge rate at $300 \mathrm{~s}$. It is expected that a quadratic decrease in the countercurrent flow will be observed as the source is introduced, and that the countercurrent flow rate will go to zero when the purge rate is attained.

The density of $21 \%$ oxygen, $79 \%$ nitrogen in the lower region is 28.84 . The lower region pressure is $10^{5} \mathrm{~Pa}$ and the density of this gas is $\rho=1.1635 \mathrm{~kg} / \mathrm{m}^{3}$. The pressure of the upper region is $99863 \mathrm{~Pa}$ due to static head difference, and the density of argon there is $\rho_{2}=1.6115$ $\mathrm{kg} / \mathrm{m}^{3}$. From the given flow resistance and gap height, the countercurrent flow rate is $Q_{c c}=$ $2.875 \mathrm{e}-3 \mathrm{~m} / 3 / \mathrm{s}$, and at the average of the two gas densities the mass flow rate is $4.0 \mathrm{e}-3 \mathrm{~kg} / \mathrm{s}$. The purge rate is $q=0.0115 \mathrm{~m}^{3} / \mathrm{s}$ and using the air density the purge mass flow is $0.0134 \mathrm{~kg} / \mathrm{s}$. If the pure countercurrent flow prevails for the first $100 \mathrm{~s}$ of the test, the argon mole fraction in the lower region will be slightly less than $100 \times 2.875 \mathrm{e}-3 / 10=2.87 \%$; a lesser value will be obtained because some argon is carried out with the countercurrent flow.

\subsubsection{Test Results}

Test results are shown in Figure 6-17. The unidirectional flow (upper left) increases linearly from zero at $100 \mathrm{~s}$. During the first $100 \mathrm{~s}$, the countercurrent flow rate (upper right) is about $0.004 \mathrm{~kg} / \mathrm{s}$ as expected (see above). The slight decline in this rate over the $100 \mathrm{~s}$ is due to the buildup of argon in the lower region (lower left). The expected argon mole fraction in the lower region of $2.87 \%$ is not quite obtained at $100 \mathrm{~s}$, because of the back-flow of argon. The countercurrent flow declines quadratically with time after $100 \mathrm{~s}$, and becomes nearly zero somewhat before $200 \mathrm{~s}$. This is because the lower region gas density is not the same as used to calculate the purge flow; the density is higher and hence a lower purge flow is sufficient to stop the countercurrent flow, exactly as observed. At 3.5\% argon, the lower region gas density is $\rho=1.1792 \mathrm{~kg} / \mathrm{m}^{3}$, the purge flow is $q=0.0111 \mathrm{~m}^{3} / \mathrm{s}$, and the purge mass flow is $0.0129 \mathrm{~kg} / \mathrm{s}$.

In conclusion, the test demonstrates all the behavior expected from the test requirements and test description.

\subsubsection{Reference}

Epstein, M. and Kenton, M.A., 1989, "Combined Natural Convection and Forced Flow Through Small Openings in a Horizontal Partition, with Special Reference to Flows in Multicompartment Enclosures," J. Heat Transfer 111, pp. 980-987. 
Figure 6-16. Flow pattern through ceiling gaps for a cell cover block example.

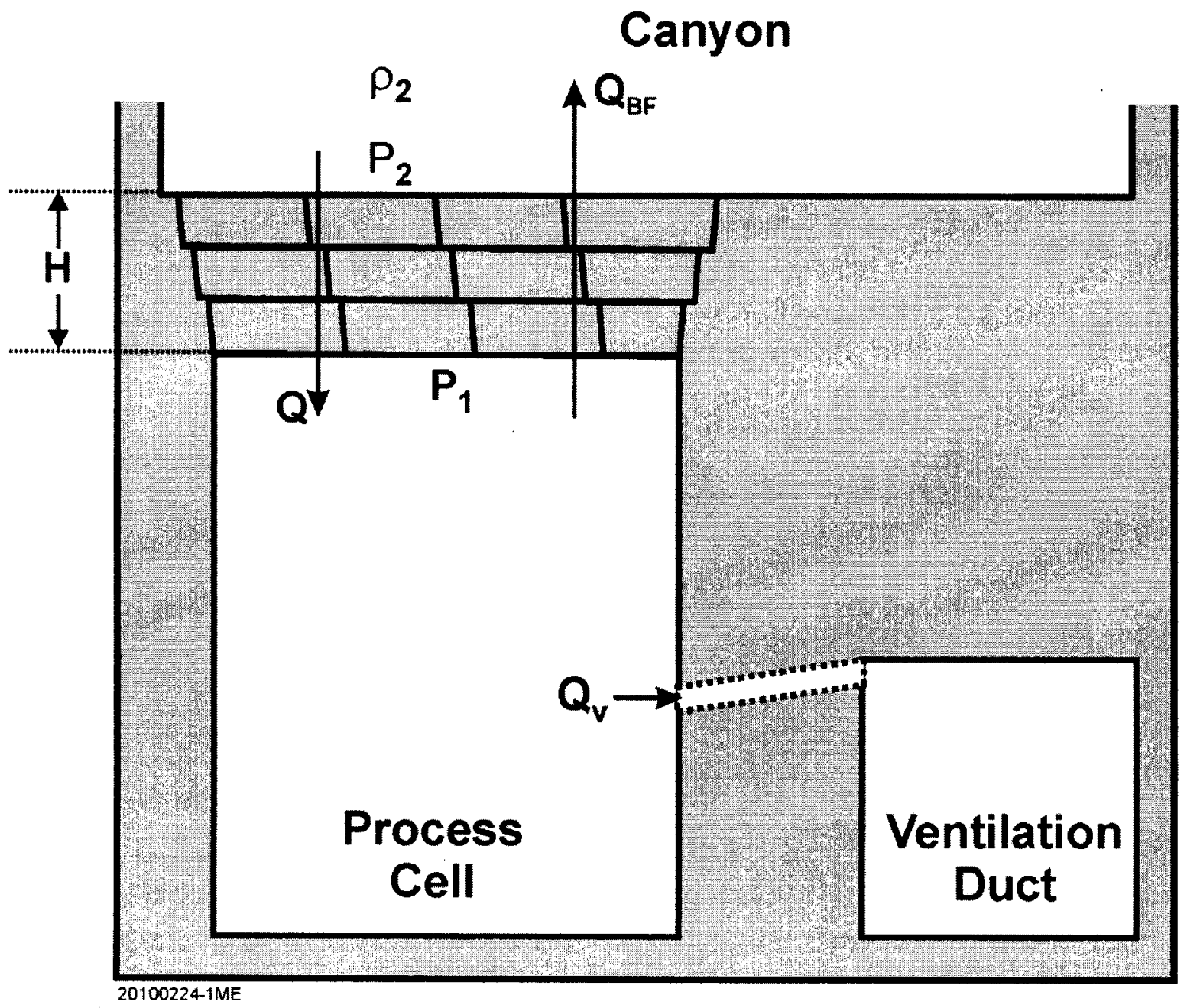


FAl/10-83

PRC-STP-00241, Rev 0

Rev. 0

Page 257 of 284

March, 2010

Figure 6-17. Ceiling gap flow test results plots.
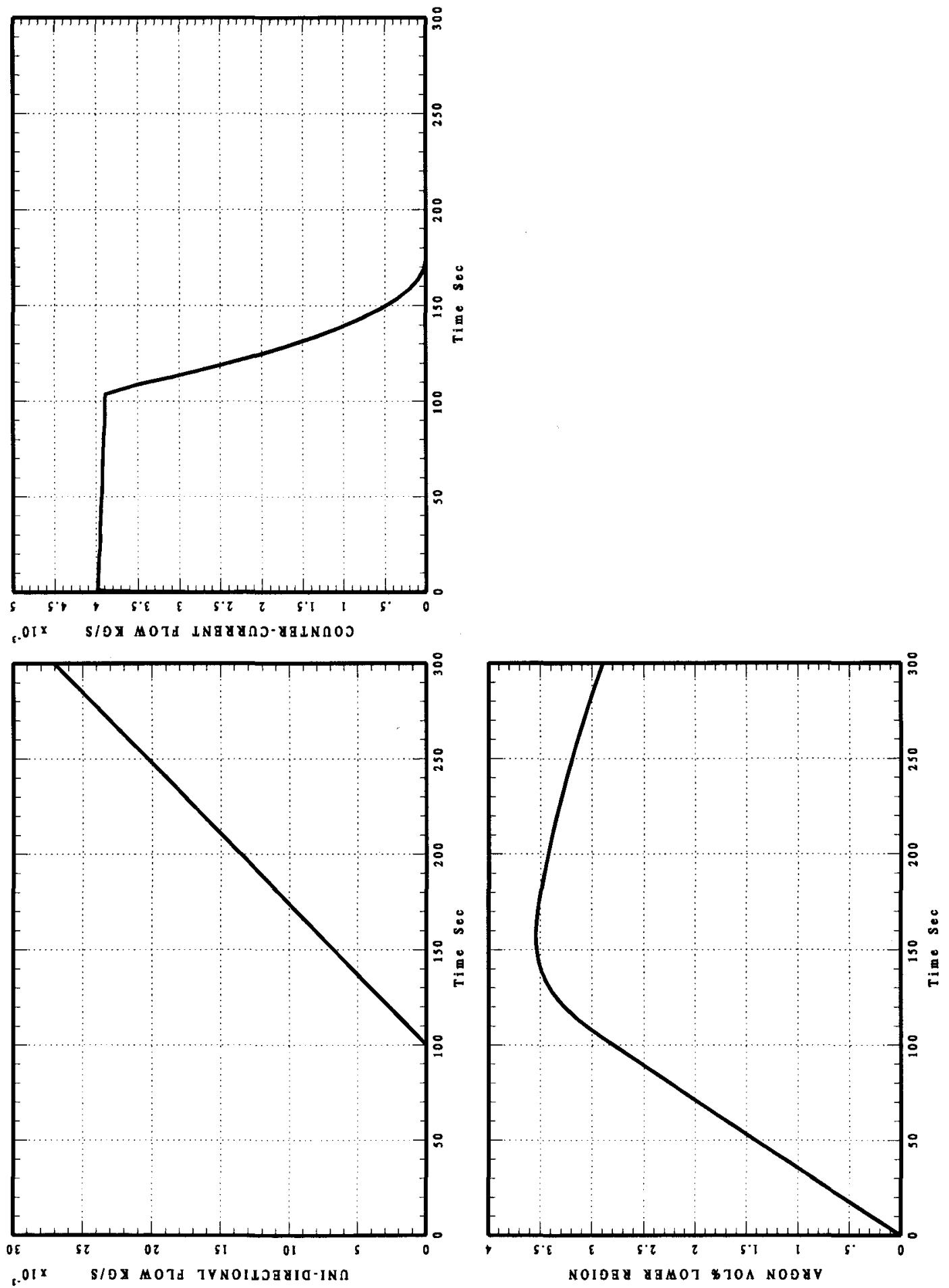
FAl/10-83

PRC-STP-00241, Rev 0

Rev. 0

C.3 TPlant Circulation Results Ouick Look

Page 258 of 284

March, 2010

DATE: March 5, 2010

TO: Jim Sloughter and Mike Johnson, CHPRC K Basins Closure Project

FROM: $\quad$ Marty Plys; Desk 1-630-887-5207, Cell 1-312-953-7299, plys@fauske.com

\section{SUBJECT: $\quad$ T Plant Circulation Results Quick Look}

In report FAl/10-83 exchange flow between a process cell and the T Plant canyon takes place via counter-current flow through gaps between the cover blocks (Apthorpe et al, 2010). This is the baseline model approach that has been in use since the first sludge analyses in 2002.

A model for buoyancy-driven flow that couples the hot process cell containing the "active" STSC, the remaining cold process cells, and the canyon is presented in a recent memo (Epstein, 2010). The model predicts the following flow rate upward $Q\left(\mathrm{~m}^{3} / \mathrm{s}\right)$ through the hot process cell cover block gaps, which is fed from the ventilation duct and further upstream by downflow from the canyon to cold cells:

$$
Q=\frac{g(L+H)}{K} \frac{N_{c}}{N_{t o t}}\left(\rho_{c n}-\rho\right)
$$

where $\mathrm{g}=9.81 \mathrm{~m} / \mathrm{s}, \mathrm{L}=$ distance between the cell vent centerline and cover blocks, $H=$ thickness of the cover blocks, $K=$ flow resistance of cover block gaps, $N_{c}=$ number of cold cells, $N_{\text {tot }}=$ total number of cells, $\rho_{c n}=$ canyon gas density, and $\rho=$ cell gas density. A priori known values are $L+H=12 \mathrm{ft}+6 \mathrm{ft}=5.488 \mathrm{~m}, \mathrm{~K}=382.15 \mathrm{~Pa}-\mathrm{s} / \mathrm{m}^{3}, \mathrm{~g}=9.81 \mathrm{~m} / \mathrm{s}^{2}, \mathrm{~N}_{\mathrm{c}}=35$, and $\mathrm{N}_{\text {tot }}=36$.

In the same memorandum, a model for counter-current flow though cover block gaps was presented. This was recently implemented into FATE 2.061 and successfully tested (Plys, 2010).

The revised FATE model was used to re-evaluate the worst case from FAI/10-83, SETTRN, settler sludge in a standard $\mathrm{T}$ Plant cell with no fans. In the reference calculation, the peak cell hydrogen concentration was just under $4 \%$, and the countercurrent flow rate through the cover block gaps was about $0.001 \mathrm{~kg} / \mathrm{s}$. The re-evaluated case is designated SETTRN2B. In this case, the canyon volume is assigned its proper value (as opposed to an infinite air reservoir), and two new regions are added, one representing 35 cold cells, and one for the ventilation duct that connects all the standard cells. The new FATE ceiling gap flow model was used to represent the junction between the hot cell and the canyon and between the cold cells and the canyon. The hot cell and the cold cells are connected to the ventilation duct by 10 " diameter vent pipes. Concrete heat structures are used to represent walls of the cold cells, ventilation duct, and canyon. The building nodalization is illustrated in Figure 1. 
FAl/10-83

PRC-STP-00241, Rev 0

Rev. 0

Page 259 of 284

March, 2010

The results of the re-evaluated case SETTRN2B are shown in Figures 2 and 3, which are in the same format as the figures of FAI/10-83 except that the upper right plot in Figure 3 contains the unidirectional flow rates through the hot and cold cell cover blocks instead of the countercurrent flow rate through the hot cell cover blocks (which is zero as expected). All the process histories for quantities internal to the STSC remain essentially unchanged from the results in FAI/10-83, except that the peak sludge temperature is slightly lower because the peak cell temperature is slightly lower.

The significant new results are found in Figure 3 on the upper and lower right. In the upper right, the gas flow upward through the hot cell cover blocks has a peak value of about $4.75 \times 10^{-3} \mathrm{~kg} / \mathrm{s}$, and a long-term value of about $3.5 \times 10^{-3} \mathrm{~kg} / \mathrm{s}$. This peak flow is about 5 times greater than the peak flow for the isolated cell model of FAl/10-83. Note that the cold cell flow rate has diurnal variation about a mean value equal to the hot cell flow rate; this is due to diurnal pressure variation that is imposed on the canyon. This diurnal variation does not have a significant impact on the circulation flow rate through the hot cell. The peak hydrogen concentration in the cell (lower right) is about $1 \%$, or $25 \%$ of the LFL which is desirable.

Detailed FATE output for at the end of the calculation provides the gas densities for the canyon $\rho_{\mathrm{cn}}$ $=1.130 \mathrm{~kg} / \mathrm{m}^{3}$ and for the hot cell $\rho=1.107 \mathrm{~kg} / \mathrm{m}^{3}$. Inserting these and the other known values into the model equation above yields a predicted flow rate $Q=3.2 \times 10^{-3} \mathrm{~m}^{3} / \mathrm{s}$, and multiplying by the cell density the flow rate is $3.5 \times 10^{-3} \mathrm{~kg} / \mathrm{s}$, in very good agreement with the FATE calculation.

In conclusion, the revised FATE code is capable of predicting circulation flows internal to T Plant that are in agreement with a closed form model. The natural circulation flow is much greater than pure countercurrent flow that has been previously modeled. Future work for $T$ Plant will invoke this new FATE model and employ a balance of T Plant input model similar to the draft model used here.

\section{References}

Apthorpe, R., S.J. Lee, and M. Plys, 2010, "Thermal and Gas Analyses for a Sludge Transfer and Storage Container (STSC) at T Plant (Draft)," FAl/10-83, Fauske \& Associates, LLC, February.

Epstein, M., 2010, "Buoyancy-Driven Flows in T Plant when the Ventilation System is Not Operating," FAI memorandum to M.E. Johnson et al, March 1.

Plys, M.G., 2010, "FATE Ceiling Crack Flow Model and Testing," FAI memorandum to R. Apthorpe, S.J. Lee, and M. Epstein, March 4. 
$\mathrm{FAl} / 10-83$

PRC-STP-00241, Rev 0

Rev. 0

Page 260 of 284

March, 2010

Figure 1: T Plant building model for circulation between the canyon and standard cells. One "hot" process cell contains STSCs. 35 empty "cold" standard process cells are lumped together. The ventilation duct elevation is the same as the cell elevation. Junctions between the cells and canyon are gaps in the cell cover blocks, junctions between the cells and vent duct are 10" diameter. Cells in sections HE, 1 , and 2 are not modeled, intrusion via cell $1 \mathrm{~L}$ is not modeled, and the vent duct exit, filter, and stack are not modeled.

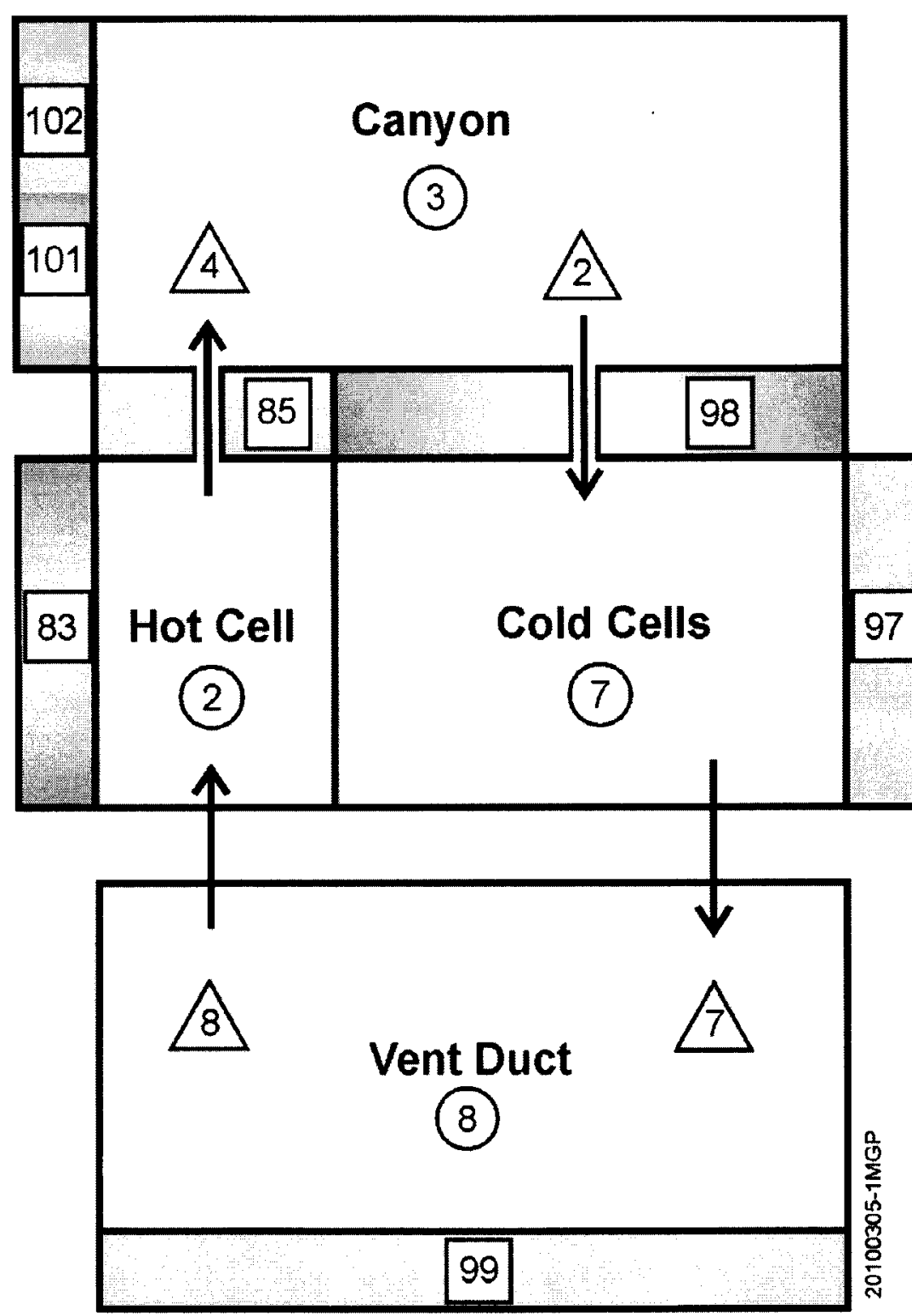

$\bigcirc$ Regions $\quad \square$ Junctions $\square$ Heat Sinks 
FAl/10-83

Rev. 0
PRC-STP-00241, Rev 0

Page 261 of 284

March, 2010

Figure 2: Transient history plots for case SETTRN2B (1 of 2).
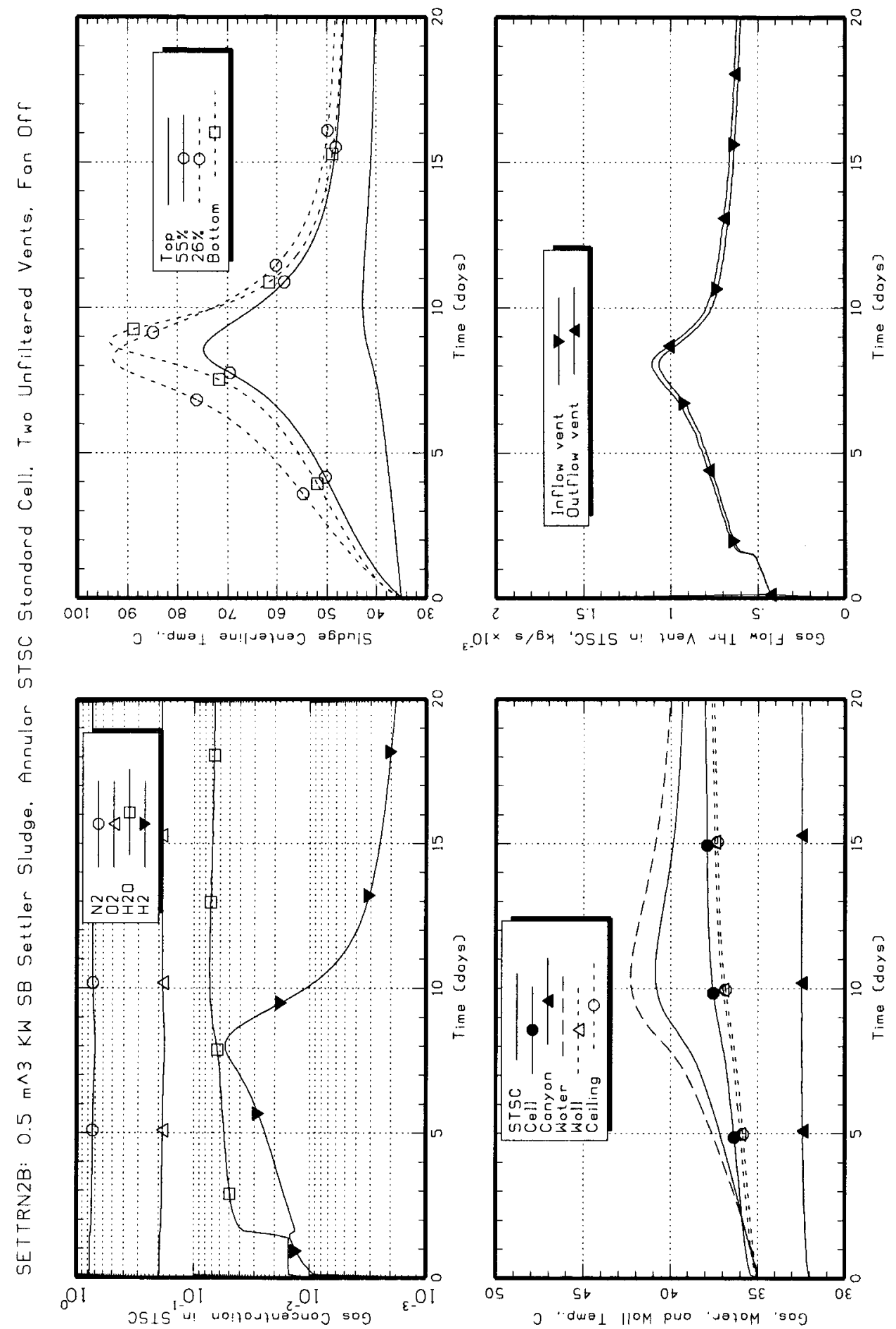
SETTRN2B: $0.5 \mathrm{~m} \wedge 3 \mathrm{KW}$ SB Settler Sludge. Annular STSC Standord Cell. Two Unfiltered Vents, Fan Off
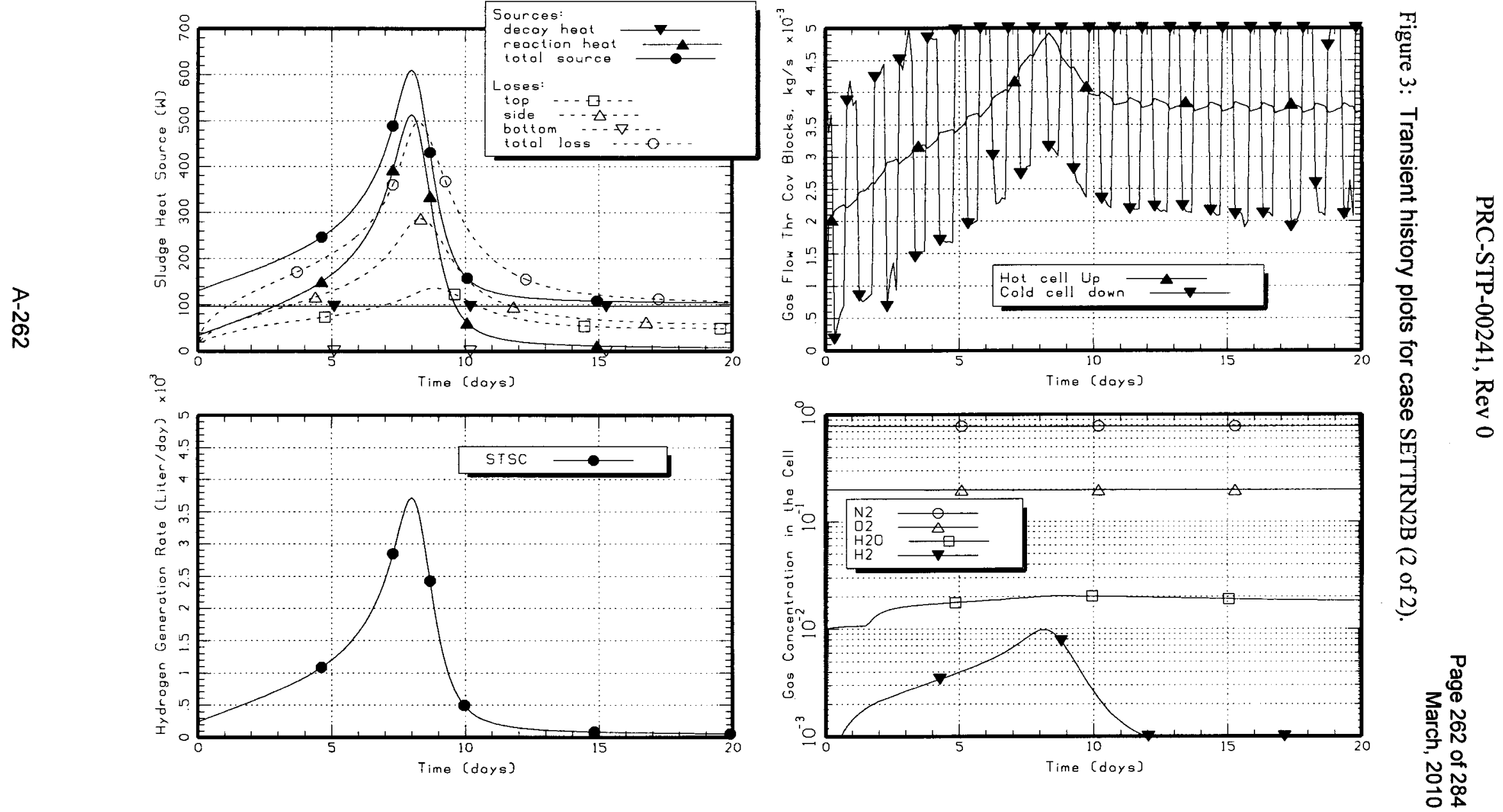
FAl/10-83

PRC-STP-00241, Rev 0

Rev. 0

C.4 Ventilation Holes in Skirt for STSC Container

Page 263 of 284

March, 2010

DATE: March 4, 2010

TO: $\quad$ Bob Apthorpe

Sung Jin Lee

Marty Plys

FROM: $\quad$ Michael Epstein Vice President, Consulting Services

SUBJECT: Ventilation Holes in Skirt for STSC Container

\section{INTRODUCTION}

Natural convection heat transfer off the bottom of the STSC container is likely to be rather weak because the air below the container is trapped in the tight space formed by the drip pan and the vertical, cylindrical skirt (hereafter referred to as the "enclosure"). The heat transfer can be improved if an exchange flow of air between the enclosure and the cell atmosphere is established. Such an exchange flow could be realized by drilling holes circumferentially around the skirt at the bottom and top of the skirt. The relatively cold cell air would then enter the enclosure through the holes at the bottom of the skirt and the hot air that moves radially outward along the bottom of the vessel would leave the enclosure through the holes at the top of the skirt. The two questions addressed in this memo are (i) what is the appropriate coefficient for the vessel wall-to-enclosure air heat transfer rate when the enclosure is ventilated? and (ii) how many holes of a specified size must penetrate the skirt in order to achieve this rate of heat transfer?

\section{HEAT TRANSFER COEFFICIENT}

If there were no air flow restrictions between the enclosure and the cell atmosphere, the hot elliptical lower head of the container could be considered to be submerged in an extensive cell air atmosphere. While there are no heat transfer correlations available for predicting rates of heat transfer from a downward facing elliptical surface, heat transfer from an equivalent spherical surface, for which correlations are available, could serve in this regard. However, unless there are many side-by-side holes in the skirt, air flow from the hot boundary layer to the holes in the top of the skirt is obstructed by the solid skirt surfaces between the holes which deflect the flow and force the flow circumferentially to the 
$\mathrm{FAl} / 10-83$

PRC-STP-00241, Rev 0

Rev. 0

Page 264 of 284

March, 2010

holes. Therefore, it is felt that selection of a heat transfer coefficient for a sphere in an extensive air atmosphere would result in overestimating the convective heat transfer rate off the lower head.

To err on the conservative side, the elliptical lower head is modeled as a downward facing flat plate. The actual vertical rise of the elliptical surface from its center to its edge is ignored and a smaller hydrostatic head is assumed which is due solely to the fact that the boundary layer is thicker at the center of the flat plate than at the edge. Of course the reduced hydrostatic head tends to decrease the heat transfer rate relative to the heat transfer rate off the actual elliptical surface. On the other hand, the heat transfer correlations that have been reported for downward facing flat surfaces do not include air confinement effects and, therefore, overestimate the heat transfer rate off a partially enclosed surface. It is felt that on balance the downward facing plate approximation is conservative but not overly conservative.

The air flow within the boundary layer on the underside of a hot plate is laminar and the heat transfer coefficient for rectangular or square plates is well represented by the correlation of Aihara et al. (1972):

$$
\mathrm{Nu}=0.5 \mathrm{Ra}^{1 / 5}
$$

where $\mathrm{Nu}$ and $\mathrm{Ra}$ are the Nusselt and Rayleigh numbers based on the half-width $\mathrm{R}$ of the plate. Here $\mathrm{R}$ is identified with the radius of the waste container's lower head. The heat transfer relation for the square plate is about the same as that for the circular plate (Fujii et al., 1973). The square plate is selected because the structure of the boundary layer beneath the square plate has been investigated more thoroughly than for the circular plate and this boundary layer information is needed to derive an expression for the required number of holes in the skirt.

Had we decided to represent the elliptical lower head by a spherical segment surface (rather than a flat plate) the following correlation by Churchill (1983) would apply:

$$
\mathrm{Nu}=0.382 \mathrm{Ra}^{1 / 4}
$$

for air in laminar or turbulent flow. For the Rayleigh numbers of interest $\left(\mathrm{Ra} \sim 4.0 \times 10^{8}\right.$ ) the Nusselt number given by Eq. (2) is about a factor of two higher than that predicted with Eq. (1). Equation (2) may be appropriate if the skirt and drip pan are replaced by a container support structure that does not interfere with the flow of cell air into and out of the enclosure. 
Suppose the temperature of the lower head wall is $\mathrm{T}_{\mathrm{w}}=50^{\circ} \mathrm{C}$ and the enclosure air temperature is $\mathrm{T}_{\mathrm{en}}=35^{\circ} \mathrm{C}$. In this temperature range the thermal diffusivity, kinematic viscosity and thermal conductivity of the enclosure air are, respectively, $v=1.82 \times 10^{-5} \mathrm{~m}^{2} \mathrm{~s}^{-1}, \alpha=2.60 \times 10^{-5} \mathrm{~m}^{2} \mathrm{~s}^{-1}$ and $\mathrm{k}=$ $2.81 \times 10^{-2} \mathrm{~W} \mathrm{~m}^{-1} \mathrm{~K}^{-1}$. The radius of the lower head wall is $\mathrm{R}=0.737 \mathrm{~m}$ (see Table 1 for a complete list of parameter values). The Rayleigh number in Eq. (1) is then

$$
\mathrm{Ra}=\frac{\mathrm{g}\left(\mathrm{T}_{\mathrm{w}}-\mathrm{T}_{\mathrm{en}}\right) \mathrm{R}^{3}}{v \alpha \mathrm{T}_{\infty}}=4.10 \times 10^{8}
$$

and the Nusselt number from Eq. (1) is

$$
\mathrm{Nu}=26.4
$$

From the definition of $\mathrm{Nu}$ the heat transfer coefficient for natural convection in the enclosure is

$$
\mathrm{h}=\frac{\mathrm{k} \mathrm{Nu}}{\mathrm{R}}=1.0 \mathrm{~W} \mathrm{~m}^{-2} \mathrm{~K}^{-1}
$$

In comparison the effective heat transfer coefficient for the thermal radiation heat loss from the lower head to the ambient at $\mathrm{T}_{\infty}=30^{\circ} \mathrm{C}$ (with the drip pan acting as a radiation shield) is

$$
\mathrm{h}_{\mathrm{rad}}=\varepsilon \sigma\left(\mathrm{T}_{\mathrm{w}}+\mathrm{T}_{\infty}\right)\left(\mathrm{T}_{\mathrm{w}}^{2}+\mathrm{T}_{\infty}^{2}\right)=2.3 \mathrm{~W} \mathrm{~m}^{-2} \mathrm{~K}^{-1}
$$

where the estimated effective emissivity is $\varepsilon=0.33$ and $\sigma$ is the Stefan-Boltzmann constant $\left(5.67 \times 10^{-8}\right.$ $\mathrm{W} \mathrm{m}^{-2} \mathrm{~K}^{-4}$ ). Thus natural convection heat transfer in the enclosure is small but not negligible compared with thermal radiation. 
FAl/10-83

Rev. 0

PRC-STP-00241, Rev 0

Table 1

\section{Parameter Values}

Page 266 of 284

March, 2010
$\mathrm{A}_{\iota}=2.35 \mathrm{~m}^{2}$

$\mathrm{B}=2.611$

$C_{D}=0.61$

$\mathrm{H}=0.3 \mathrm{~m}$

$\mathrm{k}=2.81 \times 10^{-2} \mathrm{~W} \mathrm{~m}^{-1} \mathrm{~K}^{-1}$

$\mathrm{R}=0.737 \mathrm{~m}$

$\mathrm{T}_{\mathrm{w}}=50^{\circ} \mathrm{C}$

$\mathrm{T}_{\infty}=30^{\circ} \mathrm{C}$

$\alpha=2.60 \times 10^{-5} \mathrm{~m}^{2} \mathrm{~s}^{-1}$

$v=1.82 \times 10^{-5} \mathrm{~m}^{2} \mathrm{~s}^{-1}$
Area of elliptical lower head

Area ratio parameter (see Eq. 18)

Discharge coefficient for holes in skirt

Vertical height between upper and lower rows of holes in skirt

Thermal conductivity of air

Radius (major semiaxis) of container's elliptical lower head

Temperature of elliptical lower head wall (for example problems)

Temperature of cell atmosphere outside enclosure (for example problems)

Thermal diffusivity of air

Kinematic viscosity of air 


\section{REQUIRED NUMBER OF HOLES IN SKIRT}

In order to achieve the heat transfer rate given by Eq. (1), the air flow from the cell to the enclosure must be large enough to keep up with the air flow demanded by the thermal boundary layer on the underside of the lower head. The density difference between the cell air and the enclosure air induces a buoyancy driven flow into the enclosure through the lower row of holes of flow area $A_{h}$ in the skirt and out of the enclosure through the upper row of holes of flow area $A_{h}$ in the skirt. Denoting by $H$ the vertical distance between the lower and upper rows of holes, it can be readily shown that the volumetric flow of air $Q$ into and out of the enclosure is

$$
\mathrm{Q}=\mathrm{C}_{\mathrm{D}} \mathrm{A}_{\mathrm{h}}\left[\frac{\left(\mathrm{T}_{\mathrm{en}}-\mathrm{T}_{\infty}\right) \mathrm{gH}}{\mathrm{T}_{\infty}}\right]^{1 / 2}
$$

where $T_{e n}$ is the as yet unknown enclosure air temperature, $T_{\infty}$ is the cell air temperature, $g$ is the gravitational constant and $C_{D}$ is the discharge coefficient for the holes.

An energy balance written for the enclosure is

$$
A_{\ell} h\left(T_{w}-T_{e n}\right)=\rho c_{p}\left(T_{e n}-T_{\infty}\right) Q
$$

where $A_{\ell}$ is the surface area of the elliptical lower head and $c_{p}$ and $\rho$ are the specific heat and density of air. Inserting Eq. (1) for h (see also Eqs. 3 and 5) and Eq. (7) for $\mathrm{Q}$ into Eq. (8) gives

$$
\frac{A_{\ell} k}{2 R}\left(\frac{g R^{3}}{v \alpha T_{\infty}}\right)^{1 / 5}\left(T_{w}-T_{e n}\right)^{6 / 5}=\rho c_{p} A_{h} C_{D}\left(\frac{g H}{T_{\infty}}\right)^{1 / 2}\left(T_{e n}-T_{\infty}\right)^{3 / 2}
$$

which is an implicit relation between the enclosure temperature $T_{e n}$ and the area $A_{h}$ of the holes in the upper or lower row of holes that penetrate the skirt.

Now, turning our attention to the boundary layer beneath the elliptical lower head, the experimental and theoretical work of Aihara et al. (1972) and Singh and Birkebak (1969) provided the following equations for the boundary layer thickness $\delta$ and the horizontal velocity profile $u(y)$, both evaluated at the edge of the downward facing plate:

$$
\delta=\frac{2.0 \mathrm{R}}{\mathrm{Ra}^{1 / 5}}
$$


FAl/10-83

Rev. 0

$$
u(y)=\frac{27 U_{\max }}{4} \frac{y}{\delta}\left(1-\frac{y}{\delta}\right)^{2}
$$

where $y$ is the distance coordinate perpendicular to the plate and $U_{\max }$ is the maximum fluid velocity within the boundary layer. The expression or $U_{\max }$ is

$$
\mathrm{U}_{\max }=\frac{0.8 \alpha}{\mathrm{R}} \mathrm{Ra}^{2 / 5}
$$

The volumetric flow of air at the edge of the plate $Q_{p}$, which equals the volumetric rate at which air is entrained by the boundary layer, is given by the integral

$$
\mathrm{Q}_{\mathrm{p}}=2 \pi \mathrm{R} \int_{0}^{\delta} \mathrm{udy}=\frac{27 \pi}{2} \mathrm{U}_{\max } \mathrm{R} \delta \int_{0}^{1}(1-\xi) \xi^{2} \mathrm{~d} \xi=\frac{27 \pi}{24} \mathrm{U}_{\max } \mathrm{R} \delta
$$

or, from Eqs. (10) and (12),

$$
\mathrm{Q}_{\mathrm{p}}=1.8 \pi \alpha \mathrm{R} \mathrm{Ra}^{1 / 5}
$$

As already mentioned the air flow $Q$ into the enclosure must at least equal the rate $Q_{p}$ at which the boundary layer entrains air. This condition is represented mathematically as (see Eq. 7)

$$
\mathrm{Q}_{\mathrm{p}}=1.8 \pi \alpha \mathrm{R}\left[\frac{\mathrm{g}\left(\mathrm{T}_{\mathrm{w}}-\mathrm{T}_{\mathrm{en}}\right) \mathrm{R}^{3}}{v \alpha \mathrm{T}_{\infty}}\right]^{1 / 5}=\mathrm{Q}=\mathrm{C}_{\mathrm{D}} \mathrm{A}_{\mathrm{h}}\left[\frac{\left(\mathrm{T}_{\mathrm{en}}-\mathrm{T}_{\infty}\right) \mathrm{gH}}{\mathrm{T}_{\infty}}\right]^{1 / 2}
$$

Equations (9) and (15) are two coupled algebraic equations for the unknowns $T_{e n}$ and $A_{h}$. Eliminating $A_{h}$ between Eqs. (9) and (15) results in a rather simple expression for $T_{e n}$ :

$$
\mathrm{T}_{\mathrm{en}}=\mathrm{T}_{\infty}+\frac{\mathrm{T}_{\mathrm{w}}-\mathrm{T}_{\infty}}{1+\frac{3.6 \pi \mathrm{R}^{2}}{\mathrm{~A}_{\ell}}}
$$

Substituting $T_{e n}$ from Eq. (16) back into Eq. (15) yields the desired expression for $A_{h}$ : 
FAl/10-83

PRC-STP-00241, Rev 0

Rev. 0

$$
A_{h}=\frac{1.8 \pi \alpha R}{C_{D}}\left[\frac{T_{\infty}(1+B)}{\left(T_{w}-T_{\infty}\right) g H}\right]^{1 / 2}\left[\frac{g R^{3}\left(T_{w}-T_{\infty}\right) B}{v \alpha T_{\infty}(1+B)}\right]^{1 / 5} .
$$

where

$$
\mathrm{B}=\frac{3.6 \pi \mathrm{R}^{2}}{\mathrm{~A}_{\ell}}
$$

\section{EXAMPLE CALCULATION}

Substituting the parameter values in Table 1 into Eq. (17) yields the minimum value of $A_{h}$ for improved heat transfer off the bottom of the STSC container:

$$
A_{h}=2.24 \times 10^{-2} \mathrm{~m}^{2}
$$

Recall that $A_{h}$ is the total area of the upper or lower row of holes. The total number $N$ of holes required is

$$
\mathrm{N}=\frac{4\left(2 \mathrm{~A}_{\mathrm{h}}\right)}{\pi \mathrm{D}^{2}}
$$

where $\mathrm{D}$ is the diameter of the holes. If $\mathrm{D}=5.08 \times 10^{-2} \mathrm{~m}(2.0 \mathrm{in})$ then

$$
\mathrm{N}=22 \text { holes, }
$$

or 11 holes in the bottom circumferential row and 11 holes in the top circumferential row.

The enclosure air temperature corresponding to the minimum hole area for improved lower head heat transfer is, from Eq. (16),

$$
\mathrm{T}_{\mathrm{en}}=35.5^{\circ} \mathrm{C}
$$

The coefficient for natural convection heat transfer off the lower head has already been estimated for $\mathrm{T}_{\mathrm{en}}$ $\simeq 35^{\circ} \mathrm{C}$ and is given by Eq. (5). The total power $\dot{\mathrm{q}}$ removed from the lower head by natural convection of enclosure air is

$$
\dot{\mathrm{q}}=\mathrm{A}_{\ell} \mathrm{h}\left(\mathrm{T}_{\mathrm{w}}-\mathrm{T}_{\mathrm{en}}\right)=35.3 \mathrm{~W}
$$


The total power generated in the sludge may be as high as $500 \mathrm{~W}$. It may be difficult to justify fabricating a skirt with holes given that the resulting natural convection heat transfer rate off the lower head is such a small fraction of the container power.

\section{REFERENCES}

Aihara, T., Yamada, Y., and Endo, S., 1972, "Free Convection Along the Downward-Facing Surface of a Heated Horizontal Plate," Int. J. Heat Mass Transfer 15, pp. 2535-2549.

Churchill, S. W., 1983, in Heat Exchanger Design Handbook, pt. 2, Schlunder, ed., Hemisphere, Washington, D.C.

Fujii, T., Honda, H., and Morioka, I., 1973, "A Theoretical Study of Natural Convection Heat Transfer from Downward-Facing Horizontal Surfaces with Uniform Heat Flux," Int. J. Heat Mass Transfer 16, pp. 611-627.

Singh, S. N. and Birkebak, R. C., 1969, "Laminar Free Convection from a Horizontal Infinite Strip Facing Downwards," Z. Angew. Math. Phys. 20, pp. 454-461.

ME:lak 
FAl/10-83

PRC-STP-00241, Rev 0

Rev. 0

Page 271 of 284

March, 2010

\section{C.5 FATE Natural Convection Heat Transfer Model Changes and Testing}

DATE: March 12, 2010

TO: Bob Apthorpe

Marty Plys

FROM: $\quad$ Sung Jin Lee

SUBJECT: $\quad$ FATE Natural Convection Heat Transfer Model Changes and Testing

The attached pages contain a section for FAI/10-93, the new FATE 2.061 Software Change Specification (SCS). The new models tested are for natural convection heat transfer in a narrow gap and on the underside of a hot plate. The applications are for gap heat transfer between a sludge container and shipping cask, and heat transfer from the underside of a sludge container. 
7.7 Natural Convection Heat Transfer in a Gap and on Underside of a Hot Plate

Current FATE code considers free convection on a heat conductor surface, heat transfer due to a flow driven by temperature-induced buoyancy from a single surface within quiescent surroundings as shown in Figure 7-10. The surface is assumed to be unbounded by other surfaces. The orientation, IORIHS, and characteristic height, XLHS, of the surface characterize the free convection. This model is extended to consider the presence of a second parallel wall as shown in Figure 7-11. The natural convection heat transfer across the gap is suppressed when the gap narrows and conduction becomes the dominant heat transfer mechanism as shown in Figure 7-12. New inputs for the gap distances to adjacent parallel walls on each side are introduced: XDHSI and XDHSO. These new inputs have default value of 1000 , representing free convection on a surface unbounded by other surfaces.

Another improvement made in the heat transfer model considers the heat transfer due to fluid flow within the boundary layer on the underside of a hot plate (or on the top of a cold plate) as shown in Figure 7-13. Current FATE code assumes that natural convection is completely suppressed for this stable configuration and considers only conduction heat transfer from the surface to the bulk fluid.

\subsubsection{Natural Convection Heat Transfer Across Gaps}

Laminar natural convection heat transfer across high-aspect-ratio-vertical gaps is best estimated with the following correlation that resulted from the theoretical investigations of Gill (1966) and Bejan (1979):

$$
\mathrm{Nu}=0.364\left(\frac{\delta \mathrm{Ra}}{\mathrm{H}}\right)^{1 / 4}
$$

where $\delta$ is the gap dimension, $H$ is the vertical height of the gap, $\mathrm{Nu}$ is the Nusselt number defined by 
FAl/10-83

PRC-STP-00241, Rev 0

Rev. 0

Figure 7-10. Natural Convection Heat Transfer

On a Vertical Surface Unbounded by Other

Surfaces.

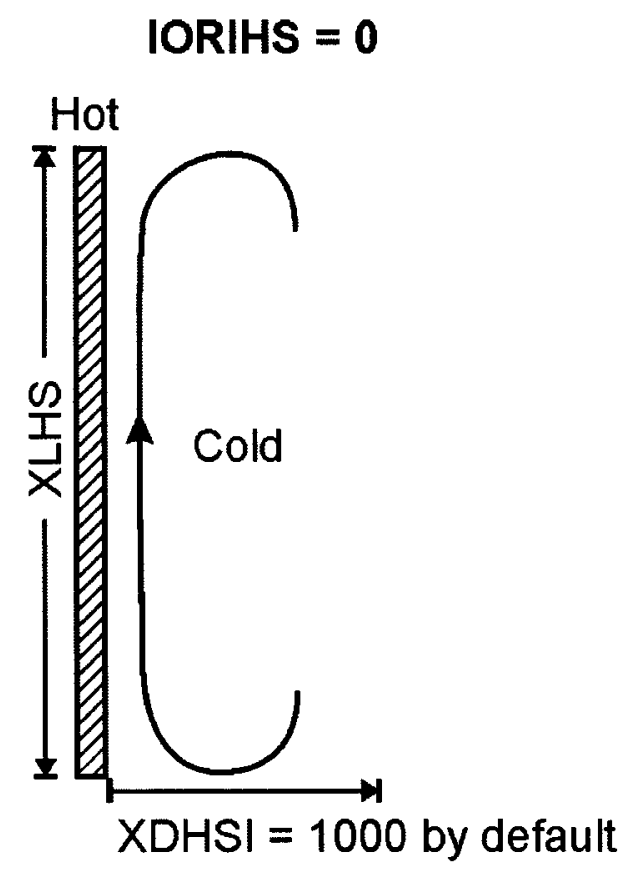

Page 273 of 284

March, 2010

Figure 7-11. Natural Convection Heat Transfer Across a Gap.

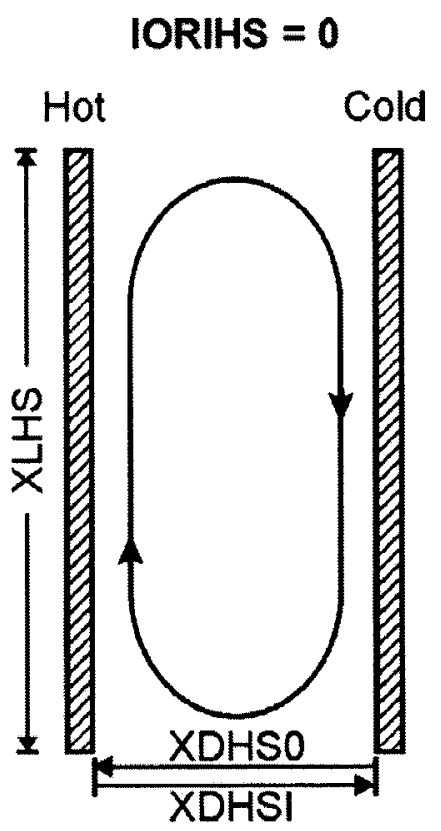


FAl/10-83

PRC-STP-00241, Rev 0

Rev. 0

Figure 7-12. Conduction Heat Transfer Across

a Narrow Gap

\section{IORIHS $=0$}

Cold Hot

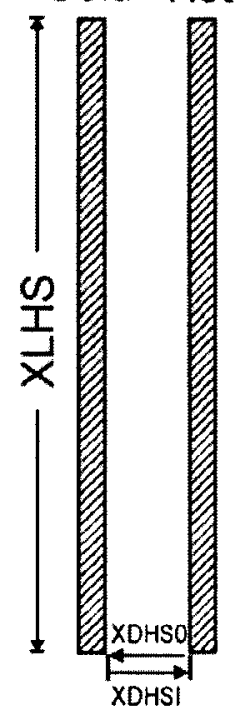

Page 274 of 284

March, 2010

Figure 7-13. Natural Convection on

Underside of a Hot Plate

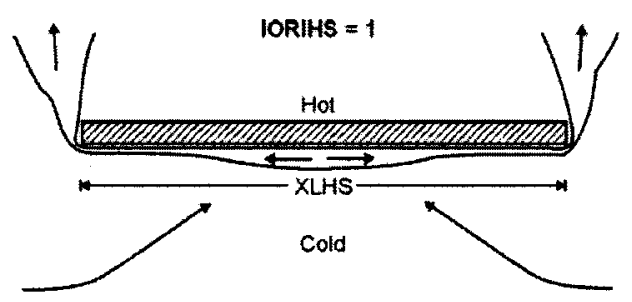


FAl/10-83

PRC-STP-00241, Rev 0

Rev. 0

$$
\mathrm{Nu}=\frac{\mathrm{h} \delta}{\mathrm{k}}
$$

March, 2010

and $\mathrm{Ra}$ is the Rayleigh number defined by

$$
\mathrm{Ra}=\frac{\mathrm{g} \beta(\Delta \mathrm{T}) \delta^{3}}{v \alpha}
$$

In Eqs. (7-16) and (7-17): $h$ is the heat transfer coefficient for heat flow across the gap due to a temperature difference $\Delta T$ across the gap; $k, \beta, v, \alpha$, are, respectively, the thermal conductivity, coefficient of thermal expansion, kinematic viscosity and thermal diffusivity of the fluid that occupies the gap; and $\mathrm{g}$ is the gravitational constant.

Equation (7-15) is valid for fluid Rayleigh numbers and gap aspect ratios that satisfy the following inequalities

$$
56.9 \frac{\mathrm{H}}{\delta} \leq \mathrm{Ra} \leq 10^{9} \quad ; \quad \frac{\mathrm{H}}{\delta}>1.0
$$

When Ra $\leq 56.9 \mathrm{H} / \delta$ heat flow occurs by conduction. Above $\mathrm{Ra}=10^{9}$ the convective flow may become turbulent and the correlation would not apply. A rational formula for the transition from Eq. (7-15) to fully turbulent flow where $\mathrm{Nu} \sim \mathrm{Ra}^{1 / 3}$ does not appear to be available in the open literature. However, in most gap heat transfer applications of practical interest $\mathrm{Ra}<10^{9}$.

\subsubsection{Model Implementation - Natural Convection Heat Transfer Across Gaps}

From the definition of the heat transfer coefficient, the heat flow $\dot{\mathrm{q}}$ (in $\mathrm{J} \mathrm{s}^{-1} \mathrm{~m}^{-2}$ ) across the gap is

$$
\dot{\mathrm{q}}=\mathrm{h}(\Delta \mathrm{T})=\mathrm{h}\left(\mathrm{T}_{\mathrm{H}}-\mathrm{T}_{\mathrm{C}}\right)
$$

where $T_{H}$ and $T_{C}$ are, respectively, the temperatures of the hot and cold surfaces that bound the gap. From Eqs. (7-15), (7-16) and (7-17) 


$$
\dot{\mathrm{q}}=0.364 \mathrm{k}\left(\frac{\mathrm{g} \beta}{v \alpha \mathrm{H}}\right)^{1 / 4}\left(\mathrm{~T}_{\mathrm{H}}-\mathrm{T}_{\mathrm{C}}\right)^{5 / 4}
$$

The structure of the FATE code requires that $\dot{q}$ be expressed in terms of the difference between a boundary temperature and the bulk fluid temperature $T_{f}$ in the gap. At steady state and sufficiently large Ra boundary layers appear on the vertical surfaces and the core region between the layers may be described by horizontal temperature profile uniformity at $T_{f}$. Under these conditions

$$
T_{H}-T_{C}=2\left(T_{H}-T_{f}\right)=2\left(T_{f}-T_{C}\right)
$$

and Eq. (7-20) becomes

$$
\dot{\mathrm{q}}=0.866 \mathrm{k}\left(\frac{\mathrm{g} \beta}{v \alpha \mathrm{H}}\right)^{1 / 4}\left(\mathrm{~T}_{\mathrm{H}}-\mathrm{T}_{\mathrm{f}}\right)^{5 / 4}
$$

or

$$
\dot{\mathrm{q}}=0.866 \mathrm{k}\left(\frac{\mathrm{g} \beta}{v \alpha \mathrm{H}}\right)^{1 / 4}\left(\mathrm{~T}_{\mathrm{f}}-\mathrm{T}_{\mathrm{c}}\right)^{5 / 4}
$$

Under quasi-steady state heatup or cool-down conditions Eqs. (7-22) or (7-23) may be used and in general we may write

$$
\mathrm{Nu}=0.866\left(\frac{\delta \mathrm{Ra}}{\mathrm{H}}\right)^{1 / 4}
$$

where it is understood that $\Delta \mathrm{T}$ is the absolute temperature difference between one of the surfaces and the bulk fluid temperature.

At high Ra number fully turbulent flow is assumed:

$$
N u=0.106 R a^{0.3333}
$$


$\mathrm{FAl} / 10-83$

PRC-STP-00241, Rev 0

Rev. 0

Page 277 of 284

March, 2010

Since the Ra number is defined in terms of the temperature difference between one surface and the bulk fluid in FATE, the equivalent high Ra number criteria consistent with Eq. $(7-18)$ is $\mathrm{Ra}>$ $0.5 \mathrm{E} 9$.

At low $\mathrm{Ra}$ number convection or in the conduction regime it is probably reasonable to identify the bulk fluid temperature $T_{f}$ with the arithmetic mean surface temperature $1 / 2\left(T_{H}+T_{C}\right)$. This is equivalent to using Eq. (7-21). Thus the heat transfer coefficient for conduction is

$$
\mathrm{Nu}=2.0
$$

where, again, $\Delta T$ is the absolute temperature difference between one of the surfaces and the bulk fluid temperature. With this temperature difference the condition for heat flow via conduction is

$$
\operatorname{Ra} \leq 28.45 \frac{\mathrm{H}}{\delta}
$$

\subsubsection{Natural Convection on the Underside of a Hot Plate (or on the Top of a Cold Plate)}

The air flow within the boundary layer on the underside of a hot plate (or on the top of a cold plate) is laminar and the heat transfer coefficient for rectangular or square plates is well represented by the correlation of Aihara et al. (1972):

$$
\mathrm{Nu}=0.5 \mathrm{Ra}^{1 / 5}
$$

where $\mathrm{Nu}$ and $\mathrm{Ra}$ are the Nusselt and Rayleigh numbers based on the half-width $\mathrm{R}$ of the plate.

The heat transfer relation for the square plate is about the same as that for the circular plate (Fujii et al., 1973).

\subsubsection{Model Implementation - Natural Convection Underside of a Hot Plate}

Note that Eq. (7-27) is based on the half-width $R$ of the plate. Since the FATE input for the characteristic length of a plate represents the total width $L$ of the plate, Eq. (7-28) needs to be rewritten in terms of ' $L$ '. The heat transfer coefficient underside of a hot plate is given by

$$
h_{c}=N u k / R
$$


FAl/10-83

PRC-STP-00241, Rev 0

Rev. 0

Page 278 of 284

Substituting Eq. (7-28),

March, 2010

$$
h_{c}=0.5 R^{1 / 5} k / R
$$

Since the Rayleigh number based on the half-width $R$ of the plate is $1 / 8$ of the Rayleigh number based on the full width $L$ of the plate, Eq. (7-30) can be rewritten as

$$
h_{c}=0.5(1 / 8)^{1 / 5} \operatorname{Ra}_{\llcorner}{ }^{5} k /(L / 2)
$$

where $R a_{L}$ is the Rayleigh number based on the full width $L$ of the plate.

Or,

$$
h_{c}=0.5 \times 4^{1 / 5} \mathrm{Ra}_{L}^{5} \mathrm{~K} / \mathrm{L}
$$

Hence, the heat transfer correlation implemented in FATE code for natural convection on the underside a hot plate, or on the top of a cold plate, is

$$
\mathrm{Nu}_{\mathrm{L}}=0.66 \mathrm{Ra}_{\mathrm{L}}{ }^{1 / 5}
$$

where $\mathrm{Nu} u_{L}$ and $\mathrm{Ra} \mathrm{L}_{\llcorner}$are Nusselt and Rayleigh numbers based on the full-width $L$ of the plate.

\subsubsection{New Inputs}

New inputs for the gap distances to adjacent parallel walls on each side are introduced: XDHSI and XDHSO. These new inputs have default value of 1000 , representing free convection on a surface unbounded by other surfaces.

\subsubsection{Test Requirements}

The natural convection in a narrow gap model should be tested to demonstrate that it can reproduce the expected heat transfer coefficient for an unbounded surface and between two surfaces separated by various size gaps. The natural convection on a downward facing hot surface should be tested to demonstrate that it can reproduce the expected heat transfer coefficient underside of a hot plate. 
FAl $/ 10-83$

The first test consists of a $10 \mathrm{~m}$ tall, $1 \mathrm{~m}$ wide, $0.01 \mathrm{~m}$ thick vertical steel plate with one surface fixed at $60^{\circ} \mathrm{C}$ and the other surface facing the atmosphere of a large room at $25^{\circ} \mathrm{C}$. The emissivity of the surface is set to $1 . E-5$ to disable the radiative heat transfer. The thermal diffusivity, kinematic viscosity and thermal conductivity of the $25{ }^{\circ} \mathrm{C}$ air are, respectively, $v=$ $1.572 E-5 \mathrm{~m}^{2} \mathrm{~s}^{-1}, \alpha=2.176 \mathrm{E}-5 \mathrm{~m}^{2} \mathrm{~s}^{-1}$ and $\mathrm{k}=0.02548 \mathrm{~W} \mathrm{~m}^{-1} \mathrm{~K}^{-1}$. The height of the wall is $\mathrm{L}=10$ $m$ and the one-side surface area of the wall is $A=10 \mathrm{~m}^{2}$. The Rayleigh number is

$$
R a=\frac{g\left|T_{w}-T_{g}\right| L^{3}}{\nu \alpha T_{g}}=3.367 E 12
$$

and the Nusselt number for turbulent natural convection on the vertical surface is

$$
N u=0.106 R a^{0.3333}=1587
$$

From the definition of $\mathrm{Nu}$ the heat transfer coefficient for natural convection on the vertical surface is

$$
h=\frac{k N u}{L}=4.044 W m^{-2} K^{-1}
$$

Finally, the heat transfer rate from the hot surface to the air in the room is given by

$$
Q=h A\left(T_{w}-T_{g}\right)=1415 W
$$

The second test consists of two vertical parallel plates, each $10 \mathrm{~m}$ tall, $1 \mathrm{~m}$ wide, and $0.01 \mathrm{~m}$ thick. The inner surface of the first plate is facing the inner surface of the second plate. The outer surface of the first plate is fixed at $50^{\circ} \mathrm{C}$ and the outer surface of the second plate is fixed at $40^{\circ} \mathrm{C}$. Initially the two plates are $20 \mathrm{~m}$ apart. The gap distance is reduced to $8 \mathrm{~m}$ at 100 seconds, to $0.1 \mathrm{~m}$ at 200 seconds, and $0.01 \mathrm{~m}$ at 300 seconds. Again, the emissivities of all surfaces are set to $1 . E-5$ to disable the radiative heat transfer. The thermal diffusivity, kinematic viscosity and thermal conductivity of the $45^{\circ} \mathrm{C}$ air are, respectively, $v=1.653 \mathrm{E}-5 \mathrm{~m}^{2}$ $\mathrm{s}^{-1}, \alpha=2.294 \mathrm{E}-5 \mathrm{~m}^{2} \mathrm{~s}^{-1}$ and $\mathrm{k}=0.02694 \mathrm{~W} \mathrm{~m}^{-1} \mathrm{~K}^{-1}$. The height of the wall is $\mathrm{L}=10 \mathrm{~m}$ and the one-side surface area of the wall is $A=10 \mathrm{~m}^{2}$. Initially, when the gap distance exceeds the 
height of the plates, the surfaces are each considered unbounded. FATE computes heat transfer rate from the first plate to the bulk gas in the gap and from the gas to the second plate. Since the gap will take up the average temperature between the two plates, $45^{\circ} \mathrm{C}$, the corresponding Rayleigh number is

$$
R a=\frac{g\left|T_{w}-T_{g}\right| L^{3}}{v \alpha T_{g}}=4.066 E 11
$$

and the Nusselt number for turbulent natural convection on the vertical surface is

$$
N u=0.106 R a^{0.3333}=784.6
$$

From the definition of $\mathrm{Nu}$ the heat transfer coefficient for natural convection on the vertical surface is

$$
h=\frac{k N u}{L}=2.114 W^{-2} K^{-1}
$$

Finally, the heat transfer rate from the hot surface to the air in the room is given by

$$
Q=h A\left(T_{w}-T_{g}\right)=106 W
$$

When the two plates are brought closer at 100 seconds, the new gap distance, $8 \mathrm{~m}$, decreases below the height of the plates, $10 \mathrm{~m}$. With $\delta=8 \mathrm{~m}$ and $\mathrm{T}_{9}=45^{\circ} \mathrm{C}$, the Rayleigh number is

$$
R a=\frac{g\left|T_{H}-T_{g}\right| \delta^{3}}{v \alpha T_{g}}=2.082 E 11
$$

It is greater than the critical Ra number for fully turbulent flow, $0.5 \mathrm{E} 9$, and the corresponding heat transfer rate is given by Eq. (7-25),

$$
N u=0.106 R a^{0.3333}=627.7
$$

From the definition of Nu the heat transfer coefficient for natural convection in the gap is 
FAl/10-83

PRC-STP-00241, Rev 0

Rev. 0

$$
h=\frac{k N u}{\delta}=2.114 W^{-2} K^{-1}
$$

Finally, the heat transfer rate across the gap is given by

$$
Q=h A\left(T_{w}-T_{g}\right)=106 W
$$

When the gap distance decreases to $0.1 \mathrm{~m}$ at 200 seconds, the Ra number in Eq. (7-42) decreases to $4.07 E 5$, below the critical value for fully turbulent flow, and the natural convection heat transfer rate across the gap is given by Eq. (7-20). With $\beta=1 / T_{g}=3.143 E-3 \mathrm{~K}^{-1}, H=10 \mathrm{~m}$, and $\left(T_{H}-T_{C}\right)=10 \mathrm{~K}$, Eq. $(7-20)$ gives

$$
\dot{\mathrm{q}}=0.364 \mathrm{k}\left(\frac{\mathrm{g} \beta}{v \alpha \mathrm{H}}\right)^{1 / 4}\left(\mathrm{~T}_{\mathrm{H}}-\mathrm{T}_{\mathrm{C}}\right)^{5 / 4}=9.312 \mathrm{~W} \mathrm{~m}^{-2}
$$

The heat transfer rate from the hot plate to the cold plate across the gap is

$$
Q=A \dot{q}=93.12 W
$$

When the gap distance decreases further to $0.01 \mathrm{~m}$ at 300 seconds, the Ra number in Eq. (7-42) decreases to $4.07 \mathrm{E} 2$. It is less than the critical value for heat flow via conduction in Eq. (7-27), $28.45 \frac{\mathrm{H}}{\delta}=2.85 \mathrm{E} 4$. The conduction heat transfer is given by $A k \frac{\left(T_{H}-T_{C}\right)}{\delta}=269 \mathrm{~W}$

The third test consists of a $2 \mathrm{~m}$ by $2 \mathrm{~m}$ square plate, with the top surface fixed at $100{ }^{\circ} \mathrm{C}$ and the bottom surface facing the atmosphere of a large room at $25^{\circ} \mathrm{C}$. The half-width of the plate $R=1 \mathrm{~m}$. The Rayleigh number in Eq. $(7-27)$ is then

$$
R a=\frac{g\left|T_{w}-T_{g}\right| R^{3}}{v \alpha T_{g}}=7.214 E 9
$$

and the Nusselt number from Eq. (7-27) is 
FAl/10-83

PRC-STP-00241, Rev 0

Rev. 0

Page 282 of 284

March, 2010

$$
N u=0.5 R a^{1 / 5}=46.8
$$

From the definition of Nu the heat transfer coefficient for natural convection on underside of the hot surface is

$$
h=\frac{k N u}{R}=1.19 \mathrm{~W} \mathrm{~m}^{-2} K^{-1}
$$

Finally, the heat transfer rate from the hot surface to the air in the room is given by

$$
Q=h A\left(T_{w}-T_{g}\right)=357 W
$$

The test cases are constructed in the FATE input file HGAP.DAT.

\subsubsection{Test Results}

Test results are shown in Figure 7-14. The upper left figure shows the vertical wall, horizontal wall, and the room temperatures for the first and third test cases. They are, respectively, $60^{\circ} \mathrm{C}, 100^{\circ} \mathrm{C}$, and $25^{\circ} \mathrm{C}$. The lower left figure shows the heat transfer rates on the vertical wall and on the underside of the horizontal wall. The code predicted values of 1413 $\mathrm{W}$ and $358 \mathrm{~W}$ agree with the expected heat transfer rates of $1415 \mathrm{~W}$ and $357 \mathrm{~W}$.

The upper right figure shows the temperature of the two parallel plates and the air gap. Two plates are kept at constant temperatures of $50^{\circ} \mathrm{C}$ and $40^{\circ} \mathrm{C}$. The air in the gap heats up gradually and assumes the average temperature between the two plates, $45^{\circ} \mathrm{C}$. Although gap heat transfer correlations are normally written in terms of the heat transfer rate from one surface to another, in FATE heat transfer occurs in two steps, from the hot surface to the bulk gas in the gap and from the gas to the cold surface. Hence, the test should demonstrate that the twostage heat transfer calculation in FATE reproduces the surface-to-surface heat transfer correlation. The lower left figure shows the heat transfer rates on the two plates as the gap distance is changed every 100 second: $20 \mathrm{~m}$ at 0 seconds, $8 \mathrm{~m}$ at 100 seconds, $0.1 \mathrm{~m}$ at 200 seconds, and $0.01 \mathrm{~m}$ at 300 seconds.

Different heat transfer correlation is exercised at each gap distance. Initially, the gap is sufficiently large for the surfaces to be treated as unbounded surfaces. The FATE calculated heat transfer rate of $106 \mathrm{~W}$ is consistent with the expected value of $106 \mathrm{~W}$. After 100 seconds, 
the fully turbulent natural convection prevails in the gap. The FATE calculated heat transfer rate of $105.5 \mathrm{~W}$ agrees with the expected value of $106 \mathrm{~W}$. After 200 seconds, when the gap distance is decreased to $0.1 \mathrm{~m}$, laminar natural convection prevails in the gap. The FATE calculated heat transfer rate of $93.03 \mathrm{~W}$ agrees with the expected value of $93.12 \mathrm{~W}$. Lastly, after 300 seconds, when the gap distance is reduced to $0.01 \mathrm{~m}$, conduction heat transfer prevails in the gap. The FATE calculated heat transfer rate of $269 \mathrm{~W}$ agrees with the expected value of $269 \mathrm{~W}$. In conclusion, the test demonstrates all the behavior expected from the test requirements and test description.

\subsubsection{Reference}

Aihara, T., Yamada, Y., and Endo, S., 1972, "Free Convection Along the Downward-Facing Surface of a Heated Horizontal Plate," Int. J. Heat Mass Transfer 15, pp. 2535-2549.

Bejan, A., 1979, "Note on Gill's Solution for Free Convection in a Vertical Enclosure," J. Fluid Mech. 90 , pp. 561-568.

Churchill, S. W., 1983, in Heat Exchanger Design Handbook, pt. 2, Schlunder, ed., Hemisphere, Washington, D.C.

Fujii, T., Honda, H., and Morioka, I., 1973, "A Theoretical Study of Natural Convection Heat Transfer from Downward-Facing Horizontal Surfaces with Uniform Heat Flux," Int. J. Heat Mass Transfer 16, pp. 611-627.

Gill, A. E., 1966, "The Boundary-Layer Regime for Convection in a Rectangular Cavity," J. Fluid Mech. 26, pp. 515-536.

Singh, S. N. and Birkebak, R. C., 1969, "Laminar Free Convection from a Horizontal Infinite Strip Facing Downwards," Z. Angew. Math. Phys. 20, pp. 454-461. 
Figure 7-14. Test Results for Natural Convection Heat Transfer in a Gap and on Underside of a Hot Plate.
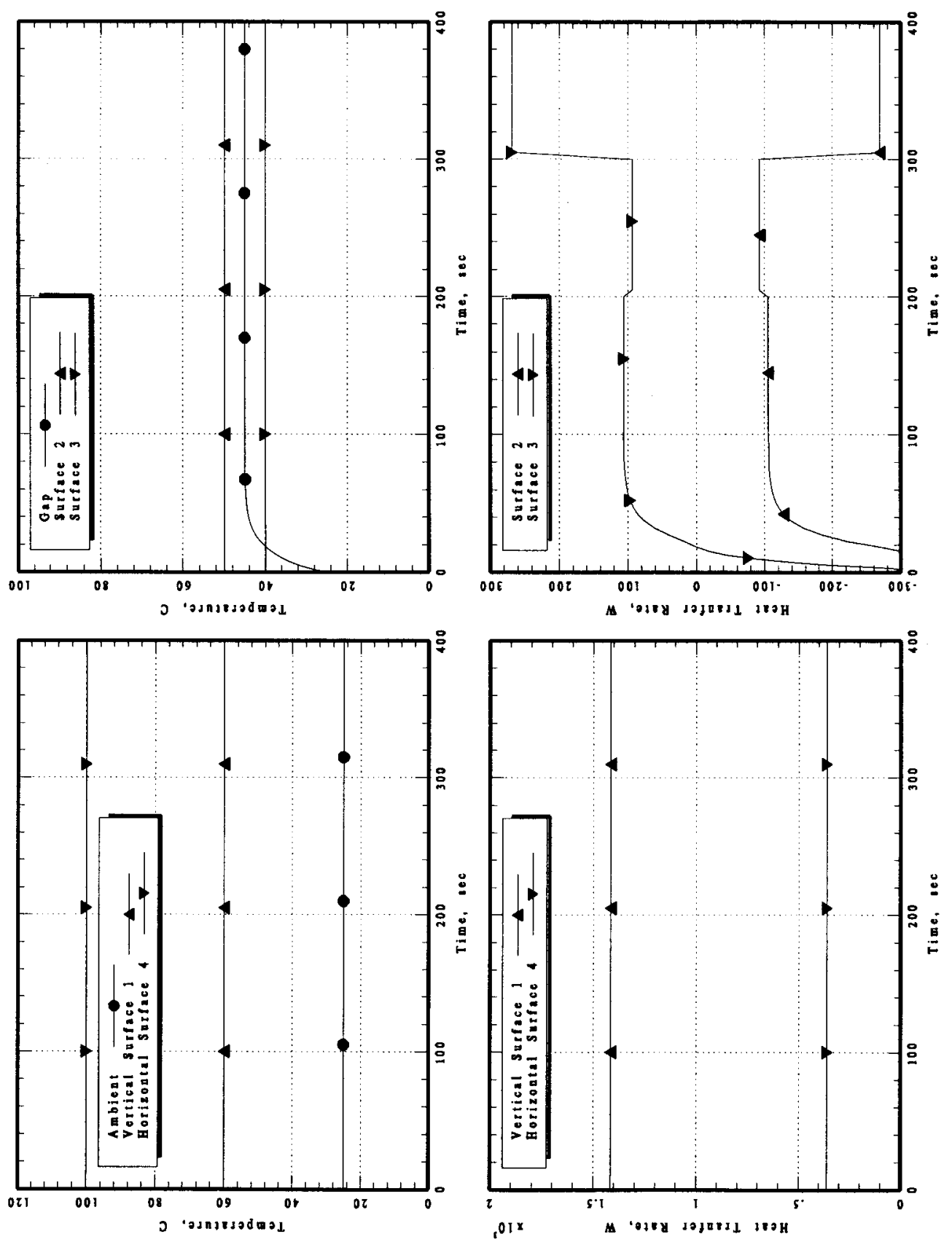